\author{
UNIVERSIDADE DE SÃO PAULO \\ INSTITUTO DE PSICOLOGIA \\ DEPARTAMENTO DE PSICOLOGIA SOCIAL E DO TRABALHO
}

CLEIDE PIVOTT

A CONSTRUÇÃO COMPARTILHADA DE UM PLANO DE TURISMO PARA MONTEIRO LOBATO, SP: A SUSTENTABILIDADE COMO HORIZONTE

São Paulo

2014 


\title{
A CONSTRUÇÃO COMPARTILHADA DE UM PLANO DE TURISMO PARA MONTEIRO LOBATO, SP: A SUSTENTABILIDADE COMO HORIZONTE.
}

\author{
(Versão Corrigida)
}

Tese apresentada ao Programa de Pós-Graduação do Instituto de Psicologia, no Departamento de Psicologia Social e do Trabalho, da Universidade de São Paulo - IP/USP como requisito para a obtenção do título de Doutora em Psicologia.

Área de concentração: Psicologia Social.

Orientadora: Profa. Dra. Eda Terezinha de Oliveira Tassara.

São Paulo 
Autorizo a reprodução e divulgação total ou parcial deste trabalho, por qualquer meio convencional ou eletrônico, para fins de estudo e pesquisa, desde que citada a fonte.

\section{Catalogação na publicação}

Biblioteca Dante Moreira Leite

Instituto de Psicologia da Universidade de São Paulo

Pivott, Cleide.

A construção compartilhada de um plano de Turismo para Monteiro Lobato, SP: a sustentabilidade como horizonte / Cleide Pivott; orientadora Eda Terezinha de Oliveira Tassara. - São Paulo, 2014.

$398 \mathrm{f}$.

Tese (Doutorado - Programa de Pós-Graduação em Psicologia. Área de Concentração: Psicologia Social) - Instituto de Psicologia da Universidade de São Paulo.

1. Intervenção Socioambiental 2. Planejamento participativo 3. Plano de Turismo Sustentável 4. Monteiro Lobato, SP I. Título. 
Nome: Cleide Pivott

Título: A construção compartilhada de um plano de Turismo para Monteiro Lobato, SP: a sustentabilidade como horizonte.

Aprovado em: 30 de abril de 2014.

Banca Examinadora

Profa. Dra. Eda Terezinha de Oliveira Instituição: IP/USP

Tassara

Julgamento

Assinatura:

Profa. Dra. Doris van de Meene

Instituição: ECA/USP

Ruschmann

Julgamento

Assinatura:

Prof. Dr. José Oswaldo Soares de

Instituição: UNITAU

Oliveira

Julgamento

Assinatura:

Prof. Dr. Alessandro de Oliveira dos Instituição: IP/USP

Santos

Julgamento

Assinatura:

Profa. Dra. Sandra Maria Patrício

Vichietti

Instituição: IP/USP

Julgamento

Assinatura:

Instituto de Psicologia, Departamento de Psicologia Social e do Trabalho, Universidade de São Paulo

São Paulo, 24 de fevereiro de 2014. 
Dedico este trabalho ao Grupo Planejatur, representantes legítimos do povo lobatense, com todas as suas características de acolhimento, força de vontade, persistência, simplicidade, autenticidade, comprometimento e amor à própria terra: André Barreto, Andrejs Ceruks, Antonio Renato de Sá Sonnewend, Benedita Ivana da Rocha Claro, Célia Ceruks, Deise Datti Rosa, Ednea Goulart de Andrade, Larissa Claro, Leila Miranda, Odette Antonia Casimiro da Silva e Regina de Fátima Araujo. 


\section{AGRADECIMENTOS}

Agradeço ao Deus do meu coração e da minha compreensão por todas as pessoas queridas que colocou em meu caminho.

Minha imensa gratidão aos professores educadores, Professora Doutora Eda Terezinha de Oliveira Tassara pela orientação pacienciosa e os ensinamentos preciosos, Professor Doutor José Oswaldo Soares de Oliveira que desde nosso encontro no Curso de Mestrado apoia e tem colaborado com meus projetos, tendo sido pelas suas mãos que cheguei ao Curso de Doutorado, Professora Doutora Vera Maria Almeida Rodrigues da Costa, amiga, protetora e grande incentivadora dos meus estudos e Professora Doutora Doris van de Meene Ruschmann pela referência profissional que me representa, mas principalmente pelo carinho que me dedica.

Gratidão aos professores do Curso de Doutorado Eda Terezinha de Oliveira Tassara, Gustavo Martineli Massola, Sandra Maria Patrício Vichietti, Denise Dias Barros e Maria Luisa Sandoval Schmidt por compartilharem tão prazerosamente seus conhecimentos com os alunos.

A todas as pessoas de Monteiro Lobato que me fizeram sentir uma "de dentro" desde o primeiro "bom dia" sorridente que recebi na rua dado por uma pessoa que nunca me vira antes, mas que, com esse ato, mostrou-me o prazer que é viver em comunidade.

Para com os membros do Grupo Planejatur, COMTUR-ML, Prefeitura de Monteiro Lobato e SINHORES manterei eterna gratidão por terem me apoiado e compartilhado não só informações e ideias, mas inestimáveis sentimentos e sonhos. 
Rangel,

Você me pede um conselho e atrevidamente eu dou o Grande Conselho: seja você mesmo, porque ou somos nós mesmos ou não somos coisa nenhuma. E para ser si mesmo é preciso um trabalho de mouro e uma vigilância incessante na defesa, porque tudo conspira para que sejamos meros números, carneiros de vários rebanhos - os rebanhos políticos, religiosos, estéticos. Há no mundo ódio à exceção - e ser si mesmo é ser exceção.

José Bento Monteiro Lobato 


\section{RESUMO}

Pivott, Cleide. A construção compartilhada de um plano de Turismo para Monteiro Lobato, SP: a sustentabilidade como horizonte. 2014. 399 f. Tese (Doutorado) - Instituto de Psicologia, Universidade de São Paulo, São Paulo, 2014.

O Turismo, inserido no setor terciário da economia, o da prestação de serviços, promove atividades geradoras de trabalho e renda, representando uma atividade econômica complementar para pequenos municípios com potencial turístico e com limitações para desenvolver os setores primário e secundário. A atividade turística recebe críticas quanto a aspectos destrutivos do consumo e produção e do Turismo de Massa e por, também, cumprir função prócapitalista. O Turismo Sustentável planejado com Participação Social surge como um modelo da atividade turística capaz de minimizar o que é considerado negativo sem, no entanto, eliminar os impactos porque não há Turismo sem impactos. O tema deste estudo é o Planejamento do Turismo Sustentável com Participação Social na localidade de Monteiro Lobato, SP. Insere-se no processo da interdisciplinaridade ao envolver conhecimentos das áreas do planejamento do Turismo Sustentável, da Psicologia Social e da Participação Social. Aborda a problemática da inexistência, no Brasil, de políticas públicas eficazes não só em Turismo Sustentável como também para uma Participação Social que o apoie. O objetivo foi promover o planejamento do Turismo Sustentável por meio de estratégias participativas de planejamento e de programas educativos que estimulassem a atuação social na sua construção, gestão e implementação. A técnica utilizada neste trabalho foi a pesquisaintervenção na tentativa de desviar o desenvolvimento turístico do município dos padrões do Turismo tradicional para o caminho do planejamento turístico com base nos critérios de sustentabilidade. Diz-se tentativa porque o resultado efetivo só poderá ser verificado no futuro. Entretanto, já se notam mudanças no discurso e atitudes dos atores sociais envolvidos. Porém, verificou-se nos estudos que as pessoas, ao realizarem a atividade, fazem escolhas conforme seus interesses econômicos, políticos e ideológicos baseados em seus valores e crenças, o que se torna a causa dos impactos positivos ou negativos à própria comunidade e ao espaço geográfico onde vivem. Portanto, é importante promover a ação educativa para a elaboração de um Plano Diretor de Turismo Sustentável com a participação da comunidade, capacitando um grupo multiplicador comprometido com a sua implementação e manutenção em um primeiro momento e envolvendo paulatinamente os demais moradores na sua prática.

Palavras-chave: Intervenção Socioambiental. Planejamento participativo. Plano de Turismo Sustentável. Monteiro Lobato (SP). 


\begin{abstract}
Pivott, Cleide. A Tourism plan shared construction for Monteiro Lobato, SP: the sustainability as the horizon. 2014. 399 p. Ph.D. thesis - Post-Graduate Program in Social Psychology (IP), São Paulo University, São Paulo, 2014.
\end{abstract}

Tourism concerns economy tertiary sector, the one of services, and the activities it promotes create jobs and increase income. It represents a complementary economic activity for the small cities which despite having tourist potential also have limitations in developing primary and secondary economic sectors. Tourist activity has been criticized concerning consumption, production, and Mass Tourism destructive aspects and also for developing a pro-capitalist function. The Sustainable Tourism planned with Social Participation arises as another pattern of tourist activity capable of minimizing what is considered negative without, however, eliminating impacts as there is no Tourism without them. This study theme is the Sustainable Tourism Planning developed with Social Participation in the city of Monteiro Lobato, SP. It involves an interdisciplinary process which brings together areas of knowledge on Sustainable Tourism, Social Psychology and Social Participation. The highlighted issue is that there are no effective public policies in Brazil concerning not only Sustainable Tourism as well as Social Participation which could support it. The objective was to promote the Sustainable Tourism planning by means of participative planning strategies and educative programs which would stimulate the social interaction for its building, management and implementation. The technique used in this thesis was the intervention-research trying to divert the city tourist development from the traditional Tourism patterns and to redirect its planning on criteria basis of sustainability. It is said an attempt because the effective result will be verified only in the future. However, some changes in speeches and attitudes have already been observed relating the involved social actors. Nevertheless, it was verified through these studies that people, when performing activities, make choices according to their ideological, political and economic interests which are based on their values and beliefs, being the causes of positive and negative impacts to the community itself and to the geographical space where they live on. Therefore, it is important to promote the educative action toward a Sustainable Tourism Master Plan elaborated with the community active involvement, thus capacitating a group which will act as a multiplier committed to its implementation and maintenance in a first moment and gradually enrolling other people to successfully do the same.

Keywords: Social and environmental intervention. Participative Planning. Sustainable Tourism Plan. Monteiro Lobato (SP). 


\section{RESUMÉ}

Pivott, Cleide. La construction partagée d'un plan de Tourisme pour la ville de Monteiro Lobato, SP: la viabilité environnementale comme horizont. 2014. 399 p. Thèse (Doctorat) - Instituto de Psicologia, Universidade de São Paulo, São Paulo, 2014.

Le Tourisme, inseré dans le troisième secteur de l'économie, celui de la prestation des services et qui promouvoit des activités génératrices de travail et de ressources se présente comme une activité économique complementaire pour des petites municipalités qui ont un potentiel touristique et en même temps des limitations pour developper les secteurs primaires et secondaires. L'activité touristique reçoit des critiques concernant l'aspect destructif de la consommation, de la production et du Tourisme de Masse et aussi pour sa fonction pró-capitaliste. Le Tourisme Durable, planifié avec la participation sociale apparaît comme un modède d'activité touristique capable de réduire au minimum ce qui est considéré négatif, sans éliminer les impacts, car il n'éxiste pas de Tourisme sans impact. Le thème de cette étude est la Planification du Tourisme Durable avec la Participation Sociale dans la municipalité de Monteiro Lobato, SP. Elle s'insère dans un procès interdisciplinaire, car y sont associés les secteurs de la planification du Tourisme Durable, de la Psychologie Sociale et de la Participation Sociale. L'étude aborde aussi le problème du manque de politiques publiques éfficaces pas seulement pour le Tourisme Durable mais aussi pour une participation Sociale capable de l'appuyer. Son objectif a été la promotion de la planification du Tourisme Durable au moyen de stratégies participatives de planification et de programmes de formation capables d'encourager l'action sociale dans sa construction, gestion et implantation. La technique utilisée dans cette étude a été la recherche-intervention en essayant d'écarter le développement touristique de la municipalité des standards du Tourisme traditionnel et le diriger vers le chemin de la planification touristique basée sur les critères de durabilité. On parle d'essai car le resultat éffectif ne pourra être vérifié que dans le futur. On note déjà, malgré tout, des changements dans le discours et dans les attitudes des acteurs sociaux qui y participent. Nous avons vérifié, pendant les études, que les personnes, lors de la realisation des activités, font des choix selon leurs intérêts économiques, politiques et ideologiques, basés sur leurs valeurs et croyances, ce qui peut devenir la cause d'impacts positifs ou négatifs pour la communauté elle même et pour l'espace géographique où elles vivent. II est pourtant important de promouvoir l'action éducative pour l'élaboration d'un Plan Directeur pour le Tourisme Durable avec la participation de la communauté, en capacitant dans un premier moment un groupe multiplicateur compromis avec son implantation et maintien pour ensuite, petit à petit, faire participer les autres membres de la communauté à cette pratique.

Mots-clés: Intervention Socio-environnementale. Planification participative. Plan de Tourisme Durable. Monteiro Lobato (SP). 


\section{LISTA DE FOTOS}

Foto 1 - Faixa de divulgação da primeira Oficina....................................... 125

Foto 2 - Conjunto de fotos da primeira Oficina - Técnica ZOPP................ 153

Foto 3 - Faixa de divulgação da segunda Oficina.................................... 158

Foto 4 - Conjunto de fotos da segunda Oficina........................................ 204

Foto 5 - $\quad$ Faixa de divulgação da terceira Oficina...................................... 208

Foto 6 - Conjunto de fotos da terceira Oficina - dia 19 de setembro de 2013............................................................................ 223

Foto 7 - Conjunto de fotos da terceira Oficina (continuação) - 07 de novembro de 2013.

Foto 8 - Conjunto de fotos Atrativos Culturais - Patrimônio

Histórico/Monumentos e Igrejas................................................. 265

Foto 9 - Conjunto de fotos Manifestações Populares/Artesanatos e Gastronomia Típica................................................................... 266

Foto 10 - Conjunto de fotos de artesanato.............................................. 267

Foto 11 - Conjunto de fotos da Trilha do Mel........................................... 268

Foto 12 - Conjunto de fotos de Atrativos Naturais - Hidrografia................... 269

Foto 13 - Conjunto de fotos de Atrativos Naturais - Relevo.......................... 269

Foto 14 - Conjunto de fotos de Atrativos Naturais - Vegetação.................... 270

Foto 15 - Conjunto de fotos Curso para Professores e Mostra Pedagógica alunos do 3 ‥ Ano - Tema - Animais da Mata Atlântica - 12 e 13 de dezembro de 2013............................................................... 276

Foto 16 - Grupo Planejatur............................................................................... 307 


\section{LISTA DE FIGURAS}

Figura 1 - Entrelaçamento das áreas de conhecimento envolvidas nesse trabalho................................................................ 78

Figura 2 - $\quad$ Fluxograma da pesquisa................................................. $\quad 80$

Figura 3 - $\quad$ Cartazete de divulgação da primeira Oficina............................ 125

Figura 4 - $\quad$ Cartazete de divulgação da segunda Oficina............................ 158

Figura 5 - $\quad$ Cartazete de divulgação da terceira Oficina.............................. 208

Figura 6 - $\quad$ Brasão do município.......................................................... 357

Figura 7 - $\quad$ Bandeira do Município de Monteiro Lobato............................. 358

Figura 8 - $\quad$ Mapa de localização do município de Monteiro Lobato........... 360 


\section{LISTA DE GRÁFICOS}

Gráfico 1 - Local de nascimento dos participantes da primeira Oficina ......... 129

Gráfico 2 - $\quad$ Cidade de residência dos participantes da primeira Oficina......... 130

Gráfico 3 - $\quad$ Bairro onde mora - participantes da primeira Oficina................... 130

Gráfico 4 -

Gráfico 5 -

Local de nascimento dos participantes da segunda Oficina........ 161

Nascidos em São José dos Campos x residentes em Monteiro Lobato.

161

Gráfico 6 -

Cidades onde residem os participantes da segunda Oficina......

162

Gráfico 7 -

Bairros onde residem os participantes da segunda Oficina.........

162

Gráfico 8 -

Local de nascimento dos participantes da terceira Oficina...........

Gráfico 9 -

Cidades onde residem os participantes da terceira Oficina..........

210

Gráfico 10 -

Gráfico 11 -

Bairros onde residem os participantes da terceira Oficina...........

210

Gráfico 12 -

Local de nascimento (pesquisa com moradores)

211

Gráfico 13 -

Bairro onde reside.

225

Gráfico 14 -

Sexo.

226

227

Gráfico 15 -

Faixa etária.

227

Gráfico 16 -

Estado civil.

227

Gráfico 17 -

Número de m

228

Gráfico 18 -

Setor de trabalho

228

Gráfico 19 -

Cidade em que trabalha

229

Gráfico 20 -

Grau de instrução.

229

Gráfico 21 -

Gráfico 22 -

Atividade cultural de interesse.

230

Gráfico 23 -

Tipo de música.

231

Gráfico 24 -

Gráfico 25 -

Gráfico 26 -

Gráfico 27 -

Conhece livros

231

Livros que leu

232

Você é favorável à exploração do Turismo em Monteiro Lobato?

233

233

Tipo de benefício que o turista traz

234

Gráfico 28 -

Local para visitar.....

235

Você considera que a cidade tem condições de receber

turistas?

236

Gráfico 29 -

Gráfico 30 -

Gráfico 31 -

Em que cidade reside? (pesquisa com turistas).

243

Cidade em que reside por região.

Se estiver de passagem, qual a cidade de destino após Monteiro Lobato?.

243

Gráfico 32 -

Sexo.

244

Gráfico 33 -

Faixa Etária.

245

Gráfico 34 -

Estado Civil.

245

Gráfico 35 -

Renda familiar

246

Gráfico 36 -

Grau de instruça..................

246

Gráfico 37 -

Grau de instrução

247

Gráfico 38 -

Interesse cultural

247

Gráfico 39 -

Tipo de música.

248

Gráfico 40 -

Conhece os livros de Monteiro Lobato?.

248

Gráfico 41 -

Livros que leu.

249

Gráfico 42 -

Motivo da viagem.

249

Gráfico 43 -

Como soube de Monteiro Lobato?.

250

Gráfico 44 - Tempo de permanência em Monteiro Lobato?

Com que frequência costuma visitar Monteiro Lobato..

251 
Gráfico 45 - Qual o meio de hospedagem utilizado em Monteiro Lobato?.... 252

Gráfico 46 - Meio de transporte utilizado................................................... 252

Gráfico 47 - Como viaja?................................................................ 253

Gráfico 48 - Como paga as despesas de viagem?.................................... 254

Gráfico 49 - Você costuma fazer as refeições na cidade?.............................. 254

Gráfico 50 - Onde faz as refeições? ....................................................... 255

Gráfico 51 Você faz compras em Monteiro Lobato?................................... 255

Gráfico 52 - Em caso afirmativo, o que compra?....................................... 256

Gráfico 53 - Antes de chegar, qual era a sua expectativa em relação aos atrativos turísticos de Monteiro Lobato?.................................. 257

Gráfico 54 - Como classifica a paisagem urbana de Monteiro Lobato?.......... 258

Gráfico 55 - Como classifica a paisagem rural de Monteiro Lobato?.............. 258

Gráfico 56 - Como classifica a limpeza em Monteiro Lobato?........................ 259

Gráfico 57 - Que produtos procurou e não encontrou?................................ 259

Gráfico 58 - Que serviços procurou e não encontrou?................................. 260

Gráfico 59 - Como classifica o atendimento no comércio?............................. 260

Gráfico 60 - O que mais Ihe agradou em Monteiro Lobato?............................ 261

Gráfico 61 - O que menos Ihe agradou em Monteiro Lobato?........................ 262

Gráfico 62 - Sugestões para tornar a cidade mais atraente........................... 263

Gráfico 63 - Voltaria a Monteiro Lobato em outra oportunidade?................... 263

Gráfico 64 - Precipitação média mensal no período de 1939 a 2004 - posto D2-020.................................................................... 393 


\section{LISTA DE QUADROS}

Quadro 1 -

Quadro 2 -

Quadro 3 -

Quadro 4 -

Quadro 5 -

Quadro 6 -

Quadro 7 -

Quadro 8 -

Quadro 9 -

Quadro 10 -

Quadro 11 -

Quadro 12 -

Quadro 13 -

Quadro 14 -

Quadro 15 -

Quadro 16 -

Quadro 17 -

Quadro 18 -

Quadro 19 -

Quadro 20 -

Quadro 21 -

Quadro 22 -

Quadro 23 -

Quadro 24 -

Quadro 25 -

Quadro 26 -

Quadro 27 -

Quadro 28 -

Quadro 29 -

Quadro 30 -

Quadro 31 -

Quadro 32 -

Quadro 33 -

Quadro 34 -

Quadro 35 -

Quadro 36 -

Quadro 37 -

Quadro 38 -

Quadro 39 -
Modelo de painel para apresentação dos participantes.

Modelo de painel para análise de envolvimento..................................

Modelo de Árvore de Problemas..

Modelo de Árvore dos Objetivos

Questões relativas à MPP

Configuração da MPP.

Explicações dos tópicos da MPP.

Modelo de matriz de cooperação institucional.....................................

Sugestão de avaliação.

Grupos, temas para trabalho e tutores.

Modelo de projeto.

Diagrama de Análise FOFA.

Matriz das Diretrizes para o Turismo Sustentável de Monteiro Lobato.

Esquema do projeto de interdisciplinaridade proposto aos professores.

Sugestões de possíveis inter-relacionamentos entre Meio Ambiente e Turismo

Número de participantes nas atividades com a comunidade.

Apresentação e sonho dos participantes da primeira Oficina............. 126

Fichas de inscrição da primeira Oficina.

Relação de Participantes da primeira Oficina................................... 128

Relação de Bairros em Monteiro Lobato

Relação de bairros dos participantes da primeira Oficina................... 131

Árvore dos Problemas............................................................... 133

Árvore dos Objetivos.

Configuração da MPP aplicada na primeira Oficina............................ 147

Modelo de Avaliação do Potencial Turístico na primeira Oficina........ 150

Modelo de quadro de análise do envolvimento

Quadro de análise do envolvimento elaborado pelo Grupo Planejatur Modelo de Matriz de Cooperação Institucional...

Quadro para registros dos grupos de trabalhos voluntários para realização dos projetos.

Avaliação da Oficina.

Relação de participantes da segunda Oficina................................... 159

Grupos e temas para trabalho - segunda Oficina............................. 163

Programa de Ação - 1. Educação.

Projeto 1.1.1. Capacitação de professores nas áreas de Turismo Sustentável, Turismo Rural e Educação Ambiental.............................. Projeto 1.1.2. Empreendedorismo na Escola.....................................

Projeto 1.1.3. Cursos profissionalizantes.

Projeto 1.2.1. Conscientização da população para o Turismo Sustentável e para a preservação do Meio Ambiente.

Projeto 1.2.2. Nova sede da biblioteca com bibliotecário responsável

Projeto 1.2.3. Criação de curso supletivo para 0 Ensino Fundamental/Ciclo 2 e Ensino Médio. 
Quadro 40 Quadro 41 -

Quadro 42 -

Quadro 43 -

Quadro 44 -

Quadro 45-

Quadro 46 -

Quadro 47 -

Quadro 48 -

Quadro 49 -

Quadro 50 -

Quadro 51 -

Quadro 52 -

Quadro 53 -

Quadro 54 -

Quadro 55 -

Quadro 56 -

Quadro 57 -

Quadro 58 -

Quadro 59 -

Quadro 60 -

Quadro 61 -

Quadro 62 -

Quadro 63-

Quadro 64 -

Quadro 65 -

Quadro 66 -

Quadro 67
Projeto 2. Infraestrutura Turística.

Projeto 2.1.1. Formatação dos atrativos como produtos turísticos com infraestrutura adequada e preparados para receberem turistas com qualidade no atendimento

Projeto 2.1.2. Turismo Receptivo.

Projeto 2.2.1. Criação de uma agenda de eventos

Projeto 2.3.1. Exposição e venda de artesanato e de produtos da terra em feira realizada na Praça Cunha Bueno (praça de cima) nos finais de semana e feriados

Projeto 2.4.1. Elaboração do Plano de Marketing Turístico de Monteiro Lobato..

Projeto 3. Infraestrutura da Cidade.

Projeto 3.1.1. Plano de conservação de estradas.

Projeto 3.2.1. Reestruturação de cargos e salários.

Projeto 3.3.1. Melhoria da prestação de serviços da empresa de ônibus Cidade Natureza.

Projeto 3.4.1. Melhoria da prestação de serviços da empresa EDP Bandeirante.

Projeto 3.5.1. Adequação dos banheiros da rodoviária.

Projeto 3.6.1. Reestruturação das atividades de esporte e lazer para a população e revitalização dos equipamentos existentes para tal fim

Projeto 3.7.1. Articulação para melhorar a segurança pública no município.

Projeto 3.8.1. Melhoria da acessibilidade nas vias públicas

Projeto 3.9.1. Revitalização da Praça Comendador Freire (praça de baixo).

Projeto 3.10.1. Melhoria da comunicação telefônica na zona rural do município.

Projeto 4. Comunicação.

Projeto 4.1.1. Ações para divulgar informações sobre o Turismo do município.

Projeto 5. Comportamento

Projeto 5.1.1. Mudança de comportamento do lobatense em relação aos aspectos pessoais, sociais, empresariais e de relacionamento governo-comunidade-iniciativa privada.

Projeto 6. Legislação.

Projeto 6.1.1. Criação de leis municipais para disciplinar os fatos que acontecem no município e que prejudicam a comunidade e visitantes.

Projeto 7. Saúde Pública em Relação ao Turismo

Projeto 7.1.1. Abandono de Animais

Projeto 7.1.2.Drogas e Alcoolismo.

8. Cultura.

Projeto 8.1.1. Criação da Política Pública de Cultura em Monteiro Lobato. 
Quadro 68 -

Quadro 69 -

Quadro 70 -

Quadro 71 -

Quadro 72 -

Quadro 73 -

Quadro 74 -

Quadro 75-

Quadro 76 -

Quadro 77 -

Quadro 78 -

Quadro 79 -

Quadro 80 -

Quadro 81 -

Quadro 82 -

Quadro 83 -

Quadro 84 -

Quadro 85 -

Quadro 86 -

Quadro 87 -

Quadro 88 -

Quadro 89 -

Quadro 90 -

Quadro 91 -

Quadro 92 -

Quadro 93 -

Quadro 94 -

Quadro 95 Quadro 96 -

Quadro 97 -

Quadro 98 -

Quadro 99 -

Quadro 100 -

Quadro 101 -

Quadro 102 -

Quadro 103 -

Quadro 104 -
Projeto 8.2.1. Viabilidade de um projeto para criação do museu histórico para Monteiro Lobato.

Projeto 9. Recursos Financeiros

Projeto 9.1.1. Incentivo ao empreendedorismo............................... 203

Relação de participantes da terceira Oficina..................................... 209

Diagrama de análise FOFA.

Análise FOFA - Atrativos Naturais.............................................. 213

Análise FOFA - Atrativos Culturais............................................. 213

Análise FOFA - Infraestrutura Turística.......................................... 214

Análise FOFA - Infraestrutura de apoio........................................ 214

Análise FOFA - Políticas públicas para Turismo Sustentável e de inserção no Turismo regional.

Matriz das diretrizes para o Turismo Sustentável de Monteiro Lobato.

Matriz das diretrizes para Vocação - Turismo de Natureza e Turismo Rural.

Matriz das diretrizes para Vocação - Turismo Cultural - Escritor e Manifestações Culturais.

Matriz das diretrizes para tipo de eventos

Matriz das diretrizes para Regras de convívio morador x turista......

Matriz das diretrizes para atitudes dos governos executivo e legislativo em relação ao Turismo Sustentável no município............

Matriz das diretrizes para atitudes dos empresários

Matriz das diretrizes para atitudes da comunidade.

Participantes da Oficina no dia 07 de novembro de 2014.

Visão dos participantes para o Turismo Sustentável em Monteiro Lobato.

Síntese da visão de futuro.

Qual o motivo que o trouxe para Monteiro Lobato? (caso não tenha nascido no município).

O que deve ser feito na cidade para receber bem o turista?

Quais os cursos profissionalizantes você acha que devem ser feitos em Monteiro Lobato?

O que há de melhor em Monteiro Lobato que você não quer que seja perdido?

O que há de ruim em Monteiro Lobato que precisa melhorado?.....

Indique os eventos que você considera bom e os que considera ruim para os moradores da cidade?

Qual a vocação turística de Monteiro Lobato?

De uma maneira geral, o que considera que seja bom para toda a comunidade de Monteiro Lobato?.

Como classifica os preços dos produtos em Monteiro Lobato?.......

Relação de Artesãos e Artistas plásticos.

Relação de Propriedades que oferecem produtos rurais.

Capacidade hoteleira - Monteiro Lobato - novembro/2013...

Relação de restaurantes e respectivos números de lugares............ 271

Estrutura para Eventos................................................................... 271

Eventos.

Projetos elaborados pelos professores. 
Quadro 105 - Modelo de registro de pautas e decisões em reuniões

Quadro 106 - Resultado da tempestade de ideias para o nome do Grupo Planejatur

Quadro 107 - Expectativas para o trabalho de planejamento e o sonho para 0 município de cada membro do Grupo Planejatur.

Quadro 108 - Resumo dos sonhos para o município apresentados pelos participantes da primeira Oficina em 15 de março de 2012

Quadro 109 - Check list para a organização da primeira Oficina em 15 de março de 2012.

Quadro 110 -

Localização do município de Monteiro Lobato.

Quadro 111

Relação de Bairros.

Quadro 112 - Acessos.

Quadro 113 -

Informações sobre as escolas do município...

Unidades de Conservação.

Quadro 115 Uso Potencial da Terra.

Quadro 116 Relação de mamíferos encontrados no Vale do Paraíba... 


\section{LISTA DE TABELAS}

Tabela 1 -

População do município

Tabela 2 -

Evolução da População Urbana e Rural em Monteiro Lobato.....

Tabela 3 -

Evolução da taxa de crescimento populacional de Monteiro Lobato

Tabela 4 Faixa etária da população de acordo com o Censo 2010 do IBGE..

Tabela 5 Mães adolescentes.

Tabela 6 -

Densidade Demográfica.

Tabela 7 -

Densidade Demográfica Região de Governo de São José dos Campos e Estado

Tabela 8 Eleitores.

Tabela 9

IDH do município e região

Tabela 10

Condições de Vida Região de Governo de São José dos Campos e Estado.

Tabela 11 .

Tabela 12 -

Taxa de natalidade do município, Região de Governo de São José dos Campos e Estado

Coeficiente de Mortalidade Infantil.

Taxa de mortalidade infantil Estado de São Paulo e DRS 17 Taubaté.

Tabela 14 -

Taxa de Mortalidade Infantil Monteiro Lobato e São José dos Campos

Tabela 15 -

Proporção de moradores abaixo da linha da pobreza e indigência 2010.

Tabela 16 Emprego

Tabela 17 Rendimento Médio dos Empregos Formais

Tabela 18 Número de estabelecimentos em Monteiro Lobato - ano 2012.........

Tabela 19 Dados sobre os produtores rurais e a produção do total de 314 UPAs.

Tabela 20 Propriedade que dispõem de energia elétrica.

Tabela 21 -

Dados do uso e ocupação do solo das propriedades.

Tabela 22 -

Produção rural - Cultura...

Tabela 23 -

Produção rural - animais.

377

Tabela 24 -

Dados econômicos do município

378

Tabela 25 -

Valor Adicionado do município.

378

Tabela 26 .

População Economicamente Ativa (PEA).

379

Tabela 27 -

Receitas e Repasses de Tributos aos municípios em 2012.

379

Tabela 28 -

Arrecadações.

380

Tabela 29 -

Resíduos Sólidos Domiciliares (RSD) gerados pelo município de Monteiro Lobato, em 2009, em relação aos demais municípios da UGRHI 02

Tabela 30 - Resumo dados do saneamento básico do município 


\section{SUMÁRIO}

1 INTRODUÇÃO

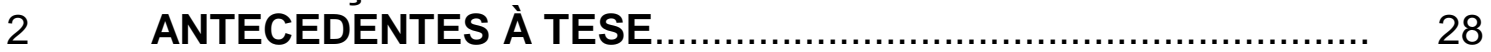

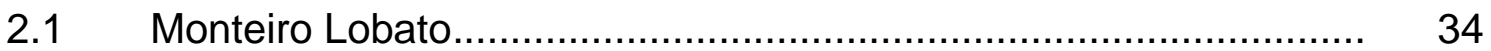

$2.2 \quad$ Tese de doutorado................................................................. 38

2.3 Circunstâncias sociopolíticas em Monteiro Lobato......................... 39

2.4 Economia do município de Monteiro Lobato.................................. 41

$3 \quad$ CONCEITUAÇÃO TEÓRICA .................................................. 43

3.1 Turismo Sustentável.......................................................... 43

3.2 Turismo Sustentável e a Produção Social do Espaço..................... 46

3.3 Planejamento Turístico e Participação Social................................. 47

3.4 Psicologia Socioambiental..................................................... 58

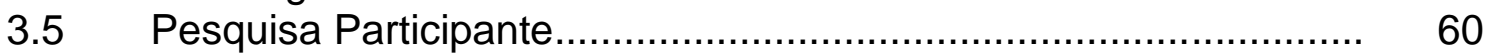

3.6 Pesquisa-ação e Pesquisa-intervenção......................................... 63

3.7 Intervenção Social.................................................................. 65

3.8 Planejamento do Turismo Sustentável.......................................... 68

$4 \quad$ METODOLOGIA .......................................................... $\quad 76$

$4.1 \quad$ Técnica ZOPP............................................................. 84

4.2 Oficina para definição do Programa de Ações............................... 95

4.3 Oficina de Análise FOFA........................................................... 97

$4.4 \quad$ Levantamento de dados....................................................... 100

4.5 O envolvimento das escolas da rede municipal no Plano Diretor do Turismo Sustentável de Monteiro Lobato.................................. 102

$5 \quad$ CARACTERIZAÇÃO DO MUNICÍPIO......................................... 106

6 DESCRIÇÃO DO TRABALHO DE CAMPO.............................. 112

6.1 Interação com a comunidade................................................ 115

6.2 O planejamento do Turismo Sustentável com participação social 118

6.2.1 PlaneJÁtur - Oficina de Planejamento Participativo em Turismo Sustentável no Município de Monteiro Lobato, SP, 15 de março de 2012

6.2.2 PlaneJÁtur - Oficina de Planejamento Participativo em Turismo Sustentável no Município de Monteiro Lobato, SP, 28 de fevereiro de 2013

6.2.3 PlaneJÁtur - Oficina de Planejamento Participativo em Turismo Sustentável no Município de Monteiro Lobato, SP, 19 de setembro, 10 se outubro e 07 de novembro de 2013.

6.3 Pesquisa de opinião dos moradores e pesquisa de demanda...... 224

6.4 Inventário Turístico.............................................................. 265

6.5 Reativação do Conselho Municipal de Turismo de Monteiro Lobato (COMTUR-ML)...................................................... 272

6.6 O envolvimento das escolas da Rede Municipal de Ensino no Plano Diretor do Turismo Sustentável de Monteiro Lobato............ 273

7 O PROCESSO DO DESENVOLVIMENTO DA PESQUISAINTERVENÇÃO..

7.1 Situação de contorno: a circunstância sociopolítica do município..

7.2 Os "de fora" e a não-participação dos nativos..................................

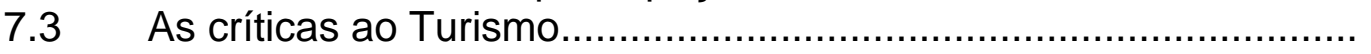

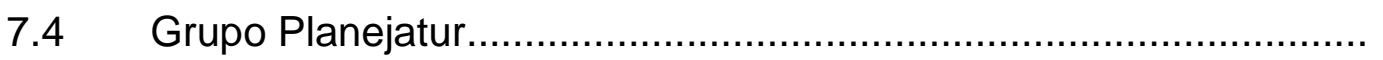


APÊNDICE A - Programa de Ensino do Curso para Capacitação em Turismo Sustentável...

APÊNDICE B - Pesquisa de Opinião de Moradores sobre o Turismo em Monteiro Lobato - Grupo Planejatur - 2013.

APÊNDICE C - Pesquisa de Demanda Turística - Grupo

Planejatur - Monteiro Lobato - 2013.

APÊNDICE D - Divulgação do Curso de Capacitação em Turismo Sustentável.

APÊNDICE E - Documento aos Candidatos a Prefeito - Eleições 2012

ANEXO A - Convite para o lançamento do projeto que tem como objetivo a elaboração do Plano Diretor do Turismo Sustentável para Monteiro Lobato.

ANEXO B - 5 Caracterização do Município - Dados Secundários 


\section{INTRODUÇÃO}

Este trabalho surge dos estudos e da experiência da pesquisadora que, desde 1991, tem se dedicado a projetos de fomento ao Turismo na região recentemente transformada na Região Metropolitana do Vale do Paraíba e Litoral Norte (RMVPLN) pelo governo do Estado de São Paulo, a qual abrange 39 municípios das cinco microrregiões localizadas no eixo entre São Paulo e Rio de Janeiro, quais sejam: Vale do Paraíba, Alto Paraíba, Serra da Mantiqueira, Vale Histórico e Litoral Norte.

Os municípios dessas microrregiões apresentam características socioambientais similares, mas com algumas peculiaridades que as distinguem como, por exemplo, nível de desenvolvimento econômico, manifestações culturais e paisagens considerando o aspecto geográfico que contém o vale do Rio Paraíba do Sul, a Serra da Mantiqueira e a Serra do Mar que, por outro lado, oferecem potencialidade turística à região.

O trabalho de campo foi desenvolvido no período de junho de 2011 a dezembro de 2013, no município de Monteiro Lobato, SP. Localizado na região de administração de São José dos Campos, Vale do Paraíba, suas características socioambientais estão mais próximas daquelas da microrregião da Serra da Mantiqueira (Campos do Jordão, São Bento do Sapucaí e Santo Antonio do Pinhal) e, portanto, sua paisagem serrana é um dos atrativos turísticos. Desde a década de 1970, as lideranças locais buscam a classificação de estância turística como mecanismo político para incrementar suas finanças. Porém, Monteiro Lobato não possui plano diretor e a atividade turística, que se encontra no início de seu ciclo de vida, na fase de exploração, acontecia sem planejamento. A importância de um município ordenar o uso e ocupação do seu território por meio da elaboração de um plano diretor apoiase, entre outros aspectos, na constatação de Santos (1988, p. 71) de que "o espaço é resultado da ação dos homens sobre o próprio espaço, intermediados pelos objetos, naturais e artificiais". Portanto, os processos sociais se inserem no território, essa interação resulta a produção social do espaço que reflete a relação dialética entre sociedade e espaço. 
Assim, o planejamento urbano, idealmente, deve conter estratégias que garantam a integração de visões de urbanistas com as de profissionais das ciências sociais (Geografia, Sociologia, Antropologia, Psicologia Social, etc.) para evitar planos diretores distorcidos de acordo com uma visão tecnicista preponderante que não considere as questões sociais. O plano diretor de um município turístico deve incluir um plano específico para Turismo igualmente articulado com disciplinas das Ciências Sociais, tendo em mente que o Turismo é uma atividade desenvolvida por pessoas, cujas decisões impactam o meio ambiente. Por conseguinte, Turismo é um fenômeno que envolve o espaço e a sociedade na sua materialização.

Há vários fatores indicativos de que um município tem condições para se tornar turístico. Entre eles, destacam-se: a melhoria das infraestruturas básica e turística, a formação e qualificação de mão de obra, a capacitação gerencial de empresários e lideranças governamentais, a adequação e comercialização dos produtos turísticos, a criação de políticas públicas para o Turismo. No que tange o Turismo Sustentável, esses fatores constituem partes de um plano de desenvolvimento turístico cuidadosamente elaborado com participação dos atores sociais da localidade turística e orientado pelos princípios de sustentabilidade que, segundo Jara (1998, p. 167), são: democracia política, equidade social, eficiência econômica, conservação ambiental, diversidade cultural e liberdade espiritual.

Para o setor do Turismo, o planejamento participativo é fundamental à sustentabilidade do núcleo receptor que pode sofrer impactos negativos caso não aconteça o estabelecimento de objetivos comuns e os interesses individuais prevaleçam sobre os coletivos. Portanto, buscar o apoio da comunidade desde o início da organização territorial destinada a impulsionar o Turismo, é preciso para que sejam alcançados os resultados satisfatórios do desenvolvimento sustentável do Turismo com base local (MAGALHÃES, 2002, p. 90). A elaboração de um Plano Diretor de Turismo com base nos critérios de sustentabilidade, demanda um trabalho de sensibilização e conscientização dos atores sociais da localidade a respeito das implicações de questões como a preservação e a conservação do meio ambiente, o resgate da história do município, a valorização da cultura local, a identificação e a preservação dos 
patrimônios materiais e imateriais, as relações entre residentes e visitantes, a estruturação de um sistema político-social de gestão do Turismo, entre outras.

Apesar de constar do Estatuto da Cidade (Lei no 10.257/01, Capítulo IV - Da gestão Democrática da Cidade), a cultura de planejamento com participação da população, com raras exceções, não é disseminada no Brasil. Os conselhos temáticos (saúde, educação, segurança, assistência social entre outros) estão entre os espaços de cogestão pública entre governo e comunidade e, segundo Gohn (2001, p. 90), “o papel dos conselhos incide na discussão sobre as estratégias de gestão pública de uma forma geral e sobre o caráter das próprias políticas em particular". A autora salienta que:

De um lado, observa-se que a operacionalização não plena dessas novas instâncias democratizantes se dá devido à falta de tradição participativa da sociedade civil em canais de gestão dos negócios públicos; a curta trajetória de vida desses conselhos e, portanto, a falta de exercício prático (ou até a sua inexistência); e ao desconhecimento - por parte da maioria da população, de suas possibilidades (deixando-se espaço livre para que eles sejam ocupados e utilizados como mais um mecanismo da política das velhas elites, e não como um canal de expressão dos setores organizados da sociedade).

Consideram-se, portanto, necessários programas de educação para a prática do planejamento participativo nos diversos segmentos da sociedade. Capacitada, a sociedade se insere nos processos de participação social podendo gerar ações que lhe garantam a condição de corresponsável pela construção compartilhada do futuro do município.

Okamura et al. $(2005 \text {, p. } 276)^{1}$ indicam que a Psicologia Ambiental, a Psicologia Social e a Psicologia Comunitária buscam olhar, nos processos participativos, como é construído o destino das populações no Brasil e no mundo. Para esses autores, se o ambiente é entendido como a construção do espaço objetivo e material realizado pelo sujeito, a Psicologia Ambiental poderia investigar a construção do ambiente como espaço simbólico e como essa construção pode se dar de forma participativa, interferindo e sendo

\footnotetext{
${ }^{1}$ Esta citação corresponde ao texto do "Documento Síntese do Fórum Olhando para o Futuro", redigido com base nos artigos apresentados no Simpósio Internacional Psicologia e Ambiente, realizado em 2002, na Universidade de São Paulo. Os autores desse documento são: Cíntia Okamura (Coord.), Alessandro de Oliveira Santos, Ana Maria Blanques, Anaruez Ferreira Morais, Carmem Beatriz Rodrigues Fabriani, Héctor Omar Ardans Bonifacino, Leila Aparecida Bomfim, Leila Vieira Kim, Nancy Ramacciotti de Oliveira e Ricardo Burg Mlymarz.
} 
interferida pelo ambiente de forma retroalimentadora. Assim, considerando que se encontram embricados no Turismo os fenômenos social e espacial a interagir e a se influenciar mutuamente, produzindo impactos positivos e negativos que afetam diretamente as relações entre 0 homem e o meio ambiente, acredita-se ser a aplicação do método de planejamento participativo um dos caminhos para a construção de uma planificação do Turismo baseada nos critérios de sustentabilidade em municípios turísticos de pequeno porte.

Identifica-se como problemática o fato de não haver políticas públicas eficazes de fomento ao planejamento participativo em Turismo, bem como não haver cultura de participação social no Brasil.

Os municípios de pequeno porte com potencial turístico não têm recursos financeiros para contratar empresas de consultoria que elaborem planos diretores do município e/ou de Turismo. Por conseguinte, a atividade turística é desenvolvida de forma espontânea, sem ordenamento, de acordo com as forças sociais, em especial as econômicas como as do mercado imobiliário, provocando riscos de degradação ao socioambiente.

O presente estudo apoia-se em duas hipóteses. A primeira considera que, se o processo de planejamento do Turismo for desenvolvido em uma comunidade por meio de estratégias participativas envolvendo a população, haverá uma adesão maior dos atores sociais nelas implicados, pelo fato de que os mesmos se sentirão motivados por terem construído uma visão coletiva da realidade local e do seu contexto social, na direção de um projeto coletivo com base no que pensam ser potencialidades e oportunidades do contexto. Dessa forma, supõe-se que os atores sociais passem a considerar, em suas análises, aspectos socioambientais locais e podem optar por pautar-se na busca de um futuro desejado compartilhado. A segunda hipótese refere-se à continuidade das ações iniciadas a partir do processo de planejamento participativo. Entende-se que a sustentação do Turismo, com base em critérios considerados de sustentabilidade - em um município turístico de pequeno porte - será favorecida se os atores sociais envolvidos no processo de planejamento participativo e de planificação das ações locais de empreendimentos turísticos transferirem os métodos utilizados, em benefício da consolidação de uma cultura do trabalho voltada para o coletivo e desenvolverem mecanismos para 
a gestão continuada do Turismo no município que, assim, se aproximará gradativamente dos ideais de sustentabilidade.

$O$ objetivo geral deste estudo foi promover o planejamento e a implementação de processos sociais atinentes ao desenvolvimento de atividades econômicas no setor de Turismo com base em critérios compartilhados de sustentabilidade (respeito à justiça social, aos valores culturais e à correção ecológica) e como forma de fundamentar, em um comprometimento coletivo, a manutenção da prática dessas atividades setoriais. Os objetivos específicos foram promover, por meio da implementação de estratégias participativas de planejamento, programas educativos que estimulassem a participação social e propiciassem o planejamento institucional de atividades turísticas; ampliar e aprimorar o repertório de comportamentos, conhecimentos e atitudes de grupos de pessoas de um município turístico de pequeno porte, no Brasil, a fim de que os mesmos possam vir a formar um grupo multiplicador capaz de conduzir iniciativas em prol da implantação de um programa sustentável de atividades turísticas, englobando uma crescente atuação social na sua construção, gestão e implementação.

As seções 6 e 7 contêm a descrição do trabalho de campo e do processo de desenvolvimento dessa pesquisa que foi conduzida por meio da técnica de intervenção social, em um trabalho interdisciplinar entrelaçando conhecimentos nas áreas do planejamento do Turismo Sustentável, da Psicologia Social e da Participação Social. O trabalho foi desenvolvido por meio das seguintes estratégias: inserção da pesquisadora na comunidade; oferta do Curso de Capacitação em Turismo Sustentável, com o objetivo de conscientizar os participantes sobre a importância do planejamento do Turismo Sustentável; convite aos concluintes do curso para participarem de uma equipe de trabalho para o planejamento do Turismo Sustentável no município. O grupo, autodenominado Planejatur, realizou a Oficina de Planejamento do Turismo Sustentável com a comunidade em 15 de março de 2012, iniciando a etapa de diagnóstico e levantando os obstáculos que impedem o desenvolvimento turístico no município. No segundo semestre de 2012, o grupo empreendeu a realização do inventário turístico, levantando informações sobre a infraestrutura turística do município (atrativos turísticos, meios de hospedagem, restaurantes, espaços para eventos etc.). Em janeiro de 2013, o 
Grupo Planejatur criou e aplicou questionários para as pesquisas de opinião de moradores e turistas a respeito da atividade turística no município. Em 28 de fevereiro de 2013, foi realizada a segunda Oficina de Planejamento do Turismo Sustentável em continuidade à etapa do diagnóstico, na qual foi definido o Programa de Ações. Em 19 de setembro de 2013, foi realizada a Oficina de Prognóstico com o objetivo de elaborar as diretrizes para o Turismo do município juntamente com a comunidade.

No modelo de planejamento participativo, as atividades são adaptativas, isto é, algumas delas não previstas no projeto inicial são realizadas enquanto outras são descartadas, dependendo do encaminhamento do trabalho. Nesse estudo, houve duas atividades não previstas inicialmente que foram realizadas: a reativação do Conselho Municipal de Turismo de Monteiro Lobato (COMTURML) no dia 03 de julho de 2013 e o curso sobre Turismo Sustentável e Meio Ambiente ministrado para os professores da Rede Municipal de Ensino, no dia 26 de julho de 2013. Ambas as atividades já identificadas como necessárias na primeira Oficina.

Neste estudo, houve ainda o envolvimento de uma parcela da população em dois níveis de participação. O primeiro refere-se à formação do Grupo de Planejamento Participativo do Turismo Sustentável de Monteiro Lobato (Planejatur) que aceitou a proposta de elaboração do Plano Diretor de Turismo Sustentável para o município e o segundo se refere às pessoas que foram convidadas a participar das oficinas de planejamento e de outras atividades promovidas pelo Grupo Planejatur.

O trabalho de pesquisa foi desenvolvido com tranquilidade, sem dificuldades ou conflitos, porque houve o encontro oportuno do projeto da pesquisadora com a busca por mecanismos para fomentar o desenvolvimento socioeconômico do município. Salienta-se o grande mérito dos membros do Grupo Planejatur que mantiveram o comprometimento do início ao fim da elaboração do Plano Diretor do Turismo Sustentável de Monteiro Lobato. 


\section{ANTECEDENTES À TESE}

Dentro de um senso comum, o Turismo é divulgado como uma atividade econômica que proporciona diversos benefícios, a saber: como a geração de empregos em curto prazo, maior arrecadação de impostos, aumento do consumo na localidade, resgate e valorização da cultura local, preservação do meio ambiente, melhoria da qualidade de vida para residentes e visitantes etc. Mas o Turismo é uma prática social e as atividades a ele comumente associadas decorrem dessa prática (CRUZ, 2000, p. 21). Assim sendo, não há Turismo sem impactos (RUSCHMANN, 2005, p. 13) os quais, no entanto, podem ser minimizados se houver a planificação para o Turismo Sustentável com base em estratégias participativas de planejamento que considere as interrelações sociedade, espaço e atividades turísticas.

Diante da complexidade de tais aspectos, estão as limitações dos atores sociais em relação ao planejamento turístico: "O que fazer? Como? Onde? Quando? Quem faz? Quanto custa? Por onde começar?" etc. É compreensível a dificuldade que os municípios de pequeno porte têm em viabilizar a elaboração de um plano de Turismo, cientes que a maioria deles depende de repasses financeiros dos governos federal e estadual e, portanto, seus recursos são reduzidos e insuficientes para a contratação de empresas especializadas. No entanto, em alguns municípios, são empresas de consultorias que elaboram um Plano Diretor de Turismo. Embora competentes, raramente oferecem assessoria para a implementação dos planos elaborados os quais, por vezes, permanecem engavetados e ignorados pelas gestões públicas posteriores. Além disso, outros planos de Turismo não são implantados porque a comunidade não participou da sua elaboração e, portanto, desconhece como the dar continuidade ou ainda por decisões políticas dos atores sociais da localidade.

No Brasil, segundo Beni (2006, p. 19), o início do planejamento do Turismo em nível nacional ocorreu no período entre 1948 e 1958 com a criação da Comissão Brasileira de Turismo (COMBRATUR), pelo Ministério do Trabalho, Indústria e Comércio. Em 1966, pelo Decreto-Lei nº 55/1966, foi 
criado o Sistema Nacional de Turismo, composto pela EMBRATUR, Conselho Nacional de Turismo (CNTur) e envolvendo o Ministério das Relações Exteriores. Vinte e cinco anos mais tarde, no governo Collor de Mello, foi promulgada a Lei ํo $8.181 / 91^{2}$ e o Decreto o $448 / 92^{3}$ que deram as bases jurídicas para a "Política Nacional de Turismo - 1996-1999", instituída no primeiro mandato do Presidente Fernando Henrique Cardoso e reorientada para o período de 2000-2003. No âmbito dessa política nacional, foi instituído o Programa Nacional de Municipalização do Turismo (PNMT), coordenado pelo Instituto Brasileiro de Turismo (EMBRATUR) "com o propósito de implementar um novo modelo de gestão da atividade turística, simplificado e uniformizado, para os Estados e Municípios, de maneira integrada, buscando maior eficiência e eficácia na administração da atividade turística, de forma participativa"4

De acordo com o Demonstrativo Geral do PNMT, no período de 1998 a 2000, houve um total de 1.476 municípios engajados. Na dinâmica do PNMT, a Capacitação em Oficinas ocorria em três fases: 1르 Fase: Conscientização para a mobilização, sensibilização e conscientização da comunidade; $2^{\underline{a}}$ Fase: Capacitação para a orientação dos diversos segmentos da comunidade com vistas à constituição do Conselho Municipal do Turismo e do Fundo Municipal do Turismo; $3^{\mathrm{a}}$ Fase: Planejamento: capacitação dos Agentes Multiplicadores Nacionais, Estaduais e dos Monitores Municipais, como Facilitadores na Metodologia Simplificada de Elaboração da Estratégia Municipal de Desenvolvimento Sustentável do Turismo ${ }^{5}$.

Em 2003, o governo Luis Inácio Lula da Silva criou o Ministério de Turismo, que coordenou o lançamento do Plano Nacional de Turismo 2003/2007 (reorientado para 2007/2010) ${ }^{6}$ e a criação da Lei Geral do Turismo

\footnotetext{
${ }^{2}$ Lei no 8.181/91: Altera a denominação de Empresa Brasileira de Turismo (Embratur) para Embratur - Instituto Brasileiro de Turismo, e dá outras providências. Disponível em: <http://www.planalto.gov.br/ccivil_03/leis/L8181.htm >. Acesso em: 08 jan. 2014.

${ }^{3}$ Decreto no 448/92: Regulamenta dispositivos da Lei no 8.181, de 28 de março de 1991, dispõe sobre a Política Nacional de Turismo e dá outras providências. Disponível em: <http://www.jusbrasil.com.br/topicos/11900815/decreto-n-448-de-14-de-fevereiro-de-1992>. Acesso em: 08 jan. 2014.

${ }^{4}$ EMBRATUR. Brasília. Disponível em:

<http://www.embratur.gov.br/conheca/programas/pnmt.asp>. Acesso em: 23 dez. 2002

${ }^{5}$ EMBRATUR. Brasília. Disponível em:

<http://www.embratur.gov.br/conheca/programas/pnmt.asp>. Acesso em: 23 dez. 2002.

6 Este plano é o que ainda está em vigor no Ministério do Turismo. Disponível em: <http://www.Turismo.gov.br/Turismo/o_ministerio/plano_nacional/index.htm>l. Acesso em: 01 jun. 2013.
} 
(Lei 11.771 de 17/09/2008) dispondo sobre a Política Nacional do Turismo e definindo as atribuições do Governo Federal no planejamento, desenvolvimento e estímulo ao setor turístico, disciplinando a prestação de serviços turísticos, o cadastro, a classificação e a fiscalização dos prestadores destes serviços (CARVALHO, 2009, p. 65). Após a criação do Ministério do Turismo, a EMBRATUR foi reestruturada, tendo muitas de suas atribuições transferidas às novas secretarias e diretorias do Ministério do Turismo, restando-Ihe apenas a atribuição de fazer a promoção do Turismo brasileiro no exterior. Em 2008, esse Ministério ofereceu, por meio de ensino a distância via internet, o Curso de Regionalização do Turismo que atingiu um público seleto de pessoas interessadas em Turismo (3.000 alunos originados de 1.500 municípios em todo o Brasil $)^{7}$. Embora de excelente qualidade, elaborado e executado pela Universidade Federal de Santa Catarina (UFSC), não houve nesse programa um mecanismo definido para assegurar que esse contingente de alunos repassaria os conhecimentos adquiridos às respectivas comunidades. Houve, portanto, a iniciativa de capacitação de agentes sociais para o desenvolvimento e gerenciamento do Turismo, mas não houve garantias de que a rede de participantes formada pelo curso se comprometesse e/ou tivesse condições em termos de recursos humanos, físicos e financeiros de implementar os programas elaborados em suas respectivas áreas de atuação.

Em que pesem os esforços do governo federal, deve-se lembrar que o Brasil é um país rico em recursos naturais e culturais com grandes diversidades regionais e, portanto, a gestão centralizada do Turismo será sempre precária, sob o ponto de vista político-administrativo, pela dificuldade de articulação intragovernamental (dentro das três esferas de governo e entre suas respectivas secretarias e departamentos) e de gestão das relações do setor público com a iniciativa privada.

De acordo com Beni (2006, p. 21), a inconsistência da vinculação institucional (dos órgãos oficiais de Turismo nacional) foi reproduzida nos estados e municípios, evidenciando que "o setor de Turismo nunca esteve entre as prioridades das políticas públicas nos três níveis de governo", mas

\footnotetext{
${ }^{7}$ MINISTÉRIO DO TURISMO. Curso de Regionalização do Turismo. Programa de qualificação a distância para o desenvolvimento do Turismo. Teleconferências, 2008. 1 DVD.
} 
que, entretanto, tem servido frequentemente de "moeda de troca nas composições políticas da base de apoio do Legislativo ao Executivo". Em complementação, Beni (2006, p. 22) indica que esse quadro, na atualidade, contribui decisivamente para:

A descontinuidade de gestão; inexistência de diretrizes e macroindicações claras, objetivas e reproduzíveis em todos os níveis para os atores públicos e privados e comunidades, o que resulta na dificuldade de participação dos níveis regionais e locais, bem como de iniciativa privada e da sociedade civil nos processos de planejamento e desenvolvimento sustentável do Turismo.

Historicamente, apesar das iniciativas privadas e públicas (no âmbito das três esferas de governo), não há articulações satisfatórias no que tange à eficácia e à continuidade das iniciativas empreendidas para o desenvolvimento do Turismo na Região Metropolitana Vale do Paraíba e Litoral Norte. López (2000) fez uma pesquisa com 35 proprietários de estabelecimentos diferenciados de gastronomia e hotelaria, incluindo algumas autoridades do setor, e registrou:

Em nenhum dos níveis governamentais se observa esforços sérios, programados e continuados para o desenvolvimento do Turismo globalmente. Não existe planejamento estratégico concreto, não se especificam claramente os objetivos e não se dispõe, de orçamento medianamente significativo. Há casos em que se realizam opções promocionais, mas, quase na totalidade, isolados e pouco ou nada continuados. No Cone Leste Paulista ${ }^{8}$, apesar de algumas poucas ações do Governo do Estado de São Paulo, não se encontra planejamento nem diretriz global, tampouco meios financeiros necessários para alcançar o desenvolvimento que a região precisa. No âmbito municipal, começam a surgir, de forma tímida e incipiente, os Conselhos Municipais de Turismo, em muitos casos após forte pressão da iniciativa privada, na prática os quais são, em sua totalidade, demasiadamente burocratizados e pouco atuantes, além de desprovidos de recursos financeiros.

\footnotetext{
${ }^{8}$ Cone Leste Paulista foi a proposta para um nome que designasse de forma conjunta as cinco microrregiões localizadas entre São Paulo e Rio de Janeiro: Vale do Paraíba, Alto Paraíba, Litoral Norte, Serra da Mantiqueira e Vale Histórico, levantada no III Fórum de Desenvolvimento Turístico do Vale do Paraíba, promovido pelo SENAC, em Campos do Jordão, em 28/06/96. A expressão foi aceita e utilizada inclusive pela mídia regional, porém, Região Metropolitana Vale do Paraíba e Litoral Norte é o nome instituído pelo Governo do Estado a partir de 2012.
} 
Desta forma, identifica-se a descontinuidade histórica das iniciativas governamentais na organização do Turismo nacional, colaborando para o surgimento de impactos negativos à sociedade e ao meio ambiente nos municípios que têm o Turismo como uma das suas principais atividades econômicas. Como relata Fraga (2003, p. 7):

\begin{abstract}
A escassa integração das políticas públicas de Turismo com as demais políticas de governo, a insuficiência de recursos destinados aos órgãos públicos de administração do Turismo, assim como a falta de recursos públicos para obras de infraestrutura básica e para fiscalização das atividades turísticas, que somados à carência de dados para a construção de indicadores de sustentabilidade, são os que mais se destacam dentro do setor público. No setor privado, falta ainda maior engajamento e investimentos para uma gestão socioambiental responsável.
\end{abstract}

Além dos fatores citados por Fraga, a dificuldade na consolidação da atividade turística em um município está também nos conflitos de interesses políticos, comerciais e até mesmo pessoais que inibem a elaboração e implementação de planos de Turismo que se propõem a organizar o setor e capacitar seus atores sociais. Há uma relação direta entre os desejos desses atores e os resultados que são obtidos. São desejos originados nas crenças e valores ${ }^{9}$ dos envolvidos e, em geral, atrelados a ideologias de "redes prócrescimento", exemplificadas por Gottdiener (1997, p. 219) quando indica que "a ação do Estado em geral se realiza em conjunto com 'coalizões de crescimento', muitas vezes, composto de um grupo seleto de indivíduos que formam uma rede que perpassa os setores privado e público, de modo a tornar indistinguíveis os dois setores".

Um dos resultados negativos do cenário é a falta de um programa de educação para o Turismo que promova a conscientização dos brasileiros sobre os aspectos socioambientais do ponto de vista do Turismo Sustentável (importância da justiça social, da distribuição de renda, do respeito à cultura local e da conservação e preservação dos atrativos turísticos naturais e artificiais), além de incentivar e regulamentar cursos de gestão e de formação de mão de obra em Turismo para suprir o mercado de trabalho do segmento,

\footnotetext{
${ }^{9}$ Os valores são os princípios que norteiam nossa conduta, atitudes e comportamento e as crenças resultam de um conjunto de valores (INSTITUTO ECOSOCIAL, 2013 p. 12).
} 
tanto privado como público, com profissionais capacitados e conscientes da importância do seu papel no desenvolvimento do setor no país. Na prática do Turismo Sustentável, é enfatizado que as comunidades locais devem estar envolvidas em todas as etapas do desenvolvimento, não apenas no planejamento e principalmente devem ser protagonistas do processo, zelando para que não fiquem à margem mas, muito pelo contrário, sejam capazes de conduzi-lo de forma participativa e participante.

Segundo Gohn (2001, p. 27), a participação voltou a ser utilizada no sentido da participação da sociedade civil, na década de 1970, devido aos regimes político-militares vigentes em grande número de países latinos. Para participar, os indivíduos devem desenvolver autoestima e ter motivações assim como estarem articulados a redes societárias e desenvolverem interações frequentes e contínuas com seus pares (GOHN, 2001, p. 28).

O Estatuto da Cidade, Lei 10.257/2001, estabelece, em seu Artigo 2º, Inciso II, a "necessidade de gestão democrática por meio da participação da população e de associações representativas dos vários segmentos da comunidade na formulação, execução e acompanhamento de planos, programas e projetos de desenvolvimento urbano".

O planejamento participativo integra a sociedade, ou parte dela, na identificação de problemas e na elaboração de planificação de ações de intervenção socioambiental em territórios do município, incluindo questões como ordenamento do solo, saúde, educação, infraestrutura, Turismo etc. e a gestão das diretrizes estabelecidas. Considera-se que a educação da população para a prática do planejamento participativo contribuirá para a participação social porque possibilita abranger não somente a visão de planejadores técnicos, mas também as visões daqueles que vivem no município e que receberão diretamente as influências das intervenções propostas. Além do que, são eles que detêm o saber sobre o local em termos sociais, culturais, ambientais e políticos.

Portanto, assim como para o Turismo Sustentável, também é necessário o desenvolvimento de programas que propiciem o aprendizado para a participação social, promovendo a cultura do planejamento participativo, levando ao incremento da inclusão da população nos processos decisórios 
relativos ao destino do seu município, considerando-se que os resultados desses processos repercutirão de forma positiva para o próprio país.

A ideia de se alinhar não só a vontade política do governo, mas também a da iniciativa privada e da sociedade de um município turístico mediante um planejamento que envolva participação social em torno de um projeto coletivo, no caso o Turismo comprometido com a manutenção dos critérios de sustentabilidade, surge como uma possibilidade de se obter um compromisso ou, de forma mais otimista, um pacto social entre os atores sociais para a implementação do Turismo Sustentável no município. Desta forma, a prática do planejamento com participação social pode contribuir para que processos de desenvolvimento turístico tenham maiores chances de não sofrerem descontinuidade, mesmo com a mudança de governos ou desestímulo de lideranças locais.

Considerando tais fatos, observa-se que a educação para o Turismo Sustentável, assim como para a Participação Social, necessita de métodos socializadores dos conhecimentos nessas áreas que estimulem as comunidades locais a pensar e a agir de forma interativa e a se tornarem aptas a participar de planejamentos em seus municípios.

\subsection{Monteiro Lobato}

O município de Monteiro Lobato está localizado na Região Metropolitana do Vale do Paraíba e Litoral Norte (RMVPLN) do Estado de São Paulo, na microrregião da Serra da Mantiqueira, com uma população de 4.120 habitantes (IBGE, 2010). Em 26 de abril de 2013, completou 133 anos. Sua história está inserida no contexto valeparaibano como caminho de bandeirantes e de tropeiros e com sua participação nos ciclos econômicos do café e da pecuária leiteira. Em 1948, os moradores de Buquira homenagearam o escritor José Bento Monteiro Lobato que viveu parte da infância na Fazenda São José do Buquira (hoje conhecida como Sítio do Pica-pau Amarelo) e onde também residiu no período de 1911 a 1917 (BARRETO, 2012, p. 39;41).

$\mathrm{Na}$ busca do desenvolvimento socioeconômico do município, o exPrefeito José Cauby de Oliveira (1977 a 1983) viu no Turismo a possibilidade 
de viabilizar as finanças do município e a oportunidade de geração de renda e trabalho para a população. Segundo Barreto (2012, p. 89), o ex-Prefeito juntamente com um grupo de professores idealizaram um projeto para transformar o município em Estância Histórica e, através desse mecanismo, "obter recursos do governo estadual para investir na infraestrutura turística, gerando empregos e aumento no fluxo de visitantes". O projeto foi entregue ao governo estadual cumprindo todas as exigências. A cidade aguardava a visita de especialistas para a avaliação do projeto para posterior aprovação do Governador Paulo Maluf que, no entanto, negou todas as requisições dos municípios com menos de 10.000 habitantes (BARRETO, 2012, p. 90).

Além dessa decepção, o município sofreu um golpe em sua economia pois, nesse período, houve a construção da estrada de rodagem ligando Campos do Jordão à Rodovia Presidente Dutra, na cidade de Taubaté. A Rodovia Floriano Rodrigues Pinheiro (SP-123) foi inaugurada no ano de 1978, na administração do Governador Paulo Egydio Martins (1975 a 1979) ${ }^{10}$. O município de Monteiro Lobato, cortado pela Rodovia Monteiro Lobato (SP-50) que liga São José dos Campos a Campos do Jordão, estava estrategicamente localizado entre esses dois municípios e se beneficiava, na época, com a parada de carros e ônibus de linha e de Turismo, cujos passageiros movimentavam o comércio local, comprando queijos, doces caseiros, manteiga, flores, pinhão, frango, chapéus e toalhas, além do artesanato (BARRETO, 2012, p. 89).

Para a gestão seguinte, foi eleito o Prefeito João Bueno da Silva (1983 a 1988). Encontrando o município ainda com dificuldades financeiras, o prefeito criou e liderou um movimento para buscar recursos, formado por outros prefeitos da região, conhecido como a "Revolta dos Pequenos Municípios Paulistas contra a União". O grupo reivindicou e obteve do governo federal o aumento do repasse do Fundo de Participação dos Municípios (FPM), o que ajudou os municípios a equilibrarem suas contas (BARRETO, 2012, p. 93).

Seu sucessor, Carlos Maria Auricchio (1989-1992), assumiu a Prefeitura com as metas de desenvolver as atividades agrícolas, atrair indústrias e

\footnotetext{
10 Rodovia Floriano Rodrigues Pinheiro (SP-123). Disponível em: $<$ http://www.camposdojordaocultura.com.br/fotografias-semana_det2.asp?idfoto=1024>. Acesso em: 02 jun. 2013.
} 
fomentar o Turismo. Em seu projeto, vislumbrou a fruticultura e promoveu campanhas de conscientização para os produtores rurais com reuniões, palestras e visitas técnicas de especialistas. Os jornais da época noticiavam: "Monteiro Lobato vai virar pomar". Porém, meses após a campanha, o movimento não conseguiu competir com os campos destinados à criação de gado leiteiro que já ocupavam 27.500 hectares no município e o projeto foi esquecido. Entre suas realizações, constam a construção de 24 casas habitacionais e o Centro de Esportes e Lazer em 1992 (BARRETO, 2012, p. 94).

Vinte anos após a iniciativa do Prefeito Cauby de Oliveira, Henrique Martins Filho (1997 a 2000) também se comprometeu com o objetivo de transformar Monteiro Lobato em Estância Turística e incluiu o município no Programa Nacional de Municipalização do Turismo (PNMT) do governo federal. Cumpriu as orientações desse programa, recebendo, em 1996, o Selo de Município com Potencial Turístico e, em 1997, o Selo de Município Prioritário para o Desenvolvimento do Turismo, ambos outorgados pelo Ministério da Indústria, do Comércio e do Turismo e EMBRATUR. Na sequência, igualmente, o governo do Estado de São Paulo, por meio da Secretaria de Esportes e Turismo, outorgou o Selo de Município Prioritário para o Desenvolvimento do Turismo - Ano 1997/1998. O Prefeito Henrique Martins Filho, conhecido como Kike, acreditava no Turismo como uma das principais fontes de renda do município, bem como as parcerias com os governos estadual e federal que representariam a saída para a crise financeira do município na época. Os Deputados Estaduais Paulo Julião e Chico Bezerra foram os autores de dois projetos para Monteiro Lobato ser classificado como estância turística. Dentro desse esforço, criou-se o Conselho Municipal de Turismo de Monteiro Lobato (COMTUR-ML) através da Lei $n^{0} 1.090$, em 18 de novembro de 1997, e elaborou-se o inventário turístico do município de acordo com as orientações do Programa Nacional de Municipalização do Turismo (PNMT). Entretanto, novamente o município não conseguiu a almejada classificação de estância turística ${ }^{11}$. O Vice-Prefeito Sebastião Coelho de Andrade assumiu a Prefeitura, após o falecimento de João Bueno da Silva, em 03 de dezembro de 2006,

\footnotetext{
${ }^{11}$ Jornal O Minarete. Publicação bimestral do município de Monteiro Lobato. Ano 1, no. 1, agosto de 1997 e Inventário Turístico do município de Monteiro Lobato,1997.
} 
governando de 2006 a 2008. Em seu mandato, reestruturou a administração pública do município, transformando diretorias em secretarias, dando atenção às questões sociais e criando cursos profissionalizantes para a população como estímulo à economia local (BARRETO, 2012, p. 97). Em abril de 2007, criou a Secretaria de Meio Ambiente, Cultura e Turismo (SEMACTUR) ${ }^{12}$.

No governo do Prefeito Gabriel Vargas Moreira (2009 a 2012), iniciou-se um novo movimento pró-desenvolvimento do Turismo no município. Em maio de 2011, o pedido de apoio a este trabalho foi apresentado ao Prefeito e ao então Secretário de Cultura e Turismo, Eduardo Rocha Dellú. Já no primeiro encontro com a pesquisadora aceitaram a proposta, uma vez que o produto desse estudo, a elaboração do Plano Diretor de Turismo Sustentável de Monteiro Lobato com participação social, era do interesse da administração porque representava um instrumento para apoiar a busca pelo título de Estância Turística para o município. A Prefeitura e o Sindicato dos Hotéis, Restaurantes, Bares e Similares de São José dos Campos e Região (SINHORES) ofereceram apoio. Dessa forma, a elaboração do Plano Diretor de Turismo Sustentável de Monteiro Lobato foi viabilizada apoiando-se na participação do governo, do empresariado e da comunidade do município.

Daniela de Cássia Santos Brito, eleita Prefeita em 2012, tomou posse no dia $1^{\circ}$ de janeiro de 2013. Sua proposta de plano de governo, entre outras questões incluiu o Turismo Sustentável. A busca agora é para a classificação de Monteiro Lobato como Município de Interesse Turístico (MIT), uma nova categoria prevista pelo Projeto de Lei Complementar no 32 , de 2012, coordenado pela Frente Parlamentar pelo Desenvolvimento dos Municípios de Interesse Turístico (FREMITUR), composta pelos Deputados Estaduais João Caramez, Analice Fernandes, Beto Trícoli, Dilador Borges, Edmir Chedid, Gilson de Souza e Orlando Bolçone ${ }^{13}$. O Projeto de Lei Complementar № 32/2012 tem o objetivo de alterar a Lei no 10.426, de 8 de dezembro de 1971 que estabelece os requisitos para a criação de estâncias no Estado de São Paulo. Se aprovada, a nova lei manterá em 70 o número de estâncias turísticas e concederá 140 títulos de Municípios de Interesse Turístico (MIT) os quais

\footnotetext{
${ }^{12}$ Ata de reunião no Instituto Eco-Solidário em 18/09/2007 com Marcos Fernandes Costa, Roberto Aguiar, Roberto Simão e Daniela de Cássia Santos (cópia cedida por Roberto Aguiar).

${ }_{13}$ Informativo da Frente Parlamentar pelo Desenvolvimento do Municípios de Interesse Turístico (FREMITUR). Assembleia Legislativa do Estado de São Paulo, 2013.
} 
receberão uma verba anual do Governo do Estado para investir em infraestrutura turística ${ }^{14}$. Entre as exigências a serem cumpridas pelo município candidato a MIT estão a apresentação de cópia do Plano Diretor de Turismo e das seis últimas atas de reunião do Conselho Municipal de Turismo (COMTUR), criado por Lei Municipal.

O COMTUR de Monteiro Lobato tem sua lei de criação em vigor, mas seus trabalhos estiveram inativos desde 2002. Geminiano Jorge dos Santos, ex-Presidente do COMTUR-ML, relata que, no início, os membros eram motivados e organizaram festas. Uma delas, a da "Fogueira" em 2002, realizou-se com apoio da Dona Venina Moscoso que conta ter a festa atraído tanta gente que, na cidade, faltaram alimentos e bebidas no dia seguinte. Realizaram-se visitas técnicas com o objetivo de os empresários lobatenses conhecerem o trabalho das cidades turísticas e se motivassem a participar, com o apoio do SINHORES, de feiras para troca de experiências. Houve participação no projeto da criação da Agenda 21 para o município e as reuniões do COMTUR-ML aconteciam nos empreendimentos turísticos da cidade para que todos os conhecessem. No entanto, havia resistências por parte do prefeito à época, João Bueno da Silva, em relação ao Turismo. Somente, por muita insistência dos membros do COMTUR-ML, ele assinou o termo de adesão ao Circuito Mantiqueira ${ }^{15}$. A necessidade de reativar 0 COMTUR-ML foi identificada na primeira Oficina de planejamento em 15 de março de 2012 e reconfirmada na segunda Oficina de planejamento em 28 de fevereiro de 2013. Dando andamento às ações propostas nas duas Oficinas, o COMTUR-ML foi reativado por meio do Decreto Municipal № 1.358, de 17 de junho de 2013.

\subsection{Tese de doutorado}

O critério para definição do município, objeto desse estudo, foi o de ser de pequeno porte; com cerca de 10.000 habitantes e que tivesse a atividade

\footnotetext{
${ }^{14}$ Deputado João Caramez (Informação verbal). 4. Encontro Estadual dos Municípios de Interesse Turístico, Guararema, 08 de novembro de 2013.

${ }^{15}$ Geminiano Jorge dos Santos (informação verbal) em 06 de dezembro de 2013.
} 
turística inserida em sua economia. Na região do Cone Leste Paulista, identificaram-se os municípios de Silveiras e São José do Barreiro no Vale Histórico, e São Bento do Sapucaí e Monteiro Lobato na Serra da Mantiqueira. Após contatos com suas lideranças políticas e empresariais, ficou definido Monteiro Lobato em função da receptividade dada ao estudo, oferecendo o apoio logístico necessário para a realização do trabalho: sala, telefone, internet, impressora, datashow, sala para cursos e reuniões com a comunidade e carro com motorista para as visitas técnicas.

\subsection{Circunstâncias sociopolíticas em Monteiro Lobato}

A Pesquisa Perfil dos Municípios Brasileiros - Finanças Públicas - que analisou as receitas e despesas de todos os municípios brasileiros, de 1998 a 2000, realizada pelo Instituto Brasileiro de Geografia e Estatística (IBGE) e revelou que a maioria dos municípios brasileiros tem grande dependência das transferências de recursos, principalmente do Fundo de Participação dos Municípios (FPM), o Fundo de Manutenção e Desenvolvimento do Ensino Fundamental e de Valorização do Magistério (FUNDEF) e o Imposto sobre Circulação de Mercadorias e Serviços (ICMS). Juntos, eles totalizam cerca de $72 \%$ do total das transferências para os municípios. No caso dos municípios com até 5 mil habitantes, segundo a pesquisa, o FPM foi responsável por $57,3 \%$ das receitas disponíveis das Prefeituras, reduzindo-se o percentual na mesma proporção em que aumentava o porte populacional dos municípios, demonstrando ser ele o mais forte mecanismo de redistribuição a beneficiar tanto as regiões menos desenvolvidas, quanto os menores municípios brasileiros $^{16}$.

Monteiro Lobato, portanto, como tantos outros, é um município brasileiro com forte dependência dos repasses federal e estadual. Segundo a Secretaria de Finanças municipal, do total da receita municipal de $R \$ 12.314 .097,29$, em $2012,23,87 \%$ foram provenientes do repasse de tributos estaduais e $44,64 \%$

\footnotetext{
${ }^{16}$ Disponível em:

<http://www.ibge.gov.br/home/presidencia/noticias/26102004financasmunic.shtm>. Acesso em: 22 dez. 2013.
} 
do FPM, sendo a diferença composta por ICMS, IPTU e ISS. Para realizar atividades sociais e obras, a Prefeitura recorre a convênios com os governos federal e estadual e a verbas parlamentares, além de parcerias com entidades como SENAI, SEBRAE, SINHORES entre outras.

Em 2013, a Secretaria de Finanças coordenou a elaboração do Plano Plurianual (PPA), da Lei de Diretrizes Orçamentárias (LDO), da Lei Orçamentária Anual (LOA) e do planejamento orçamentário para o período de 2014 a 2017. Realizada de forma participativa com as demais secretarias, a Câmara de Vereadores e os munícipes, por meio de audiências públicas, essa atividade foi um fato inédito na história da administração pública do município e importante para a gestão da execução orçamentária, dentro dos rigores da Lei da Responsabilidade Fiscal (Lei Complementar $n^{\circ}$ 101, de 04 de maio de $2000)^{17}$.

O município faz parte do Consórcio Mantiqueira juntamente com Campos do Jordão, Santo Antonio do Pinhal, São Bento do Sapucaí e Tremembé que se propõem à prática de colaborações mútuas nas áreas de Saúde, Educação, Turismo etc., além do compartilhamento de máquinas e equipamentos. Mais que uma força política importante no cenário regional, o consórcio representa soluções ao alcance dos consorciados, apoiando-se no desempenho das respectivas gestões.

No campo do Turismo regional, o município faz parte do Circuito Mantiqueira articulado pelo SEBRAE-SP e pelas prefeituras dos sete municípios envolvidos: Piquete, Pindamonhangaba, Campos do Jordão, São Bento do Sapucaí, Santo Antonio do Pinhal, Monteiro Lobato e São Francisco Xavier (Distrito de São José dos Campos). Esses municípios participam de projetos conjuntos e de atividades de promoção do circuito em feiras e eventos. Por participar do Circuito Mantiqueira, Monteiro Lobato foi admitido no Programa Brasil Próximo/Programa Descentralizado de Cooperação BrasilItália do governo federal que prevê a instalação do Observatório sobre Turismo da Região da Mantiqueira, com sede em Santo Antonio do Pinhal, envolvendo 5 municípios paulistas: Campos do Jordão, São Bento do Sapucaí, Monteiro Lobato, Santo Antonio do Pinhal e São Francisco Xavier (Distrito de São José

\footnotetext{
${ }^{17}$ Disponível em: <http://www.planalto.gov.br/ccivil_03/leis/lcp/lcp101.htm>. Acesso em: 07 fev. 2014.
} 
dos Campos) e 10 mineiros: Sapucaí Mirim, Gonçalves, Brazópolis, Piranguçu, Piranguinho, Pedralva, Conceição das Pedras, Cristina, Carmo de Minas, São Lourenço. O Observatório sobre Turismo tem como finalidade auxiliar os municípios no que diz respeito ao desenvolvimento integrado do território da Mantiqueira. Em 20 de junho de 2013, a Prefeita assinou o termo de adesão à Associação de Desenvolvimento Integrado do Território Mantiqueira (ADITM). Se Monteiro Lobato conseguir o título de Município de Interesse Turístico instituído no Projeto de Lei Estadual 32/2012, em tramitação na Assembleia Legislativa do Estado de São Paulo, o município passará a receber uma verba anual para investimentos na infraestrutura turística e, assim, reforçará suas receitas. Além disso, se o município empreender um planejamento estratégico em relação ao desenvolvimento da economia local, o cenário pode tornar-se otimista pelas vantagens que Monteiro Lobato tem como: área territorial, localização estratégica, Rodovia SP-50 com manutenção recente, recursos naturais e culturais. Há, porém, a necessidade de um trabalho de fomento ao empreendedorismo, à capacitação dos empresários e funcionários, ao associativismo empresarial e à participação social.

\subsection{Economia do município de Monteiro Lobato}

De acordo com a Secretaria de Finanças, Monteiro Lobato tinha 02 indústrias, 60 lojas comerciais e 200 empresas prestadoras de serviços instaladas no município em 2012. Porém, por oferecer alíquotas menores para o ISS do que as cidades da região, o cadastro da Prefeitura registrou, naquele ano, 02 indústrias, 246 lojas comerciais e 773 empresas prestadoras de serviços. Esse mecanismo utilizado pelas empresas para recolherem menos impostos gera ISS para o município, mas não gera empregos e, portanto, renda.

Em relação à Participação dos Empregos Formais, em 2011, segundo o SEADE (2013), a área rural participava com $11,4 \%$, a indústria com $7,4 \%$, a construção civil com $4,5 \%$, o comércio com $34,5 \%$ e os serviços com $42,2 \%$.

O Levantamento Censitário das Unidades de Produção Agropecuária do Estado de São Paulo (LUPA, 2007-2008), realizado pelo Governo Estadual, 
indica 314 propriedades rurais com $26.162,8$ hectares. O maior número das propriedades (96) possui áreas entre 20 a 50 hectares. A maioria produz braquiária (254) e eucalipto (59), e as demais produzem banana, cana-deaçúcar, milho, café, mandioca, laranja, feijão etc. Em relação à criação de animais, há com destaque a bonivicultura de corte e de leite, a apicultura e a equinocultura. A área rural conta atualmente com duas associações, a Associação dos Pequenos Produtores Rurais de Monteiro Lobato e Região (APPR) e a Associação de Agroecologia de Monteiro Lobato e Região (AGROECO) que buscam melhores condições de produção e comercialização para seus associados. O comércio supre o município com alimentos, bebidas, roupas, produtos agropecuários, artesanato etc. Os produtos não encontrados são adquiridos, em geral, em São José dos Campos, pela proximidade e facilidade do transporte interurbano. Entre as empresas prestadoras de serviços estão 2 postos de combustível, borracheiro, mecânicos, lan house, correios, os bancos do Brasil e Bradesco etc. Em relação ao Turismo, o cenário é de otimismo porque a elaboração do Plano Diretor de Turismo Sustentável, realizado no período de 2012 a 2013 com participação social, pelo Grupo Planejatur, com apoio da Secretaria de Cultura e Turismo, colabora para a atividade ser desenvolvida de forma planejada. Além da importância do processo em si que envolveu a população e a elaboração do Programa de Ações para a atividade turística no município, o documento do plano e a reativação do COMTUR são os principais requisitos para Monteiro Lobato pleitear a classificação de Município de Interesse Turístico. 


\section{CONCEITUAÇÃO TEÓRICA}

\subsection{Turismo Sustentável}

Os estudos acadêmicos recentes sobre o Turismo, no Brasil, têm desmistificado velhos paradigmas criados por setores políticos estatais e por capitalistas no desenvolvimento dessa atividade tal como o de que oferece diversos benefícios à sociedade com destaque aos econômicos. De acordo com Ruschmann (2005, p. 13), não há Turismo sem impactos e estes assumem vários aspectos e escalas de espaço e de tempo, envolvendo o meio ambiente, a economia, a cultura e questões sociológicas e antropológicas que surgem mais cedo ou mais tarde. Cruz (2000, p. 21) acredita que as atividades turísticas são decorrentes da prática social e esse entendimento "contraria abordagens historicamente construídas, que reduzem a prática do Turismo a uma atividade econômica, e permite avançar no sentido de desmontar alguns dos mitos que rondam os estudos sobre Turismo, de modo geral". Segundo Costa (1997, p. 36), o Turismo se apropria e explora a natureza e as sociedades locais, sendo que esse tipo de Turismo predatório/extrativista, após exaurir os recursos e produtos turísticos, abandona a localidade em busca de outros destinos.

De acordo com Ruschmann (1997, p. 86), há a necessidade de planejamento e desenvolvimento do Turismo nos locais onde empresas turísticas estão se estabelecendo com sucesso, onde há um crescimento acelerado da demanda, originado pelo Turismo de Massa, onde o Turismo não se desenvolveu satisfatoriamente, apesar de disporem de recursos consideráveis e nos locais onde o desenvolvimento do Turismo concorre para a degradação ou erosão de sítios ou recursos únicos. O declínio de destinos turísticos, a par de outros possíveis motivos, ocorre devido ao não planejamento e monitoramento da atividade.

Por outro lado, constata-se que apenas o planejamento não garante uma implementação da atividade turística bem sucedida. É preciso planejá-la de forma sustentável em relação aos aspectos ecológicos, econômicos e 
socioculturais, com visão de futuro em relação à população residente e trabalhadora, aos visitantes e ao meio ambiente, como atesta a Organização Mundial do Turismo ao definir o Turismo Sustentável como aquele que:

\begin{abstract}
Atende às necessidades dos turistas de hoje e das regiões receptoras, ao mesmo tempo em que protege e amplia as oportunidades para o futuro. É visto como um condutor ao gerenciamento de todos os recursos, de tal forma que as necessidades econômicas, sociais e estéticas possam ser satisfeitas sem desprezar a manutenção da integridade cultural, dos processos ecológicos essenciais, da diversidade biológica e dos sistemas que garantem a vida.
\end{abstract}

Dentro desses parâmetros, a OMT (2003, p. 24) indica os princípios para o desenvolvimento do Turismo Sustentável:

a) os recursos naturais, históricos, culturais e outros voltados ao Turismo são conservados para que continuem a ser utilizados no futuro, sem deixar de trazer benefícios para a sociedade atual: segue os preceitos do desenvolvimento sustentável, sendo que em muitos casos o Turismo colabora para a conservação do ambiente natural e patrimônio histórico-cultural;

b) o desenvolvimento turístico é planejado e gerenciado de modo a não gerar sérios problemas ambientais ou socioculturais para a área turística: os planos diretores de Turismo desenvolvidos, incluindo técnicas como o planejamento ambiental e o estudo de capacidade de carga contribuem para a redução dos efeitos adversos causados pelo desenvolvimento turístico;

c) a qualidade ambiental geral da área turística é mantida e melhorada onde necessária: a qualidade ambiental do destino turístico é tão importante para os turistas quanto o é para os residentes;

d) um alto nível de satisfação dos turistas é mantido para que os destinos turísticos conservem seu valor de mercado e sua popularidade: a área turística deve investir periodicamente na sua conservação e revitalização de seus atrativos;

e) os benefícios do Turismo são amplamente estendidos à maior parcela possível de sua sociedade: os benefícios socioeconômicos advindos do Turismo devem envolver também a população local por meio de projetos turísticos que tenham 
por base a comunidade e que garantam a expansão dos benefícios do Turismo aos residentes locais.

Em consonância com a Agenda 21, adotada por 182 governos na Conferência da Terra, em 1992, a Organização Mundial do Turismo (OMT), o Conselho Mundial de Viagens e Turismo (WTTC) e o Conselho da Terra (Earth Council) elaboraram o relatório Agenda 21 para Viagens e Turismo: Rumo ao Desenvolvimento Ambiental Sustentável. O relatório define o papel do setor de Viagens e Turismo em relação à sustentabilidade turística e aos objetivos para áreas de prioridade de ação para administrações públicas e privadas do Turismo e para empresas turísticas (OMT, 2003, p. 25).

Para departamentos do governo, administrações nacionais de Turismo e as organizações comerciais representantes, o objetivo principal consiste em incorporar os preceitos do desenvolvimento sustentável nos processos de tomada de decisões e identificar as ações que conduzam ao mesmo, quais sejam:

a) avaliação da capacidade dos parâmetros reguladores, econômicos e voluntários existentes para a realização do Turismo Sustentável;

b) avaliação das implicações econômicas, sociais, culturais e ambientais das operações da organização;

c) treinamento, educação e conscientização pública;

d) planejamento para o desenvolvimento do Turismo Sustentável;

e) facilitação da troca de informações, habilidades e tecnologia relacionadas ao Turismo Sustentável entre países desenvolvidos e em desenvolvimento;

f) inclusão da participação de todos os setores da sociedade;

g) design de novos produtos turísticos com foco central na sustentabilidade;

h) mensuração do progresso na conquista do desenvolvimento sustentável;

i) parcerias pelo desenvolvimento sustentável (OMT, 2003, p. 145).

Para as empresas, a meta seria estabelecer sistemas e procedimentos para incorporar as questões do desenvolvimento sustentável como parte da função central de gerenciamento e identificar as ações necessárias para sua realização, tais como: 


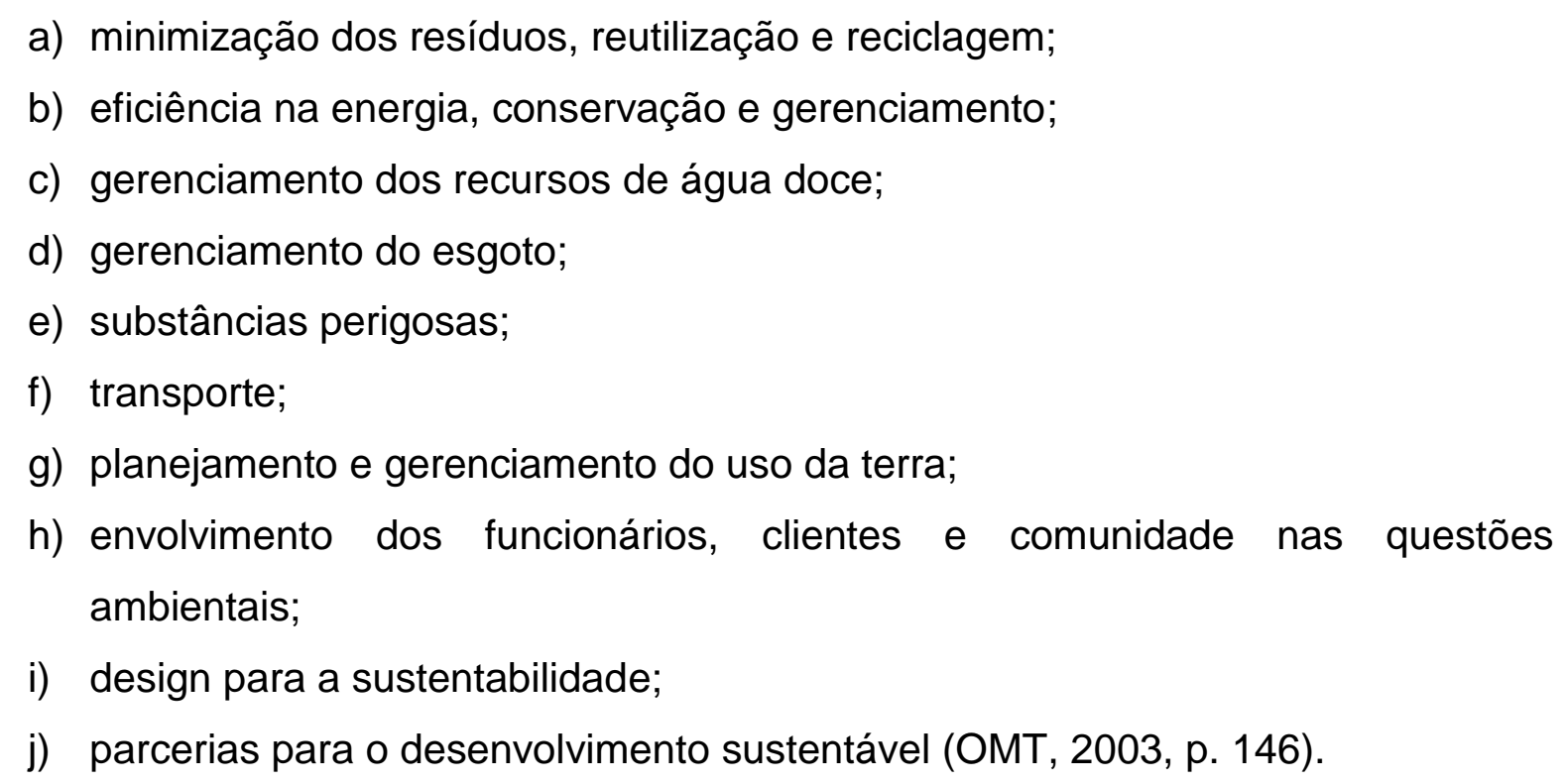

\subsection{Turismo Sustentável e a Produção Social do Espaço}

Sendo o Turismo um fenômeno social que se realiza por meio de uma prática social a qual invariavelmente é rebatida no território transformando-o em um lugar turístico (CORIOLANO, 1998; CRUZ, 2000), é pertinente que se compreenda a dinâmica das relações humanas e as suas formas de organização, de cujas decisões dependem o desenvolvimento local em seus aspectos político, econômico, cultural, social, espacial e ambiental. Necessário também se faz o entendimento de como a sociedade e o espaço interagem, resultando na expressão "produção social do espaço" que reflete a relação dialética entre essas duas instâncias no que se refere às influências que exercem uma na outra.

Para Santos (1985, p. 1;2), o espaço é uma instância da sociedade assim como as instâncias econômica, cultural-ideológica e político-institucional, existindo entre essas instâncias um processo de imbricação que resulta na transformação da configuração espacial. Santos (1985, p. 50) apresenta os conceitos de forma (conjunto de objetos geográficos, naturais e artificiais) e funções (processos sociais representativos de uma sociedade em um dado momento) que, por meio de seus inter-relacionamentos, geram um "produto", classificado pelo autor como "forma-conteúdo" (formas geográficas que contêm frações do social), caracterizando a produção social do espaço. Portanto, as 
ações sociais (funções) exercidas sobre a forma geográfica (lugar) modificam o espaço, por meio de uma interação dinâmica, cujos reflexos produzem e/ou modificam o espaço a cada dia em micro e/ou macro escalas, assim como o espaço modificado provoca mudanças na sociedade. Essa interação é bem visível nos municípios turísticos como, por exemplo, Campos do Jordão, que, por causa de seu clima, luminosidade e altitudes médias, no passado, foi comparado a Davos-Platz, dos Alpes Suíços (COSTA, 1969, p.18), e tem sido divulgado pela marca "identitária" de "Suíça brasileira".

O fenômeno da cenarização do lugar turístico "atende a parcelas importantes da demanda turística atual e tem reflexos significativos no processo de urbanização e na configuração da paisagem urbana" (SILVA, 2004, p. 22). Com a tematização de cidade europeia, Campos do Jordão emprestou estilos vernaculares da arquitetura do interior europeu como o chalé alpino (pequenos sobrados, com telhados muito inclinados) ou normando (com telhados complexos, mansardas e varandas) e fachadas com estrutura em madeira aparente (enxaimel) (SILVA, 2004, p. 66), remetendo a um Turismo étnico europeu que não é o seu caso porque o município não foi destino de imigrantes europeus no passado.

\subsection{Planejamento Turístico e Participação Social}

O planejamento é entendido por Buarque (1999, p. 72) como um processo ordenado e sistemático de decisão, conferindo ao planejamento uma conotação técnica e racional de formulação e de suporte para as escolhas da sociedade. A importância do planejamento está no bom senso, aliado à competência técnica, estabelecidos nas etapas de elaboração do plano (estudos preliminares, diagnóstico e prognóstico). As decisões tomadas hoje, por um grupo de indivíduos, obviamente terão implicações sociais e ambientais no futuro. Constata-se, no entanto, que, em geral, os planos diretores municipais ficam reduzidos à produção técnica de um relatório e dificilmente são implementados em sua totalidade.

Trazendo o foco para o Turismo, o planejamento do desenvolvimento turístico é definido por Ruschmann (1997, p. 84) como aquele que: 
Constitui o instrumento fundamental na determinação e seleção das prioridades para a evolução harmoniosa da atividade, determinando suas dimensões ideais, para que, a partir daí, possa-se estimular, regular ou restringir sua evolução.

Para Hall (2001, p. 29), o planejamento deve ser considerado um elemento crítico que garanta o desenvolvimento sustentável de longo prazo dos destinos turísticos. Segundo Murphy (1985 apud HALL, 2001, p. 29), "planejar tem a ver com prever e regular a mudança em um sistema e promover um crescimento ordenado a fim de aumentar os benefícios sociais, econômicos e ambientais do processo de desenvolvimento". Porém, a pesquisa de Turismo, a análise da política pública e o planejamento turístico não têm sido considerados prioritários, sendo que o setor e os governos em todos os níveis, mostram-se mais preocupados com a divulgação e os retornos de curto prazo do que com o investimento estratégico e a sustentabilidade (HALL, 2001, p. 41). Por outro lado, tem crescido a preocupação dos planejadores turísticos com os impactos sociais da atividade e, segundo Hall (2001, p. 53), como a passagem a seguir atesta:

Um exame dos impactos sociais do Turismo passou a ser
considerado essencial não apenas do ponto de vista ético da
necessidade do envolvimento da comunidade nos processos
de tomada de decisão, mas também porque sem ele o
crescimento e o desenvolvimento turístico podem tornar-se
cada vez mais difíceis.

Acredita-se, portanto, que com a participação da sociedade no processo de planejamento turístico haverá um enraizamento do conhecimento adquirido durante o desenvolvimento das atividades de planejamento e compromisso com as metas estabelecidas pelos moradores com base no que entendem e querem para o Turismo do município.

Gadotti (2014, p. 2;3) em seu artigo "Gestão Democrática da Educação com Participação Popular no Planejamento e na Organização da Educação Nacional", produzido como uma colaboração para a discussão do tema geral da Conferência Nacional de Educação (Conae 2014): "O PNE na articulação do Sistema Nacional de Educação: participação popular, cooperação federativa e regime de colaboração" afirma que, no Documento-Referência da Conae 2014, 
fala-se em "participação social e popular" sem maiores distinções entre os dois conceitos. Porém o autor apresenta a diferença que faz entre os dois termos:

No Instituto Paulo Freire costumamos chamar de Participação Social aquela que se dá nos espaços e mecanismos do controle social como nas conferências, conselhos, ouvidorias etc. São os espaços e formas de organização e atuação da Participação Social. É assim que ela é entendida como categoria e como conceito metodológico e político pelos gestores públicos que a promovem. Essa forma de atuação da sociedade civil organizada é fundamental para o controle, a fiscalização, o acompanhamento e a implementação das políticas públicas, bem como para o exercício do diálogo e de uma relação mais rotineira e orgânica entre os governos e a sociedade civil. [...] Por outro lado, a Participação Popular corresponde às formas mais independentes e autônomas de organização e de atuação política dos grupos das classes populares e trabalhadoras e que se constituem em movimentos sociais, associações de moradores, lutas sindicais etc. A Participação Popular corresponde a formas de luta mais direta, por meio de ocupações, marchas, lutas comunitárias etc. Embora dialogando e negociando pontualmente com os governos, em determinados momentos, essas formas de organização e mobilização não atuam dentro de programas públicos e nem se subordinam as suas regras e regulamentos.

Em adição, apresenta-se a conceituação de participação comunitária que fazem Almeida, Santos e Paiva (2012, p. 254):

A participação comunitária tem sido concebida como o esforço dos membros de um território e/ou que compartilham de determinadas características ou afinidades (orientação sexual, estilo de vida, religiosidade, por exemplo), para enfrentar seus próprios problemas enquanto um coletivo organizado. Desse modo, manifesta-se de diferentes formas: ao compartilhar informações, responsabilidades e decisões; na ação direta por meio de projetos; ao exercer pressão junto às organizações públicas e privadas para 0 atendimento de demandas específicas; no exercício de controle social do investimento público; no aumento da capacidade de auto-organização e de consciência para a ação política. Pesquisas e projetos sociais realizados por universidades, institutos e organismos internacionais que tem como referência os direitos humanos apontam a "participação", em especial a "participação comunitária", como imprescindível no enfrentamento dos problemas sociais e para subsidiar a formulação de políticas públicas no campo da saúde. 
Esses autores argumentam que 0 incremento da participação comunitária produz decisões coletivas em relação às atividades que serão implantadas nas comunidades pelas pesquisas, programas ou projetos, favorecendo, assim, sua continuidade e que, quando essas atividades são planejadas e executadas exclusivamente por agentes externos às comunidades, tendem, em geral, a durar pouco, uma vez que as pessoas da comunidade não consideram as atividades como suas.

No entendimento de Gohn (2001, p. 95), a participação de um representante nos conselhos gestores é "o processo mediante o qual as diferentes camadas sociais da população têm acesso aos espaços de definir e avaliar as políticas públicas, especialmente as de caráter social". Considerando os pontos de vista de Gadotti, Almeida, Santos e Paiva e Gohn e, embora outros autores também não façam distinção entre os termos "Participação Popular" e "Participação Social", empregando um pelo outro, opta-se pelo segundo termo para referência nesse estudo, considerando-o mais abrangente para representar a diversidade das ações envolvidas no movimento próTurismo Sustentável em Monteiro Lobato.

A Participação Social é uma ação complexa e um aspecto cultural que não está inserido no tecido social brasileiro, não é uma atitude comum do cotidiano do brasileiro. É preciso que os brasileiros a conheçam para aprenderem a exercê-la. Dessa forma, apoia-se nos estudos da Psicologia Socioambiental na busca da criação de um projeto coletivo a ser perseguido na construção compartilhada de futuro para o desenvolvimento do Turismo Sustentável em um município pela própria população. De acordo com Okamura et al. (2005, p. 274):

As estratégias participativas de planejamento constituem-se em ferramentas para a transformação da realidade social na direção do bem comum. Desse modo, deveriam ser utilizadas para fazer o diagnóstico da realidade social, levantar aspirações da população e também para ajudar a implementar soluções capazes de aproximar o ideal de bem comum da sua realização. [...] A Participação Popular é fundamental não só porque reduz a arbitrariedade envolvida na definição dos problemas que exigem solução nas formas de solucionar, mas porque indica um caminho na definição de bem comum que, de fato, dá voz às diferentes concepções de bem comum. 
Quando as pessoas estão sensíveis e organizadas em torno de um interesse coletivo, as ações alinhadas a esse interesse, propostas pelos diversos programas do Estado e de outras organizações, tornam-se mais eficientes, e as consequências são os benefícios mais facilmente distribuídos entre todos (BRASIL, 2008, p. 39).

Os instrumentos da Participação são: o referendo, o plebiscito e a iniciativa popular, três formas de manifestação da soberania popular de acordo com o Artigo 14 da Constituição Federal de 1988:

A soberania popular será exercida pelo sufrágio universal ${ }^{18} \mathrm{e}$ pelo voto direto e secreto, com valor igual para todos, e, nos termos da lei, mediante: I - plebiscito; II - referendo; III iniciativa popular.

Essas manifestações da vontade popular exprimem o desejo de complementar a democracia representativa com elementos de democracia semidireta segundo Garcia (2004, p. 4) que define esses três instrumentos: a) plebiscito: é uma consulta anterior à formalização do ato ou à conduta a ser adotada pelo Estado; b) referendo: consiste na consulta à população sobre emendamentos constitucionais ou até sanção de leis ordinárias, quando esta inferir sobre interesse público nacional e c) iniciativa popular: configura-se num direito do eleitorado de propor ao Poder Legislativo, projetos de lei, iniciando o processo legislativo, ao lado de outros agentes políticos como presidente da República, Tribunais Superiores, deputados e senadores.

Um argumento relevante a favor da participação é que, apesar dela não eliminar os erros nem ser uma garantia de acerto, pois uma coletividade bem pode, livre e soberanamente, tomar uma decisão injusta ou equivocada; no entanto, uma ampla participação pode contribuir para minimizar certas fontes de distorção (SOUZA, 2004, p. 333). Outro argumento é que, ao participar de uma decisão, o cidadão se sente mais responsável pelo seu resultado, o que faz a população cuidar e fiscalizar mais, por exemplo, do patrimônio público evitando sua depredação (SOUZA, 2004, p. 334).

De acordo com Gohn (2004, p. 24), os pressupostos gerais que sustentam suas afirmações sobre a participação são:

\footnotetext{
${ }^{18}$ Sufrágio universal: direito de voto a todos os cidadãos (FERREIRA, 1995, p. 615).
} 
a) Uma sociedade democrática só é possível via o caminho da participação dos indivíduos e grupos sociais organizados;

b) Não se muda a sociedade apenas com a participação no plano local, micro, mas é a partir do plano micro que se dá o processo de mudança e transformação na sociedade;

c) É no plano local, especialmente num dado território, que se concentram as energias e forças sociais da comunidade, constituindo o poder local daquela região; no local onde ocorrem as experiências, ele é a fonte do verdadeiro capital social $^{19}$, aquele que nasce e se alimenta da solidariedade como valor humano. O local gera capital social quando gera autoconfiança nos indivíduos de uma localidade, para que superem suas dificuldades. Gera, junto com a solidariedade, coesão social, forças emancipatórias, fontes para mudanças e transformação social;

d) É no território local que se localizam instituições importantes no cotidiano de vida da população, como as escolas, os postos de saúde etc. Mas o poder local de uma comunidade não existe a priori, tem que ser organizado, adensado em função de objetivos que respeitem as culturas e diversidades locais, que criem laços de pertencimento e identidade sociocultural e política. Existem, também, algumas premissas básicas relativas à participação da sociedade civil das quais se destaca a participação da sociedade civil na esfera pública - via conselhos e outras formas institucionalizadas - não é para substituir o Estado, mas para lutar para que este cumpra seu dever: propiciar educação, saúde e demais serviços sociais com QUALIDADE, e para todos. Essa participação deve ser ativa e considerar a experiência de cada cidadão que nela se insere e não tratá-los como corpos amorfos a serem enquadrados em estruturas prévias, num modelo pragmatista.

Para o município oferecer qualidade de vida aos seus moradores e visitantes é necessário que os munícipes tenham visão do todo, compreensão das partes, união e comprometimento na busca de soluções para seus problemas sociais, econômicos, ambientais e turísticos.

Magalhães (2002, p. 41;42) salienta que os efeitos divulgados como benéficos do Turismo Sustentável não podem ocorrer sem uma mudança de atitude por parte dos governos, da iniciativa privada e da população. Esclarece

19 Capital social refere-se à conexão entre indivíduos, redes sociais e às normas de reciprocidade e lealdade que nascem deles (PUTNAM, 1993 apud GOHN, 2004, p. 24). 
ainda que desejar implementar o desenvolvimento sustentável dentro da atividade turística sem antes promover um movimento de conscientização turística nas regiões abrangidas, deixando claro seus benefícios, seus prejuízos e a importância da participação comunitária, significa apresentar resultados negativos. Em complementação, a autora afirma que "valorizar a participação da população local no processo de tomada de decisão e no planejamento integral para o Turismo é, nos dias atuais, uma condição sine qua non para o desenvolvimento sustentável dessa atividade" (MAGALHÃES, 2002, p. 90). Portanto, a Participação Social ocorre em um cenário em que, logicamente, há democracia.

Complementando, nas palavras de Popper (apud ABBAGNANO, 2007, p. 278), "temos necessidade de liberdade para evitar os abusos de poder do Estado e também temos necessidade do Estado para evitar o abuso da liberdade, conscientes, aliás de que esse problema jamais será completamente resolvido".

Para Bobbio (1987 apud GARCIA, 2004, p. 3), a democracia direta engloba "todas as formas de participação no poder", com prevalência do agente popular sobre o político. Com base em Souza (2004, p. 322), citam-se alguns exemplos de democracia direta ocorrida no passado ainda que em curtos períodos de tempo na história da humanidade:

- Atenas, Grécia Antiga (510 a.C. a 322 a.C): os cidadãos que podiam decidir (demos) decidiam livremente sobre os fins da atividade política e da vida na cidade (pólis). Não participavam os escravos e os estrangeiros (metecos) e as mulheres (que tinham um status jurídicopolítico inferior aos homens). Não havia "políticos profissionais", uma vez que a atividade política, entendida como a discussão e deliberação em torno dos fins, era compreendida como direito e como ocupação de todos, e não como matéria para especialistas. Porém, a escolha dos meios mais adequados para a consecução de determinados fins podia ser delegada a um especialista.

- Revolução Russa: sovietes (conselhos de operários e soldados), mas que foram gradualmente esvaziados com o crescimento do poder centralizador do Partido Bolchevique, ainda no tempo de Lênin. 
- Algumas regiões da Espanha: organização autogestionária instaurada durante os anos da guerra civil sob inspiração anarquista.

- Europa: alguns conselhos de fábricas como parte das experiências de organização autônoma no seio do movimento operário.

$\mathrm{Na}$ democracia semidireta, repousa um sistema mais bem-sucedido, pois contempla equilíbrio pela operação, de um lado, da representação política e, de outro, da soberania popular direta (BOBBIO, 1987 apud GARCIA, 2004, p. 3). A democracia representativa, diversamente da democracia direta, assenta-se, como o próprio nome sugere, no princípio da representação legítima que, diferentemente da delegação, significa alienar poder decisório em favor de outrem (SOUZA, 2004, p. 325). Na realidade, contudo, mais do que presumir a não-viabilidade da participação popular direta, os defensores do sistema representativo costumam ir mais longe, argumentando que essa participação não seria desejável, sob os ângulos da eficácia e da eficiência, uma vez que, no Executivo, os técnicos seriam os únicos capazes de deliberarem racionalmente e com isenção a respeito da administração, o mesmo valendo, no Legislativo, para os políticos profissionais encarregados de discutir e votar as leis. Essa resistência à participação pública, explica Hall (2001, p. 56), ocorre porque:

Para muitos integrantes do governo, eleitos ou não, o controle da comunidade também pode ser interpretado como perda de seu poder e controle sobre o processo de planejamento. De fato, o grau de envolvimento público no planejamento turístico em quase todo o mundo pode ser mais bem descrito como uma forma de concessões simbólicas em que as decisões, ou, igualmente importante, a direção das decisões, já foram determinadas pelo governo. As comunidades, raramente têm a oportunidade de dizer não.

Também para Jara (1998, p. 174), dentro do pensamento liberal, a participação é reduzida ao envolvimento passivo do povo, havendo apenas a busca de adesão ou apoio às propostas emanadas pelas autoridades e limitando o envolvimento a meras consultas para legitimar a ação governamental, assim como para fins eleitorais e, nesse caso, há uma "pseudoparticipação". 
No processo participativo, a busca do consenso é sempre privilegiada, porém o dissenso é necessário para que os diversos pontos de vista sejam amplamente debatidos. De acordo com Buarque (2002, p. 89), a diversidade não pode ser tão grande que leve a uma desagregação da sociedade e à impossibilidade de diálogo e formação de um projeto coletivo. Por outro lado, a partir de certo ponto, a coesão da sociedade pode, ao contrário, diminuir o ambiente de inovação e aprendizagem (redução da capacidade de inovar) se o consenso se transformar em uma excessiva unidade de visão. Como exemplo, cita-se o texto extraído da publicação referente ao relatório do projeto "Participação Social, Associativismo e Desenvolvimento Local" realizado na Serra do Papagaio em Minas Gerais (FUNDAÇÃO MATUTU, Caderno 3, p. 31):

\begin{abstract}
A AMA Matutu se fortaleceu, em parceria com outras iniciativas locais que foram surgindo, como a Coopera Matutu (o entreposto comunitário de alimentos), a Fundação Matutu e a Associação Broto Brasilis. [...] Claro que, nessa década e meia de existência, houve desafios, conflitos e nem sempre todos estiveram de acordo em tudo. Mas estamos conseguindo manter o diálogo e vencer os obstáculos, criando acordos e priorizando os interesses coletivos; e, assim, a cada ano, afirmamos mais o propósito principal da AMA: preservar a excepcional qualidade de vida no vale do Matutu, para os moradores, os visitantes e as gerações futuras.
\end{abstract}

A participação da sociedade no processo de planejamento pode colaborar em mudanças positivas para o município, considerando que, de acordo com Buarque (2002, p. 89):

O planejamento participativo é o processo de tomada de decisões com o envolvimento dos atores sociais diretamente interessados e comprometidos com o futuro da localidade, vale dizer, com o ativo comprometimento da sociedade organizada com seus múltiplos interesses e visões de mundo. Trata-se de implementar e assegurar um processo de decisão compartilhada sobre as ações necessárias e adequadas ao desenvolvimento local, envolvendo, portanto, todos os segmentos da sociedade, desde a compreensão e o conhecimento da realidade até a definição e a implementação das ações prioritárias para o desenvolvimento. 
Para o planejamento participativo poder ser efetivado, é preciso, principalmente: dar $\mathrm{voz}$ às pessoas diretamente envolvidas na situação/problema na qual se pretende fazer a intervenção. Não importa que sejam as que sofrem as consequências da situação problemática ou as que dela tiram proveito; desenvolver um conhecimento da situação, com base nos saberes dos especialistas e das pessoas da comunidade detentoras do saber local; apresentar alternativas, indicar modos de agir e tomar decisões em conjunto e respeitar o princípio teórico do planejamento participativo, isto é, planejar "com" e não "para" a comunidade (BRASIL, 2008, p. 90). Segundo Okamura et al. (2005, p. 274), a Universidade deve estimular a investigação e o desenvolvimento de estratégias participativas de planejamento, uma vez que:

\begin{abstract}
A participação popular é condição fundamental para a construção do bem comum, ou seja, a tomada de decisão sobre o patrimônio material e não material da Terra. As estratégias participativas de planejamento constituem-se em ferramentas para a transformação da realidade social na direção do bem comum. Desse modo, deveriam ser utilizadas para fazer o diagnóstico da realidade social, levantar aspirações da população e também para ajudar a implementar soluções capazes de aproximar o ideal de bem comum da sua realização.
\end{abstract}

Porém, de acordo com Issa (2003, p. 12), tem-se insistido no planejamento participativo, mas, atualmente, a população é consultada sobre determinados programas de cuja formulação e concepção não teve ingerência. No planejamento participativo, a população deve dispor de informações, meios de comunicação e condições de influenciar a condução da máquina pública. Martins de Carvalho (1996 apud JARA, 1998, p. 178) argumenta que o planejamento local interativo (construído nas relações dialéticas entre governo local e sociedade civil organizada), como sistema, precisa incorporar os seguintes componentes: atores sociais da sociedade política, civil e da economia; instâncias e canais de participação, tanto em nível espacial (comunidades e bairros urbanos) como em nível setorial (educação, saúde, agricultura, infraestrutura e meio ambiente) e local-municipal (Conselhos Municipais); produtos concretos (planos, programas, políticas setoriais, diretrizes, decretos, estudos, relatórios setoriais e temáticos, compromissos e manifestos); e insumos que viabilizem as propostas de mudança (recursos 
financeiros, constituição de uma equipe técnica local, regras administrativas e jurídicas indispensáveis à gestão dos processos, da modernização institucional).

Nos estudos sobre a produção social do espaço, encontrou-se em Milton Santos (1985) e Mark Gottdiener (1997) o conceito de instâncias da sociedade - ou sistema de organização social - identificadas como forças econômicas, políticas e ideológico-culturais (Sistema EPI) que norteiam as decisões da sociedade de acordo com seus interesses. Entende-se que o processo de mudança nos paradigmas de desenvolvimento é lento e dependente desse sistema, muitas vezes conflitante, como pode ser exemplificado com Rattner (1979, p. 132):

Ademais, os sistemas sociais não têm necessidades, objetivos, requisitos ou motivações, mas indivíduos e os grupos sociais os têm! Não podemos tampouco, observar a "estrutura" social e ao observarmos seu "funcionamento" verificamos que nem todas as ações e atividades de seus membros são orientadas para a manutenção e sobrevivência do conjunto!

É preciso, não obstante, deixar de lado as utopias de situações ideais e buscar ações efetivas e úteis em torno de objetivos comuns da coletividade que garantam a qualidade de vida ${ }^{20}$ para as populações do presente, colaborando para que as do futuro tenham a mesma chance.

Isso ocorrerá mediante um planejamento estratégico feito a partir de dados sociais, econômicos e ambientais regularmente atualizados, de recursos humanos e de mecanismos técnicos disponíveis, aliado ao desenvolvimento sustentável com visão de longo prazo, abordagem sistêmica, tratamento multi e interdisciplinar, negociação política e, principalmente, Participação Social.

Além disso, é necessário capacitar a população para os processos participativos e as intervenções que the garantam a condição de cidadão corresponsável pelo destino de seu município.

\footnotetext{
${ }^{20}$ Para Rodrigues (apud MAGALHÃES, 2002, p. 33), deve-se diferenciar nível de vida e qualidade de vida: "o primeiro identifica-se com o 'ter' e é a relação do acesso da população ao consumo de determinados bens e serviços. O segundo diz respeito ao 'ser', que é um conceito de ordem qualitativa que implica uma série de subjetividades e especificidades dificilmente medidas de maneira objetiva".
} 


\subsection{Psicologia Socioambiental}

No estudo do planejamento participativo, considera-se importante conhecer as características e particularidades da sociedade sob o ponto de vista das Psicologias Social e Ambiental. Calegare (2010, p. 28) indica que "as raízes da Psicologia Social moderna, na esteira de Robert M. FARR (1998), são encontradas na interface com a Psicologia e a Sociologia. O autor complementa:

O desenvolvimento das 'Psicologias Sociais', acompanhando os debates das demais disciplinas das ciências humanas e sociais também ocorreu sob o crivo das discussões sobre objetividade/subjetividade, pesquisa quantitativa/qualitativa, experimentalismo/pesquisa aplicada, marcando diferenças nos fundamentos epistemológicos e estatuto ontológico de cada linha teórica. Até hoje, tais discussões ainda permeiam as abordagens em Psicologia Social utilizadas para trabalhos de investigação e intervenção, não havendo unidades entre elas.

Sobre a Psicologia Social aplicada, Pol (2002, p. 294) discute a Global (Environmental) Change com a intenção de reforçar que os impactos ambientais de atividades locais têm efeitos na globalidade do planeta. Ao discutir a globalização como plural e diversa, respondendo a dinâmicas e interesses diferentes, inclusive contraditórios, indica que há as globalizações econômica, populacional e informacional e, nesse contexto, defende:

Sin entrar ahora a valorar cada una de las globalizaciones por separado, desde una persperctiva psicosocial, todo lo que suponga uniformización de valores, hábitos, comportamientos, etc., es decir, pérdida de diversidad cultural, acaba comportando fuertes impactos sociales, necesidades de adaptación a nuevas situaciones que pueden ser traumáticas para algunas personas y, por tanto ámbitos de intervención para la psicología aplicada, sea individual o social. Una gestión ambiental orientada al desarrollo sostenibre requiere, pues, de una visión y una perspectiva de globalidad de las cuestiones sociales, econômicas, informacionales y ambientales, pero adaptada a las posibilidades y las características locales, tanto ecológicas como de vertebración social de la comunidad.

Entende-se, assim, a relevância da integração dos estudos das "Psicologias Sociais" nas micro e macro escalas dos contextos sociais e 
ambientais bem como nas dimensões espaciais e temporais. Portanto, a Psicologia Ambiental definida por Moser (2005a, p. 280) como "uma disciplina que trata do 'psicológico', quer dizer, do indivíduo enquanto ser que pensa, sente e age de um lado, e do ambiente, de outro lado" bem se aplica para a busca de soluções para problemas e problemáticas socioambientais. Segundo o autor (2005a, p. 286):

Na medida em que a Psicologia Ambiental é tanto uma disciplina acadêmica quanto uma abordagem de campo, ela necessariamente se confronta com diferentes culturas. Identificando o seu objeto como sendo o estudo das interrelações entre o indivíduo e seu ambiente físico e social nas suas dimensões espaciais e temporais, ela oferece os meios de apreender estas relações em contextos culturalmente diferentes e analisá-los enquanto tal.

Com relação ao objeto de estudo da Psicologia Ambiental, Wiesenfeld (2005, p. 54) apresenta os principais, segundo com os estudiosos pioneiros da disciplina:

- estudar a relação pessoa-ambiente no contexto natural, vista como totalidade (ontologia),

- abordar a dita relação de maneira holística (metodologia),

- incorporar diversas perspectivas teóricas em seu estudo (epistemologia),

- enfatizar a dimensão social da relação humano ambiental,

estabelecer vínculos com outras disciplinas interessadas na temática humano ambiental (interdisciplinaridade),

- aplicar os conhecimentos obtidos para melhorar a qualidade ambiental e, por conseguinte, a qualidade de vida dos usuários dos ambientes (pertinência social).

Salientando a complexidade desse universo de conhecimentos, expressa-se o seguinte pensamento: sendo a Psicologia usualmente definida como a ciência do comportamento humano enquanto que a Psicologia Social é o ramo dessa ciência que lida com a interação humana (GERGEN, 2008, p. 1) e apresentando a definição de Psicologia Ambiental dada por Mira, Stea e Elguea (2005, p. 250) como aquela que se refere ao estudo do comportamento humano relacionado ao ambiente, pode-se dizer que a Psicologia 
Socioambiental é a interação dessas disciplinas e que sua aplicação abrange a busca de soluções para as questões sociais e ambientais.

\title{
3.5 Pesquisa Participante
}

No trabalho de campo deste estudo, foi utilizada a técnica da pesquisa participante que figura dentre os tipos de pesquisas da Psicologia Social. Grossi (1977 apud DEMO, 1999, p. 126) define a pesquisa participante como:

\begin{abstract}
Um processo de pesquisa no qual a comunidade participa na análise da sua própria realidade, com vistas a promover uma transformação social em benefício dos participantes, que são oprimidos. Portanto, é uma atividade de pesquisa, educacional e orientada para a ação. Em certa medida, a tentativa da PP foi vista como uma abordagem que poderia resolver a tensão contínua entre o processo de geração do conhecimento e o uso deste conhecimento, entre o mundo "acadêmico" e o "irreal", entre intelectuais e trabalhadores, entre ciência e vida.
\end{abstract}

Embora Grossi mencione "participantes que são oprimidos", a pesquisa participante é uma técnica que não se orienta apenas para esse perfil de público uma vez que as características específicas da pesquisa participante, segundo Gianotten e Wit (1999, p. 159) "fazem dela uma ferramenta necessária para todos aqueles programas que buscam a participação nos setores populares na produção de novos conhecimentos (científicos) e em uma prática orientada a uma ação transformadora da sociedade".

As expressões "pesquisa participante" e "pesquisa-ação" são frequentemente dadas como sinônimas. Porém, Thiollent (1986, p. 7;74) as diferencia, quando afirma que a pesquisa-ação, além da participação, supõe uma forma de ação planejada de caráter social, educacional, técnico ou outro, que nem sempre se encontra em propostas de pesquisa participante e pelo fato da pesquisa-ação focalizar ações ou transformações específicas a exigir um direcionamento bastante explicitado. Schmidt (2006, p. 13) afirma que:

A pesquisa participante abriga um sem-número de discursos e práticas de pesquisa qualitativa em Ciências Humanas: matrizes e modelos de pesquisa reivindicam o termo que, 
historicamente, foi se desdobrando em tendências ou linhas teórico-metodológicas que, embora aparentadas, apresentam singularidades que as distinguem.

Thiollent (1999, p. 83) indica que a distinção clara é que a pesquisa-ação é uma forma de pesquisa participante, mas nem todas as pesquisas participantes são pesquisas-ação. Na pesquisa participante, identifica-se o caráter de autoria coletiva do resultado da pesquisa participante de acordo com Santos (2010, p. 73):

Neste tipo de pesquisa, os participantes deixam de ser objetos para serem pesquisadores, produtores de conhecimento sobre a própria realidade. Pesquisador acadêmico, parceiro do pesquisador comunitário, cada um tem um papel dentro da pesquisa: delineamento coletivo e participativo, democrático as respostas do que se vai investigar, como e para que se investigar são compartilhadas e respondidas coletivamente. Os temas da pesquisa ao invés de tratados como objetivo são temas geradores.

Em geral, a pesquisa participante integra projetos de envolvimento e mútuo compromisso de ações sociais de vocação popular, de acordo com Brandão (2005, p. 259;260) que indica alguns fundamentos e princípios relativos à pesquisa participante, dos quais se destacam:

a) o ponto de origem da pesquisa participante deve estar em uma perspectiva de uma realidade social, mas não se deve perder de vista outros aspectos que compõem essa vida social;

b) deve-se partir da realidade concreta da vida cotidiana dos próprios participantes do processo (individuais e coletivos) em suas dimensões e interações;

c) os processos e as estruturas, as organizações e os diferentes sujeitos sociais devem ser contextualizados em sua dimensão histórica;

d) a relação de sujeito-objeto entre investigador-educador e os grupos populares devem ser progressivamente convertida na relação sujeitosujeito;

e) deve-se buscar a unidade entre teoria e a prática e deve ser pensada como um momento dinâmico de um processo de ação social comunitária; 
f) as questões e os desafios surgidos ao longo de ações sociais definem a necessidade e o estilo de procedimentos de pesquisa participante;

g) a participação popular comunitária deve se dar, preferencialmente, através do processo de investigação-educação-ação, incorporando no processo agentes assessores e agentes populares;

h) o propósito de uma ação social de vocação popular é a autonomia de seus sujeitos na gestão do conhecimento e das ações sociais dele derivadas;

i) deve-se reconhecer e aprender a lidar com o caráter político e ideológico da atividade científica e pedagógica uma vez que não existe neutralidade em pesquisas e não se deve pré-ideologizar partidariamente os pressupostos da investigação e a aplicação dos resultados. O compromisso social, político e ideológico do investigador é com a comunidade e suas causas sociais;

j) a pesquisa participante é um momento de trabalhos de educação popular realizados junto com e a serviço das comunidades, grupos e movimentos sociais, em geral, populares.

De acordo com Schmidt (2006, p. 16), no caso das metodologias coletivas e a produção cooperativa que "quebram" as hierarquias burocráticas das instituições e as divisões por especialidades e da neutralidade e a objetividade ou não do pesquisador, a pesquisa participante:

É tomada como uma referência histórica que se radicaliza teórica e metodologicamente tanto no questionamento da participação do pesquisador quanto na implementação da participação de grupos institucionais e/ou comunidades populares no planejamento e condução de pesquisas que visam à ação transformadora de coletivos. Não há o rompimento com a designação pesquisa participante, mas, talvez, a necessidade de marcar uma posição crítica sobre suas origens por meio da adoção de novas terminologias, pesquisa-ação e pesquisa-intervenção, nas quais a questão do agir coletivo se torna essencial (grifo nosso).

A seguir, elabora-se uma breve introdução aos tipos de pesquisas: pesquisa participante, pesquisa-ação e pesquisa-intervenção, utilizadas no âmbito das Ciências Sociais. 


\subsection{Pesquisa-ação e Pesquisa-intervenção}

Thiollent (1986, p. 15) afirma que "toda pesquisa-ação é do tipo participativo: a participação das pessoas implicadas nos problemas investigados é absolutamente necessária" e, portanto, a pesquisa-ação exige uma estrutura de relação entre pesquisadores e pessoas da situação investigada que seja do tipo participativo. $O$ autor salienta que, na pesquisaação, "os pesquisadores desempenham um papel ativo no equacionamento dos problemas encontrados, no acompanhamento e na avaliação das ações desencadeadas em função dos problemas". Em complementação, acrescenta que a pesquisa-ação é uma orientação destinada ao estudo e à intervenção em situações reais operando, principalmente, como pesquisa aplicada em suas áreas prediletas, a saber: educação, comunicação social, organização, tecnologia (em particular no meio rural) e práticas políticas e sindicais (THIOLLENT, 1986, p.73;103).

Especificando a pesquisa-ação, Thiollent (1986, p. 26) a define como método (ou como estratégia de pesquisa) que contém diversos métodos ou técnicas particulares em cada fase ou operação do processo de investigação. Indica que a diferença entre técnica e método está no fato de que a técnica possui, em geral, um objetivo muito mais restrito do que o método. No caso da pesquisa-ação, os pesquisadores recorrem a métodos e técnicas para lidar com a dimensão coletiva e interativa da investigação bem como a técnicas de registro, processamento e de exposição de resultados. Em complementação, para Thiollent (1986, p. 14) a pesquisa-ação é:

\footnotetext{
Um tipo de pesquisa social com base empírica que é concebida e realizada em estreita associação com uma ação ou com a resolução de um problema coletivo e no qual os pesquisadores e os participantes representativos da situação ou do problema estão envolvidos de modo cooperativo ou participativo.
}

A pesquisa-intervenção é definida por Schmidt (2006, p. 16) como "uma proposta de atuação transformadora da realidade sociopolítica". Em Antropologia e em Psicologia Social, são colocados frente a frente 0 pesquisador e um "outro" que, de objeto de estudo e de intervenção, passa à 
condição de sujeito de um conhecimento e agente de uma transformação social favorecida pela prática da pesquisa participante (SCHMIDT, 2006, p. 16). Aqui, é oportuno fazer uma reflexão sobre a relação entre pesquisador e pesquisado quando o primeiro, ao fazer uma pesquisa-intervenção, pode influenciar com suas próprias crenças, valores, objetivos e ética, de forma consciente ou inconsciente, o grupo de indivíduos ou a comunidade com os quais trabalha. Oliveira (2004, p. 23) chama a atenção, no caso da Antropologia, para o caráter interventivo que a pesquisa antropológica pode assumir:

Se olharmos um pouco para trás, verificamos que há uma tendência em nossa disciplina em reconhecermos a participação ativa do antropólogo na realidade investigada como que realizando um tipo de "participação observante" uma expressão sobrevivente das atividades de "observadores atuantes", como são os assistentes sociais ou os educadores. Uma expressão, porém, que remete mais para o caráter de intervenção na realidade estudada do que para a questão ética que a envolve, já que uns e outros tendem a levar consigo procedimentos e objetivos previamente definidos e, sobretudo, legitimados na própria ética de suas respectivas profissões: certamente com seus próprios códigos de ética, nem sempre permeáveis à crítica daqueles que são alvo de sua ação.

Thiollent (1986, p. 22) acredita que, sem abandonar o espírito científico, pode-se conceber dispositivos de pesquisa social com base empírica nos quais, em vez de separação entre observador e observado, haja um tipo de coparticipação dos pesquisadores e das pessoas implicadas no problema investigado. Essas colocações remetem à importância do pesquisador ter clareza sobre seus objetivos e agir eticamente nas escolhas que faz para a condução da pesquisa, além de saber ouvir, respeitar o ponto de vista do outro, não julgar, compreender o outro em suas motivações e o indivíduo enquanto indivíduo. Ao mesmo tempo, compreendê-lo enquanto um indivíduo que faz parte de um coletivo, isto é, um indivíduo preenchido por motivações coletivas além das pessoais. Portanto, promovendo uma interação entre pesquisador e comunidade dentro de uma relação não de sujeito/objeto, mas de sujeito/sujeito (MATHEUS; MORAES; CAFFAGNI, 2005, p. 28). 


\subsection{Intervenção social}

De acordo com Lewin (1948, p. 218), "a pesquisa social se preocupa com dois tipos de problemas assaz diferentes, o estudo das leis gerais da vida grupal e o diagnóstico de uma situação específica". Complementando, o autor esclarece que os problemas de leis gerais tratam da relação entre condições possíveis e resultados possíveis e que, para agir corretamente, deve-se conhecer o caráter específico da situação em apreço e "esse caráter é determinado por uma averiguação científica de fatos denominada diagnóstico". Por outro lado, Lewin (1948, p. 219) alerta que "nas relações intergrupais, como nos outros campos da administração social, o diagnóstico tem que ser complementado por estudos experimentais comparativos da eficiência das diversas técnicas de mudança". O diagnóstico vai apontar a problemática e o conjunto de problemas que a compõem. Para o emprego da pesquisaintervenção como uma proposta de atuação transformadora da realidade sociopolítica (SCHMIDT, 2006, p. 16), depreende-se que a intervenção social é uma ação sociopolítica na proposição de soluções para uma problemática ou conjunto de problemas relacionados aos campos social e ambiental, apoiandose na intenção de operar mudanças nesses campos por meio de estratégias de ação sobre a realidade de membros de um território delimitado e/ou que compartilham de determinadas características ou afinidades (Almeida; Santos; Paiva, 2012, p. 254), sendo, pois, uma ação de fora para dentro, ou seja, promovida por agentes externos àquela realidade.

Como exemplo de intervenção social, relata-se o caso do município de Monteiro Lobato, SP, onde, no período de 1996 a 2005, ocorreram dois movimentos sociais que foram importantes pelo grau de envolvimento da população e pelos resultados obtidos em seus desdobramentos. Os movimentos são descritos em seguida para contextualizar a intervenção realizada no âmbito político pelo governo federal com o Programa Comunidade Ativa (PCA). Instituído em 1999, no governo Fernando Henrique Cardoso, o PCA objetivava implantar o projeto conhecido como Desenvolvimento Local Integrado e Sustentável (DLIS) em municípios com menos de 50 mil habitantes 
e Índice de Desenvolvimento Humano Municipal (IDH-M) inferior ao índice regional de 0,5 (LIMA, 2006, p. 75).

O primeiro movimento social tem o nome de Grupo Ambientalista Ribeirão dos Pássaros (GARP), uma entidade legalmente constituída em 1996 por um grupo de professores preocupados com a degradação ambiental no município e com a possível contaminação dos recursos hídricos. Foram focados os trabalhos em educação ambiental e reciclagem do lixo. O GARP promoveu concursos, oficinas, cursos de formação de agentes ambientais mirins e eventos, como a I Semana de Meio Ambiente, envolvendo as escolas do município. Participou do Núcleo Regional de Educação Ambiental da Serra da Mantiqueira e do Projeto Serra Viva do governo do Estado ${ }^{21}$.

O segundo movimento iniciou-se a partir da palestra do Prof. Roberto Simão sobre Desenvolvimento Sustentável e Agenda 21, em um evento comemorativo ao Dia Internacional do Meio Ambiente, em 05 de junho de 2000, promovido pelo GARP, em Monteiro Lobato. Cerca de 15 participantes, sensibilizados com a causa ambiental, decidiram formar um grupo de estudos que resultou na proposta de criação do Fórum Pró-Desenvolvimento Sustentável e Agenda 21 que, no entanto, não teve continuidade. Nesse período, o município foi inserido no Programa Comunidade Ativa do governo federal que visava a implantação do Fórum de Desenvolvimento Local Integrado e Sustentável (DLIS). Desse programa, foram criadas a Diretoria Municipal de Meio Ambiente e a Associação dos Pequenos Produtores Rurais de Monteiro Lobato e Região (APPR), além de plantar a semente para a criação da OSCIP Associação Sócio-Ambiental para a Sustentabilidade de Monteiro Lobato (ASAS). A maior contribuição do Fórum DLIS foi a elaboração participativa, a partir do diagnóstico, de um Plano de Desenvolvimento Local e sua reformatação em duas Agendas com ações objetivas - a Agenda Local, cumprida parcialmente, e a Agenda Negociada encaminhada para inclusão em Programas estatais/federais existentes e/ou nos orçamentos setoriais ${ }^{22}$.

O Programa Comunidade Ativa, criado no governo Fernando Henrique Cardoso, não teve continuidade devido à mudança no governo federal em

\footnotetext{
${ }^{21}$ Jornal Voz da Serra. Veículo Independente a serviço da comunicação humana. Monteiro Lobato. Ano I - n. 2, Nov./Dez. 2000 - Jan. 2001.

${ }_{22}$ AGUIAR, Roberto. Caso do Plano Diretor - Época do Prefeito João Bueno [mensagem pessoal]. Mensagem recebida por <pivott.cleide@gmail.com>em 21 jan. 2014.
} 
2003. A ASAS foi criada em 22 de julho de 2003 e buscou a realização de diversos projetos em parceria com o poder público local, as Sociedades Amigos dos Bairros do Souza e da Ponte Nova, associações locais, universidades de Taubaté (UNITAU) e do Vale do Paraíba (UNIVAP), o Instituto Nacional de Pesquisas Espaciais (INPE), incluindo a participação em editais como o Projeto Água e Vida da Petrobrás. Promoveu cursos e eventos nas áreas de cultura, Turismo, meio ambiente e desenvolvimento rural. A ASAS não foi encerrada juridicamente, mas cessou suas atividades.

Em adição, apresenta-se um segundo exemplo de intervenção social e política, relatado por Machado e Guimarães Netto (2007, p. 111) com relação à experiência do Projeto Cabuçu realizado no Bairro Cabuçu, Guarulhos, SP, localizado no entorno do Núcleo de mesmo nome do Parque Estadual da Cantareira. De acordo com os autores, o projeto surgiu em dezembro de 2002 com o envolvimento de alunos recém-formados das faculdades de Turismo da Universidade Paulista, Anhembi-Morumbi e Escola de Comunicação e Artes da Universidade de São Paulo, tendo como objetivos a "organização social e política mediante um série de ações de caráter socioambiental, de forma a criar uma 'cultura de participação' e de integração local" por meio da atividade turística. $\mathrm{Na}$ articulação com outras entidades, os atores sociais envolvidos descobriram que as estratégias que desenvolviam eram semelhantes às do Programa DLIS e, com apoio do Escritório Regional do SEBRAE-SP, em Guarulhos, incorporaram-nas ao Projeto Cabuçu. Como resultados dessa intervenção social, no período de 2003 a 2005, Machado e Guimarães Netto (2007, p. 119) apresentam: criação de uma cooperativa de trabalho composta por moradores, pesquisadores e professores, para trabalhar com desenvolvimento local, meio ambiente e Turismo; criação de uma ONG pelos moradores; 16 ações subdivididas em Cultura e Lazer, Informação e Educação e Geração de Trabalho e Renda entre outras. Os autores salientam que o Projeto passou a reconhecer-se como Projeto Cabuçu de Desenvolvimento Local e também como uma rede, a Rede Cabuçu, composta por relações entre pessoas, ideias e ações. 


\subsection{Planejamento do Turismo Sustentável}

O Planejamento do Turismo Sustentável busca intervir no processo de turisficação de um município ou região considerando o ordenamento e a planificação das atividades turísticas dentro dos critérios de sustentabilidade.

De acordo com Ruschmann (1997, p. 10), somente as ações planejadas com metodologia científica, visando um desenvolvimento "sustentável" da atividade turística, poderiam conduzir a uma evolução favorável para empreendedores, populações receptoras, turistas e, consequentemente, para todas as destinações.

O Turismo Sustentável segue os preceitos do desenvolvimento sustentável, cuja definição é dada no relatório "Nosso Futuro Comum" de 1987 da Comissão Mundial para o Ambiente e Desenvolvimento da Assembleia Geral das Nações Unidas: "desenvolvimento que satisfaz as necessidades da atualidade sem comprometer a capacidade das gerações futuras para satisfazer as suas" (OMT, 1998, p. 1). De acordo com Santos (1998, p. 173), o desenvolvimento sustentável é "uma forma de relacionamento homem/natureza e homem/sociedade em que não se busquem vantagens levando ao prejuízo de qualquer outra espécie atual ou futura".

Veiga (2010, p. 9) lembra que, na origem, a ideia expressa pelo adjetivo sustentável se referia à necessidade de que o processo socioeconômico conservasse suas bases naturais ou sua biocapacidade. Segundo Nascimento (2012, p. 2), a noção de sustentabilidade tem duas origens:

A primeira, na biologia, por meio da ecologia. Refere-se à capacidade de recuperação e reprodução dos ecossistemas (resiliência) em face de agressões antrópicas (uso abusivo dos recursos naturais, desflorestamento, fogo etc.) ou naturais (terremoto, tsunami, fogo etc.). A segunda, na economia, como adjetivo do desenvolvimento, em face da percepção crescente ao longo do século $X X$ de que o padrão de produção e consumo em expansão no mundo, sobretudo no último quarto desse século, não tem possibilidade de perdurar. Ergue-se, assim, a noção de sustentabilidade sobre a percepção da finitude dos recursos naturais e sua gradativa e perigosa depleção. 
Hoje, o desenvolvimento é um conceito abrangente diferente de crescimento econômico, um processo que ocorre quando há aumento da renda, mas necessariamente não implica em uma melhor distribuição dos benefícios dessa renda, em geral, concentrados nas mãos de uma minoria da população. Para Sachs (1997), o crescimento econômico ainda é considerado uma condição necessária, mas de forma alguma suficiente enquanto que:

O desenvolvimento inclui as dimensões ética, política, social, ecológica, econômica, cultural e territorial, todas elas sistematicamente inter-relacionadas e formando um todo. A natureza processual do desenvolvimento exige, além disso, que se leve em consideração sua sustentabilidade (perenidade) para satisfazer o postulado ético da solidariedade diacrônica com as futuras gerações, simétrico ao postulado da solidariedade sincrônica com a geração presente que, por sua vez, explica a primazia das considerações sociais na determinação dos objetivos de desenvolvimento (grifo do autor).

Segundo Beni (2003, p. 12), o "desenvolvimento sustentável é um conceito útil à medida que aponta para a necessidade de reflexões ao estabelecimento de uma visão da estrutura da organização da economia, da sociedade e de suas relações de troca com o meio ambiente". Entretanto, Milton Santos (apud TIBÚRCIO; BAVA, 2001) classifica os termos "qualidade de vida e desenvolvimento sustentado" como neoliberais, que matam qualquer discussão porque são usados nos discursos dos políticos que, na hora de implementá-los, não têm como fazê-lo, sendo termos vazios sem condições de serem estudados de forma substantiva. Por outro lado, Nascimento (2012, p. 6) defende que a consequência do esquecimento da dimensão da política é uma despolitização do desenvolvimento sustentável, sendo que a política é necessária no processo de mudanças. Buarque (2002, p. 27) acredita na importância da política quando afirma que o desenvolvimento local sustentável resulta da interação e sinergia entre qualidade de vida da população local redução da pobreza, geração de riqueza e distribuição de ativos - a eficiência econômica - com agregação de valor na cadeia produtiva - e a gestão pública eficiente.

No caso do Turismo Sustentável, existe um consenso mundial de que o mesmo tem de se firmar em quatro pilares, de acordo com Beni (2003, p. 14): 
1) Ambiental, principal fonte de matéria-prima dos atrativos;

2) social, e aí se entende em sua abrangência, a comunidade receptora, o patrimônio histórico-cultural e a interação com os visitantes, ao mesmo tempo em que eleva o padrão de vida e a autoestima dessa comunidade;

3) econômico, com todos os inter-relacionamentos e interdependências da cadeia produtiva, permitindo sua articulação com a identificação correta de suas unidades de produção e de negócios para estabelecer uma rede de empresas a fim de atuar de forma integrada, pró-ativa e interativa, obtendo níveis de comparatividade e produtividade para 0 alcance de competitividade;

4) político, que se instrumentaliza mediante estratégias de gestão que possibilitem coordenar as iniciativas locais na criação de um entorno emulativo de produção, favorecendo o desenvolvimento sustentável.

Em complementação, o autor indica que o Turismo Sustentável, em sua vasta e complexa abrangência, envolve: compreensão dos impactos turísticos, distribuição justa de custos e benefícios; geração de empregos locais diretos e indiretos; fomento de negócios lucrativos; injeção de capital com consequente diversificação da economia local; interação com todos os setores e segmentos da sociedade; desenvolvimento estratégico e logístico de modais de transporte; encorajamento ao uso produtivo de terras tidas como marginais (Turismo no espaço rural); subvenções para os custos de conservação ambiental. Importante ressaltar que deve haver consciência sobre os impactos do Turismo e que os benefícios devem ser para a localidade, assim como deve haver a conservação do seu meio ambiente.

Salienta-se, no entanto, o fato para o qual Lefebvre (apud GOTTDIENER, 1997, p. 129), chama a atenção indicando que, além do espaço de consumo (espaço como área de impacto para o consumo coletivo) há também o consumo do espaço (espaço como objeto de consumo) como acontece no segmento de Turismo no qual "o meio ambiente é consumido por meio da recreação ou pela relocalização dos negócios devido a atratividades naturais", ou seja, o próprio design espacial juntamente com a terra pode ser convertido em mercadoria. A aproximação do Turismo à produção social do espaço é colocada por Coriolano (1998, p. 21) quando afirma que o Turismo é, 
antes de tudo, uma experiência geográfica, considerando que o espaço sofrerá uma forte estruturação ou reestruturação em função dessa atividade:

Apresenta-se como fenômeno geográfico no sentido de representar uma relação direta entre o homem e os espaços, ou seja, o homem e o ambiente. É um indutor da organização espacial e da mobilização de fluxos populacionais. Por meio do Turismo, a natureza, o litoral, as cidades, os espaços geográficos transformam-se em lugares turísticos.

Beni (2003, p. 6) constata que o Turismo vem se firmando como ciência humana e social, mas que "seus efeitos econômicos são os que habitualmente mais se destacam, merecendo não só a atenção maior dos pesquisadores e empreendedores, como também maior e melhor tratamento estatístico" e salienta que:

O equilíbrio pretendido entre a atividade humana e o desenvolvimento e a proteção do ambiente exige uma repartição de responsabilidades equitativas e claramente definidas com relação ao consumo e ao comportamento face aos recursos naturais. Isto implica a integração de considerações ambientais na formulação e na implementação das políticas econômicas e setoriais, nas decisões das autoridades públicas, na operação e no desenvolvimento dos processos de produção e nos comportamentos e nas escolhas individuais (grifo nosso).

Em seu artigo "Turismo, Território e o Mito do Desenvolvimento", Cruz (2000, p. 26) apresenta os seguintes questionamentos:

O mito do desenvolvimento associado à prática do turismo apoia-se sobre confusões conceituais (desenvolvimento, desenvolvimento econômico, geração de riqueza, distribuição de renda...) e sobre, naturalmente, o discurso ideológico dos atores hegemônicos diretamente beneficiados com 0 desenvolvimento turístico dos lugares. 0 turismo gera riqueza? Sim. Mas o turismo distribui a riqueza gerada pelo setor? Isso dependerá da forma como está organizada a sociedade em que a prática do turismo está inserida. Não é atribuição do turismo resolver problemas de ordem econômica ou social dos lugares. Desenvolvimento não é sinônimo de desenvolvimento turístico. Fazer da prática do turismo um possível veículo da melhoria da qualidade de vida das sociedades deve ser um compromisso da chamada public choice ${ }^{5}$. Enquanto este compromisso não existir, não se poderá 
esperar do turismo mais do que ele é capaz de fazer (grifo nosso).

Nota de rodapé da autora: ${ }^{5}$ Expressão utilizada por Castro (1998), referindo-se à escolha da política pública.

Igualmente Issa (2002, p. 28) entende que "o turismo pode contribuir para a captação de impostos, gerar empregos - em muitos casos sazonais -, mas não detém o poder de resolver todos os problemas sociais e econômicos do lugar". Chama-se a atenção para essas citações porque remetem a características psicossociais que são consideradas neste estudo: a gestão do Turismo feita de acordo com os interesses e escolhas de pessoas e de grupos de pessoas. A atividade turística se concretiza enquanto fenômenos social e espacial, envolvendo, portanto, a sociedade e o modo como ela se apropria dos espaços. Assim, surgem inter-relações com outras áreas de conhecimento que apoiam seus estudos ao mesmo tempo em que é objeto de estudos dessas outras áreas. Segundo Theobald (2001 apud ISSA, 2002, p. 28), "o turismo foi definido (ou redefinido) de modos variados, por órgãos governamentais e acadêmicos, como uma área relacionada à economia, sociologia, antropologia cultural e geografia", de tal forma que:

Os economistas estão interessados nas contribuições do turismo para a economia e o desenvolvimento econômico da área de destino e estudam particularmente sua oferta e demanda, o câmbio e o balanço de pagamentos, o emprego e outros fatores monetários. Sociólogos e antropólogos culturais estudam o comportamento dos indivíduos e de grupos de pessoas nas viagens, e se interessam pelos costumes, hábitos, tradições e estilos de vida tanto das populações locais quanto de seus hóspedes. Os geógrafos cuidam dos aspectos espaciais do turismo e estudam fluxos das viagens e as locações, a dispersão do desenvolvimento, o uso da terra e as modificações do ambiente físico.

As técnicas de pesquisa em Psicologia Socioambiental tornam-se instrumentos de grande importância para estudiosos do Turismo, uma vez que é uma atividade circunscrita nas Ciências Humanas, desenvolvida por indivíduos ou grupo deles cujas escolhas podem impactar positiva ou negativamente o socioambiente de acordo com seus interesses econômicos, políticos e ideológicos. 
Em adição, os estudos das Ciências Biológicas que estudam os seres vivos e sua relação com o meio ambiente têm especial valor para o Turismo, uma vez que o meio ambiente constitui a "matéria-prima" da atividade (RUSCHMANN, 1997, p. 19). Porém, o Turismo pode tanto causar benefícios ao ambiente e à cultura do local visitado, quanto colaborar para a sua degradação. Para Ruschmann (1997, p. 24), "torna-se imprescindível estimular o desenvolvimento harmonioso e coordenado do Turismo; se não houver equilíbrio com o meio ambiente, a atividade turística comprometerá sua própria sobrevivência".

Considerando esses apontamentos, identifica-se que a gestão do Turismo Sustentável envolve a interdisciplinaridade que, em sentido geral, significa a relação entre as disciplinas (YARED, 2008, p. 161). Entretanto, a interdisciplinaridade ultrapassa as disciplinas, sua finalidade também permanece inscrita na pesquisa disciplinar, mas diz respeito à transferência de métodos de uma disciplina para outra (NICOLESCU, 1999, p. 45;46). Para Dencker (2002, p. 83), disciplina é uma categoria de conhecimento, enquanto interdisciplinaridade é uma categoria de ação e, portanto:

A interdisciplinaridade é uma atitude de superação e equilíbrio aplicada a contextos específicos e não destinada a generalizações. É uma nova forma de pensar a realidade, buscando a resposta mais adequada para cada situação e não estabelecendo normas de caráter absoluto. É um processo antes que um produto.

Moser (2005b, p. 136) indica que, do ponto de vista da Psicologia Ambiental, o funcionamento da interdisciplinaridade consiste em:

Uma abordagem múltipla e paralela de um mesmo objeto ou
problema. A abordagem implementada tem recorrido a
diferentes disciplinas que intervêm com sua lógica específica
para analisar o tópico. Cada disciplina proporciona uma
solução com referência a sua própria lógica científica. Mesmo
se as soluções possíveis forem específicas a uma disciplina, as
confrontações interdisciplinares no estágio final garantem a
pertinência ecológica da proposição.

A interdisciplinaridade, presente no desenvolvimento deste estudo, envolve as áreas de conhecimento sobre a Psicologia Socioambiental, a 
Participação Social e o Planejamento do Turismo Sustentável. Da Psicologia Socioambiental, foram utilizadas as técnicas relativas à pesquisa-intervenção que orientou a aproximação com a comunidade e apresentou a técnica da intervenção social como uma ação aplicada no social com a intenção de se implantar o modelo de Turismo Sustentável no município de Monteiro Lobato, intervindo em um provável desenvolvimento turístico sem planejamento que prejudicaria a comunidade e degradaria o meio ambiente se ocorresse de tal forma. A participação dos atores sociais é imprescindível para o planejamento do Turismo Sustentável e, nesse estudo, a participação deve ocorrer por meio do enraizamento no tecido social com o objetivo de que as pessoas que participaram desta pesquisa-intervenção tenham conhecimentos e vivências que Ihes ofereçam condições de darem continuidade ao processo de planificação do Turismo Sustentável local. Os conhecimentos foram compartilhados por meio dos cursos de Capacitação em Turismo Sustentável para a comunidade e de Turismo Sustentável \& Meio Ambiente em Monteiro Lobato para Professores da Rede Municipal de Ensino, do "aprender fazendo" quando da organização e realização das três Oficinas de planejamento turístico com a comunidade, do desenvolvimento das etapas de planejamento turístico (estudo preliminar - levantamento de dados socioculturais, econômicos e ambientais -, inventário turístico, diagnóstico e prognóstico e diretrizes, pesquisas qualitativas com moradores e turistas), da articulação para reativação do Conselho Municipal de Turismo (COMTUR-ML) e principalmente do trabalho em equipe para atingir um objetivo coletivo, no caso a elaboração do Plano Diretor do Turismo Sustentável para o município.

Assim, a Psicologia Socioambiental apoia a compreensão sobre como os grupos de pessoas agem, interagem e decidem em comunidade dentro das regras de convívio no seu processo histórico, permitindo compreender as relações socioculturais, as forças políticas, como as pessoas decidem sobre as questões coletivas, em especial, aquelas que envolvem a produção social do espaço em um município. A Participação Social apresenta-se como um instrumento fundamental para a gestão participativa e demonstra que basta "querer participar com vontade política dos políticos, vontade política da iniciativa privada e vontade política da comunidade", isto é, quando há a determinação de sair da intenção e ir para a ação para realizar o projeto 
coletivo definido por um coletivo de cidadãos que deseja o melhor para a sua cidade. O planejamento do Turismo Sustentável chama a atenção para a preservação e conservação do meio ambiente que é o seu principal insumo, para o respeito e à manutenção da cultura local que dá vida ao lugar e para o trabalho e a renda que dão condições para uma vida digna aos cidadãos. Salienta-se que, no seu desenvolvimento, o Turismo Sustentável conta com outras áreas do conhecimento para subsidiar seu trabalho. Desta forma, nesse estudo apresentam-se relações entre Psicologia Socioambiental, Participação Social e Planejamento do Turismo Sustentável que são interdependentes e colaboram para um olhar, sob um novo ângulo, na direção de um conhecimento sobre Sociedade, Espaço e Turismo. 


\section{METODOLOGIA}

A metodologia é entendida por Thiollent (1986, p. 25), como disciplina que se relaciona com a epistemologia (teoria do conhecimento) ou com a filosofia da ciência e seu "objetivo consiste em analisar as características dos vários métodos disponíveis, avaliar suas capacidades, potencialidades, limitações ou distorções e criticar os pressupostos ou as implicações de sua utilização".

Em geral, os termos metodologia, método e técnica de pesquisa são tomados como sinônimos, porém, segundo alguns autores, há diferenças entre os mesmos. De acordo com Abbagnano (2007, p. 781):

Com o nome de metodologia hoje é frequentemente indicado o conjunto de procedimentos técnicos de averiguação ou verificação à disposição de determinada disciplina ou grupo de disciplinas. Nesse sentido fala-se, por exemplo, de "Metodologia das ciências naturais" ou de "Metodologia historiográfica". Nesse aspecto, a Metodologia é elaborada no interior de uma disciplina científica ou de um grupo de disciplinas, e não tem outro objetivo além de garantir às disciplinas em questão o uso cada vez mais eficaz das técnicas de procedimento de que dispõem.

Segundo Thiollent (1986, p. 26), o papel da metodologia consiste também no controle detalhado de cada técnica auxiliar utilizada na pesquisa. Para Ruiz (1991, p. 138), "a rigor, reserva-se a palavra método para significar o traçado das etapas fundamentais da pesquisa, enquanto que a palavra técnica significa os diversos procedimentos ou a utilização de diversos recursos peculiares a cada objeto de pesquisa, dentro das diversas etapas do método". Díaz (2005, p. 142) salienta que "é evidente que os métodos (e técnicas) em ciência não são algo 'naturalmente dado', mas são criações ou instrumentos culturais construídos para certos propósitos - resolver perguntas e problemas em um momento determinado".

"A construção compartilhada de um plano de Turismo para Monteiro Lobato, SP: a sustentabilidade como horizonte" é o título dessa pesquisa de 
doutorado, cujo trabalho de campo foi desenvolvido, no período de junho de 2011 a dezembro de 2013. Contrariamente ao que se pensou no início da elaboração do projeto da tese em 2009 , este trabalho não aplica a pesquisaação porque o projeto inicial já identificava a problemática relacionada ao Turismo e já se propunha desenvolver um trabalho interdisciplinar envolvendo as áreas de conhecimento da Psicologia Social, Participação Social e Planejamento do Turismo Sustentável, com a comunidade de um município de pequeno porte no Brasil que tivesse a potencialidade turística. Na pesquisaação o pesquisador vai a campo sem um objetivo prático e somente após contato, conversas e discussões com a comunidade é que se levanta uma problemática e se define o problema a ser resolvido em conjunto com os atores sociais envolvidos da localidade. Para Souza (2010, p. 202), "a pesquisa-ação pode surgir de contatos e diálogos com a população, os quais podem denotar uma questão central para ela, tornando-se a população foco de interesse em torno da qual reflexões e ações passam a ser desenvolvidas". Por outro lado, na pesquisa-intervenção, o pesquisador vai a campo com uma ação intencionada, com um projeto de intervenção que também é um projeto de planejamento estratégico para solucionar um problema em função de uma problemática na área social. A pesquisa tem elementos de educação, segundo determinados valores. Tem, também, educação como uma pedagogia e não partiu de um problema levantado pela população. Partiu de uma leitura que se fez a respeito dos riscos de um município promover o Turismo no modelo tradicional (predatório, extrativista) em detrimento do Turismo Sustentável (apoiado em critérios de sustentabilidade). Dessa forma, conhecendo-se a área de Turismo e seus desdobramentos, foi elaborado e apresentado às lideranças governamentais e empresariais de Monteiro Lobato um projeto para elaboração do Plano Diretor do Turismo Sustentável, uma proposta de trabalho que foi ao encontro da busca política local de um mecanismo para colaborar na captação de recursos financeiros para o município que seria transformá-lo em estância turística e, assim, a aceitação da proposta pela prefeitura foi imediata. $O$ Planejamento do Turismo Sustentável passa a ser o contexto para o desenvolvimento dessa pesquisa-intervenção. Especificamente, da Psicologia Socioambiental, utilizou-se a técnica da intervenção social para provocar a mudança do entendimento da população sobre o Turismo, apresentando-lhe o 
Turismo Sustentável como uma alternativa ao modelo tradicional de Turismo que já se provou prejudicial em destinos como Porto Seguro e Campos do Jordão, onde o Turismo foi desenvolvido sem levar em consideração os critérios de sustentabilidade. A cultura da Participação Social, apesar de iniciativas no passado recente (Lei do Estatuto da Cidade, orçamento participativo, conselhos, fóruns etc.), é muito pouco praticada no Brasil. A inserção de estratégias participativas no Planejamento do Turismo Sustentável, promovendo o engajamento gradativo da população é uma ação educativa que incentiva a prática da Participação Social. Também para o Planejamento do Turismo Sustentável, a ação educativa do compartilhar o conhecimento com a comunidade sobre as técnicas de planejamento, implantação, gestão e (re)avaliação do Turismo Sustentável no município é o caminho para capacitála na gestão da implantação do Turismo Sustentável. As Figuras 1 e 2 ilustram o que foi anteriormente exposto:

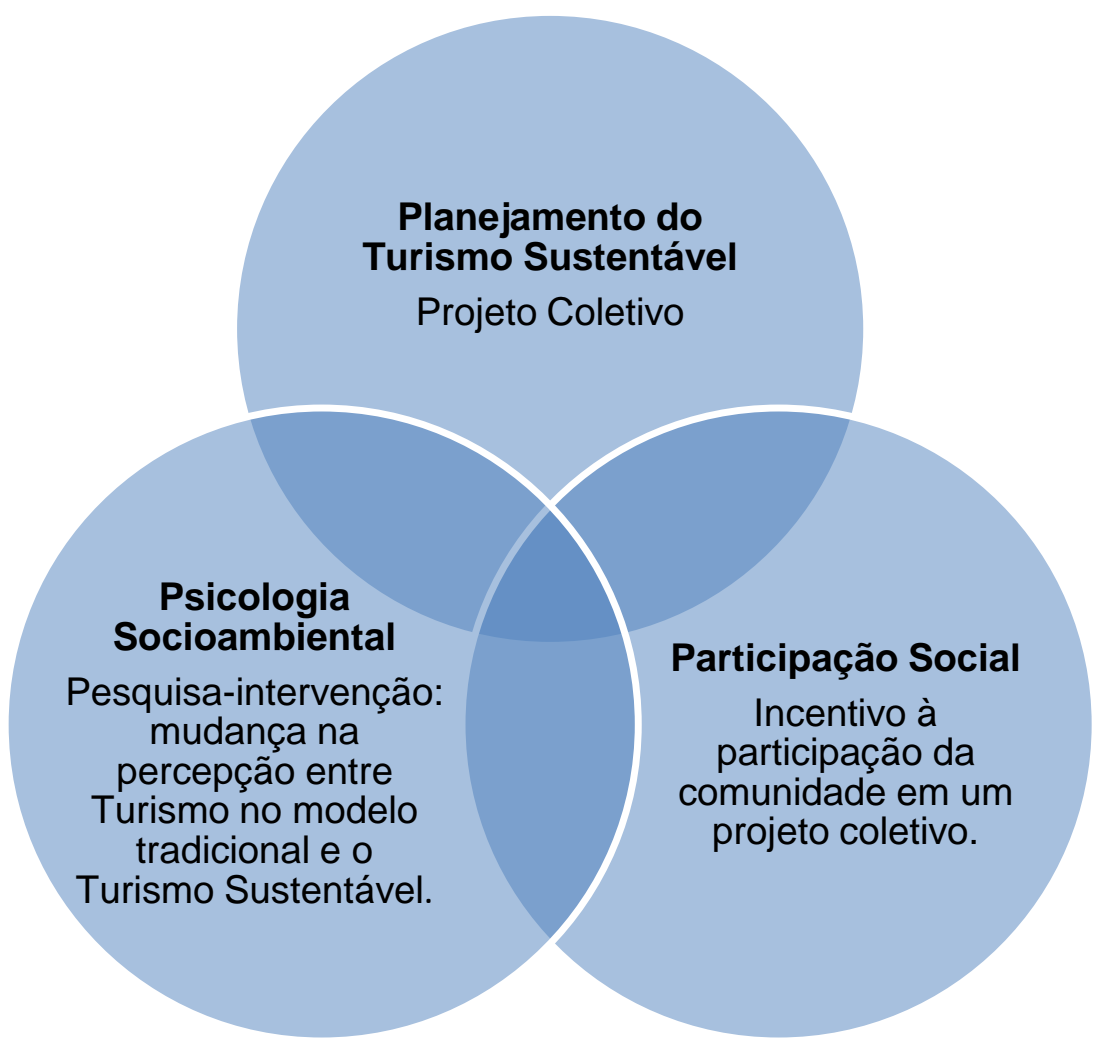

Figura 1: Entrelaçamento das áreas de conhecimento envolvidas nesse trabalho. 
O Planejamento do Turismo Sustentável é aquele que tem como objetivo trazer determinados benefícios socioeconômicos para a sociedade, sem deixar de manter a sustentabilidade do setor turístico através da proteção à natureza e à cultura local (OMT, 2003, p. 40).

A Psicologia Socioambiental é a interação das disciplinas Psicologia, Psicologia Social e Psicologia Ambiental cuja aplicação abrange a busca de soluções para as questões sociais e ambientais.

A Participação Social diz respeito ao envolvimento dos diversos atores sociais na vida social, econômica e política, mediante mecanismos e canais que permitam entrar e influir na esfera decisória, na qual se define a direção que vai tomar o processo de desenvolvimento (JARA, 1998, p. 174).

Portanto, esta pesquisa:

a) é um estudo de caso, caracterizado como estratégico porque definido pela pesquisadora que identificou a problemática e a delimitou mediante suas análises e estudos, apresentando-o ao município de Monteiro Lobato, SP;

b) utiliza a técnica da pesquisa-intervenção das Ciências Sociais;

c) compartilha o conhecimento sobre $\circ$ Planejamento do Turismo Sustentável com a comunidade em um processo de aprendizagem como forma de exercer a cidadania;

d) introduz a prática da Participação Social quando envolve uma parcela da população de um município que se torna um grupo multiplicador do conceito do Turismo Sustentável;

e) faz a relação da sociedade com o meio ambiente por meio da abordagem da Psicologia Socioambiental e da produção social do espaço, uma vez que o Turismo são fenômenos social e espacial (MAGALHÃES, 2002, p. 1) porque envolve a sociedade e o espaço os quais se influenciam mutuamente. 
A construção compartilhada de um plano de Turismo para Monteiro Lobato, SP: a sustentabilidade como horizonte.

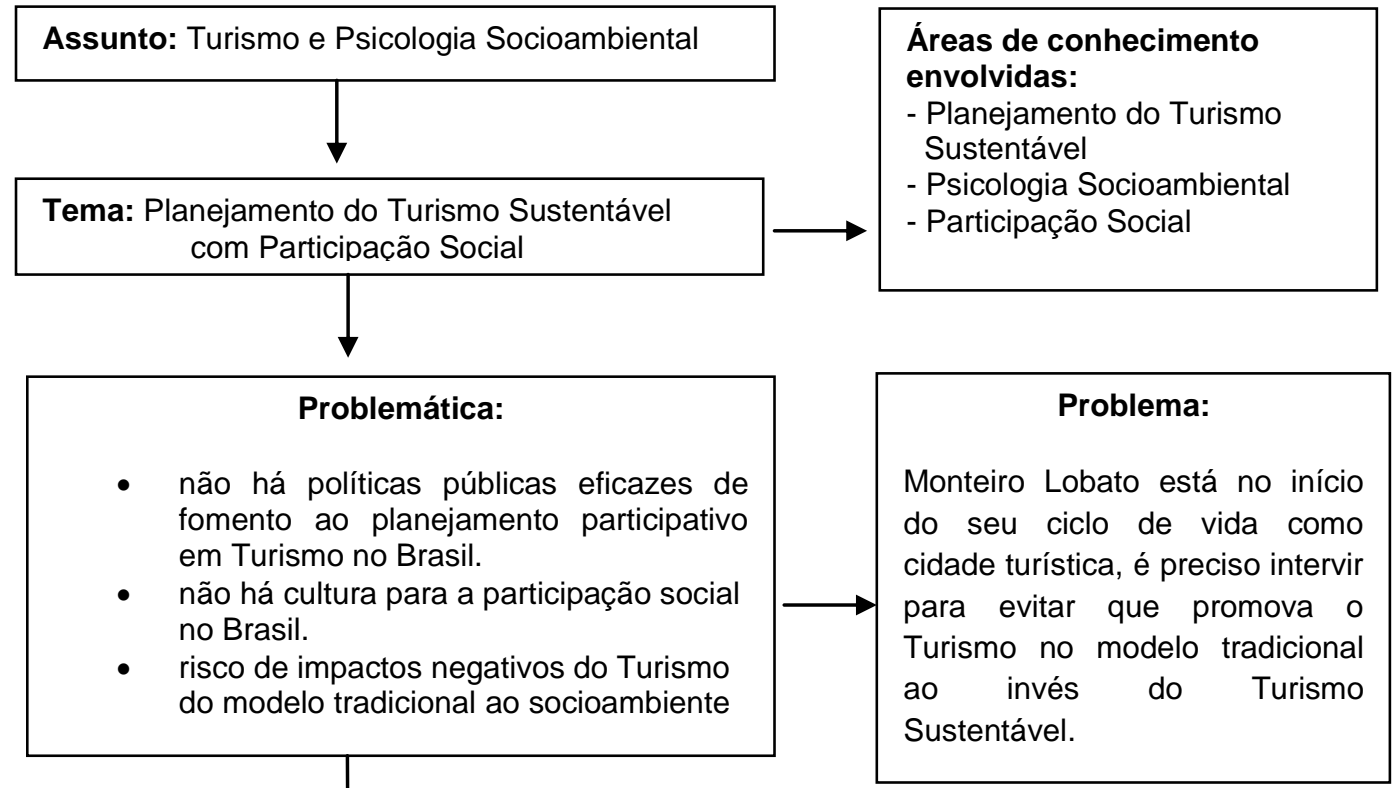

Objetivo geral: Promover o planejamento e a implementação de processos sociais atinentes ao desenvolvimento de atividades econômicas no setor de Turismo com base em critérios compartilhados de sustentabilidade (respeito à justiça social, aos valores culturais e à correção ecológica) e como forma de fundamentar, em um comprometimento coletivo, a manutenção da prática dessas atividades setoriais.

\begin{tabular}{|c|c|}
\hline $\begin{array}{l}\text { Objetivos Específicos: Turismo } \\
\text { Ação educativa } \\
\text { Planejamento do Turismo Sustentável } \\
\text { Resultados alcançados: } \\
\text { 1) curso de capacitação em } \\
\text { Turismo Sustentável para a comunidade } \\
\text { 2) elaboração Plano Diretor de Turismo } \\
\text { Sustentável com participação da } \\
\text { comunidade: } \\
\text { - Estudo preliminar (inventário turístico) } \\
\text { - Diagnóstico } \\
\text { - Prognóstico } \\
\text { Produto: Plano Diretor de Turismo } \\
\text { Sustentável de Monteiro Lobato }\end{array}$ & $\begin{array}{l}\text { Objetivos Específicos: Psicologia } \\
\text { Socioambiental e Participação Social } \\
\text { Intervenção Social } \\
\text { mudança na percepção da população } \\
\text { em relação ao Turismo tradicional x } \\
\text { Turismo Sustentável } \\
\text { Resultados alcançados: } \\
\text { Incentivo à Participação Social } \\
\text { formação do Grupo Planejatur } \\
\text { organização de oficinas de } \\
\text { planejamento em Turismo com a } \\
\text { comunidade } \\
\text { reativação do COMTUR } \\
\text { treinamento para professores da rede } \\
\text { municipal para o Turismo Sustentável }\end{array}$ \\
\hline \multicolumn{2}{|c|}{ Trabalho de campo - Pesquisa-Intervenção } \\
\hline $\begin{array}{l}\text { Redação do Relatório contendo o Plano } \\
\text { Diretor de Turismo Sustentável de Monteiro } \\
\text { Lobato }\end{array}$ & $\begin{array}{l}\text { Redação da tese contendo a descrição e a } \\
\text { análise da intervenção. }\end{array}$ \\
\hline
\end{tabular}

Figura 2: Fluxograma da pesquisa 
A pesquisa-intervenção colabora para a construção de um conhecimento sobre Sociedade, Espaço e Turismo vistos sob novos ângulos, o da Psicologia Socioambiental, da Participação Social e do Planejamento Turístico. Em seu desenvolvimento, essa pesquisa-intervenção envolveu: 1) Psicologia Socioambiental: questões relativas ao socioambiente de Monteiro Lobato quando aborda as características físicas do espaço, sociais, culturais e as formas de organização sociopolítica da comunidade; 2) Planejamento do Turismo Sustentável: a ação educativa para o Planejamento do Turismo Sustentável quando apresenta o Plano de Turismo Sustentável desenvolvido junto com o Grupo Planejatur; e 3) Participação Social: o envolvimento de munícipes no desenvolvimento do trabalho com vistas à criação de um grupo de habitantes que venha a se tornar um coletivo gestor do Turismo Sustentável: Secretaria de Cultura e Turismo, Grupo Planejatur e Conselho Municipal de Monteiro Lobato (COMTUR-ML).

O desenvolvimento do trabalho envolveu dois níveis de estratégias participativas de planejamento. O primeiro nível se refere à formação de um grupo que se tornasse multiplicador da ideia do planejamento do Turismo Sustentável com participação social e o segundo foi a chamada da população para participar das oficinas, reuniões e das pesquisas desenvolvidas pelo grupo multiplicador.

No início do trabalho de campo, em agosto de 2011, foi oferecido à comunidade o Curso de Capacitação em Turismo Sustentável como instrumento de sensibilização para o planejamento turístico. As pessoas só têm condições de debater um assunto após conhecer seus fundamentos e implicações. Por isso, o curso teve como objetivos gerais: apresentar e debater os fatores que compõem a atividade turística, em especial aqueles inerentes ao Turismo Sustentável, levando os participantes do curso ao entendimento das conceituações específicas, da dinâmica do setor e da importância do planejamento do Turismo Sustentável. A Carga Horária foi de 24 horas com 2 horas/aula semanais, no período de setembro a dezembro de 2011. O conteúdo programático (APÊNDICE A) incluiu: Turismo, Marketing Turístico, Turismo Sustentável, Participação Social, Planejamento turístico, Produção social do espaço, Como acontece a formação de cidades turísticas e $(R e)$ Conhecendo Monteiro Lobato. Para este último tópico, foi feito um 
levantamento de dados sociais, físico-geográficos, econômicos e das infraestruturas básica e turística do município. O objetivo foi oferecer aos participantes do curso uma visão geral sobre os aspectos socioambientais do município que, dificilmente, teriam de outra forma, considerando a falta de iniciativas nesse sentido, mesmo nas escolas locais (isso também foi identificado pelos participantes da Oficina de Turismo), a formação de cada um, os interesses, o acesso a informações, o cotidiano de cada participante do curso etc. As aulas foram conduzidas por meio de debates com textos-guia, mapas, imagens de satélite, fotografias e vídeos. Observou-se que poucos conheciam a história do município e do escritor Monteiro Lobato. O curso teve 20 inscritos e 14 concluintes $(70 \%)$ dos quais 10 aceitaram o convite para fazer parte da equipe que voluntariamente iria planejar o Turismo Sustentável do município juntamente com a pesquisadora. Dessa forma, em janeiro de 2012, surgiu o Grupo Planejatur (Grupo de Planejamento Participativo do Turismo Sustentável de Monteiro Lobato) que passou a se reunir a cada 15 dias por 2 horas. Aceitando o desafio de elaborar o Plano Diretor de Turismo Sustentável de Monteiro Lobato, o Grupo Planejatur tornou-se o núcleo irradiador dos conhecimentos compartilhados desenvolvendo as ações inerentes às etapas de planejamento turístico junto com a pesquisadora. As etapas do planejamento turístico são:

a) estudo preliminar cujo objetivo é levantar os dados sociais, econômicos, culturais, ambientais e turísticos do município, registrados em documento denominado inventário turístico. Os dados turísticos referem-se ao levantamento das informações sobre a oferta e a demanda turísticas. A oferta turística é composta pelos atrativos turísticos, empresas turísticas, infraestrutura de suporte e marketing turístico (BALANZÁ; NADAL, 2003, p. 75). A demanda turística é constituída pelas pessoas que se deslocam sozinhas ou em grupos do seu local de residência para um determinado destino por motivações de descanso, lazer, cultura, recreação, negócios etc.

b) a análise dos dados coletados e a elaboração de um diagnóstico (análise e avaliação da situação atual, identificando os pontos fortes e os fracos, as oportunidades e os riscos). Esta etapa consiste na 
"investigação, reflexão, compreensão e juízo dos dados da realidade a partir de um quadro normativo definido, com fins operativos com vistas à intervenção". (BARRETTO, 1998, p. 34);

c) o estabelecimento de um prognóstico a partir do qual são elaboradas diretrizes de ação que consistem em propostas para evitar os impactos negativos, otimizar os benefícios do Turismo e para propiciar o desenvolvimento sustentável da atividade turística. Ruschmann (2001, p. 72) complementa que o prognóstico deve vir acompanhado da definição de objetivos, metas e estratégias, assim como da avaliação e estudos que determinarão a viabilidade do plano elaborado.

O plano é o documento final onde são registrados os resultados do planejamento turístico, os programas referentes a cada um dos setores do plano e os projetos que abrangem o detalhamento de cada ação interventiva proposta dentro dos programas. Ruschmann (2001, p. 72), lembra que:

O processo de planejamento não tem seu término estabelecido pela redação e entrega do plano aos órgãos competentes. $\mathrm{O}$ trabalho vai além, uma vez que, como todo planejamento não é estático, necessitando de acompanhamento depois da implementação, a fim de se efetuarem possíveis correções ou ajustes, em virtude da dinâmica dos acontecimentos.

Para que a atividade turística se desenvolva em uma comunidade receptora é necessário que haja cooperação e integração de ações entre o governo, a iniciativa privada e a comunidade de tal forma que o visitante tenha uma infraestrutura turística que lhe permita encontrar o que busca, seja lazer, descanso, cultura etc. com tranquilidade e segurança. Ao governo cabe formular diretrizes que conduzam a atividade de forma sustentável, fomentar e fazer a promoção institucional do Turismo do município. A iniciativa privada deve garantir a prestação de serviços e produtos com qualidade, eticamente, praticando preços justos que mantenham o seu negócio, mas não explorem o turista. A comunidade, mais que ser envolvida, deve participar de todo 0 processo para entender a dinâmica do Turismo, ficar ciente dos impactos positivos e negativos e participar do planejamento turístico do município. Por 
último, esse tripé deve trabalhar junto para oferecer o acolhimento turístico, isto é, o reconhecimento, a hospitalidade e o amparo que uma cidade dedica a seus visitantes, através da receptividade de sua população, do planejamento e ordenamento de sua infraestrutura turística e da qualidade dos serviços prestados (YASOSHIMA, 2003, p. 84).

Neste trabalho, foram realizadas três Oficinas nas quais foram utilizadas as técnicas de planejamento participativo: Oficina de Planejamento de Projetos Orientado por Objetivos (Ziel Orientierte Projekt Planung - ZOPP), Oficina para definição do Programa de Ações com os atores sociais e a Oficina de Análise FOFA (Forças, Oportunidades, Fraquezas e Ameaças) ou SWOT (Strengths, Weaknesses, Opportunities, Threats). Os resultados dessas Oficinas são apresentados na Seção 6 Descrição do Trabalho de Campo.

\subsection{Técnica ZOPP}

De acordo com Buarque (2002, p. 123), a técnica ZOPP também é conhecida como Metaplan, como referência à empresa de consultoria que a desenvolveu para as instituições alemãs que difundiram o ZOPP no Brasil (GTZ e BMZ/DES). Segundo o Manual modelo CEFE da Deutsche Gesellschaft fur Technische Zusammenarbeit (GTZ) [1995], trata-se de um sistema aplicável e aberto que conduz durante o processo de planejamento a um consenso de diferentes opiniões e deve ser aplicado realisticamente. Compreende três elementos que se apoiam mutuamente: a) o método que serve de fio condutor ao trabalho no grupo de planejamento; b) o enfoque do trabalho em equipe que serve de quadro para o estudo de problemas multissetoriais e c) a visualização que ajuda a reter por escrito as contribuições dos participantes e a fixar os resultados (GTZ, 1995). Suas características são: procedimento gradual através de uma sequência de etapas sucessivas e interligadas de planejamento; permanente visualização e documentação de todas as etapas do planejamento e enfoque do trabalho em equipe. A técnica é aplicada em reuniões tipo oficinas com carga horária devidamente calculada de acordo com as tarefas a serem desempenhadas. Os materiais utilizados são painéis móveis, em geral, montados com placas de cortiça ou isopor para ficarem mais 
leves, podendo-se, como alternativa mais prática, afixar folhas de flip chart ou papel Kraft em paredes; fichas de cartolina coloridas cortadas no formato retangular; fita crepe e pincéis atômicos coloridos. O local ideal é amplo, arejado, iluminado, com cadeiras colocadas em forma de roda.

Quando o moderador da oficina coloca uma pergunta norteadora, os participantes, partindo da técnica de tempestade de ideias (brainstorming), lançam suas ideias nas fichas de cartolina. Recomenda-se aos participantes que escrevam no máximo quatro linhas por ficha com letra de forma para facilitar a leitura a uma certa distância, escrevam uma ideia por ficha porque facilita a estruturação de ideias, e que escrevam cada ideia de forma concisa e precisa para evitar mal-entendido (CROCOMO, 1998 apud KUMMER, 2007 p. 53). As fichas são afixadas no painel, à medida que são preenchidas. Juntamente com o moderador, os participantes as organizam por tópicos. Em seguida, são analisadas e reorganizadas se necessário. O quadro é deixado onde está ou em outro painel ou parede para ser visualizado por todos e fará parte do relatório. A visualização tem como vantagem facilitar a participação, criar um evento de atração comum, facilitar a estruturação das discussões, registrar todas as contribuições, possibilitar que, a qualquer momento, o estágio da discussão possa ser verificado e apoiar a apresentação dos resultados.

No início e na condução da oficina é frisado que o trabalho é feito "com" e não "para", porque todos os envolvidos participam do processo; que não há hierarquia entre pessoas e grupos e que ética, valores morais e profissionalismo são pressupostos para a eficácia da técnica; a criatividade é estimulada e todas as ideias são aceitas e analisadas; é evidenciada a dependência entre os participantes e o papel de cada um; e a discussão permite a melhoria da comunicação e estimula a transparência. $O$ objetivo desse acordo entre os participantes visa melhorar o processo de planejamento, permitir a cada um a visão do impacto de seu trabalho, aprender com os erros e agir com responsabilidade e autonomia.

Os resultados são: definição de objetivos (claros e realistas) de curto, médio e longo prazos, melhoria da comunicação e cooperação entre projeto, agente central e organização de parceiros através do planejamento conjunto e de clara documentação com definições igualmente claras; determinação da 
área de responsabilidade da equipe do projeto e instrumento de base à monitoração e avaliação. Essa técnica pode ser utilizada para diversos objetivos envolvendo o planejamento participativo nos setores de governo, empresarial e comunitário. As etapas descritas abaixo remetem ao modelo utilizado pela EMBRATUR nas oficinas de planejamento turístico organizadas no âmbito do Programa Nacional de Municipalização do Turismo (PNMT), nas duas gestões do ex-Presidente Fernando Henrique Cardoso. As atividades podem sofrer variações em função do assunto, da necessidade de respostas, do tempo etc.

A primeira Oficina foi realizada no dia 15 de março de 2012 com uma carga horária de 7 horas. No entanto, não tendo sido suficiente, o Grupo Planejatur completou as atividades pendentes durante suas reuniões quinzenais. A primeira atividade da técnica ZOPP na Oficina de planejamento turístico é a apresentação dos participantes, cujas informações são escritas nas fichas. Cada participante afixa a sua informação abaixo dos tópicos definidos pelo moderador previamente indicadas no painel com fichas coladas e se apresenta.

\begin{tabular}{|l|l|l|l|l|l|}
\hline NOME & FORMAÇÃO & INSTITUIÇÃO & CARGO/FUNÇÃO & $\begin{array}{l}\text { O QUE } \\
\text { ESPERA DO } \\
\text { TRABALHO }\end{array}$ & $\begin{array}{l}\text { UM } \\
\text { SONHO }\end{array}$ \\
\hline & & & & & \\
\hline & & & & & \\
\hline & & & & & \\
\hline & & & & & \\
\hline
\end{tabular}

Quadro 1 - Modelo de painel para apresentação dos participantes.

A segunda atividade é a análise de envolvimento, cujo objetivo é levantar informações sobre indivíduos, grupos e instituições relevantes para o planejamento. Permite o detalhamento das atividades e as responsabilidades que poderiam assumir para contribuir com o desenvolvimento turístico da localidade. 


\begin{tabular}{|l|l|l|}
\hline Instituições & Função que tem (o que faz) & $\begin{array}{l}\text { Potencial (o que poderia fazer para } \\
\text { colaborar) }\end{array}$ \\
\hline Municipais & & \\
\hline Regionais & & \\
\hline Estaduais & & \\
\hline Nacionais & & \\
\hline Internacionais & & \\
\hline Financeiras & & \\
\hline Empresas & & \\
\hline Ong's & & \\
\hline Outras & & \\
\hline
\end{tabular}

Quadro 2 - Modelo de painel para análise de envolvimento

A terceira atividade é a análise dos problemas que tem como objetivo identificar e delinear o problema central e os problemas correlatos em termos de causa e efeito. É a base para que seja desenvolvida uma hierarquia de objetivos com diversas alternativas de soluções. Visa a identificar os principais problemas e suas relações e organizá-los no formato de uma "árvore de problemas" que é um instrumento que permite a ordenação e hierarquização das causas e efeitos de um problema escolhido para dar início ao processo de planejamento (MINGUILLO, s. d.). A análise de problemas é um conjunto de técnicas para analisar uma situação existente à volta de um determinado problema, identificar problemas importantes nesse meio, definir o problema central da situação e visualizar num diagrama as relações de causa-efeito (hierarquia de problemas) (GTZ, 1995). A atividade tem a sequência de:

1. sessão de tempestade de ideias para que os participantes respondam a pergunta norteadora como, por exemplo, "Quais são os problemas que impedem o desenvolvimento turístico?";

2. as ideias são registradas em fichas e afixadas no painel com o título: “ÁRVORE DE PROBLEMAS” (que representa um cenário negativo);

3. é feita a análise de cada ideia e ordenação no painel, eliminando-se aquelas que se sobrepõem;

4. o critério é que as relações de causa e efeito sejam diretas e essenciais;

5. a visualização permite que, com o desenvolvimento do trabalho, seja possível voltar a esse painel sempre que o grupo sentir a necessidade. 
Passo a passo:

1. formular os problemas como condições negativas;

2. escrever um problema por ficha;

3. identificar os problemas existentes e não os que são possíveis, imaginados ou futuros;

4. um problema não é a ausência de uma solução, mas sim um estado negativo existente;

5. a importância de um problema não se mede pela sua posição na hierarquia;

6. formular o problema central (deve focar com exatidão o cerne da problemática);

7. formular as causas do problema central;

8. formular os efeitos causados pelo problema central;

9. desenhar um diagrama representando as relações de causa-efeito sob a forma de uma hierarquia de problemas;

10. examinar o diagrama no seu todo, verificando se as conexões estão corretas e se não foram omitidas nenhumas relações das causas principais ou dos seus efeitos. 


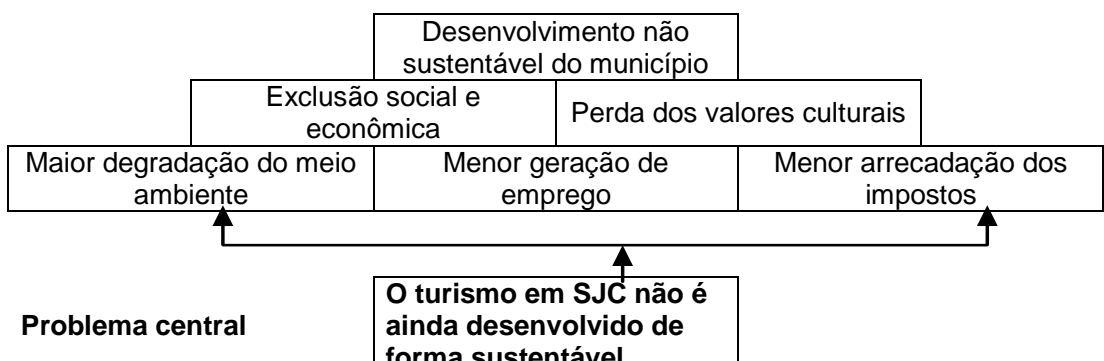

Causas

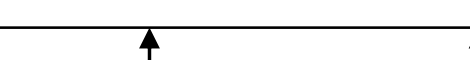

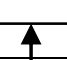

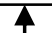

4

\begin{tabular}{|c|c|c|c|c|c|c|}
\hline $\begin{array}{c}\text { A gestão do turismo é } \\
\text { embrionária }\end{array}$ & $\begin{array}{l}\text { Baixo envolvimento da } \\
\text { comunidade }\end{array}$ & $\begin{array}{l}\text { Infraestrutura e serviços } \\
\text { básicos insuficientes }\end{array}$ & $\begin{array}{l}\text { Equipamentos e serviços } \\
\text { turísticos insuficientes }\end{array}$ & $\begin{array}{c}\text { Atrativos turísticos e } \\
\text { entretenimentos } \\
\text { deficientes }\end{array}$ & $\begin{array}{c}\text { Desarmonia na paisagem } \\
\text { local }\end{array}$ & $\begin{array}{c}\text { Promoção turística } \\
\text { precária }\end{array}$ \\
\hline $\begin{array}{l}\text { Inexistência de um plano } \\
\text { Diretor de Turismo }\end{array}$ & $\begin{array}{l}\text { Pouca atuação de } \\
\text { lideranças na comunidade }\end{array}$ & $\begin{array}{l}\text { Dificuldade de locomoção } \\
\text { e localização }\end{array}$ & $\begin{array}{l}\text { Dificuldades para } \\
\text { realização de grandes } \\
\text { exposições e convenções }\end{array}$ & $\begin{array}{l}\text { O patrimônio histórico e } \\
\text { museus não são } \\
\text { trabalhados como atrativo } \\
\text { turístico }\end{array}$ & $\begin{array}{l}\text { Crescimento desordenado } \\
\text { da cidade }\end{array}$ & $\begin{array}{l}\text { População desconhece o } \\
\text { próprio município e as suas } \\
\text { potencialidades turísticas }\end{array}$ \\
\hline $\begin{array}{l}\text { Políticas do Setor } \\
\text { desarticuladas } \\
\text { (não é participativa) }\end{array}$ & $\begin{array}{l}\text { Baixo interesse da } \\
\text { comunidade pelo turismo }\end{array}$ & Sinalização insuficiente & $\begin{array}{l}\text { № insuficiente de U.H. } \\
\text { (hotéis med/sup) e } \\
\text { ausência de } 5 \text { estrelas }\end{array}$ & $\begin{array}{l}\text { Falta entretenimentos para } \\
\text { os acompanhantes }\end{array}$ & $\begin{array}{c}\text { Conscientização/orien- } \\
\text { tação insuficientes com a } \\
\text { preservação da mata: } \\
\text { queimadas e cortes para } \\
\text { estradas }\end{array}$ & $\begin{array}{c}\text { A divulgação dos atrativos } \\
\text { turísticos se dá de forma } \\
\text { isolada }\end{array}$ \\
\hline $\begin{array}{l}\text { Insensibilidade dos } \\
\text { empresários do trade } \\
\text { turístico }\end{array}$ & $\begin{array}{c}\text { Não tem informação sobre } \\
\text { o turismo }\end{array}$ & $\begin{array}{c}\text { Coleta de lixo - poucas } \\
\text { lixeiras rurais } \\
\text { (SFX) }\end{array}$ & $\begin{array}{c}\text { Falta de placas de } \\
\text { informações turísticas no } \\
\text { município }\end{array}$ & $\begin{array}{l}\text { Ausência de infraestrutura } \\
\text { nos parques da cidade }\end{array}$ & $\begin{array}{c}\text { Conscientização e } \\
\text { orientação insuficientes } \\
\text { para cuidados com a } \\
\text { moradia }\end{array}$ & $\begin{array}{c}\text { O calendário de eventos } \\
\text { não é adequadamente } \\
\text { divulgada interna e } \\
\text { externamente }\end{array}$ \\
\hline $\begin{array}{l}\text { Ações isoladas do órgão } \\
\text { gestor (COMTUR) }\end{array}$ & $\begin{array}{c}\text { Não há educação para o } \\
\text { turismo (em todas as } \\
\text { escolas) }\end{array}$ & Falta de estacionamentos & $\begin{array}{c}\text { Não existe um serviço } \\
\text { organizado de apoio aos } \\
\text { turistas nac./estr. }\end{array}$ & $\begin{array}{l}\text { Atrativos e entretenimentos } \\
\text { pouco divulgados }\end{array}$ & $\begin{array}{l}\text { Favelas e loteamentos } \\
\text { clandestinos }\end{array}$ & $\begin{array}{c}\text { Material promocional } \\
\text { inadequado e insuficiente }\end{array}$ \\
\hline & $\begin{array}{l}\text { Não tem conscientização } \\
\text { da comunidade }\end{array}$ & $\begin{array}{l}\text { Energia elétrica deficiente } \\
\text { (SFX) }\end{array}$ & $\begin{array}{l}\text { Baixa qualificação de mão } \\
\text { de obra especializada }\end{array}$ & $\begin{array}{l}\text { Artesanato pouco } \\
\text { valorizado }\end{array}$ & $\begin{array}{l}\text { Ausência e má } \\
\text { conservação de calçadas }\end{array}$ & $\begin{array}{l}\text { O município não tem } \\
\text { produtos turísticos } \\
\text { formatados }\end{array}$ \\
\hline & & $\begin{array}{c}\text { Telefonia extremamente } \\
\text { deficiente (SFX) }\end{array}$ & & & Poluição visual & \\
\hline
\end{tabular}

Fossas sépticas

insuficientes (SFX)

Segurança ineficaz

Quadro 3 - Modelo de Árvore de Problemas

Fonte: Crocomo (2000) 
A quarta atividade é a construção da "Árvore de Objetivos" que consiste no estabelecimento da situação futura desejada, com a solução ou abrandamento dos problemas atuais, é um prognóstico positivo, sendo considerados os objetivos possíveis de serem alcançados. A construção do diagrama de objetivos (árvore dos objetivos) obedece a uma relação meio-fim, substituindo a relação causa-efeito da árvore dos problemas (MINGUILLO, s. d.). A partir do cenário negativo, os participantes são estimulados a elaborar um cenário positivo que resulta na "ÁRVORES DE OBJETIVOS". A análise de objetivos descreve a situação futura que será alcançada quando os problemas forem resolvidos e identifica possíveis alternativas para o projeto.

Passo a passo:

1) reformular todas as condições negativas da hierarquia de problemas, convertendo-as em condições positivas que sejam desejáveis e realisticamente alcançáveis;

2) examinar as relações meios-fins, verificando se as conexões estão corretas e se não foram omitidas nenhumas relações importantes;

3) Se necessário:

a) alterar as formulações;

b) acrescentar novos objetivos, se estes forem necessários para alcançar o objetivo formulado no nível imediatamente superior;

c) suprimir objetivos que não pareçam desejáveis ou necessários. 


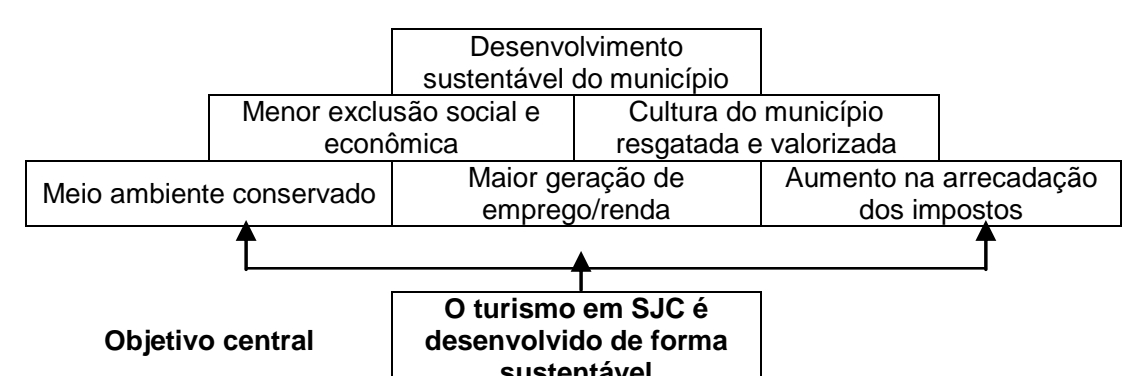

Fins

sustentável
suma

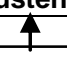

Meios

\begin{tabular}{|c|c|c|c|c|c|c|}
\hline 4 & 4 & 4 & 4 & 4 & 4 & 4 \\
\hline $\begin{array}{l}\text { A gestão do turismo } \\
\text { eficiente/ participativa }\end{array}$ & $\begin{array}{l}\text { Grande envolvimento da } \\
\text { comunidade }\end{array}$ & $\begin{array}{l}\text { Infraestrutura e serviços } \\
\text { básicos suficientes }\end{array}$ & $\begin{array}{l}\text { Equipamentos e serviços } \\
\text { turísticos suficientes }\end{array}$ & $\begin{array}{c}\text { Atrativos turísticos e } \\
\text { entretenimentos } \\
\text { eficientes }\end{array}$ & $\begin{array}{c}\text { Harmonia na paisagem } \\
\text { local }\end{array}$ & Boa promoção turística \\
\hline $\begin{array}{l}\text { Existência de um plano } \\
\text { Diretor de Turismo em } \\
\text { execução }\end{array}$ & $\begin{array}{l}\text { Lideranças da comunidade } \\
\text { envolvidas nas ações do } \\
\text { turismo }\end{array}$ & $\begin{array}{l}\text { Facilidade de locomoção } \\
\text { ao local desejado }\end{array}$ & $\begin{array}{l}\text { Facilidades para realização } \\
\text { de grandes exposições e } \\
\text { convenções }\end{array}$ & $\begin{array}{l}\text { O patrimônio histórico e } \\
\text { museus são atrativos } \\
\text { turísticos muito visitados }\end{array}$ & $\begin{array}{l}\text { Crescimento ordenado da } \\
\text { cidade }\end{array}$ & $\begin{array}{l}\text { A população conhece e } \\
\text { valoriza o potencial } \\
\text { turístico }\end{array}$ \\
\hline Política do Setor articulada & & $\begin{array}{l}\text { Aumento e adequação da } \\
\text { sinalização municipal }\end{array}$ & $\begin{array}{l}\text { № suficiente de U.H. } \\
\text { (hotéis med/sup) e } \\
\text { existência de } 5 \text { estrelas }\end{array}$ & $\begin{array}{l}\text { Os acompanhantes } \\
\text { dispõem de programação } \\
\text { específica }\end{array}$ & $\begin{array}{l}\text { População bem orientada } \\
\text { quanto ã preservação } \\
\text { ambiental }\end{array}$ & $\begin{array}{l}\text { Divulgação dos atrativos } \\
\text { turísticos de forma } \\
\text { coordenada }\end{array}$ \\
\hline $\begin{array}{l}\text { Empresários do trade } \\
\text { turístico parceiros na } \\
\text { aplicação das políticas }\end{array}$ & $\begin{array}{l}\text { Facilidade de acesso a } \\
\text { fartas informações } \\
\text { turísticas }\end{array}$ & $\begin{array}{l}\text { Melhoria na coleta de lixo } \\
\text { (SFX) }\end{array}$ & $\begin{array}{l}\text { Criação de placas de } \\
\text { informações turísticas no } \\
\text { município alocadas } \\
\text { adequadamente }\end{array}$ & $\begin{array}{l}\text { Os parques da cidade } \\
\text { estão dotados de uma boa } \\
\text { infraestrutura para } \\
\text { visitantes }\end{array}$ & $\begin{array}{l}\text { Moradias e fachadas bem } \\
\text { conservadas }\end{array}$ & $\begin{array}{l}\text { O calendário de eventos é } \\
\text { adequadamente divulgado } \\
\text { interna e externamente }\end{array}$ \\
\hline \multirow[t]{5}{*}{$\begin{array}{l}\text { COMTUR atuando de } \\
\text { forma integrada com o } \\
\text { trade turístico, comunidade } \\
\text { e poder público }\end{array}$} & $\begin{array}{l}\text { Educação para o turismo } \\
\text { como um tema transversal } \\
\text { nas escolas }\end{array}$ & $\begin{array}{l}\text { Ampliação do № de vagas } \\
\text { p/ estacionamento do } \\
\text { município }\end{array}$ & $\begin{array}{l}\text { Serviço de apoio aos } \\
\text { turistas nac./estr. } \\
\text { organizado }\end{array}$ & $\begin{array}{l}\text { Há uma ampla divulgação } \\
\text { dos atrativos e } \\
\text { entretenimentos }\end{array}$ & $\begin{array}{l}\text { Não existem habitações } \\
\text { subnormais (precárias) no } \\
\text { município }\end{array}$ & $\begin{array}{l}\text { Material promocional } \\
\text { adequado e suficiente }\end{array}$ \\
\hline & \multirow[t]{4}{*}{ Comunidade consciente } & $\begin{array}{l}\text { Melhoria nas linhas de } \\
\text { transformação de energia } \\
\text { elétrica (SFX) }\end{array}$ & $\begin{array}{l}\text { Qualificação especializada } \\
\text { de mão de obra }\end{array}$ & $\begin{array}{l}\text { Artesanato valorizado e } \\
\text { promovido }\end{array}$ & $\begin{array}{l}\text { Ruas calçadas, asfaltadas } \\
\text { e conservadas }\end{array}$ & $\begin{array}{l}\text { Os produtos turísticos de } \\
\text { SJC estão bem formatados }\end{array}$ \\
\hline & & $\begin{array}{l}\text { Melhoria no sistema de } \\
\text { telefonia } \quad(\text { SFX) }\end{array}$ & & & Boa estética urbana & \\
\hline & & $\begin{array}{l}\text { Melhoria no tratamento de } \\
\text { esgoto - estação de } \\
\text { tratamento (SFX) }\end{array}$ & & & & \\
\hline & & Há segurança eficaz & & & & \\
\hline
\end{tabular}

Quadro 4: Modelo de Árvore dos Objetivos

Fonte: Crocomo (2000) 
A quinta atividade é a identificação de alternativas. É nessa etapa que se definem as prioridades, segundo critérios preestabelecidos, que vão compor a estratégia do projeto em fase de planejamento. É essa análise que permite escolher as diversas e possíveis abordagens para a resolução de um problema, qual é a mais indicada e com maiores chances de êxito (MINGUILLO, s. d.). A identificação de alternativas é um conjunto de técnicas para:

a) identificar soluções alternativas que o projeto queira possivelmente alcançar;

b) selecionar uma ou mais estratégias do projeto;

c) decidir por uma estratégia a ser adotada pelo projeto.

\section{Passo a passo:}

1. identificar os objetivos que não são susceptíveis de serem alcançados devido à limitação de recursos (indesejáveis ou inviáveis). Uma técnica é dar nota de 0 a 5 para cada objetivo. Ficam definidos os que estiverem mais próximos da nota 5 ;

2. identificar diferentes "escadas meios-fins", como possíveis estratégias alternativas ou como componentes do projeto;

3. identificar a alternativa que na opinião dos participantes representa a melhor estratégia do projeto, usando critérios como:
a) limitação de recursos;
b) probabilidade de êxito;
c) medidas políticas governamentais;
d) relação custo-benefício;
e) riscos sociais;
f) horizonte temporal etc.

A análise de alternativas se propõe, portanto, a identificar soluções alternativas que possam se constituir em estratégias do projeto, analisá-las e selecionar a melhor estratégia a ser implementada (MINGUILLO, s. d.).

A sexta atividade é a construção da Matriz de Planejamento do Projeto MPP. O grupo de planejamento pode reformular os objetivos, mas a estrutura básica da análise descrita pela alternativa escolhida deve estar contida na descrição sumária. Isto gera a Matriz de Planejamento do Projeto - MPP que se resume em: 


\begin{tabular}{|l|l|}
\hline Porque & o projeto é executado? \\
\hline O que & o projeto quer alcançar? \\
\hline Como & o projeto vai obter os resultados? \\
\hline Quais & os fatores externos importantes para o êxito do projeto? \\
\hline Através & de que se consegue medir o êxito do projeto? \\
\hline Onde & serão encontrados os dados para proceder a avaliação do projeto? \\
\hline Quanto & custará o projeto? \\
\hline
\end{tabular}

Quadro 5 - Questões relativas à MPP

Fonte: GTZ [1995].

A partir da MPP é possível a elaboração de um plano operacional que detalhe melhor a contribuição de cada grupo ou instituição envolvida, ou seja, "quem executará o projeto".

Os Quadros 6 e 7 apresentam a Configuração da MPP e a respectiva explicação de cada tópico da MPP.

\section{CONFIGURAÇÃO DA MPP}

\begin{tabular}{|l|l|l|l|}
\hline $\begin{array}{l}\text { Descrição } \\
\text { Sumária }\end{array}$ & $\begin{array}{l}\text { Indicadores } \\
\text { objetivamente } \\
\text { comparáveis }\end{array}$ & $\begin{array}{l}\text { Fontes de } \\
\text { verificação/comprovação }\end{array}$ & Pressupostos/Suposições \\
\hline $\begin{array}{l}\text { Objetivo } \\
\text { superior } \\
\text { (para o qual o } \\
\text { projeto deve } \\
\text { contribuir) }\end{array}$ & $\begin{array}{l}\text { Objetivo do } \\
\text { projeto }\end{array}$ & & \\
\hline Resultados & & & \\
\hline Atividades & Estrutura quantificada & \\
\hline Pré-requisitos & & \\
\hline
\end{tabular}

Quadro 6 - Configuração da MPP

Fonte: GTZ [1995]. 


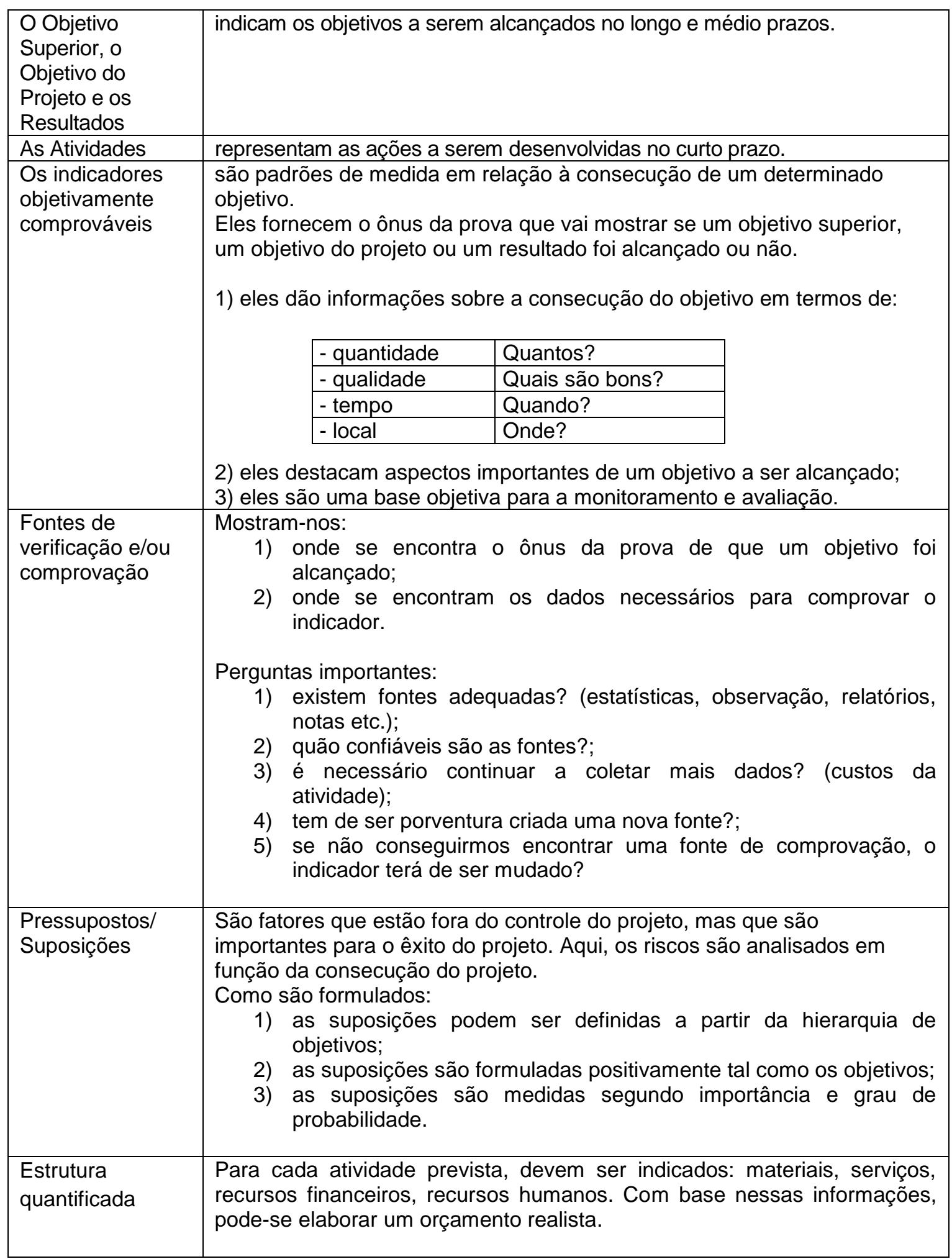

Quadro 7: Explicações dos tópicos da MPP

Fonte: Adaptado de GTZ [1995].

A sétima atividade é a construção da Matriz de Cooperação Institucional que apresenta as possibilidades de integração dos parceiros para desenvolverem um trabalho conjunto para atingir os objetivos propostos na MPP. 


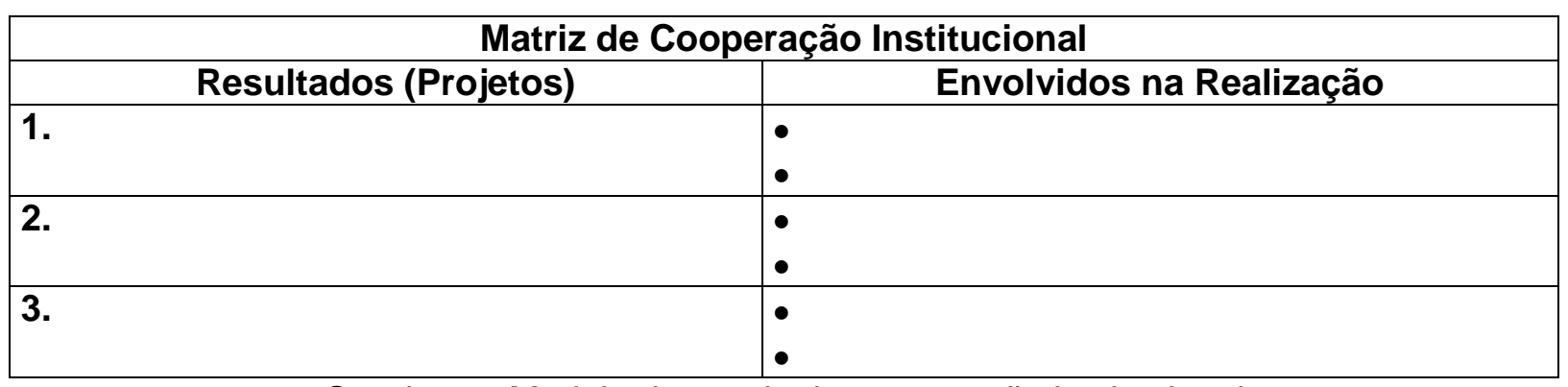

Quadro 8 - Modelo de matriz de cooperação institucional

A oitava atividade é a avaliação da Oficina. É o momento no qual os participantes expressam de satisfação ou não com o desenvolvimento da Oficina e dão sugestões para a melhoria do processo. O Quadro 09 é uma sugestão de avaliação.

\begin{tabular}{|l|l|l|l|}
\hline Pontos Negativos & Pontos Positivos & Sugestões & Sentimento \\
\hline & & & \\
\hline
\end{tabular}

Quadro 9 - Sugestão de avaliação

\subsection{Oficina para definição do Programa de Ações}

A segunda Oficina de planejamento participativo foi realizada no dia 28 de fevereiro de 2013 com uma carga horária de 7 horas. Essa Oficina foi realizada para elaboração do Programa de Ações com os atores sociais. Na abertura da Oficina, a moderadora apresentou os objetivos do trabalho de planejamento do Turismo Sustentável de Monteiro Lobato e os resultados da primeira Oficina. Com base nesses resultados, os participantes foram convidados a se dividirem em grupos por afinidades aos temas para discussões que foram gerados a partir da Matriz de Planejamento por Projeto - MPP, elaborada na primeira Oficina. Para que pudessem desempenhar a tarefa de análise da MPP e tomar a decisão sobre quais projetos seriam mantidos ou não no trabalho de planejamento em curso, cada grupo recebeu um conjunto de materiais para auxiliar nas discussões, a saber: a) dados socioeconômicos e ambientais do município; b) relatório da primeira Oficina de março/2012; c) resultado da pesquisa com moradores; d) resultado da pesquisa com 
turistas, e) inventário turístico, mapa turístico e mapas do município e f) Matriz de Planejamento por Projeto, elaborada com base na primeira Oficina. Em uma das mesas, ficaram à disposição para consultas dos participantes livros, apostilas, trabalhos acadêmicos e revistas com informações sobre o município e um computador para acesso à internet. Os grupos foram acompanhados por tutores convidados e por membros do Grupo Planejatur para orientarem as discussões. $O$ Quadro 10 apresenta os 9 resultados gerados na primeira Oficina e colocados para análise dos participantes agora divididos em 6 grupos.

\begin{tabular}{|c|c|c|c|c|}
\hline $\begin{array}{l}\text { Resultados } \\
\text { desejados dessa } 2 \text {. } \\
\text { oficina }\end{array}$ & Grupo/Tema & $\begin{array}{l}\text { Resultados da } 1^{\text {a. }} \text {. } \\
\text { Oficina a serem } \\
\text { analisados }\end{array}$ & $\begin{array}{l}\text { Tutor } \\
\text { convidado }\end{array}$ & $\begin{array}{l}\text { Tutor } \\
\text { Planejatur }\end{array}$ \\
\hline $\begin{array}{l}\text { 1. identificar a } \\
\text { principal vocação } \\
\text { turística do município; } \\
\text { 1.1. identificar os } \\
\text { principais atrativos }\end{array}$ & $\begin{array}{l}\text { Grupo } 1 \\
\text { Marketing } \\
\text { Turístico }\end{array}$ & $\begin{array}{l}\text { 2: Infraestrutura } \\
\text { turística } \\
\text { 4:Comunicação }\end{array}$ & $\begin{array}{l}\text { Profa. Dra. } \\
\text { Doris van de } \\
\text { Meene } \\
\text { Ruschmann }\end{array}$ & $\begin{array}{l}\text { André } \\
\text { Barreto } \\
\text { Antonio } \\
\text { Renato de } \\
\text { Sá } \\
\text { Sonnewend }\end{array}$ \\
\hline \multirow{5}{*}{$\begin{array}{l}\text { 1. Identificar os } \\
\text { projetos } \\
\text { prioritários para } \\
\text { implementação } \\
\text { e que } \\
\text { dependem da } \\
\text { iniciativa da } \\
\text { comunidade, } \\
\text { dos empresários } \\
\text { e dos governos } \\
\text { executivo e } \\
\text { legislativo de } \\
\text { Monteiro Lobato }\end{array}$} & $\begin{array}{l}\text { Grupo } 2 \\
\text { Infraestrutura da } \\
\text { cidade }\end{array}$ & $\begin{array}{l}\text { 3: Infraestrutura } \\
\text { da cidade }\end{array}$ & $\begin{array}{l}\text { Mestra } \\
\text { Marilene } \\
\text { Mesquita }\end{array}$ & Cleide Pivott \\
\hline & $\begin{array}{l}\text { Grupo } 3 \\
\text { Educação }\end{array}$ & 1: Educação & $\begin{array}{l}\text { Profa. Dra. } \\
\text { Vera Maria } \\
\text { Almeida } \\
\text { Rodrigues da } \\
\text { Costa }\end{array}$ & $\begin{array}{l}\text { Célia } \\
\text { Ceruks }\end{array}$ \\
\hline & $\begin{array}{l}\text { Grupo } 4 \\
\text { Cultura }\end{array}$ & 8: Cultura & $\begin{array}{l}\text { Roberval } \\
\text { Rodolfo }\end{array}$ & $\begin{array}{l}\text { Leila } \\
\text { Miranda }\end{array}$ \\
\hline & $\begin{array}{l}\text { Grupo } 5 \\
\text { Políticas públicas } \\
\text { para o Turismo } \\
\text { em Monteiro } \\
\text { Lobato }\end{array}$ & $\begin{array}{l}\text { 6: Legislação } \\
\text { 7: Saúde Pública } \\
\text { em relação ao } \\
\text { turismo } \\
\text { 9: Recursos } \\
\text { Financeiros }\end{array}$ & $\begin{array}{l}\text { Prof. Dr. José } \\
\text { Oswaldo } \\
\text { Soares de } \\
\text { Oliveira }\end{array}$ & $\begin{array}{l}\text { Ednea } \\
\text { Goulart de } \\
\text { Andrade }\end{array}$ \\
\hline & $\begin{array}{l}\text { Grupo } 6 \\
\text { Conscientização } \\
\text { da comunidade } \\
\text { para o Turismo }\end{array}$ & 5: Comportamento & $\begin{array}{l}\text { Profa. Dra. } \\
\text { Eda } \\
\text { Terezinha de } \\
\text { Oliveira } \\
\text { Tassara }\end{array}$ & $\begin{array}{l}\text { Odette A. C. } \\
\text { da Silva }\end{array}$ \\
\hline
\end{tabular}

Quadro 10 - Grupos, temas para trabalho e tutores.

A carga horária desta Oficina foi de 7 horas. Os grupos trabalharam durante a manhã e, após o almoço, cada grupo apresentou a sua respectiva análise esquematizada em folhas de flip chart, em plenária, aos demais grupos que 
puderam fazer perguntas de esclarecimentos e dar sugestões enriquecendo o assunto debatido. Com base no resultado final dessa Oficina, o Grupo Planejatur elaborou o Programa de Ações para o Plano Diretor de Turismo Sustentável de Monteiro Lobato, criando projetos, dentro de um modelo padronizado, para cada ação definida pelos participantes dessa segunda Oficina para ser realizada.

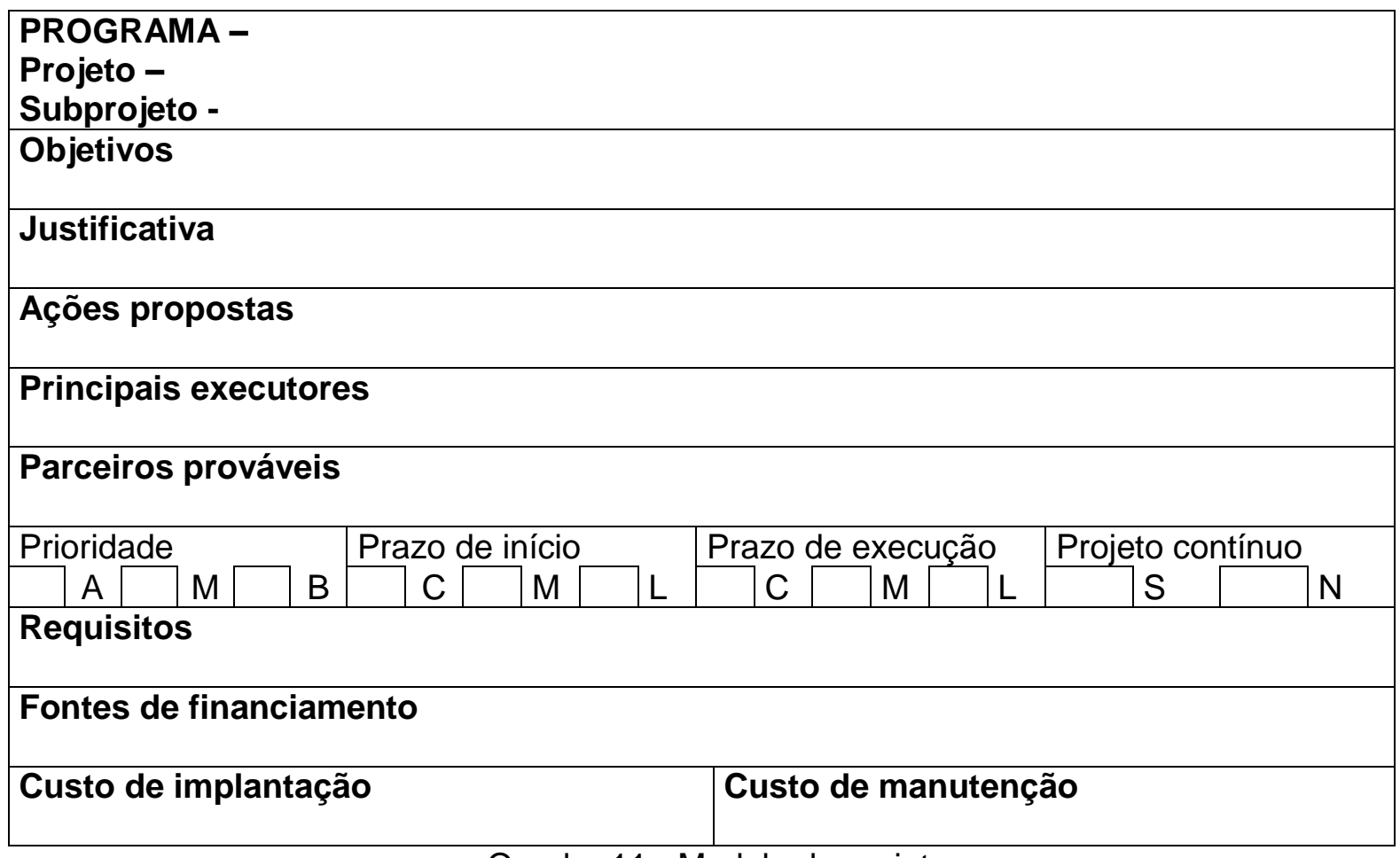

Quadro 11 - Modelo de projeto

Fonte: Ruschmann (2003)

\subsection{Oficina de Análise FOFA}

A terceira Oficina foi realizada em três etapas e em 3 dias devido ao número de atividades e ao tempo dispensado pelos participantes para discutir os temas apresentados. A carga horária foi dividida em 7 horas na primeira parte que incluiu palestra do Secretário de Turismo e Cultura de Cunha, SP, Marivaldo Luiz Almeida Rodrigues, sobre a experiência dessa Estância Turística e a Análise FOFA; 4 horas para a segunda parte que tratou do prognóstico e diretrizes e 2 horas para a terceira parte quando a visão de futuro para o Turismo Sustentável de Monteiro Lobato foi discutida e definida. 
$\mathrm{Na}$ primeira etapa, foi realizada a análise FOFA (Forças, Oportunidades, Fraquezas e Ameaças) ou SWOT (Strengths, Weaknesses, Opportunities, Threats) que, segundo Buarque (2002, p. 133) é:

Um método de organização de problemas e potencialidades e de ameaças e oportunidades que recorre a diagrama que distribui tais componentes em blocos diferenciados, permitindo uma percepção clara dos fatores facilitadores e dificultadores internos e externos. Não é exatamente uma técnica de seleção e hierarquização, mas apenas de apresentação estruturada de fatores já identificados e trabalhados anteriormente.

Portanto, o Diagrama de Análise FOFA orienta e conduz o trabalho dos participantes da Oficina de planejamento para refletirem e avaliarem cada tópico de análise colocado em questão quanto aos seus pontos fortes e fracos e às oportunidades e ameaças que podem prejudicar o seu desempenho ou realização. O modelo do diagrama abaixo é uma adaptação daquele apresentado por Buarque (2002, p. 132):

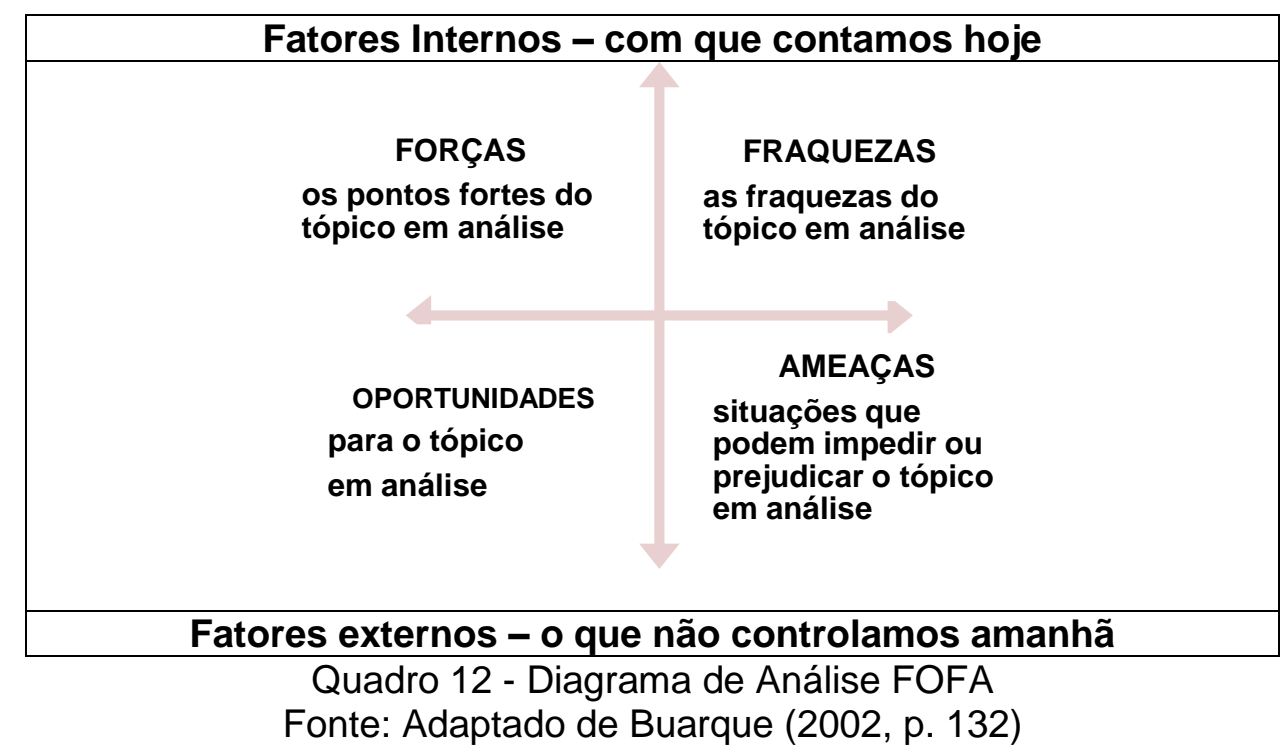

Para apoiar a análise do cenário atual do Turismo no município, antes da análise de cada tópico, a moderadora projetou e apresentou um breve resumo do levantamento de informações constantes no inventário turístico feito pelo Grupo Planejatur sobre os tópicos: a) recursos e atrativos turísticos (naturais e culturais); b) infraestrutura turística; c) infraestrutura de apoio; e d) políticas públicas para Turismo Sustentável e de inserção no Turismo Regional. Por meio de tempestade de ideias, 
os participantes dessa Oficina se manifestaram e suas opiniões foram anotadas pela moderadora nos respectivos quadrantes já indicados em folhas de flip chart para que todos pudessem acompanhar e rever o que estava sendo registrado.

$\mathrm{Na}$ segunda parte dessa Oficina, realizada no dia 10 de outubro de 2013, o objetivo foi formular o prognóstico e as diretrizes para o Turismo Sustentável no município. A partir do prognóstico são elaboradas diretrizes de ação que consistem em propostas para evitar os impactos negativos, otimizar os benefícios do Turismo e para propiciar o desenvolvimento sustentável da atividade turística (RUSCHMANN, 2001, p. 72). A pergunta norteadora "Quais são as diretrizes para o Turismo Sustentável de Monteiro Lobato?" foi respondida pelos participantes, relacionandose os tópicos de definição das diretrizes aos critérios de sustentabilidade (conservação e preservação do meio ambiente, respeito à cultura e identidade local e distribuição da renda com justiça social) conforme o Quadro 13:

\begin{tabular}{|l|l|l|l|}
\hline $\begin{array}{l}\text { Tópicos para definição } \\
\text { das diretrizes X critérios } \\
\text { de sustentabilidade }\end{array}$ & $\begin{array}{l}\text { Conservação e } \\
\text { preservação do } \\
\text { Meio Ambiente }\end{array}$ & $\begin{array}{l}\text { Respeito à } \\
\text { cultura e } \\
\text { identidade local }\end{array}$ & $\begin{array}{l}\text { Distribuição da } \\
\text { renda com } \\
\text { justiça social }\end{array}$ \\
\hline $\begin{array}{l}\text { Vocação - Turismo de } \\
\text { Natureza e Turismo Rural }\end{array}$ & & & \\
\hline $\begin{array}{l}\text { Vocação - Turismo } \\
\text { Cultural - Escritor e } \\
\text { Manifestações Culturais }\end{array}$ & & & \\
\hline Tipo de eventos & & & \\
\hline $\begin{array}{l}\text { Regras de convívio } \\
\text { morador x turista }\end{array}$ & & & \\
\hline $\begin{array}{l}\text { Atitudes dos governos } \\
\text { executivo e legislativo } \\
\text { em relação ao Turismo } \\
\text { Sustentável no município }\end{array}$ & & & \\
\hline Atitudes dos empresários & & & \\
\hline Atitudes da comunidade & & & \\
\hline
\end{tabular}

Quadro 13 - Matriz das Diretrizes para o Turismo Sustentável de Monteiro Lobato

Novamente, os participantes se manifestaram por meio de tempestade de ideias e preencheram a Matriz das Diretrizes para o Turismo Sustentável de Monteiro Lobato após breves discussões sobre os tópicos para definição das diretrizes em relação aos critérios de sustentabilidade.

A etapa da construção da visão de futuro para o Turismo Sustentável de Monteiro Lobato aconteceu durante a reunião do Conselho Municipal de Turismo 
(COMTUR-ML), no dia 07 de novembro de 2013, com a carga horária de 2 horas. Inicialmente, a moderadora apresentou algumas definições de visão com exemplos. Após breve debate, a pergunta norteadora foi colocada: Qual é a sua visão para o Turismo Sustentável em Monteiro Lobato? Os participantes, através de tempestade de ideias, anotaram suas visões em fichas que foram afixadas em folhas de flip chart na parede. Em seguida, todas as fichas foram lidas pela moderadora em voz alta para que todos acompanhassem as visões de cada um. Após o compartilhamento das visões, os participantes analisaram uma a uma, buscando o significado dos respectivos conteúdos e apresentaram por meio de palavras e expressões o que entenderam delas. Com base nessa relação de palavras e expressões, os participantes construíram a frase que sintetizou a visão de futuro para o Turismo Sustentável de Monteiro Lobato.

\subsection{Levantamento de dados}

Com relação ao levantamento das informações que caracterizam o município, as pesquisas foram feitas em fontes secundárias, bibliográficas e documentais, recorrendo-se a trabalhos acadêmicos produzidos por pesquisadores da Universidade do Vale do Paraíba (UNIVAP) e Universidade de Taubaté (UNITAU), livro "Monteiro Lobato: Cidade e Escritor" de autoria de André Barreto, publicado em 2012, relatórios técnicos produzidos pela Secretaria Estadual de Planejamento, sites do IBGE, IPEA, SEADE entre outros, e dados obtidos junto às secretarias municipais de Monteiro Lobato.

O inventário turístico é a elaboração de uma lista detalhada de todas as estruturas, serviços, equipamentos e atrativos relacionados à localidade de interesse de planejamento turístico (STIGLIANO; CÉSAR, 2005, p. 5). A pesquisa da infraestrutura turística foi iniciada com base nas informações preliminares fornecidas pela Secretaria de Cultura e Turismo. A pesquisa de campo foi feita pelo Antonio Renato de Sá Sonnewend que percorreu quase $400 \mathrm{~km}$ de estradas vicinais do município, acompanhado e auxiliado pelo motorista da Prefeitura, Milton Gomes, chamado pelo apelido de Guir, que conhece muito bem o município. Ambos encontraram e fotografaram cachoeiras, bicas, mirantes, sítios, capelas e curiosidades como um cupim de quase 6 metros de altura e outro em uma cerca. 
Também foram ao Pico do Trabiju e ao Mirante das Posses. Houve um momento de tensão para o Renato e o Guir no dia em que se perderam na mata quando procuravam atrativos na divisa de Sapucaí Mirim com Monteiro Lobato. Felizmente, - Guir subiu em uma árvore e logo se localizou. Paralelamente, a pesquisadora visitou as pousadas, restaurantes e atrativos turísticos, entrevistando os proprietários. O inventário foi registrado no modelo do Conselho Estadual de Turismo. Este trabalho foi estrategicamente escolhido para ser feito no segundo semestre de 2012 porque o Grupo Planejatur não quis desenvolver nenhuma atividade com a comunidade no período de eleições para que suas ações não fossem confundidas com ações eleitoreiras. Dessa forma, o Grupo Planejatur zelou pelo caráter técnico do trabalho, evitando que fosse eventualmente mal entendido durante as eleições.

O Grupo Planejatur realizou pesquisas quantitativas e qualitativas com moradores e turistas nos meses de janeiro e fevereiro de $2013 \mathrm{com}$ os objetivos de saber a opinião dos moradores sobre a atividade turística no município e conhecer o perfil dos turistas que vêm a Monteiro Lobato. Todas as perguntas para os dois formulários foram detalhadamente discutidas nas reuniões quinzenais do Grupo Planejatur, em especial quanto aos dados que cada uma poderia trazer que contribuísse para a elaboração do Plano Diretor de Turismo Sustentável do município.

Em ambas as pesquisas, a coleta de dados foi feita por meio do método do inquérito pessoal, utilizando dois modelos de formulários estruturados com questões abertas e fechadas que foram aplicados inicialmente como pré-teste a 10 moradores e 10 turistas respectivamente. Algumas perguntas foram modificadas porque não estavam claras para o entrevistado. No formulário para os moradores, a pergunta sobre a renda familiar deixava os respondentes um pouco constrangidos. Como os dados sobre a renda da população constam do censo do IBGE de 2010, os membros do Grupo Planejatur decidiram retirá-la. Porém, mantiveram-na no formulário para os turistas porque era necessário ter noção do nível de renda dos visitantes. Os formulários foram aplicados a uma amostra definida, dentro da classificação de amostragens, como não-probabilística por conveniência, pela qual "os elementos da amostra são selecionados de acordo com a conveniência do pesquisador. São pessoas que estão ao alcance do pesquisador e dispostas a responder a pesquisa" (SAMARA; BARROS, 1997, p. 70). O Grupo Planejatur dividiu 
entre si os formulários e aplicou 124 por meio de abordagens pessoais a turistas encontrados nas ruas, praças e restaurantes e através de parcerias com os proprietários de pousadas e lojas que pediram aos seus clientes para responderem a pesquisa. Para aplicação dos formulários a moradores, houve igualmente a abordagem pessoal e, para garantir uma representatividade maior, além daqueles que residem no centro, foram feitas entrevistas durante a Festa de São Sebastião na Paróquia de Nossa Senhora de Bonsucesso, no dia 20 de janeiro de 2013, que atrai pessoas do município todo e visitas aos bairros mais afastados do centro como Vila Esperança, Rio Manso, Santa Maria, Souza, São Benedito, Matinada, Forros, Teixeiras, Serrinha, Pedra Branca, Morada do Sol, Descoberto, Ponte Nova e Taquari. Foram 159 formulários aplicados a moradores nos meses de janeiro e fevereiro de 2013. Após a tabulação dos formulários, o Grupo Planejatur analisou com atenção as informações que o resultado de cada questão trazia. Essas pesquisas trouxeram informações importantes para a continuidade do trabalho de planejamento turístico de Monteiro Lobato.

Os modelos dos formulários para moradores e turistas constam como APÊNDICE B e APÊNDICE C.

\section{5 $O$ envolvimento das escolas da rede municipal no Plano Diretor do Turismo Sustentável de Monteiro Lobato}

No Brasil, a Política Nacional de Educação Ambiental foi instituída pela Lei Federal no 9.795 de 27/04/1999 e pelo Decreto № 4.281, de 25/06/2002, estabelecendo a obrigatoriedade de trabalhar o tema ambiental de forma transversal para propor maior conscientização dos diversos setores da sociedade em relação ao socioambiente, evidenciando a responsabilidade de todos para com 0 desenvolvimento sustentável das nações. O Turismo é considerado como um dos serviços ambientais de uso indireto da floresta, podendo ser trabalhado como instrumento para geração de renda e fixação do homem rural no campo. Dentre os resultados das duas primeiras Oficinas com a comunidade, foi identificada a necessidade das escolas ensinarem a história, a geografia, o meio ambiente e a cultura do município, bem como a vida e obra do escritor Monteiro Lobato. Essa questão foi incluída no Programa de Ações como: 1. Educação, Projeto - 1.1. 
Educação escolar e subprojeto - 1.1.1. Capacitação de professores nas áreas de Turismo Sustentável, Turismo Rural e Educação Ambiental. As secretarias municipais de Educação, Cultura e Turismo e Meio Ambiente e Agricultura demonstraram interesse em alavancar este projeto já em 2013. Assim, foi articulada a realização de um curso para os professores no dia 26 de julho de 2013 para que pudessem pensar em projetos interdisciplinares para o segundo semestre. De forma resumida, a proposta feita aos professores da rede municipal de ensino em Monteiro Lobato para realizarem projetos interdisciplinares apresentou as seguintes informações:

$\checkmark$ o projeto interdisciplinar considera os pilares da educação e conhecimento: aprender a fazer, a ser, a conviver e a conhecer (aprender a aprender);

$\checkmark$ na interdisciplinaridade, os professores lecionam suas disciplinas normalmente, mas com o enfoque em um projeto predefinido para o curso no bimestre, semestre ou no ano - as disciplinas se inter-relacionam no desenvolvimento do projeto. A interdisciplinaridade é postura, atitude e visão.

$\checkmark$ No projeto interdisciplinar, há integração entre as disciplinas de forma que as características particulares de cada disciplina sejam mantidas, mas se integrem conceitualmente e metodologicamente com o enfoque pertinente a um projeto que cria um produto de forma coletiva.

O Quadro 14 apresenta o esquema do projeto interdisciplinar proposto aos professores indicando as disciplinas que poderiam fazer parte da elaboração de um ou mais projetos com visão ecológica considerando a preservação e conservação dos atrativos naturais do município (Turismo e Meio Ambiente).

\begin{tabular}{|l|l|l|}
\hline DISCIPLINAS \\
História \\
Geografia \\
Ciências \\
Português \\
Matemática \\
Arte \\
$\begin{array}{l}\text { Cultura (artes plásticas, } \\
\text { folclore, artesanato, } \\
\text { música, gastronomia) }\end{array}$
\end{tabular}

Quadro 14 - Esquema do projeto de interdisciplinaridade proposto aos professores 
Quanto à abordagem, a visão ecológica incentiva a crítica do modelo de desenvolvimento vigente na sociedade e amplia a noção de interdependência entre as espécies - ecologia. Quanto ao tema, a visão ecológica possibilita uma compreensão das necessidades da vida social como um todo e da atividade turística em particular - Turismo Sustentável.

O estudo do meio é um estudo direto do contexto natural e social no qual o educando se insere, visando analisar e compreender uma determinada problemática de modo interdisciplinar ${ }^{23}$. De acordo com a OMT (2003, p. 24), o Turismo Sustentável é aquele que:

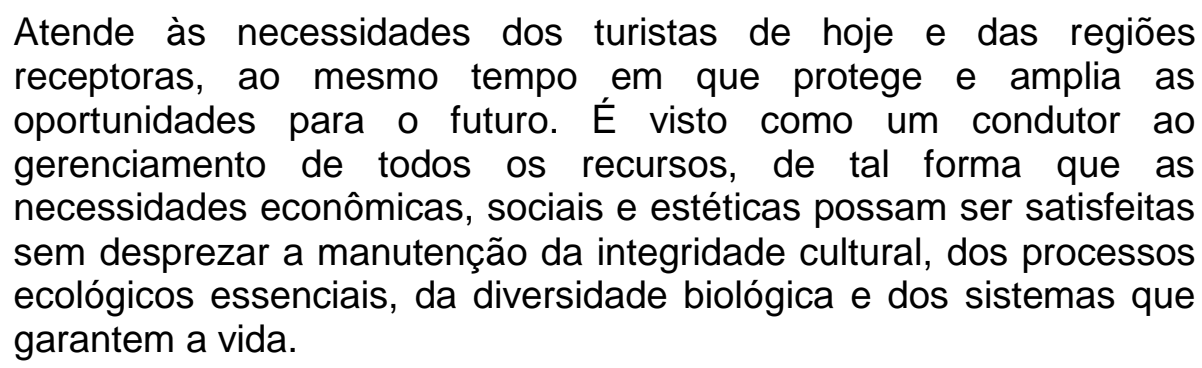

O Quadro 15 resume as sugestões de possíveis inter-relacionamentos entre Meio Ambiente e Turismo apresentadas aos professores:

\begin{tabular}{|l|l|}
\hline Meio Ambiente & Turismo \\
\hline $\begin{array}{l}\text { Biodiversidade: } \\
\text { Vegetação: Mata Atlântica, floresta ombrófila densa } \\
\text { Animais: silvestres e domésticos }\end{array}$ & $\begin{array}{l}\text { Trilhas } \\
\text { Observação de pássaros }\end{array}$ \\
\hline $\begin{array}{l}\text { Água: nascentes, rios, cachoeiras, água de chuva, } \\
\text { água potável } \\
\text { Mantiqueira = a serra que chora } \\
\text { Buquira = ribeirão dos pássaros }\end{array}$ & $\begin{array}{l}\text { Esporte de aventura: rapel, } \\
\text { tirolesa, rafting, canoagem, etc. } \\
\text { Ecoturismo } \\
\text { Extração de água mineral }\end{array}$ \\
\hline Alimentação: Agricultura, Pecuária, Apicultura & Turismo Rural \\
\hline $\begin{array}{l}\text { Saneamento } \\
\text { Lixo: coleta seletiva, limpeza das ruas }\end{array}$ & Onde há sujeira, não há turistas \\
\hline
\end{tabular}

$\mathrm{Na}$ segunda parte do curso, os professores discutiram, em grupos, temas possíveis para o trabalho interdisciplinar como descritos na Seção 6. No entanto, para atingir um resultado interdisciplinar, de fato, os conteúdos programáticos das disciplinas deveriam não só incorporar os temas, como também teriam que serem

${ }^{23}$ Cardoso (2008). Disponível em: <http://www.partes.com.br/educacao/estudodomeio.asp >. Acesso em: 04 jun. 2013. 
feitos uma forma integrada, com visão interativa e com diálogo entre as disciplinas, como argumenta José (2008, p. 87):

Os estudos da interdisciplinaridade no Brasil apontam para uma concepção de que a própria interdisciplinaridade realiza esse movimento de transformação no currículo, na didática e na sala de aula. Isto porque considera que a escola precisa trabalhar com um conhecimento vivo, que tenha sentido para os que nela habitam: professores e alunos. $O$ processo pedagógico precisa se fundamentar no diálogo, tanto entre as pessoas quanto entre disciplinas.

Por outro lado, Dencker (2002, p. 79), em seu trabalho sobre a Pesquisa e Interdisciplinaridade no ensino superior, recomenda que "o projeto interdisciplinar não pode ficar restrito a alguns professores idealistas, mas deve fazer parte do universo cotidiano de todos os professores, encontrando seu espaço dentro da universidade". Porém, apesar das iniciativas de algumas instituições de ensino como a Universidade Paulista (UNIP) que criou a disciplina de Trabalho de Análise Interdisciplinar (TAI) no curso de Turismo, a interdisciplinaridade acontece como projeto e não como uma disciplina instituída na grade curricular ${ }^{24}$. De acordo com essa autora, "as práticas interdisciplinares de ensino devem ser sistematizadas de forma a permitir a iniciação do professor no processo de forma gradativa, buscando compatibilização entre a sua carga de trabalho e sua disponibilidade para aprender e praticar o pensar interdisciplinar" (DENCKER, 2002, p. 79).

Nos dias 12 e 13 de dezembro de 2013, os professores organizaram a Mostra Pedagógica com exposição dos trabalhos feitos pelos alunos na Escola Micheletto, representando a introdução da pesquisa interdisciplinar nas escolas do município.

\footnotetext{
${ }^{24}$ A esse respeito, ver Projeto Trabalho de Análise Interdisciplinar (TAI), Dencker (2002, p. 72).
} 


\section{CARACTERIZAÇÃO DO MUNICÍPIO}

O levantamento dos dados econômicos, sociais e ambientais de Monteiro Lobato foi iniciado no segundo semestre de 2011 para compor a apostila do Curso de Capacitação em Turismo Sustentável. A apostila foi dividida em três partes: Turismo, Participação e Estudo do Território. Nos dois anos seguintes, os dados sobre o município foram atualizados à medida que havia acesso a novos materiais de consulta. Salientam-se as seguintes informações sobre o município:

- O município possui 4.120 habitantes (IBGE, 2010) com uma área territorial de $332,742 \mathrm{Km}^{2}$, que resulta em uma densidade demográfica de $12,38 \mathrm{hab} / \mathrm{km}^{2}$, indicando que o município tem pouca ocupação do seu espaço em comparação com a Região de Governo de São José dos Campos que é de $258,24 \mathrm{hab} / \mathrm{km}^{2}$;

- A taxa de urbanização é de $43,15 \%$, demonstrando que pouco mais da metade da população reside na zona rural.

- Um dos grandes problemas quanto à propriedade da terra é a falta de registro. Há bairros rurais com ocupações irregulares, como por exemplo, com chácaras em áreas menores do que é estabelecido pela Instrução Especial Incra № 26, de 09/06/82 - a Fração Mínima de Parcelamento (FMP) dos imóveis rurais é de 02 ou 03 hectares (20.000 ou $30.000 \mathrm{~m}^{2}$ ), de acordo com Freitas [s. d. $]^{25}$.

- A Prefeitura possui poucas áreas e prédios e tem dificuldade para acomodar suas secretarias e os projetos de assistência social, tendo que alugar imóveis para tais fins. Possui áreas e prédios que também não estão devidamente escriturados.

- Segundo o IBGE (2010), o município tem 1.335 domicílios particulares permanentes, sendo 554 na zona urbana e 781 na zona rural. Há casas simples e de autoconstrução, mas não há formação de favelas.

\footnotetext{
25 Disponível em: <http://www.avilesp.org.br/joomla/loteamentos-clandestinos-jose-carlos-defreitas.pdf> Acesso em: 17 jan. 2014.
} 
- A conservação e preservação do meio ambiente são vitais para o futuro do município porque as características do seu meio físico indicam muita fragilidade, considerando que:

a) $50,80 \%$ da sua cobertura vegetal é composta por mata nativa do bioma da Mata Atlântica (SÃO PAULO, 2010a, p. 64), abrigando rica flora e fauna, inclusive formando um corredor ecológico com a flora de São Francisco Xavier, Distrito de São José dos Campos, onde comprovadamente há indivíduos do macaco muriqui (mono carvoeiro) que se encontra ameaçado de extinção no Brasil. Em complementação, de acordo com Ferreira e Fisch (2007, p. 41), o tipo de vegetação predominante no município é a Floresta Ombrófila Densa, cuja maior característica é a presença de árvores altas, atingindo entre 20 e $30 \mathrm{~m}$. Isto é um ponto muito positivo para o município, mas pode se tornar um problema crítico se Monteiro Lobato for alvo de especulação imobiliária;

b) $57,69 \%$ do relevo de Monteiro Lobato é classificado como de Classe E (declividade de 15 a 45\%), o que significa áreas fortemente inclinadas, cujo escoamento superficial é muito rápido na maior parte dos solos (ISSA, 2003, p. 49), sendo, portanto, áreas impróprias para ocupação segundo a Lei Federal № 6.766/79 que proíbe urbanização em áreas com declividade acima de $30 \%$, salvo se atendidas exigências específicas das autoridades competentes;

c) $59,72 \%$ da área do município está entre as cotas altimétricas de 700 a 1.000 $\mathrm{m}$, que representam a transição entre o relevo de morros e as escarpas da Serra da Mantiqueira (ISSA, 2003, p. 53);

d) $83,64 \%$ dos solos em Monteiro Lobato correspondem ao grande grupo Latossolo Vermelho Amarelo. A abundância de Cambissolos, presentes em todos os grupos, caracteriza o relevo montanhoso do município enquanto que o grupo do Podzólico Vermelho Amarelo recobre pequena área no sul do município (ISSA, 2003, p. 56). Considerando que os tipos de solo de Monteiro Lobato são semelhantes aos de Campos de Jordão, constata-se que o primeiro corre o risco de ter os mesmos deslizamentos de terras ocorridas no segundo.

- As restrições de relevo e de solo e o manejo inadequado dificultam ainda mais o desenvolvimento das atividades agropecuárias como setor gerador de 
renda no município. Além disso, as atividades agropecuárias existentes, além de oferecer poucos empregos formais, estão baseadas em práticas e culturas de baixa rentabilidade e desligadas de mecanismos de mercado. De acordo com o SEADE (2011), o setor da agropecuária emprega apenas $12,21 \%$ da mão de obra no município, enquanto que o comércio e os serviços empregam respectivamente $31,10 \%$ e $43,10 \%$.

- A população é jovem, 45,31\% com menos de 29 anos. Há um alto grau de parentesco (é dito que "aqui ou é parente ou é compadre").

- A Associação Sociedade de Obras Religiosas de Monteiro Lobato mantém um asilo (Cantinho de São Vicente) que recebe ajuda de outras entidades e dos munícipes.

- Há 11 escolas da pré-escola ao ensino médio. Há uma faculdade que oferece cursos de Administração e Pedagogia, no sistema de ensino a distância, porém com aulas presenciais com tutores locais e videoconferências.

- O serviço de saúde conta com um posto no centro que mantém o Programa Saúde da Família (PSF) com 2 equipes. O posto tem bons indicadores para o SUS, Recursos Humanos capacitados e atendimento pré-hospitalar. Mas é alvo de críticas por falta de remédios, de médicos e demora para fazer exames.

- Pela classificação do Índice Paulista de Responsabilidade Social (IPRS), Monteiro Lobato passou do Grupo 4 para o Grupo 3 em virtude da melhora no indicador de escolaridade. $\mathrm{O}$ grupo 3 indica município com nível de riqueza baixo, mas com bons indicadores nas dimensões escolaridade e longevidade. Este grupo é caracterizado por pequenos e médios municípios. Em relação ao Índice de Desenvolvimento Humano (IDH), o município de Monteiro Lobato está incluído como sendo de médio desenvolvimento humano, com o índice de IDH no valor de 0,710 (IBGE, 2010), a referência é: $0,5<\mathrm{IDH}<0,8=$ Médio Desenvolvimento Humano.

- O serviço de saneamento básico é adequado, considerando que: a) o abastecimento de água na área urbana é de 99\%; b) o nível de coleta de esgoto sanitário na área urbana é de $73 \%$; c) o esgoto sanitário tratado dos $73 \%$ coletados na área urbana é de $88 \%$; e d) a coleta de lixo tem um nível de atendimento de $99,5 \%$, sendo o que lixo orgânico é enviado para o aterro 
sanitário privado em Tremembé, SP enquanto que há coleta seletiva para o lixo reciclável.

- A questão da legislação para o uso e ocupação do solo do município é urgente porque a Lei Municipal ํㅡ 544/81 se refere ao uso e ocupação do solo urbano apenas. O Parágrafo 2ํ․ do Artigo 178 da Lei Orgânica do Município (1990) estabelece "uma faixa marginal com largura mínima seja de 2 (dois) metros, a contar do nível mais alto do curso d'água, para a preservação e recuperação das matas ciliares" enquanto que o Inciso I do Artigo $4^{\circ}$. da Lei Federal $n^{\circ}$ 12.727, de 17 de outubro de 2012, (novo Código Florestal) estabelece que as faixas marginais de qualquer curso d'água natural perene e intermitente, excluídos os efêmeros, desde a borda da calha do leito regular, deve ter a largura mínima de 30 (trinta) metros, para os cursos d'água de menos de 10 (dez) metros de largura. Portanto, a elaboração do Plano Diretor do município deverá fazer as correções devidas.

- A segurança pública tem problemas estruturais: a delegacia da Polícia Civil não abre nos finais de semanas e, portanto, qualquer boletim de ocorrência nesse período deve ser feito em São José dos Campos. Isto prejudica as estatísticas e dá a falsa ideia de que o número de delitos e crimes no município é reduzido. A Polícia Militar tem uma base com 12 policiais que se revezam nos plantões para atendimento 24 horas. Em maio de 2012, foi criado o Conselho Comunitário de Segurança de Monteiro Lobato (CONSEG) nos moldes da Secretaria de Segurança Pública do Estado de São Paulo. Uma de suas atividades foi promover uma pesquisa com 353 alunos regularmente matriculados nos $8^{\circ}$ e $9^{\circ}$ ano do Ensino Fundamental e nas três séries do Ensino Médio do município. O resultado apresenta um quadro crítico em relação a drogas quando $88 \%$ dos alunos presenciaram o uso de drogas por adultos (54\%, maconha e 32\% cocaína) e $90 \%$ por crianças e adolescentes (48\%, maconha e $27 \%$ cocaína). Os locais indicados onde presenciaram o uso de drogas foram: ruas $(76 \%)$, praças $(40 \%)$, escola $(17 \%)$ e poliesportivo (25\%).

- A comunidade é reticente a projetos por causa daqueles que aconteceram no passado e não deram os resultados esperados ou não tiveram continuidade como, por exemplo, a Agenda 21 Local e o Projeto de Desenvolvimento Local Sustentável (DLIS). 
- As empresas e as entidades do terceiro setor são pouco articuladas. Não há associação comercial e industrial e nem dos empresários de Turismo. Porém, a Associação dos Pequenos Produtores Rurais de Monteiro Lobato e Região (APPR), criada como resultado do projeto DLIS, manteve-se e está se fortalecendo com o apoio da Faculdade de Agronomia da UNITAU, Taubaté, com o projeto Apicultura Sustentável. A associação de artesãos que contava com um ponto de vendas alugado pela prefeitura como apoio foi encerrada em 2012.

- A postura é positiva em relação ao Turismo. Segundo as pesquisas de opinião feitas por Costa (2000): são favoráveis ao Turismo: 93,5\% em 1991 e $95,5 \%$ em 2000. A pesquisa feita pelo Grupo Planejatur, nos meses de janeiro e fevereiro de 2013 , revela que $90 \%$ dos residentes são favoráveis à exploração do Turismo no município Os comerciantes do centro visam o "turista de passagem" para Campos do Jordão, Sul de Minas e São Francisco Xavier (Distrito de São José dos Campos).

- Há uma tematização espontânea no comércio local que coloca nomes dos personagens e de livros do escritor Monteiro Lobato em seus comércios.

- Nota-se que a infraestrutura turística é suficiente para a demanda atual, necessitando, porém, de organização e de planejamento para o futuro. $O$ SEBRAE-SP apoia o Circuito Mantiqueira e oferece cursos de capacitação gerencial para os proprietários de pousadas, restaurantes e atrativos turísticos. O SINHORES já realizou Cursos de Recepção, Qualidade no Atendimento, Garçom, Camareira, Inglês para Turismo, Organização de Eventos, Turismo Receptivo e Plano de Negócios.

- O município carece de projetos para preservar sua memória. Há o desejo de um museu e há pessoas que gostariam de doar objetos utilitários, acervos de livros, fotografias históricas etc. Há pessoas idosas atuantes no passado que guardam muitas informações e têm condições de dar seus depoimentos como história oral.

- O município recebeu seu Hino em 28 de abril de 2012, durante as comemorações de seus 132 anos completados em 26 de abril de 2012. Adauto Felisário Munhoz compôs letra e música.

- As finanças do município dependem dos repasses feitos pelos governos 
estadual e federal, 23,87\% e 44,64\% respectivamente em 2013.

Os dados socioambientais pesquisados são apresentados no ANEXO B tal como foram organizados e disponibilizados no Plano Diretor do Turismo Sustentável de Monteiro Lobato (Grupo Planejatur, 2014, p. 242) e constituem um material de apoio para futuros pesquisadores. A relevância dessa pesquisa de dados sobre o município repousa no fato de que não se encontrou material idêntico e, uma vez reunidos em um só documento, tais dados auxiliam na composição de uma visão geral da situação socioambiental do município. 


\section{DESCRIÇÃO DO TRABALHO DE CAMPO}

Peço permissão aos membros da banca e aos futuros leitores para deixar ouvir a minha voz nesta seção. O motivo foi ter sido o trabalho de campo realizado como uma pesquisa participante. Especificamente, foi uma pesquisa-intervenção caracterizada pela participação ativa do pesquisador objetivando promover uma ação transformadora no socioambiente da área em estudo, como anteriormente abordado no trabalho. Descrever esta experiência de modo impessoal seria criar no texto um distanciamento que não existiu no desenrolar do trabalho, porque a relação observador/observado, desde o início, foi de sujeito/sujeito e não de sujeito/objeto.

Antes de começar a descrição, relato meu envolvimento com o Turismo, o que também explica meus pontos de vista em relação à área. O primeiro contato que tive com o Turismo, em termos profissionais, foi no período de 1991 a 1995 quando atuei como técnica de projetos no Escritório Regional do Serviço de Apoio às Micro e Pequenas Empresas de São Paulo (SEBRAE-SP) em São José dos Campos, SP. Para desempenhar minhas funções, busquei oportunidades para projetos com micro e pequenas empresas, na região hoje denominada Região Metropolitana do Vale do Paraíba e Litoral Norte (RMVPLN) que reúne cinco microrregiões (Vale do Paraíba, Litoral Norte, Serra da Mantiqueira, Alto Paraíba e Vale Histórico) formadas por municípios com atividades econômicas baseadas na indústria, comércio, serviços e rural.

No entanto, o potencial turístico era e é muito forte nesses municípios, despertando meu interesse pelo setor de uma forma entusiasta, no início, porque é "uma atividade que gera renda e trabalho a curto prazo, proporciona maior arrecadação de impostos, oferece bem-estar a moradores e turistas, resgata a cultura, distribui renda de forma democrática, preserva o meio ambiente etc." Esse era o discurso que ouvi e que repetia na época como uma "missionária do Turismo". Porém, à medida que conhecia mais a respeito do assunto e viajava pela região, surgiram questionamentos como: "Se o Turismo é realmente bom, por que Campos do Jordão, uma estância turística, tem favelas?; Se gera de fato empregos, quero vê-los gerados perto de mim". Para buscar as respostas, empreendi meus estudos sobre Turismo. Primeiro, o Curso MBA em Turismo: Planejamento, Gestão e Marketing que me permitiu compreender como a atividade turística é 
operacionalizada e, após, o Curso de Mestrado em Planejamento Urbano e Regional com o qual entendi como ocorre a formação das cidades e a produção social do espaço. A dissertação de mestrado, com o título "O Turismo e a produção social do espaço urbano. Estudos sobre Campos do Jordão, SP", trouxe a clareza de que o Turismo não é "tudo de bom" e nem "tudo de ruim". A cidade, turística ou não, é formada por espaços segregados e desigualdades sociais porque assim é o modo como se realiza a produção social do espaço urbano de municípios de um país, cujo modelo econômico é o capitalismo que regula mercados e promove a distribuição de renda desigual porque coloca o lucro acima do bem-estar social da coletividade e da qualidade ambiental. Portanto, os impactos tanto positivos quanto negativos, atribuídos ao Turismo são produzidos como consequência da forma como a atividade é conduzida pelos atores sociais da localidade. O Turismo não é o grande vilão da história, mas sim as pessoas ou grupos delas que desempenham a atividade de forma maléfica à própria sociedade.

Dessa maneira, o questionamento passou a ser: "Como é que as pessoas decidem sobre o socioambiente?" Remete-se aqui ao conceito do Sistema EPI tal como apresentado por Milton Santos (1985) e Mark Gottdiener (1997) referindo-se às instâncias Econômicas, Políticas e Ideológico-culturais, articuladas por "redes pró-crescimento" que orientam as decisões da sociedade na direção do que desejam realizar em benefício próprio, mas cujo discurso dissimula a real intenção. Através da ideologia do crescimento, constituem o modo principal pelo qual a transferência local da terra se transforma num motor para a produção de espaço (GOTTDIENER, 1997, p. 269). O mesmo pensamento é tido por Souza (2004, p. 326) o qual afirma que "o Estado tende a produzir, como vetor resultante em termos de ações, intervenções conforme aos interesses dos grupos e classes dominantes, que dispõem de mais recursos e maior capacidade de influência". Observa-se que, em geral, a instância econômica lidera o processo e, por meio do mercado imobiliário, o espaço torna-se um meio de adquirir riqueza.

A característica marcante da segregação espacial expressa pela especulação imobiliária é visível nas cidades turísticas, onde o preço da terra é elevado nas áreas de entorno dos atrativos turísticos, nos bairros de casas de segunda residência e nas áreas onde se concentram os hotéis e o comércio. Dentro da ideologia de crescimento com base nas argumentações das coalizões de crescimento, o Estado prioriza investimentos nas infraestruturas básica e viária das áreas onde estão 
aqueles que têm poder econômico em detrimento de outras ocupadas pela população.

Os estudos sobre o Turismo Sustentável apresentam-no como alternativa ao modelo tradicional da atividade que explora a potencialidade turística do local até a sua degradação socioambiental e o substitui por novos destinos que, no futuro, poderão sofrer os mesmos processos do ciclo de vida de uma destinação turística que, de acordo com Butler (1980 apud RUSCHMANN 1997, p. 103), são: exploração, envolvimento, desenvolvimento, consolidação, estagnação, declínio ou rejuvenescimento. Por outro lado, acredito que uma destinação turística na qual o Turismo seja desenvolvido com base nos critérios da sustentabilidade, no planejamento da atividade e com participação social tem chances de se sustentar e não entrar na fase do declínio.

Surge, então, a questão: "Como fazer um planejamento do Turismo Sustentável com participação da população se "planejamento é coisa para acadêmicos e técnicos e, participação, no Brasil, só existe a pseudoparticipação, aquela para a qual a população é chamada apenas para legitimar o que já foi decidido de antemão pelas coalizões de crescimento?" Este é o desafio proposto neste trabalho que se intitula: "A construção compartilhada de um plano de Turismo para Monteiro Lobato, SP: a sustentabilidade como horizonte", cujo trabalho de campo foi desenvolvido no período de junho de 2011 a dezembro de 2013.

A definição do município para desenvolver o trabalho de campo teve como critérios: população de cerca de 10.000 habitantes; com potencial turístico, predisposto a elaborar um plano de Turismo Sustentável e a apoiar o trabalho. A delimitação da área de estudo para um município de pequeno porte foi estratégia estabelecida para atingir os objetivos da pesquisa, uma vez que seria muito difícil, por questões políticas, financeiras, de tempo e de equipe, desenvolver o trabalho em um município como São José dos Campos com cerca de 630.000 habitantes. Fiz sondagens em Silveiras e São José do Barreiro e contatos com São Bento do Sapucaí e Monteiro Lobato cujo prefeito aceitou a proposta imediatamente. Outro apoiador do projeto foi o Sindicato de Hotéis, Restaurantes, Bares e Similares de São José dos Campos e Região (SINHORES) que, entre seus objetivos, visa a apoiar a estruturação turística dos municípios de sua base territorial ${ }^{26}$.

${ }^{26}$ O SINHORES São José dos Campos tem como área de abrangência os seguintes municípios: Caçapava, Campos do Jordão, Guararema, Igaratá, Jacareí, Jambeiro, Monteiro Lobato, Natividade 


\subsection{Interação com a comunidade}

A primeira atividade foi me inserir no cotidiano da comunidade de Monteiro Lobato. A estratégia utilizada foi observar a sua dinâmica, os fatos, as situações e os comportamentos. Aos poucos, nos dois primeiros meses, fui conhecendo as em suas atividades de trabalho na Prefeitura, no comércio, nas escolas e nos empreendimentos turísticos entre outras. A organização sociopolítica do município também foi se revelando a mim. Por manhãs ou tardes, caminhei pelas ruas centrais prestando atenção nas atitudes das pessoas; em cenas como a de um cavalo amarrado a um poste; pessoas conversando nos bancos das praças ou em frente a suas casas, sentadas em banquetas de madeira.

Um dia, meu carro não pegou e decidi ir a pé até a Prefeitura pedir ajuda para achar um mecânico. No trajeto, fui encontrando gente que me cumprimentava com um "bom dia" acompanhado de um sorriso. Respondi a todos, encantada com tanta cordialidade, não mais vista nas cidades de São José dos Campos e Caçapava onde morei. As pessoas sabiam que eu era uma "de fora", mas mesmo assim me sorriam, fazendo-me sentir uma "de dentro".

Em uma caminhada pelo centro, vi, no balcão de um restaurante, um doce típico da região, chamado "João deitado". É uma broa feita com fubá, assada em folha de bananeira. $\mathrm{O}$ dono do restaurante, ao observar o meu olhar, convidou-me a entrar e a provar o doce com um café, como cortesia. Recém-chegada, eu ainda não tinha transferido minha conta bancária para o Banco do Brasil, único banco na época na cidade. Em uma ocasião, por não ter dinheiro algum para utilizar a lan house, pedi à vendedora da loja ao lado para me voltar um troco se eu comprasse algo no cartão de débito, contando-lhe minha situação. A vendedora disse que eu não precisava comprar nada e retirou $\mathrm{R} \$ 5,00$ da sua bolsa para me emprestar. Fiquei surpresa e exclamei: "Mas você não me conhece!". Ao que ela respondeu: "Eu confio em você". Com esses episódios, conheci a cortesia das pessoas e aprendi que a confiança é patrimônio imaterial do lobatense que ainda utiliza a "caderneta" para anotar compras do tipo "fiado" no mercadinho e refeições no restaurante para

da Serra, Paraibuna, Redenção da Serra, Santa Branca, Santa Isabel, Santo Antonio do Pinhal, São Bento do Sapucaí, São José dos Campos (incluindo os distritos de São Francisco Xavier e Eugênio de Melo), São Luiz do Paraitinga, Taubaté, Tremembé. 
pagar no final do mês.

Continuando o esforço para me socializar, aceitei o convite feito por uma funcionária da Prefeitura, para participar do grupo de ginástica, mesmo sendo avessa a atividades físicas. Exatamente no primeiro dia, consegui machucar meu polegar esquerdo em um jogo de vôlei "para terceira idade" e passei uma semana com o dedo engessado. Entendi que eu deveria "ir com menos sede ao pote" e tive a desculpa que precisava para não frequentar mais o grupo de ginástica.

Nesse período, iniciei o trabalho de coleta de informações sobre o município em fontes secundárias que obtive nas bibliotecas da UNIVAP e UNITAU, nos relatórios que o Secretário de Cultura e Turismo e a Secretária de Meio Ambiente e Agricultura me emprestaram, além daqueles disponíveis nos sites do IBGE, IPEA, SEADE, entre outros.

Com o objetivo de conhecer e me envolver na dinâmica do município, participei das atividades da Secretaria de Cultura e Turismo, acompanhando o Secretário, Eduardo Rocha Dellú ou como sua representante nas seguintes atividades:

- Reuniões do Circuito Mantiqueira - Sebrae-SP e C\&VB de Campos do Jordão;

- Reuniões do Projeto Araucária - Sebrae-SP em Campos do Jordão;

- Reunião promovida pelo Banco do Brasil = projeto para financiamentos para Turismo Rural;

- Turismo do Saber - Secretaria de Cultura do Estado de São Paulo - a cidade recebeu 34 crianças de Cananéia para conhecerem o campo em julho de 2011 e, em contrapartida, enviou crianças de Monteiro Lobato para conhecer o litoral no verão de 2012;

- Participação na organização do II Festival de Literatura Infantil de Monteiro Lobato;

- Participação na reunião do CODIVAP TURISMO em 13/9/2011.

- Revisão do livro sobre a história do Município de Monteiro Lobato, escrito pelo jornalista André Barreto, funcionário da Prefeitura;

- Apoio ao SINHORES para implantação do Centro de Capacitação em Hospitalidade e Gastronomia em parceria com a Pousada Monteiro Lobato, e

- Lançamento do pacote de divulgação turística de Monteiro Lobato. 
Igualmente, participei de atividades relativas a outros projetos da Prefeitura e de seus parceiros. Em consequência, o meu relacionamento com moradores aumentou, ao mesmo tempo em que conhecia as questões sociais do município:

- I Conferência Municipal de Saúde;

- I Conferência Municipal dos Direitos da Pessoa Idosa;

- Comunidade Mulher (Fundo Social) - apoio na organização do grupo de mulheres voluntárias. Em 27/08/11, coordenei a reunião para definição de visão, missão, valores e crenças e objetivos para o grupo, utilizando a técnica ZOPP;

- Reunião com artesãs do Projeto Apicultura Sustentável do Vale do Paraíba da UNITAU e Sebrae-SP;

- Reunião para discussão da reurbanização da Praça Largo Comendador Freire ("praça de baixo");

- Reunião para elaboração de edital para vagas na feira de artesanato e produção rural a ser organizada na Praça Cunha Bueno;

- Curso para Lideranças, promovido pelo Gabinete da Prefeitura para secretários e funcionários, em 03/12/2011;

- Projeto para o Horto Municipal, em janeiro de 2012, escrevi um primeiro esboço de argumentações para sua criação, a pedido da Secretária de Meio Ambiente e Agricultura;

- Reunião referente à participação de Monteiro Lobato no projeto do SEBRAESP de Prefeito Empreendedor em Caçapava;

- Apresentação do Projeto Apicultura Sustentável do Vale do Paraíba da UNITAU e SEBRAE-SP;

- A pedido do Sindicato Rural e da coordenadora do SENAR para o projeto Circuito Ecológico de Artesanato, conduzi uma reunião com as artesãs do Bairro da Pedra Branca, inscritas nesse projeto, em 27/01/12;

- A pedido da coordenadora do projeto Apicultura Sustentável da Faculdade de Agronomia da Universidade de Taubaté, conduzi uma reunião com empresários rurais interessados em participar de um roteiro de Turismo Rural no Bairro da Pedra Branca;

- A pedido da Secretária de Meio Ambiente e Agricultura, participei de reunião com empresários interessados em comprar áreas no município para lançar 
um conjunto residencial de alto padrão. Apresentei-lhes os conceitos de sustentabilidade com o propósito de alertá-los sobre os erros cometidos em Campos do Jordão que deveriam ser evitados em Monteiro Lobato;

- A pedido do Prefeito Gabriel Vargas Moreira, orientei a equipe da Prefeitura a organizar o evento referente à reunião do Consórcio de Desenvolvimento Integrado do Vale do Paraíba (CODIVAP) realizada no município no dia 20/04/2012.

- Participei da criação do Conselho de Segurança e das reuniões para a criação do Conselho Municipal dos Direitos do Idoso (CMDI).

O retorno da participação nessas atividades foi ganhar a confiança das pessoas que, certamente, avaliavam-me a cada ação, colocações feitas durante os debates e postura. Meu comportamento demonstraria meu caráter e as pessoas levariam isso em consideração na hora de participar do meu projeto.

\subsection{O planejamento do Turismo Sustentável com Participação Social}

O Curso de Capacitação em Turismo Sustentável foi oferecido como primeira etapa do projeto. Era necessário que as pessoas conhecessem os temas inerentes ao projeto, seus fundamentos e implicações. Assim, poderiam formar opiniões prós e/ou contras e obter discernimento para futuras decisões em relação à elaboração ou não do Plano Diretor de Turismo Sustentável do município. Nessa etapa, busquei mobilizar os grupos de habitantes a serem envolvidos com o trabalho, objetivando sensibilizá-los para a importância do Turismo Sustentável e do planejamento participativo. No início de agosto, a divulgação do curso começou com a carta do Secretário de Cultura e Turismo (ANEXO A) e as fichas de inscrições distribuídas pelo comércio local (APÊNDICE D), convidando a população para o evento de lançamento do projeto no dia 25 de agosto de 2011. Foram enviados convites por meio eletrônico para empresários e moradores cadastrados na Secretaria de Cultura e Turismo. Foi feito, também, um telemarketing reforçando o convite. $O$ evento contou com 27 participantes, resultando em 18 inscrições. Com o objetivo de conseguir mais interessados no projeto e formar uma segunda turma do curso, promovi evento idêntico, em 04 de outubro do mesmo ano, no Bairro do Souza, onde há 2 pousadas, restaurante com cachoeira e artesãos. Houve 13 participantes e 2 
inscrições. O curso foi ministrado com o mesmo conteúdo e carga horária daquele realizado no centro do município. As duas participantes me questionaram se valeria a pena dar o curso só para elas. Respondi que, mesmo que houvesse um interessado apenas, eu daria o curso porque já seria uma pessoa a mais a conhecer os preceitos do Turismo Sustentável. Assim, o curso teve 20 inscritos ao todo e 14 concluintes (70\%). Em uma das aulas, Célia Ceruks demonstrou preocupação com o resultado da proposta de elaboração do Plano Diretor do Turismo Sustentável, indagando: "Estamos discutindo assuntos tão importantes sobre o município e somos tão poucos, será que conseguiremos?" Respondi: "Em junho de 2011, quando cheguei aqui, eu era uma e agora já somos 14". No último dia de aula e encerramento do curso da primeira turma, em 08 de dezembro de 2011, perguntei aos concluintes se tinham interesse e disposição para compor um grupo de trabalho para o planejamento do Turismo no município com a minha coordenação. Aceitaram o convite, 09 alunos. São eles: André Barreto (funcionário da Secretaria de Cultura e Turismo), Andrejs e Célia Ceruks (produtores rurais e proprietários do Recanto do Sauá), Antonio Renato de Sá Sonnewend (artesão), Benedita Ivana da Rocha Claro e Larissa Claro (proprietárias do Pesca e Campo Pedra Branca), Ednea Goulart de Andrade (proprietária da Academia Mantiqueira), Leila Miranda (moisacista), Odette Antonia Casimiro Silva (proprietária da Loja Serralimp).

Em 26 de janeiro de 2012, o trabalho de planejamento foi iniciado discutindose com o grupo a forma, a periodicidade e o local dos encontros. Definiu-se que os encontros seriam a cada 15 dias, no horário das $18 \mathrm{~h} 00$ às $20 \mathrm{~h} 00$, às terças-feiras, na sala de reuniões e treinamento localizada no prédio denominado de Centro de Desenvolvimento Municipal (CDM) onde estava instalada a Secretaria de Cultura e Turismo. Apresentei ao grupo a técnica ZOPP, ilustrando-a com documentos e vídeos. No dia 14 de fevereiro de 2012, já utilizando essa técnica, o grupo criou para si o nome de Planejatur Monteiro Lobato (Grupo de Planejamento Participativo do Turismo Sustentável de Monteiro Lobato). Na ocasião, propus, e o grupo concordou, realizar uma Oficina de Planejamento de Turismo com a comunidade, no dia 15 de março de 2012, cujo nome seria PlaneJÁtur Oficina de Turismo em Monteiro Lobato. Todas as atividades relativas à organização e realização da Oficina foram feitas pelo grupo nas reuniões seguintes. Sem enfatizar que, na verdade, era um curso de planejamento e organização de eventos, apresentei as respectivas etapas do trabalho, ilustrando com exemplos vivenciados por mim, de modo que o grupo 
tivesse parâmetros para a tomada de decisões em relação à organização da Oficina. A realização da Oficina com a comunidade, exigiu que fosse elaborado um planejamento específico, a saber: discutiu-se a Técnica ZOPP; relacionaram-se as atividades a serem desempenhadas e, para o sucesso, os respectivos responsáveis pela limpeza do salão, recepção, decoração, cardápio para o café da manhã e o almoço, materiais de papelaria, equipamentos, brindes para sorteios, estacionamento, sinalização do local da Oficina etc. A decoração foi um dos itens mais bem cuidados: toalhas nas mesas,mudinhas de flores que os participantes podiam levar, além de banners das empresas apoiadoras. O local foi o salão de eventos da Fazenda Serrinha, cedido pela Sra. Venina Gondim Moscoso. Nas três oficinas, o Grupo Planejatur contou com o apoio da Prefeitura Municipal, Secretaria de Cultura e Turismo, SINHORES, Câmara Municipal, Espaço Mantiqueira, Serralimp, Casarão do Mosaico, Recanto do Sauá, Academia Mantiqueira, Pesca e Campo Pedra Branca, Doces Dona Nena, O Arteiro, Geleia Boa, Água Mineral Monteiro Lobato, Sítio Jatobá, Associação dos Pequenos Produtores Rurais de Monteiro Lobato e Região (APPR), Padaria El Shaday, Pousada Monteiro Lobato, Venina Gondim Moscoso, Pousada Aconchego do Caboclo e Pousada Aldeias do Paraíso. Salienta-se que essas entidades e empresas doaram todos os produtos necessários para o público estimado nas atividades. Foi uma parceria que provou poder ser a comunidade solidária e colaborativa quando o trabalho é em prol da coletividade. Após a realização do evento, os membros do grupo, satisfeitos com o resultado, ficaram surpresos com a sua capacidade de organizar um evento.

No planejamento e organização dessa Oficina, o Planejatur optou por uma abertura informal, sem cerimonial com composição de mesa, entendendo ser a Oficina um espaço de expressão dos munícipes sem hierarquias. Dessa forma, foi definida como primeira atividade, após a recepção com o café da manhã, a entrega dos certificados de conclusão do curso de Capacitação em Turismo Sustentável e do arquivo da sua apostila em CD. Foi a oportunidade de revelar ao público a origem do grupo e seus membros, bem como, a sua proposta de trabalho.

Uma vez que não houve limites rígidos de horário, com o propósito de não desestimular a participação, o tempo não foi o suficiente para a realização de todas as etapas da técnica ZOPP previstas. Foram cumpridas as etapas de 1 a 5 do programa sendo a etapa referente à construção da Árvore dos Problemas totalmente cumprida de forma intensa e com grande quantidade de ideias. Essa etapa é a base 
para a construção da Árvore dos Objetivos e da Matriz de Planejamento por Projeto (MPP). No entanto, a construção da MPP não foi finalizada na Oficina. O Grupo Planejatur assumiu a tarefa de terminá-la nas reuniões quinzenais.

Na primeira reunião de trabalho após a Oficina, o Grupo Planejatur decidiu convidar as pessoas, que participaram da Oficina, para que a ele se juntassem. Foram discutidas as formas do convite, se e-mail, telefone ou corpo a corpo), e os membros distribuíram entre si a lista de presença dos participantes da Oficina. Houve, então, a adesão inicial, de 5 pessoas, dentre as quais Deise Datti Rosa e Regina de Fátima Araujo permaneceram no Grupo Planejatur. Nota-se que o grupo tem pensado como coletivo, preocupado como aumentar o número de membros para seu fortalecimento, ciente da importância de maior participação nesse processo.

Tendo finalizado a MPP e considerando ser 2012 ano eleitoral, o Grupo Planejatur decidiu elaborar um documento com os resultados da Oficina para entregar aos futuros candidatos a Prefeito como contribuição aos respectivos planos de governo. O documento (APÊNDICE E) foi entregue aos quatro candidatos, no dia 19 de julho de 2012, em reunião pública, na qual o Grupo Planejatur fez uma apresentação do projeto com o objetivo de sensibilizar os candidatos a assumirem compromisso com o Turismo Sustentável. Com isso, o Grupo Planejatur demonstrou plena compreensão da dinâmica do Turismo que envolve os três pilares: governo, iniciativa privada e comunidade. Sabedores da importância de conscientizar os candidatos a prefeito nas eleições de 2012 sobre o Turismo Sustentável, ao mesmo tempo o grupo articulava a continuidade do processo do planejamento turístico na próxima gestão.

A segunda Oficina de Planejamento aconteceu no dia 28 de fevereiro de 2013, com o objetivo de definir o Programa de Ações para os projetos identificados na MPP na primeira Oficina. Na organização, houve o mesmo entusiasmo que na primeira (preocupação com o cardápio, a decoração, os materiais para o trabalho dos grupos etc.). O local foi o salão de eventos do Espaço Mantiqueira, cedido pelo Sr. José Benedito de Andrade (Zé Dito) e Sra. Ednea Goulart de Andrade. A forma de condução da Oficina foi decidida em reunião específica, ficando definido que seria em grupos que discutiriam os aspectos levantados na primeira Oficina. A segunda Oficina contou com a presença de 71 participantes, incluindo munícipes, empresários, a Prefeita, secretários da administração, vereadores e professores 
convidados. Os participantes representaram 15 bairros, indicando que o processo de sensibilização cresceu em número de habitantes e de bairros. Todos contribuíram com suas ideias e experiências na análise dos projetos apresentados respectivamente aos nove aspectos resultantes da primeira Oficina (educação, infraestrutura turística, infraestrutura da cidade, comunicação, comportamento, legislação, saúde pública, cultura e recursos financeiros), tendo como apoio os seguintes documentos: a) dados socioeconômicos e ambientais do município; b) relatório da primeira Oficina de março/2012; c) resultado da pesquisa com moradores; d) resultado da pesquisa com turistas, e) inventário turístico e f) matriz de planejamento por projeto. Por afinidades e áreas de interesse, os participantes dividiram-se em seis grupos e foram acompanhados nas discussões pelos tutores convidados Profa. Dra. Eda Tassara, Prof. Dr. Marcello Tassara, Prof. Dr. Omar Ardans, Profa. Dra. Doris van de Meene Ruschmann, Prof. Dr. José Oswaldo Soares de Oliveira, Profa. Dra. Vera Maria Rodrigues da Costa, Roberval Rodolfo, do Projeto Ponto de Cultura em Monteiro Lobato e Marilene Mesquita Silva, Secretária de Meio Ambiente e Agricultura de Monteiro Lobato. Igualmente, os membros do Grupo Planejatur se dividiram para acompanhar o trabalho dos grupos. Após as discussões no período da manhã, cada grupo apresentou suas conclusões em plenária na parte da tarde. Nas reuniões quinzenais, o Grupo Planejatur procedeu à análise dos resultados da segunda Oficina e produziu o documento "Programa de Ações", com projetos especificados de acordo com o resultado dos trabalhos dos grupos. Esse documento foi entregue à Prefeita, no dia 20 de maio de 2013, como subsídio para a elaboração do orçamento municipal destinado à pasta da Secretaria de Cultura e Turismo.

A terceira Oficina aconteceu nos dias 19 de setembro, 10 de outubro e 7 de novembro de 2013 com os objetivos de 1) realizar a análise FOFA (Forças, Oportunidades, Fraquezas e Ameaças) sobre os tópicos: a) recursos e atrativos turísticos (naturais e culturais); b) infraestrutura turística; c) infraestrutura de apoio; e d) políticas públicas para Turismo Sustentável e de inserção no Turismo Regional; 2) formular o prognóstico e as diretrizes para o Turismo Sustentável no município; e 3) elaborar a visão de futuro para o Turismo Sustentável de Monteiro Lobato.

O envolvimento do Grupo Planejatur na organização desta Oficina aconteceu como nas duas anteriores, com muito zelo e entusiasmo. O local foi, novamente, o salão de eventos da Fazenda Serrinha. Durante a discussão sobre a forma de se 
conduzir a Oficina, além da aplicação da análise FOFA, foi sugerido que houvesse um palestrante convidado de uma cidade que já tivesse passado pela experiência de organização e planejamento turístico para contar como foi o processo. Foi lembrada a cidade de Cunha sempre citada por mim como exemplo de organização da comunidade. Contatada a Secretaria de Turismo e Cultura de Cunha, o Sr. Marivaldo Luiz Almeida Rodrigues, Secretário Municipal de Cultura e Turismo, aceitou o convite com o intuito de poder colaborar com Monteiro Lobato porque participou do processo de organização do Turismo em Cunha desde a década de 1990, segundo afirmou o Secretário.

O Quadro 16, a seguir, apresenta as atividades feitas com a comunidade e os respectivos números de participantes no período de 2011 a 2013. Foram 298 participações em 8 encontros específicos para falar do planejamento do Turismo Sustentável com a comunidade. De acordo com a tabela de Gerardi e Bárbara (1981), para a determinação do tamanho da amostra a partir do tamanho da população, uma amostragem de 297 equivale a um universo de 1.300 pessoas, o que representa $31,55 \%$ da população do município. Porém, o percentual aumentará se forem consideradas as apresentações feitas sobre o trabalho pelo Grupo Planejatur em outros eventos e reuniões no município.

\begin{tabular}{|l|l|c|}
\hline Data & Atividade & $\begin{array}{c}\text { Partici- } \\
\text { pantes }\end{array}$ \\
\hline $25 / 08 / 2011$ & Palestra de Apresentação do Projeto - Centro & 27 \\
\hline $04 / 10 / 2011$ & Palestra de Apresentacão do Projeto - Souza & 13 \\
\hline $15 / 03 / 2012$ & Primeira Oficina de Comunidade & 48 \\
\hline $28 / 02 / 2013$ & Segunda Oficina de Comunidade & 71 \\
\hline $23 / 05 / 2013$ & $\begin{array}{l}\text { Palestra de Apresentação do Projeto para sensibilização da } \\
\text { comunidade para formação do COMTUR-ML }\end{array}$ & 26 \\
\hline $26 / 07 / 2013$ & Curso de capacitação em Turismo e Meio Ambiente para professores & 50 \\
\hline $19 / 09 / 2013$ e & Terceira Oficina de Comunidade & 48 \\
$10 / 10 / 2013$ & Definição de visão - comunidade e COMTUR & 15 \\
\hline $07 / 11 / 2013$ & \multicolumn{1}{|c|}{ Total: } & 298 \\
\hline
\end{tabular}

Quadro 16 - Número de participantes nas atividades com a comunidade

A seguir, são apresentados os relatórios das três Oficinas de Planejamento do Turismo Sustentável de Monteiro Lobato que, igualmente, constam do Plano Diretor de Turismo Sustentável de Monteiro Lobato (GRUPO PLANEJATUR, 2014a, p. 26). 


\title{
6.2.1 PlaneJÁtur - Oficina de Planejamento Participativo em Turismo Sustentável no Município de Monteiro Lobato, SP, 15 de março de 2012
}

Moderadora: Profa. Ma. Cleide Pivott - USP/IP

Equipe da Organização:

André Barreto

Andrejs Ceruks

Antonio Renato de Sá Sonnewend

Benedita Ivana da Rocha Claro

Célia Ceruks

\author{
Ednea Goulart de Andrade \\ Larissa A. Claro \\ Leila Miranda \\ Maíra Barbosa Varela \\ Odette A. C. Silva
}

\section{ABERTURA}

No planejamento e organização da Oficina, o Grupo PLANEJATUR optou por uma abertura informal, sem cerimonial com composição de mesa, considerando que a oficina é um espaço de expressão dos munícipes sem hierarquias.

A moderadora, Cleide Pivott, apresentou sua tese de doutorado e a metodologia utilizada para a primeira etapa, quais sejam: a) realização do Curso de Capacitação em Turismo Sustentável, no período de 15 de setembro a 08 de dezembro de 2011, com carga horária de 24 horas; b) convite aos concluintes para fazerem parte de um grupo de planejamento do Turismo em Monteiro Lobato; c) reuniões para definir local, dia e horário dos encontros para identificação, planejamentos e ações do grupo; d) treinamento da equipe para aplicar a Metodologia ZOPP (do alemão: Ziel Orientierte Projekt Planung - Planejamento de Projetos Orientado por Objetivos); e) planejamento e organização da oficina que recebeu o título de PlaneJÁtur - Oficina de Planejamento Participativo em Turismo Sustentável no Município de Monteiro Lobato, SP; f) realização da oficina; g) análise dos resultados; h) definição de grupos de trabalho para estruturação e realização das ações identificadas e registradas na MPP - Matriz de Planejamento por Projetos.

A divulgação da oficina foi feita por meio de cartazetes afixados nos comércios, nas secretarias da Prefeitura e nas escolas. Cartas convites com a programação anexa foram enviadas a todas as autoridades do município, incluindo secretários e vereadores, presidentes de entidades e instituições, pároco e pastores. As cartas convites endereçadas aos vereadores foram entregues em mãos durante a sessão mensal no dia 05 de março de 2012. A oficina foi divulgada no Jornal Diário da Região, no site da Prefeitura, através do envio de e-mails e de faixa na 
entrada da cidade. Os componentes do grupo Planejatur fizeram um trabalho corpo

a corpo, reforçando o convite à comunidade.

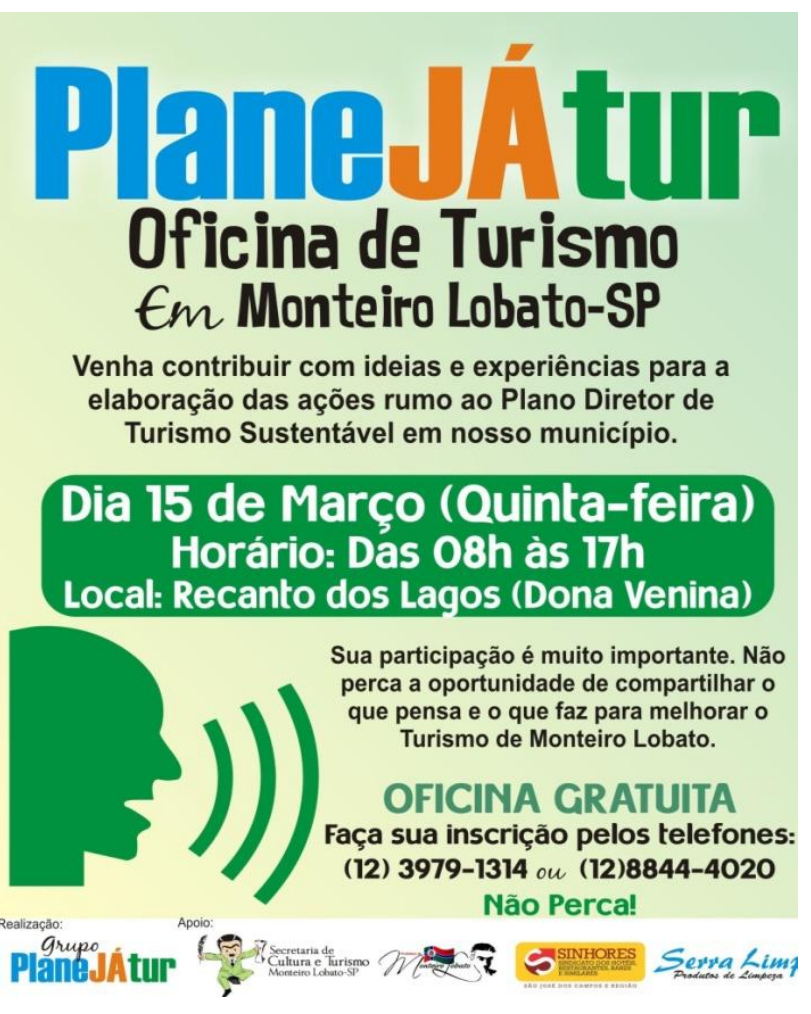

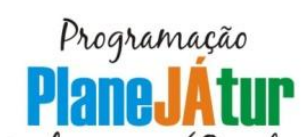

Dia 15 de marco (Quinta-feira)

08h00 - Recepção e café

$08 \mathrm{~h} 30$ - Abertura da oficina

$08 \mathrm{~h} 45$ - Entrega dos certificados aos alunos do curso de capacitação em Turismo Sustentável

09h00 - Início da oficina

Atividade 1: Apresentação dos participantes e levantamento das expectativas.

Atividade 2: Árvore dos problemas - em relação ao turismo no municipio. $12 \mathrm{~h} 00$ - Almoço Especial

$13 \mathrm{~h} 00$ - Retorno à oficina

Atividade 3: Árvore dos objetivos - em relação ao turismo de Monteiro Lobato.

Atividade 4: Construção da matriz de planejamento do projeto MPP. Atividade 5: Análise do potencial turistico de Monteiro Lobato. 15h15 - Café da tarde

$15 \mathrm{~h} 30$ - Retorno à oficina

Atividade 6: Análise do envolvimento de entidades, órgãos municipais, estaduais, federais, empresas e comunidade com o turismo do municipio. Atividade 7: Matriz de cooperação institucional para o turismo. Atividade 8: Formação de grupos de trabalho para implantar ações definidas.

17 h00 - Encerramento

Oficina gratuita

Figura 3 - Cartazete de divulgação da primeira Oficina

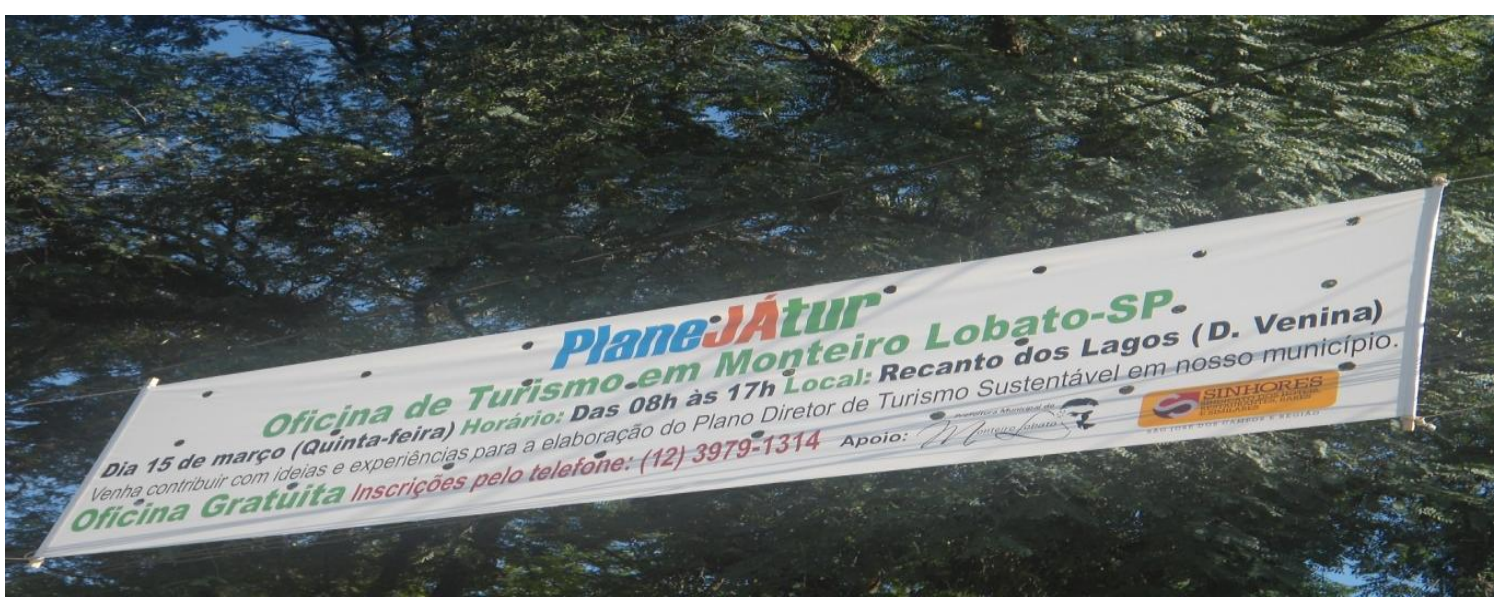

Foto 1 - Faixa de divulgação da primeira Oficina 


\section{ETAPAS DA OFICINA}

\section{ATIVIDADE 1: APRESENTAÇÃO DOS PARTICIPANTES}

No quadro de folha de papel Kraft, são colocados os tópicos abaixo e cada participante fixa a sua informação escrita em fichas e se apresenta de forma dinâmica e rápida.

\begin{tabular}{|c|c|c|}
\hline NOME & PROFISSÃO & UM SONHO PARA MONTEIRO LOBATO \\
\hline Alessandra & professora & união \\
\hline André Barreto & jornalista & moradores com orgulho da cidade \\
\hline Andrejs Ceruks & $\begin{array}{l}\text { engenheiro, aposentado, } \\
\text { agricultor }\end{array}$ & $\begin{array}{l}\text { conseguir para Monteiro Lobato o status de } \\
\text { Estância Turística }\end{array}$ \\
\hline Bruno & $\begin{array}{l}\text { estagiário Secretaria de Meio } \\
\text { Ambiente }\end{array}$ & se tornar mais conhecida e visitada \\
\hline Cecília & professora (Educação Física) & que seja o melhor para a cidade \\
\hline Célia & empresária & $\begin{array}{l}\text { que Monteiro Lobato possa prosperar também } \\
\text { através do Turismo }\end{array}$ \\
\hline César & $\begin{array}{l}\text { estagiário Secretaria de Cultura } \\
\text { e Turismo }\end{array}$ & que se torne conhecida internacionalmente \\
\hline Cida & do lar & melhorar a praça debaixo \\
\hline Daniela & gestora pública & $\begin{array}{l}\text { Monteiro Lobato - cidade referência nacional em } \\
\text { desenvolvimento sustentável }\end{array}$ \\
\hline Deise & comerciante & união \\
\hline Edjelson & comerciante e vereador & transformar Monteiro Lobato Estância Turística \\
\hline Ednea & $\begin{array}{l}\text { agente técnica de saúde } \\
\text { estadual }\end{array}$ & $\begin{array}{l}\text { conhecido como o melhor município em Turismo } \\
\text { Sustentável, melhores artesanatos da Serra da } \\
\text { Mantiqueira }\end{array}$ \\
\hline $\begin{array}{l}\text { Eduardo Rocha } \\
\text { Dellú }\end{array}$ & Secretário de Cultura e Turismo & continuidade \\
\hline Estefânia & atendente de comércio & $\begin{array}{l}\text { que nosso município seja reconhecido pelas } \\
\text { oportunidades de emprego sustentável. Que } \\
\text { todos tenham uma grande oportunidade de } \\
\text { crescer profissionalmente neste município. }\end{array}$ \\
\hline $\begin{array}{l}\text { Evandro } \\
\text { Damasceno }\end{array}$ & jornalista & $\begin{array}{l}\text { conscientização e compromisso dos cidadãos } \\
\text { para com o imenso potencial da cidade e do } \\
\text { município }\end{array}$ \\
\hline Fernanda & estagiária & $\begin{array}{l}\text { ver a cidade mais desenvolvida com mais } \\
\text { oportunidade para os jovens }\end{array}$ \\
\hline Gabriel Vargas & comerciante e prefeito & qualidade de vida para todos os munícipes \\
\hline Geminiano & engenheiro civil & Monteiro Lobato Estância Turística \\
\hline Higor & garçom & melhorar o campo e Turismo \\
\hline Irani & professora & união \\
\hline Jorge Moreira & engenheiro civil - PMML & interação \\
\hline
\end{tabular}

Quadro 17 - Apresentação e sonho dos participantes da primeira Oficina 


\begin{tabular}{|c|c|c|}
\hline NOME & PROFISSÃO & UM SONHO PARA MONTEIRO LOBATO \\
\hline Karina & empresária & $\begin{array}{l}\text { que a cidade de Monteiro Lobato se torne uma } \\
\text { cidade turística e que viva do Turismo! }\end{array}$ \\
\hline Larissa & estudante & $\begin{array}{l}\text { 1. shopping; 2. cursos para adolescentes; } 3 \text {. } \\
\text { mais festas }\end{array}$ \\
\hline Leila & mosaicista & Monteiro Lobato: cidade sustentável \\
\hline Luis Carlos Pip & comerciante e vereador & $\begin{array}{l}\text { fazer acontecer a sustentabilidade, promover a } \\
\text { dignidade }\end{array}$ \\
\hline $\begin{array}{l}\text { Manoel dos } \\
\text { Santos Almeida }\end{array}$ & lavrador & $\begin{array}{l}\text { divulgar e ensinar o Moçambique e a Catira - } \\
\text { manifestação cultural }\end{array}$ \\
\hline Mara & $\begin{array}{l}\text { professora e secretária de } \\
\text { Educação }\end{array}$ & uma administração moderna e participativa \\
\hline Marilene & $\begin{array}{l}\text { ecóloga e Secretária de Meio } \\
\text { Ambiente e Agricultura }\end{array}$ & $\begin{array}{l}\text { uma cidade sustentável e com qualidade de vida } \\
\text { para a população }\end{array}$ \\
\hline Mario & consultor de Feng Shui & Vá! Corra atrás do seu destino \\
\hline Michela & comerciante & $\begin{array}{l}\text { que comerciantes e moradores acreditem que } \\
\text { vale a pena investir, que aqui é o lugar! Que a } \\
\text { união vai fazer acontecer }\end{array}$ \\
\hline Mirna & boleira e artesã & $\begin{array}{l}\text { que a cidade cresça com o Turismo Sustentável } \\
\text { que possa ter oportunidades de empregos para } \\
\text { adolescentes. Uma galeria para expositores }\end{array}$ \\
\hline Odette & comerciante & $\begin{array}{l}\text { recebermos turista de maneira sustentável sem } \\
\text { perder nossas origens e cultura }\end{array}$ \\
\hline Olga & do lar & desenvolva nas áreas sociais e turísticas \\
\hline Regina Conrado & pecuarista & vê-la crescer como cidade turística \\
\hline Renato & artesão e guia de Turismo & virar Estância Turística com o seu plano diretor \\
\hline Ruth & doces artesanais & $\begin{array}{l}\text { 1. emprego para menores, 2. shopping, 3. cursos } \\
\text { profissionalizantes }\end{array}$ \\
\hline Silvia Conrado & berçarista & $\begin{array}{l}\text { Que desenvolva na área de Turismo sem perder } \\
\text { o chão caipira, respeitando a natureza sempre }\end{array}$ \\
\hline Sonia Mognon & $\begin{array}{l}\text { turismóloga atuando como } \\
\text { Coordenadora do Programa de } \\
\text { Qualificação - SINHORES }\end{array}$ & ter um futuro, por que não em Monteiro Lobato? \\
\hline Ulisses & funcionário público & $\begin{array}{l}\text { que a população tome conta que ela será a } \\
\text { responsável pela mudança social, cultural, } \\
\text { econômica e turística, enfim que o principal fator } \\
\text { de mudança será e deve ser o povo, atuante e } \\
\text { principal responsável pelo seu sucesso. Que o } \\
\text { Lobatense perceba que o dragão escondido em } \\
\text { cada um tem a força para mudar a realidade de } \\
\text { um povo nunca ocorrida. }\end{array}$ \\
\hline Venina & empresária & ver Monteiro Lobato brilhar no campo turístico \\
\hline
\end{tabular}

Quadro 17 - Apresentação e sonho dos participantes da primeira Oficina (continuação)

Os participantes preencheram fichas de inscrições (37 dos 48 participantes que assinaram a lista de presença), reproduzida a seguir: 
FICHAS DE INSCRIÇÃO - PLANEJÁTUR - OFICINA DE TURISMO - 15/03/2012

\begin{tabular}{|l|l|l|l|}
\hline Nome: & \multicolumn{2}{l|}{ Local de nascimento: } & Data de nascimento: \\
\hline Endereço: & E-mairro: & & \\
\hline Tel.: & & Cidade, Estado: \\
\hline Empresa: & & \\
\hline
\end{tabular}

Quadro 18 - Fichas de inscrição da primeira Oficina

\section{PARTICIPANTES}

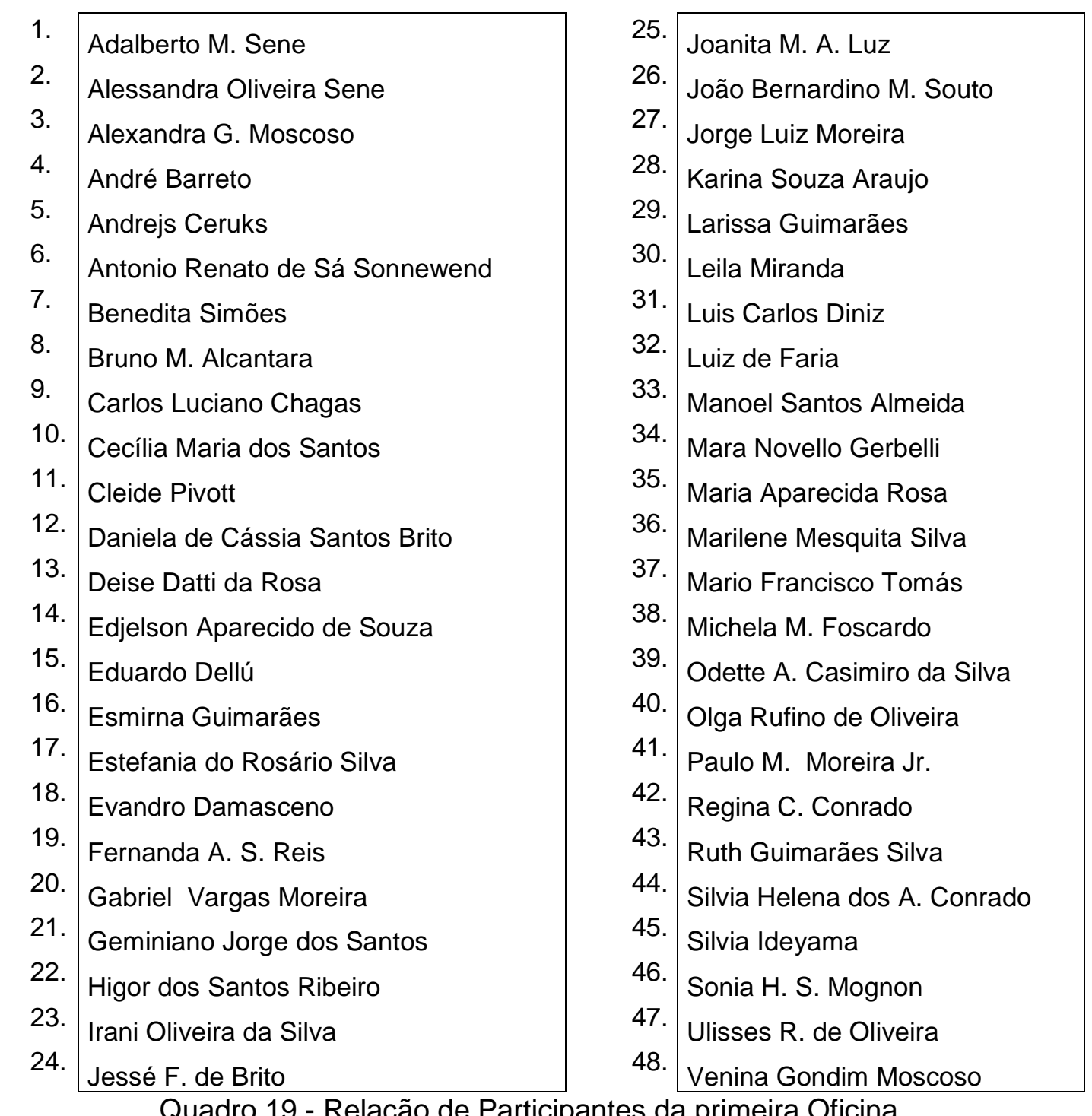

Quadro 19 - Relação de Participantes da primeira Oficina 
Após o evento, foi feita a seguinte tabulação representada nos Gráficos 1, 2 e 3.

Gráfico 1: como local de nascimento, 33\% (12) dos participantes nasceram em São José dos Campos e 22\% (8) em Monteiro Lobato. Porém, é um caso a ser investigado uma vez que o município não tem maternidade e as parturientes são levadas para as maternidades de São José dos Campos.

Gráfico 2: como local de residência, 81\% (30) moram em Monteiro Lobato.

Gráfico 3: indica o bairro de origem dos participantes que moram em Monteiro Lobato (31).

Estes dados são considerados importantes no sentido de que legitimam as informações que compõem a árvore dos problemas que reflete o pensamento de quem vive seu cotidiano no município.

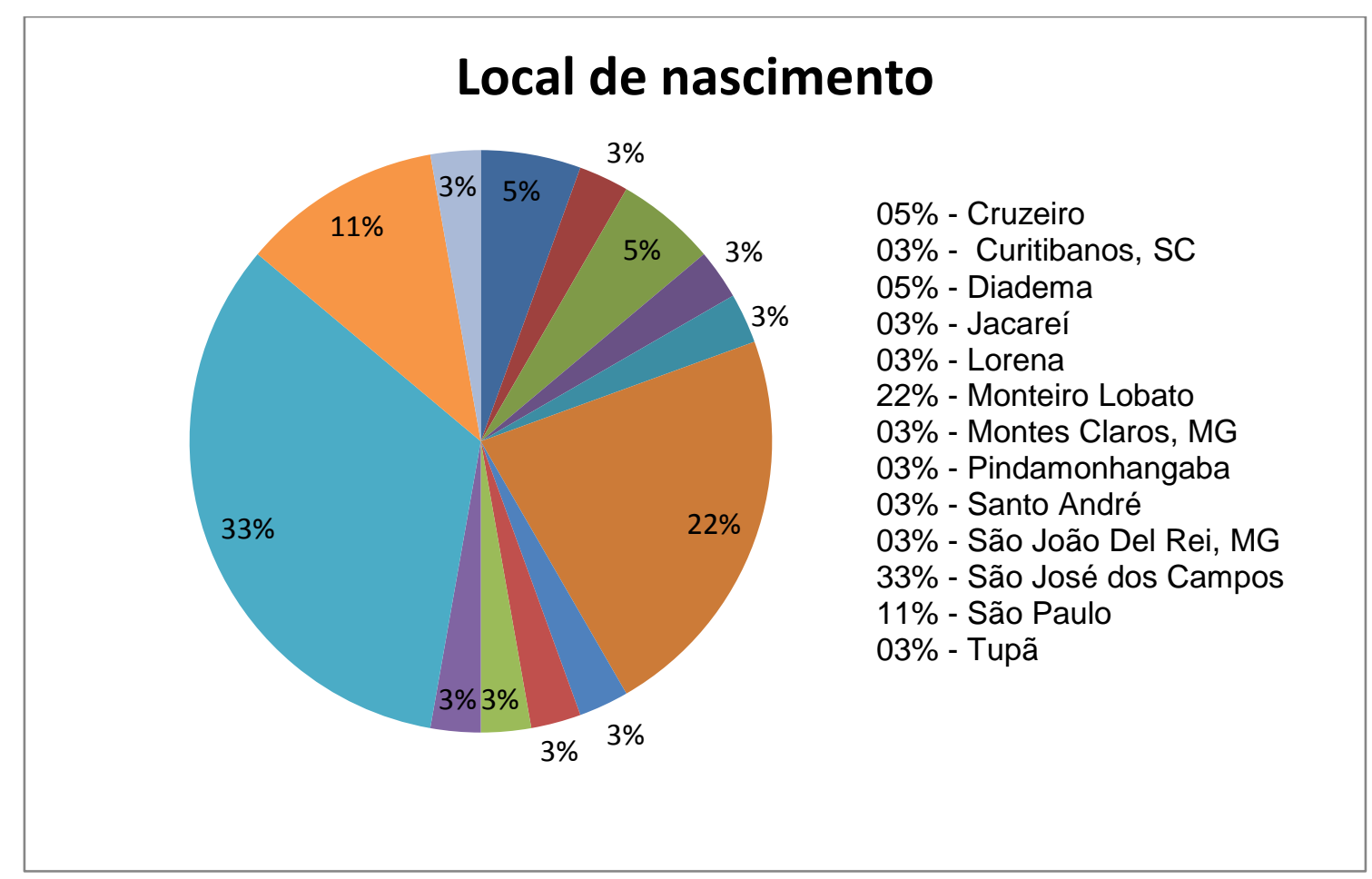

Gráfico 1 - Local de nascimento dos participantes da primeira Oficina 


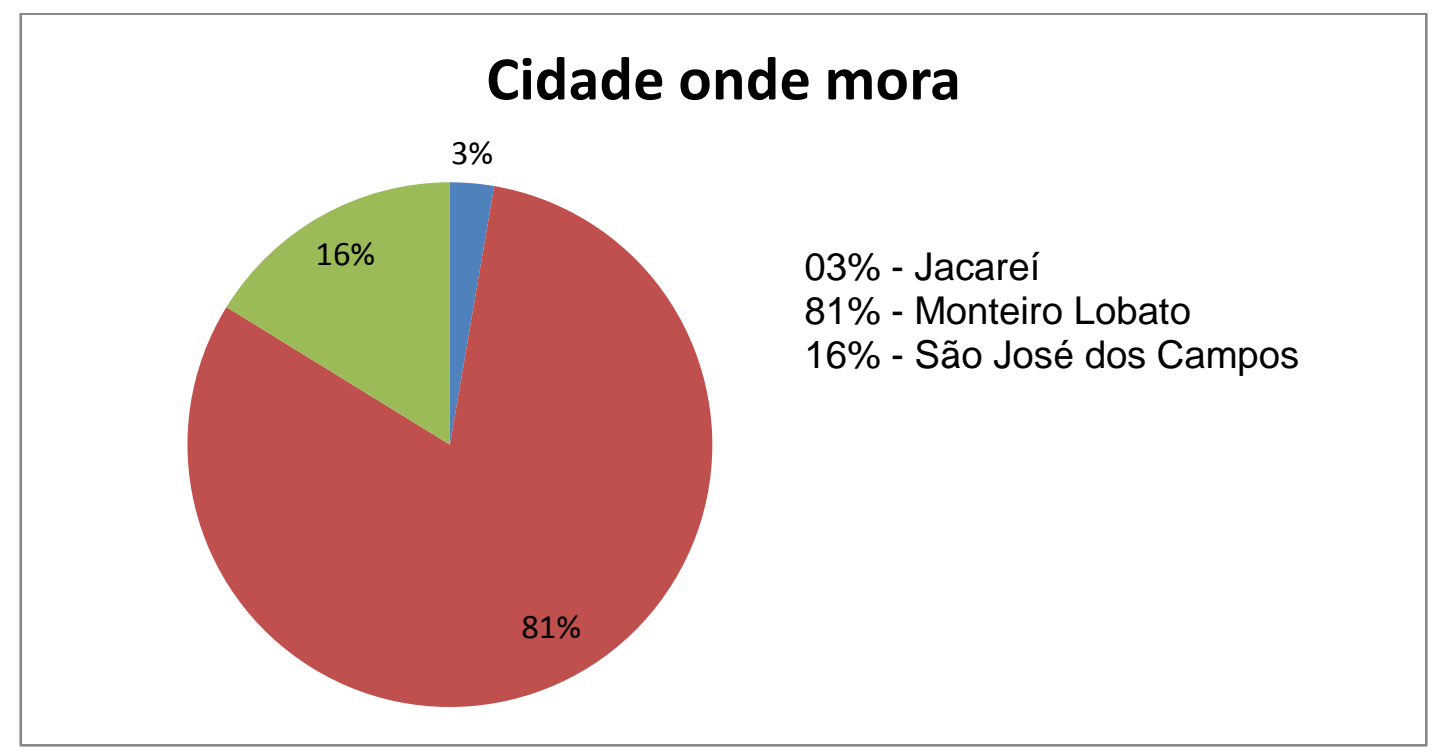

Gráfico 2 - Cidade de residência dos participantes da primeira Oficina

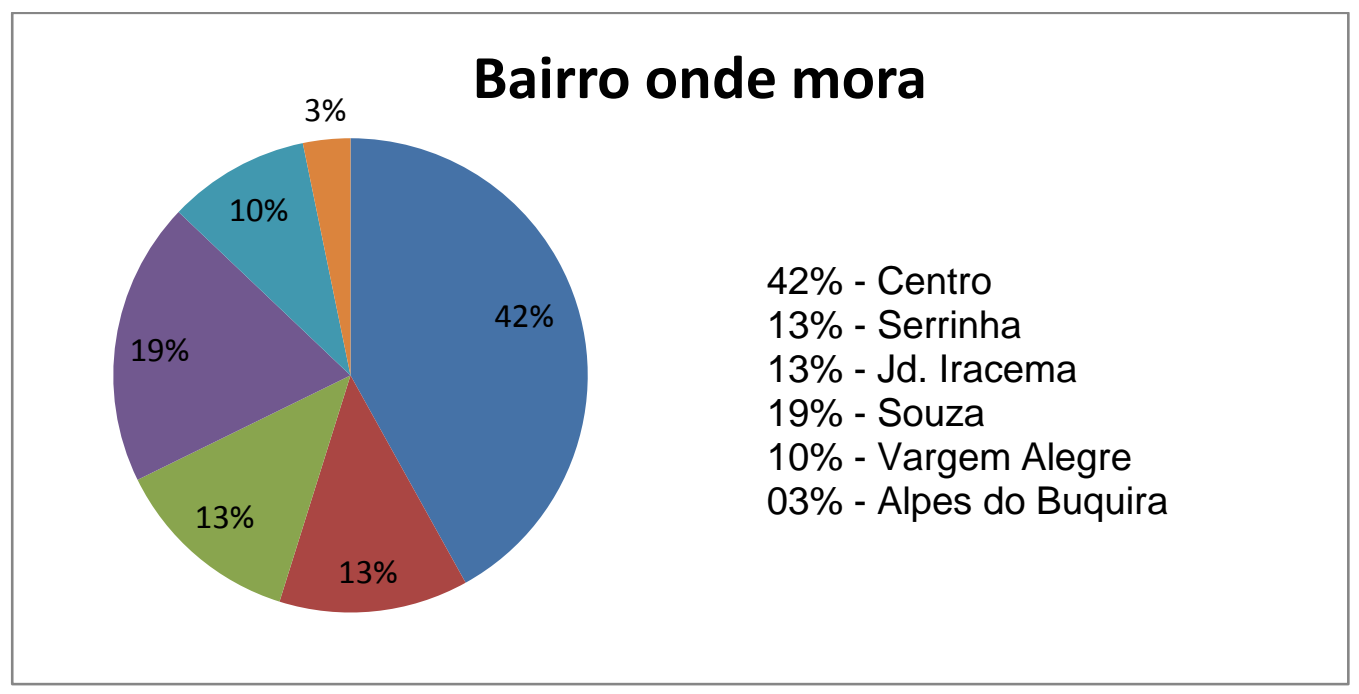

Gráfico 3 - Bairro onde mora - participantes da primeira Oficina

Monteiro Lobato possui 19 bairros, além da sede (centro), a saber:

\begin{tabular}{|l|l|l|}
\hline 1. Damião & 8. Rio do Braço & 15. Teixeiras \\
2. Descoberto & 9. Rio Manso & 16. Trabiju \\
3. Ferreira & 10. Santa Maria & 17. Turvo \\
4. Forros & 11. Santa Rita do Souza & 18. Vargem Alegre \\
5. Matinada & 12. São Benedito & 19. Visconde \\
6. Pedra Branca & 13. Serrinha & 20. Centro \\
7. Ponte Nova & 14. Taquari & \\
\hline
\end{tabular}

Quadro 20 - Relação de Bairros em Monteiro Lobato

Fonte: Moreira et al. (2004) 
Dos 37 participantes da Oficina que preencheram as fichas de inscrições, 31 moram em Monteiro Lobato, 5 em São José dos Campos e 1 em Jacareí.

Os participantes da Oficina, que moram em Monteiro Lobato, representam 6 bairros incluindo o Centro. Esse número indica uma representatividade de $22,5 \%$ do total de bairros:

\begin{tabular}{|l|r|}
\hline Centro & 13 \\
\hline Serrinha & 4 \\
\hline Jd. Iracema & 4 \\
\hline Souza & 6 \\
\hline Vargem Alegre & 3 \\
\hline Alpes do Buquira & 1 \\
\hline & 31 \\
\hline
\end{tabular}

Quadro 21 - Relação de bairros dos participantes da primeira Oficina

\section{ATIVIDADE 2: ÁRVORE DOS PROBLEMAS - EM RELAÇÃO AO TURISMO NO MUNICÍPIO}

É a base para que seja desenvolvida uma hierarquia de objetivos com diversas alternativas de soluções. Visa identificar os principais problemas e suas relações.

1. Sessão de tempestade de ideias para a pergunta norteadora: QUAIS SÃO OS PROBLEMAS QUE IMPEDEM O DESENVOLVIMENTO TURÍSTICO DE MONTEIRO LOBATO?;

2. as ideias são registradas em fichas e fixadas no quadro: "ÁRVORE DE PROBLEMAS" (cenário negativo);

3. análise de cada ideia e ordenação no quadro, eliminando-se as que se sobrepõem;

4. o critério é que as relações de CAUSA E EFEITO sejam diretas e essenciais;

5. a visualização permite que, com o desenvolvimento do trabalho, seja possível voltar a esse quadro sempre que o grupo sentir a necessidade. 


\section{Passo a passo:}

1. identificar os problemas centrais que existem dentro da situação;

2. formular os problemas como condições negativas;

3. escrever um problema por ficha;

4. identificar os problemas existentes e não os que são possíveis, imaginados ou futuros;

5. um problema não é a ausência de uma solução, mas sim um estado negativo existente;

6. a importância de um problema não se mede pela sua posição na hierarquia;

7. formular o problema central;

8. formular as causas do problema central;

9. formular os efeitos causados pelo problema central;

10. desenhar um diagrama representando as relações de causa-efeito sob a forma de uma hierarquia de problemas;

11. examinar o diagrama no seu todo, verificando se as conexões estão corretas e se não foram omitidas nenhumas relações das causas principais ou dos seus efeitos. 


\section{EFEITOS}

\section{PROBLEMA}

PRINCIPAL

\begin{tabular}{|l|l|l|}
\hline $\begin{array}{l}\text { falta de } \\
\text { investimentos } \\
\text { empresariais }\end{array}$ & risco ao meio ambiente & $\begin{array}{l}\text { falta de receita para a } \\
\text { cidade }\end{array}$ \\
\hline estagnação da cidade & fuga para outras cidades & $\begin{array}{l}\text { falta de fiscalização } \\
\text { (trânsito, comércio) }\end{array}$ \\
\hline baixa autoestima & Não há turistas & $\begin{array}{l}\text { falta de perspectivas para } \\
\text { jovens }\end{array}$ \\
\hline
\end{tabular}

FALTA DE

INFRAESTRUTURA

DA CIDADE E

TURÍSTICA
NECESSIDADE

DE MUDANÇA

DE

MENTALIDADE

\section{CAUSAS}

\begin{tabular}{|c|c|c|c|c|c|c|c|c|}
\hline EDUCAÇÃO & $\begin{array}{l}\text { INFRAESTRUTURA } \\
\text { TURÍSTICA }\end{array}$ & $\begin{array}{l}\text { INFRAESTRUTURA } \\
\text { DA CIDADE }\end{array}$ & COMUNICAÇÃO & COMPORTAMENTO & LEGISLAÇÃO & $\begin{array}{l}\text { SAÚDE } \\
\text { PÚBLICA }\end{array}$ & CULTURA & \begin{tabular}{|l} 
RECURSOS \\
FINANCEIROS \\
\end{tabular} \\
\hline
\end{tabular}




\begin{tabular}{|c|c|c|c|c|c|c|c|c|}
\hline EDUCAÇÃO & $\begin{array}{l}\text { INFRAESTRUTURA } \\
\text { TURÍSTICA }\end{array}$ & $\begin{array}{l}\text { INFRAESTRUTURA } \\
\text { DA CIDADE }\end{array}$ & COMUNICAÇÃO & COMPORTAMENTO & LEGISLAÇÃO & SAÚDE PÚBLICA & CULTURA & \begin{tabular}{|l|} 
RECURSOS \\
FINANCEIROS
\end{tabular} \\
\hline $\begin{array}{l}\text { falta divulgar, } \\
\text { ensinar Geografia } \\
\text { e História da } \\
\text { cidade }\end{array}$ & $\begin{array}{l}\text { sinalização e } \\
\text { informação turística } \\
\text { deficiente }\end{array}$ & $\begin{array}{l}\text { estacionamento } \\
\text { insuficiente para } \\
\text { turistas no centro da } \\
\text { cidade }\end{array}$ & $\begin{array}{l}\text { falta de telefone: e } \\
\text { internet na zona } \\
\text { rural }\end{array}$ & $\begin{array}{l}\text { falta ter uma visão } \\
\text { melhor do potencial } \\
\text { das pessoas }\end{array}$ & $\begin{array}{l}\text { "proibiçãa" fazer } \\
\text { valer a "lei de } \\
\text { proibição" de } \\
\text { tráfego de } \\
\text { carretas na } \\
\text { SP50 } \\
\end{array}$ & $\begin{array}{l}\text { há muitos } \\
\text { bêbados }\end{array}$ & $\begin{array}{l}\text { Eu, Manoel, peço mais } \\
\text { apoio para a cultura, o } \\
\text { Moçambique e Catira. O } \\
\text { grupo representa a cidade } \\
\text { no Vale do Paraíba e no } \\
\text { Revelando São Paulo. O } \\
\text { meu objetivo é que essa } \\
\text { cultura continue } \\
\text { melhorando mais para a } \\
\text { cidade de Monteiro } \\
\text { Lobato. }\end{array}$ & $\begin{array}{l}\text { não há recurso } \\
\text { financeiro para } \\
\text { pequenos } \\
\text { produtores, } \\
\text { artesão, enfim - } \\
\text { investir em } \\
\text { seres humanos } \\
\text { em potencial, } \\
\text { pois muitos se } \\
\text { sentem } \\
\text { desvalorizados } \\
\end{array}$ \\
\hline $\begin{array}{l}\text { não tem Turismo } \\
\text { regional para } \\
\text { moradores } \\
\text { conhecerem a } \\
\text { cidade e os pontos } \\
\text { turísticos }\end{array}$ & $\begin{array}{l}\text { falta informação } \\
\text { técnica na recepção } \\
\text { ao turista }\end{array}$ & $\begin{array}{l}\text { Turismo rural, } \\
\text { estradas ruins }\end{array}$ & $\begin{array}{l}\text { falta divulgação do } \\
\text { município }\end{array}$ & $\begin{array}{l}\text { falta integração das } \\
\text { iniciativas }\end{array}$ & $\begin{array}{l}\text { fazer valer a lei } \\
\text { da } \\
\text { acessibilidade }\end{array}$ & $\begin{array}{l}\text { falta um centro de } \\
\text { zoonose, há } \\
\text { muitos cachorros } \\
\text { pelas ruas e } \\
\text { bairros }\end{array}$ & $\begin{array}{l}\text { falta divulgação da cultura } \\
\text { popular: dança CACURIÁ, } \\
\text { que acontece no Bairro do } \\
\text { Souza }\end{array}$ & \\
\hline $\begin{array}{l}\text { faltam técnicos } \\
\text { para viabilizar } \\
\text { ideias e projetos }\end{array}$ & $\begin{array}{l}\text { falta museu para } \\
\text { expor toda a história } \\
\text { da cidade para ela } \\
\text { ser lembrada por } \\
\text { todos }\end{array}$ & $\begin{array}{l}\text { é cruel o que a } \\
\text { empresa de ônibus } \\
\text { faz com os idosos do } \\
\text { município. Cidadania } \\
\text { já! }\end{array}$ & $\begin{array}{l}\text { falta "saber" vender } \\
\text { para o turista a sua } \\
\text { cidade - o que ela } \\
\text { tem para oferecer!! }\end{array}$ & $\begin{array}{l}\text { falta de conselho de } \\
\text { Turismo atuante }\end{array}$ & $\begin{array}{l}\text { falta plano } \\
\text { diretor da cidade }\end{array}$ & & $\begin{array}{l}\text { utilizar os pereirões em } \\
\text { todas as festas }\end{array}$ & \\
\hline $\begin{array}{l}\text { falta de cursos } \\
\text { para } \\
\text { aperfeiçoamento } \\
\text { dos jovens }\end{array}$ & $\begin{array}{l}\text { faltam serviços } \\
\text { emergenciais para } \\
\text { final de final no } \\
\text { posto de saúde }\end{array}$ & $\begin{array}{l}\text { salário baixo para } \\
\text { funcionários-chave } \\
\text { da prefeitura. Ex.: } \\
\text { operador de } \\
\text { máquinas para } \\
\text { conservação de } \\
\text { estradas }\end{array}$ & $\begin{array}{l}\text { falta divulgar a } \\
\text { cidade para a nossa } \\
\text { população }\end{array}$ & falta de esperança & $\begin{array}{l}\text { falta reativar os } \\
\text { projetos } \\
\text { inativados } \\
\text { (engavetados) }\end{array}$ & & $\begin{array}{l}\text { remunerar os jovens que } \\
\text { movimentam os bonecos }\end{array}$ & \\
\hline $\begin{array}{l}\text { faltam cursos } \\
\text { profissionalizantes }\end{array}$ & $\begin{array}{l}\text { falta um ponto de } \\
\text { apoio turístico (CAT) }\end{array}$ & $\begin{array}{l}\text { falta de ação das } \\
\text { Polícias Civil e } \\
\text { militar. Estarem } \\
\text { presentes e servir os } \\
\text { cidadãos } \\
\end{array}$ & $\begin{array}{l}\text { falta divulgar a } \\
\text { cidade nas escolas }\end{array}$ & $\begin{array}{l}\text { falta acreditar no } \\
\text { potencial turístico }\end{array}$ & $\begin{array}{l}\text { faltam incentivos } \\
\text { fiscais para que } \\
\text { empresas se } \\
\text { instalem na } \\
\text { cidade } \\
\end{array}$ & & & \\
\hline $\begin{array}{l}\text { falta inserir o } \\
\text { adolescente no } \\
\text { processo cultural e } \\
\text { turístico da cidade }\end{array}$ & $\begin{array}{l}\text { o próprio morador } \\
\text { não conhece a } \\
\text { cidade }\end{array}$ & $\begin{array}{l}\text { eletricidade na zona } \\
\text { rural (rede precária } \\
\text { com interrupções e } \\
\text { danos aos } \\
\text { eletrodomésticos e } \\
\text { outros equipamentos } \\
\text { elétricos) }\end{array}$ & $\begin{array}{l}\text { falta divulgar a } \\
\text { cidade na mídia }\end{array}$ & $\begin{array}{l}\text { falta de interesse } \\
\text { político }\end{array}$ & $\begin{array}{l}\text { falta lei para } \\
\text { proibir som } \\
\text { automotivo }\end{array}$ & & & \\
\hline
\end{tabular}




\begin{tabular}{|c|c|c|c|c|c|c|c|c|}
\hline EDUCAÇÃO & $\begin{array}{l}\text { INFRAESTRUTURA } \\
\text { TURISTICA }\end{array}$ & $\begin{array}{l}\text { INFRAESTRUTURA } \\
\text { DA CIDADE }\end{array}$ & COMUNICAÇÃO & COMPORTAMENTO & LEGISLAÇÃO & $\begin{array}{l}\text { SAÚDE } \\
\text { PÚBLICA }\end{array}$ & CULTURA & \begin{tabular}{|l} 
RECURSOS \\
FINANCEIROS
\end{tabular} \\
\hline $\begin{array}{l}\text { o Lobatense precisa conhecer } \\
\text { o escritor Monteiro Lobalto }\end{array}$ & $\begin{array}{l}\text { dar mais atenção aos } \\
\text { artesãos e condições } \\
\text { de evoluire } \\
\text { comercializar os seus } \\
\text { trabalhos }\end{array}$ & falta banheiro público & $\begin{array}{l}\text { falta sinalização } \\
\text { viária }\end{array}$ & $\begin{array}{l}\text { falta de união dos } \\
\text { munícipes }\end{array}$ & $\begin{array}{l}\text { faltam políticos } \\
\text { mais capacitados }\end{array}$ & & & \\
\hline $\begin{array}{l}\text { faltam empreendedores e } \\
\text { educação empreendedora }\end{array}$ & $\begin{array}{l}\text { falta oportunidade de } \\
\text { trabalho aos jovens }\end{array}$ & $\begin{array}{l}\text { falta energia de } \\
\text { qualidade }\end{array}$ & $\begin{array}{l}\text { comércio - moradores } \\
\text { não sabem o que } \\
\text { acontece na cidade. } \\
\text { Ex. quando vereador } \\
\text { faz algo bom, só } \\
\text { somos informados } \\
\text { das coisas ruins } \\
\end{array}$ & \begin{tabular}{|l} 
parar com o \\
individualismo (parar \\
de olhar para o \\
próprio umbigo) \\
\end{tabular} & $\begin{array}{l}\text { falta organizar os } \\
\text { ambulantes }\end{array}$ & & & \\
\hline $\begin{array}{l}\text { Faltam projetos escolares } \\
\text { (envolver alunos) voltados ao } \\
\text { Turismo historico e cultural }\end{array}$ & $\begin{array}{l}\text { falta um mercadão } \\
\text { para todos os tipos } \\
\text { de produtos do } \\
\text { município }\end{array}$ & $\begin{array}{l}\text { iluminar as entradas } \\
\text { dos bairros para } \\
\text { melhorar segurança } \\
\text { dos moradores }\end{array}$ & $\begin{array}{l}\text { não há oportunidades } \\
\text { de divulgaçōes de } \\
\text { produtos feitos na } \\
\text { regiâo }\end{array}$ & $\begin{array}{l}\text { falta de amor próprio, } \\
\text { gostar do lugar onde } \\
\text { reside }\end{array}$ & $\begin{array}{l}\text { falta regularizar os } \\
\text { ambulantes na sua } \\
\text { área - trabalhar } \\
\text { livremente }\end{array}$ & & & \\
\hline $\begin{array}{l}\text { faltam motivacão para estudos } \\
\text { (cursos superiores) }\end{array}$ & $\begin{array}{l}\text { não tem placas de } \\
\text { indicação de lugares, } \\
\text { cachoeira, pesqueiro, } \\
\text { pousadas }\end{array}$ & $\begin{array}{l}\text { falta estruturação } \\
\text { física e de uso do } \\
\text { poliesportivo }\end{array}$ & $\begin{array}{l}\text { divulgação de pontos } \\
\text { turísticos }\end{array}$ & $\begin{array}{l}\text { parar de esperar tudo } \\
\text { do poder público }\end{array}$ & \begin{tabular}{|l} 
falta tribuna livre \\
para a população \\
expor críticas e \\
elogios na Câmara \\
de Vereadores \\
\end{tabular} & & & \\
\hline $\begin{array}{l}\text { Não temos supletivo para } \\
\text { adolescentes evadidos e que } \\
\text { querem voltar a estudar }\end{array}$ & $\begin{array}{l}\text { não temos apoio para } \\
\text { eventos }\end{array}$ & $\begin{array}{l}\text { falta uma piscina } \\
\text { para a população em } \\
\text { geral de Monteiro } \\
\text { Lobato }\end{array}$ & $\begin{array}{l}\text { não temos mapa } \\
\text { turístico }\end{array}$ & $\begin{array}{l}\text { falta interesse } \\
\text { político. Briga-se } \\
\text { muito, faz-se muito } \\
\text { pouco pelo municííio }\end{array}$ & & & & \\
\hline biblioteca em local adequado & $\begin{array}{l}\text { falta aperfeiçoar } \\
\text { pereirão } \\
\text { (artisticamente) e } \\
\text { artesanato }\end{array}$ & $\begin{array}{l}\text { O ginásio } \\
\text { poliesportivo não está } \\
\text { sendo utilizado para } \\
\text { a finalidade principal } \\
\text { que seria ter } \\
\text { equipamentos, } \\
\text { inclusive piscina para } \\
\text { treinar os jovens } \\
\text { visando seu } \\
\text { aproveitamento em } \\
\text { jogos intermunicipais } \\
\text { e até mesmo } \\
\text { olímpicos } \\
\end{array}$ & falta rádio & \begin{tabular}{|l} 
falta sensibilização \\
para os assuntos de \\
Turismo. \\
"comunidade - poder \\
público - setor \\
privado" \\
\end{tabular} & & & & \\
\hline
\end{tabular}




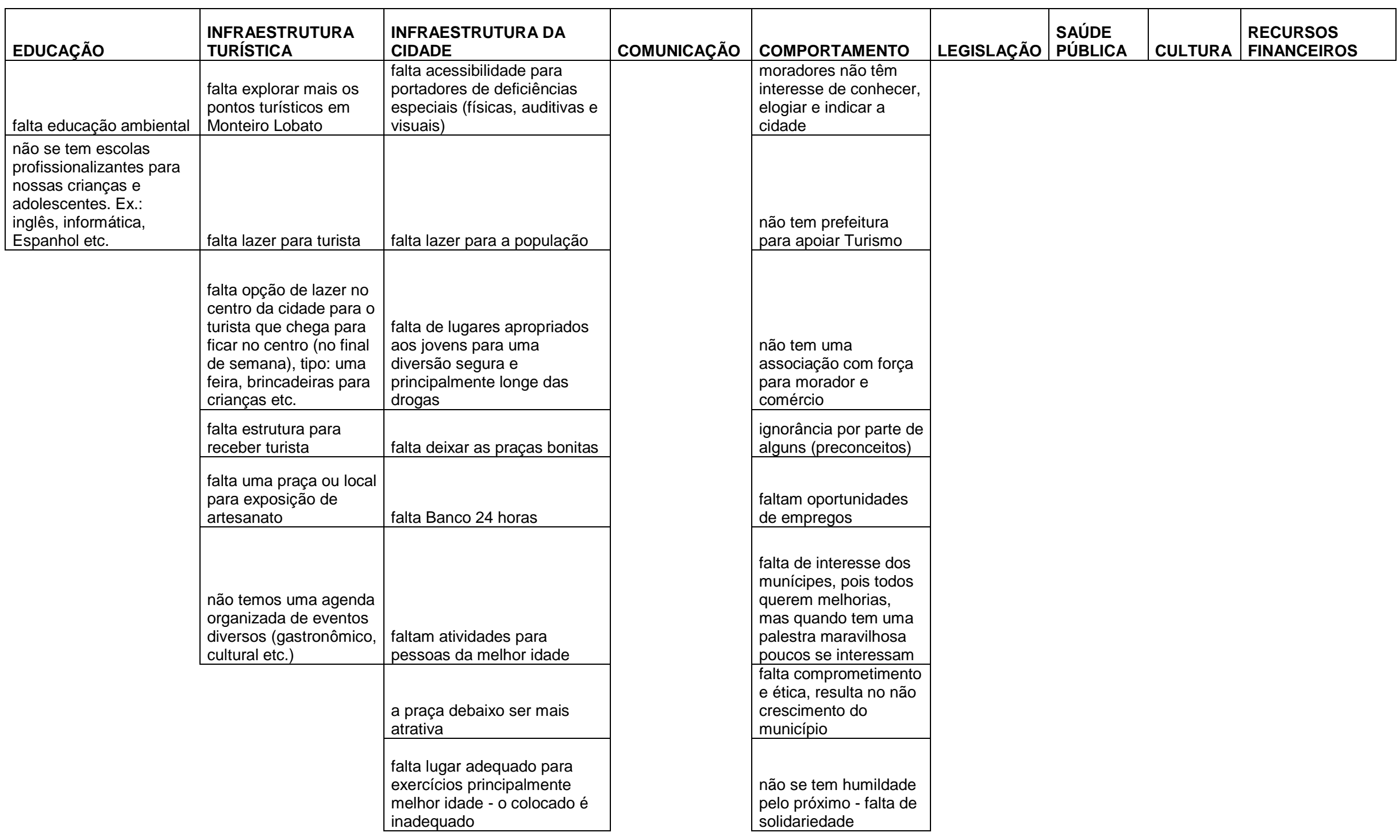




\begin{tabular}{|c|c|c|c|c|c|c|c|c|}
\hline EDUCAÇÃO & $\begin{array}{l}\text { INFRAESTRUTURA } \\
\text { TURÍSTICA }\end{array}$ & $\begin{array}{l}\text { INFRAESTRUTURA } \\
\text { DA CIDADE }\end{array}$ & COMUNICAÇÃO & COMPORTAMENTO & \multirow[t]{12}{*}{ LEGISLAÇÃO } & \multirow[t]{12}{*}{$\begin{array}{l}\text { SAÚDE } \\
\text { PÚBLICA }\end{array}$} & \multirow[t]{12}{*}{ CULTURA } & \multirow[t]{12}{*}{$\begin{array}{l}\text { RECURSOS } \\
\text { FINANCEIROS }\end{array}$} \\
\hline & & & & $\begin{array}{l}\text { o Lobatense não } \\
\text { deve ter medo do } \\
\text { progresso }\end{array}$ & & & & \\
\hline & & & & tratar todos iguais & & & & \\
\hline & & & & $\begin{array}{l}\text { falta de união dos } \\
\text { empresários }\end{array}$ & & & & \\
\hline & & & & $\begin{array}{l}\text { fazer mais pela } \\
\text { nossa cidade, cuidar } \\
\text { dos espaços } \\
\text { públicos, zelar pela } \\
\text { limpeza e segurança } \\
\text { e não depredação } \\
\text { não se pode viver só } \\
\text { em um poder político } \\
\text { e de hierarquia, } \\
\text { somos livres e temos } \\
\text { que lutar } \\
\end{array}$ & & & & \\
\hline & & & & $\begin{array}{l}\text { falta continuidade } \\
\text { nos projetos }\end{array}$ & & & & \\
\hline & & & & $\begin{array}{l}\text { Aqui é muito "eu } \\
\text { posso, você não", só } \\
\text { que não faz nada } \\
\text { para a mudança }\end{array}$ & & & & \\
\hline & & & & $\begin{array}{l}\text { muitas ideias, pouco } \\
\text { incentivo }\end{array}$ & & & & \\
\hline & & & & $\begin{array}{l}\text { valorizar o povo } \\
\text { daqui }\end{array}$ & & & & \\
\hline & & & & $\begin{array}{l}\text { a grandeza da } \\
\text { cidade depende da } \\
\text { participação do seu } \\
\text { povo. Chega de } \\
\text { passividade! }\end{array}$ & & & & \\
\hline & & & & $\begin{array}{l}\text { não valorizamos os } \\
\text { historiadores da } \\
\text { cidade }\end{array}$ & & & & \\
\hline & & & & $\begin{array}{l}\text { falta sociedade civil } \\
\text { organizada }\end{array}$ & & & & \\
\hline
\end{tabular}




\section{ATIVIDADE 3: ÁRVORE DOS OBJETIVOS - EM RELAÇÃO AO TURISMO NO MUNICÍPIO}

A partir do cenário negativo, os participantes são estimulados a elaborar um cenário positivo que resulta na "ÁRVORES DOS OBJETIVOS". A análise de objetivos descreve a situação futura que será alcançada quando os problemas forem resolvidos e identifica possíveis alternativas para o projeto.

\section{Passo a passo:}

1. reformular todas as condições negativas da hierarquia de problemas, convertendo-as em condições positivas que sejam desejáveis e realisticamente alcançáveis;

2. examinar as relações meios-fins, verificando se as conexões estão corretas e se não foram omitidas nenhumas relações importantes;

3. Se necessário:

d) alterar as formulações;

e) acrescentar novos objetivos, se estes forem necessários para alcançar o objetivo formulado no nível imediatamente superior;

f) suprimir objetivos que não pareçam desejáveis ou necessários. 


\begin{tabular}{|c|}
\hline ÁRVORE DOS \\
OBJETIVOS
\end{tabular}

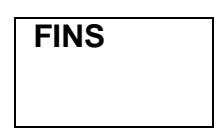

\begin{tabular}{|l|l|l|}
\hline há investimentos empresariais & $\begin{array}{l}\text { o meio } \\
\text { ambiente é } \\
\text { preservado }\end{array}$ & a cidade tem receita \\
\hline $\begin{array}{l}\text { dinamismo da cidade } \\
\text { (desenvolvimento) }\end{array}$ & $\begin{array}{l}\text { Permanência } \\
\text { dos munícipes }\end{array}$ & $\begin{array}{l}\text { há fiscalização (trânsito e } \\
\text { comércio) }\end{array}$ \\
\hline alta autoestima & $\begin{array}{l}\text { atração de } \\
\text { turistas }\end{array}$ & $\begin{array}{l}\text { há perspectivas para os } \\
\text { jovens }\end{array}$ \\
\hline
\end{tabular}

\begin{tabular}{|c|c|c|c|c|c|}
\hline $\begin{array}{l}\text { OBJETIVO } \\
\text { CENTRAL }\end{array}$ & $\begin{array}{l}\text { há } \\
\text { infraestruturas } \\
\text { da cidade e } \\
\text { turística }\end{array}$ & mais & há educação & igual a & $\begin{array}{l}\text { há mudança } \\
\text { de } \\
\text { mentalidade }\end{array}$ \\
\hline
\end{tabular}

\begin{tabular}{|c|c|c|c|c|c|c|c|c|c|}
\hline MEIOS & $\begin{array}{l}\text { RESULTADO } \\
1\end{array}$ & $\begin{array}{l}\text { RESULTADO } \\
2\end{array}$ & $\begin{array}{l}\text { RESULTADO } \\
3\end{array}$ & RESULTADO 4 & $\begin{array}{l}\text { RESULTADO } \\
5\end{array}$ & $\begin{array}{l}\text { RESULTADO } \\
6\end{array}$ & $\begin{array}{l}\text { RESULTADO } \\
7\end{array}$ & $\begin{array}{l}\text { RESULTADO } \\
8\end{array}$ & $\begin{array}{l}\text { RESULTADO } \\
9\end{array}$ \\
\hline & EDUCAÇÃO & $\begin{array}{l}\text { INFRA- } \\
\text { ESTRUTURA } \\
\text { TURÍSTICA }\end{array}$ & $\begin{array}{l}\text { INFRA- } \\
\text { ESTRUTURA } \\
\text { DA CIDADE }\end{array}$ & $\begin{array}{l}\text { COMUNICA- } \\
\text { ÇÃO }\end{array}$ & $\begin{array}{l}\text { COMPORTA- } \\
\text { MENTO }\end{array}$ & $\begin{array}{l}\text { LEGISLA- } \\
\text { ÇÃO }\end{array}$ & SAÚDE PÚBLICA & CULTURA & $\begin{array}{l}\text { RECURSOS } \\
\text { FINANCEI- } \\
\text { ROS }\end{array}$ \\
\hline
\end{tabular}

Quadro 23 - Árvore dos Objetivos (continua) 


\begin{tabular}{|c|c|c|c|c|c|c|c|c|}
\hline EDUCAÇÃO & \begin{tabular}{|l|} 
INFRAESTRUTURA \\
TURÍSTICA
\end{tabular} & $\begin{array}{l}\text { INFRAESTRUTURA } \\
\text { DA CIDADE }\end{array}$ & COMUNICAÇÃO & COMPORTAMENTO & LEGISLAÇÃO & $\begin{array}{l}\text { SAÚDE } \\
\text { PÚBLICA }\end{array}$ & CULTURA & \begin{tabular}{|l|} 
RECURSOS \\
FINANCEIROS
\end{tabular} \\
\hline $\begin{array}{l}\text { a Geografia e a } \\
\text { História da } \\
\text { cidade são } \\
\text { divulgadas e } \\
\text { ensinadas }\end{array}$ & $\begin{array}{l}\text { a sinalização e a } \\
\text { informação turística } \\
\text { são suficientes }\end{array}$ & $\begin{array}{l}\text { há estacionamento } \\
\text { suficiente para } \\
\text { turistas no centro da } \\
\text { cidade }\end{array}$ & $\begin{array}{l}\text { há telefone e } \\
\text { internet na zona } \\
\text { rural }\end{array}$ & $\begin{array}{l}\text { há uma visão melhor } \\
\text { do potencial das } \\
\text { pessoas }\end{array}$ & $\begin{array}{l}\text { a lei que } \\
\text { proíbe o } \\
\text { tráfego de } \\
\text { carretas na } \\
\text { SP50 é } \\
\text { cumprida }\end{array}$ & $\begin{array}{l}\text { os muitos } \\
\text { bêbados da } \\
\text { cidade } \\
\text { recebem } \\
\text { assistência } \\
\text { social }\end{array}$ & $\begin{array}{l}\text { Há mais } \\
\text { apoio para a } \\
\text { cultura, o } \\
\text { Moçambique } \\
\text { e Catira. }\end{array}$ & \begin{tabular}{|l} 
há recurso \\
financeiro para \\
pequenos \\
produtores, \\
artesão. Há \\
investimento \\
em seres \\
humanos em \\
potencial, e \\
eles se sentem \\
valorizados
\end{tabular} \\
\hline $\begin{array}{l}\text { há Turismo } \\
\text { regional para } \\
\text { moradores } \\
\text { conhecerem a } \\
\text { cidade e os } \\
\text { pontos turísticos }\end{array}$ & $\begin{array}{l}\text { há informação } \\
\text { técnica na recepção } \\
\text { ao turista }\end{array}$ & $\begin{array}{l}\text { há Turismo rural, as } \\
\text { estradas são boas }\end{array}$ & $\begin{array}{l}\text { há divulgação do } \\
\text { município }\end{array}$ & $\begin{array}{l}\text { há integração das } \\
\text { iniciativas }\end{array}$ & $\begin{array}{l}\text { a lei da } \\
\text { acessibilidade } \\
\text { é cumprida }\end{array}$ & $\begin{array}{l}\text { há um centro } \\
\text { de zoonose, } \\
\text { não há } \\
\text { cachorros } \\
\text { abandonados } \\
\text { pelas ruas e } \\
\text { bairros }\end{array}$ & $\begin{array}{l}\text { há divulgação } \\
\text { da cultura } \\
\text { popular: } \\
\text { dança } \\
\text { CACURIÁ, } \\
\text { que acontece } \\
\text { no Bairro do } \\
\text { Souza }\end{array}$ & \\
\hline $\begin{array}{l}\text { há técnicos para } \\
\text { viabilizar ideias } \\
\text { e projetos }\end{array}$ & $\begin{array}{l}\text { há museu para } \\
\text { expor toda a história } \\
\text { da cidade para ela } \\
\text { ser lembrada por } \\
\text { todos }\end{array}$ & $\begin{array}{l}\text { a empresa de } \\
\text { ônibus trata bem os } \\
\text { idosos do município. }\end{array}$ & $\begin{array}{l}\text { "sabe-se" vender } \\
\text { para o turista a } \\
\text { sua cidade - o } \\
\text { que ela tem para } \\
\text { oferecer!! }\end{array}$ & $\begin{array}{l}\text { o conselho de } \\
\text { Turismo é atuante }\end{array}$ & $\begin{array}{l}\text { a cidade tem } \\
\text { plano diretor } \\
\text { de Turismo }\end{array}$ & & $\begin{array}{l}\text { os pereirões } \\
\text { são utilizados } \\
\text { em todas as } \\
\text { festas }\end{array}$ & \\
\hline
\end{tabular}




\begin{tabular}{|c|c|c|c|c|c|c|c|c|}
\hline EDUCAÇÃO & $\begin{array}{l}\text { INFRAESTRUTURA } \\
\text { TURÍSTICA }\end{array}$ & $\begin{array}{l}\text { INFRAESTRUTURA } \\
\text { DA CIDADE }\end{array}$ & COMUNICAÇÃO & COMPORTAMENTO & LEGISLAÇÃO & $\begin{array}{l}\text { SAÚDE } \\
\text { PÚBLICA }\end{array}$ & CULTURA & $\begin{array}{l}\text { RECURSOS } \\
\text { FINANCEIROS }\end{array}$ \\
\hline $\begin{array}{l}\text { há cursos para } \\
\text { aperfeiçoamento } \\
\text { dos jovens }\end{array}$ & $\begin{array}{l}\text { há serviços } \\
\text { emergenciais para } \\
\text { final de final no } \\
\text { posto de saúde }\end{array}$ & \begin{tabular}{|l|} 
há salário \\
compatível com o \\
mercado regional \\
para funcionários- \\
chave da prefeitura. \\
Ex.: operador de \\
máquinas para \\
conservação de \\
estradas
\end{tabular} & $\begin{array}{l}\text { a cidade é } \\
\text { divulgada para a } \\
\text { nossa população }\end{array}$ & há esperança & $\begin{array}{l}\text { os projetos } \\
\text { inativados são } \\
\text { resgatados e } \\
\text { realizados }\end{array}$ & & $\begin{array}{l}\text { os jovens que } \\
\text { movimentam } \\
\text { os bonecos } \\
\text { pereirões são } \\
\text { remunerados }\end{array}$ & $\begin{array}{l}\text { há cursos para } \\
\text { aperfeiçoamento } \\
\text { dos jovens }\end{array}$ \\
\hline $\begin{array}{l}\text { há cursos } \\
\text { profissionalizantes }\end{array}$ & $\begin{array}{l}\text { há um ponto de } \\
\text { apoio turístico (CAT) }\end{array}$ & $\begin{array}{l}\text { há ação eficaz das } \\
\text { Polícias Civil e } \\
\text { Militar. Estão } \\
\text { presentes e servem } \\
\text { os cidadãos }\end{array}$ & $\begin{array}{l}\text { a cidade é } \\
\text { divulgada nas } \\
\text { escolas }\end{array}$ & $\begin{array}{l}\text { acredita-se no } \\
\text { potencial turístico }\end{array}$ & $\begin{array}{l}\text { há incentivos } \\
\text { fiscais para } \\
\text { que empresas } \\
\text { se instalem na } \\
\text { cidade }\end{array}$ & & & \\
\hline $\begin{array}{l}\text { o adolescente } \\
\text { está inserido no } \\
\text { processo cultural } \\
\text { e turístico da } \\
\text { cidade }\end{array}$ & $\begin{array}{l}\text { os moradores } \\
\text { conhecem a cidade }\end{array}$ & $\begin{array}{l}\text { a eletricidade na } \\
\text { zona rural é } \\
\text { eficiente (não há } \\
\text { interrupções e } \\
\text { danos aos } \\
\text { eletrodomésticos e } \\
\text { outros } \\
\text { equipamentos } \\
\text { elétricos) }\end{array}$ & $\begin{array}{l}\text { a cidade é } \\
\text { divulgada na } \\
\text { mídia }\end{array}$ & há interesse político & $\begin{array}{l}\text { há lei para } \\
\text { proibir som } \\
\text { automotivo }\end{array}$ & & & \\
\hline $\begin{array}{l}\text { o Lobatense } \\
\text { conhece o } \\
\text { escritor Monteiro } \\
\text { Lobalto e suas } \\
\text { obras }\end{array}$ & $\begin{array}{l}\text { os artesãos recebem } \\
\text { mais atenção e têm } \\
\text { condições de evoluir } \\
\text { e comercializar os } \\
\text { seus trabalhos }\end{array}$ & há banheiro público & $\begin{array}{l}\text { há sinalização } \\
\text { viária }\end{array}$ & $\begin{array}{l}\text { há união entre os } \\
\text { munícipes }\end{array}$ & $\begin{array}{l}\text { há políticos } \\
\text { mais } \\
\text { capacitados }\end{array}$ & & & \\
\hline
\end{tabular}




\begin{tabular}{|c|c|c|c|c|c|c|c|c|}
\hline EDUCAÇÃO & $\begin{array}{l}\text { INFRAESTRUTURA } \\
\text { TURÍSTICA }\end{array}$ & $\begin{array}{l}\text { INFRAESTRUTURA } \\
\text { DA CIDADE }\end{array}$ & COMUNICAÇÃO & COMPORTAMENTO & LEGISLAÇÃO & $\begin{array}{l}\text { SAÚDE } \\
\text { PÚBLICA }\end{array}$ & CULTURA & $\begin{array}{l}\text { RECURSOS } \\
\text { FINANCEIROS }\end{array}$ \\
\hline $\begin{array}{l}\text { há } \\
\text { empreendedores } \\
\text { e educação } \\
\text { empreendedora }\end{array}$ & $\begin{array}{l}\text { há oportunidade de } \\
\text { trabalho aos jovens }\end{array}$ & $\begin{array}{l}\text { há energia de } \\
\text { qualidade }\end{array}$ & $\begin{array}{l}\text { comércio - } \\
\text { moradores } \\
\text { sabem o que } \\
\text { acontece na } \\
\text { cidade. Ex. há } \\
\text { divulgação do } \\
\text { que o vereador } \\
\text { faz de bom }\end{array}$ & $\begin{array}{l}\text { iniciar parcerias e } \\
\text { solidariedade, o } \\
\text { munícipe olha o } \\
\text { coletivo }\end{array}$ & $\begin{array}{l}\text { há organização } \\
\text { no setor dos } \\
\text { ambulantes }\end{array}$ & & & \\
\hline $\begin{array}{l}\text { há projetos } \\
\text { escolares que } \\
\text { envolvem alunos } \\
\text { em temas } \\
\text { voltados ao } \\
\text { Turismo } \\
\text { histórico e } \\
\text { cultural }\end{array}$ & $\begin{array}{l}\text { há um mercadão } \\
\text { para todos os tipos } \\
\text { de produtos do } \\
\text { município }\end{array}$ & $\begin{array}{l}\text { as entradas dos } \\
\text { bairros são } \\
\text { iluminadas para a } \\
\text { segurança dos } \\
\text { moradores }\end{array}$ & $\begin{array}{l}\text { há oportunidades } \\
\text { de divulgações } \\
\text { de produtos } \\
\text { feitos na região }\end{array}$ & $\begin{array}{l}\text { o Lobatense tem } \\
\text { amor próprio, gosta } \\
\text { do lugar onde reside }\end{array}$ & $\begin{array}{l}\text { há } \\
\text { regularização } \\
\text { para os } \\
\text { ambulantes na } \\
\text { sua área - } \\
\text { trabalharem } \\
\text { livremente }\end{array}$ & & & \\
\hline $\begin{array}{l}\text { há motivação } \\
\text { para estudos } \\
\text { (cursos } \\
\text { superiores) }\end{array}$ & $\begin{array}{l}\text { há placas de } \\
\text { indicação de } \\
\text { lugares, cachoeira, } \\
\text { pesqueiro, } \\
\text { pousadas }\end{array}$ & $\begin{array}{l}\text { o poliesportivo tem } \\
\text { estruturação física e } \\
\text { de uso }\end{array}$ & $\begin{array}{l}\text { há divulgação de } \\
\text { pontos turísticos }\end{array}$ & $\begin{array}{l}\text { a população não } \\
\text { espera tudo do } \\
\text { poder público }\end{array}$ & $\begin{array}{l}\text { há tribuna livre } \\
\text { para a } \\
\text { população } \\
\text { expor críticas e } \\
\text { elogios na } \\
\text { Câmara de } \\
\text { Vereadores }\end{array}$ & & & \\
\hline $\begin{array}{l}\text { Há supletivo } \\
\text { para } \\
\text { adolescentes } \\
\text { evadidos e que } \\
\text { querem voltar a } \\
\text { estudar }\end{array}$ & $\begin{array}{l}\text { temos apoio para } \\
\text { eventos }\end{array}$ & $\begin{array}{l}\text { há uma piscina para } \\
\text { a população em } \\
\text { geral de Monteiro } \\
\text { Lobato }\end{array}$ & há mapa turístico & $\begin{array}{l}\text { há interesse político. } \\
\text { Briga-se muito pelo } \\
\text { município }\end{array}$ & & & & \\
\hline $\begin{array}{l}\text { a biblioteca está } \\
\text { instalada em } \\
\text { local adequado }\end{array}$ & $\begin{array}{l}\text { as técnicas de } \\
\text { produção artística } \\
\text { do pereirão e do } \\
\text { artesanato são } \\
\text { melhoradas }\end{array}$ & $\begin{array}{l}\text { O ginásio } \\
\text { poliesportivo é } \\
\text { utilizado para a sua } \\
\text { finalidade principal } \\
\text { que é: ter } \\
\text { equipamentos, } \\
\text { inclusive piscina } \\
\text { para treinar os } \\
\text { jovens visando seu } \\
\text { aproveitamento em } \\
\text { jogos } \\
\text { intermunicipais e até } \\
\text { mesmo olímpicos }\end{array}$ & há rádio & $\begin{array}{l}\text { "comunidade - poder } \\
\text { público - setor } \\
\text { privado" estão } \\
\text { sensibilizados para } \\
\text { os assuntos de } \\
\text { Turismo }\end{array}$ & & & & \\
\hline
\end{tabular}




\begin{tabular}{|c|c|c|c|c|c|c|c|c|}
\hline EDUCAÇÃO & $\begin{array}{l}\text { INFRAESTRUTURA } \\
\text { TURÍSTICA }\end{array}$ & $\begin{array}{l}\text { INFRAESTRUTURA } \\
\text { DA CIDADE }\end{array}$ & COMUNICAÇÃO & COMPORTAMENTO & LEGISLAÇÃO & $\begin{array}{l}\text { SAÚDE } \\
\text { PÚBLICA }\end{array}$ & CULTURA & $\begin{array}{l}\text { RECURSOS } \\
\text { FINANCEIROS }\end{array}$ \\
\hline & & $\begin{array}{l}\text { há acessibilidade } \\
\text { para portadores de } \\
\text { deficiências } \\
\text { especiais (físicas, } \\
\text { auditivas e visuais) } \\
\end{array}$ & & & & & & \\
\hline $\begin{array}{l}\text { há educação } \\
\text { ambiental }\end{array}$ & $\begin{array}{l}\text { os pontos turísticos } \\
\text { em Monteiro Lobato } \\
\text { são bem explorados }\end{array}$ & $\begin{array}{l}\text { há atividades de } \\
\text { lazer para a } \\
\text { população }\end{array}$ & & $\begin{array}{l}\text { moradores têm } \\
\text { interesse de } \\
\text { conhecer, elogiar e } \\
\text { indicar a cidade } \\
\end{array}$ & & & & \\
\hline \multirow[t]{4}{*}{$\begin{array}{l}\text { há escolas } \\
\text { profissionalizantes } \\
\text { para nossas } \\
\text { crianças e } \\
\text { adolescentes. Ex.: } \\
\text { inglês, } \\
\text { informática, } \\
\text { Espanhol etc. } \\
\end{array}$} & $\begin{array}{l}\text { há atividades de } \\
\text { lazer para turista }\end{array}$ & $\begin{array}{l}\text { há lugares } \\
\text { apropriados aos } \\
\text { jovens para uma } \\
\text { diversão segura e } \\
\text { principalmente } \\
\text { longe das drogas }\end{array}$ & & $\begin{array}{l}\text { a prefeitura apoia } \\
\text { Turismo }\end{array}$ & & & & \\
\hline & $\begin{array}{l}\text { há opção de lazer } \\
\text { no centro da cidade } \\
\text { para o turista que } \\
\text { chega para ficar no } \\
\text { centro (no final de } \\
\text { semana), tipo: uma } \\
\text { feira, brincadeiras } \\
\text { para crianças etc. }\end{array}$ & $\begin{array}{l}\text { as praças são } \\
\text { bonitas }\end{array}$ & & $\begin{array}{l}\text { há uma associação } \\
\text { com força para } \\
\text { morador e comércio }\end{array}$ & & & & \\
\hline & $\begin{array}{l}\text { há estrutura para } \\
\text { receber turista }\end{array}$ & há Banco 24 horas & & $\begin{array}{l}\text { compreensão por } \\
\text { parte de todos (não } \\
\text { há preconceitos) }\end{array}$ & & & & \\
\hline & $\begin{array}{l}\text { há uma praça ou } \\
\text { local para exposição } \\
\text { de artesanato }\end{array}$ & $\begin{array}{l}\text { há atividades para } \\
\text { pessoas da melhor } \\
\text { idade }\end{array}$ & & $\begin{array}{l}\text { há oportunidades de } \\
\text { empregos }\end{array}$ & & & & \\
\hline
\end{tabular}




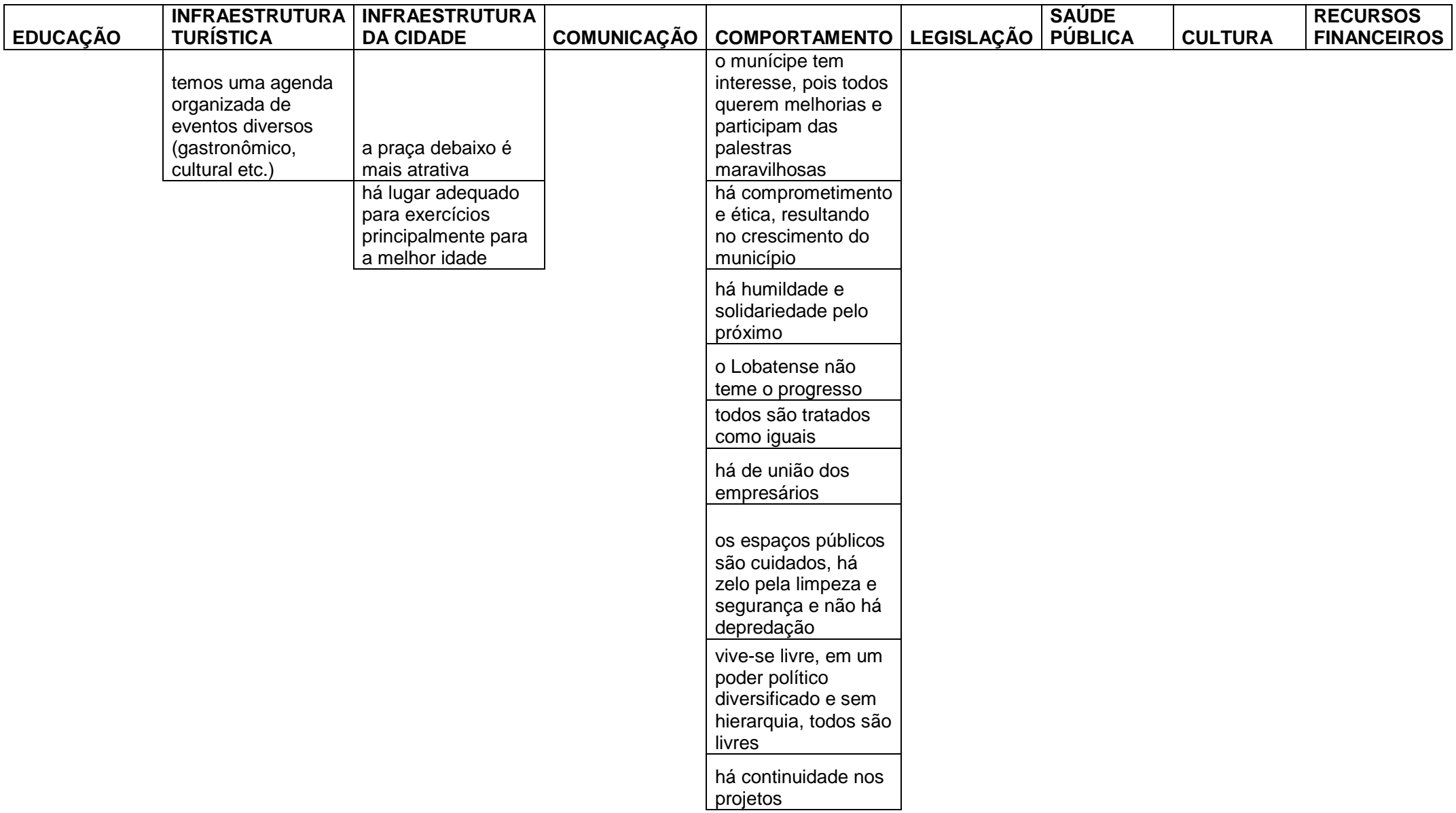




\begin{tabular}{|c|c|c|c|c|c|c|c|c|}
\hline EDUCAÇÃO & $\begin{array}{l}\text { INFRAESTRUTURA } \\
\text { TURÍSTICA }\end{array}$ & $\begin{array}{l}\text { INFRAESTRUTURA } \\
\text { DA CIDADE }\end{array}$ & COMUNICAÇÃO & COMPORTAMENTO & LEGISLAÇÃO & $\begin{array}{l}\text { SAÚDE } \\
\text { PÚBLICA }\end{array}$ & CULTURA & $\begin{array}{l}\text { RECURSOS } \\
\text { FINANCEIROS }\end{array}$ \\
\hline & & & & \begin{tabular}{|l|} 
Aqui todos podem e \\
trabalha-se para a \\
mudança de \\
mentalidade \\
\end{tabular} & & & & \\
\hline & & & & $\begin{array}{l}\text { há muitas ideias e } \\
\text { muitos incentivos }\end{array}$ & & & & \\
\hline & & & & $\begin{array}{l}\text { o povo daqui é } \\
\text { valorizado }\end{array}$ & & & & \\
\hline & & & & $\begin{array}{l}\text { a grandeza da } \\
\text { cidade depende da } \\
\text { participação do seu } \\
\text { povo. Participem! }\end{array}$ & & & & \\
\hline & & & & $\begin{array}{l}\text { os historiadores da } \\
\text { cidade são } \\
\text { valorizados }\end{array}$ & & & & \\
\hline & & & & $\begin{array}{l}\text { a sociedade civil é } \\
\text { organizada }\end{array}$ & & & & \\
\hline
\end{tabular}




\section{ATIVIDADE 4: CONSTRUÇÃO DA MATRIZ DE PLANEJAMENTO DO PROJETO - MPP}

Por uma questão do pouco tempo para esta Oficina, a MPP foi feita de forma simplificada de acordo com o quadro abaixo, deixando os tópicos: Indicadores objetivamente comparáveis, Fontes de verificação/comprovação, Estrutura quantificada, Pressupostos/Suposições e Pré-requisitos para serem trabalhados pela equipe do Planejatur após a Oficina. 


\begin{tabular}{|c|c|c|}
\hline \multirow[b]{2}{*}{$\begin{array}{l}\text { CONFIGURAÇÃO DA MPP APLICADA } \\
\text { NESTA OFICINA: }\end{array}$} & \multicolumn{2}{|r|}{ Descrição Sumária } \\
\hline & $\begin{array}{l}\text { Objetivo superior } \\
\text { (finalidade): }\end{array}$ & $\begin{array}{l}\text { Havendo infraestruturas da cidade e turística juntamente com a } \\
\text { educação, haverá a mudança de mentalidade necessária para o } \\
\text { desenvolvimento do Turismo Sustentável em Monteiro Lobato. }\end{array}$ \\
\hline
\end{tabular}

\begin{tabular}{|c|c|c|c|c|c|c|c|c|}
\hline \multirow[b]{2}{*}{ RESULTADO 1} & \multirow{3}{*}{$\begin{array}{l}\text { RESULTADO } 2 \\
\text { INFRAESTRUTUR } \\
\text { A TURÍSTICA } \\
\end{array}$} & \multicolumn{3}{|c|}{ MATRIZ DE PLANEJAMENTO POR PROJETO } & \multirow[b]{2}{*}{ RESULTADO 6} & \multirow[b]{2}{*}{ RESULTADO 7} & \multirow[b]{2}{*}{ RESULTADO 8} & \multirow[b]{2}{*}{ RESULTADO 9} \\
\hline & & RESULTADO 3 & RESULTADO 4 & RESULTADO 5 & & & & \\
\hline EDUCAÇÃO & & $\begin{array}{l}\text { INFRAESTRUTURA } \\
\text { DA CIDADE }\end{array}$ & COMUNICAÇÃO & COMPORTAMENTO & LEGISLAÇÃO & $\begin{array}{l}\text { SAÚDE } \\
\text { PÚBLICA }\end{array}$ & CULTURA & $\begin{array}{l}\text { RECURSOS } \\
\text { FINANCEIROS }\end{array}$ \\
\hline $\begin{array}{l}\text { 1.1. Projetos } \\
\text { interdisciplinares } \\
\text { dentro das } \\
\text { escolas para } \\
\text { conhecer o } \\
\text { município - } \\
\text { geografia, história, } \\
\text { cultura, danças, } \\
\text { pereirão, } \\
\text { manifestações } \\
\text { populares } \\
\text { (gastronomia, } \\
\text { artesanato etc. } \\
\end{array}$ & $\begin{array}{l}\text { 2.1. formatação de } \\
\text { atrativos turísticos }\end{array}$ & $\begin{array}{l}\text { 3.1. acessibilidade - } \\
\text { vias públicas e } \\
\text { estradas rurais }\end{array}$ & $\begin{array}{l}\text { 4.1. WIFI para o } \\
\text { centro }\end{array}$ & $\begin{array}{l}\text { 5.1. criar associação } \\
\text { "unidos por Monteiro } \\
\text { Lobato" }\end{array}$ & $\begin{array}{l}\text { 6.1. posto de } \\
\text { fiscalização da } \\
\text { Polícia } \\
\text { Rodoviária ou } \\
\text { DER }\end{array}$ & $\begin{array}{l}\text { 7.1. zoonose = } \\
\text { castração em } \\
\text { massa }\end{array}$ & $\begin{array}{l}\text { 8.1. pereirões }= \\
\text { apadrinhamento por } \\
\text { empresas locais }\end{array}$ & $\begin{array}{l}\text { 9.1. banco do } \\
\text { povo }\end{array}$ \\
\hline $\begin{array}{l}\text { 1.2. Ieituras dirigidas } \\
\text { sobre o escritor } \\
\text { Monteiro Lobato }\end{array}$ & $\begin{array}{l}\text { 2.2. organizar } \\
\text { agenda de eventos }\end{array}$ & $\begin{array}{l}\text { 3.2. melhoria da } \\
\text { energia elétrica - } \\
\text { iluminação de ruas }\end{array}$ & $\begin{array}{l}\text { 4.2. marketing } \\
\text { turístico }\end{array}$ & $\begin{array}{l}\text { 5.2. campanha para } \\
\text { resgate da cultura e } \\
\text { valorização por meio } \\
\text { da apresentação de } \\
\text { resultados }\end{array}$ & $\begin{array}{l}\text { 6.2. PLANO } \\
\text { DIRETOR DO } \\
\text { MUNICÍPIO }\end{array}$ & $\begin{array}{l}\text { 7.2. trabalho de } \\
\text { assistência social } \\
\text { para alcoólatras } \\
\text { e viciados em } \\
\text { drogas }\end{array}$ & $\begin{array}{l}\text { 8.2. moçambique, } \\
\text { catira e cacuriá = } \\
\text { mais incentivo e } \\
\text { apoio }\end{array}$ & $\begin{array}{l}\text { 9.2. assessoria } \\
\text { do SINHORES } \\
\text { (CONSULTOR) }\end{array}$ \\
\hline $\begin{array}{l}\text { 1.3. cursos } \\
\text { profissionalizantes } \\
\text { (jovens e adultos) }\end{array}$ & $\begin{array}{l}\text { 2.3. sinalização } \\
\text { turística (para } \\
\text { Monteiro Lobato - } \\
\text { interna e externa) } \\
\end{array}$ & $\begin{array}{l}\text { 3.3. acessibilidade } \\
\text { para portadores de } \\
\text { deficiências especiais } \\
\text { (físicas, auditivas e } \\
\text { visuais) }\end{array}$ & $\begin{array}{l}\text { 4.3. divulgação de } \\
\text { eventos através de } \\
\text { painel com mapa } \\
\text { turístico }\end{array}$ & & & $\begin{array}{l}\text { 7.3. atendimento } \\
\text { médico no finais } \\
\text { de semana no } \\
\text { posto de saúde }\end{array}$ & $\begin{array}{l}\text { 8.3. melhoria das } \\
\text { técnicas de } \\
\text { artesanato }\end{array}$ & \\
\hline & $\begin{array}{l}\text { 2.4. formação de } \\
\text { monitores de } \\
\text { Turismo local }\end{array}$ & $\begin{array}{l}\text { 3.4. há banheiro } \\
\text { público }\end{array}$ & $\begin{array}{l}4.4 . \\
\text { conscientização } \\
\text { dos taxistas em } \\
\text { relação ao turista }\end{array}$ & & & & $\begin{array}{l}\text { 8.4. assessoria de } \\
\text { profissionais técnicos } \\
\text { e designers para } \\
\text { novos produtos e } \\
\text { aperfeiçoar } \\
\text { artesanato existente }\end{array}$ & \\
\hline
\end{tabular}

Quadro 24 - Configuração da MPP aplicada na primeira Oficina 
MATRIZ DE PLANEJAMENTO POR PROJETO

\begin{tabular}{|c|c|c|c|c|c|c|c|c|}
\hline & & & & & & & & \\
\hline RESULTADO 1 & RESULTADO 2 & RESULTADO 3 & RESULTADO 4 & RESULTADO 5 & $\begin{array}{l}\text { RESULTADO } 6 \\
\end{array}$ & RESULTADO 7 & RESULTADO 8 & RESULTADO 9 \\
\hline EDUCAÇÃO & $\begin{array}{l}\text { INFRAESTRUTUR } \\
\text { A TURÍSTICA }\end{array}$ & $\begin{array}{l}\text { INFRAESTRUTURA } \\
\text { DA CIDADE }\end{array}$ & COMUNICAÇÃO & COMPORTAMENTO & LEGISLAÇÃO & $\begin{array}{l}\text { SAÚDE } \\
\text { PÚBLICA }\end{array}$ & CULTURA & $\begin{array}{l}\text { RECURSOS } \\
\text { FINANCEIROS }\end{array}$ \\
\hline & $\begin{array}{l}\text { 2.5. projeto conheça } \\
\text { sua cidade: para } \\
\text { população e visita } \\
\text { técnica para } \\
\text { empresários) }\end{array}$ & $\begin{array}{l}\text { 3.5. revitalização e } \\
\text { organização dos usos } \\
\text { do Poliesportivo }\end{array}$ & & & & & $\begin{array}{l}\text { 8.5. criar identidade } \\
\text { para artesanato local }\end{array}$ & \\
\hline & $\begin{array}{l}\text { 2.6. CAT - Centro } \\
\text { de Apoio ao Turista }\end{array}$ & $\begin{array}{l}\text { 3.6. atuação das } \\
\text { polícias civil e militar } \\
\text { (rodízio de policiais) }\end{array}$ & & & & & & \\
\hline
\end{tabular}

Quadro 24 - Configuração da MPP aplicada na primeira Oficina (continuação) 


\section{5: ANÁLISE DO POTENCIAL TURÍSTICO DE MONTEIRO LOBATO}

Esta etapa visa conhecer a percepção dos participantes da Oficina sobre o Turismo do município.

A pergunta norteadora foi: QUAL O SEGMENTO DO TURISMO COM MAIOR POTENCIALIDADE PARA SER DESENVOLVIDO EM MONTEIRO LOBATO?

Os participantes da Oficina acordaram que Monteiro Lobato tem vocação turística para:

> TURISMO ECOLÓGICO

$>$ TURISMO RURAL

$>$ TURISMO GASTRONÔMICO

> TURISMO CULTURAL: 1) MONTEIRO LOBATO (ESCRITOR) E 2) MANIFESTAÇÕES POPULARES

$>$ TURISMO DE PASSAGEM = MAIS FORTE

$>$ TURISMO DE AVENTURA

Foi consenso que o Turismo de passagem - o turista que passa pela cidade em direção a São Francisco Xavier (Distrito de São José dos Campos), Campos de Jordão e Sul de Minas e faz uma parada para beber ou comer algo - é o mais forte dentre os segmentos citados. Observa-se que a Rodovia SP-50 passa pelo centro da cidade.

Não houve tempo hábil nesta Oficina para aplicar as atividades 6, 7, 8 e 9. A atividade 6 foi elaborada no dia 14 de abril de 2012 pelos membros do Grupo Planejatur. A atividade 7 foi elaborada após a segunda Oficina na composição do Programa de Ações. As atividades 8 e 9 não foram elaboradas.

Pergunta norteadora para levantamento e avaliação dos potenciais turísticos pelos participantes:

QUAIS SÃO OS POTENCIAIS TURÍSTICOS MAIS IMPORTANTES PARA O TURISMO NO MUNICÍPIO? 


\begin{tabular}{|c|c|c|c|c|c|c|}
\hline Potencial Turístico & \multicolumn{6}{|c|}{$\begin{array}{c}\text { Potenciais mais importantes para o desenvolvimento } \\
\text { turístico no município }\end{array}$} \\
\hline Avaliação: & 0 & 1 & 2 & 3 & 4 & 5 \\
\hline A & & & & & & Z \\
\hline$B$ & & & Z & & & \\
\hline C & & & & & & $\begin{array}{l}Z \\
\nabla\end{array}$ \\
\hline $\mathrm{D}$ & & $\nabla$ & & & & \\
\hline
\end{tabular}

Quadro 25 - Modelo de Avaliação do Potencial Turístico na primeira Oficina

As notas de 0 a 5 serão dadas pelos participantes por meio de riscos agrupados de 5 em 5 . Cada participante dará apenas uma nota para cada potencial.

\section{ATIVIDADE 6: ANÁLISE DO ENVOLVIMENTO}

Pergunta norteadora:

\section{QUAIS SÃO OS GRUPOS, ENTIDADES, INSTITUIÇÕES ENVOLVIDOS COM O TURISMO EM NOSSO MUNICÍPIO?}

Objetivo: levantar informações sobre indivíduos, grupos e instituições relevantes para o planejamento. Permite o detalhamento das atividades $\mathrm{e}$ as responsabilidades que poderiam assumir para contribuir com o desenvolvimento turístico da localidade.

\begin{tabular}{|c|c|c|}
\hline & Função própria: & $\begin{array}{ll}\text { Função potencial em } \\
\text { relação ao Turismo }\end{array}$ \\
\hline \multicolumn{3}{|l|}{ Instituições municipais } \\
\hline Empresas municipais & & \\
\hline $\begin{array}{l}\text { Outras: } \\
\text { ONG's } \\
\text { Instituições regionais } \\
\text { Instituições estaduais } \\
\text { Instituições nacionais } \\
\text { Instituições internacionais } \\
\text { Instituições financeiras }\end{array}$ & & \\
\hline
\end{tabular}

Quadro 26 - Modelo de quadro de análise do envolvimento 
Os quadros abaixo foram elaborados no dia 14 de abril de 2012 com os membros do Planejatur.

\begin{tabular}{|c|c|c|}
\hline $\begin{array}{l}\text { Instituições } \\
\text { municipais }\end{array}$ & Função própria: & $\begin{array}{l}\text { Função potencial em } \\
\text { relação ao Turismo }\end{array}$ \\
\hline $\begin{array}{l}\text { Prefeitura Municipal } \\
\text { de Monteiro Lobato e } \\
\text { suas } \\
\text { Secretarias }\end{array}$ & $\begin{array}{l}\text { Prefeito, Gabinete } \\
\text { Cultura e Turismo; Meio Ambiente e } \\
\text { Agricultura; Educação; } \\
\text { Desenvolvimento Social; } \\
\text { Transportes; Esportes e Lazer; } \\
\text { Administração; Saúde }\end{array}$ & $\begin{array}{l}\text { trabalho conjunto } \\
\text { parcerias }\end{array}$ \\
\hline Câmara Municipal & Legislação & $\begin{array}{lll}\text { Legislar } & \text { para } & \text { Turismo } \\
\text { também }\end{array}$ \\
\hline Conselho Tutelar & Zelar pelas crianças e adolescentes & Parcerias \\
\hline Instituto Pandavas & Ensino, Projetos Ecológicos & $\begin{array}{l}\text { Turismo Pedagógico } \\
\text { Valorização de ML } \\
\text { Educação para o Turismo }\end{array}$ \\
\hline Sindicato Rural & $\begin{array}{l}\text { Serviços a empresários do setor de } \\
\text { agropecuária } \\
\text { Capacitação de mão de obra }\end{array}$ & Parcerias \\
\hline APPR & $\begin{array}{l}\text { Serviços a empresários do setor de } \\
\text { agropecuária } \\
\text { Produtos locais }\end{array}$ & $\begin{array}{l}\text { Parcerias } \\
\text { Venda dos produtos locais a } \\
\text { turistas }\end{array}$ \\
\hline
\end{tabular}

\begin{tabular}{|l|l|l|}
\hline $\begin{array}{l}\text { Empresas no } \\
\text { município }\end{array}$ & Função própria: & $\begin{array}{l}\text { Função potencial em } \\
\text { relação ao Turismo }\end{array}$ \\
\hline SABESP & Serviços de saneamento básico & parcerias \\
\hline COOPER & $\begin{array}{l}\text { Comercialização de produtos } \\
\text { agropecuários }\end{array}$ & parcerias \\
\hline EDP BANDEIRANTE & Serviços de eletricidade & parcerias \\
\hline $\begin{array}{l}\text { Mineradora de água } \\
\text { Monteiro Lobato }\end{array}$ & Produtora de água & parcerias \\
\hline Pousadas & Serviços em Turismo - hospedagem & parcerias \\
\hline Restaurantes & Serviços em Turismo - alimentação & parcerias \\
\hline Atrativos Turísticos & Serviços em Turismo - visitação & parcerias \\
\hline
\end{tabular}

\begin{tabular}{|l|l|l|}
\hline $\begin{array}{l}\text { Instituições } \\
\text { estaduais }\end{array}$ & Função própria: & $\begin{array}{l}\text { Função potencial em } \\
\text { relação ao Turismo }\end{array}$ \\
\hline UNIARARAS & Ensino superior & parcerias \\
\hline UNITAU & Ensino superior & parcerias \\
\hline SENAR & $\begin{array}{l}\text { Capacitação de mão de obra e } \\
\text { gerencial }\end{array}$ & parcerias \\
\hline SINHORES & $\begin{array}{l}\text { Capacitação de mão de obra e } \\
\text { gerencial }\end{array}$ & parcerias \\
\hline SEBRAE & Capacitação gerencial & parcerias \\
\hline Polícias Civil e Militar & Zelar pela segurança & parcerias \\
\hline
\end{tabular}

Quadro 27 - Quadro de análise do envolvimento elaborado pelo Grupo Planejatur 


\begin{tabular}{|l|l|l|}
\hline $\begin{array}{l}\text { Instituições } \\
\text { financeiras }\end{array}$ & Função própria: & $\begin{array}{l}\text { Função potencial em } \\
\text { relação ao Turismo }\end{array}$ \\
\hline Banco do Brasil & Atividades financeiras & parcerias \\
\hline Bradesco & Atividades financeiras & parcerias \\
\hline
\end{tabular}

\begin{tabular}{|l|l|l|}
\hline $\begin{array}{l}\text { Instituições } \\
\text { nacionais }\end{array}$ & Função própria: & $\begin{array}{l}\text { Função potencial em } \\
\text { relação ao Turismo }\end{array}$ \\
\hline Correios & comunicação & parcerias \\
\hline $\begin{array}{l}\text { Ponto de Cultura } \\
\text { Montanha } \\
\text { Encantada }\end{array}$ & $\begin{array}{l}\text { Projetos culturais subsidiados pelo } \\
\text { Governo Federal }\end{array}$ & parcerias \\
\hline
\end{tabular}

Quadro 27 - Quadro de análise do envolvimento elaborado pelo Grupo Planejatur

(continuação)

\section{ATIVIDADE 7: MATRIZ DE COOPERAÇÃO INSTITUCIONAL PARA O TURISMO DO MUNICÍPIO}

A Matriz de Cooperação Institucional apresenta as possibilidades de integração dos parceiros para desenvolverem um trabalho conjunto para se atingir os objetivos propostos na MPP.

\section{Matriz de Cooperação Institucional}

\begin{tabular}{|l|l|}
\hline Resultados (Projetos) & Envolvidos na Realização \\
\hline 1. & $\bullet$ \\
& $\bullet$ \\
\hline 2. & $\bullet$ \\
\hline 3. & $\bullet$ \\
\hline
\end{tabular}

Quadro 28 - Modelo de Matriz de Cooperação Institucional

\section{ATIVIDADE 8: FORMAÇÃO DE GRUPOS DE TRABALHO PARA IMPLANTAR AS AÇÕES DEFINIDAS.}

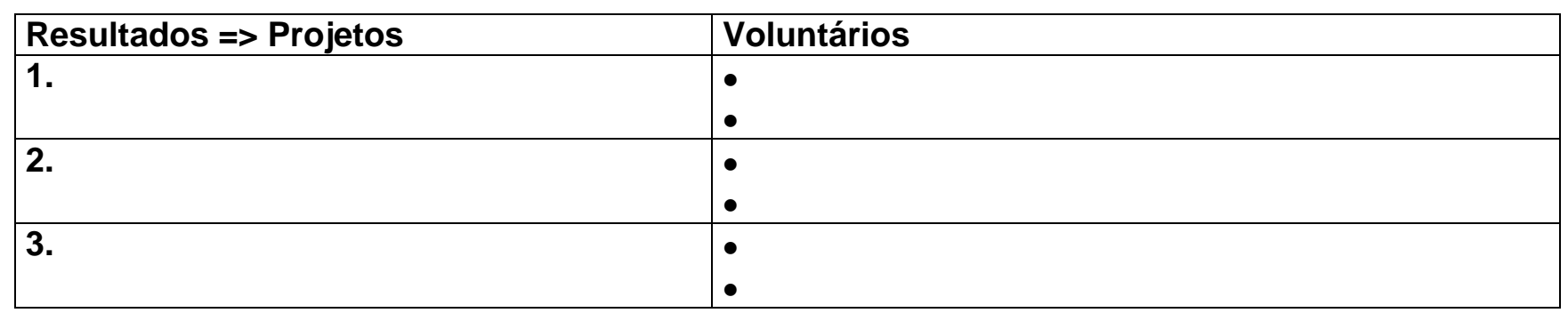

Quadro 29 - Quadro para registros dos grupos de trabalhos voluntários para realização dos projetos 
ATIVIDADE 9: AVALIAÇÃO DA OFICINA

\begin{tabular}{|l|l|l|l|}
\hline Pontos Negativos & Pontos Positivos & Sugestões & Sentimento \\
\hline & & & \\
\hline
\end{tabular}

Quadro 30 - Avaliação da Oficina
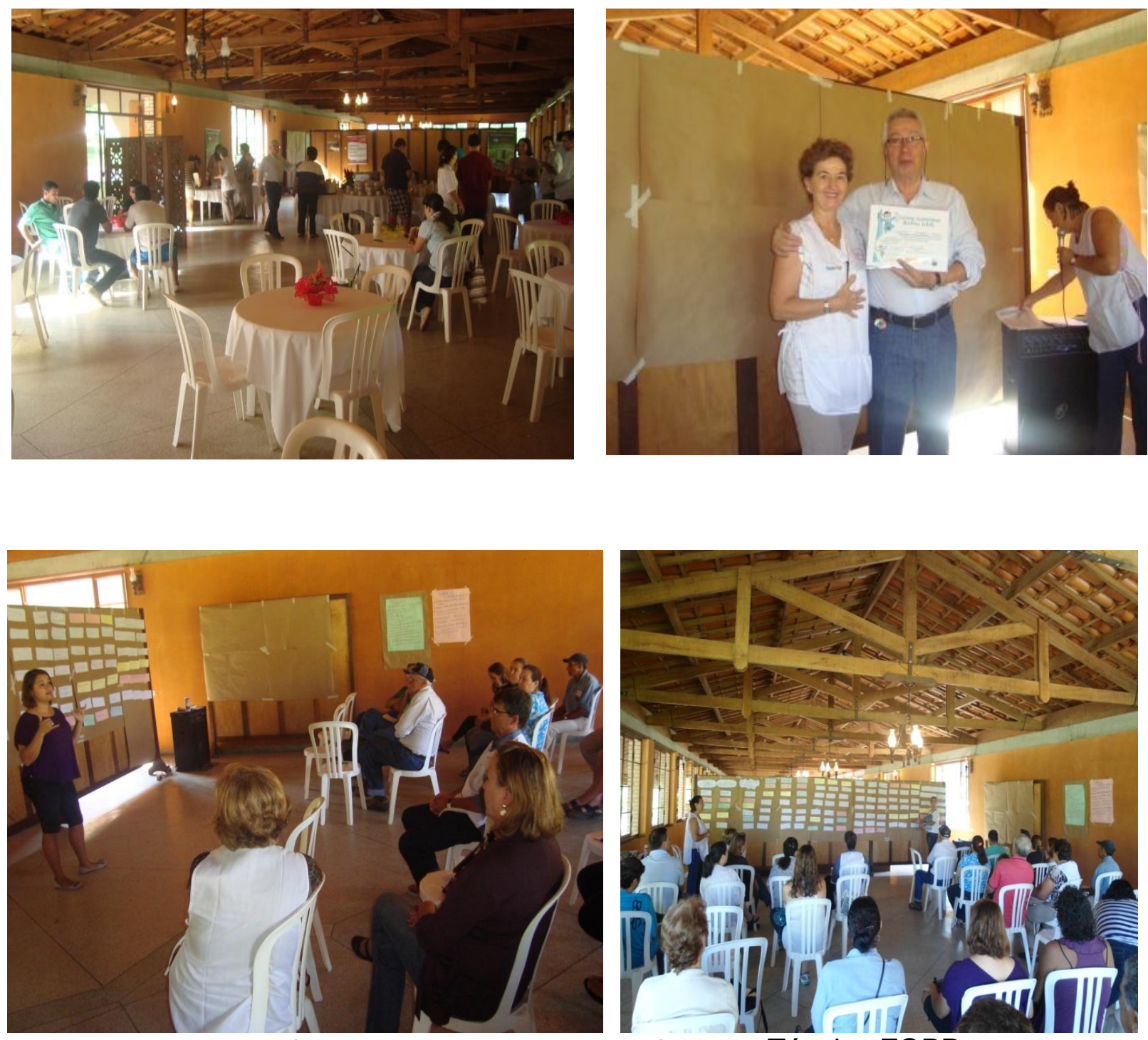

Foto 02 - Conjunto de fotos da primeira Oficina - Técnica ZOPP 


\title{
6.2.2 PlaneJÁtur - Oficina de Planejamento Participativo em Turismo
} Sustentável no Município de Monteiro Lobato, SP, 28 de fevereiro de 2013

Moderadora: Profa. Ma. Cleide Pivott - USP/IP

\section{Equipe da Organização:}

André Barreto

Antonio Renato de Sá Sonnewend

Benedita Ivana da Rocha Claro

Célia Ceruks

Deise Datti Rosa

\author{
Ednea Goulart de Andrade \\ Larissa A. Claro \\ Leila Miranda \\ Odette A. C. Silva \\ Regina de Fátima Araujo
}

\section{Apresentação}

O município de Monteiro Lobato está localizado na Região Metropolitana do Vale do Paraíba e Litoral Norte (RMVPLN), na microrregião da Serra da Mantiqueira, com uma população de 4.120 habitantes. Em 26 de abril de 2013, completou 133 anos. Sua história está inserida no contexto valeparaibano como o caminho de bandeirantes e de tropeiros e a participação nos ciclos econômicos do café e da pecuária leiteira. Em 1948, os moradores de Buquira homenagearam o escritor José Bento Monteiro Lobato que viveu parte da infância na Fazenda São José do Buquira (hoje conhecida como Sítio do Pica-pau Amarelo) e onde residiu no período de 1911 a 1917.

Sempre na busca do desenvolvimento socioeconômico do município, os Prefeitos José Cauby de Oliveira (1977-1983) e Henrique Martins Filho (1997-2000) buscaram a classificação do município como estância histórica, porém sem sucesso. Em 18 de novembro de 1997, o Prefeito Henrique Martins Filho criou o Conselho Municipal de Turismo através da Lei $n^{0} 1.090 / 97$, dentro das orientações do Programa Nacional de Municipalização do Turismo (PNMT). Neste mesmo ano, Monteiro Lobato recebeu o Selo de Município Prioritário para o Desenvolvimento do Turismo emitido pelo Ministério da Indústria, do Comércio e do Turismo/EMBRATUR e pela Secretaria de Esportes e Turismo do Governo do Estado de São Paulo. No governo do Prefeito Gabriel Vargas Moreira (2009-2012), iniciou-se um novo movimento pró-Turismo no município também apoiado pela atual Prefeita.

Este movimento surgiu com a proposta de apoio à tese de Doutorado da Profa. Ma. Cleide Pivott pelo Instituto de Psicologia da USP (linha de pesquisa de Psicologia Socioambiental e Intervenção) que objetiva a elaboração do Plano Diretor 
de Turismo Sustentável de Monteiro Lobato com participação social. Juntamente com o Sindicato dos Hotéis, Restaurantes, Bares e Similares de São José dos Campos e Região (SINHORES), a prefeitura oferece todo o apoio logístico para a elaboração desse plano.

A primeira atividade realizada foi capacitar um grupo de moradores por meio do Curso de Capacitação em Turismo Sustentável, oferecido à comunidade de Monteiro Lobato no segundo semestre de 2011. Dez dos alunos concluintes aceitaram o convite para fazerem parte da equipe com a Profa. Ma. Cleide Pivott e, desde janeiro de 2012, desenvolvem voluntariamente as etapas do planejamento do Turismo Sustentável com participação social que incluem a) estudo preliminar e inventário turístico, b) diagnóstico e c) prognóstico.

Dessa forma, com a participação efetiva e ativa em encontros quinzenais do grupo que se autodenominou Planejatur, foram realizadas as seguintes atividades:

1) Oficina de Planejamento do Turismo Sustentável com a comunidade no dia 15 de março de 2012 que recebeu o nome de PlaneJÁtur Oficina de Turismo em Monteiro Lobato. Utilizando-se a técnica ZOPP (Planejamento de Projetos Orientado por Objetivos), foram levantados os principais obstáculos ao desenvolvimento turístico do município classificados em nove aspectos, quais sejam: educação, infraestrutura turística, infraestrutura da cidade, comunicação, comportamento, legislação, saúde pública, cultura e recursos financeiros. Esta Oficina contou com 48 participantes.

2) Nas reuniões seguintes, foi feita a avaliação geral da Oficina e os resultados foram discutidos com o objetivo de propor possíveis soluções às questões levantadas pelos participantes da Oficina e organizá-las dentro da Matriz de Planejamento por Projeto da Técnica ZOPP.

3) Considerando as eleições no segundo semestre de 2012, o grupo se propôs a produzir um documento com esses resultados para entregar aos candidatos a prefeito do município como contribuição aos respectivos planos de governos. A entrega desse documento foi feita no dia 19 de julho de 2012, após a apresentação da proposta de trabalho do grupo. $O$ resultado foi muito positivo porque todos os quatro candidatos incluíram o Turismo Sustentável em seus planos de governos.

4) No segundo semestre de 2012, o grupo empreendeu a realização do inventário turístico, levantando informações sobre a infraestrutura turística do 
município (recursos e atrativos turísticos, hospedagem, restaurantes, espaços para eventos etc.).

5) Nos meses de janeiro e fevereiro de 2013, o Grupo Planejatur criou e aplicou questionários para as pesquisas de opinião de moradores e turistas a respeito da atividade turística no município. Foram aplicados 159 questionários a moradores de 21 bairros e 124 a turistas. Essas pesquisas trouxeram informações importantes para a continuidade do trabalho de planejamento turístico de Monteiro Lobato uma vez que moradores e turistas indicaram suas percepções, críticas e sugestões para o desenvolvimento do Turismo no município.

6) Em 28 de fevereiro de 2013, no Espaço Mantiqueira, das 08h00 às 17h30, o Grupo Planejatur realizou a segunda Oficina de Planejamento do Turismo Sustentável para as etapas do Diagnóstico e Prognóstico. A Oficina contou com a presença de 71 participantes, incluindo munícipes, a prefeita, secretários da administração, vereadores, professores e colaboradores convidados. Todos contribuíram com suas ideias e experiências na análise dos projetos apresentados, tendo como apoio os seguintes documentos: a) dados socioeconômicos e ambientais do município; b) relatório da primeira Oficina de março/2012; c) resultado da pesquisa com moradores; d) resultado da pesquisa com turistas, e) inventário turístico e f) Matriz de Planejamento por Projeto. Por afinidades e áreas de interesse, os participantes dividiram-se em seis grupos e foram acompanhados nas discussões pelos tutores convidados Profa. Dra. Eda Tassara, Prof. Dr. Marcello Tassara, Prof. Dr. Omar Ardans, Profa. Dra. Doris van de Meene Ruschmann (professores da USP) e Prof. Dr. José Oswaldo Soares de Oliveira e Profa. Dra. Vera Maria Rodrigues da Costa (professores da UNIVAP), Roberval Rodolfo, do Projeto Ponto de Cultura em Monteiro Lobato e Marilene Mesquita Silva, Secretária de Meio Ambiente e Agricultura de Monteiro Lobato. Igualmente, os membros do Grupo Planejatur se dividiram para acompanhar os grupos de trabalho.

7) Nos encontros quinzenais seguintes, os membros do Planejatur fizeram a avaliação da Oficina, analisaram os resultados que foram colocados no formato de projetos. Igualmente analisaram os resultados das pesquisas de opinião com moradores e turistas. 
Este relatório apresenta os resultados dessa segunda Oficina no formato de Programa de Ações contendo os respectivos projetos definidos pelos participantes como importantes e prioritários para os nove aspectos por eles trabalhados: 1) educação, 2) infraestrutura turística, 3) infraestrutura da cidade, 4) comunicação, 5) comportamento, 6) legislação, 7) saúde pública, 8) cultura e 9) recursos financeiros. Algumas das ações propostas indicadas nos projetos já estão em andamento como a reativação do Conselho Municipal de Turismo (COMTUR-ML), enquanto outras já foram realizadas como a reforma da Praça Comendador Freire (Praça de baixo) que foi inaugurada em 27 de abril de 2013. Entretanto, no momento, o Programa de Ações ora apresentado representa o horizonte, o norte, para onde devem ser canalizados os esforços e as energias dos lobatenses para a implantação do Turismo Sustentável no município. Esse Programa de Ações fará parte do Plano Diretor de Turismo Sustentável de Monteiro Lobato e deverá ser revisto e ajustado na medida em que seus projetos forem realizados e em função de novas situações que suscitem mudanças. O Grupo Planejatur conta com 11 membros: André Barreto, Antonio Renato de Sá Sonnewend, Benedita Ivana da Rocha Claro, Célia Ceruks, Cleide Pivott, Deise Datti Rosa, Ednea Goulart de Andrade, Larissa A. Claro, Leila Miranda, Odette A. C. Silva e Regina de Fátima Araujo. O Grupo pensa e atua como um coletivo dentro de uma estrutura organizativa ainda não formalizada, mas que se conduz por meio de regras interdependentes previamente pactuadas entre seus membros. Estes são agentes multiplicadores comprometidos com uma gestão do Turismo Sustentável com o objetivo de colaborar para a perenidade dos critérios de sustentabilidade turística no município.

Grupo Planejatur - Monteiro Lobato, 28 de abril de 2013. 
PROGRAMAÇÃO

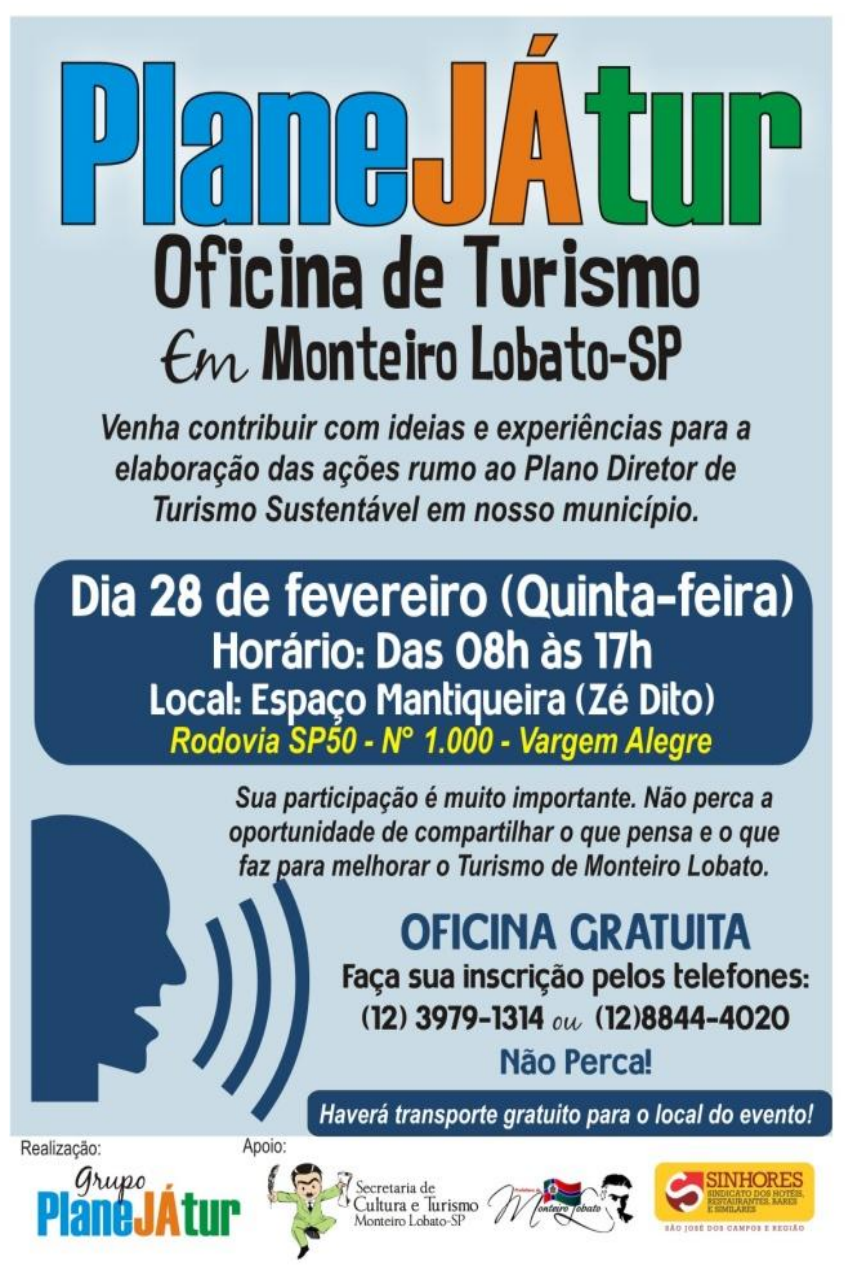

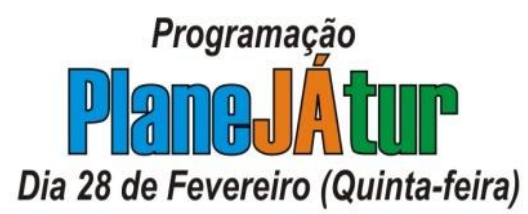

08h00 - Recepção e café

\author{
08h30 - Abertura da oficina \\ - Apresentação do projeto de elaboração do Plano Diretor do Turismo - \\ Sustentável em Monteiro Lobato \\ - Breve histórico do caminho percorrido até o momento
}

09h00 - Início da segunda oficina - Etapas do Diagnóstico e Prognóstico -Apresentação do material que os grupos de trabalho receberão:

-Resumo dos dados sociais e ambientais do município

-Resultado da primeira oficina de planejamento de 15 de março de 2012

-Resultado da pesquisa de opinião com moradores e turistas

- Inventário turístico

-Apresentação do trabalho a ser feito em grupos

-Apresentação do videoclipe: Monteiro Lobato 30 anos

-Dinâmica para integração dos participantes

09 h45 - Inicio dos trabalhos em grupos

12h45 - ALMOÇO

14h00 - Apresentação do trabalho de cada grupo

$15 \mathrm{~h} 45$ - Intervalo para café

16 h00 - Reunião plenária para fechamento do Diagnóstico e indicação de diretrizes para o Plano Diretor de Turismo Sustentável para Monteiro Lobato

17 h30 - Encerramento.

Figura 4 - Cartazete de divulgação da segunda Oficina

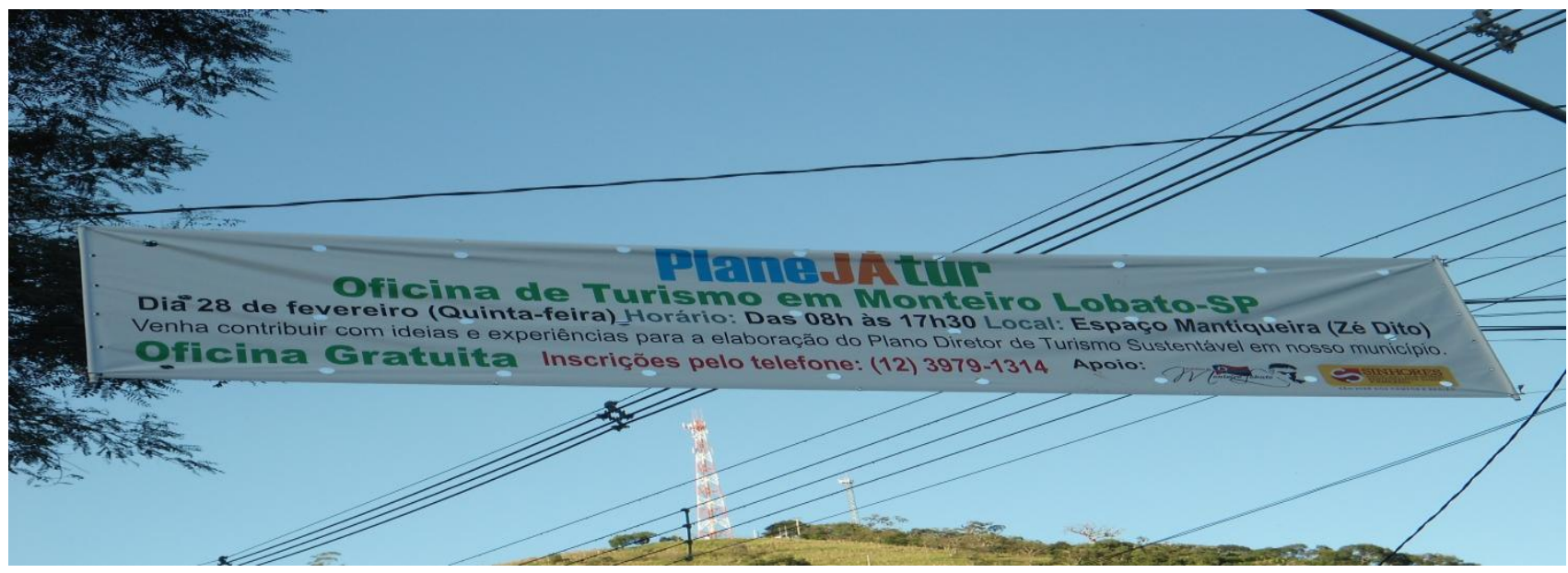

Foto 3 - Faixa de divulgação da segunda Oficina 
PARTICIPANTES

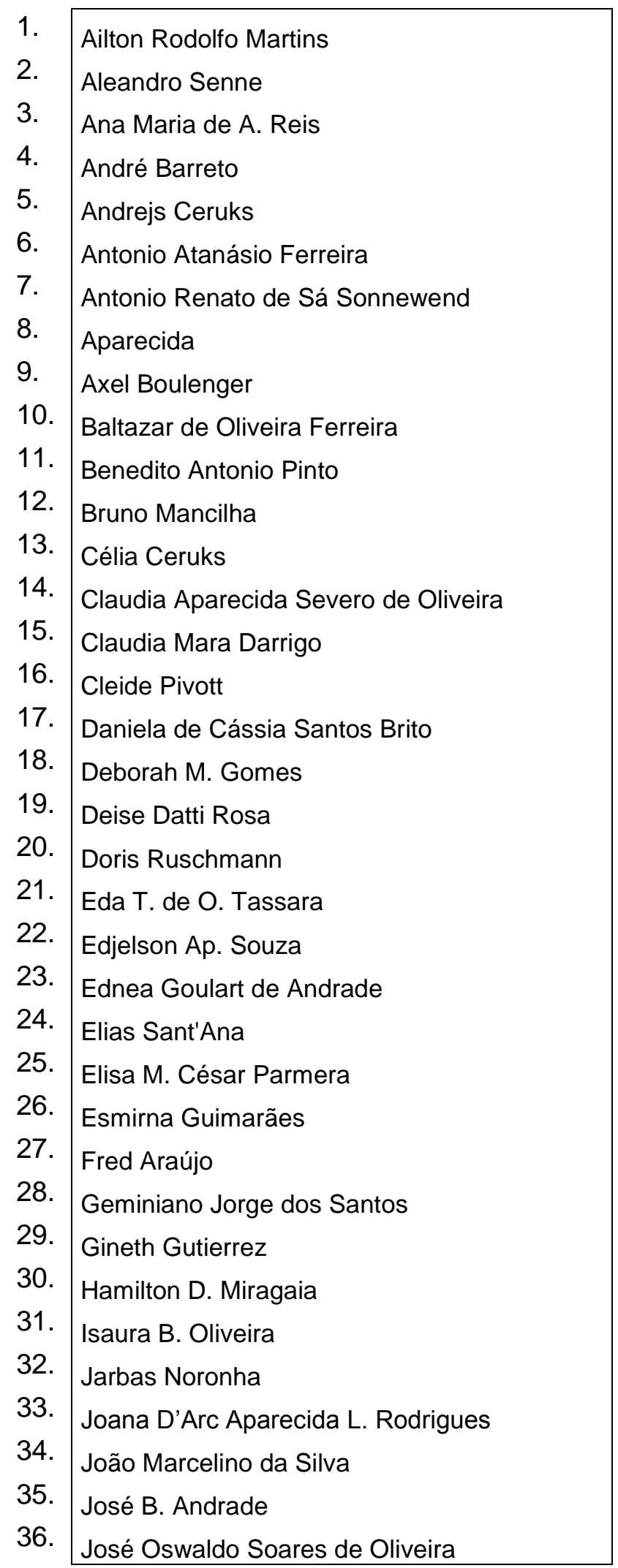

\begin{tabular}{|c|c|}
\hline 37. & Julio Cesar Silva \\
\hline & Lauro Aparecido da Silva \\
\hline & Leila Miranda \\
\hline & Leni de Oliveira Sene \\
\hline & Leonardo Carvalho \\
\hline & Luis Pereira de Melo Filho \\
\hline & Luiz Ricardo Moreira \\
\hline & Manoel S. Almeida \\
\hline & Marcello G. Tassara \\
\hline & Marcio José Rodrigues \\
\hline & Maria Aparecida Batista Claro \\
\hline & Maria Aparecida Rosa \\
\hline & Maria das Gracias Siqueira Leiva \\
\hline & Maria Inês F. Ferreira \\
\hline & Marina Luciene de Souza Silva \\
\hline & Maria Luiza X. Auricchio \\
\hline & Mariana Flores \\
\hline & Marilene Mesquita Silva \\
\hline & Marinália C. Teixeira \\
\hline & Neiva Glória Dias \\
\hline & Nyara Campos \\
\hline & Odette A. C. Silva \\
\hline & Omar Ardans \\
\hline & Raymundo G. Silva \\
\hline & Regina de Fátima Araújo \\
\hline & Regina F. O. Honório \\
\hline & Roberval Rodolfo \\
\hline & Rosane Maria Fujisawa \\
\hline & Rosangela Pereira dos Santos \\
\hline & Roseneid dos Santos \\
\hline & Sonia Maria O. Lima \\
\hline & Sueli Osmarina de Oliveira \\
\hline & Vanessa Tomaz \\
\hline & Venina Gondim Moscoso \\
\hline & Vera Maria Rodrigues da Costa \\
\hline
\end{tabular}
Quadro 31 - Relação de participantes da segunda Oficina 


\section{PERFIL DOS PARTICIPANTES}

Com o objetivo de identificar as características dos participantes dessa Oficina, elaboraram-se os gráficos abaixo apresentados sobre o local de nascimento, nascidos em São José dos Campos x residentes em Monteiro Lobato, a cidade onde mora, e o bairro onde mora. Observa-se que 27\% dos participantes nasceram em São José dos Campos e 21\% em Monteiro Lobato. O gráfico "nascidos em São José dos Campos x residentes em Monteiro Lobato" indica que dos 19 participantes nascidos em São José dos Campos, 84\% moram em Monteiro Lobato (16). Este fato nos remete à inferência que podemos fazer de que muitos moradores de Monteiro Lobato nascem em São José dos Campos e lá são registrados, uma vez que Monteiro Lobato não possui maternidade. O gráfico "a cidade onde mora" indica que $77 \%$ dos participantes residem em Monteiro Lobato. Igualmente, na primeira Oficina realizada em 15 de março de 2012, dos 37 participantes que preencheram a ficha de inscrição (houve 48 participantes), 81\% também residem em Monteiro Lobato. Estes dados indicam a importante participação dos munícipes que estão interessados em colaborar para o processo de desenvolvimento turístico no município. Na primeira Oficina, os munícipes eram oriundos de 6 bairros. Nesta segunda Oficina, os participantes residem em 15 bairros, sendo $23 \%$ no Centro e $15 \%$ no Bairro do Souza. Estes dados demonstram que a participação dos que residem nos bairros aumentou, uma vez que na primeira Oficina, $42 \%$ residiam no Centro. 


\section{Local de nascimento}

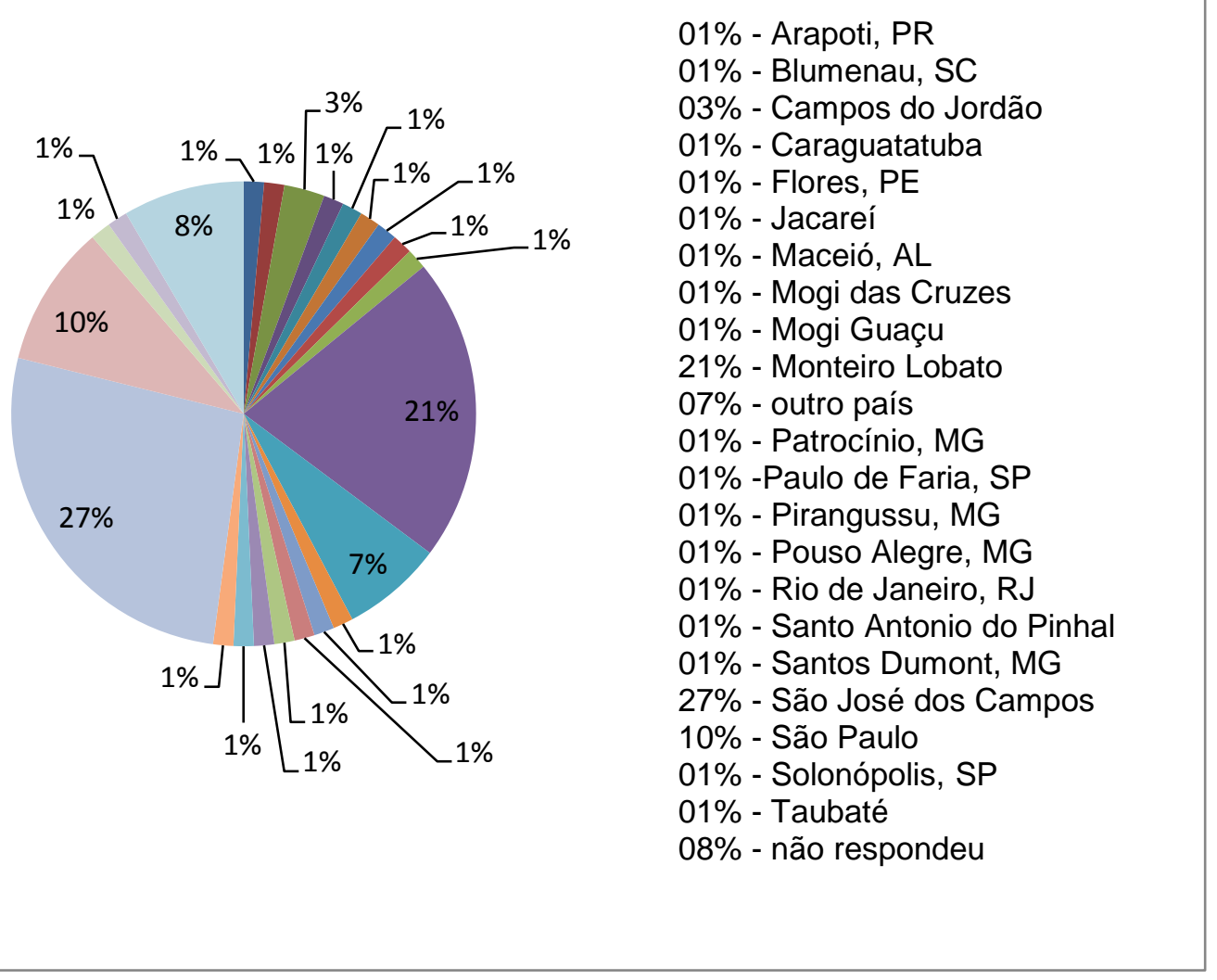

Gráfico 4 - Local de nascimento dos participantes da segunda Oficina

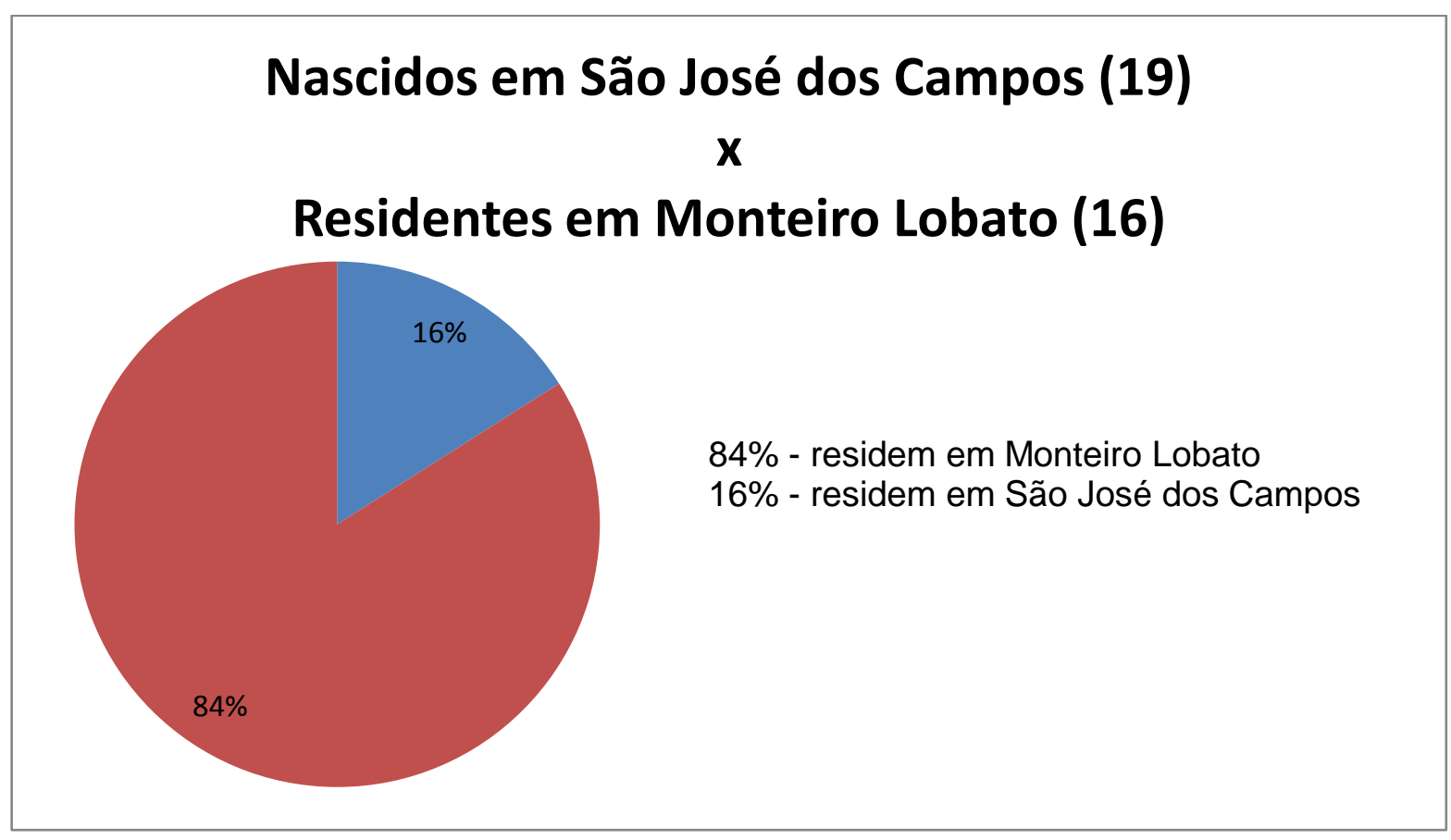

Gráfico 5 - Nascidos em São José dos Campos x residentes em Monteiro Lobato 


\section{Cidade onde mora}

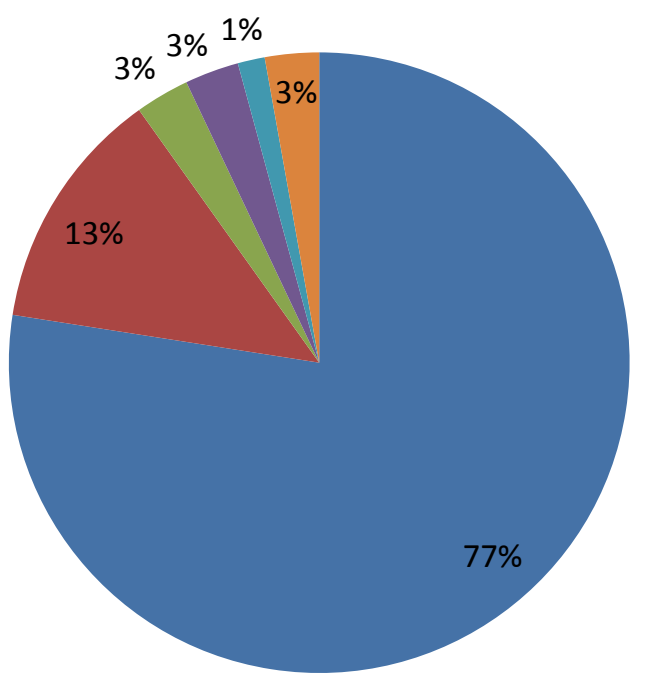

77\% - Monteiro Lobato 13\% - São José dos Campos

03\% - São Paulo

$03 \%$ - não respondeu

$01 \%$ - Santa Maria, RS

03\% - São Francisco Xavier, SJC

Gráfico 6 - Cidades onde residem os participantes da segunda Oficina

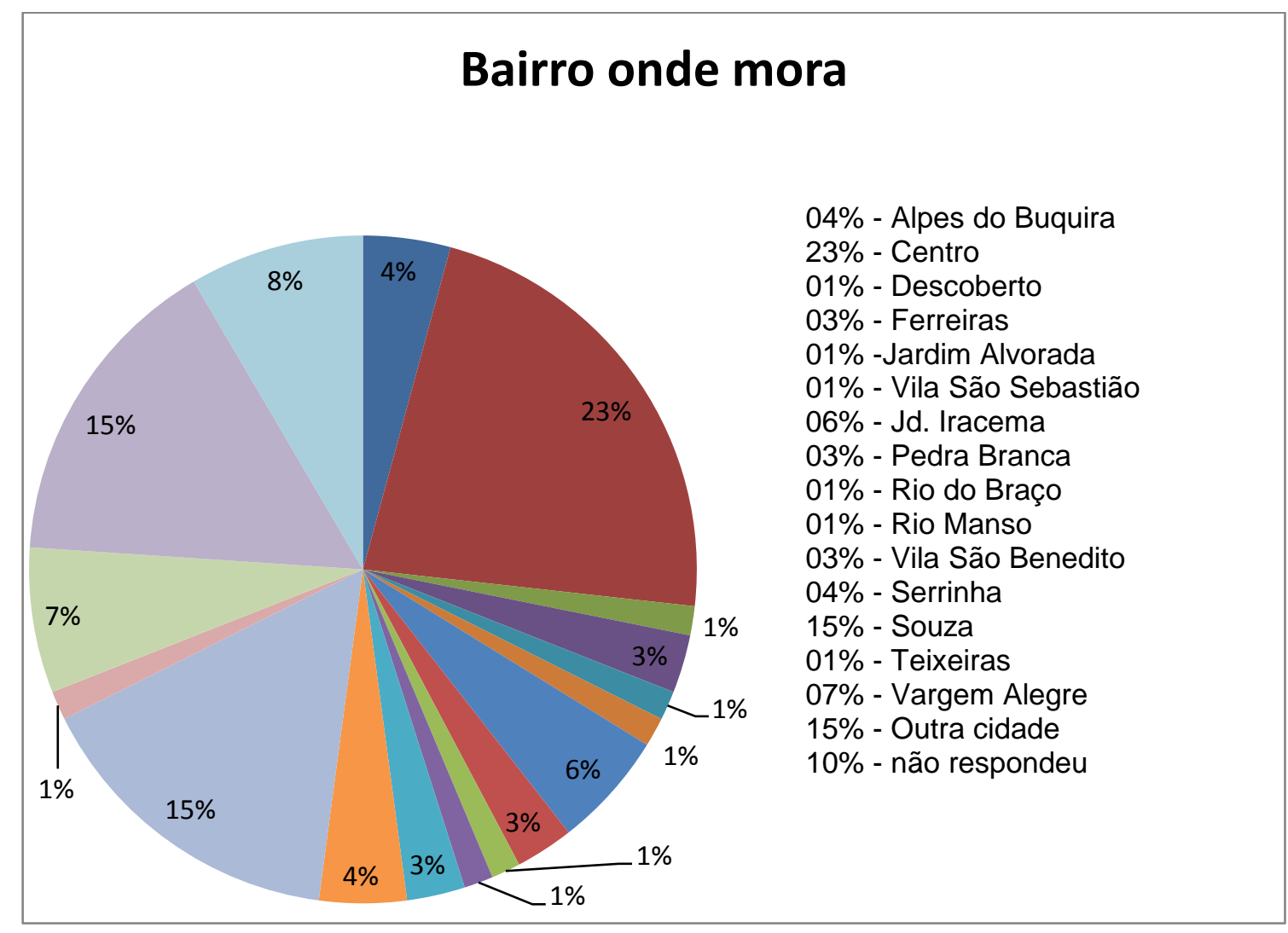

Gráfico 7 - Bairros onde residem os participantes da segunda Oficina 
GRUPOS E TEMAS PARA TRABALHO:

\begin{tabular}{|c|c|c|c|c|}
\hline $\begin{array}{l}\text { Resultados } \\
\text { desejados dessa } 2^{\mathrm{a}} \text {. } \\
\text { Oficina }\end{array}$ & Grupo/Tema & $\begin{array}{l}\text { Resultados da } 1^{a} \text {. } \\
\text { Oficina a serem } \\
\text { analisados }\end{array}$ & $\begin{array}{l}\text { Tutor } \\
\text { convidado }\end{array}$ & $\begin{array}{l}\text { Tutor } \\
\text { Planejatur }\end{array}$ \\
\hline $\begin{array}{l}\text { 1. identificar a } \\
\text { principal vocação } \\
\text { turística do } \\
\text { município; } \\
\text { 1.1. identificar os } \\
\text { principais atrativos }\end{array}$ & $\begin{array}{l}\text { Grupo 1 } \\
\text { Marketing } \\
\text { Turístico }\end{array}$ & $\begin{array}{l}\text { 2: Infraestrutura } \\
\text { turística } \\
\text { 4:Comunicação }\end{array}$ & $\begin{array}{l}\text { Profa. Dra. } \\
\text { Doris Van } \\
\text { Meene } \\
\text { Ruschmann }\end{array}$ & $\begin{array}{l}\text { André } \\
\text { Barreto } \\
\text { Antonio } \\
\text { Renato de } \\
\text { Sá } \\
\text { Sonnewend }\end{array}$ \\
\hline \multirow{5}{*}{$\begin{array}{l}\text { 2. Identificar os } \\
\text { projetos } \\
\text { prioritários } \\
\text { para } \\
\text { implementação } \\
\text { e que } \\
\text { dependem da } \\
\text { iniciativa da } \\
\text { comunidade, } \\
\text { dos } \\
\text { empresários e } \\
\text { dos governos } \\
\text { executivo e } \\
\text { legislativo de } \\
\text { Monteiro } \\
\text { Lobato }\end{array}$} & $\begin{array}{l}\text { Grupo } 2 \\
\text { Infraestrutura } \\
\text { da cidade }\end{array}$ & $\begin{array}{l}\text { 3: Infraestrutura } \\
\text { da cidade }\end{array}$ & $\begin{array}{l}\text { Marilene } \\
\text { Mesquita } \\
\text { Silva, Mestre } \\
\text { em Ecologia }\end{array}$ & $\begin{array}{l}\text { Cleide } \\
\text { Pivott }\end{array}$ \\
\hline & $\begin{array}{l}\text { Grupo } 3 \\
\text { Educação }\end{array}$ & 1: Educação & $\begin{array}{l}\text { Profa. Dra. } \\
\text { Vera Maria } \\
\text { Almeida } \\
\text { Rodrigues da } \\
\text { Costa }\end{array}$ & $\begin{array}{l}\text { Célia } \\
\text { Ceruks }\end{array}$ \\
\hline & $\begin{array}{l}\text { Grupo } 4 \\
\text { Cultura }\end{array}$ & 8: Cultura & $\begin{array}{l}\text { Roberval } \\
\text { Rodolfo }\end{array}$ & $\begin{array}{l}\text { Leila } \\
\text { Miranda }\end{array}$ \\
\hline & $\begin{array}{l}\text { Grupo } 5 \\
\text { Políticas } \\
\text { públicas para o } \\
\text { Turismo em } \\
\text { Monteiro Lobato }\end{array}$ & $\begin{array}{l}\text { 6: Legislação } \\
\text { 7: Saúde Pública } \\
\text { em relação ao } \\
\text { Turismo } \\
\text { 9: Recursos } \\
\text { Financeiros }\end{array}$ & $\begin{array}{l}\text { Prof. Dr. } \\
\text { José } \\
\text { Oswaldo } \\
\text { Soares de } \\
\text { Oliveira }\end{array}$ & $\begin{array}{l}\text { Ednea } \\
\text { Goulart de } \\
\text { Andrade }\end{array}$ \\
\hline & $\begin{array}{l}\text { Grupo } 6 \\
\text { Conscientização } \\
\text { da comunidade } \\
\text { para o Turismo }\end{array}$ & 5: Comportamento & $\begin{array}{l}\text { Profa. Dra. } \\
\text { Eda } \\
\text { Terezinha de } \\
\text { Oliveira } \\
\text { Tassara }\end{array}$ & $\begin{array}{l}\text { Odette A. } \\
\text { C. da Silva }\end{array}$ \\
\hline
\end{tabular}

Quadro 32 - Grupos e temas para trabalho - segunda Oficina 
PROGRAMA DE AÇÕES ELABORADO COM BASE NA MATRIZ DE PLANEJAMENTO POR PROJETO (MPP) DA OFICINA DE 15 DE MARÇO 2012

1. EDUCAÇÃO

1.1. Educação escolar

1.1.1. Capacitação de professores nas áreas de Turismo Sustentável, Turismo Rural e Educação Ambiental

1.1.2. Empreendedorismo na Escola

1.1.3. Cursos profissionalizantes
1.2. Educação para a comunidade

1.2.1. Conscientização da população para o Turismo Sustentável e para a preservação do Meio Ambiente

1.2.2. Nova sede da biblioteca com bibliotecário responsável

1.2.3. Criação de curso supletivo para o Ensino Fundamental/Ciclo 2 e Ensino Médio 


\section{PROGRAMA - 1. EDUCAÇÃO \\ Projeto - 1.1. Educação escolar \\ 1.1.1 Capacitação de professores nas áreas de Turismo Sustentável, Turismo Rural e Educação Ambiental}

\section{Objetivos}

Investir na capacitação de professores para que possam desenvolver projetos interdisciplinares voltados para as áreas de Turismo Sustentável, Turismo Rural e Educação Ambiental com os alunos da rede escolar do município.

\section{Justificativa}

O Turismo Sustentável é um novo modelo de Turismo que se baseia em três principais critérios: a preservação do meio ambiente, o respeito à cultura do local e a distribuição da renda gerada pela atividade de forma mais justa entre os envolvidos.

A educação é a chave para a disseminação do conceito de Turismo Sustentável e os professores são os protagonistas para a educação dos alunos, portanto, é preciso conscientizar e capacitar primeiramente os professores para a ação educativa em Turismo Sustentável.

\section{Ações propostas}

a) Oferecer um curso de capacitação em Turismo Sustentável aos professores da rede escolar municipal de Monteiro Lobato;

b) Incluir os conceitos de Turismo Sustentável e os temas geografia, história, cultura e as manifestações populares (gastronomia, artesanato, danças, pereirão etc.) específicos do município assim como a vida e obra do escritor Monteiro Lobato como conteúdos disciplinares nas matérias de Geografia, História, Língua Portuguesa e Artes.

c) A educação ambiental, como previsto no Artigo $2^{\circ}$. da Lei Federal no 9.795 de 27 de abril de 1999 que dispõe sobre Política Nacional de Educação Ambiental, "é um componente essencial e permanente da educação nacional, devendo estar presente, de forma articulada, em todos os níveis e modalidades do processo educativo, em caráter formal e não formal". O Turismo é considerado como um dos serviços ambientais de uso indireto da floresta, podendo ser trabalhado como instrumento para geração de renda e fixação do homem rural no campo. Portanto, a educação ambiental deve permear todos os projetos como tema transversal permanente.

\section{Principais executores}

Secretaria de Educação, Secretaria de Cultura e Turismo, Secretaria de Meio Ambiente e Agricultura

Parceiros prováveis

COMTUR-ML, APPR, Sindicato Rural de Monteiro Lobato, SINHORES, UNITAU, SENAR, SENAC e SEBRAE-SP

\begin{tabular}{|l|l|l|l|}
\hline Prioridade & Prazo de início & Prazo de execução & Projeto contínuo \\
\cline { 2 - 4 } & &
\end{tabular}

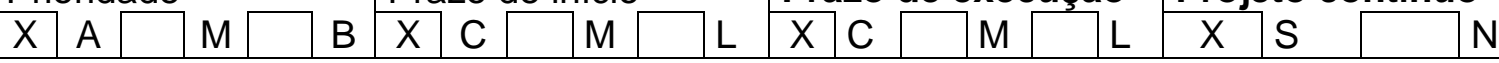

\section{Requisitos}

Formatação e implantação dos cursos de capacitação para o Turismo Sustentável, Turismo Rural e Educação Ambiental.

\section{Fontes de financiamento}

Orçamento municipal, patrocinadores, parcerias.

\begin{tabular}{|l|l|}
\hline Custo de implantação & Custo de manutenção \\
A definir & A definir \\
\hline
\end{tabular}

Quadro 34 - Projeto 1.1.1. Capacitação de professores nas áreas de Turismo Sustentável, Turismo Rural e Educação Ambiental 


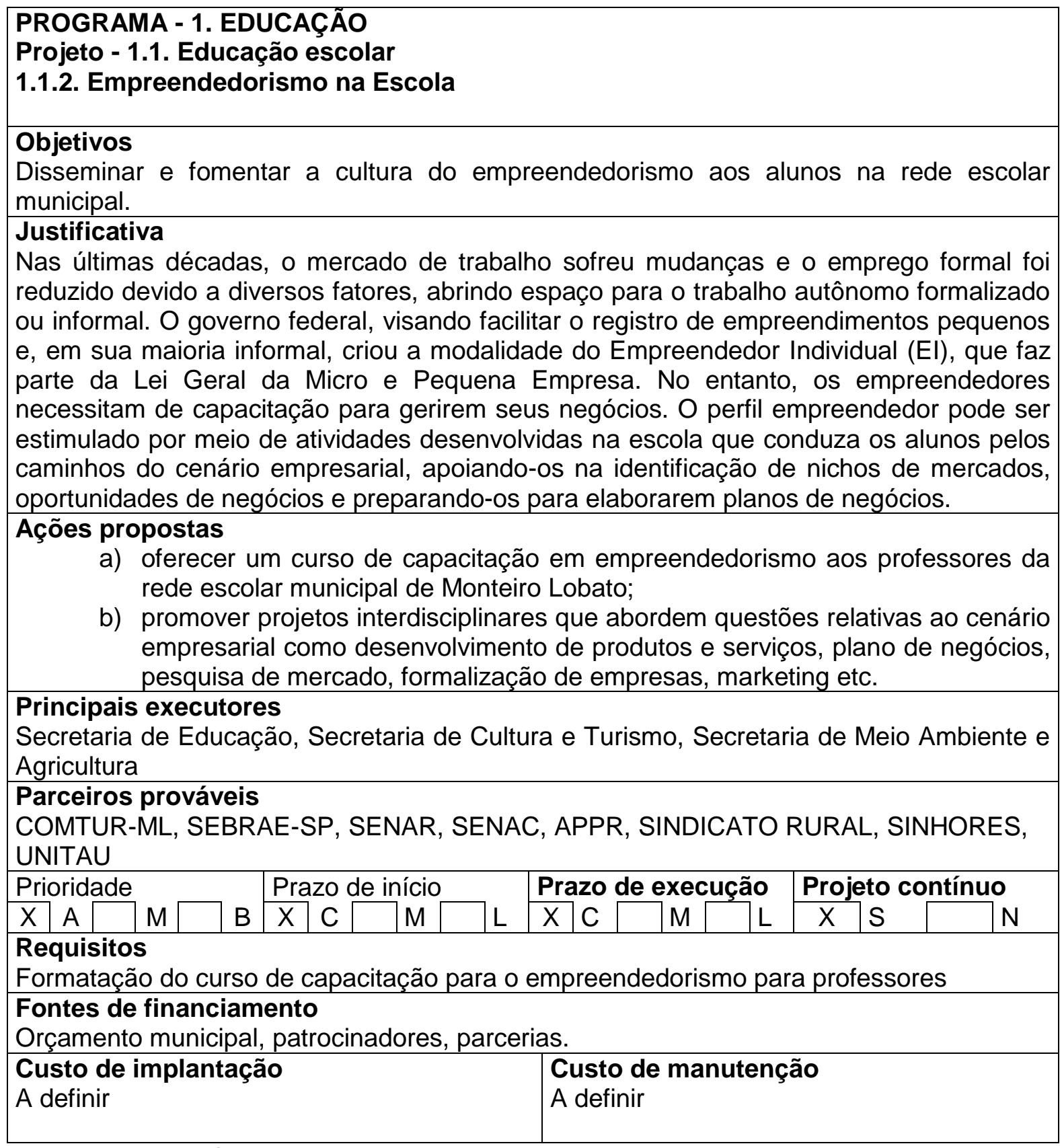

Quadro 35 - Projeto 1.1.2. Empreendedorismo na Escola 


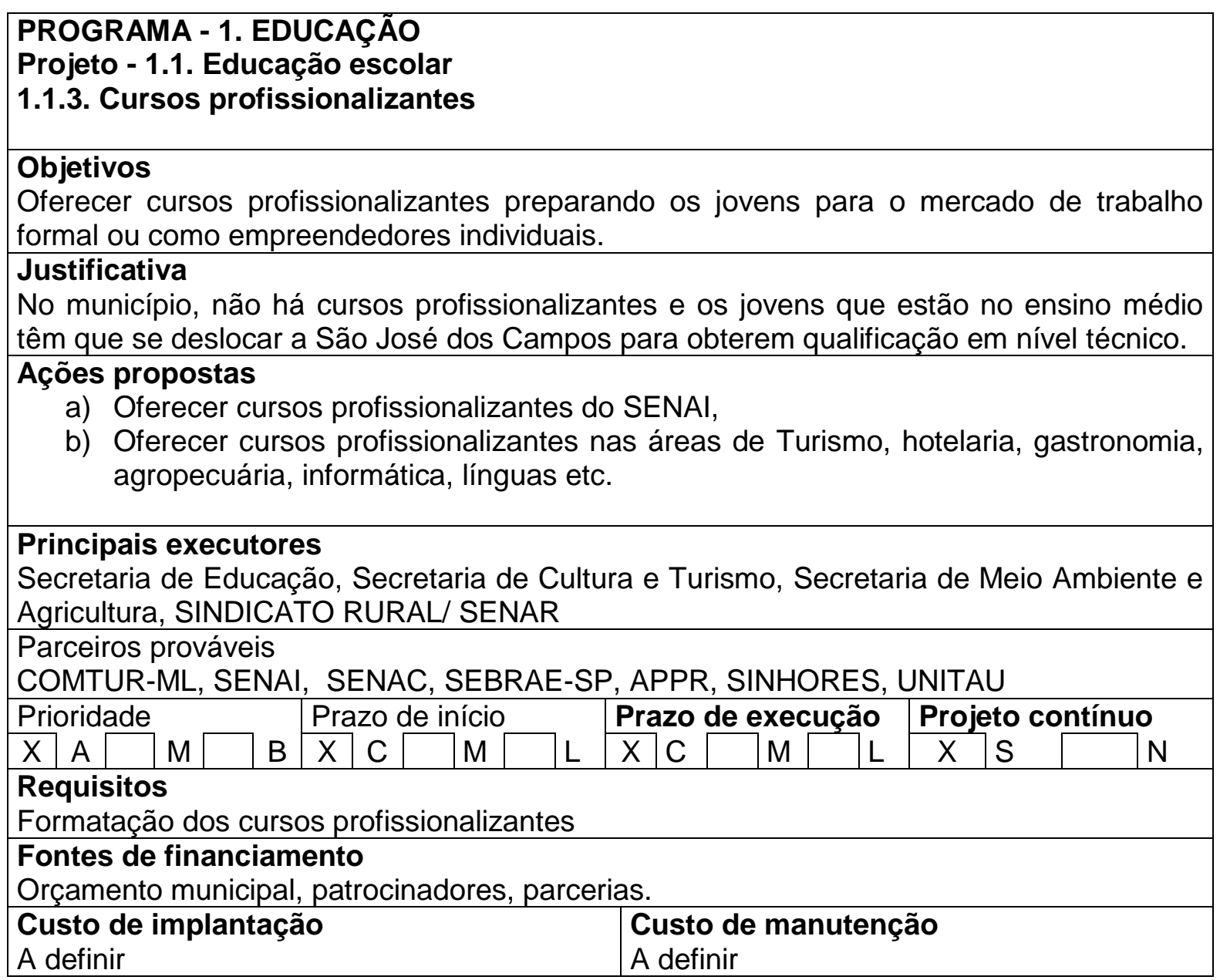

Quadro 36 - Projeto 1.1.3. Cursos profissionalizantes 


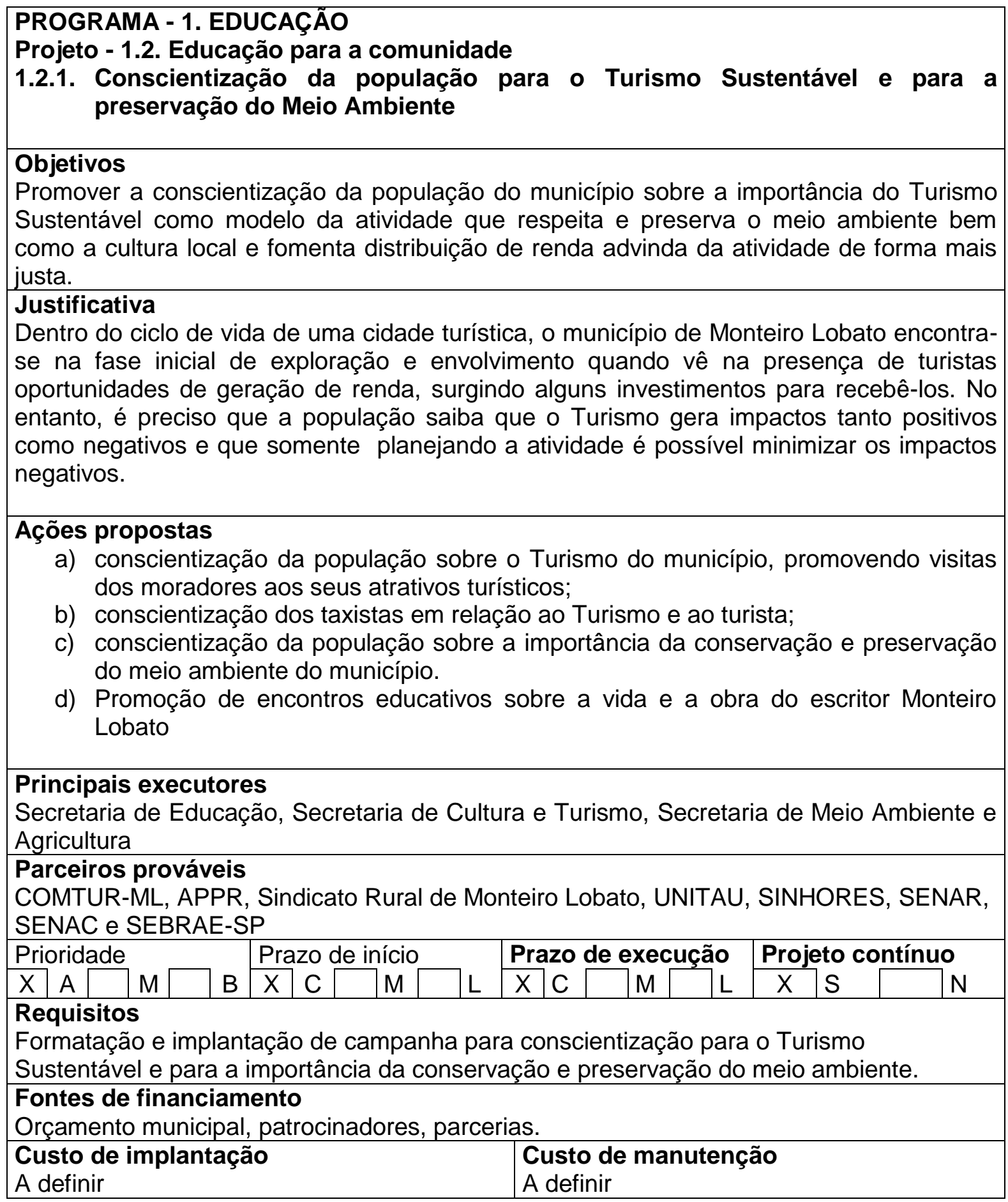

Quadro 37 - Projeto 1.2.1. Conscientização da população para o Turismo

Sustentável e para a preservação do Meio Ambiente 


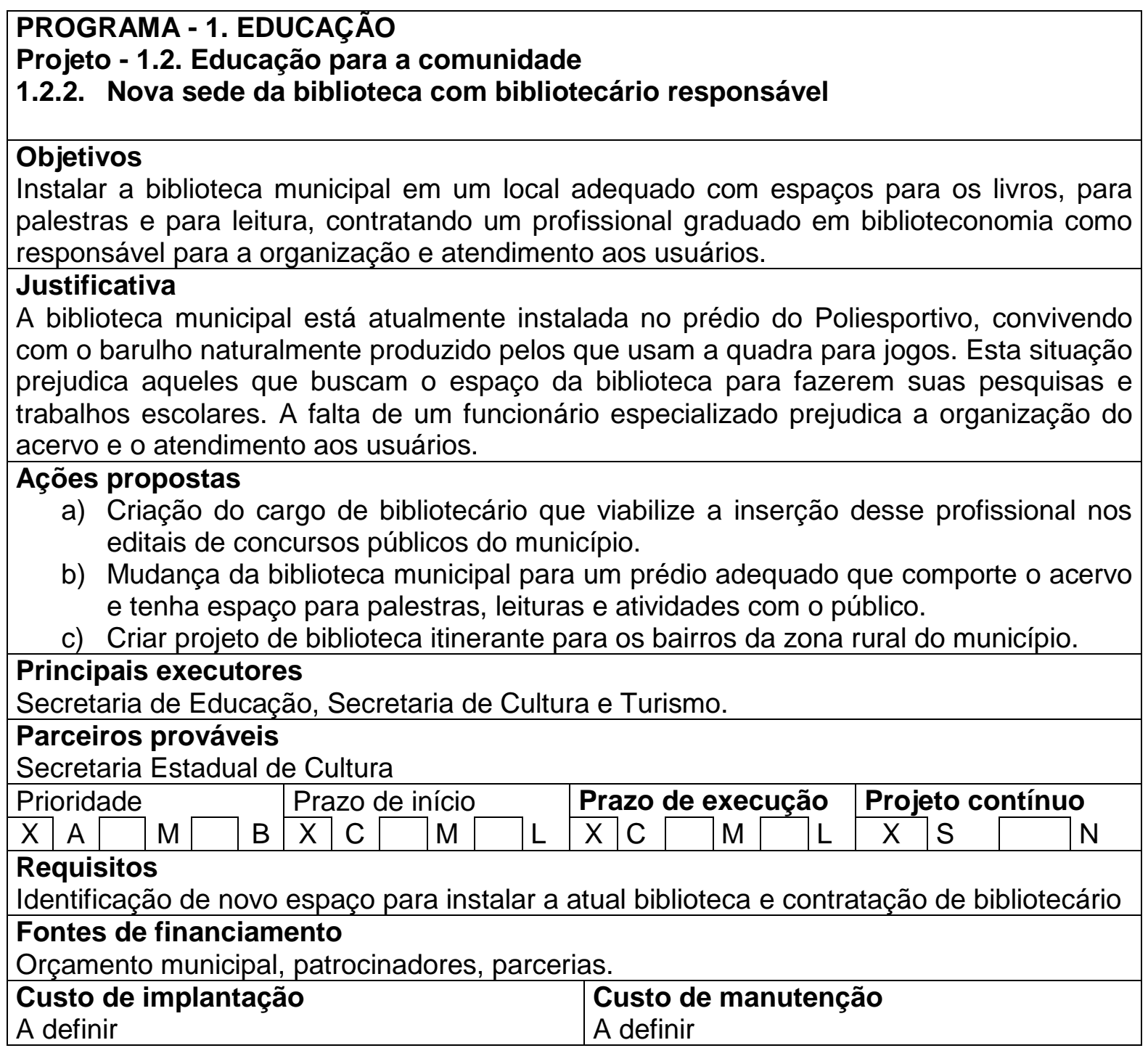

Quadro 38 - Projeto 1.2.2. Nova sede da biblioteca com bibliotecário responsável 


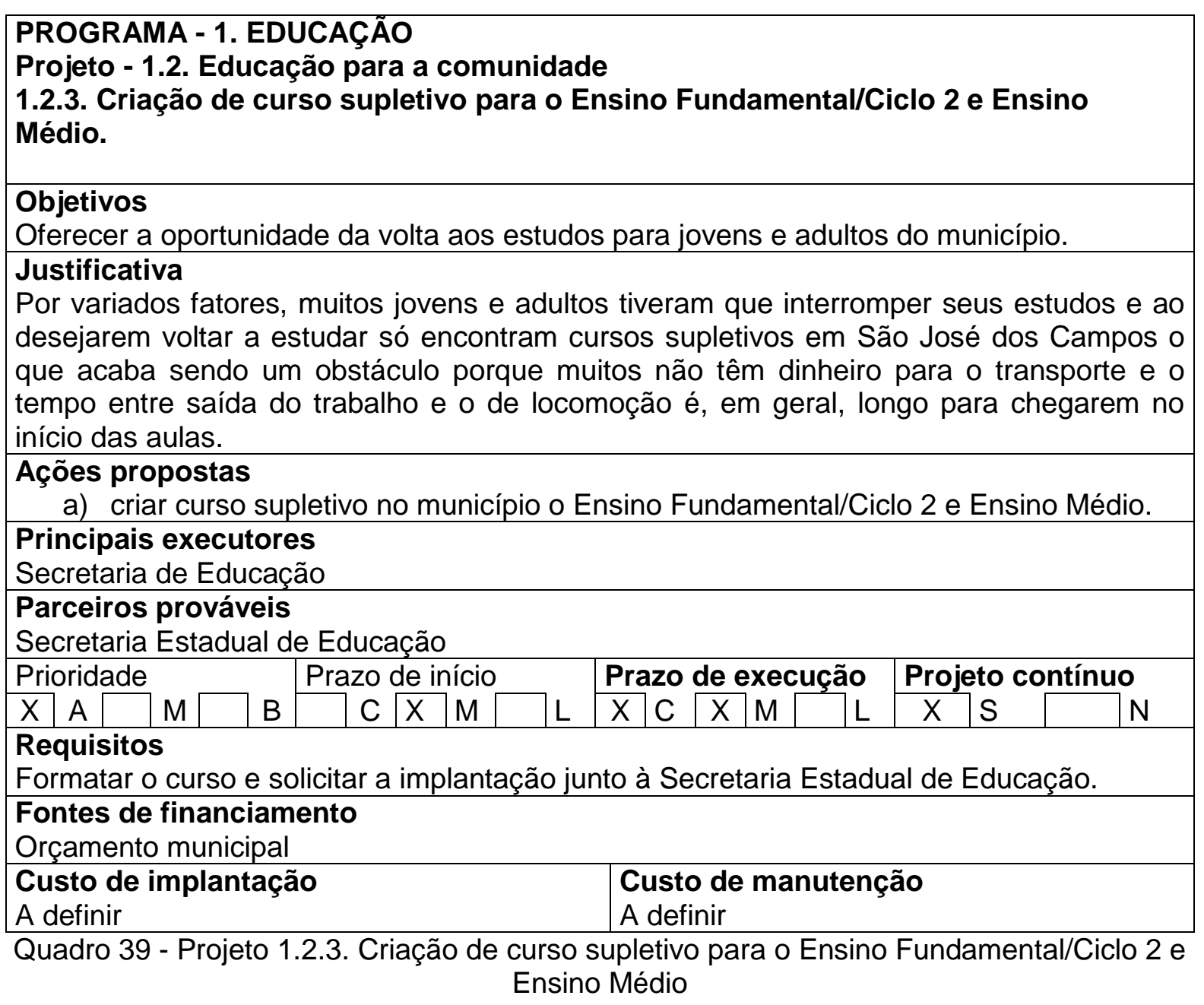


2. INFRAESTRUTURA TURÍSTICA

\begin{tabular}{l|l|l|l}
\hline $\begin{array}{l}\text { 2.1. Organização do } \\
\text { município para o } \\
\text { Turismo }\end{array}$ & $\begin{array}{l}\text { 2.2. Fomento à } \\
\text { promoção de } \\
\text { eventos }\end{array}$ & $\begin{array}{l}\text { 2.3. Organização } \\
\text { da Feira de } \\
\text { Artesanato e de } \\
\text { Produtos da Terra }\end{array}$ & $\begin{array}{l}\text { 2.4. Marketing } \\
\text { Turístico }\end{array}$ \\
$\begin{array}{l}\text { 2.1.1. Formatação } \\
\text { dos atrativos como } \\
\text { produtos turísticos } \\
\text { com infraestrutura } \\
\text { adequada e } \\
\text { preparados para } \\
\text { receberem turistas } \\
\text { com qualidade no } \\
\text { atendimento }\end{array}$ & $\begin{array}{l}\text { uma agenda de } \\
\text { eventos }\end{array}$ & $\begin{array}{l}\text { 2.3.1. Exposição e } \\
\text { venda de } \\
\text { artesanato e de } \\
\text { produtos da terra } \\
\text { em feira realizada } \\
\text { na Praça Cunha } \\
\text { Bueno (praça de } \\
\text { cima) nos finais de } \\
\text { semana e feriados }\end{array}$ & $\begin{array}{l}\text { 2.4.1. Elaboração } \\
\text { do Plano de } \\
\text { Marketing } \\
\text { Turístico de } \\
\text { Monteiro Lobato }\end{array}$ \\
$\begin{array}{l}\text { 2.1.2. Turismo } \\
\text { Receptivo }\end{array}$ & & \\
\hline
\end{tabular}

Quadro 40 - Projeto 2. Infraestrutura Turística 
PROGRAMA - 2. INFRAESTRUTURA TURÍSTICA

Projeto - 2.1. Organização do município para o Turismo

2.1.1. Formatação dos atrativos como produtos turísticos com infraestrutura adequada e preparados para receberem turistas com qualidade no atendimento

\section{Objetivos}

Analisar e avaliar os empreendimentos que já têm condições de receber turistas com qualidade e dentro dos critérios de sustentabilidade.

Analisar e avaliar os empreendimentos que ainda não estão em condições de receber turistas com qualidade, mas cujos proprietários estão dispostos a fazer investimentos para tal fim.

Definir e formatar os atrativos e fazer a composição da oferta turística do município.

\section{Justificativa}

A Oferta turística é o conjunto de bens e serviços organizados por empresas especializadas, que podem ser comprados por um preço estabelecido para desfrute em um lugar e momento determinados. Dessa forma, a atividade turística é desenvolvida por uma rede de serviços prestados por diversos produtores que são vistos como um todo pelos visitantes e, portanto, esses serviços devem ser integrados para que a experiência oferecida aos visitantes seja satisfatória tanto para estes como para os que prestam os serviços. Portanto, a qualidade da formatação dos atrativos turísticos e a qualidade dos serviços prestados determinarão o fluxo de turistas.

\section{Ações propostas}

a) Fazer pesquisa sobre quais atrativos estão aptos para atender os turistas e só assim divulgá-los para o público visitante e moradores

b) Controle de leitos - capacidade das pousadas - criar base de dados

c) Possibilitar visitas técnicas nos atrativos modelos a fim de promover a integração e aprendizagem dos empresários

\section{Principais executores}

Secretaria de Cultura e Turismo, patrocinadores e parcerias

\section{Parceiros prováveis}

COMTUR-ML, APPR, Sindicato Rural de Monteiro Lobato, UNITAU, SINHORES, SENAR, SENAC e SEBRAE-SP

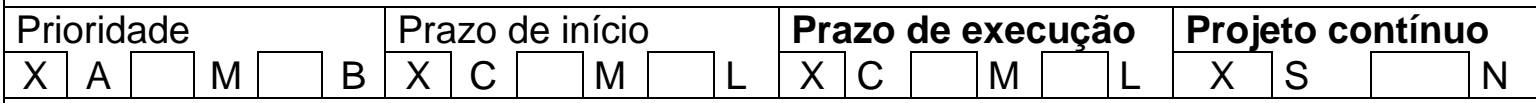

\section{Requisitos}

Definição da oferta turística

Fontes de financiamento

Orçamento municipal, patrocínios e parcerias

\begin{tabular}{|l|l|}
\hline $\begin{array}{l}\text { Custo de implantação } \\
\text { A definir }\end{array}$ & $\begin{array}{l}\text { Custo de manutenção } \\
\text { A definir }\end{array}$ \\
\hline
\end{tabular}

Quadro 41 - Projeto 2.1.1. Formatação dos atrativos como produtos turísticos com infraestrutura adequada e preparados para receberem turistas com qualidade no atendimento 


\section{PROGRAMA - 2. INFRAESTRUTURA TURÍSTICA \\ Projeto - 2.1. Organização do município para o Turismo \\ 2.1.2. Turismo Receptivo}

\section{Objetivos}

Estruturar o conjunto de atrativos e serviços turísticos para o atendimento ao turista.

\section{Justificativa}

O Turismo receptivo é composto pela oferta turística que, por sua vez, envolve os atrativos turísticos, as empresas turísticas, a infraestrutura de suporte do município e o marketing turístico.

No entanto, sendo o Turismo um fenômeno social que promove inter-relações entre moradores e visitantes, não se pode deixar de acrescentar a estes componentes 0 acolhimento turístico que demonstra a hospitalidade e o amparo que uma cidade dedica a seus visitantes, através da receptividade de sua população, do planejamento e ordenamento de sua infraestrutura turística e da qualidade dos serviços prestados.

\section{Ações propostas}

a) mapeamento das áreas e atrativos turísticos;

b) formatação de roteiros turísticos no município;

c) sinalização turística;

d) criação do Centro de Informações Turísticas;

e) formação de monitores locais

f) integração dos empresários na comunicação

g) reativação do Conselho Municipal de Turismo

h) gestão para a instalação de um Banco 24 horas para atendimento de correntistas de outros bancos além do Banco do Brasil e Bradesco.

\section{Principais executores}

Secretaria de Cultura e Turismo, patrocinadores, parcerias, Secretaria Estadual de Turismo

\section{Parceiros prováveis}

COMTUR-ML, APPR, Sindicato Rural de Monteiro Lobato, UNITAU, SINHORES, SENAR, SENAC E SEBRAE-SP

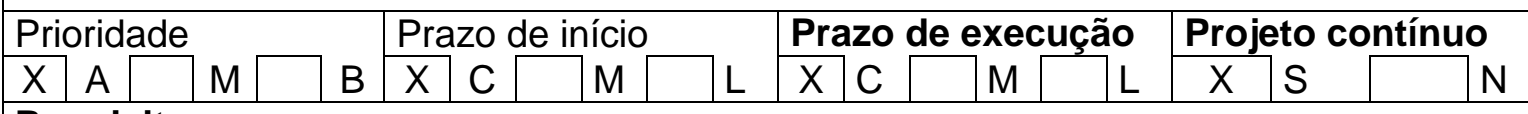

\section{Requisitos}

Definição de um Grupo de Trabalho empenhado em colaborar na realização das ações propostas e busca de recursos em conjunto com a Prefeitura.

\section{Fontes de financiamento}

Orçamento municipal, patrocínios e parcerias

Custo de implantação

A definir
Custo de manutenção

A definir

Quadro 42 - Projeto 2.1.2. Turismo Receptivo 


\section{PROGRAMA - 2. INFRAESTRUTURA TURÍSTICA \\ Projeto - 2.2. Fomento à promoção de eventos \\ 2.2.1. . Criação de uma agenda de eventos}

\section{Objetivos}

Estimular a realização de eventos que proporcionem lazer e entretenimento aos moradores e que ao mesmo tempo seja um fator de atração de turistas.

\section{Justificativa}

Os eventos quando somados à atividade turística proporciona maior geração de renda uma vez que envolve vários profissionais em sua organização, aumenta a média da permanência dos visitantes beneficiando a ocupação hoteleira e os demais serviços turísticos, colabora para a geração de trabalho e renda e para a diminuição da sazonalidade quando programados para a baixa estação.

No caso de Monteiro Lobato, recomenda-se definir a realização de eventos que agradem tanto moradores quanto visitantes em especial aqueles eventos que atraiam o público visitante que tenha o perfil de pessoas mais conscientizadas para a preservação do meio ambiente e para o respeito à cultura local

\section{Ações propostas}

a) Integrar os principais eventos da cidade no calendário regional: Festival de Literatura Infantil, Campeonato de Border Colier, Expomonteiro e Festa da Padroeira;

b) Criar festivais gastronômicos (doces caseiros, pratos típicos etc.);

c) Promover eventos musicais e teatro no coreto

d) divulgação de eventos através de painéis instalados em local de fácil visualização para moradores e turistas nas 2 praças e na rodoviária;

e) divulgação de eventos nos bairros

\section{Principais executores}

Secretarias Municipais: Cultura e Turismo, Desenvolvimento e Assistência Social, Fundo Social, Educação e Meio Ambiente e Agricultura

Parceiros prováveis

COMTUR-ML, APPR, Sindicato Rural de Monteiro Lobato, UNITAU, SINHORES, SENAR, SENAC e SEBRAE-SP

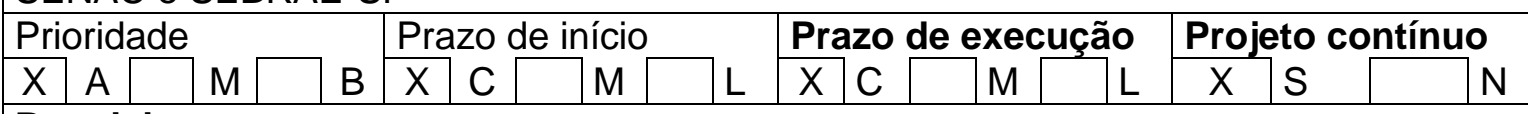

\section{Requisitos}

Definição de um Grupo de Trabalho empenhado em colaborar na realização das ações propostas e busca de recursos em conjunto com a Prefeitura.

\section{Fontes de financiamento}

Orçamento municipal, patrocínios e parcerias

Custo de implantação

A definir

Custo de manutenção

A definir

Quadro 43 - Projeto 2.2.1. Criação de uma agenda de eventos 
PROGRAMA - 2. INFRAESTRUTURA TURÍSTICA

Projeto - 2.3. Organização da Feira de Artesanato e de Produtos da Terra

2.3.1. Exposição e venda de artesanato e de produtos da terra em feira realizada na Praça Cunha Bueno (praça de cima) nos finais de semana e feriados

\section{Objetivos}

Fortalecer a produção do artesanato local e de produtos rurais, em especial dos produtos orgânicos por meio de um ponto de venda em local público.

\section{Justificativa}

O artesanato local está diretamente ligado ao Turismo representando o suvenir desejado pelo turista para seu uso, decoração de sua casa ou como presente para amigos e familiares. Da mesma forma, o turista deseja, além de conhecer o município, consumir os produtos nele produzidos.

\section{Ações propostas}

a) organizar a feira de artesanato e de produtos orgânicos e rurais na praça de cima

b) apoiar a união de artesãos e produtores rurais para que os mesmos façam a autogestão da feira;

c) promover atividades culturais e de lazer para moradores e turistas no espaço da feira para atrair visitação

d) fazer a divulgação da feira por meio de cartazetes e faixas

\section{Principais executores}

Artesãos, produtores rurais, Secretarias de Administração, Cultura e Turismo, Meio Ambiente e Agricultura, Assistência e Desenvolvimento Social, Esporte e Lazer e Fundo Social

\section{Parceiros prováveis}

COMTUR-ML, APPR, Sindicato Rural de Monteiro Lobato, ONG Agroeco, UNITAU, SINHORES, SENAR, SENAC e SEBRAE-SP

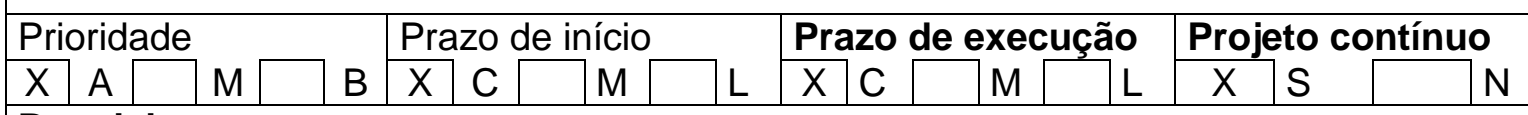

\section{Requisitos}

Definição de um Grupo de Trabalho empenhado em colaborar na realização das ações propostas e busca de recursos em conjunto com a Prefeitura.

Fontes de financiamento

Orçamento municipal, patrocínios e parcerias

\begin{tabular}{|l|l|}
\hline $\begin{array}{l}\text { Custo de implantação } \\
\text { A definir }\end{array}$ & $\begin{array}{l}\text { Custo de manutenção } \\
\text { A definir }\end{array}$ \\
\hline
\end{tabular}

Quadro 44 - Projeto 2.3.1. Exposição e venda de artesanato e de produtos da terra em feira realizada na Praça Cunha Bueno (praça de cima) nos finais de semana e feriados 
PROGRAMA - 2. INFRAESTRUTURA TURÍSTICA

Projeto - 2.4. Marketing Turístico

2.4.1. Elaboração do Plano de Marketing Turístico de Monteiro Lobato

\section{Objetivos}

Elaborar o Plano de Marketing Turístico para o município

Justificativa

O marketing é um processo social e gerencial que se inicia desde a decisão de se criar um produto e segue pelo seu desenvolvimento (incluindo pesquisas de mercado), comercialização (incluindo os 4 Ps: produto, praça, promoção e preço), pós-venda, fidelização de clientes etc.

O marketing turístico é a adaptação do marketing empresarial para as empresas de Turismo bem como para a divulgação institucional de um município turístico, podendo ser dimensionado para os planos local, regional, nacional e internacional. O município que pretende ser turístico precisa elaborar seu plano de marketing de acordo com suas especificidades e dentro dos objetivos e metas desejados. Na segunda Oficina de Planejamento Participativo do Turismo Sustentável para Monteiro Lobato, foram definidas como principais vocações turísticas o Turismo Cultural e o Turismo Rural.

\section{Ações propostas}

a) elaboração de plano de marketing turístico para o município (definição da vocação turística, formatação dos produtos turísticos, produção de folhetos e mapas turísticos, divulgação em feiras e eventos regionais e estaduais, criação de site específico para a divulgação turística do município etc.)

b) divulgação institucional pela Prefeitura;

c) divulgação comercial pelos empresários.

d) desenvolvimento de um portal na internet efetivo com o apoio e participação dos empresários

e) criação de um novo mapa turístico com informações completas para os visitantes tais como serviços disponíveis e informações como latitude e longitude (GPS nos carros)

f) divulgação nas redes sociais

\section{TURISMO CULTURAL}
a) Igrejas
b) Trincheiras da Revolução de 1932 e Rota Tropeira
c) Arte e artesanato
d) Escritor Monteiro Lobato
e) Cultura e tradições: o cotidiano do homem do campo - queijo, café com garapa etc.
f) manifestações populares
g) culinária
h) roda de viola

\section{TURISMO RURAL -}
a) Turismo no espaço rural e natural
b) Caminhadas, trilhas
c) Cachoeiras
d) Tradições caipiras
e) Visitar fazendas

3. OPORTUNIDADES: produção de postais, lembranças (camisetas), chaveiros, brindes etc.

Quadro 45 - Projeto 2.4.1. Elaboração do Plano de Marketing Turístico de Monteiro Lobato 


\section{ROÇA TOUR}

a) Conhecer as potencialidades turísticas do município de Monteiro Lobato

b) Exercitar o orgulho de morar na roça

\section{TEMAS PARA MARKETING E DIVULGAÇÃO}

- $51 \%$ de mata preservada

- Culinária regional

- Literatura

- Escritor Monteiro Lobato

- Portal de Entrada da Serra da Mantiqueira

- Cultura caipira

\section{Principais executores}

Secretarias de Cultura e Turismo, Desenvolvimento e Assistência Social, Fundo Social Parceiros prováveis

COMTUR-ML, APPR, Sindicato Rural de Monteiro Lobato, ONG Agroeco, UNITAU, SINHORES, SENAR, SENAC E SEBRAE-SP

\begin{tabular}{|c|c|c|c|c|c|c|c|c|c|c|c|}
\hline Prior & & & Pra & $\mathrm{ZOO}$ & nício & & Pra & 200 & exec & & \\
\hline$X$ & $\mathrm{M}$ & B & $X$ & C & M & $\mathrm{L}$ & & C & $M$ & & \\
\hline
\end{tabular}

\section{Requisitos}

Definição de um Grupo de Trabalho empenhado em colaborar na realização das ações propostas e busca de recursos em conjunto com a Prefeitura.

Fontes de financiamento

Orçamento municipal, patrocínios e parcerias

Custo de implantação

A definir

\section{Custo de manutenção \\ A definir}

Quadro 45 - Projeto 2.4.1. Elaboração do Plano de Marketing Turístico de Monteiro Lobato (continuação) 
3. INFRAESTRUTURA DA CIDADE

\begin{tabular}{|c|c|c|c|c|c|c|c|c|c|}
\hline $\begin{array}{l}3.1 . \\
\text { Conservação } \\
\text { das estradas } \\
\text { municipais } \\
\text { (prioridade) }\end{array}$ & $\begin{array}{l}\text { 3.2. Serviço } \\
\text { Público } \\
\text { Municipal }\end{array}$ & $\begin{array}{l}3.3 . \\
\text { Transporte } \\
\text { Público }\end{array}$ & $\begin{array}{l}\text { 3.4. Energia } \\
\text { Elétrica }\end{array}$ & $\begin{array}{l}3.5 . \\
\text { Banheiro } \\
\text { público }\end{array}$ & $\begin{array}{l}\text { 3.6. Esporte } \\
\text { e Lazer }\end{array}$ & $\begin{array}{l}3.7 . \\
\text { Segurança } \\
\text { Pública }\end{array}$ & $\begin{array}{l}\text { 3.8. Acessibi- } \\
\text { lidade }\end{array}$ & $\begin{array}{l}\text { 3.9. Espaços } \\
\text { Públicos }\end{array}$ & $\begin{array}{l}3.10 . \\
\text { Telefonia } \\
\text { Rural }\end{array}$ \\
\hline $\begin{array}{l}\text { 3.1.1. Plano } \\
\text { de } \\
\text { conservação } \\
\text { de estradas }\end{array}$ & $\begin{array}{l}\text { 3.2.1. } \\
\text { Reestruturação } \\
\text { de cargos e } \\
\text { salários }\end{array}$ & $\begin{array}{l}3.3 .1 . \\
\text { Melhoria } \\
\text { da } \\
\text { prestação } \\
\text { de } \\
\text { serviços } \\
\text { da } \\
\text { empresa } \\
\text { de ônibus } \\
\text { Cidade } \\
\text { Natureza }\end{array}$ & $\begin{array}{l}\text { 3.4.1. } \\
\text { Melhoria da } \\
\text { prestação } \\
\text { de serviços } \\
\text { da empresa } \\
\text { EDP } \\
\text { Bandeirante }\end{array}$ & $\begin{array}{l}\text { 3.5.1. } \\
\text { Adequação } \\
\text { dos } \\
\text { banheiros } \\
\text { da } \\
\text { rodoviária }\end{array}$ & $\begin{array}{l}\text { 3.6.1. } \\
\text { Reestrutu- } \\
\text { ração das } \\
\text { atividades } \\
\text { de esporte e } \\
\text { lazer para a } \\
\text { população e } \\
\text { revitalização } \\
\text { dos equipa- } \\
\text { mentos } \\
\text { existentes } \\
\text { para tal fim }\end{array}$ & $\begin{array}{l}\text { 3.7.1. } \\
\text { Articulação } \\
\text { para } \\
\text { melhorar a } \\
\text { segurança } \\
\text { pública no } \\
\text { município }\end{array}$ & $\begin{array}{l}\text { 3.8.1. } \\
\text { Melhoria da } \\
\text { acessibilidade } \\
\text { nas vias } \\
\text { públicas }\end{array}$ & $\begin{array}{l}\text { 3.9.1. } \\
\text { Revitalização } \\
\text { da Praça } \\
\text { Comendador } \\
\text { Freire (praça } \\
\text { de baixo) }\end{array}$ & $\begin{array}{l}\text { 3.10.1. } \\
\text { Melhoria } \\
\text { da comu- } \\
\text { nicação } \\
\text { telefônica } \\
\text { na zona } \\
\text { rural do } \\
\text { município }\end{array}$ \\
\hline
\end{tabular}

Quadro 46 - Projeto 3. Infraestrutura da Cidade 


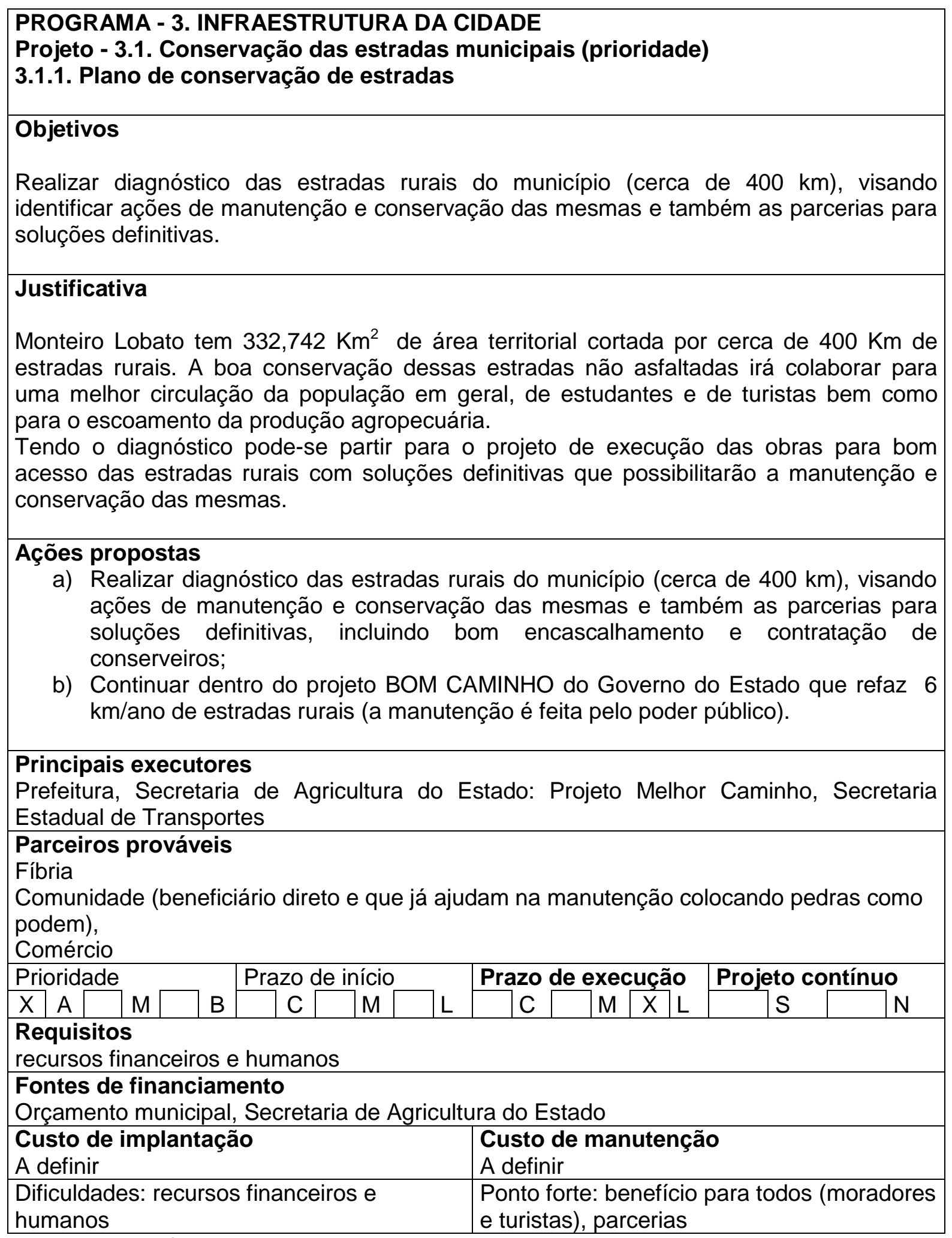

Quadro 47 - Projeto 3.1.1. Plano de conservação de estradas 


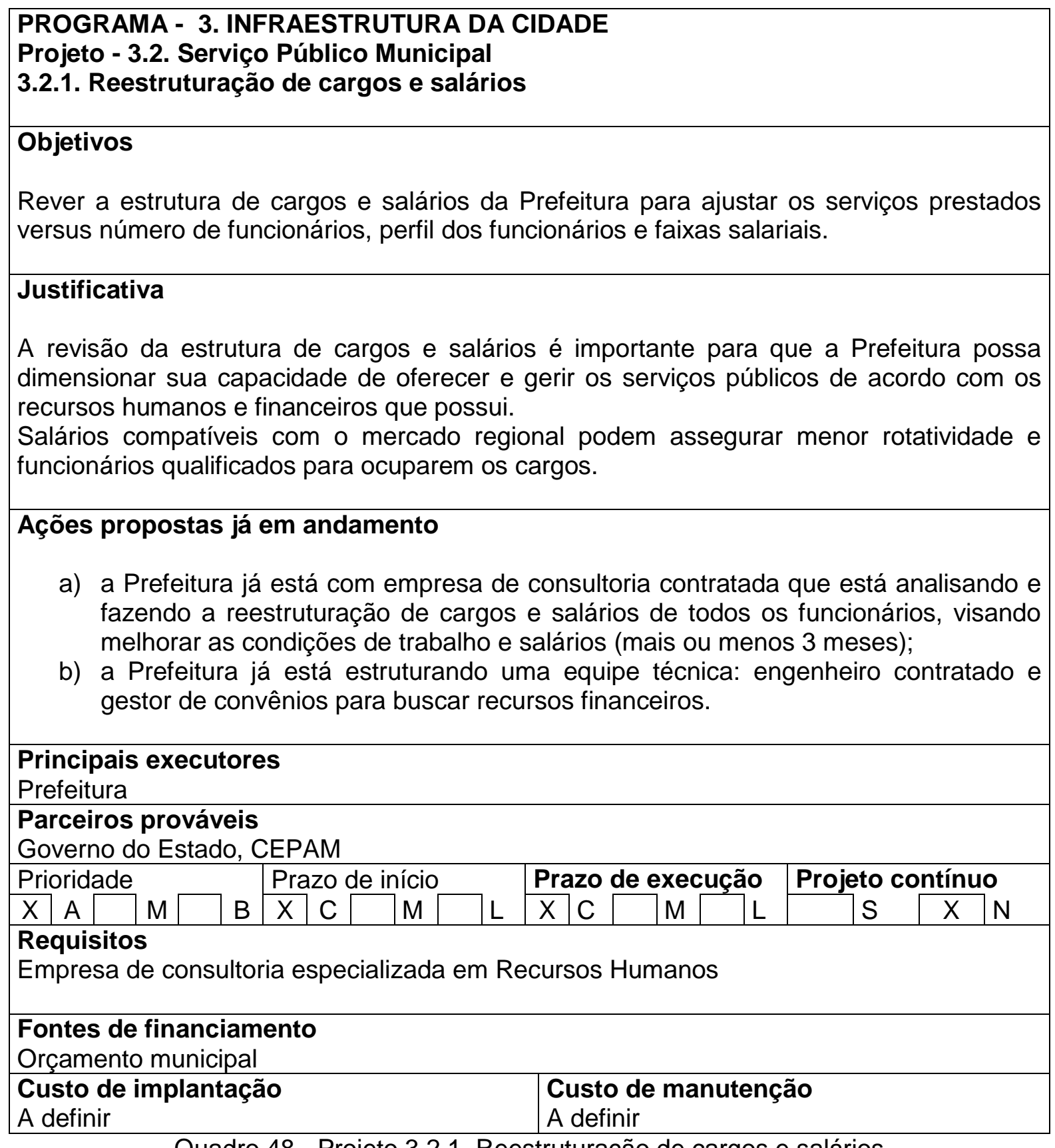

Quadro 48 - Projeto 3.2.1. Reestruturação de cargos e salários 


\begin{abstract}
PROGRAMA - 3. INFRAESTRUTURA DA CIDADE
Projeto - 3.3. Transporte Público

3.3.1. Melhoria da prestação de serviços da empresa de ônibus Cidade Natureza

\section{Objetivos}

Obter da empresa de ônibus Cidade Natureza uma melhor prestação de serviços.

\section{Justificativa}

A empresa de ônibus Cidade Natureza faz a linha São José dos Campos a São Francisco Xavier, com paradas na rodoviária de Monteiro Lobato. Os usuários lobatenses se queixam do mau atendimento dos motoristas aos passageiros idosos, da manutenção dos ônibus e da pouca oferta de horários dos ônibus.

Considerando a ligação forte que os moradores de Monteiro Lobato têm com São José dos Campos seja para trabalho, estudos, saúde, compras etc. e a distância entre os dois municípios, essa linha apresenta-se como a única forma de locomoção para os moradores que não possuem veículos próprios. Dessa forma, entende-se como justo o atendimento dessas demandas.

Com o planejamento turístico do município levantou-se por meio de pesquisas que há turistas que vêm ao município usando essa linha e daí surgiu a sugestão de se implantar uma linha de ônibus de Turismo, além da linha regular.
\end{abstract}

\title{
Ações propostas já em andamento
}

a) Já existe conversação entre a Prefeitura e a empresa de ônibus Cidade Natureza para melhorias de atendimento e possíveis parcerias, inclusive na questão de ônibus voltado para o turismo.

\section{Principais executores}

Prefeitura, Empresa Cidade Natureza

Parceiros prováveis

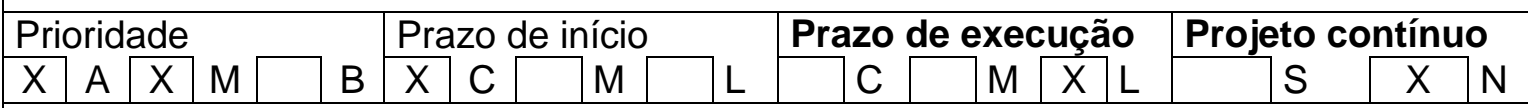

Requisitos

Fontes de financiamento

Orçamento municipal

Custo de implantação

A definir

Custo de manutenção

A definir

Quadro 49 - Projeto 3.3.1. Melhoria da prestação de serviços da empresa de ônibus Cidade Natureza 


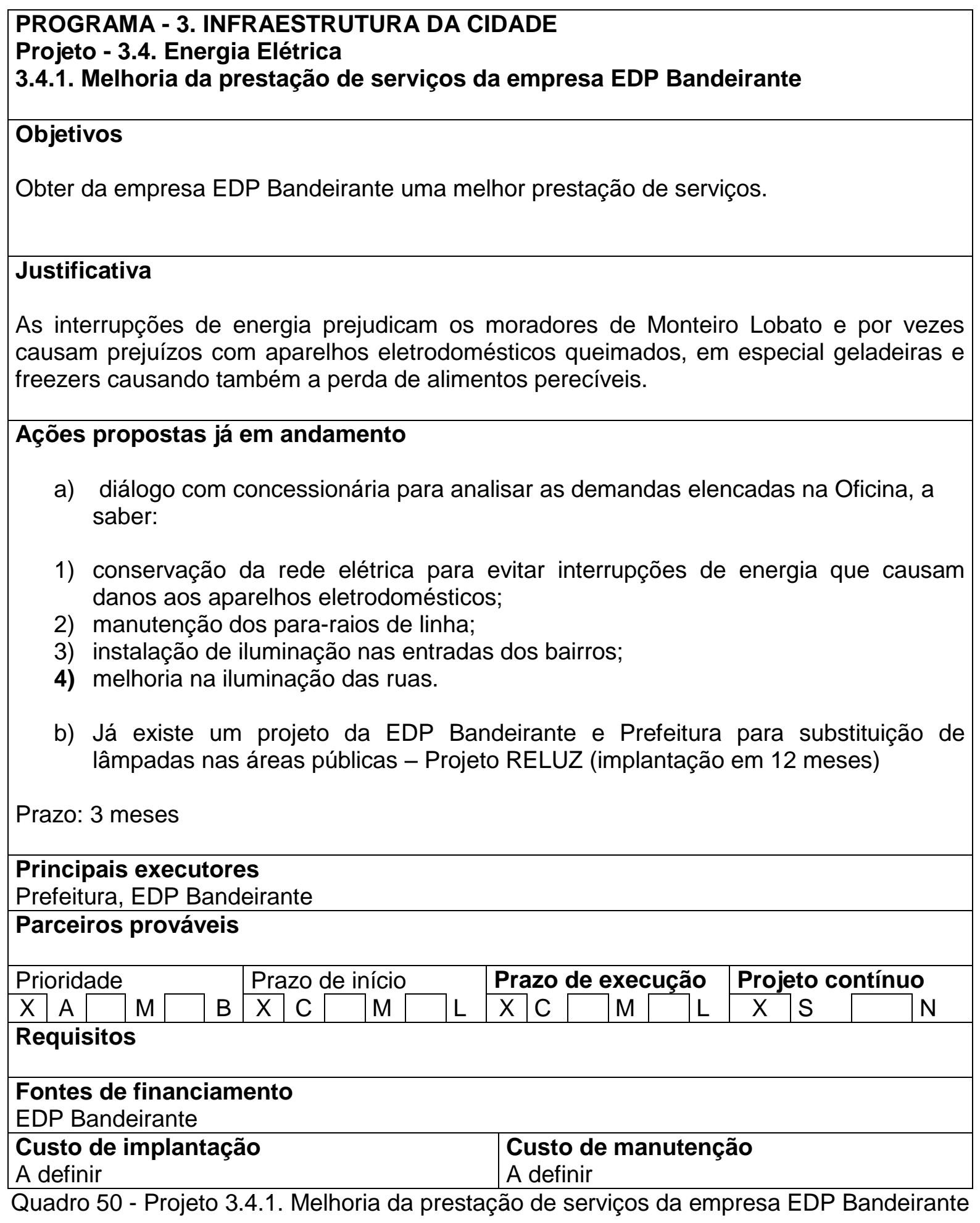




\section{PROGRAMA - 3. INFRAESTRUTURA DA CIDADE \\ Projeto - 3.5. Banheiro público \\ 3.5.1. Adequação dos banheiros da rodoviária}

\section{Objetivos}

Oferecer banheiro público para moradores e visitantes no centro da cidade.

\section{Justificativa}

Nós seres humanos temos necessidades fisiológicas e necessitamos de banheiros higienizados tanto quando estamos em nossas casas como quando estamos fora delas.

No Brasil, os municípios turísticos, como ação de hospitalidade, primam por oferecer banheiros públicos limpos em locais estratégicos como calçadões, mercados municipais, parques, etc. Em geral, são localizados em imóveis próximos a esses locais ou dentro deles. O mesmo acontece nos países europeus, nos Estados Unidos, Canadá etc. Em Paris, há banheiros públicos nas calçadas que são acessados pelo pagamento em moedas e possuem sistema de auto-higienização após o uso.

Comprovadamente por meio de pesquisa, Monteiro Lobato recebe turistas tanto os de passagem (diariamente) quanto aqueles que vêm para passar um dia ou o final de semana no município. Estes turistas movimentam a economia ao consumirem produtos e serviços no comércio local e oferecer banheiros limpos é um sinal de acolhimento e respeito aos visitantes.

\section{Ações propostas}

a) melhorar as condições dos banheiros da rodoviária;

b) fazer adaptações para as pessoas portadoras de necessidades especiais

c) conscientizar os comerciantes sobre a importância de oferecem banheiros em boas condições de uso aos seus clientes e sobre a possibilidade de mais consumo quando oferecem banheiros para turistas

Prazo: médio - 6 meses a um ano

Principais executores

Prefeitura, comerciantes

Parceiros prováveis

COMTUR-ML, comunidade

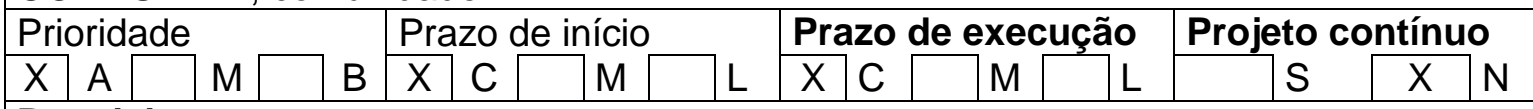

Requisitos

Fontes de financiamento

Prefeitura, comerciantes

Custo de implantação

A definir

Custo de manutenção

A definir

Quadro 51 - Projeto 3.5.1. Adequação dos banheiros da rodoviária 
PROGRAMA - 3. INFRAESTRUTURA DA CIDADE

Projeto - 3.6. Esporte e Lazer

3.6.1. Reestruturação das atividades de esporte e lazer para a população e revitalização dos equipamentos existentes para tal fim

\section{Objetivos}

Oferecer aos munícipes atividades de esporte e lazer utilizando equipamentos adequados e com qualidade.

\section{Justificativa}

O Art. 6ํ da Constituição Federal de 1988 estabelece que o lazer é um dos direitos sociais do povo brasileiro. O lazer pode ser definido como um conjunto de atividades que o indivíduo faz por escolha própria em seu tempo livre seja para repousar, divertir-se, viajar etc. Nas administrações públicas, o esporte encontra-se diluído em setores sociais que o instrumentalizam e o utilizam como atividades nos setores de educação e de saúde.

Dessa forma, esporte e lazer são itens inerentes à qualidade de vida das pessoas.

Ações propostas em andamento

a) a reestruturação da Secretaria Municipal de Esportes já está contemplando os itens citados na Oficina, a saber:

1) revitalização e organização dos usos do Ginásio Poliesportivo com outras modalidades de esportes (basquete, vôlei, tae kwon do etc.) além das já realizadas; criação de pista para corrida e atletismo em volta do prédio;

2) Instalação de academia ao ar livre nos bairros;

3) oferecimento de atividades de lazer para a população;

4) organização de atividades para pessoas da melhor idade: promover outras atividades de convivência, xadrez, damas, bocha etc.;

b) Já está prevista uma reforma interna do poliesportivo (quadra, troca de tablado)

c) há academias ao ar livre com equipamentos adequados para exercícios físicos ao lado da Gruta de Nossa Senhora de Lourdes, no Poliesportivo, Vila Esperança, Morada do Sol, Souza e São Benedito.

d) Atividades iniciadas a partir de março-abril:

- Mais professores

- Time de basquete (treinar na cidade e jogar pela cidade - 60 jovens da cidade)

- Orientação nas academias ao ar livre

e) Projeto: propor eventos esportivos que alavancam o Turismo como, por exemplo, corridas ecológicas, passeios ciclísticos, cavalgadas etc.

Prazo: 6 meses

Principais executores

Prefeitura, Secretaria de Esportes e Lazer, Secretaria de Educação e Secretaria de Cultura e Turismo

Parceiros prováveis

Secretarias Estaduais de Esportes, Cultura, Turismo e Educação, comércio local \begin{tabular}{|l|l|l}
\hline Prioridade & Prazo de início \\
\hline
\end{tabular}

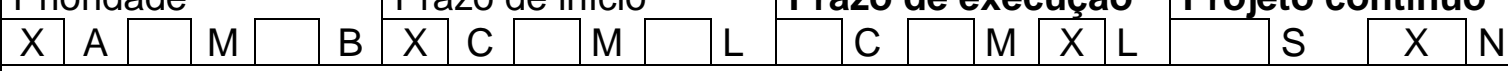

Requisitos

Recursos financeiros, articulação entre secretarias municipais e estaduais

Fontes de financiamento

Prefeitura, comerciantes

Custo de implantação

A definir

Custo de manutenção

A definir

Dificuldade: articulação

Ponto forte: visibilidade

Quadro 52 - Projeto 3.6.1. Reestruturação das atividades de esporte e lazer para a

população e revitalização dos equipamentos existentes para tal fim 


\section{PROGRAMA - 3. INFRAESTRUTURA DA CIDADE \\ Projeto - 3.7. Segurança Pública}

3.7.1. Articulação para melhorar a segurança pública no município

\section{Objetivos}

Fazer articulações para melhoria da segurança pública tanto para moradores como para turistas no município.

\section{Justificativa}

Muitos são os aspectos ligados à segurança pública que incluem desde a ação educativa no trânsito até os mais variados tipos de crimes praticados contra pessoas, animais e o meio ambiente.

Monteiro Lobato conta com um posto da Polícia Militar e uma delegacia da Polícia Civil, sendo que o Corpo de Bombeiro, a Polícia Florestal e a Polícia Rodoviária Estadual são acionados quando há ocorrências.

Infelizmente, o município tem sido alvo de assaltos a lojas e casas feitos por quadrilhas que inclusive estouraram o caixa eletrônico do Banco Bradesco no primeiro semestre de 2013. Além do tráfico de drogas, há casos de furtos e brigas entre pessoas embriagadas e dentro das famílias.

Dessa forma, a segurança pública é um assunto muito importante que diz respeito a toda a sociedade.

\section{Ações propostas}

a) Abertura de comunicação/diálogo com a Polícia Militar e a Polícia Civil (Secretaria Estadual de Segurança Pública);

b) Foco: atendimento às demandas levantadas e possibilidade de parceira e/ou convênio com a Prefeitura (analisar a questão do custo $x$ benefício):

1) melhoria da atuação das polícias civil e militar (mais profissionais e rodízio de policiais);

2) organização da aplicação de multas por meio de convênio entre a Prefeitura e a Polícia Militar para que o município tenha receita;

3) melhoria da sinalização de trânsito.

c) parceria com Polícia Ambiental;

d) colocar câmaras na cidade.

Prazo: 3-6 meses

Principais executores

Prefeitura, Câmara Municipal, CONSEG

\section{Parceiros prováveis}

Secretaria Estadual de Segurança Pública, Polícia Militar, Polícia Civil

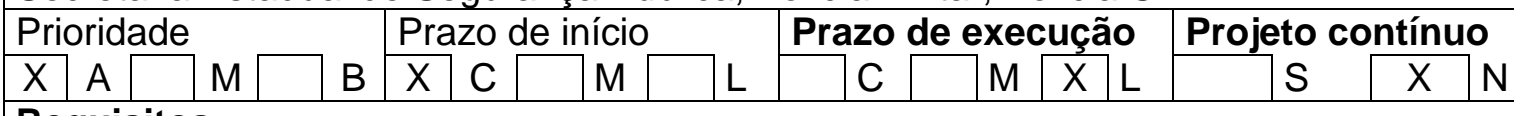

\section{Requisitos}

Recursos financeiros, articulação entre secretarias municipais e estaduais

\section{Fontes de financiamento}

Prefeitura, Secretaria Estadual de Segurança Pública

\section{Custo de implantação}

A definir

\section{Custo de manutenção \\ A definir}

Quadro 53 - Projeto 3.7.1. Articulação para melhorar a segurança pública no município 


\section{PROGRAMA - 3. INFRAESTRUTURA DA CIDADE \\ Projeto - 3.8. Acessibilidade \\ 3.8.1. Melhoria da acessibilidade nas vias públicas}

\section{Objetivos}

Aplicar a Lei $n^{0} 10.098$, de 19 de dezembro de 2000 que estabelece normas gerais e critérios básicos para a promoção da acessibilidade das pessoas portadoras de deficiência ou com mobilidade reduzida.

\section{Justificativa}

Monteiro Lobato, com 133 anos de fundação, praticamente mantém seu traçado original na área central e, portanto, possui ruas e calçadas estreitas com árvores. Por não ter um plano diretor que estabeleça o uso e ocupação do solo, código de obras etc. há irregularidades nas vias públicas que dificultam a mobilidade de pedestres, em especial das pessoas portadoras de deficiência física (físicas, auditivas e visuais).

\section{Ações propostas}

a) Prioridade: melhoria das calçadas - estudo sobre a situação das calçadas, em todo o município, definindo as responsabilidades (poder público, moradores e comerciantes);

b) identificar as questões referentes à acessibilidade e drenagem;

c) verificar a possibilidade de criar legislação municipal sobre padronização das calçadas e acessibilidade

Prazo: curto prazo (3 meses)

Principais executores

Prefeitura, Câmara Municipal

\section{Parceiros prováveis}

moradores, comerciantes, universidades (UNITAU, UNIVAP)

Prioridade

$\mathrm{X} A \square \mathrm{A}$

Requisitos

Recursos financeiros, projeto técnico

\section{Fontes de financiamento}

Prefeitura, parcerias com moradores e comerciantes

\section{\begin{tabular}{|l|l|}
\hline Custo de implantação & Custo de manutenção
\end{tabular}}

A definir

A definir

Pontos Fortes: acessibilidade,

Pontos fracos: recursos financeiros

embelezamento

Quadro 54 - Projeto 3.8.1. Melhoria da acessibilidade nas vias públicas 


\begin{abstract}
PROGRAMA - 3. INFRAESTRUTURA DA CIDADE
Projeto - 3.9. Espaços Públicos

3.9.1. Revitalização da Praça Comendador Freire (praça de baixo)

\section{Objetivos}

Revitalização da Praça Comendador Freire e criação de vagas para estacionamento no seu entorno.

\section{Justificativa}

Em geral, as praças centrais de municípios de pequeno porte são localizadas próximas à Igreja Matriz, não sendo o caso de Monteiro Lobato, cuja praça principal localiza-se na parte mais baixa da cidade. A praça é um espaço de encontros de pessoas e, portanto, tem um papel social muito importante na dinâmica do cotidiano dos moradores. Por ser circundada pela maior parte do comércio local, é na Praça Comendador Freire que, durante o dia, moradores e visitantes circulam, conversam, trocam informações, descansam, passam o tempo observando o movimento ou enquanto esperam o ônibus. À noite, o movimento diminui uma vez que os moradores se recolhem e apenas os bares, padarias e a pizzaria ficam abertos. Esporadicamente, são realizados eventos como quermesses beneficentes, shows, projeção de filmes e o carnaval e, nesses momentos, a praça ganha vida noturna.

Quando a questão da revitalização da Praça Comendador Freire foi levantada na primeira Oficina de Planejamento do Turismo Sustentável de Monteiro Lobato, já havia a iniciativa de um projeto de reforma da praça e o esforço da prefeitura em buscar recursos para a sua execução. A verba necessária foi conseguida por meio de emenda parlamentar feita pelo Deputado Estadual Helio Nishimoto. As obras foram iniciadas em janeiro de 2013 e a praça deverá ser entregue á população em abril de 2013.

Foram criadas vagas para carros em $45 \%$ em volta da praça, porém essas vagas são insuficientes, sendo necessário criar mais vagas organizadas e sinalizadas nas ruas próximas à praça.
\end{abstract}

\title{
Ações propostas
}

a) revitalização da praça de baixo em andamento;

b) criação de mais vagas para estacionamento no centro da cidade;

\section{Principais executores}

Prefeitura, Secretaria de Transportes

\section{Parceiros prováveis}

moradores, comerciantes, vereadores

\begin{tabular}{l|l} 
Prioridade & Prazo de início
\end{tabular}

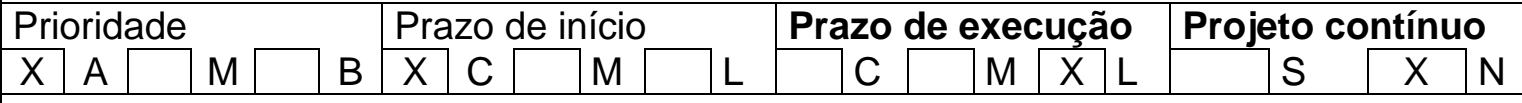

\section{Requisitos}

Definição de projeto de localização das vagas e recursos materiais para sinalização das mesmas.

\section{Fontes de financiamento}

Orçamento municipal, parcerias com moradores e comerciantes

\section{Custo de implantação}

A definir

Pontos Fortes: acessibilidade, embelezamento

\section{Custo de manutenção}

A definir

Pontos fracos: recursos financeiros

Quadro 55 - Projeto 3.9.1. Revitalização da Praça Comendador Freire (praça de baixo) 


\begin{abstract}
PROGRAMA - 3. INFRAESTRUTURA DA CIDADE
Projeto - 3.10. Telefonia Rural

3.10.1. Melhoria da comunicação telefônica na zona rural do município

Objetivos

Estabelecer contato com as empresas de telefonias para buscar a melhoria da comunicação na zona rural do município.

\section{Justificativa}

O Inciso I do Artigo $2^{\circ}$ da Lei $n^{\circ}$ 9.472, de 16 de julho de 1997 que dispõe sobre a organização dos serviços de telecomunicações estabelece que o Poder Público tem o dever de garantir a toda a população o acesso às telecomunicações, a tarifas e preços razoáveis, em condições adequadas. Esta lei também cria a Agência Nacional de Telecomunicações (ANATEL) vinculada ao Ministério das Comunicações, com a função de órgão regulador das telecomunicações no Brasil. A telefonia celular é classificada pela ANATEL como um serviço privado, porém, regulamentado pela essa agência.

Desta forma é justo que a população da zona rural tenha acesso à comunicação móvel e para tal efeito é necessário que os poderes executivo e legislativo de Monteiro Lobato façam gestões para que esse direito seja atendido.
\end{abstract}

\title{
Ações propostas
}

a) Levantar informações junto à ANATEL sobre os compromissos que as operadoras de telefonia têm com os municípios através de leis;

b) Abertura de diálogo com as empresas de telefonia, contatando os respectivos diretores de Relações Institucionais;

c) Cobrar soluções das empresas de telefonias via ANATEL.

Prazo: 3 meses

Principais executores

Prefeitura, Câmara Municipal, empresas de telefonia,

Parceiros prováveis

Moradores da zona rural de Monteiro Lobato

\begin{tabular}{|l|l|}
\hline Prioridade & Prazo de início \\
\hline$X$
\end{tabular}

\begin{tabular}{|c|c|c|c|c|}
\hline & $\mathrm{X} A \mathrm{~A} \longrightarrow \mathrm{M}$ & B & $\mathrm{x}$ & C \\
\hline
\end{tabular}

Requisitos

Busca de diálogo com ANATEL e empresas de telefonia

Fontes de financiamento

Empresas de telefonia, usuários

Custo de implantação

A definir

Prazo de execução

Projeto contínuo

Quadro 56 - Projeto 3.10.1. Melhoria da comunicação telefônica na zona rural do município

Custo de manutenção

A definir S $\mathrm{X} N$ 


\section{COMUNICAÇÃO}

4.1. Comunicação turística para visitantes

4.1.1. Ações para divulgar informações sobre o Turismo do município

Quadro 57 - Projeto 4. Comunicação 


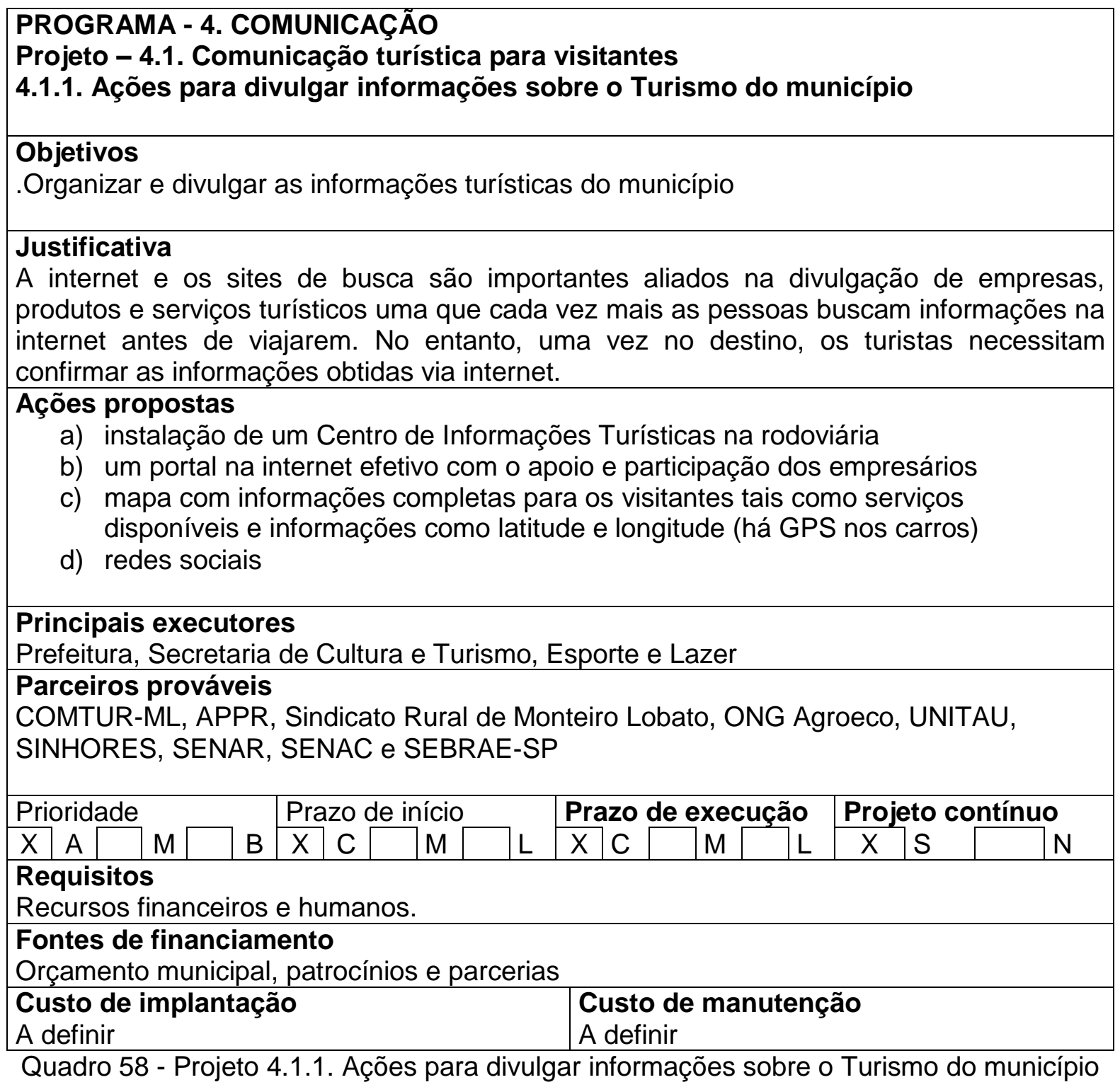




\section{COMPORTAMENTO}

5.1. Conscientização da comunidade para o Turismo Sustentável

5.1.1. Mudança de comportamento do lobatense em relação aos aspectos pessoais, sociais, empresariais e de relacionamento governo-comunidadeiniciativa privada

Quadro 59 - Projeto 5. Comportamento 


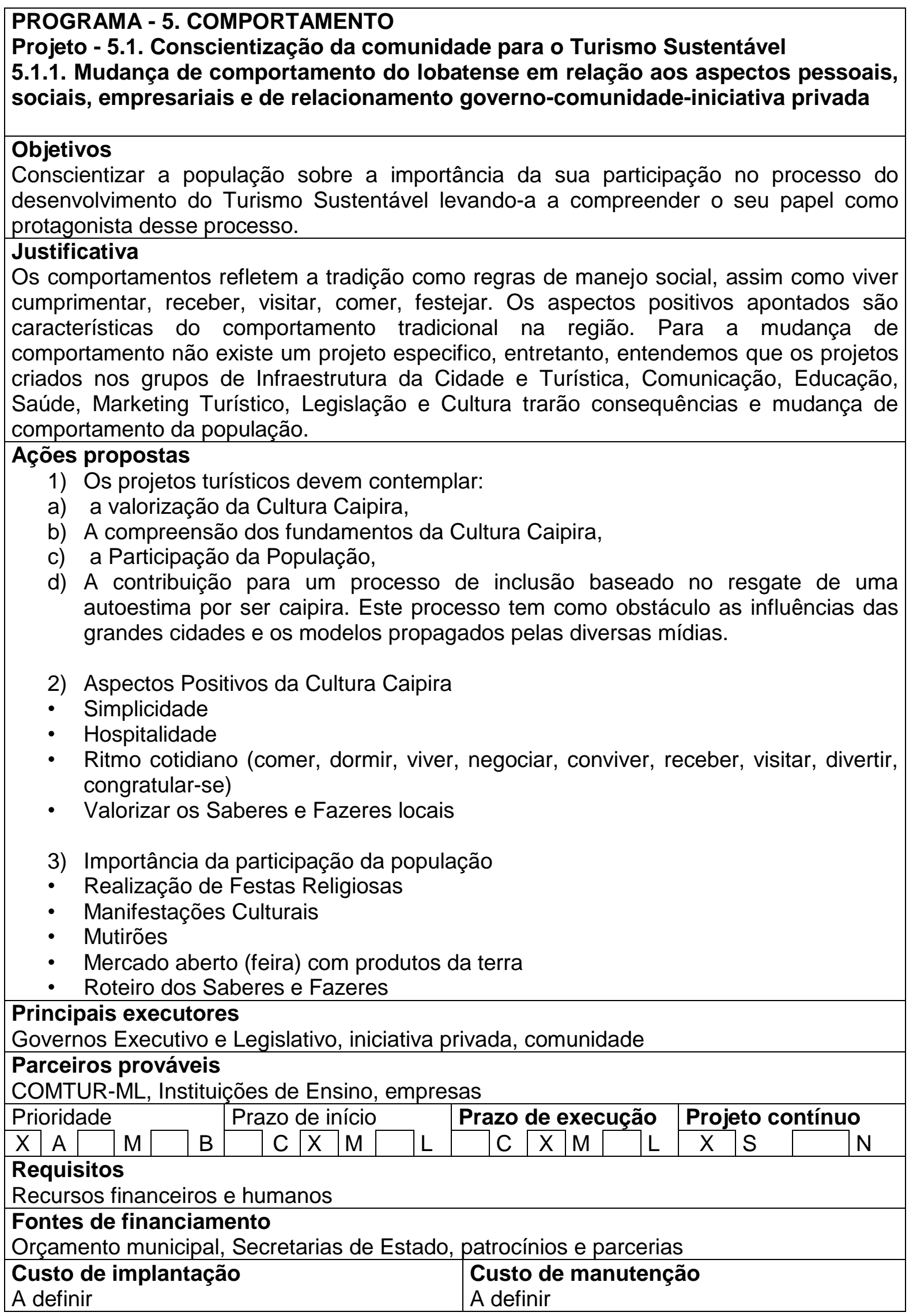

Quadro 60 - Projeto 5.1.1. Mudança de comportamento do lobatense em relação aos aspectos pessoais, sociais, empresariais e de relacionamento governo-comunidadeiniciativa privada 


\section{LEGISLAÇÃO}

6.1. Criação de leis municipais e aplicação das leis estaduais e federais

6.1.1. Criação de leis municipais para disciplinar os fatos que acontecem no município e que prejudicam a comunidade e visitantes

Quadro 61 - Projeto 6. Legislação 


\begin{abstract}
PROGRAMA - 6. LEGISLAÇÃO
Projeto - 6.1. Criação de leis municipais e aplicação das leis estaduais e federais

6.1.1. Criação de leis municipais para disciplinar os fatos que acontecem no município e que prejudicam a comunidade e visitantes

\section{Objetivos}

Criar leis municipais específicas para o disciplinamento dos fatos que ocorrem no município e que prejudicam a comunidade e visitantes.

Justificativa

Em Monteiro Lobato, assim como em todos os municípios, há acontecimentos cuja dinâmica nem sempre é antevista pelos seus governos executivo e legislativo. No entanto, à medida que tais acontecimentos começam a causar problemas à comunidade local, tornam-se necessárias leis que os disciplinem e garantam a ordem no município. Essas leis devem conter mecanismos para que sejam cumpridas.
\end{abstract}

\title{
Ações propostas
}

1) Elaborar Lei do Plano Diretor do Município: regulamentação do uso e a ocupação do solo e código de obras

2) Aplicar a Lei do Estatuto da Cidade (Lei no 10.257/01) para terrenos ou imóveis abandonados: ter fiscalização e aplicar o IPTU Progressivo no tempo

3) Acessibilidade: aplicar a Lei $\mathbf{n}^{\circ} \mathbf{1 0 . 0 9 8}$, de 19 de dezembro de 2000

4) Criar lei para padronização de calçadas

5) Criar lei para implantação de ciclovias

6) criar lei para proibir som automotivo em ruas e praças do município

7) criar lei para regulamentar o comércio ambulante

8) criar mecanismos de fiscalização para regularização das empresas do município (indústrias, agroindústrias, comércio, meios de alimentação e de hospedagem, atrativos turísticos e empresas prestadoras de serviços)

9) cobrar do DER e da Polícia Rodoviária Estadual a fiscalização na Rodovia SP-50 para impedir que carretas com especificações acima do permitido circulem pela Rodovia e por conseguinte pelo centro de Monteiro Lobato

Principais executores

Prefeitura e Câmara Municipal

Parceiros prováveis

Governos Estadual e Federal

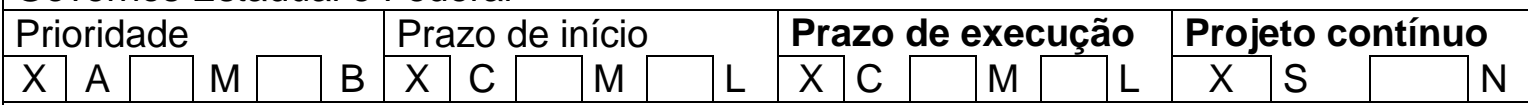

Requisitos

Recursos Humanos

Fontes de financiamento

Orçamento municipal, Câmara Municipal

Custo de implantação

A definir

Custo de manutenção

A definir

Quadro 62 - Projeto 6.1.1. Criação de leis municipais para disciplinar os fatos que acontecem no município e que prejudicam a comunidade e visitantes 
7. SAÚDE PÚBLICA EM RELAÇÃO AO TURISMO

7.1. Busca de solução para fatos relacionados à saúde pública que prejudicam moradores e visitantes

7.1.1. Abandono de Animais

7.1.2. Drogas e Alcoolismo

Quadro 63 - Projeto 7. Saúde Pública em Relação ao Turismo 


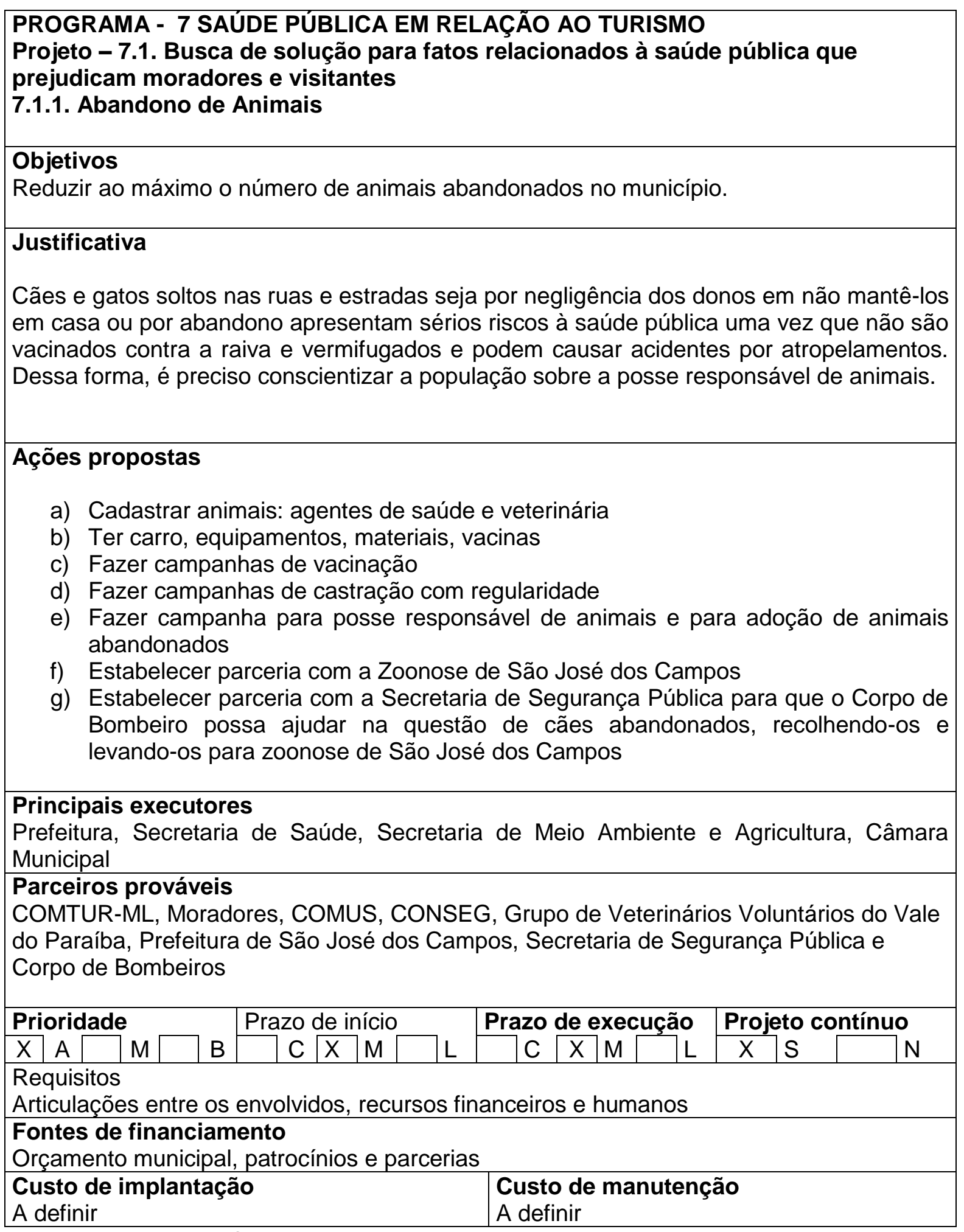

Quadro 64 - Projeto 7.1.1. Abandono de Animais 


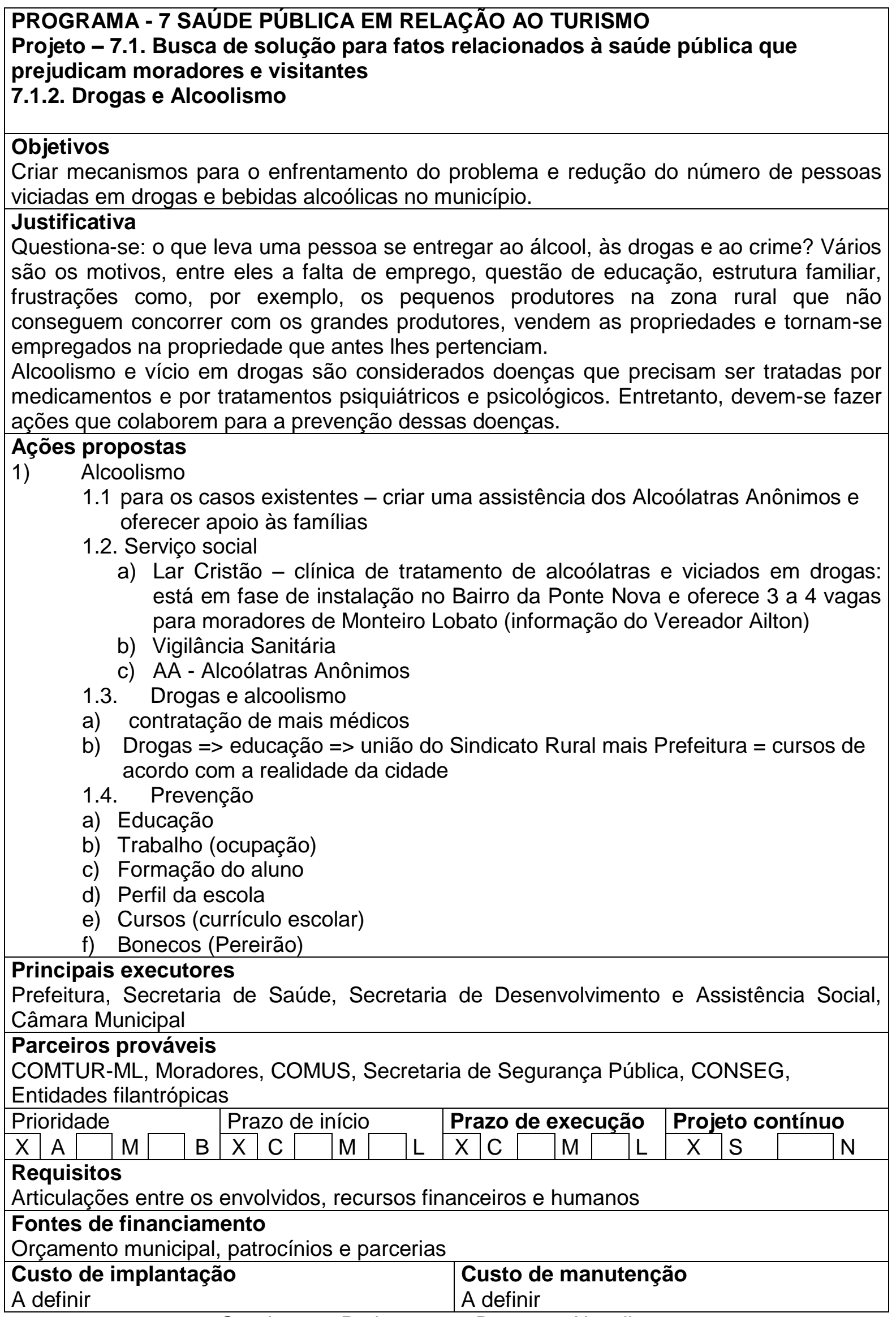


8. CULTURA

\begin{tabular}{l|l}
\hline 8.1. Política de Cultura & $\begin{array}{l}\text { 8.2. Criação do Museu Histórico de } \\
\text { Monteiro Lobato }\end{array}$ \\
$\begin{array}{l}\text { 8.1.1. Criação da Política Pública } \\
\text { de Cultura em Monteiro Lobato }\end{array}$ & $\begin{array}{l}\text { 8.2.1. Viabilidade de um projeto } \\
\text { para criação do museu histórico } \\
\text { para Monteiro Lobato }\end{array}$ \\
\hline
\end{tabular}

Quadro 66 - 8. Cultura 


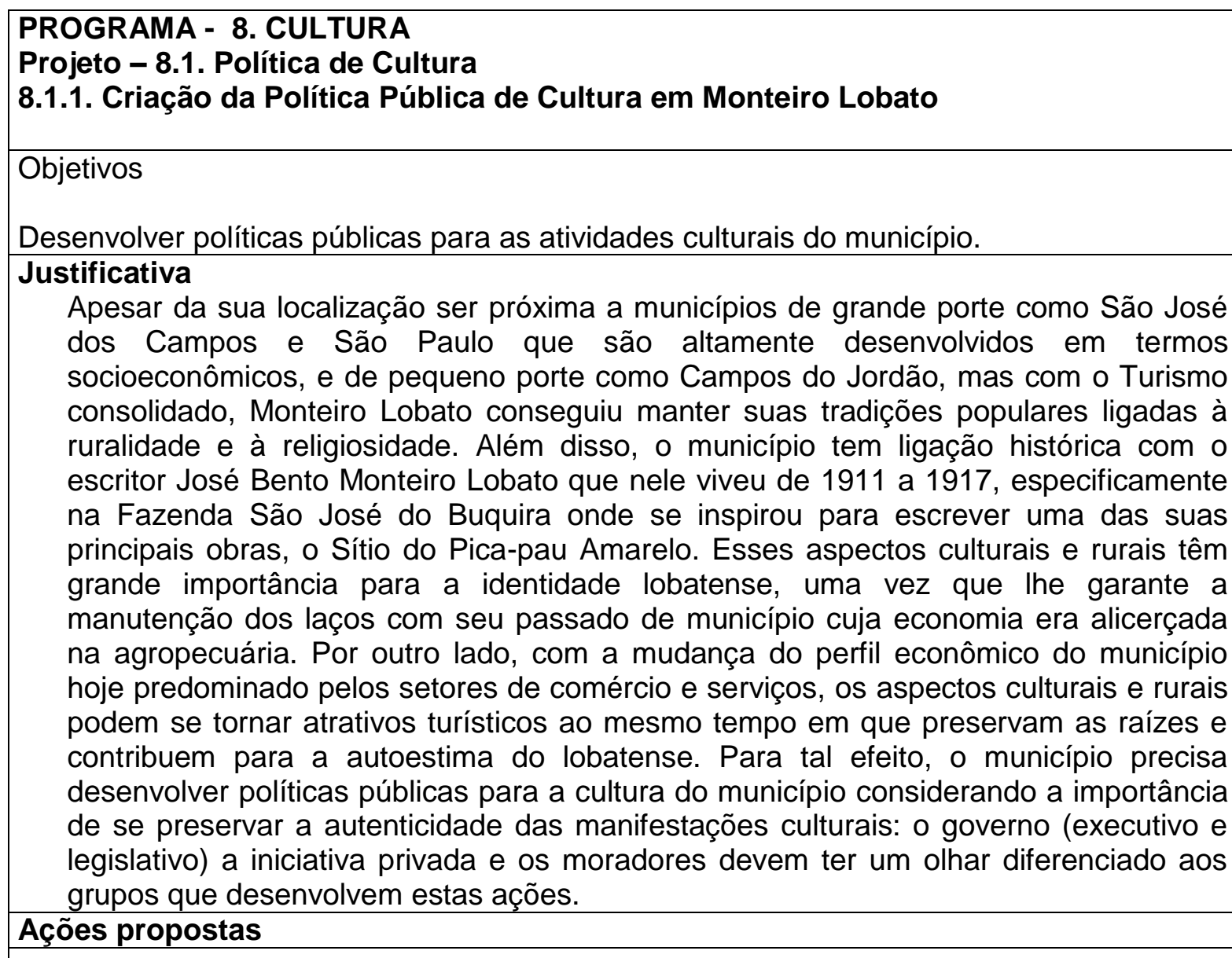

\section{1) POLÍTICA PÚBLICA DE CULTURA}

a) elaborar as diretrizes para a política pública de cultura para o município

b) aliar Cultura e Turismo, Turismo Cultural

- promover ações culturais como atrativos turísticos

- empoderamento dos grupos de cultura e apoios financeiro e logístico (locais para ensaios e apresentações, uniformes etc.).

- Pereirão: apresentações constantes na cidade, oferecer material e local para confecção dos pereirões, apoio à bateria que acompanha os bonecos e aos bonequeiros que os anima (dia do Pereirão: depois do sábado de Aleluia).

- Moçambique: apresentações constantes na cidade

- Artesanato: desenvolver uma identidade, melhorar qualidade, técnicas e materiais

- Banda musical: apresentações constantes na cidade

- Criar um folheto para divulgação do Moçambique e do Catira explicativo sobre essas danças, incluindo sua história

c) Equipamento público de cultura

d) Criar o Museu da cidade

e) Melhorar a infraestrutura da Biblioteca (local, acervo, equipamentos, bibliotecário responsável, funcionários treinados, atividades)

f) Rede de contatos com divulgação antecipada

g) Criar agenda e eventos

h) Realizar feira de artesanato e produtos rurais na Praça Deputado Cunha Bueno

Quadro 67 - Projeto 8.1.1. Criação da Política Pública de Cultura em Monteiro Lobato 
2) AÇÕES CULTURAIS ESTENDIDAS AOS BAIRROS

a) Dança

b) Cinema

c) Música

d) Teatro

e) Banda

\section{Principais executores}

Prefeitura, Secretaria de Cultura e Turismo, Secretaria de Educação, Secretaria de Desenvolvimento e Assistência Social, Fundo Social

\section{Parceiros prováveis}

COMTUR-ML, Empresários, moradores, Secretaria Estadual de Cultura, Ponto de Cultura, SESC

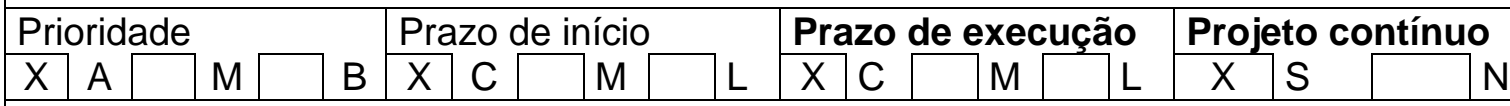

\section{Requisitos}

Recursos financeiros, recursos humanos

Fontes de financiamento

Prefeitura, Secretaria Estadual de Cultura, patrocínios e parcerias

Custo de implantação

A definir

Custo de manutenção

A definir

Quadro 67 - Projeto 8.1.1. Criação da Política Pública de Cultura em Monteiro Lobato (continuação) 
PROGRAMA - 8. CULTURA

Projeto - 8.2. Criação do Museu Histórico de Monteiro Lobato

8.2.1. Viabilidade de um projeto para criação do museu histórico para Monteiro Lobato

\section{Objetivos}

Viabilizar a elaboração do projeto para criação do Museu Histórico de Monteiro Lobato

\section{Justificativa}

O desejo de um museu do município é sempre manifestado quando o assunto debatido é cultura. No entanto, a iniciativa não vai além desse desejo porque quando se pensa "no como fazer" o entusiasmo acaba diante da complexidade da criação de um museu. São muitos aspectos específicos que passam pela definição do processo de criação (documentação), do plano museológico (planejamento estratégico, objetivos etc.), do espaço físico, do acervo, dos recursos humanos e financeiros etc. Porém, para que um sonho se realize é preciso sair da intenção e caminhar em direção à ação e, no caso, a primeira ação é elaborar um projeto para a criação de um museu que preserve a memória do município e, com ele, buscar os recursos financeiros, físicos e humanos necessários para a criação do museu.

\section{Ações propostas}

a) Levantar os custos do trabalho de elaboração de projeto para museu municipal

b) Buscar recursos financeiros para a contratação do profissional com formação em museologia para elaboração do projeto

c) Definir um local para instalação do museu

d) Definir pessoa responsável pelo projeto

\section{Principais executores}

Prefeitura, Secretaria de Cultura e Turismo, Secretaria de Educação

Parceiros prováveis

COMTUR-ML, Ministério da Cultura, Instituto Brasileiro de Museus (Ibram), Secretaria Estadual de Cultura, Instituto Pandavas, moradores, empresários

\begin{tabular}{|c|c|c|c|c|}
\hline Prioric & & & Prazo de início & \\
\hline $\mathrm{X} A$ & $\mathrm{M}$ & B & $\Rightarrow$ C $X$ & 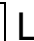 \\
\hline
\end{tabular}

\section{Requisitos}

Recursos financeiros

Fontes de financiamento

Prefeitura, patrocínios e parcerias, apresentação do projeto para financiamento por meio das leis de incentivos fiscais: federal (Lei Rouanet), estadual (Lei de Incentivo à Cultura); por intermédio dos fundos já existentes: Fundo Nacional da Cultura (FNC), Fundo de Investimento Cultural e Artístico

(Ficart - MINC), Fundo de Apoio à Cultura (FAC - Sedac), Fundo dos Direitos Difusos (FDD - MJ); por meio de editais específicos do Ministério da Cultura, do Banco Nacional de Desenvolvimento Social (BNDES), do Banco do Nordeste do Brasil (BNB), da Caixa Econômica Federal (CEF), da Petrobras e outros; por intermédio das fundações de amparo à pesquisa, CNPq, Capes e outras; por meio de Emendas Parlamentares; por intermédio de editais específicos do Instituto Brasileiro de Museus, tais como: Editais Mais Museus e Edital de Modernização de Museus.

\begin{tabular}{|l|l}
\hline Custo de implantação & $\begin{array}{l}\text { Custo de manutenção } \\
\text { A definir }\end{array}$ \\
\hline
\end{tabular}

Quadro 68 - Projeto 8.2.1. Viabilidade de um projeto para criação do museu histórico para Monteiro Lobato 


\section{RECURSOS FINANCEIROS}

9.1. Busca de investimentos empresariais e geração de renda

9.1.1. Incentivo ao empreendedorismo

Quadro 69 - Projeto 9. Recursos Financeiros 
PROGRAMA - 9. RECURSOS FINANCEIROS

Projeto - 9.1. Busca de investimentos empresariais e geração de renda

9.1.1. Incentivo ao empreendedorismo

\section{Objetivos}

Incentivar jovens e adultos a terem negócio próprio.

Justificativa

O perfil econômico em termos de rendimento do município mudou. Embora a atividade agropecuária aconteça no município, ela foi ultrapassada pelos setores de comércio e serviços. Porém, as empresas locais não têm condições de absolver a mão de obra disponível que procura empregos nas cidades vizinhas. Uma possibilidade de manter jovens e adultos no município é incentivá-los a abrirem a própria empresa.

Ações propostas

1) Incentivar novas empresas, porém, fiscalizar quanto ao pagamento dos encargos sociais dos funcionários (vincular)

2) Pequenos produtores e artesãos

a) Incentivar e despertar expectativas

b) Oferecer orientações técnicas

c) Oferecer cursos direcionados

d) Buscar financiamentos: parcerias $=>$ Sindicato Rural mais Prefeitura $=$ incentivo às pequenas empresas

e) Incentivo à implantação do Banco do Povo

3) Como manter o munícipe em sua terra?

a) Promover cursos para tornar a terra produtiva: Embrapa, Secretaria de Agricultura (minhocultura, criação de rãs, cogumelos, shitake etc.)

b) Criar uma escola agrícola

c) Rede Intersetorial: promover palestras nas escolas

d) Investir em engenheiros agrônomos para perceber como aproveitar melhor a terra, o espaço, visando produtividade

\section{Principais executores}

Prefeitura, Secretarias de Educação, Desenvolvimento e Assistência Social, Fundo Social, Cultura e Turismo, Meio Ambiente e Agricultura.

Parceiros prováveis

COMTUR-ML, APPR, Sindicato Rural de Monteiro Lobato, SINHORES, UNITAU, SENAR, SENAC E SEBRAE-SP

\begin{tabular}{l|l}
\hline Prioridade & Prazo de início \\
\hline
\end{tabular}

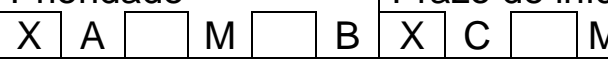

Requisitos

Recursos financeiros e humanos

Fontes de financiamento

Orçamento municipal, patrocínios e parcerias

Custo de implantação

A definir

Custo de manutenção

A definir

\section{Prazo de execução Projeto contínuo}

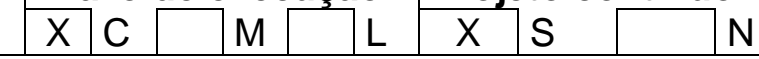

\section{$N$}




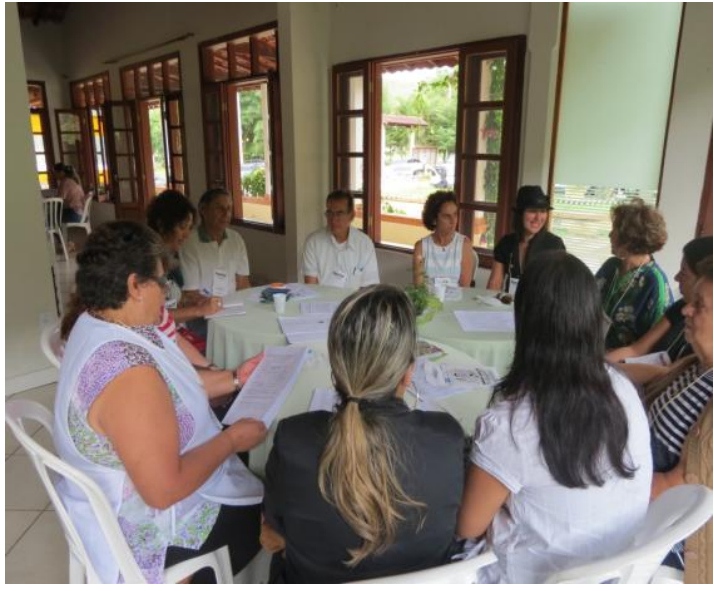

Grupo de Trabalho: Educação

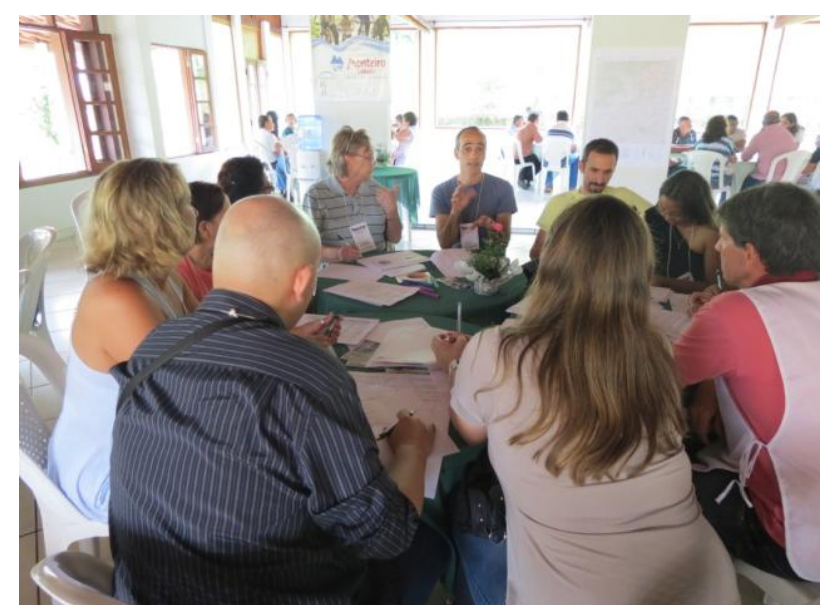

Grupo de Trabalho: Infraestrutura Turística e Comunicação

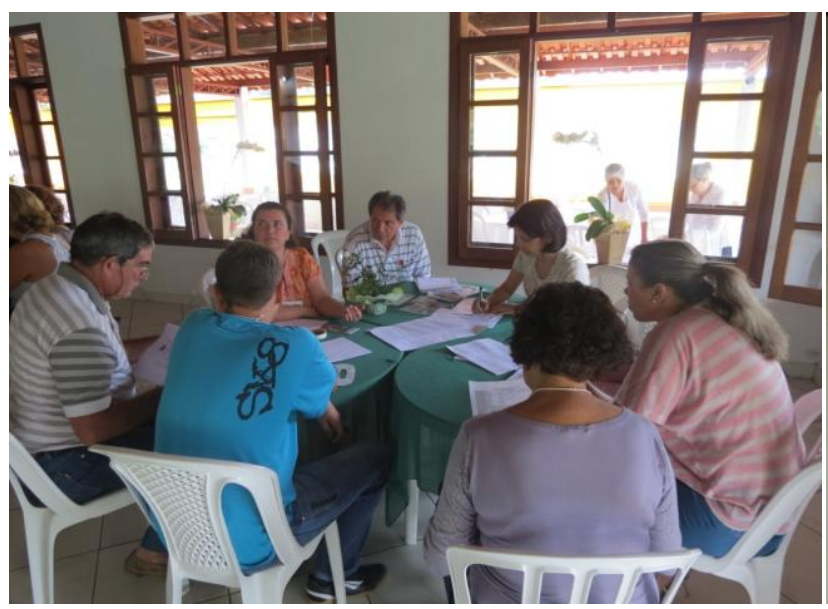

Grupo de Trabalho: Infraestrutura da Cidade

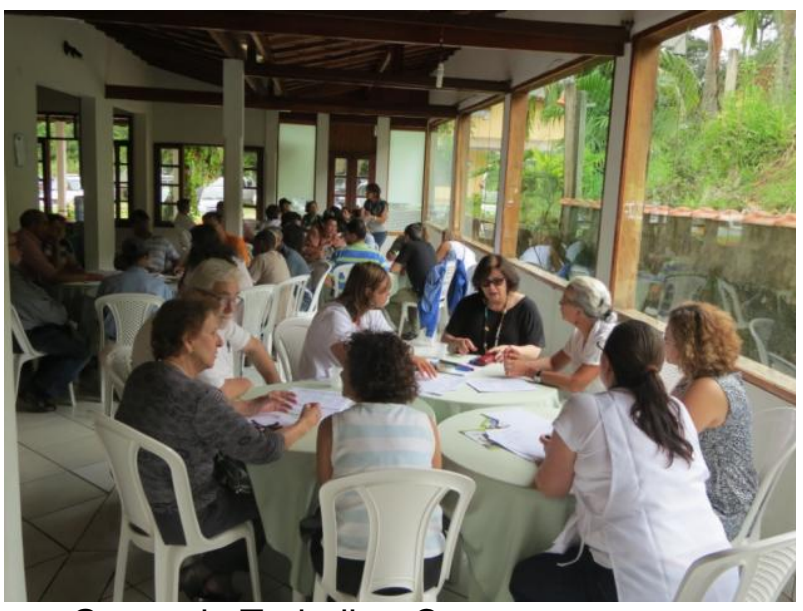

Grupo de Trabalho: Comportamento

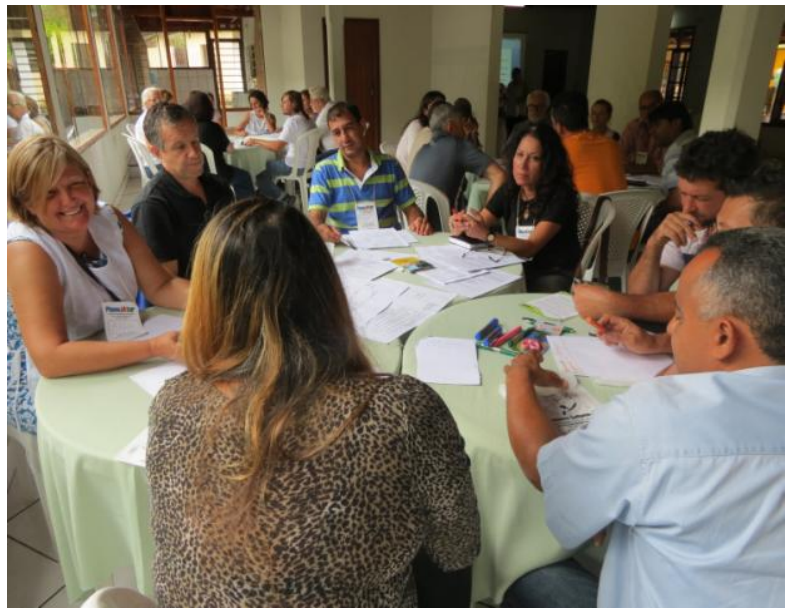

Grupo de Trabalho: Legislação; Saúde Pública em relação ao Turismo e Recursos Financeiros

Foto 4 - Conjunto de fotos da segunda Oficina de Planejamento do Turismo Sustentável 


\subsubsection{PlaneJÁtur - Oficina de Planejamento Participativo em Turismo Sustentável no Município de Monteiro Lobato, SP, 19 de setembro, 10 se outubro e 07 de novembro de 2013}

Moderadora: Profa. Ma. Cleide Pivott - USP/IP

Equipe da Organização:

André Barreto

Antonio Renato de Sá Sonnewend

Célia Ceruks

Ednea Goulart de Andrade

Leila Miranda

Odette A. C. da Silva

Deise Datti Rosa

Regina de Fátima Araujo

\section{Apresentação}

Este é o relatório da terceira Oficina com a comunidade de Monteiro Lobato, uma das etapas previstas na proposta da tese de Doutorado da Profa. Ma. Cleide Pivott pelo Instituto de Psicologia da USP (linha de pesquisa de Psicologia Socioambiental e Intervenção) que objetiva a elaboração do Plano Diretor de Turismo Sustentável de Monteiro Lobato com participação social, tendo o apoio da Prefeitura Municipal de Monteiro Lobato, do Conselho Municipal de Turismo (COMTUR-ML) e do Sindicato dos Hotéis, Restaurantes, Bares e Similares de São José dos Campos e Região (SINHORES).

Na primeira Oficina, realizada em 15 de março de 2012, foram levantados os obstáculos existentes para o desenvolvimento turístico do município, a saber: 1) educação, 2) infraestrutura turística, 3) infraestrutura da cidade, 4) comunicação, 5) comportamento, 6) legislação, 7) saúde pública, 8) cultura e 9) recursos financeiros. Aplicando a técnica ZOPP (Planejamento de Projetos Orientado por Objetivos), o Grupo Planejatur construiu a Matriz de Planejamento por Projetos (MPP) a partir da árvore de problemas e da árvore dos objetivos.

$\mathrm{Na}$ segunda Oficina com a comunidade, realizada no dia 28 de fevereiro de 2013, o trabalho foi realizado com base nesta MPP e nas informações sobre os dados sociais e ambientais do município; no resultado da primeira Oficina de planejamento de 15 de março de 2012 (Matriz de Planejamento por Projetos e relação de instituições envolvidas), no resultado da pesquisa de opinião com moradores e turistas, no inventário turístico, além de mapas e livros para consultas. O resultado dessa Oficina foi a elaboração do Programa de Ações para os nove obstáculos levantados na primeira Oficina o qual foi entregue à Prefeita em 20 de maio de 2013. Todos os projetos constantes nesse Programa de Ações foram 
inseridos no Plano Plurianual (2014-2017) do município, constituindo o primeiro passo para a implantação dos mesmos na medida do possível a partir de 2014.

Nesta terceira Oficina com a comunidade, o objetivo foi fazer uma análise do cenário atual do Turismo no município com base em todas as informações geradas nestes dois anos de planejamento bem como nas experiências vivenciadas pelo Grupo Planejatur nesse período e definir as diretrizes para a continuidade das ações, dentro dos critérios de sustentabilidade, para os seguintes tópicos de análise: a) recursos e atrativos turísticos (naturais e culturais); b) infraestrutura turística; c) infraestrutura de apoio; e d) políticas públicas para Turismo Sustentável e de inserção no Turismo Regional. Para essa análise, foram utilizadas a técnica FOFA (análise dos pontos fortes, das oportunidades, dos pontos fracos e das ameaças) e de tempestade de ideias.

O resultado demonstrou que a comunidade conhece os problemas relativos ao Turismo no município e tem discernimento para analisá-los. O trabalho da Oficina foi interrompido após esta etapa porque o tempo não foi suficiente para cumprir toda a programação. Assim, de comum acordo, os participantes marcaram o dia 10 de outubro de 2013, das $13 \mathrm{~h} 00$ às $17 \mathrm{~h} 00$, no Sindicato Rural de Monteiro Lobato para continuarem a Oficina. Na segunda parte dessa Oficina, o objetivo foi formular o prognóstico e criar uma visão de futuro para o Turismo coletivamente. Para tal efeito, primeiramente foi colocada a questão: "Quais são as diretrizes para o Turismo Sustentável de Monteiro Lobato?" para ser respondida relacionando os tópicos de definição das diretrizes aos critérios de sustentabilidade (conservação e preservação do meio ambiente, respeito à cultura e identidade local e distribuição da renda com justiça social). Dessa forma, a matriz das diretrizes para o Turismo Sustentável de Monteiro Lobato foi elaborada sob a perspectiva dos critérios de sustentabilidade em relação aos tópicos de definição das diretrizes apresentados: a) Vocação - Turismo de Natureza e Turismo Rural; b) Vocação - Turismo Cultural - Escritor e Manifestações Culturais; c) Tipo de eventos; d) Regras de convívio morador x turista; e) Atitudes dos governos executivo e legislativo em relação ao Turismo Sustentável no município; f) Atitudes dos empresários; e g) Atitudes da comunidade. Os participantes se manifestaram novamente por meio de tempestade de ideias e, dessa forma, preencheram a matriz das diretrizes para o Turismo Sustentável de Monteiro Lobato. Cada sugestão foi seguida de breves comentários feitos pelos demais participantes no sentido de melhorar ou esclarecer a ideia colocada. Assim, 
o debate foi caloroso porque todos tinham sugestões a dar. Considerando o tempo próximo ao horário previsto para o término da Oficina, os participantes decidiram deixar a etapa da construção da visão de futuro para o Turismo Sustentável de Monteiro Lobato para a próxima reunião do Conselho Municipal de Turismo (COMTUR-ML) agendada para o dia 07 de novembro de 2013 e, assim, garantir a participação dos seus membros. Nessa data, usando a técnica ZOPP de visualização e tempestade de ideias, a visão de futuro do Turismo Sustentável de Monteiro Lobato foi construída, pautada na intenção de que decisões e ações em relação ao Turismo no município sejam feitas dentro dos critérios de sustentabilidade.

Grupo Planejatur - Monteiro Lobato, 15 de novembro de 2013. 


\section{PROGRAMAÇÃo}

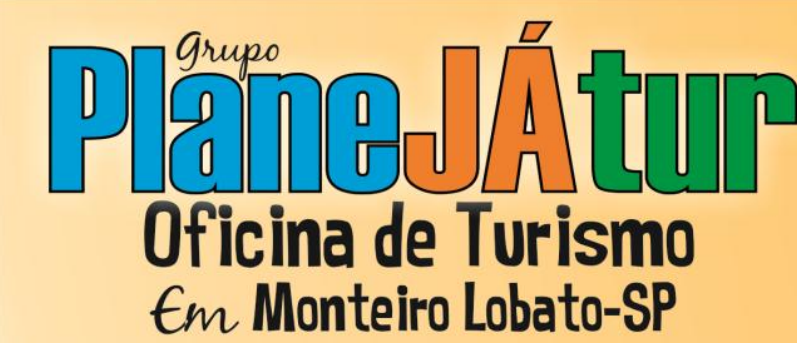

Venha contribuir com ideias e experiências para a elaboração das ações rumo ao Plano Diretor de Turismo Sustentável em nosso município.

\section{Dia 19 de Setembro (Quinta-feira) Horário: Das 08h às 17h Local: Recanto dos Lagos (Dona Venina)}

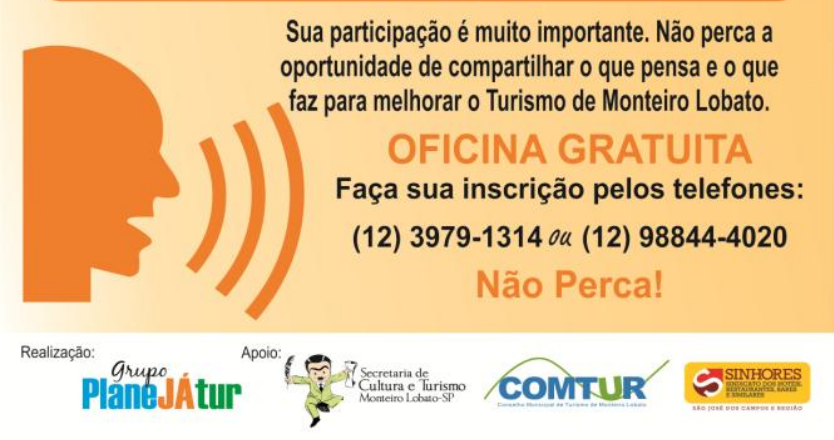

\section{Programação

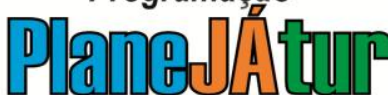 \\ Dia 19 de Setembro (Quinta-feira)}

08h00 - Recepção e café

$08 \mathrm{~h} 45$ - Abertura da oficina

09 h00 - Palestra: O Processo do Desenvolvimento Turistico em Cunha, SP Marivaldo Luiz Almeida Rodrigues, Secretário de Turismo e Cultura do municipio de Cunha, SP

$10 \mathrm{~h} 30$ - Intervalo

10h45 - Início da 3a. Etapa do Planejamento do Turismo Sustentável em Monteiro Lobato: análise do cenário turístico atual no município.

\section{H45 - ALMOÇO}

14 h00 - Continuação da 3a. Etapa do Planejamento do Turismo Sustentável em Monteiro Lobato: elaboração das diretrizes para o Turismo que o lobatense deseja para o município.

$16 \mathrm{~h} 00$ - Intervalo

16 h20 - Criação coletiva da VISÃO DE FUTURO para o Turismo Sustentável de Monteiro Lobato.

17h30 - Encerramento.

Figura 5 - Cartazete de divulgação da terceira Oficina

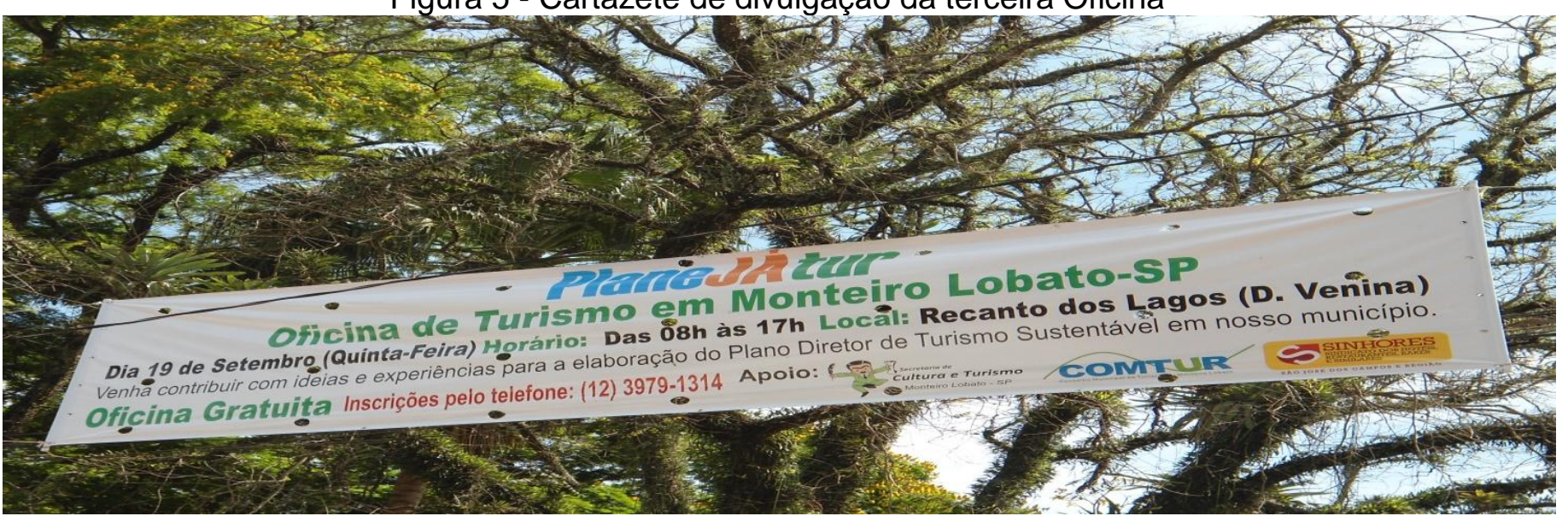

Foto 5 - Faixa de divulgação da terceira Oficina 
PARTICIPANTES

\begin{tabular}{|c|c|}
\hline 1. & Adriana Guerra \\
\hline 2. & Alexandra Moscoso \\
\hline 3. & Ana Maria de A. Reis \\
\hline 4. & Anacélia de Mello Morente \\
\hline 5. & André Barreto \\
\hline 6. & Andrea Sundfeld Penido \\
\hline 7. & Andrejs Ceruks \\
\hline 8. & Antonio Renato de Sá Sonnewend \\
\hline 9. & Aparecida Benedita Oliveira Costa \\
\hline 10 & Baltazar de Oliveira Ferreira \\
\hline 11 & Benedito Antonio Pinto \\
\hline 12. & Catharina Vera silva \\
\hline 13 & Célia Ceruks \\
\hline 14 & Cleide Pivott \\
\hline 15. & Daniela de Cássia Santos Brito \\
\hline 16 & Edjelson Ap. Souza \\
\hline 17. & Ednea Goulart de Andrade \\
\hline 18 & Elisa M. César Parmera \\
\hline 19. & Emídia Maria Andrade \\
\hline 20 & Esmirna Guimarães \\
\hline 21 & Fred Araújo \\
\hline 22 & Geminiano Jorge dos Santos \\
\hline 23 & Hamilton D. Miragaia \\
\hline 24 & João Francisco da Silva \\
\hline
\end{tabular}

25. José B. Andrade

26. Judith A. Ferreira

27. Karina s. Araujo

28. Leila Miranda

29. Lenira Aquino Reis

30. Leonardo Fernandes

31. Manoel Juarez de Oliveira

32. Maria das Gracias Siqueira Leiva

33. Maria Luiza X. Auricchio

34. Maria Paulete Martins

35. Marilene Mesquita Silva

36. Marina Luciene de Souza Silva

37. Marivaldo Rodrigues

38. Mateus Teles de Toledo

39. Monica Miyashita

40. Neiva Glória Dias

41. Odette A. C. da Silva

42. Paulo Martins Moreira Jr.

43. Raquel B. Moreira

44. Regina F. O. Honório

45. Roseneid dos Santos

46. Venina Gondim Moscoso

47. Walter Aguilhar dos Santos

48. Wilmar Andrade

Quadro 71 - Relação de participantes da terceira Oficina

\section{PERFIL DOS PARTICIPANTES}

Com o objetivo de identificar as características dos participantes dessa Oficina, elaboraram-se os gráficos abaixo apresentados sobre o local de nascimento, a cidade e o bairro onde reside.

$\mathrm{Na}$ primeira e segunda Oficinas, respectivamente $22 \%$ e $21 \%$ dos participantes nasceram em Monteiro Lobato. Nesta terceira Oficina, os nascidos em Monteiro Lobato representam $17 \%$ dos participantes. Salienta-se que a totalidade 
dos $23 \%$ dos participantes desta Oficina que nasceram em São José dos Campos reside em Monteiro Lobato.

Com relação ao local de residência, na primeira e segunda Oficinas, respectivamente $81 \%$ e $77 \%$ dos participantes residiam em Monteiro Lobato. Nesta terceira Oficina, 83\% dos participantes residem em Monteiro Lobato. Portanto, nas três Oficinas, houve uma média de $80 \%$ de participação de moradores, demonstrando a disposição dos munícipes em colaborar e participar do processo de desenvolvimento turístico no município.

$\mathrm{Na}$ primeira Oficina, os munícipes eram oriundos de 6 bairros (30\% dos 20 bairros do município), na segunda, de 15 bairros (75\%) e, nesta Oficina, participaram munícipes de 13 bairros (65\%).

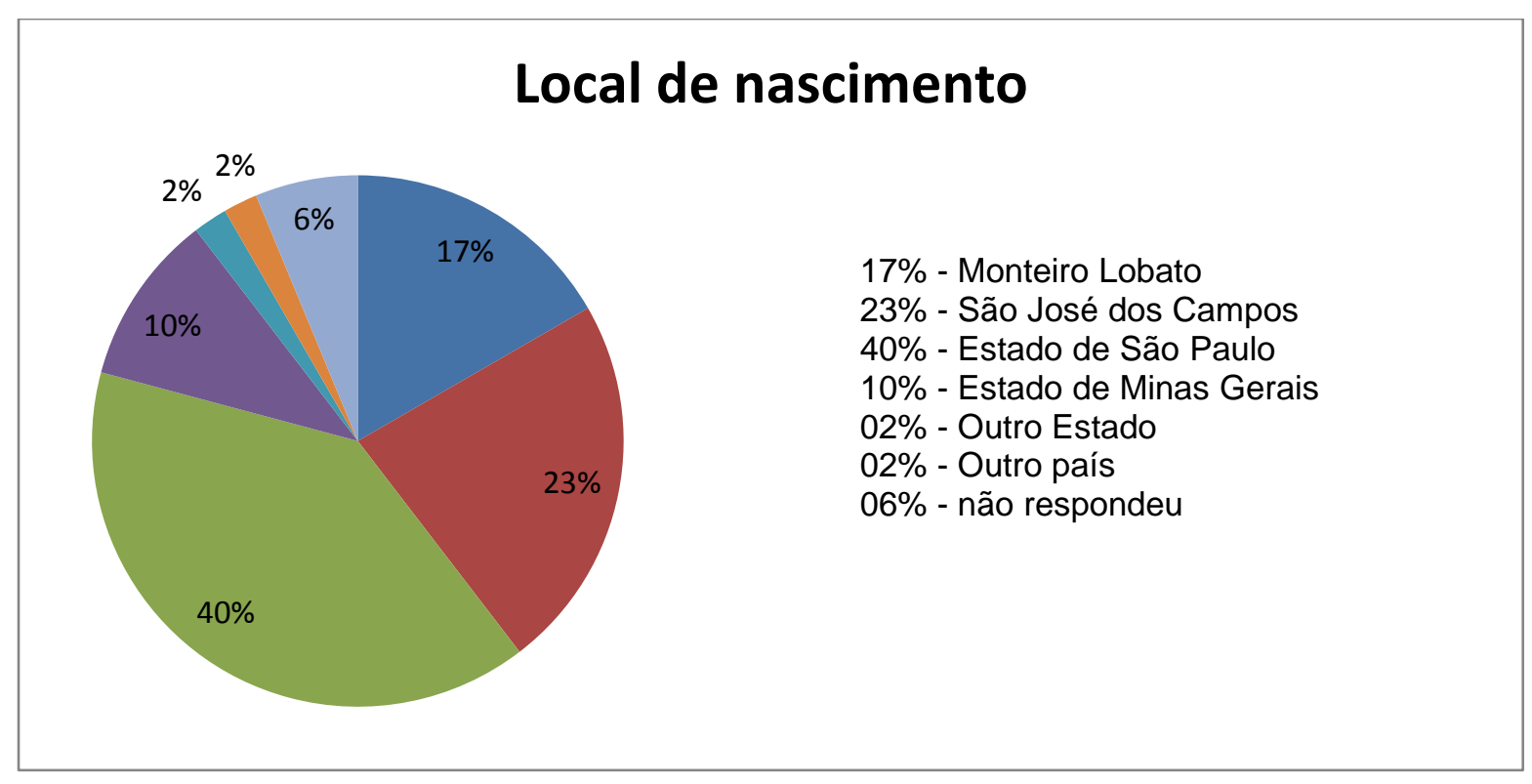

Gráfico 8 - Local de nascimento dos participantes da terceira Oficina

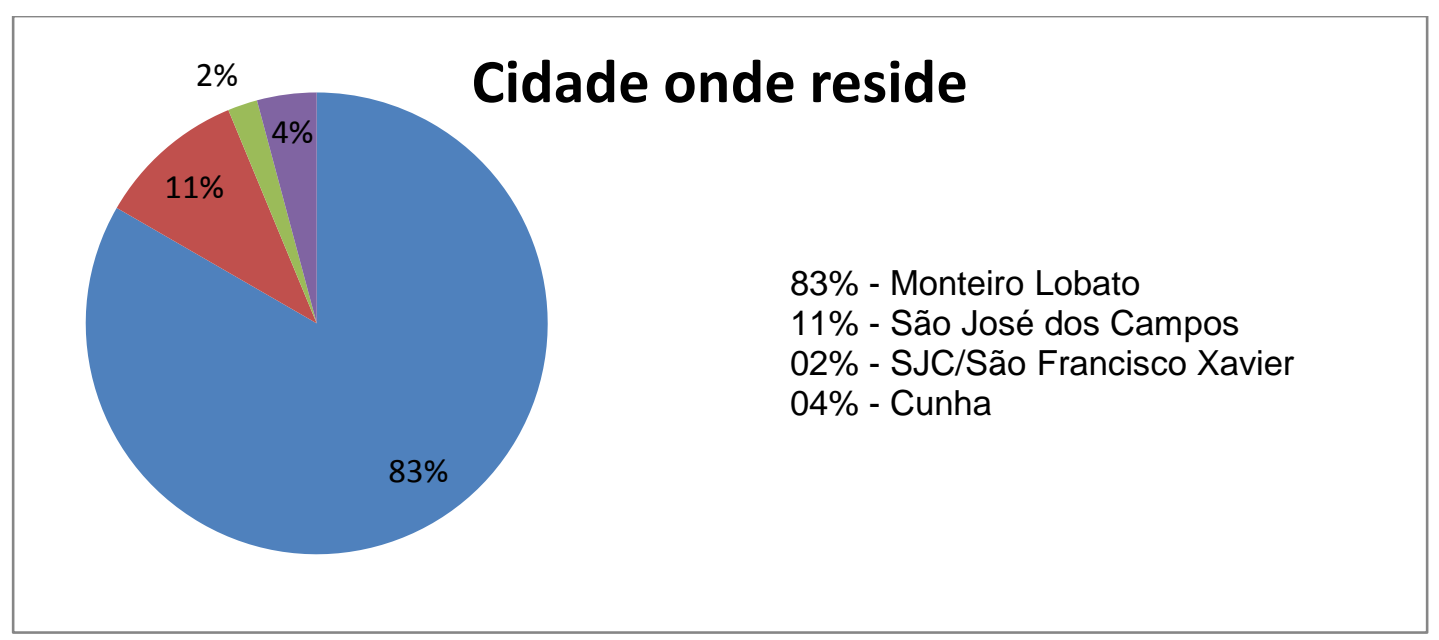

Gráfico 9 - Cidades onde residem os participantes da terceira Oficina 


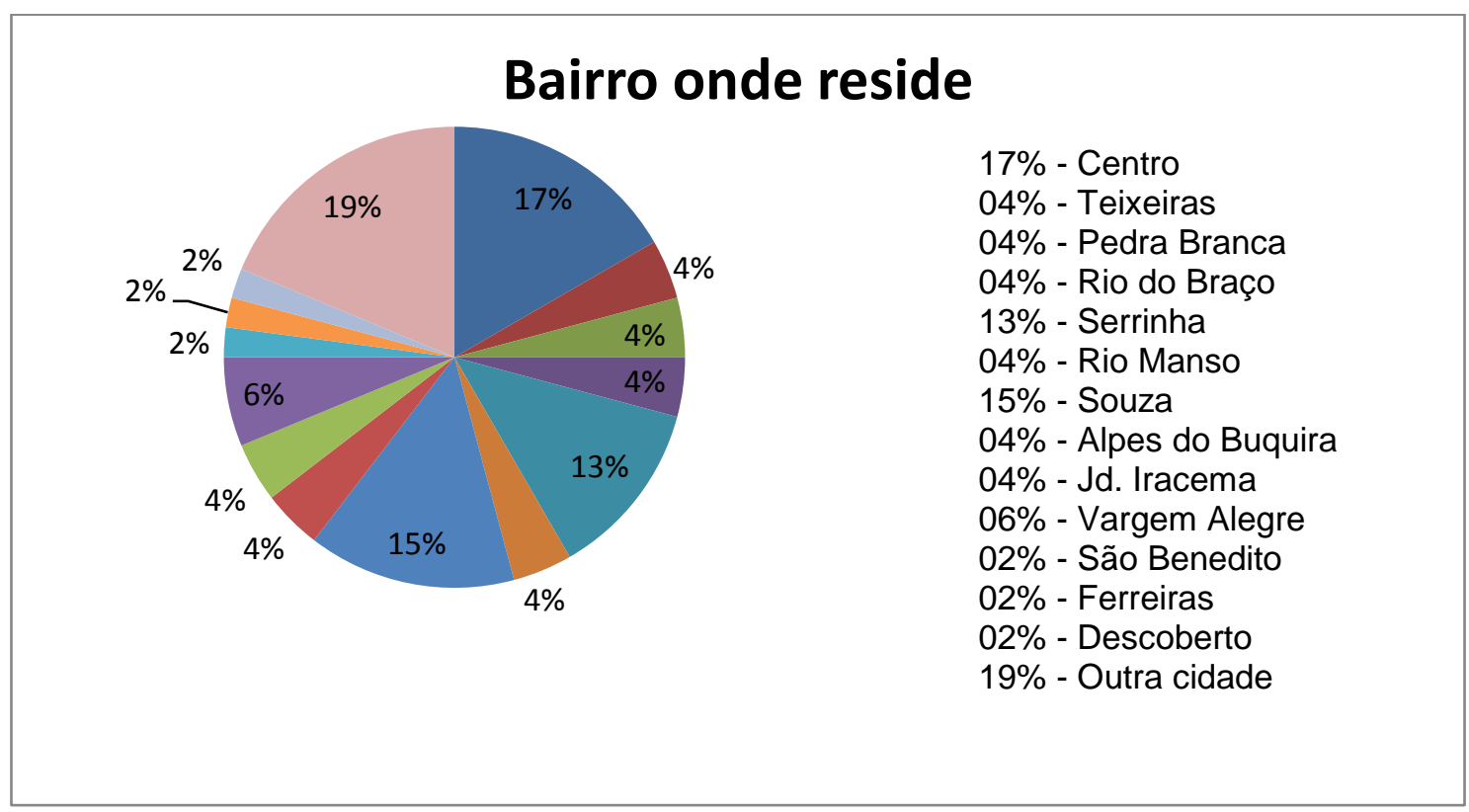

Gráfico 10 - Bairros onde residem os participantes da terceira Oficina

\section{ABERTURA DA OFICINA}

O Grupo Planejatur estabeleceu que a abertura de suas Oficinas seja feita sem um cerimonial padrão porque entende que não há hierarquias em um trabalho participativo. Porém, nesta terceira Oficina, por uma questão de apresentação das instituições que apoiam o Grupo Planejatur, foram convidadas a falar aos participantes: André Barreto, Secretário de Cultura e Turismo, João Francisco da Silva, Vice-Presidente da Câmara Municipal, Antonio Renato de Sá Sonnewend, Presidente do COMTUR-ML, e Geminiano Jorge dos Santos, Diretor do SINHORES.

Em seguida o Secretário de Turismo e Cultura de Cunha, Marivaldo Luiz Almeida Rodrigues proferiu a palestra sobre a experiência no processo de desenvolvimento turístico em Cunha iniciado na década de 1990. Marivaldo criou empatia com o público presente pela sua forma simples e objetiva de falar. Salientou que todo o trabalho da sua secretaria é voltado para o residente e que o turista gosta de compartilhar os eventos da comunidade, acrescentando que tem obtido ótimos resultados. 
$\Rightarrow$ Parte 1 - Formular o diagnóstico - análise do cenário atual

Após a palestra, foi iniciada a dinâmica de análise do Turismo em Monteiro Lobato com a apresentação do Diagrama de Análise FOFA.

\begin{tabular}{|c|c|}
\hline Fatores Internos - com que contamos hoje \\
\hline $\begin{array}{c}\text { FORÇAS } \\
\text { os pontos } \\
\text { fortes do } \\
\text { tópico em } \\
\text { análise }\end{array}$ & $\begin{array}{l}\text { FRAQUEZAS } \\
\text { as fraquezas } \\
\text { do tópico em } \\
\text { análise }\end{array}$ \\
\hline $\begin{array}{l}\text { OPORTUNIDADES } \\
\text { para o tópico } \\
\text { em análise }\end{array}$ & $\begin{array}{l}\text { AMEAçAS } \\
\text { situações que } \\
\text { podem } \\
\text { impedir ou } \\
\text { prejudicar o } \\
\text { do tópico em } \\
\text { análise }\end{array}$ \\
\hline Fatores externos - o que não controlamos amanhã \\
\hline
\end{tabular}

Quadro 72 - Diagrama de análise FOFA

Fonte: Adaptado de Buarque (2002, p. 132)

Para cada tópico de análise do Turismo, foram projetadas na tela as informações constantes do inventário turístico. A Análise FOFA foi feita para cada um dos tópicos de análise abaixo indicados, usando a técnica de tempestade de ideias. O processo foi dinâmico e cada ideia foi comentada pelos participantes da Oficina. 
TÓPICO DE ANÁLISE DO TURISMO: RECURSOS E ATRATIVOS TURÍSTICOS:

\section{ATRATIVOS NATURAIS}

\begin{tabular}{|c|c|}
\hline \multicolumn{2}{|c|}{ INTERNA } \\
\hline $\begin{array}{l}\text { PONTOS FORTES } \\
\text { Pedra do Trabiju } \\
\text { Mirante das Posses } \\
\text { Pedra do OM } \\
\text { Cachoeira do Restaurante Beira do Riacho } \\
\text { Mirante da Torre da Serrinha (Prefeitura) } \\
\text { Instituto Pandavas }\end{array}$ & $\begin{array}{l}\text { PONTOS FRACOS } \\
\text { Acesso (estradas) } \\
\text { Sinalização } \\
\text { Local (áreas particulares) }\end{array}$ \\
\hline \multicolumn{2}{|l|}{ 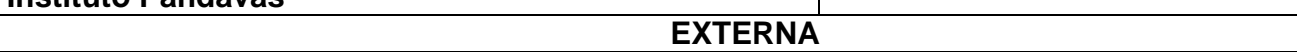 } \\
\hline $\begin{array}{l}\text { OPORTUNIDADES } \\
\text { Cachoeira João Paulo do Sítio Vista Linda (Estrada } \\
\text { do Renó - ML 34, Bairro do São Benedito) } \\
\text { Trilhas ecológicas } \\
\text { Trilha do Mel }\end{array}$ & $\begin{array}{l}\text { AMEAÇAS } \\
\text { Queimadas } \\
\text { Monocultura (eucaliptos) }\end{array}$ \\
\hline
\end{tabular}

Quadro 73 - Análise FOFA - Atrativos Naturais

\section{ATRATIVOS CULTURAIS}

\begin{tabular}{|c|c|}
\hline \multicolumn{2}{|c|}{ INTERNA } \\
\hline $\begin{array}{l}\text { PONTOS FORTES } \\
\text { Escritor Monteiro Lobato } \\
\text { Culinária (comida caseira e mineira, doces } \\
\text { caseiros) } \\
\text { Moçambique } \\
\text { Catira } \\
\text { Pereirões e batuque que os acompanha } \\
\text { O cotidiano da vida do homem rural } \\
\text { Festas populares } \\
\text { Festival de Literatura infantil } \\
\text { Feira do Balacobaco (Souza) } \\
\text { Praça com manifestações culturais }\end{array}$ & $\begin{array}{l}\text { PONTOS FRACOS } \\
\text { Risco de perda da tradição (Moçambique, } \\
\text { Catira, Pereirões, Artes personagens) } \\
\text { Falta de incentivos } \\
\text { Formar equipes de trabalho para estruturar } \\
\text { os atrativos culturais } \\
\text { Falta de local permanente para } \\
\text { comercializar artesanato }\end{array}$ \\
\hline \multicolumn{2}{|l|}{ 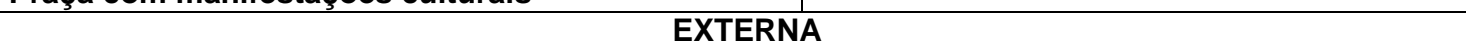 } \\
\hline $\begin{array}{l}\text { OPORTUNIDADES } \\
\text { Cordialidade } \\
\text { Tranquilidade } \\
\text { Segurança } \\
\text { Simplicidade } \\
\text { Localização estratégica } \\
\text { Içá } \\
\text { Mutirões } \\
\text { Oficinas: confecção de pereirão, artesanato, } \\
\text { danças, culinária } \\
\text { Feiras de produtores locais, mel, cogumelo, APPR } \\
\text { Cavalgada } \\
\text { Festival da goiaba e doces caseiros }\end{array}$ & AMEAÇAS \\
\hline
\end{tabular}

Quadro 74 - Análise FOFA - Atrativos Culturais 
TÓPICO DE ANÁLISE DO TURISMO: INFRAESTRUTURA TURÍSTICA: pousadas, restaurantes, comércio, guias de Turismo, transportadoras turísticas, centro de informações turísticas, agências receptivas, espaços para eventos, outros.

\begin{tabular}{|c|c|}
\hline \multicolumn{2}{|r|}{ INTERNA } \\
\hline \begin{tabular}{l}
\multicolumn{1}{c}{ PONTOS FORTES } \\
Acolhimento \\
Há estrutura para receber em \\
períodos normais \\
Comerciantes estabelecidos e \\
conhecidos (referências)
\end{tabular} & $\begin{array}{l}\text { PONTOS FRACOS } \\
\text { Ausência de Centro de Informações Turísticas } \\
\text { Ausência de agências de Turismo Receptivo } \\
\text { Falta de estrutura para eventos (restaurantes, lanches = } \\
\text { insuficiente para alimentação em eventos) } \\
\text { Atrair públicos com mais frequência } \\
\text { Viabilidade do negócio } \\
\text { Estacionamento para turistas x estacionamentos dos } \\
\text { veículos dos comerciantes } \\
\text { Comércio ilegal e ambulante na praça } \\
\text { Falta de educação }\end{array}$ \\
\hline \multicolumn{2}{|r|}{ EXTERNA } \\
\hline OPORTUNIDADES & AMEAÇAS \\
\hline
\end{tabular}
Quadro 75 - Análise FOFA - Infraestrutura Turística

TÓPICO DE ANÁLISE DO TURISMO: INFRAESTRUTURA DE APOIO: banco, telefonia, internet, posto de gasolina, mecânico, borracheiro, informações sobre o município, segurança, posto de saúde etc.

\begin{tabular}{|c|c|}
\hline \multicolumn{2}{|r|}{ INTERNA } \\
\hline $\begin{array}{l}\text { PONTOS FORTES } \\
\text { Reforma da SP-50 } \\
\text { Esportes na Cidade }\end{array}$ & $\begin{array}{l}\text { Banco } 24 \text { horas } \\
\text { Banheiros públicos com fraldário e acessibilidade (insuficiente } \\
\text { em eventos) } \\
\text { Ausência de Delegacia (PM e Civil) à noite e final de semana } \\
\text { Ausência de delegado que resida na cidade } \\
\text { Calçadas padronizadas e seguras (intransitáveis) } \\
\text { Conservação de estradas vicinais } \\
\text { Falta de chaveiro } \\
\text { Falta de estacionamento (sinalização) } \\
\text { Posto de Saúde } \\
\text { Farmácia no final de semana } \\
\text { Livrarias: venda de livros do "Nosso Escritor" } \\
\text { Sinalização na SP-50, indicando a distância da cidade } \\
\text { Redutor de velocidade na entrada da cidade } \\
\text { lluminação do totem "Bem-vindo a Monteiro Lobato" } \\
\text { Telefonia (equipamentos obsoletos) } \\
\text { Convênio com a PM e Prefeitura para disciplinamento do } \\
\text { trânsito }\end{array}$ \\
\hline \multicolumn{2}{|r|}{ EXTERNA } \\
\hline $\begin{array}{l}\text { OPORTUNIDADES } \\
\text { Serviço de chaveiro } \\
\text { Suvenires: lembranças de } \\
\text { Monteiro Lobato, livros do } \\
\text { escritor Monteiro Lobato } \\
\text { Ciclismo (local para } \\
\text { estacionamento seguro, com } \\
\text { oferta de banheiros para higiene } \\
\text { pessoal dos ciclistas na volta } \\
\text { dos passeios) }\end{array}$ & AMEAÇAS \\
\hline
\end{tabular}

Quadro 76 - Análise FOFA - Infraestrutura de apoio 


\section{TÓPICO DE ANÁLISE DO TURISMO: POLÍTICAS PÚBLICAS PARA TURISMO SUSTENTÁVEL E DE INSERÇÃO NO TURISMO REGIONAL:}

- Circuito Mantiqueira,

- ADITM (Associação de Desenvolvimento Integrado do Território Mantiqueira)

- Região Metropolitana Vale do Paraíba

- Rota Franciscana

\begin{tabular}{|c|c|}
\hline \multicolumn{2}{|c|}{ INTERNA } \\
\hline $\begin{array}{l}\text { PONTOS FORTES } \\
\text { Rota Franciscana } \\
\text { ADITM } \\
\text { Circuito Mantiqueira } \\
\text { Formalização do COMTUR-ML } \\
\text { PLANEJATUR } \\
\text { Divulgação da cidade no Jornal Mensal "Serra } \\
\text { da Mantiqueira" }\end{array}$ & $\begin{array}{l}\text { PONTOS FRACOS } \\
\text { Adesão de empresários locais } \\
\text { Adesão da comunidade } \\
\text { Canal de comunicação } \\
\text { Legislação para utilização do espaço público } \\
\text { Legislação para som automotivo } \\
\text { Pontos de sinalização e padrão da Rota } \\
\text { Franciscana: falta divulgação no site da } \\
\text { prefeitura }\end{array}$ \\
\hline \multicolumn{2}{|c|}{ EXTERNA } \\
\hline $\begin{array}{l}\text { OPORTUNIDADES } \\
\text { Rádio local } \\
\text { Jornal semanal ou quinzenal do município }\end{array}$ & AMEAÇAS \\
\hline
\end{tabular}

Quadro 77 - Análise FOFA - Políticas públicas para Turismo Sustentável e de inserção no Turismo regional:

$\Rightarrow$ Parte 2 - Formular o prognóstico = visão de futuro para o Turismo

O prognóstico prevê e projeta o comportamento esperado para o fenômeno turístico no município. As diretrizes básicas para o desenvolvimento do Turismo nas destinações turísticas são estreitamente associadas aos objetivos propostos e constituem a indicação dos rumos a tomar.

\section{TEMPESTADE DE IDEIAS}

QUAIS SÃO AS DIRETRIZES PARA O TURISMO SUSTENTÁVEL DE MONTEIRO LOBATO? 
MATRIZ DAS DIRETRIZES PARA O TURISMO SUSTENTÁVEL DE MONTEIRO LOBATO

\begin{tabular}{|l|l|l|l|}
\hline $\begin{array}{l}\text { Tópicos para definição das } \\
\text { diretrizes X critérios de } \\
\text { sustentabilidade }\end{array}$ & $\begin{array}{l}\text { Conservação e } \\
\text { preservação do } \\
\text { Meio Ambiente }\end{array}$ & $\begin{array}{l}\text { Respeito à cultura } \\
\text { e identidade local }\end{array}$ & $\begin{array}{l}\text { Distribuição da } \\
\text { renda com justiça } \\
\text { social }\end{array}$ \\
\hline $\begin{array}{l}\text { Vocação - Turismo de } \\
\text { Natureza e Turismo Rural }\end{array}$ & & & \\
\hline $\begin{array}{l}\text { Vocação - Turismo } \\
\text { Cultural - Escritor e } \\
\text { Manifestações Culturais }\end{array}$ & & & \\
\hline Tipo de eventos & & & \\
\hline $\begin{array}{l}\text { Regras de convívio } \\
\text { morador x turista }\end{array}$ & & & \\
\hline $\begin{array}{l}\text { Atitudes dos governos } \\
\text { executivo e legislativo em } \\
\text { relação ao Turismo }\end{array}$ & & & \\
Sustentável no município & & & \\
\hline Atitudes dos empresários & & & \\
\hline Atitudes da comunidade & & & \\
\hline
\end{tabular}

Quadro 78 - Matriz das diretrizes para o Turismo Sustentável de Monteiro Lobato

\begin{tabular}{|l|l|l|l|}
\hline $\begin{array}{l}\text { Tópicos para definição das } \\
\text { diretrizes X critérios de } \\
\text { sustentabilidade }\end{array}$ & $\begin{array}{l}\text { Conservação e } \\
\text { preservação do } \\
\text { Meio Ambiente }\end{array}$ & $\begin{array}{l}\text { Respeito à cultura } \\
\text { e identidade local }\end{array}$ & $\begin{array}{l}\text { Distribuição da } \\
\text { renda com justiça } \\
\text { social }\end{array}$ \\
\hline $\begin{array}{l}\text { Vocação - Turismo de } \\
\text { Natureza }\end{array}$ & $\begin{array}{l}\text { Visitas monitoradas } \\
\text { e } \\
\text { Turismo Rural } \\
\text { especializados }\end{array}$ & $\begin{array}{l}\text { Apoiar os saberes e } \\
\text { fazeres da } \\
\text { comunidade rural } \\
\text { Estudos de } \\
\text { capacidade de carga } \\
\text { nos atrativos } \\
\text { naturais }\end{array}$ & $\begin{array}{l}\text { Apoiar o produtor } \\
\text { rural agregando o } \\
\text { Turismo como renda } \\
\text { complementar } \\
\text { tradições culinárias, } \\
\text { manejo rural }\end{array}$ \\
& $\begin{array}{l}\text { informação para } \\
\text { educação ambiental } \\
\text { Incentivar roteiros a } \\
\text { cavalo para } \\
\text { visitação de sítios }\end{array}$ & \\
& formatação de & $\begin{array}{l}\text { Resgatar e valorizar } \\
\text { o jeito de ser do } \\
\text { matuto }\end{array}$ & \\
& cartilhas para \\
turistas & \\
\hline
\end{tabular}

Quadro 79 - Matriz das diretrizes para Vocação - Turismo de Natureza e Turismo Rural 


\begin{tabular}{|c|c|c|c|}
\hline $\begin{array}{l}\text { Tópicos para definição das } \\
\text { diretrizes } X \text { critérios de } \\
\text { sustentabilidade }\end{array}$ & $\begin{array}{l}\text { Conservação e } \\
\text { preservação do } \\
\text { Meio Ambiente }\end{array}$ & $\begin{array}{l}\text { Respeito à cultura } \\
\text { e identidade local }\end{array}$ & $\begin{array}{l}\text { Distribuição da } \\
\text { renda com justiça } \\
\text { social }\end{array}$ \\
\hline $\begin{array}{l}\text { Vocação - Turismo } \\
\text { Cultural - } \\
\text { Escritor } \\
\text { e } \\
\text { Manifestações Culturais }\end{array}$ & $\begin{array}{l}\text { Usar o Turismo } \\
\text { cultural para } \\
\text { conservação e } \\
\text { preservação do } \\
\text { meio ambiente } \\
\text { (queimadas, } \\
\text { desmatamento/ } \\
\text { Jeca Tatu) } \\
\text { Placas na estrada } \\
\text { do Livro com frases } \\
\text { de Monteiro em } \\
\text { relação ao meio } \\
\text { ambiente }\end{array}$ & $\begin{array}{l}\text { Apoiar os grupos } \\
\text { culturais } \\
\text { Criar uma política } \\
\text { para a Cultura de } \\
\text { Monteiro Lobato } \\
\text { Incentivar a } \\
\text { pesquisa da } \\
\text { memória da cidade }\end{array}$ & $\begin{array}{l}\text { Viabilizar } \\
\text { economicamente os } \\
\text { grupos culturais }\end{array}$ \\
\hline
\end{tabular}

Quadro 80 - Matriz das diretrizes para Vocação - Turismo Cultural: Escritor e Manifestações Culturais

\begin{tabular}{|c|c|c|c|}
\hline $\begin{array}{l}\text { Tópicos para definição das } \\
\text { diretrizes } X \text { critérios de } \\
\text { sustentabilidade }\end{array}$ & $\begin{array}{l}\text { Conservação e } \\
\text { preservação do } \\
\text { Meio Ambiente }\end{array}$ & $\begin{array}{l}\text { Respeito à cultura } \\
\text { e identidade local }\end{array}$ & $\begin{array}{l}\text { Distribuição da } \\
\text { renda com justiça } \\
\text { social }\end{array}$ \\
\hline $\begin{array}{l}\text { Tipo de eventos } \\
\text { Culturais } \\
\text { Gastronômicos } \\
\text { Esportivos } \\
\text { Exposições } \\
\text { Religiosos } \\
\text { Campeonatos }\end{array}$ & $\begin{array}{l}\text { Eventos de pequeno } \\
\text { e médio porte } \\
\text { Eventos de menores } \\
\text { impactos ambientais } \\
\text { Informações sobre } \\
\text { conservação e } \\
\text { preservação do } \\
\text { meio ambiente para } \\
\text { a população e } \\
\text { visitantes }\end{array}$ & $\begin{array}{l}\text { Criação de } \\
\text { comissão para } \\
\text { análise dos eventos } \\
\text { internos e externos: } \\
\text { Sugestão de } \\
\text { comissão: } \\
\text { Prefeitura } \\
\text { PLANEJATUR, } \\
\text { COMTUR-ML }\end{array}$ & $\begin{array}{l}\text { Priorizar mão de } \\
\text { obra local } \\
\text { Priorizar } \\
\text { empreendedores } \\
\text { locais (formais e } \\
\text { informais } \\
\text { cadastrados na } \\
\text { prefeitura) }\end{array}$ \\
\hline
\end{tabular}




\begin{tabular}{|c|c|c|c|}
\hline $\begin{array}{l}\text { Tópicos para definição das } \\
\text { diretrizes X critérios de } \\
\text { sustentabilidade }\end{array}$ & $\begin{array}{l}\text { Conservação e } \\
\text { preservação do } \\
\text { Meio Ambiente }\end{array}$ & $\begin{array}{l}\text { Respeito à cultura } \\
\text { e identidade local }\end{array}$ & $\begin{array}{l}\text { Distribuição da } \\
\text { renda com justiça } \\
\text { social }\end{array}$ \\
\hline $\begin{array}{l}\text { Regras de convívio } \\
\text { morador } x \text { turista }\end{array}$ & $\begin{array}{l}\text { Conscientização do } \\
\text { turista para a } \\
\text { conservação e } \\
\text { preservação do } \\
\text { meio ambiente } \\
\text { Campanha - } \\
\text { educativa: Jogar lixo } \\
\text { no lixo certo }\end{array}$ & $\begin{array}{l}\text { Campanha } \\
\text { educativa para } \\
\text { trânsito (respeitar as } \\
\text { normas de trânsito) } \\
\text { Conscientização do } \\
\text { turista e morador } \\
\text { para a conservação } \\
\text { e preservação do } \\
\text { patrimônio público }\end{array}$ & $\begin{array}{l}\text { Relação ética na } \\
\text { prática de preços } \\
\text { justos }\end{array}$ \\
\hline
\end{tabular}

Quadro 82 - Matriz das diretrizes para Regras de convívio morador x turista

\begin{tabular}{|l|l|l|l|}
\hline $\begin{array}{l}\text { Tópicos para definição das } \\
\text { diretrizes X critérios de } \\
\text { sustentabilidade }\end{array}$ & $\begin{array}{l}\text { Conservação e } \\
\text { preservação do } \\
\text { Meio Ambiente }\end{array}$ & $\begin{array}{l}\text { Respeito à cultura } \\
\text { e identidade local }\end{array}$ & $\begin{array}{l}\text { Distribuição da } \\
\text { renda com justiça } \\
\text { social }\end{array}$ \\
\hline $\begin{array}{l}\text { Atitudes dos governos } \\
\text { executivo e legislativo em } \\
\text { relação ao Turismo } \\
\text { Sustentável no município }\end{array}$ & $\begin{array}{l}\text { Legislação para } \\
\text { proibir novos } \\
\text { loteamentos } \\
\text { clandestinos }\end{array}$ & $\begin{array}{l}\text { Preservar e } \\
\text { incentivar a cultura } \\
\text { local }\end{array}$ & $\begin{array}{l}\text { Captar indústrias de } \\
\text { pequeno porte } \\
\text { dentro das normas } \\
\text { ambientais }\end{array}$ \\
& $\begin{array}{l}\text { Análise de possível } \\
\text { regularização } \\
\text { daqueles existentes } \\
\text { Turismo nas } \\
\text { atividades das } \\
\text { escolas }\end{array}$ & $\begin{array}{l}\text { Oferecer cursos de } \\
\text { capacitação e } \\
\text { profissionalizantes } \\
\text { para meio ambiente } \\
\text { e Turismo } \\
\text { (monitores locais, } \\
\text { comércio etc.) }\end{array}$ \\
& $\begin{array}{l}\text { Plano diretor do } \\
\text { município }\end{array}$ & $\begin{array}{l}\text { Citytour para } \\
\text { moradores e } \\
\text { escolares em } \\
\text { Monteiro Lobato }\end{array}$ & \\
& Saneamento básico \\
& $\begin{array}{l}\text { Conservação e } \\
\text { preservação das } \\
\text { nascentes e rios }\end{array}$ & & \\
& & \\
\hline
\end{tabular}

Quadro 83 - Matriz das diretrizes para atitudes dos governos executivo e legislativo em relação ao Turismo Sustentável no município 


\begin{tabular}{|l|l|l|l|}
\hline $\begin{array}{l}\text { Tópicos para definição das } \\
\text { diretrizes X critérios de } \\
\text { sustentabilidade }\end{array}$ & $\begin{array}{l}\text { Conservação e } \\
\text { preservação do } \\
\text { Meio Ambiente }\end{array}$ & $\begin{array}{l}\text { Respeito à cultura } \\
\text { e identidade local }\end{array}$ & $\begin{array}{l}\text { Distribuição da } \\
\text { renda com justiça } \\
\text { social }\end{array}$ \\
\hline Atitudes dos empresários & $\begin{array}{l}\text { Responsabilizar-se } \\
\text { pelos resíduos } \\
\text { produzidos, (óleo, } \\
\text { separação de lixo) }\end{array}$ & $\begin{array}{l}\text { Apoio à cultura local } \\
\text { Respeitar as leis } \\
\text { vigentes sobre não } \\
\text { venda de bebidas } \\
\text { alcoólicas para } \\
\text { menores } \\
\text { produtos e serviços } \\
\text { locais } \\
\text { propsas sépticas nades rurais }\end{array}$ & $\begin{array}{l}\text { Priorizar contratação } \\
\text { de mão de obra } \\
\text { local }\end{array}$ \\
& $\begin{array}{l}\text { Respeito à } \\
\text { capacidade de carga } \\
\text { Incentivo ao uso } \\
\text { consciente de } \\
\text { energia elétrica, } \\
\text { água, combustíveis } \\
\text { etc. }\end{array}$ & $\begin{array}{l}\text { Incentivo à venda de } \\
\text { produtos locais }\end{array}$ & $\begin{array}{l}\text { Investir na } \\
\text { qualificação dos } \\
\text { próprios } \\
\text { empresários e dos } \\
\text { funcionários }\end{array}$ \\
& & $\begin{array}{l}\text { Incentivar o } \\
\text { associativismo e } \\
\text { parcerias }\end{array}$ \\
\hline
\end{tabular}

Quadro 84 - Matriz das diretrizes para atitudes dos empresários

\begin{tabular}{|c|c|c|c|}
\hline $\begin{array}{l}\text { Tópicos para definição das } \\
\text { diretrizes } X \text { critérios de } \\
\text { sustentabilidade }\end{array}$ & $\begin{array}{l}\text { Conservação e } \\
\text { preservação do } \\
\text { Meio Ambiente }\end{array}$ & $\begin{array}{l}\text { Respeito à cultura } \\
\text { e identidade local }\end{array}$ & $\begin{array}{l}\text { Distribuição da } \\
\text { renda com justiça } \\
\text { social }\end{array}$ \\
\hline Atitudes da comunidade & $\begin{array}{l}\text { Respeitar o meio } \\
\text { ambiente e ser } \\
\text { agente de } \\
\text { fiscalização e } \\
\text { proteção do meio } \\
\text { ambiente } \\
\text { Não fazer } \\
\text { queimadas e } \\
\text { desmatamentos } \\
\text { Não poluir os rios } \\
\text { e nascentes }\end{array}$ & $\begin{array}{l}\text { Manter o bom } \\
\text { acolhimento } \\
\text { Dar informações } \\
\text { turísticas corretas } \\
\text { Participar e } \\
\text { colaborar na } \\
\text { melhoria do Turismo } \\
\text { na cidade }\end{array}$ & $\begin{array}{l}\text { Buscar a } \\
\text { capacitação para o } \\
\text { Turismo, artesanato, } \\
\text { comércio etc. } \\
\text { Empreender em } \\
\text { projetos turísticos e } \\
\text { de conservação do } \\
\text { meio ambiente } \\
\text { Incentivar o } \\
\text { associativismo e } \\
\text { parcerias }\end{array}$ \\
\hline
\end{tabular}

Quadro 85 - Matriz das diretrizes para atitudes da comunidade 


\section{A visão de futuro para o Turismo Sustentável de Monteiro Lobato:}

Os participantes da atividade de construção da visão de futuro para o Turismo Sustentável de Monteiro Lobato, realizada na reunião do COMTUR-ML, no dia 07 de novembro de 2013, foram:

\begin{tabular}{l|l|}
\cline { 2 - 2 } 1. & Anacélia de Mello Morente \\
\cline { 2 - 2 } 2. & Andrejs Ceruks \\
\cline { 2 - 2 } 3. & Antonio Renato de Sá Sonnewend \\
4. & Aparecida Batista Oliveira Costa \\
5. & Benedito Antonio Pinto \\
6. & Célia Ceruks \\
7. & Deise Datti da Rosa \\
\hline
\end{tabular}

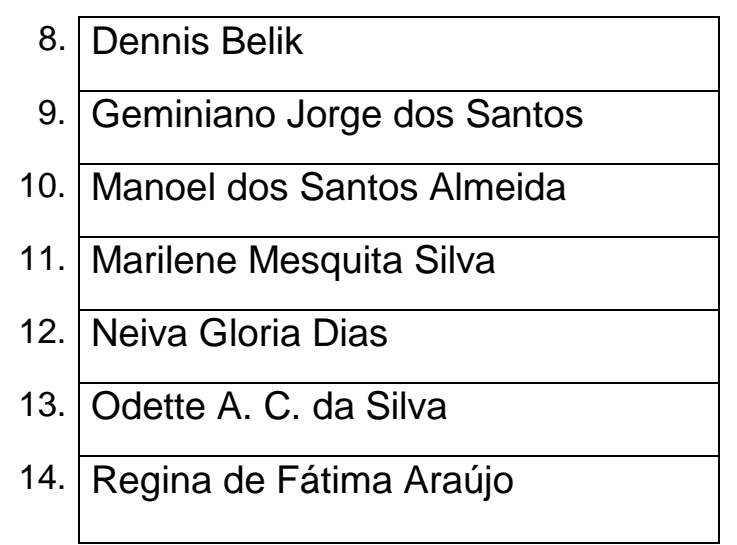

Quadro 86 - Participantes da Oficina no dia 07 de novembro de 2014

Como introdução da atividade, foram apresentadas algumas definições de visão, destacando-se:

"Visão é um alvo, é a imagem mental de um estado futuro possível e desejável. Pode ser tão vaga quanto um sonho, pode ser tão precisa quanto uma meta, não pode ser estabelecida por decreto." (Warren Bennis)

"Um enunciado claro, uma noção de propósito nobre, uma chance possível de sucesso." (Karl Albrecht)

"Uma visão é um sonho que no fundo da nossa alma sabemos que é possível realizar!" (Cleide Pivott)

A pergunta norteadora colocada foi:

\section{Qual é a sua visão para o Turismo Sustentável em Monteiro Lobato?}

Os participantes, através de tempestade de ideias, anotaram suas visões em fichas que foram afixadas em folhas de flip chart na parede. Em seguida, todas as fichas foram lidas pela moderadora em voz alta para que todos acompanhassem as visões que estão transcritas abaixo: 


\begin{tabular}{|c|c|c|c|}
\hline $\begin{array}{l}\text { Que todo nosso } \\
\text { potencial turístico } \\
\text { esteja sendo } \\
\text { desenvolvido e } \\
\text { utilizado de forma } \\
\text { sustentável e } \\
\text { controlado. }\end{array}$ & $\begin{array}{l}\text { Minha visão de futuro: } \\
\text { que todo esforço } \\
\text { desprendido através } \\
\text { do curso e oficinas } \\
\text { não caia no } \\
\text { esquecimento, que as } \\
\text { pessoas tenham } \\
\text { comprometimento e } \\
\text { todos façam a sua } \\
\text { parte da melhor forma } \\
\text { possível. }\end{array}$ & $\begin{array}{l}\text { O turista sinta } \\
\text { acolhimento caipira } \\
\text { e se surpreenda com } \\
\text { nossa culinária, } \\
\text { atrativos naturais e } \\
\text { culturais. Volte para } \\
\text { casa satisfeito! E } \\
\text { recomenda a visita à } \\
\text { cidade para amigos. }\end{array}$ & $\begin{array}{l}\text { Que o Turismo } \\
\text { Sustentável possa } \\
\text { colaborar para o } \\
\text { desenvolvimento do } \\
\text { município, trazendo } \\
\text { recursos financeiros e } \\
\text { protegendo o meio } \\
\text { ambiente. }\end{array}$ \\
\hline $\begin{array}{l}\text { Ônibus caracterizado } \\
\text { para tour Monteiro } \\
\text { Lobato (escolas). } \\
\text { Personagens das } \\
\text { histórias de Monteiro } \\
\text { Lobato espalhadas } \\
\text { em pontos } \\
\text { estratégicos da } \\
\text { cidade. E um final de } \\
\text { semana de } \\
\text { gastronomia: "Festa } \\
\text { da Goiaba". }\end{array}$ & $\begin{array}{l}\text { Monteiro Lobato, } \\
\text { cidade modelo de } \\
\text { acolhimento de ordem } \\
\text { de paz, de limpeza } \\
\text { que seus produtos } \\
\text { rurais, doces, } \\
\text { restaurantes, } \\
\text { pousadas, atrativos } \\
\text { naturais e culturais, } \\
\text { atendimento e } \\
\text { informações precisos, } \\
\text { povo alegre e } \\
\text { cativante que } \\
\text { surpreenda o turista }\end{array}$ & $\begin{array}{l}\text { Turistas hospedados } \\
\text { em pousadas de } \\
\text { Monteiro Lobato, } \\
\text { visitando pontos } \\
\text { turísticos em todo } \\
\text { município e em } \\
\text { regiões vizinhas, } \\
\text { orientados por } \\
\text { monitores com } \\
\text { orientações e } \\
\text { informações sólidas. }\end{array}$ & $\begin{array}{l}\text { A visão de uma } \\
\text { cidade alegre, com } \\
\text { parques, e que tudo } \\
\text { lembrasse a cultura, a } \\
\text { educação e tanto o } \\
\text { turista quanto a } \\
\text { própria comunidade } \\
\text { tivesse orgulho do } \\
\text { lugar que visita ou } \\
\text { que mora. Onde tudo } \\
\text { funciona com } \\
\text { harmonia e presteza. }\end{array}$ \\
\hline $\begin{array}{l}\text { Infraestrutura } \\
\text { adequada, a boa } \\
\text { locomoção em todo o } \\
\text { município, com } \\
\text { controle adequado } \\
\text { em relação à } \\
\text { segurança do meio } \\
\text { ambiente e segurança } \\
\text { pessoal. }\end{array}$ & $\begin{array}{l}\text { Uma cidade que } \\
\text { tivesse características } \\
\text { culturais e ambientais } \\
\text { que retratassem o } \\
\text { que temos de melhor: } \\
\text { "o nome e a } \\
\text { natureza". Que fosse } \\
\text { uma Disney } \\
\text { Lobatense. }\end{array}$ & $\begin{array}{l}\text { Eu Manoel, } \\
\text { lobatense de } \\
\text { coração, espero } \\
\text { melhoria para todos } \\
\text { os lobatenses. } \\
\text { Através do Turismo } \\
\text { vai criar mais } \\
\text { empregos para os } \\
\text { lobatenses. } \\
\end{array}$ & $\begin{array}{l}\text { Turistas consumindo } \\
\text { produtos da região em } \\
\text { restaurantes e } \\
\text { comércio local, } \\
\text { atendidos por } \\
\text { pessoas do município } \\
\text { de modo cortês e } \\
\text { adequado. }\end{array}$ \\
\hline $\begin{array}{l}\text { Turista tranquilo, feliz, } \\
\text { recarregado e com } \\
\text { vontade de voltar. }\end{array}$ & $\begin{array}{l}\text { Turista feliz e bem- } \\
\text { acolhido. }\end{array}$ & $\begin{array}{l}\text { Nossa cultura } \\
\text { valorizada. }\end{array}$ & $\begin{array}{l}\text { Capacitar cidadãos e } \\
\text { selecionar o turista. }\end{array}$ \\
\hline $\begin{array}{l}\text { Responsabilidade e } \\
\text { exemplo de cada } \\
\text { cidadão para com a } \\
\text { cidade em sua } \\
\text { diversidade }\end{array}$ & $\begin{array}{l}\text { Que as expectativas } \\
\text { de compra e } \\
\text { hospedagem do } \\
\text { turista sejam } \\
\text { atendidas. }\end{array}$ & $\begin{array}{l}\text { Monteiro Lobato ser } \\
\text { referência regional } \\
\text { de Turismo } \\
\text { Sustentável. }\end{array}$ & $\begin{array}{l}\text { Não só pensar em si } \\
\text { próprio, mas sim a } \\
\text { união entre } \\
\text { comerciantes e } \\
\text { produtores, pois tudo } \\
\text { isso é ligado à } \\
\text { sustentabilidade. }\end{array}$ \\
\hline $\begin{array}{l}\text { Que seja referência } \\
\text { (modelo para outras } \\
\text { cidades) em Turismo } \\
\text { Sustentável. }\end{array}$ & $\begin{array}{l}\text { Ter as respostas às } \\
\text { sugestões (turistas e } \\
\text { moradores) } \\
\text { atendidas. }\end{array}$ & $\begin{array}{l}\text { Que a nossa cultura } \\
\text { tenha um lugar } \\
\text { próprio para mostrar } \\
\text { ao nosso país e ao } \\
\text { mundo o que temos } \\
\text { de melhor }\end{array}$ & $\begin{array}{l}\text { Que tenhamos uma } \\
\text { agência e eventos } \\
\text { funcionando } \\
\text { maravilhosamente }\end{array}$ \\
\hline $\begin{array}{l}\text { Que o COMTUR e } \\
\text { PLANEJATUR } \\
\text { continuem juntos, } \\
\text { exercendo suas } \\
\text { funções muito bem. }\end{array}$ & $\begin{array}{l}\text { Que nosso plano de } \\
\text { desenvolvimento } \\
\text { turístico dê certo e } \\
\text { todos o respeitem. }\end{array}$ & $\begin{array}{l}\text { Que tenhamos } \\
\text { representantes em } \\
\text { olimpíadas, filhos da } \\
\text { terra. }\end{array}$ & $\begin{array}{l}\text { Que o turista tenha } \\
\text { prazer em vir para } \\
\text { Monteiro Lobato. }\end{array}$ \\
\hline
\end{tabular}


Após o compartilhamento das visões, os participantes analisaram-nas buscando o significado dos respectivos conteúdos e apresentaram por meio de palavras e expressões o que entenderam delas.

\begin{tabular}{|l|l|}
\hline$>$ Comprometimento & $>$ Capacitação \\
$>$ Cortesia & $>$ Respeito ao meio ambiente \\
$>$ Acolhimento & $>$ Valorização da cultura local \\
$>$ Orgulho de ser lobatense & $>$ Comprometimento e harmonia entre \\
$>$ Referência em Turismo Sustentável & $>$ cidade e campo \\
$>$ Criação de empregos & $>$ Trabalho com responsabilidade \\
$>$ Desenvolvimento socioeconômico & $>$ Comprometimento do poder público \\
&
\end{tabular}

Quadro 88 - Síntese da visão de futuro

Analisando essas palavras e expressões, após um debate, os participantes construíram a visão de futuro para o Turismo Sustentável de Monteiro Lobato:

\section{Ser referência em Turismo Sustentável, preservando o meio ambiente, valorizando a cultura local, com hospitalidade e qualidade de vida.}

Esta visão irá nortear as decisões e ações da comunidade em todas as questões relacionadas ao Turismo no município, pautando-se sempre pelos critérios de sustentabilidade. 

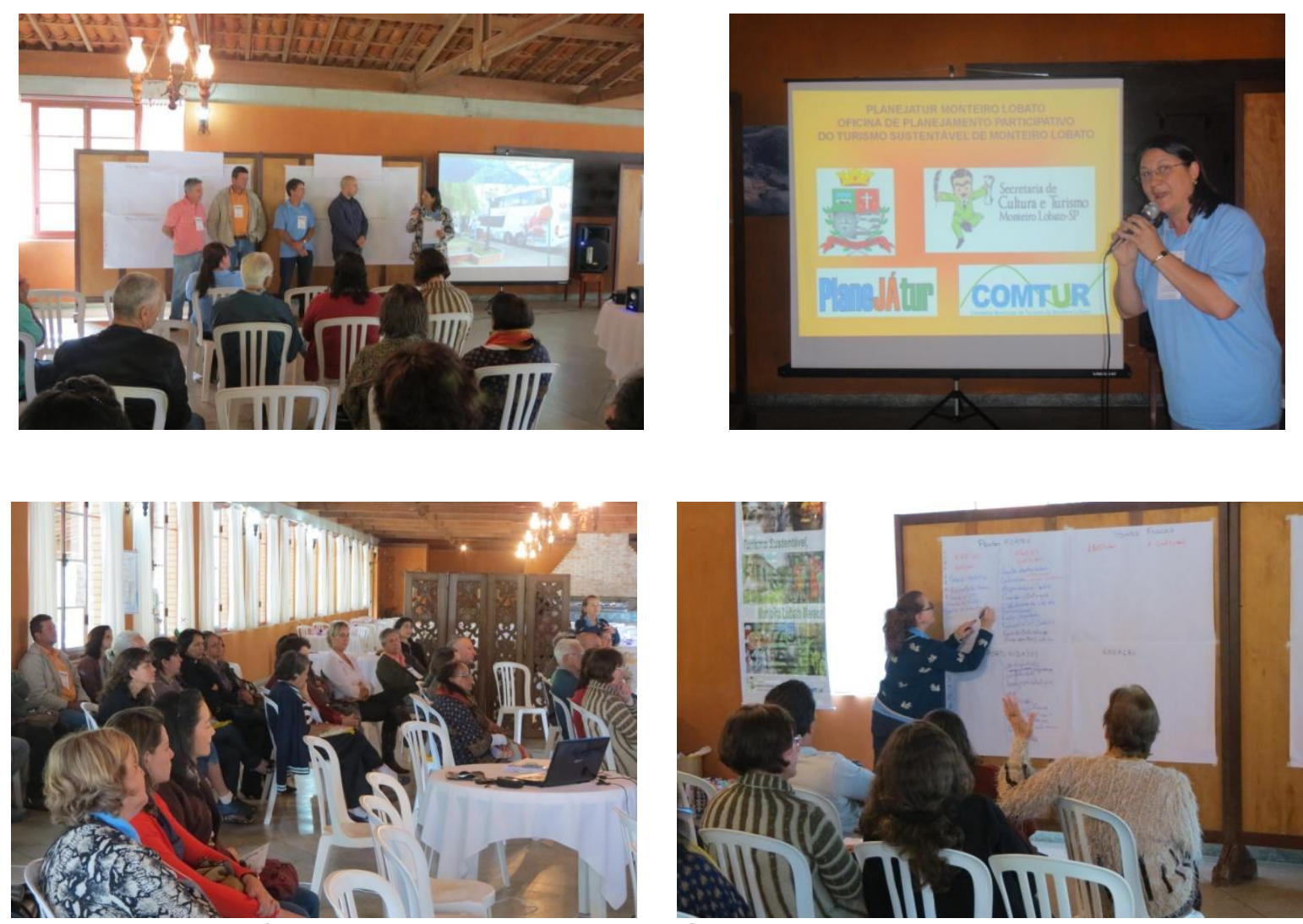

Foto 6 - Conjunto de fotos da terceira Oficina - dia 19 de setembro de 2013
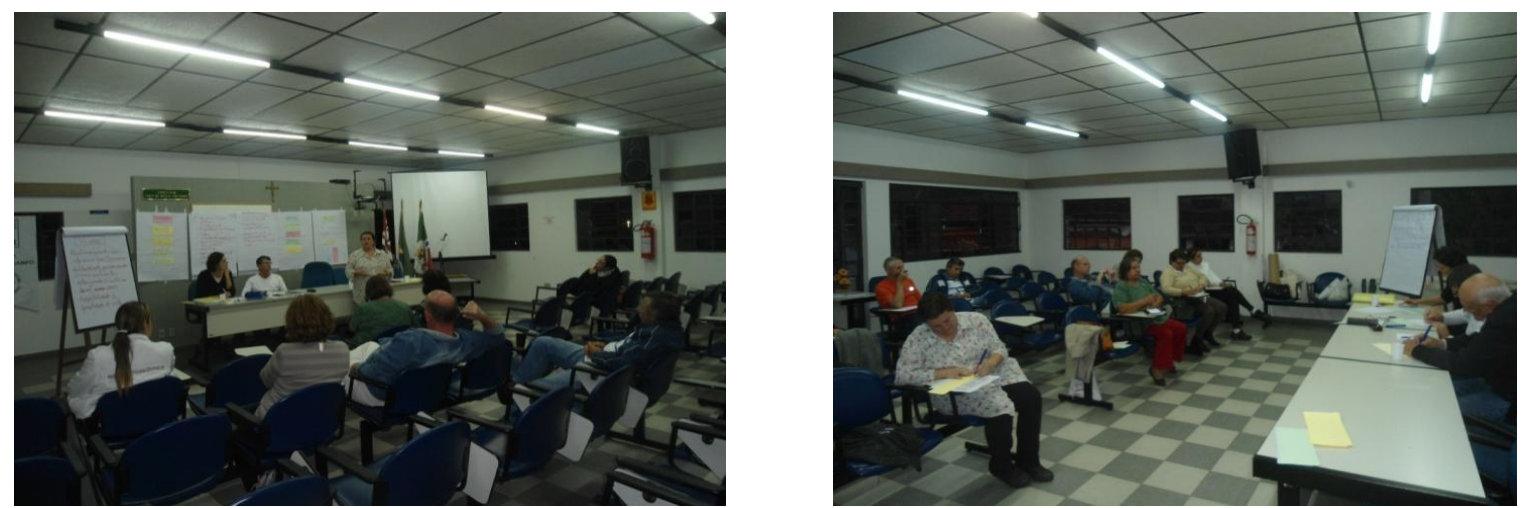

Foto 7 - Conjunto de fotos da terceira Oficina - 07 de novembro de 2013 (continuação) 


\subsection{Pesquisa de opinião dos moradores e pesquisa de demanda}

Para a aplicação das pesquisas de demanda e de opinião dos moradores, o Grupo Planejatur empreendeu uma força-tarefa dividindo entre seus membros as cópias dos questionários e buscando colaboração dos donos de pousadas, restaurantes e lojistas. O período das entrevistas foi de janeiro a fevereiro de 2013.

Para testar os questionários elaborados, foi realizado um pré-teste aplicandose 10 questionários a moradores e 10 a visitantes. Algumas questões foram refeitas, outras retiradas. Por exemplo, no questionário para moradores, os entrevistadores perceberam certo constrangimento dos entrevistados em responder à questão referente à renda. Portanto, considerando que o Censo 2010 do IBGE apresenta a renda da população, essa questão foi retirada. No caso da pesquisa com turistas, essa informação é importante para se conhecer o poder aquisitivo dos mesmos e, assim, a questão sobre a renda familiar do turista foi mantida.

Na pesquisa de opinião dos moradores, foram aplicados 159 questionários e dos turistas, 124. A amostragem foi definida de acordo com a classificação dada por Samara e Barros (1997, p. 70) como não-probabilística por conveniência pela qual, segundo os autores, "os elementos da amostra são selecionados de acordo com a conveniência do pesquisador. São pessoas que estão ao alcance do pesquisador e dispostas a responder a um questionário".

Após a aplicação e a tabulação dos questionários, o Grupo Planejatur (2014a, p. 143) fez a análise do resultado de cada questão e elaborou os relatórios transcritos a seguir: 


\section{RESULTADOS PESQUISA DE OPINIÃO DE MORADORES SOBRE O TURISMO EM MONTEIRO LOBATO \\ GRUPO PLANEJATUR - janeiro a fevereiro de 2013}

159 questionários

1. Local de nascimento?

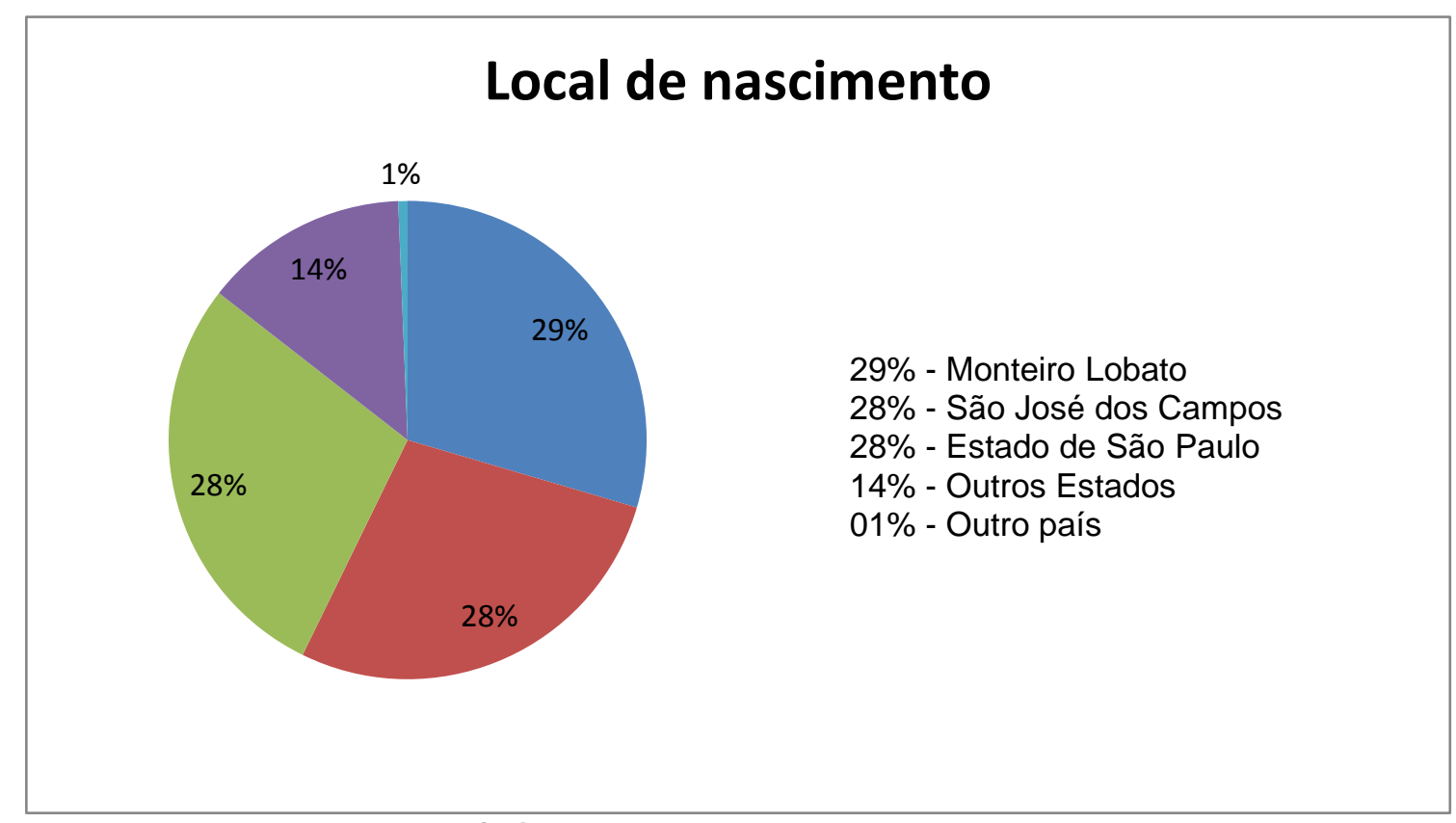

Gráfico 11 - Local de nascimento

$\mathrm{Na}$ amostragem há uma proximidade numérica entre os que nasceram em Monteiro Lobato, São José dos Campos e Estado de São Paulo. Porém, salienta-se que, em geral, com exceção dos que nascem com parteiras, os partos são feitos em São José dos Campos pelo fato de que não há maternidade em Monteiro Lobato. Consequentemente, a unidade de nascimento registrada será sempre São José dos Campos. Observa-se, ainda, que, das pessoas nascidas em outras localidades (71\%), 54\% responderam que a vinda a Monteiro Lobato foi motivada por questões relacionadas à família. Se criada uma categoria como "gosto pelo campo" e somadas as porcentagens das motivações "adquiriu propriedade rural $(2 \%)$, natureza $(2 \%)$, segunda residência $(3 \%)$, qualidade de vida $(3 \%)$, sossego $(4 \%)$, aposentadoria (3\%), e vida alternativa (2\%)", têm-se que $19 \%$ desses entrevistados vieram a Monteiro Lobato em busca de uma vida mais tranquila no campo. 
2. Qual o motivo que o trouxe para Monteiro Lobato? (caso não tenha nascido no município)

\begin{tabular}{|ll|ll|}
\hline$\bullet$ & empreender em Turismo & $\bullet$ & melhorar qualidade de vida \\
- & saúde & $\bullet$ & sossego \\
trabalho & casamento \\
- & adquiriu propriedade rural & $\bullet$ & aposentadoria \\
- & natureza \\
família & vida alternativa \\
- & segunda residência & adoção \\
\hline
\end{tabular}

3. Há quanto tempo reside em Monteiro Lobato? Respostas múltiplas resultando em uma média de 13 anos

4. Em qual bairro reside?

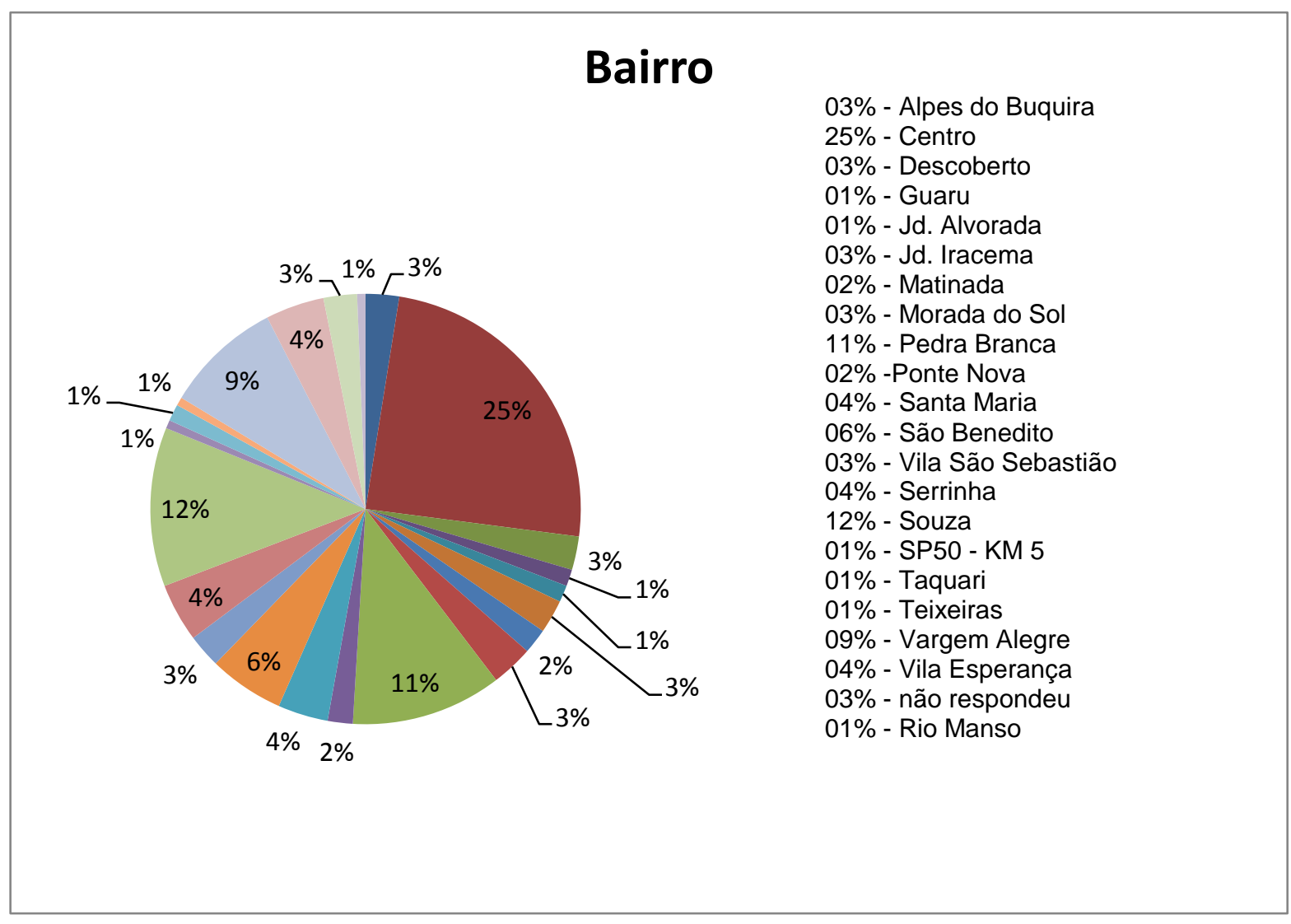

Gráfico 12 - Bairro onde reside

Nessa pesquisa, procurou-se entrevistar moradores do centro e dos bairros rurais para ter uma boa representatividade da opinião daqueles que moram na área urbana, tanto quanto daqueles que moram na zona rural. 
5. Sexo:

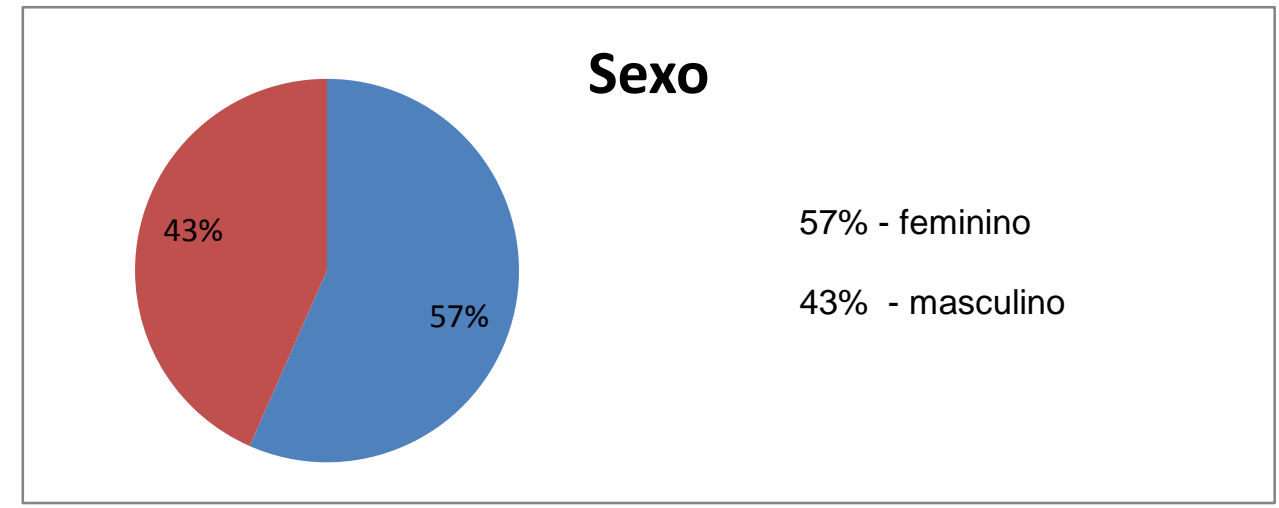

Gráfico 13 - Sexo

6. Faixa etária

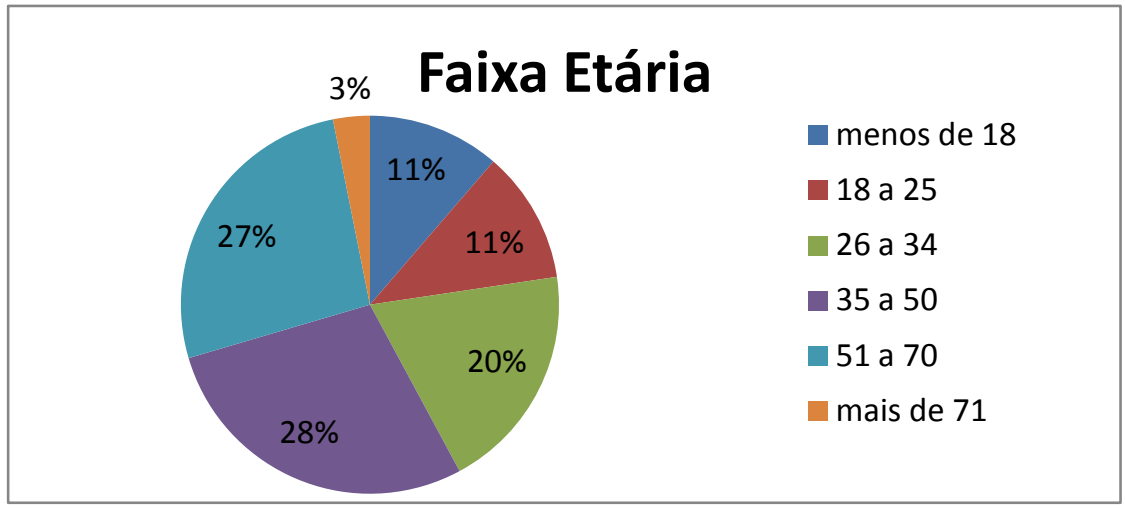

Gráfico 14 - Faixa etária

7. Estado civil:

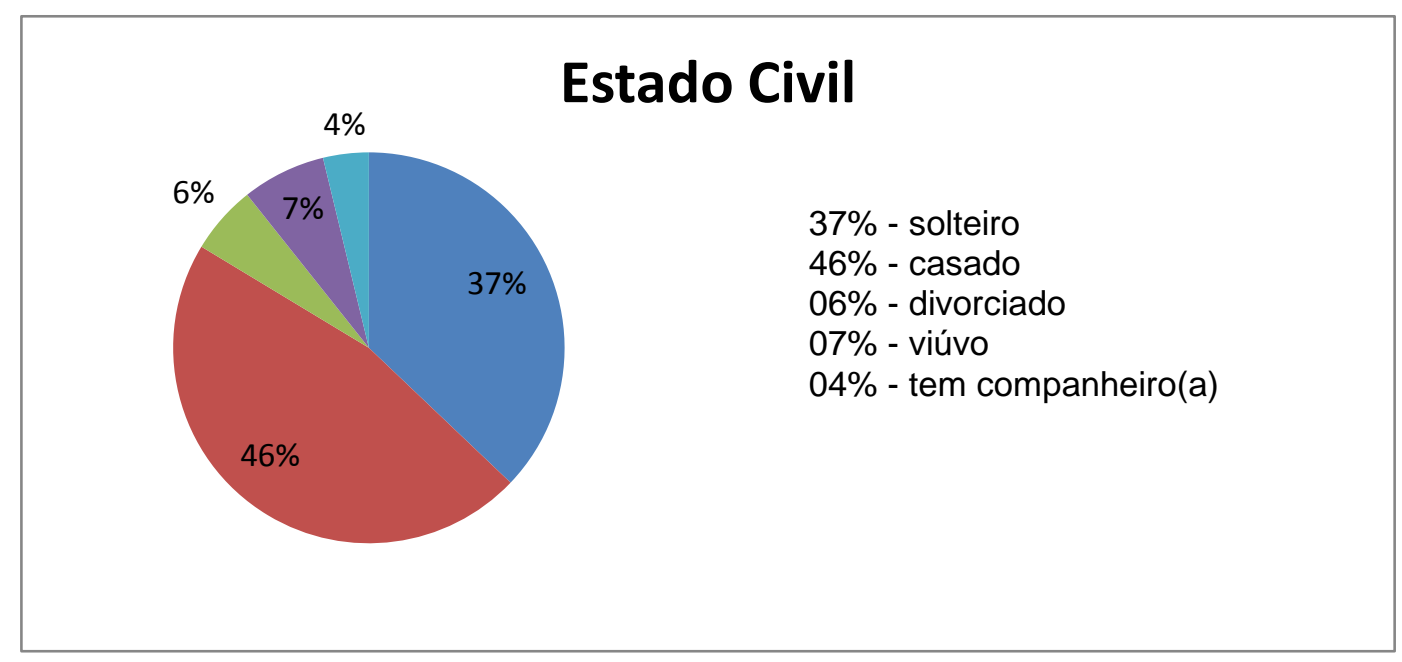

Gráfico 15 - Estado Civil 
8. Número de membros da família que habitam a mesma casa:

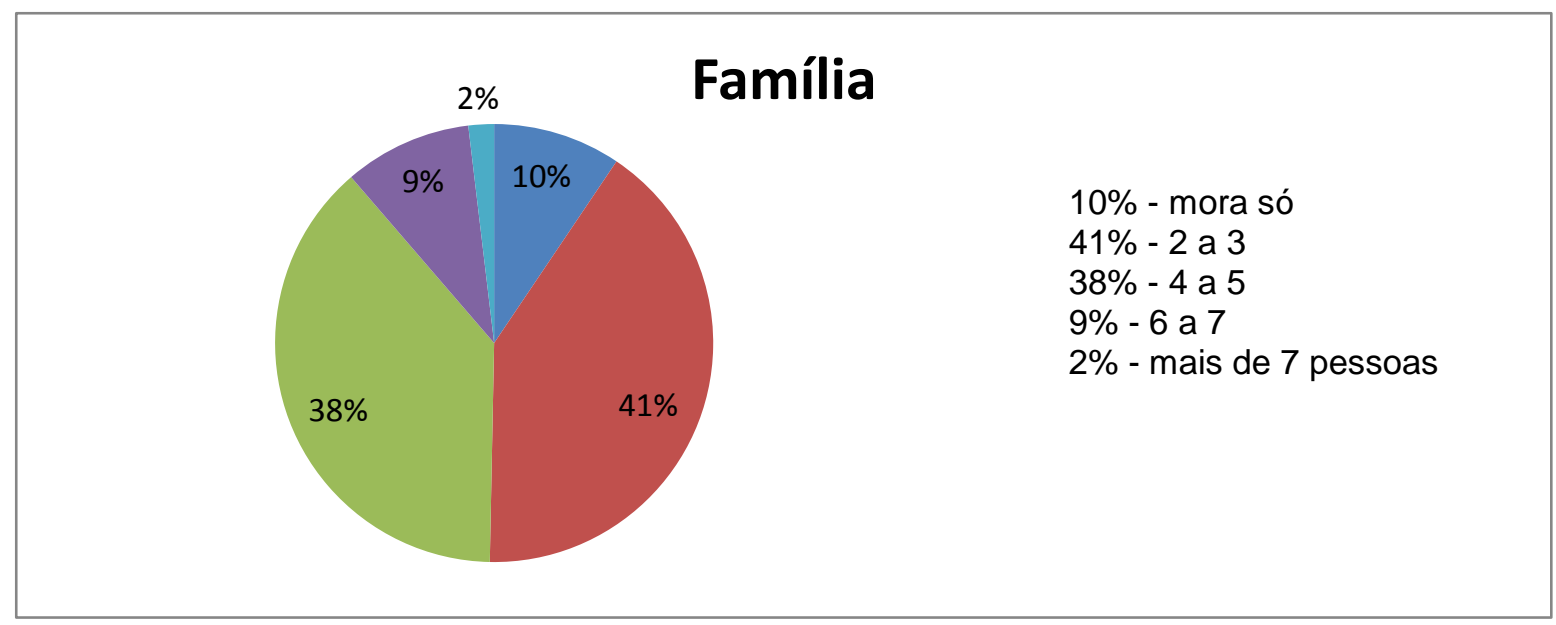

Gráfico 16 - Número de membros da família que habitam a mesma casa

9. Qual é a sua profissão?

Respostas múltiplas: engenheiros, técnicos, professores, donas de casas, estudantes, aposentados, pedreiros, metalúrgicos, oficial de justiça, funcionários públicos, artesãos, costureiras etc.

10. Em que setor trabalha?

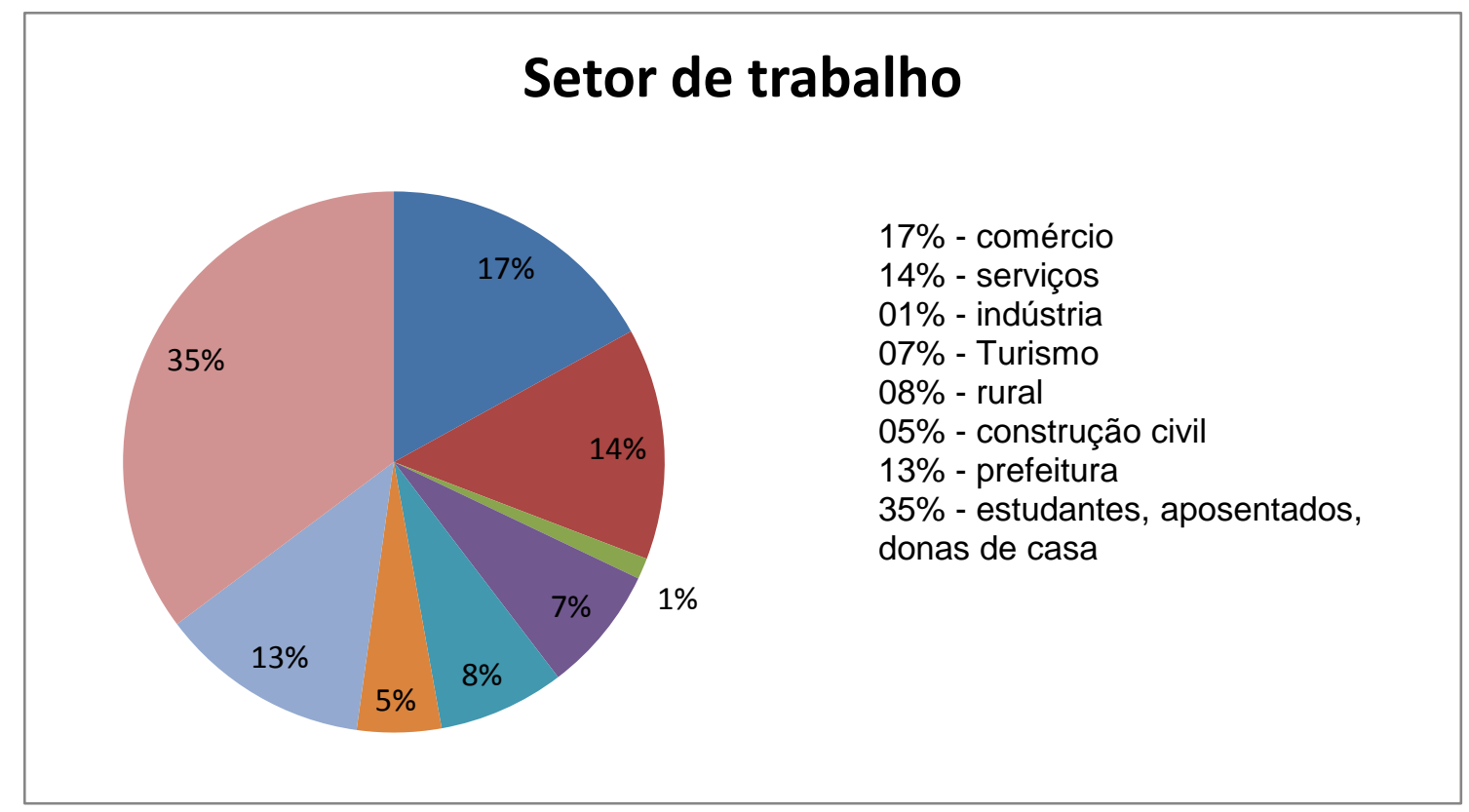

Gráfico 17 - Setor de trabalho

Nessa amostragem, verifica-se que os setores de comércio (17\%) e serviços (14\%) superam o setor rural (8\%), estando em consonância com os dados indicados 
pelo SEADE (2011) sobre vínculo empregatício no município de Monteiro Lobato em 2010: comércio $(31,10 \%)$ e serviços $(43,10 \%)$. Uma ressalva deve ser feita com referência ao vínculo empregatício na área rural de que ainda há muita informalidade na contratação de trabalhadores rurais.

11. Em que cidade trabalha?

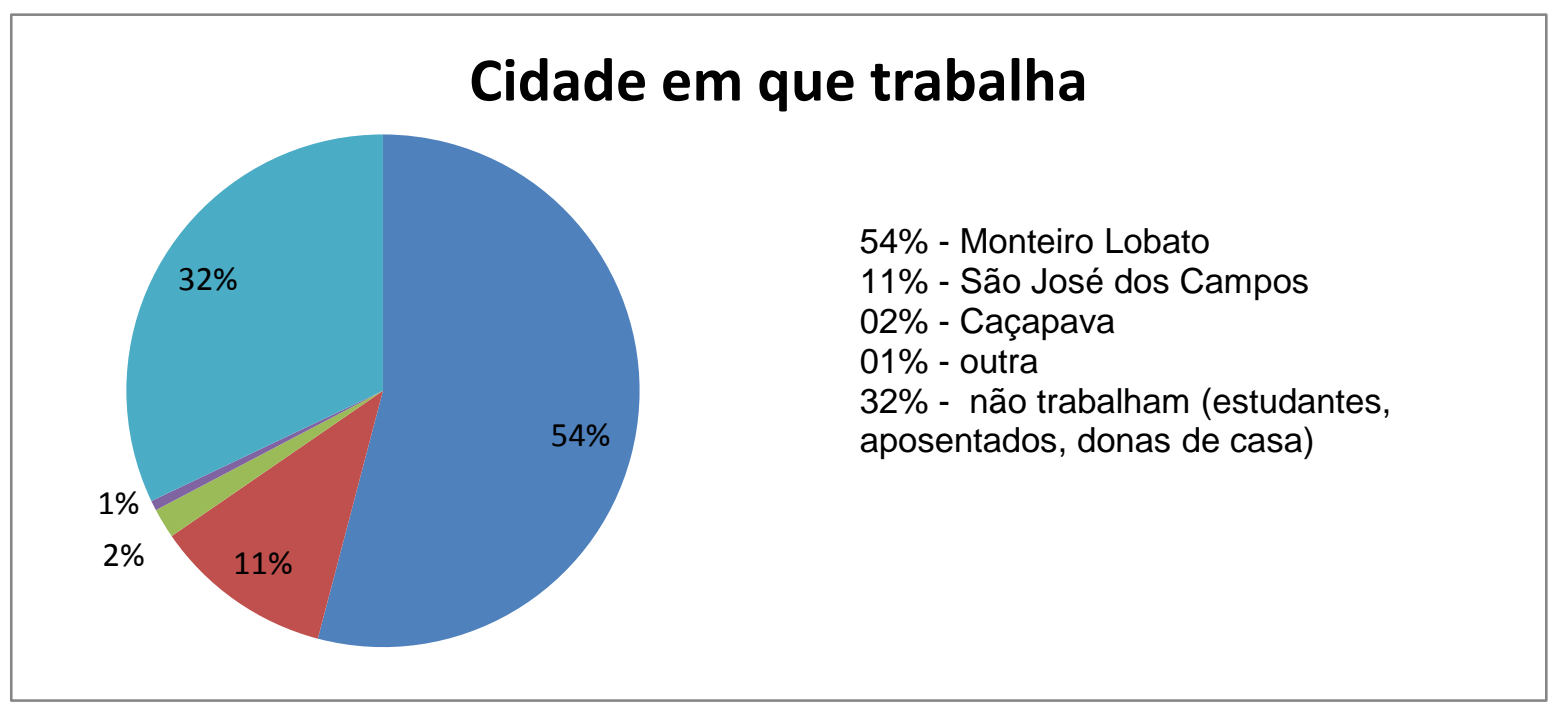

Gráfico 18 - cidade em que trabalha

12. Grau de instrução:

\section{Grau de instrução}

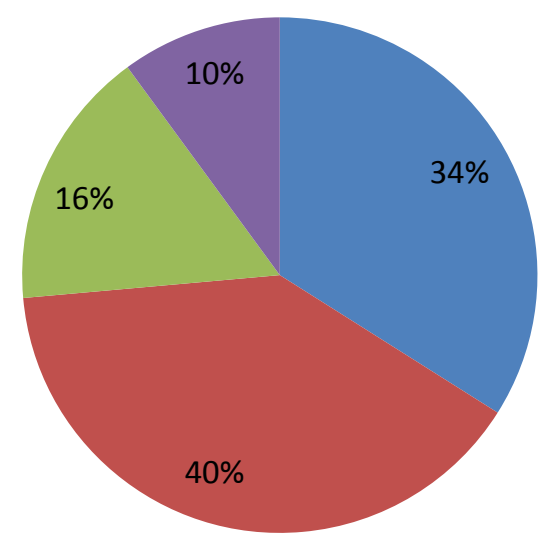

$34 \%$ - ensino fundamental $40 \%$ - ensino médio

$16 \%$ - superior $10 \%$ - pós-graduação

Gráfico 19 - Grau de instrução 
13. Qual a atividade cultural do seu interesse?

\section{Atividade cultural de interesse}

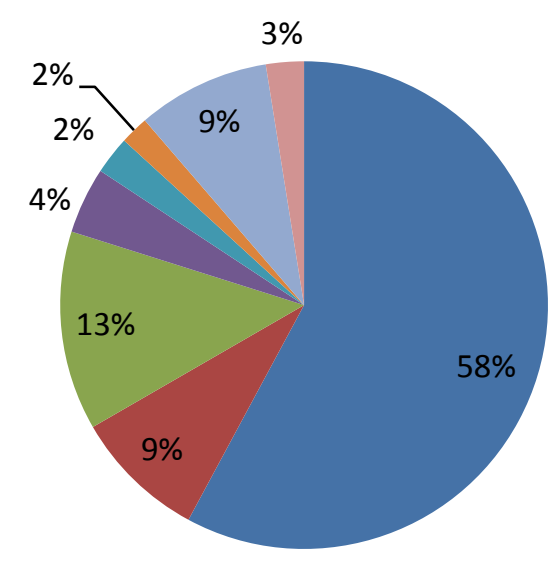

$58 \%$ - música

$09 \%$ - teatro

$13 \%$ - cinema

$04 \%$ - dança

$02 \%$ - leitura

$02 \%$ - tudo

$09 \%$ - nada

$03 \%$ - outros

Gráfico 20 - Atividade cultural de interesse

Essa questão foi inserida para identificar os eventos culturais de maior interesse da população e assim subsidiar a Prefeitura e os agentes culturais na escolha de eventos a serem realizados no município. Observa-se que a música é o que mais agrada os moradores (58\%) e a preferência do tipo de música é para a sertaneja em primeiro lugar (36\%) e Música Popular Brasileira (MPB) em segundo lugar (15\%). Traçando um paralelo com a pesquisa com turistas, vê-se que, igualmente, a maior parte dos turistas gosta de música $(60 \%)$, porém com uma inversão de porcentagens para o tipo de música, 15\% preferem a sertaneja e 38\% a MPB. Esse resultado indica que, ao fazer uma apresentação musical que inclua música sertaneja e MPB, tanto moradores quanto turistas ficarão satisfeitos. 


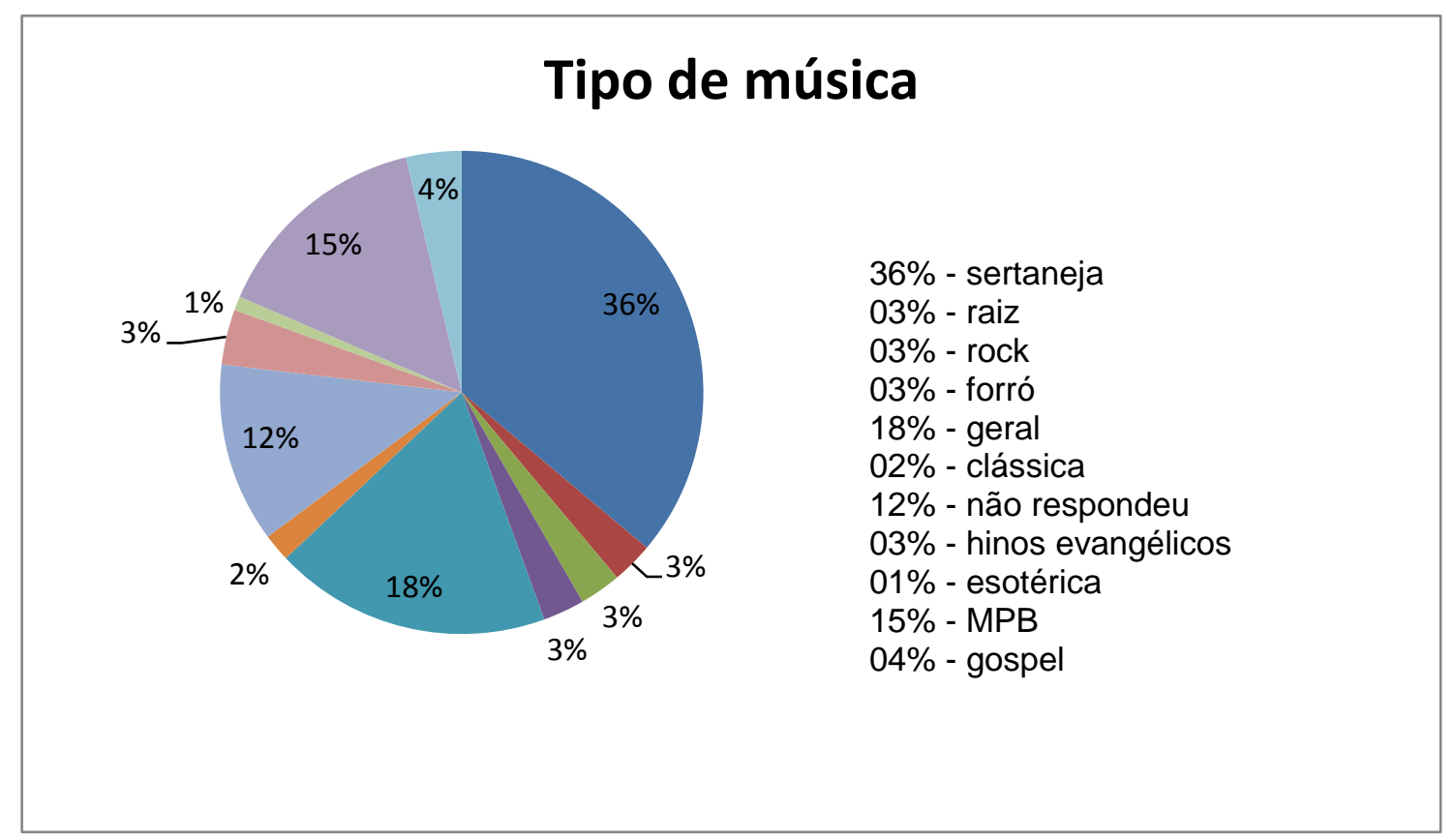

Gráfico 21 - Tipo de música

14. Conhece livros do escritor Monteiro Lobato?

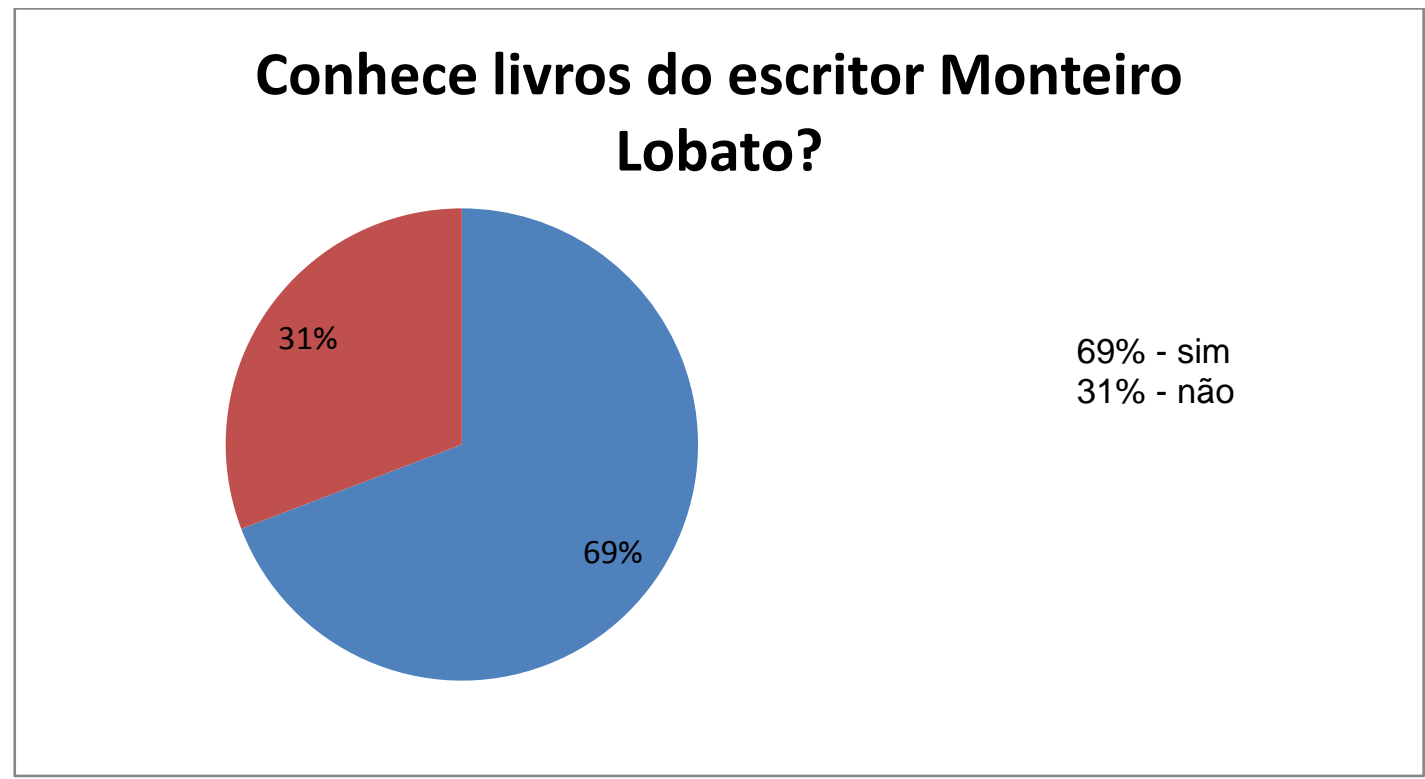

Gráfico 22 - Conhece livros do escritor Monteiro Lobato? 


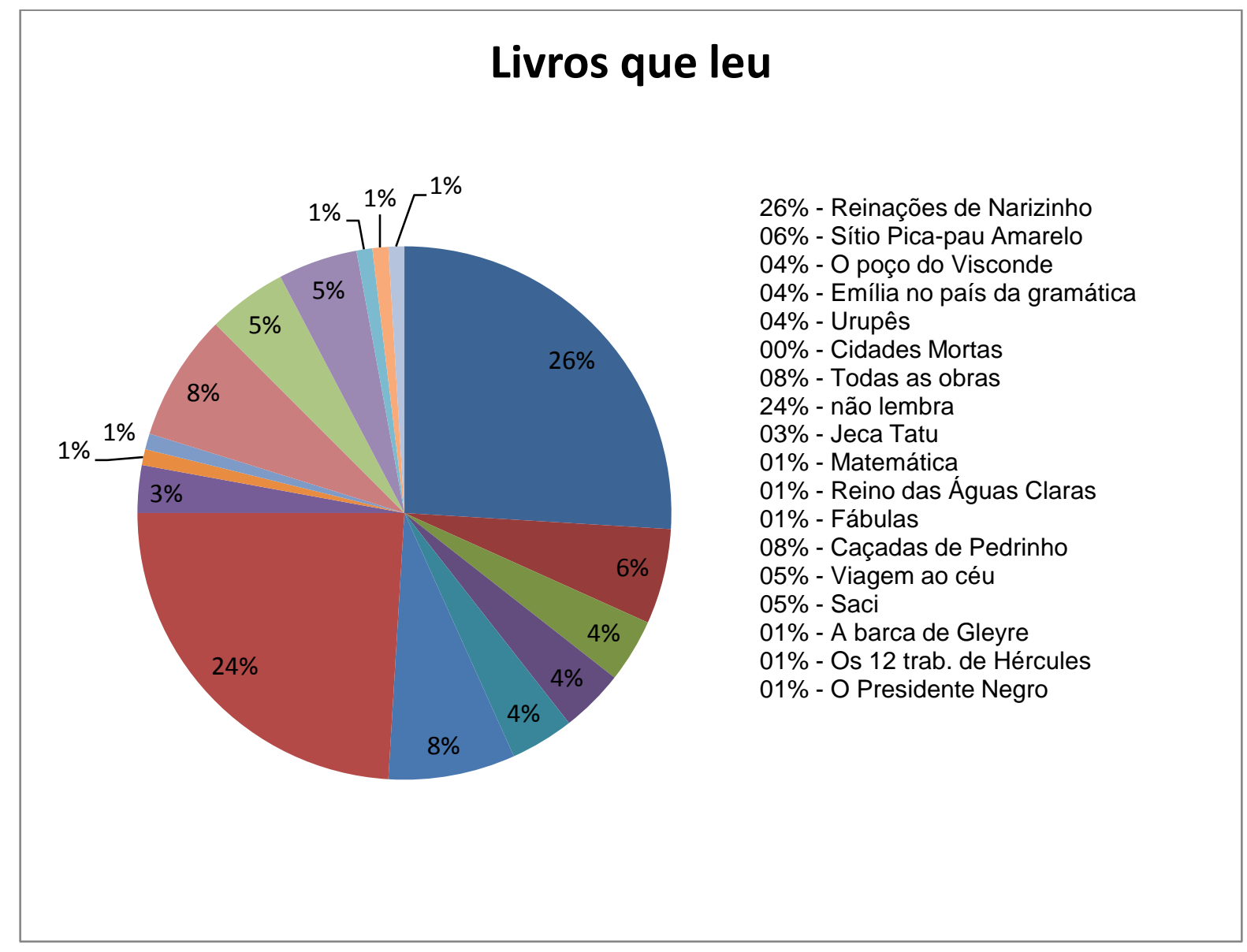

Gráfico 23 - Livros que leu

O livro Reinações de Narizinho lidera a lista de leitura dos livros do escritor Monteiro Lobato pelos moradores (26\%). Salienta-se, no entanto, que dos $69 \%$ que responderam afirmativamente que conhecem os livros do autor, 24\% responderam que não se lembram dos títulos dos livros que leram, em geral porque faz muito tempo, segundo eles. Fazendo um paralelo com a pesquisa com turistas, $79 \%$ responderam que conhecem a obra desse autor, sendo que 19\% leram Reinações de Narizinho, 15\% leram o Sítio do Pica-pau Amarelo e 38\% não lembram quais livros leram. Vale também salientar que $8 \%$ dos moradores declararam ter lido a obra completa do escritor. 
15. Você é favorável à exploração do Turismo em Monteiro Lobato?

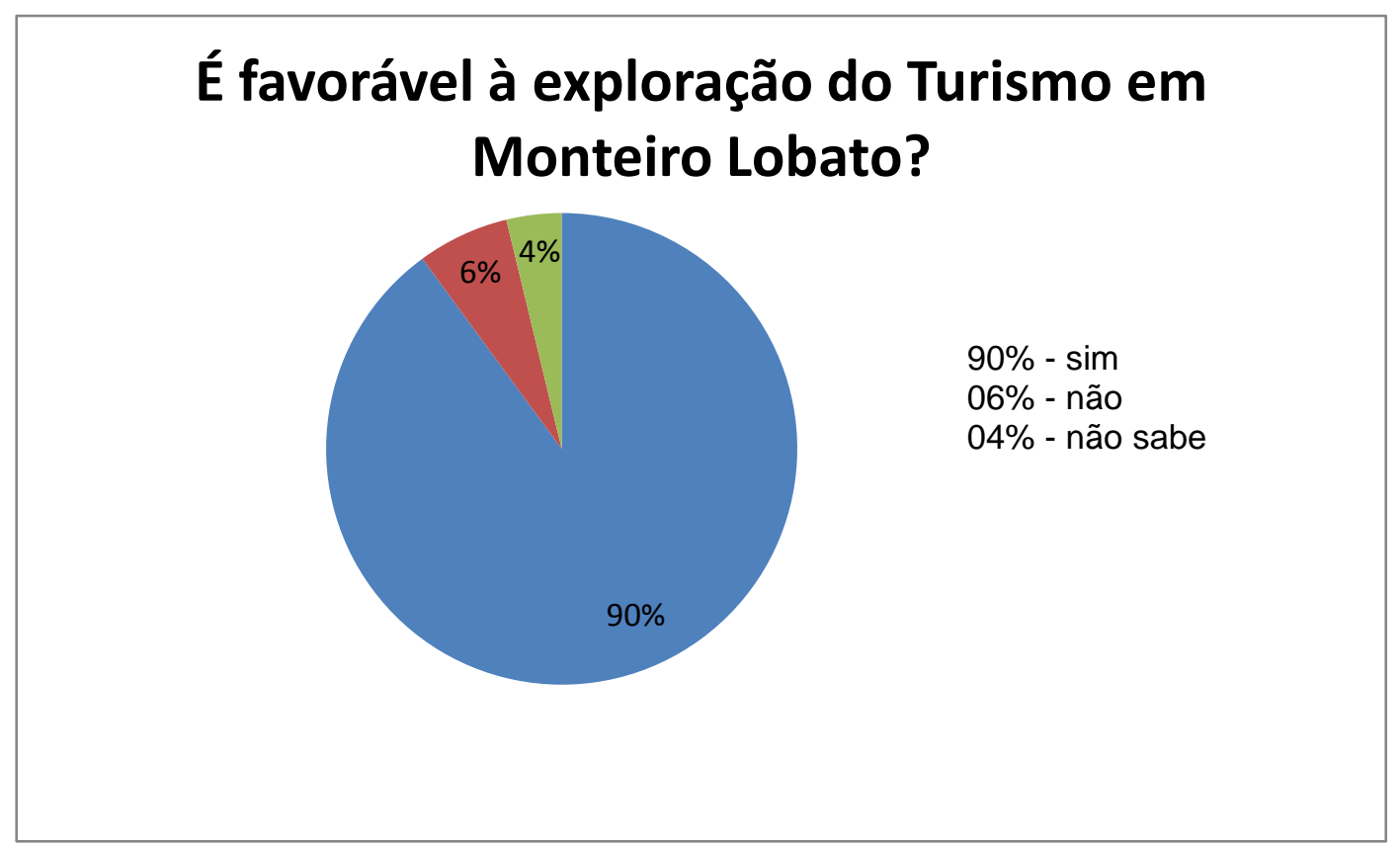

Gráfico 24 - Você é favorável à exploração do Turismo em Monteiro Lobato?

O resultado dessa questão ( $90 \%$ são favoráveis à exploração do Turismo no município) confirma os resultados das pesquisas anteriores feitas por Costa em 1997 e 1999 quando respectivamente 93,5\% e 95,5\% colocaram-se a favor da exploração do Turismo em Monteiro Lobato.

16. Que tipo de benefícios os turistas podem trazer à cidade?

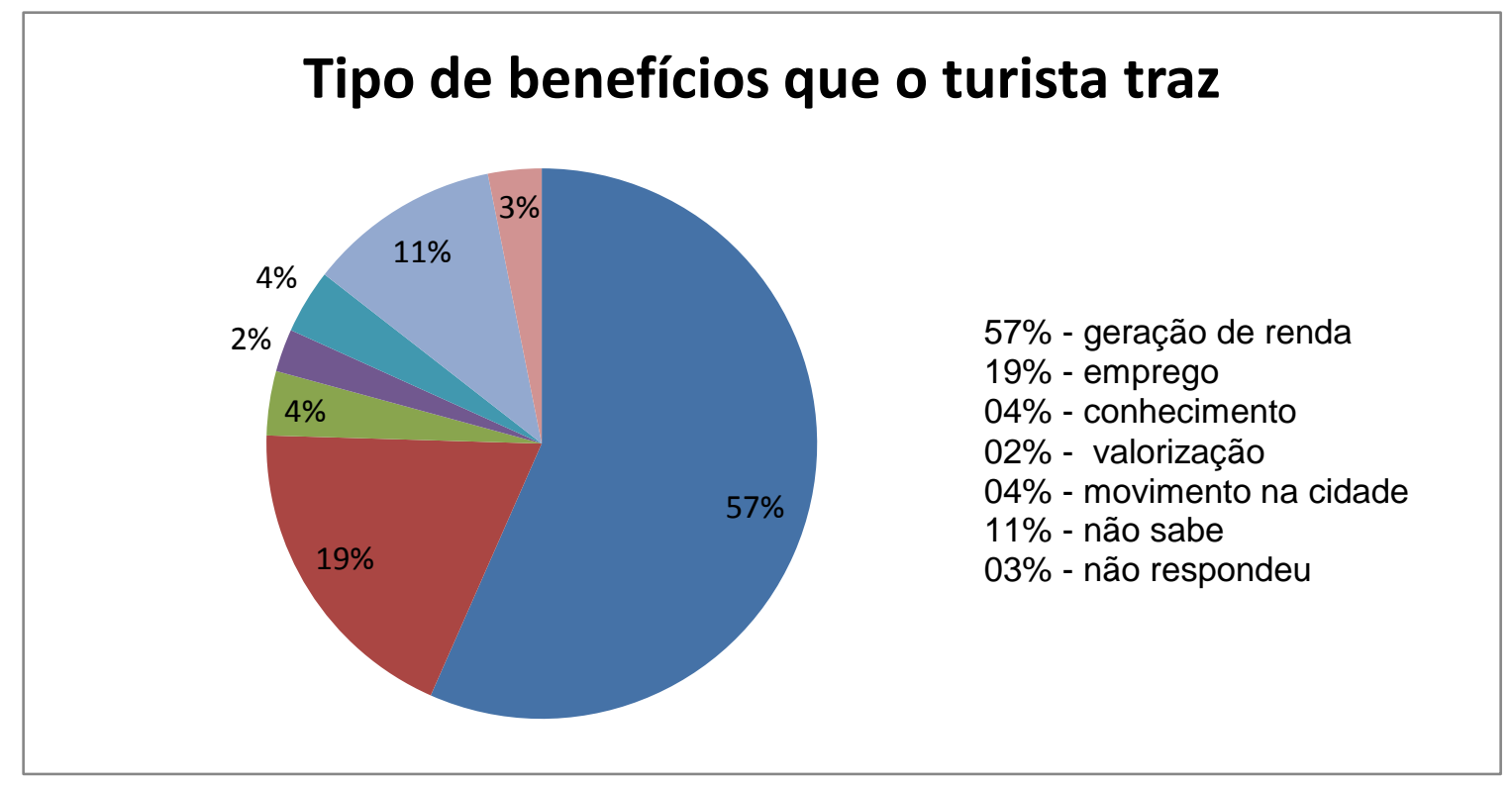

Gráfico 25 - Tipo de benefício que o turista traz 
Sem dúvida a expectativa dos moradores em relação à atividade turística é a econômica (76\% somando as respostas geração de renda e emprego). Isto indica que será preciso conscientizar a população de que este é apenas um dos aspectos do Turismo Sustentável, havendo outros aspectos igualmente importantes como a sustentabilidade do meio ambiente e a sociocultural.

17. Que tipo de malefícios os turistas podem trazer à cidade?

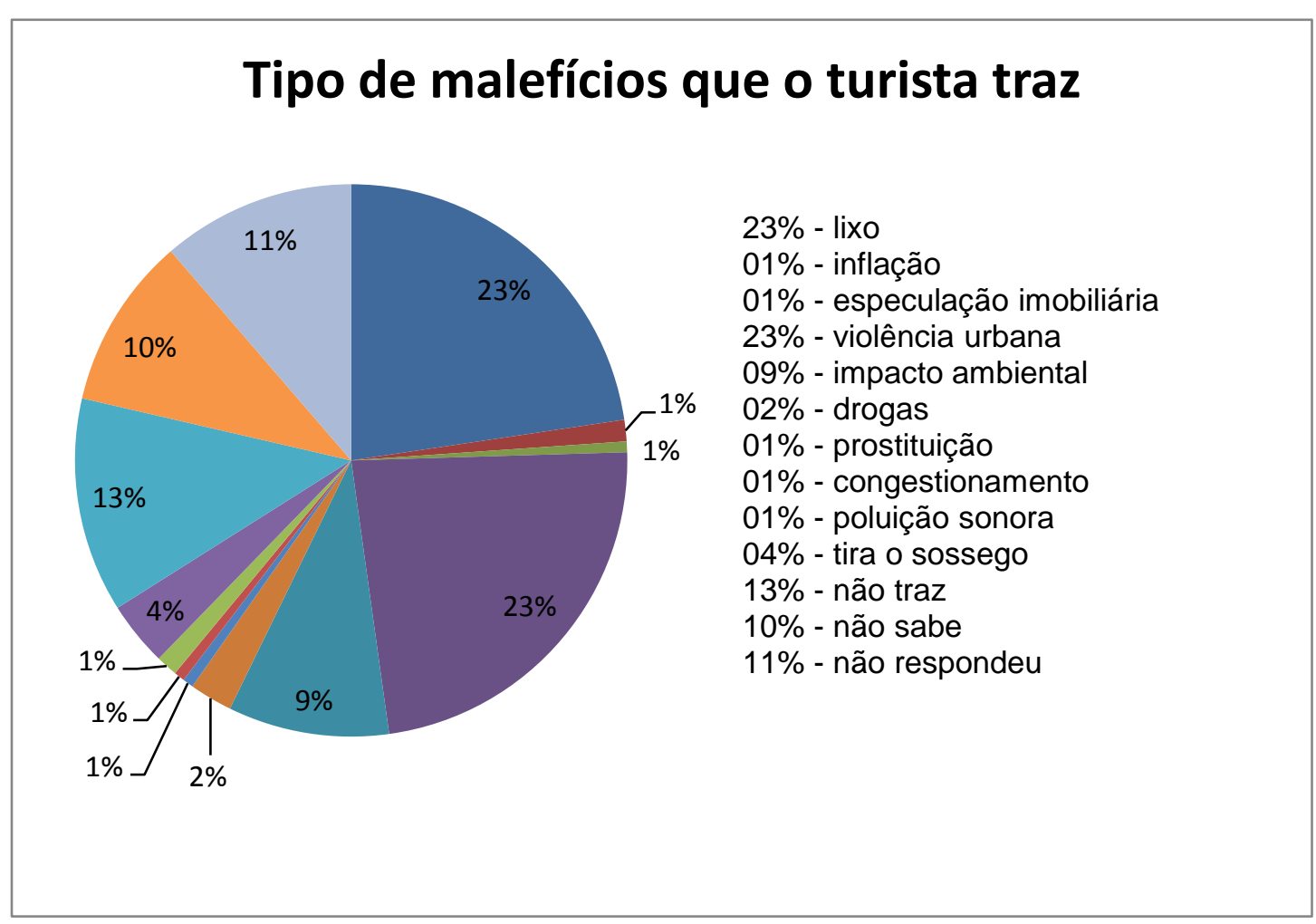

Gráfico 26 - Tipo de malefício que o turista traz

Os moradores (23\%) têm consciência de que o fluxo de visitantes aumenta a produção de lixo o que é considerado um malefício porque pressiona a capacidade do município de fazer a coleta de lixo e dar uma destinação a ele. Em adição, 9\% indicaram que a atividade turística causa impactos negativos ao meio ambiente. Outra indicação feita pelos entrevistados (23\%) é a questão da violência urbana. Entendem-se esses resultados como muito positivos no sentido de que os moradores veem o Turismo como gerador de renda e trabalho, mas sabem fazer o contraponto em relação aos impactos negativos da atividade. 
Fica reforçada aqui a necessidade da conscientização da população para o Turismo Sustentável uma vez que os espaços urbano e rural são impactados pelas decisões que as pessoas, individualmente ou em grupos, fazem conforme seus interesses econômicos, políticos, ideológicos, pessoais, etc. Portanto, não é o Turismo (a atividade turística) que causa impactos negativos, incluindo a violência, são as pessoas, sejam elas turistas ou residentes que podem tomar decisões equivocadas causando desdobramentos indesejáveis à própria sociedade.

18. Qual local em Monteiro Lobato você acha que um turista gostaria de visitar?

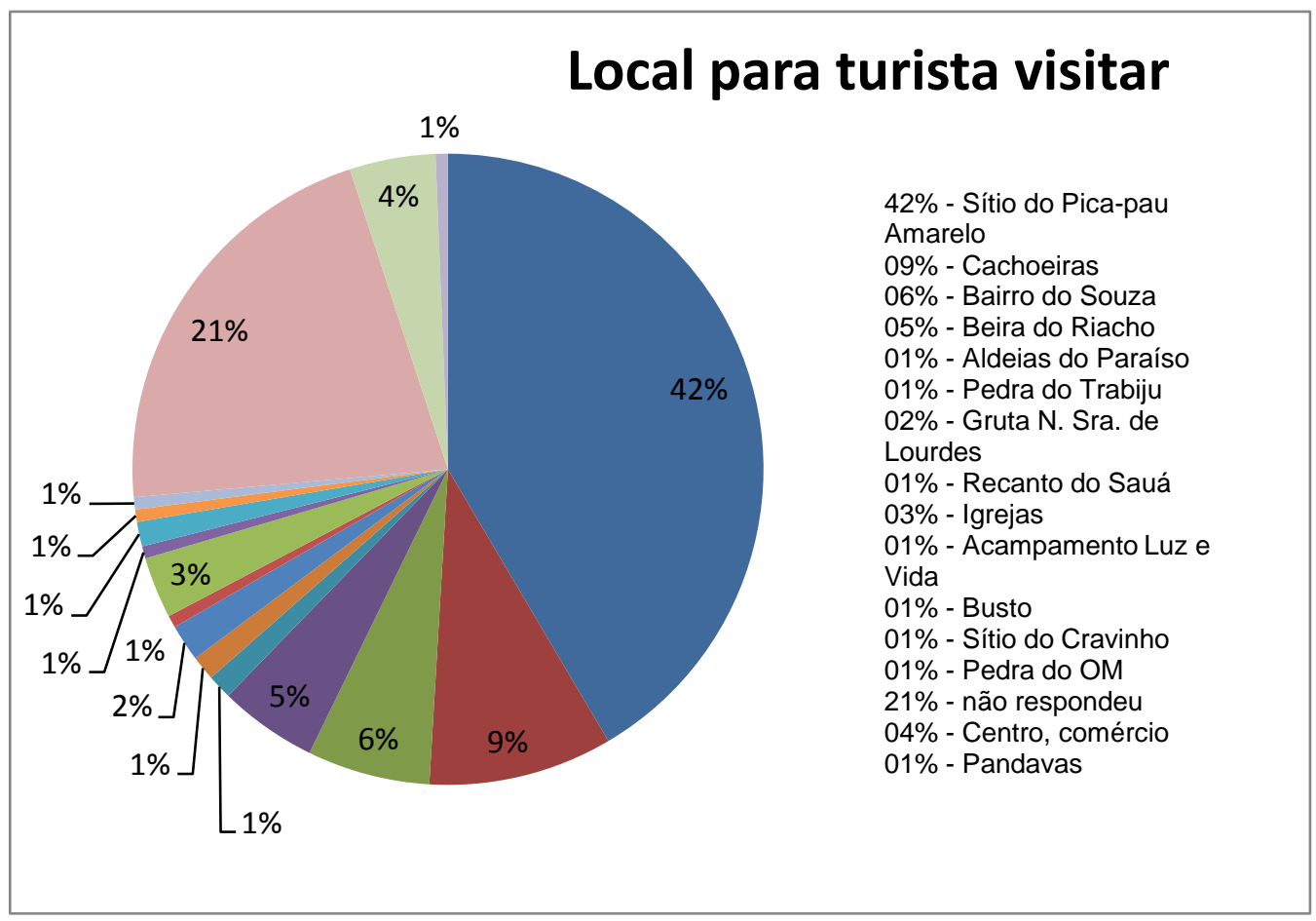

Gráfico 27 - Local para visitar

Dos moradores, 42\% sabem da existência do Sítio do Pica-pau Amarelo e da sua potencialidade turística, no entanto, uma boa parcela (21\%) não respondeu essa pergunta, indicando que há de fato desconhecimento sobre os atrativos turísticos do município. A divulgação dos atrativos apoiará a conscientização da população para o Turismo do município e isto, por sua vez, apoiará os empreendimentos turísticos porque a população saberá dar informações quando solicitadas pelos turistas. 
19. Você considera que a cidade tem condições de receber turistas?

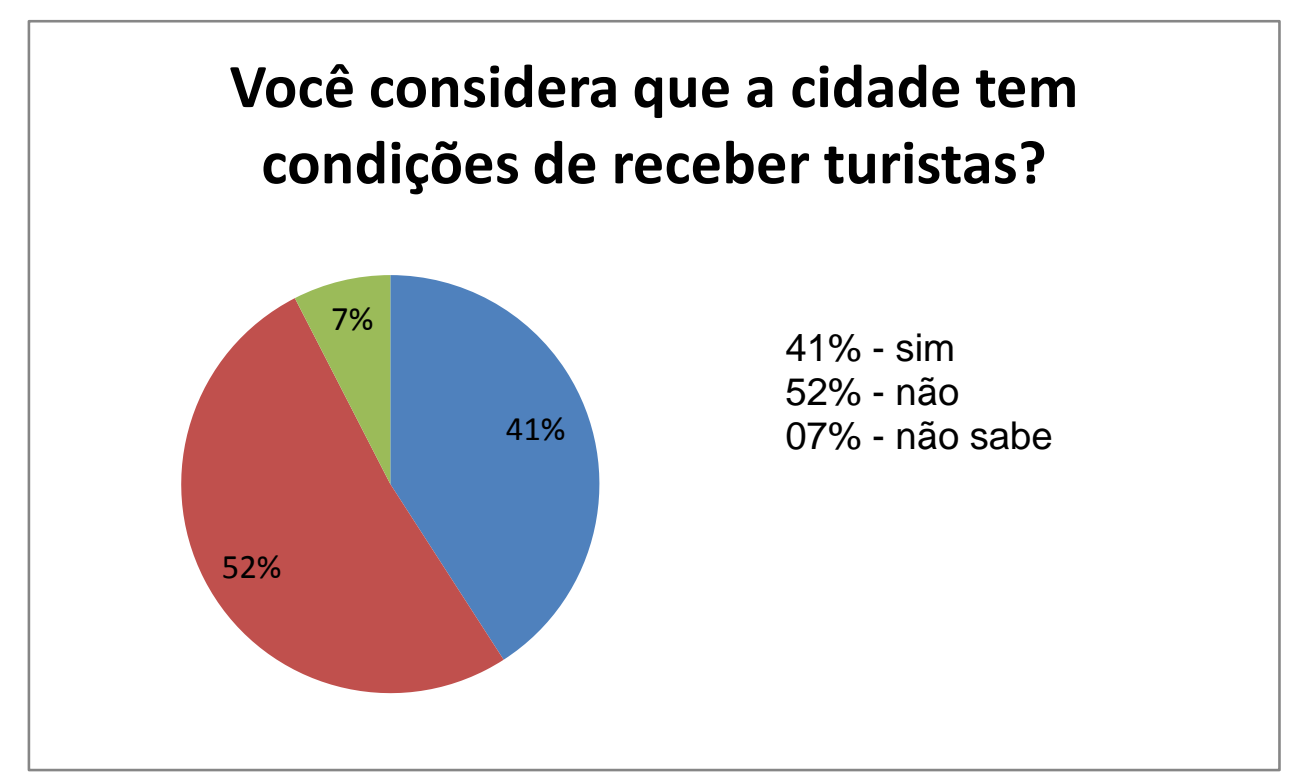

Gráfico 28 - Você considera que a cidade tem condições de receber turistas?

Embora 90\% dos moradores concordem com o desenvolvimento da atividade turística no município, a opinião fica dividida quando se trata dele ter condições para receber turista. É também um resultado positivo porque os moradores que responderam negativamente indicaram que há ainda muitos aspectos a serem melhorados tais como os que estão relacionados na resposta à questão de número 20 abaixo.

Salienta-se que esses aspectos indicados pelos moradores estão em consonância com aqueles levantados na Oficina de Planejamento Turístico realizada em 15 de março de 2012.

As questões de números $20,21,22$ e 23 foram do tipo pergunta aberta e as respostas foram reunidas em categorias para organizar melhor os resultados. 
20. O que deve ser feito na cidade para receber bem um turista?

\begin{tabular}{|c|c|c|c|}
\hline Infraestrutura da cidade & Infraestrutura turística & Mão de obra & Cultura \\
\hline $\begin{array}{ll}\text { - } & \text { cuidar das estradas } \\
\text { - } & \text { arrumar o letreiro na } \\
\text { - } & \text { banheiro público } \\
\text { - } & \text { bebedouro } \\
\text { - } & \text { refazer calçadas } \\
\text { - } & \text { pintar fachadas das } \\
\text { - } & \text { paisagismo } \\
\text { - } & \text { policiamento } \\
\text { - } & \text { estacionamento } \\
\text { - limpeza } \\
\text { - } \quad \text { planejamento } \\
\text { - } \text { reforma da praça de } \\
\text { - } \text { baixo } \\
\text { - } \text { mais lixeiras } \\
\text { - } \quad \text { seguras } \\
\text { - ciclovias entre os } \\
\quad \text { bairros }\end{array}$ & $\begin{array}{ll}\text { - } & \text { mais pousadas } \\
\text { - } & \text { diferente } \\
\text { - } & \text { explorar mais as } \\
& \text { cachoeiras } \\
\text { - } & \text { explorar uma } \\
& \text { marca, ex.: como } \\
& \text { a Literatura } \\
& \text { Infantil } \\
\text { - } & \text { sinalização } \\
\text { - } & \text { mais atrações, } \\
& \text { lugares para } \\
& \text { visitar } \\
\text { - } & \text { melhorar } \\
& \text { alimentação e } \\
& \text { hospedagem } \\
\text { - } & \text { preparar guias de } \\
& \text { Turismo } \\
\text { - } & \text { restaurantes } \\
& \text { servirem jantar } \\
\text { - } & \text { ter guias } \\
& \text { turísticos }\end{array}$ & $\begin{array}{ll}\text { - } & \text { Capacitar para } \\
& \text { atendimento } \\
& \text { ao turista } \\
\text { - } & \text { Capacitar a } \\
& \text { população } \\
\text { - } & \text { investir na } \\
& \text { educação } \\
\text { - } & \text { investir na } \\
& \text { qualificação } \\
\text { - } & \text { mais eventos } \\
& \text { culturais } \\
\text { - } & \text { ter espaço } \\
& \text { cultural }\end{array}$ & $\begin{array}{ll}\text { - } & \text { atividades } \\
\text { culturais para } \\
\text { interação entre } \\
\text { moradores e } \\
\text { turistas }\end{array}$ \\
\hline
\end{tabular}

Quadro 90 - O que deve ser feito na cidade para receber bem o turista?

21. Quais cursos profissionalizantes você acha que devem ser feitos no município?

\begin{tabular}{|c|c|c|c|}
\hline Administrativos & Técnicos & Turismo & Outros \\
\hline $\begin{array}{ll}\text { - } & \text { Administração } \\
\text { - } & \text { Informática } \\
\text { - } & \text { Segurança no } \\
& \text { trabalho }\end{array}$ & $\begin{array}{ll}\text { - } & \text { Agropecuária } \\
\text { - } & \text { Mecânica } \\
\text { - } & \text { Elétrica } \\
\text { - } & \text { Computação } \\
\text { - } & \text { Engenharia } \\
\text { - } & \text { Marcenaria } \\
\text { - } & \text { Senaintaria } \\
\text { - Pedreiro } \\
\text { - } \\
\text { - } \text { Entor } \\
\text { - } & \text { Meio } \\
& \text { ambiente } \\
\text { - } & \text { operador de } \\
& \text { máquinas }\end{array}$ & 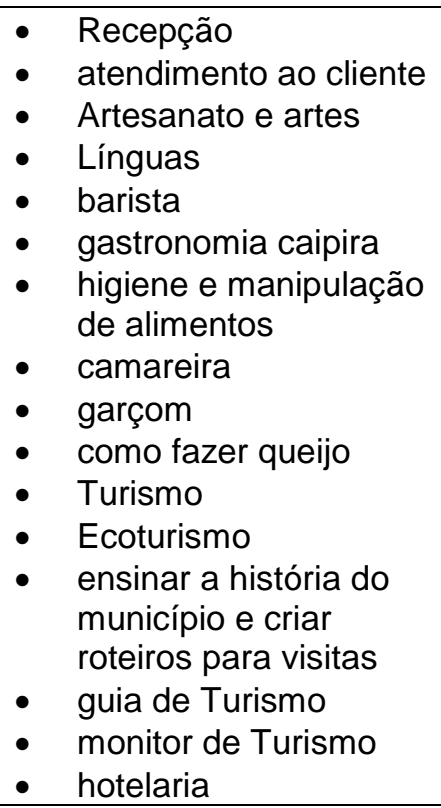 & $\begin{array}{ll}\text { - } & \text { Cabeleireira } \\
\text { - } & \text { Manicure } \\
\text { - } & \text { Estética } \\
\text { - } & \text { Jardinagem } \\
\text { - } & \text { corte e costura } \\
\text { - } & \text { dança de } \\
& \text { salão } \\
\text { - } & \text { crochê } \\
\text { - } & \text { tricô } \\
\text { - } & \text { culinária } \\
\text { - } & \text { teatro }\end{array}$ \\
\hline
\end{tabular}

Quadro 91 - Quais os cursos profissionalizantes você acha que devem ser feitos em Monteiro Lobato? 
22. O que há de melhor em Monteiro Lobato que você não quer que seja perdido?

\begin{tabular}{|c|c|c|}
\hline Patrimônio material & Patrimônio imaterial & Meio ambiente \\
\hline $\begin{array}{ll}\text { - } & \text { artesanato } \\
\text { - } & \text { campo de futebol } \\
\text { - } & \text { escolar } \\
\text { - } & \text { escola } \\
\text { - } & \text { praça de baixo } \\
\text { - } & \text { Sítio do Pica-pau } \\
& \text { Amarelo } \\
\text { - } & \text { arquitetura } \\
& \text { histórica }\end{array}$ & 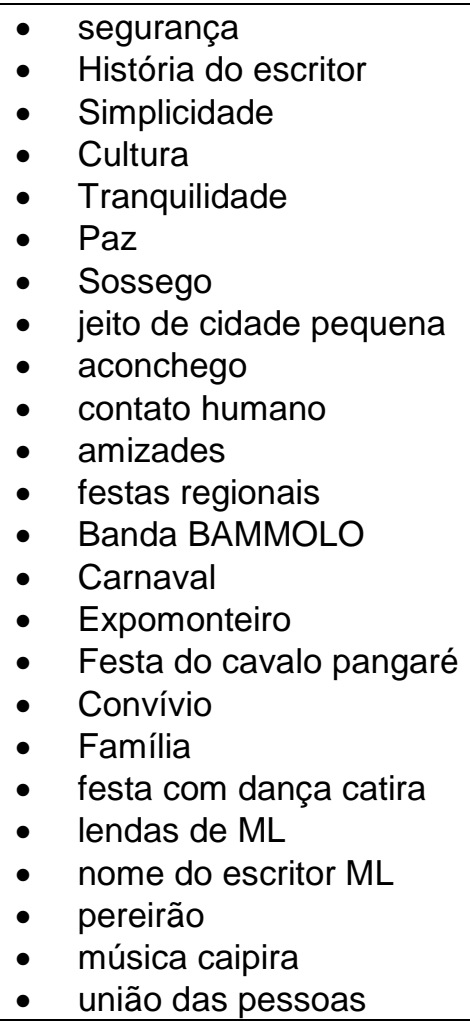 & $\begin{array}{ll}\text { - } & \text { natureza (flora e } \\
& \text { fauna) } \\
\text { - } & \text { paisagem } \\
\text { - } & \text { ar puro } \\
\text { - } & \text { clima } \\
\text { - } & \text { conservação do meio } \\
& \text { ambiente }\end{array}$ \\
\hline
\end{tabular}

Quadro 92 - O que há de melhor em Monteiro Lobato que você não quer que seja perdido?

Estas respostas demonstram que a população reconhece e valoriza os atributos do município, em especial aqueles ligados à cultura caipira e à tranquilidade de cidade pequena. Novamente, traçando um paralelo com as repostas dadas pelos turistas à questão "O que mais Ihe agradou em Monteiro Lobato?", verifica-se que o morador preza pelo que os turistas buscam: $11 \%$ - Paz, sossego, tranquilidade, $11 \%$ - hospitalidade, $13 \%$ - natureza, paisagem, 07\% - clima, ar puro, $02 \%$ - simplicidade e autenticidade, $02 \%$ - jeito caipira, pacato de cidade pequena e 06\% - gastronomia, artesanato. Dessa forma, a população de Monteiro Lobato tem um estilo de vida que os visitantes desejam compartilhar e, portanto, esse estilo não pode ser perdido porque é um dos atributos que atraem turistas. 
23. O que há de ruim em Monteiro Lobato que precisa ser melhorado?

\begin{tabular}{|c|c|c|c|}
\hline Turismo & Infraestrutura da cidade & Comportamento & Geral \\
\hline $\begin{array}{ll} & \text { Carnaval } \\
\text { - } & \text { estrutura para } \\
& \text { receber turista } \\
\text { - } & \text { banheiro público } \\
\text { - } & \text { conservação } \\
& \text { dos prédios } \\
\text { - } & \text { sinalização } \\
& \text { turística } \\
\text { - } & \text { ter guia turístico } \\
\text { - } & \text { informar } \\
& \text { morador para } \\
& \text { explicar ao } \\
& \text { turista } \\
\text { - } & \text { falta museu } \\
\text { - } & \text { falta lazer } \\
\text { - } & \text { melhor } \\
& \text { exploração do } \\
& \text { Turismo } \\
\text { - os restaurantes } \\
\text { não abrem à } \\
\text { noite }\end{array}$ & $\begin{array}{ll}\text { - } & \text { posto de saúde } \\
\text { - } & \text { segurança } \\
\text { - } & \text { calçada } \\
\text { - } & \text { estrada sem } \\
& \text { acostamento } \\
\text { - } & \text { transporte público } \\
\text { - } & \text { estradas rurais } \\
\text { - } & \text { centro urbano } \\
\text { - } & \text { Estrada do Livro } \\
\text { - } & \text { organização do lixo } \\
& \text { nos bairros } \\
\text { - } & \text { não tem sombra } \\
\text { - } & \text { nominhões pesados } \\
& \text { no centro da cidade } \\
\text { - } & \text { trânsito } \\
\text { - } & \text { arquiteturionamento } \\
\text { - } & \text { iluminação } \\
\text { - } & \text { falta Wi-Fi grátis na } \\
& \text { praça }\end{array}$ & $\begin{array}{ll}\text { - } & \text { falta de união } \\
\text { - } & \text { falta de interesse } \\
\text { - } & \text { inveja } \\
\text { - } & \text { resgate do orgulho de } \\
& \text { ser lobatense } \\
\text { - } & \text { melhorar a política } \\
\text { - } & \text { pessoas desocupadas } \\
& \text { em frente aos bares } \\
\text { - } & \text { falta mais atenção } \\
& \text { para os nossos } \\
\text { - } & \text { foloscentes } \\
\text { - e esporte incentivo ao lazer } \\
\text { - falta o compromisso } \\
\text { com seu próprio povo } \\
\text { educação para o } \\
\text { respeito ao patrimônio } \\
\text { desconhecimento da } \\
\text { cidade pelos } \\
\text { moradores }\end{array}$ & $\begin{array}{ll}\text { - } & \text { Emprego } \\
\text { - } & \text { Botecos } \\
\text { - } & \text { Drogas, } \\
\text { pessoas } \\
\text { viciadas } \\
\text { - Bebidas, } \\
\text { bêbados } \\
\text { Jovens, } \\
\text { Joltos na rua }\end{array}$ \\
\hline
\end{tabular}

Quadro 93 - O que há de ruim em Monteiro Lobato que precisa melhorado?

A saúde constou da maioria das respostas a esta questão. Entre as causas citadas estão: falta de remédios, demora no agendamento de exames, mau atendimento por parte de alguns médicos e quando o serviço de ambulâncias é utilizado. As demais respostas também estão em consonância com os aspectos levantados na Oficina de Planejamento Turístico realizada em 15 de março de 2012. 
24. Indique os eventos que você considera bom e os que considera ruim para os moradores da cidade?

BOM

\begin{tabular}{|l|r|}
\hline carnaval & $28 \%$ \\
\hline shows musicais & $32 \%$ \\
\hline trilhão & $28 \%$ \\
\hline Agropecuário & $39 \%$ \\
\hline ciclismo & $31 \%$ \\
\hline Festival de Literatura Infantil & $51 \%$ \\
\hline Beneficentes & $37 \%$ \\
\hline Festas Religiosas & $44 \%$ \\
\hline Todos & $26 \%$ \\
\hline Não respondeu & $9 \%$ \\
\hline
\end{tabular}

Quadro 94 - Indique os eventos que você considera bom e os que considera ruim para os moradores da cidade?

Nesta questão, dos eventos considerados bons, o Festival de Literatura Infantil se destaca com $51 \%$, seguido pelas festas religiosas (44\%). Dessa forma, o Festival de Literatura Infantil segue seu caminho para a quarta edição com aprovação da população.

25. Qual a vocação turística de Monteiro Lobato?

\begin{tabular}{|l|r|}
\hline conhecer ML & $20 \%$ \\
\hline romeiros & $14 \%$ \\
\hline peregrinos & $5 \%$ \\
\hline Turismo de 1 dia & $34 \%$ \\
\hline ecológico & $34 \%$ \\
\hline Turismo rural & $6 \%$ \\
\hline Turismo gastronômico & $14 \%$ \\
\hline escritor M. Lobato & $41 \%$ \\
\hline Turismo cultural & $23 \%$ \\
\hline Turismo de passagem & $17 \%$ \\
\hline Turismo de aventura & $3 \%$ \\
\hline Turismo de 2a. residência & $20 \%$ \\
\hline Turismo religioso & $11 \%$ \\
\hline não respondeu & $6 \%$ \\
\hline
\end{tabular}

Quadro 95 - Qual a vocação turística de Monteiro Lobato? 
Essa questão foi de múltipla escolha, tendo sido solicitado ao entrevistado que indicasse três tipos de vocação turística. O objetivo da questão foi levantar o segmento de Turismo mais praticado no município na percepção dos moradores. Verifica-se que $41 \%$ dos moradores reconhecem o valor do escritor Monteiro Lobato como atrativo cultural, estando em consonância com a questão de número 18 onde 42\% dos moradores citaram o Sítio do Pica-pau Amarelo como local a ser indicado aos turistas para visitação. Em segundo lugar, ficaram o Turismo de um dia e o ecológico.

26. De uma maneira geral, o que considera que seja bom para toda a comunidade de Monteiro Lobato?

\begin{tabular}{|c|c|c|}
\hline Comportamento & Coletivo & Cultural \\
\hline 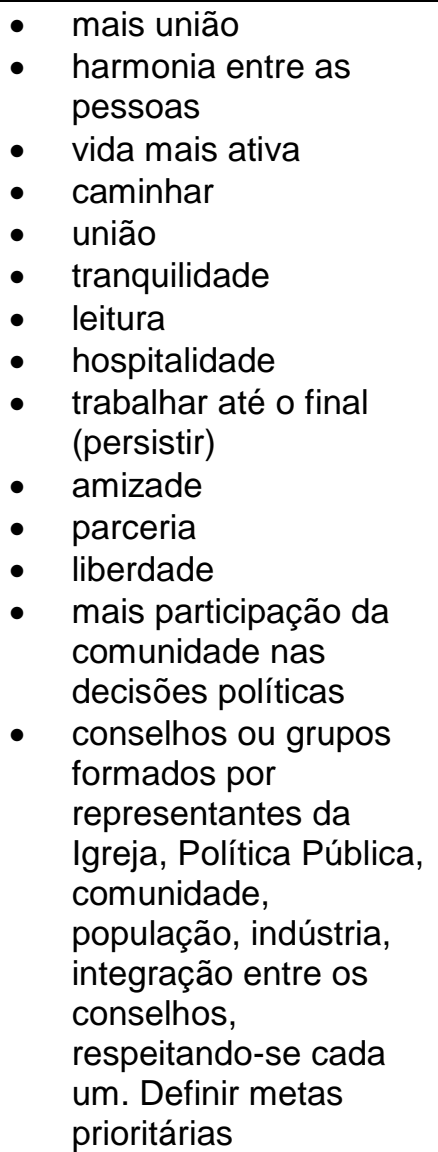 & $\begin{array}{ll}\text { - } & \text { Saúde } \\
\text { - } & \text { Empregos } \\
& \text { ar que se respira é } \\
\text { - } & \text { rio Buquira } \\
\text { - } & \text { habitação } \\
\text { - } & \text { paisagem } \\
\text { - } & \text { desenvolvimento do } \\
& \text { Turismo ordenado e } \\
\text { - } & \text { ter conejado } \\
& \text { o desenvecimento sobre } \\
& \text { sustentável e colocar } \\
\text { em prática } \\
\text { imediatamente }\end{array}$ & $\begin{array}{ll}\text { - } & \text { Carnaval } \\
\text { - } & \text { ROÇATUR } \\
\text { - } & \text { vestas religiosas } \\
\text { - } & \text { Turismo rural } \\
\text { - } & \text { Turismo sem } \\
& \text { poluição } \\
\text { - } & \text { Turismo cultural } \\
\text { - } & \text { um espaço cultural } \\
& \text { com atividades } \\
\text { para todas as } \\
\text { faixas etárias, } \\
\text { oficina de cinema, } \\
\text { história em } \\
\text { quadrinhos, } \\
\text { pintura, escultura } \\
\text { etc. }\end{array}$ \\
\hline
\end{tabular}

Quadro 96 - De uma maneira geral, o que considera que seja bom para toda a comunidade de Monteiro Lobato?

A expectativa para essa questão era verificar o que os moradores consideram como um bem comum, algo que fosse bom para a população como um todo, para o 
coletivo. Alguns não souberam dizer e, dentre os que responderam, destacaram-se as respostas acima que foram categorizadas em comportamento, coletivo e cultural. Salienta-se a preocupação que os lobatenses têm com o comportamento que também foi um dos aspectos levantados na Oficina de Planejamento Turístico de 15 de março de 2012 onde foram indicadas as limitações e as potencialidades dos lobatenses por eles mesmos demonstrando reflexividade em relação à mudança de atitudes. 


\section{RESULTADOS PESQUISA DE OPINIÃO DE TURISTAS SOBRE O \\ TURISMO EM MONTEIRO LOBATO \\ GRUPO PLANEJATUR - janeiro a fevereiro de 2013 \\ 124 questionários}

1. Em que cidade reside?

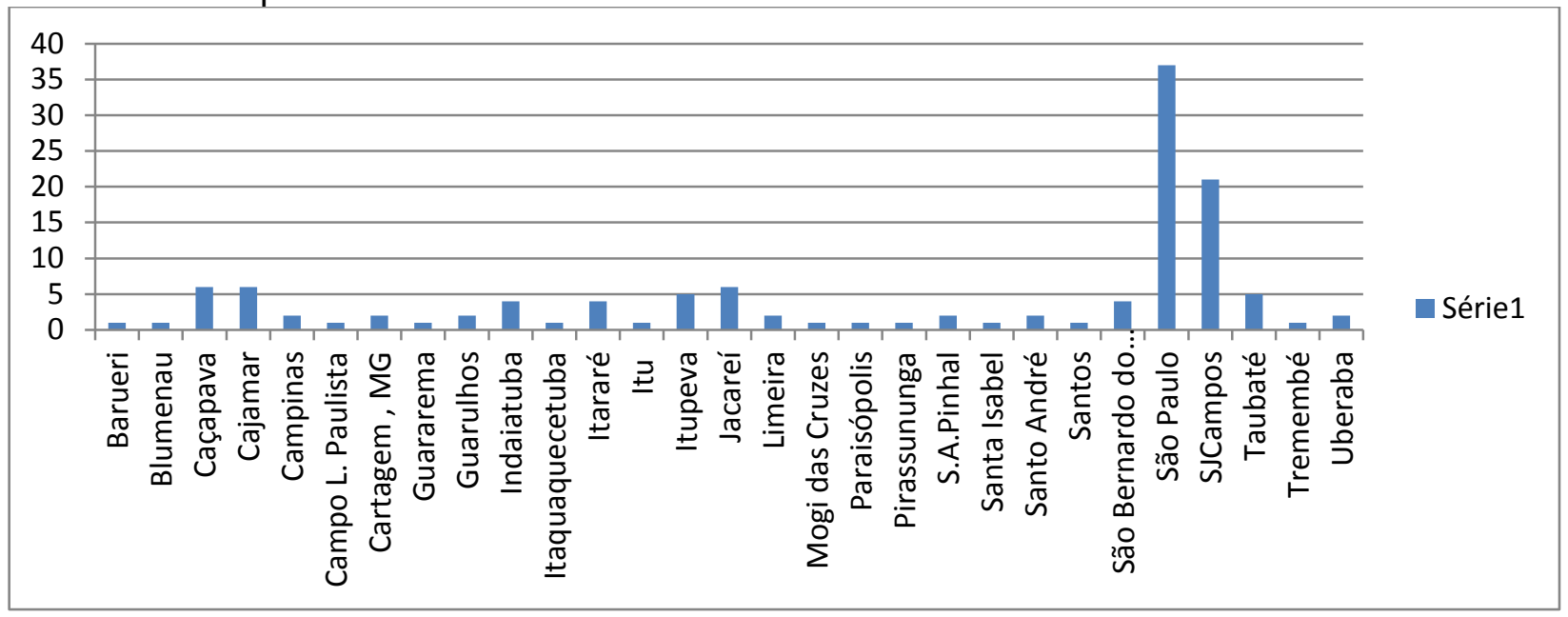

30\% - São Paulo - 17\% - São José dos Campos - 05\% - Caçapava

Gráfico 29 - Em cidade reside (turistas)

\section{Cidade em que reside por região}

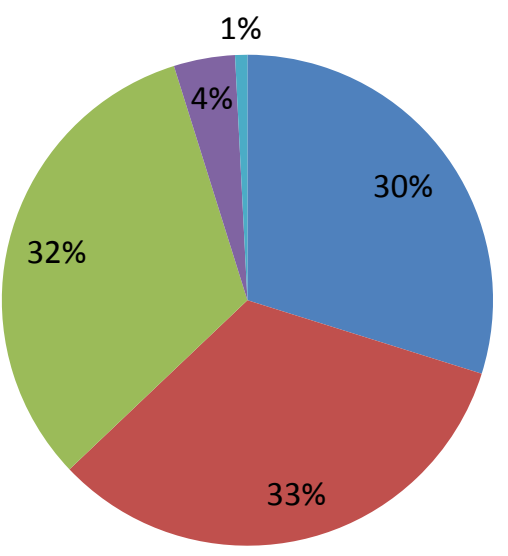

$30 \%$ - São Paulo

$33 \%$ - Vale do Paraíba

$32 \%$ - Estado de São Paulo

04\% - Estado de Minas Gerais

$01 \%$ - Outros Estados

Gráfico 30 - Cidade em que reside por região 
Esta questão apresenta a origem do fluxo turístico de Monteiro Lobato. Capital e Estado de São Paulo e o Vale do Paraíba são os grandes emissores de turistas para o município. Salienta-se que este fluxo é espontâneo uma vez que o município ainda não elaborou e implantou um plano de marketing turístico para captar turistas. Portanto, essa informação apoiará as ações do plano de marketing a ser elaborado e essas regiões poderão ser alvo da divulgação do Turismo do município de uma forma mais sistemática.

2. Se estiver de passagem, qual a cidade de destino após Monteiro Lobato?

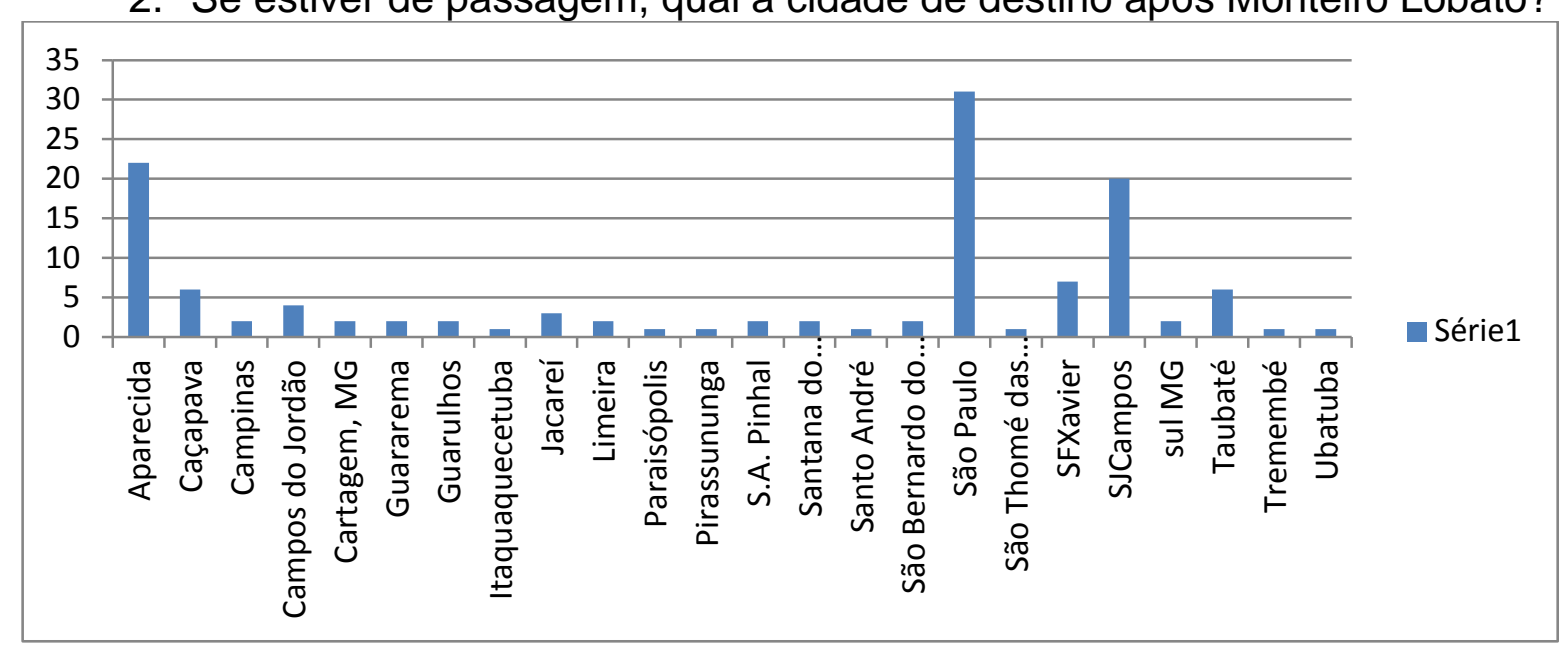

Gráfico 31 - Se estiver de passagem, qual a cidade de destino após Monteiro Lobato?

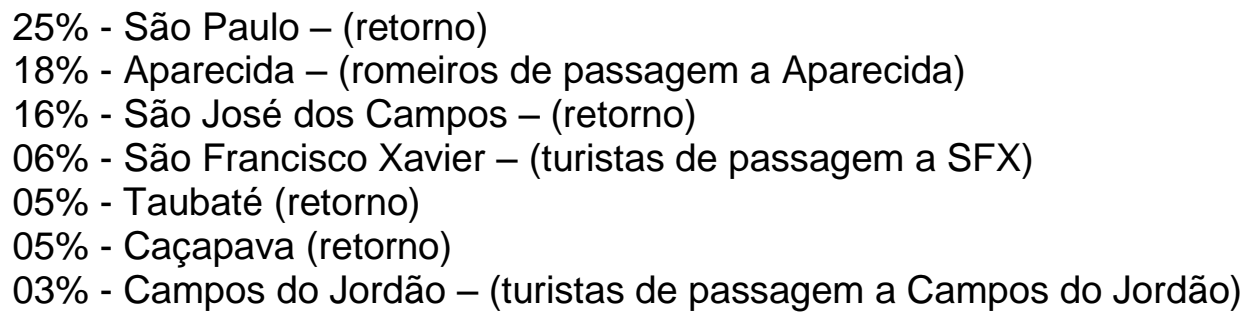

Esta questão evidencia que, de fato, o município, por estar estrategicamente localizado no caminho para Campos do Jordão, sul de Minas Gerais e São Francisco Xavier, Distrito de São José dos Campos, recebe os turistas de passagem, aqueles que param para um breve descanso, comer e beber algo e/ou usar os sanitários no período de uma a duas horas para, em seguida, continuarem a viagem. Também evidencia que o município faz parte do roteiro de grupos de romeiros a caminho de Aparecida. Estes turistas religiosos, em geral, vêm a cavalo, com uma estrutura de apoio para troca dos animais durante o percurso e se hospedam em alojamentos como o Recanto do Sauá no Bairro da Pedra Branca. 
Nessa amostragem não houve entrevista com peregrinos, aqueles que fazem o percurso a pé, mas o município está inserido na Rota Franciscana que se inicia em São Francisco Xavier e vai até Guaratinguetá e os peregrinos registram sua passagem em Monteiro Lobato por meio do totem eletrônico da rota instalado na Rodoviária. As respostas dos entrevistados que indicaram que a cidade de destino é a mesma da origem juntamente com a informação sobre meios de hospedagem (37\% se hospedam em pousada e 09\% em casa de parentes e amigos) estão nos revelando que Monteiro Lobato já é uma destinação turística, ou seja, esses turistas vêm para ficar no município.

\section{Sexo}

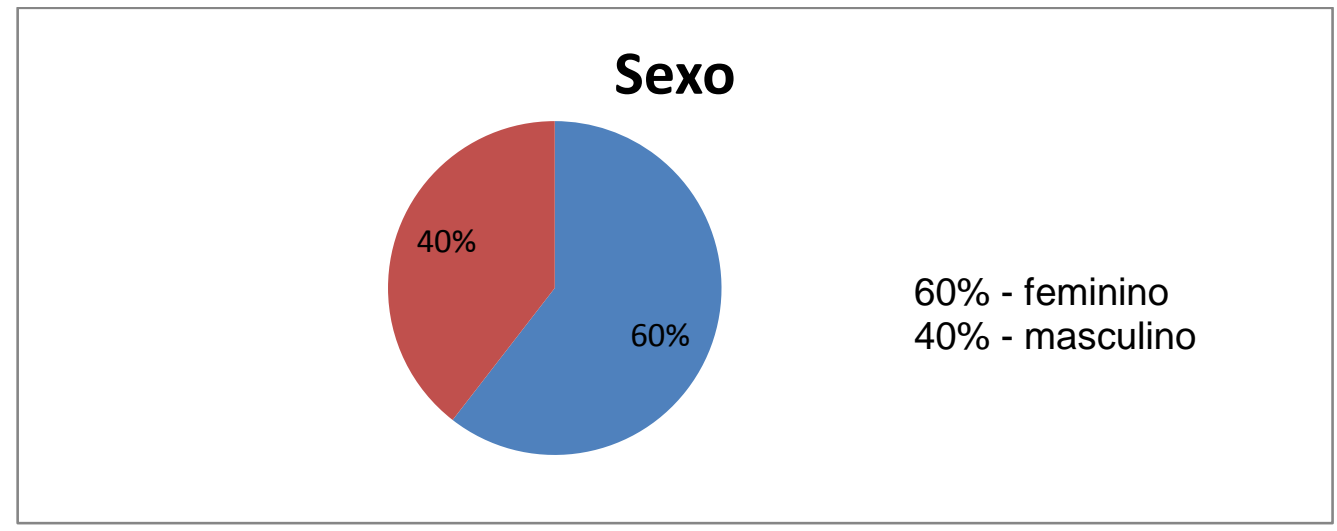

Gráfico 32 - Sexo

4. Faixa Etária

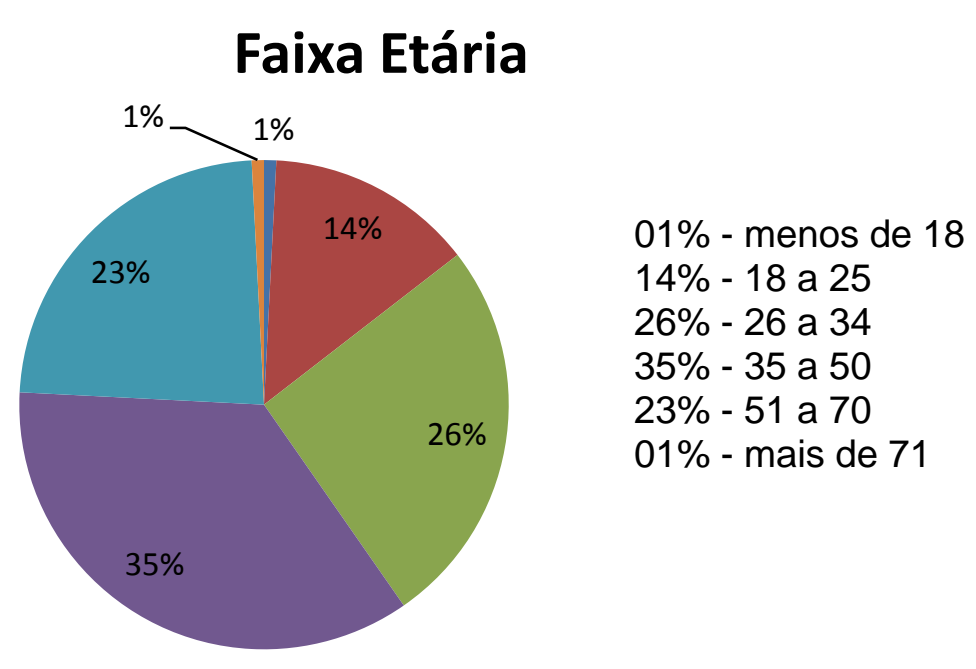

Gráfico 33 - Faixa Etária 
5. Estado civil

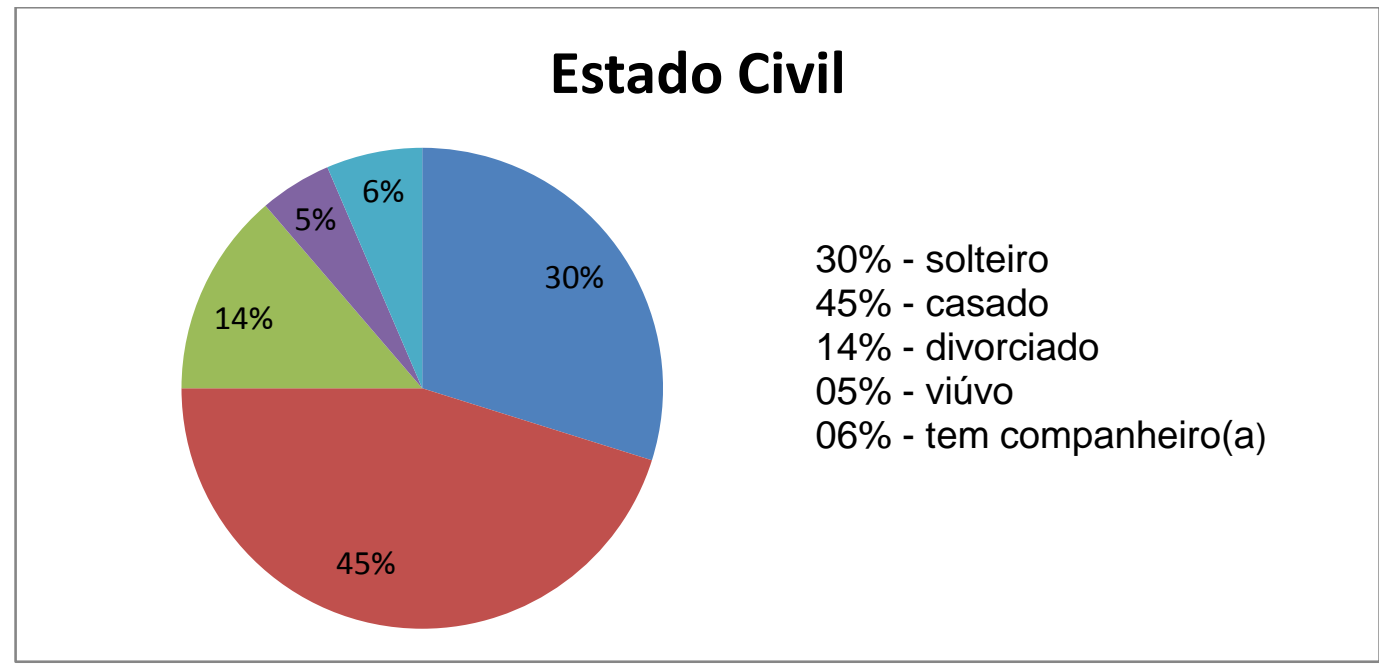

Gráfico 34 - Estado Civil

6. Qual é a sua Profissão? - Respostas variadas.

7. Qual é a sua renda familiar (salários mínimos)?

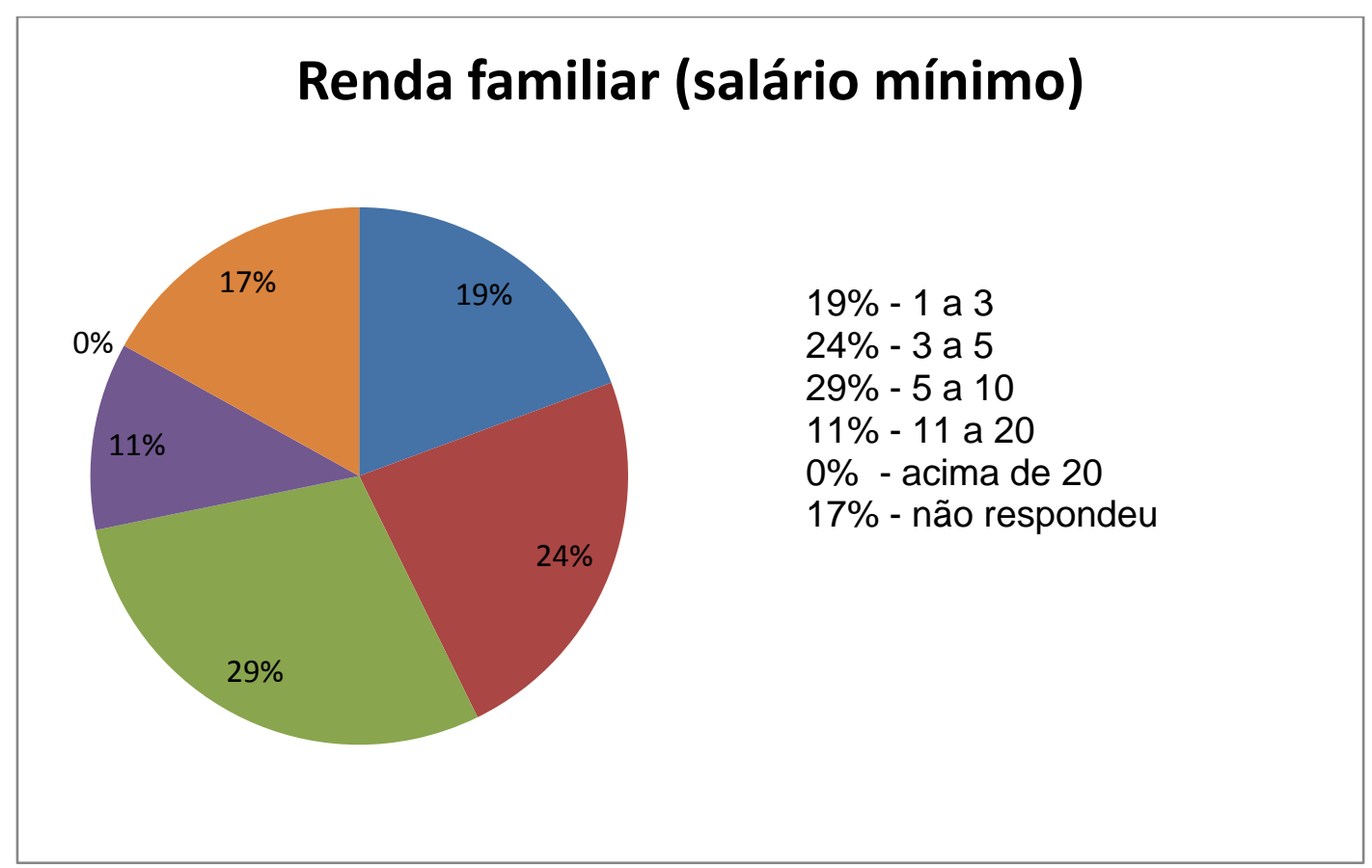

Gráfico 35 - Renda familiar (salário mínimo)

A questão referente à renda informa o nível do poder aquisitivo do visitante que, por sua vez, indica o seu padrão de vida e, consequentemente, o seu nível de exigência na compra de produtos e serviços. $O$ turista, em geral, tem parâmetros de comparação e sabe quando está pagando caro por um serviço ou produto de má 
qualidade, mas por outro lado, paga com satisfação aqueles que considera de qualidade. Vale registrar um fato interessante durante as entrevistas que foi o de uma família de 5 pessoas que, após pesquisarem preços de pousadas na internet, decidiram ficar em uma pousada mais barata em Monteiro Lobato para passarem um dia em São Francisco Xavier e outro em Gonçalves, MG. Essa foi a solução que a família encontrou para evitar os preços caros da hospedagem que são cobrados nesses dois destinos. Por oportuno, salienta-se que é importante para os empresários a prática do preço justo pelos produtos e serviços oferecidos, isto é, nem barato demais que não viabilize seu negócio, nem caro demais que lhes prejudique as vendas.

8. Grau de instrução?

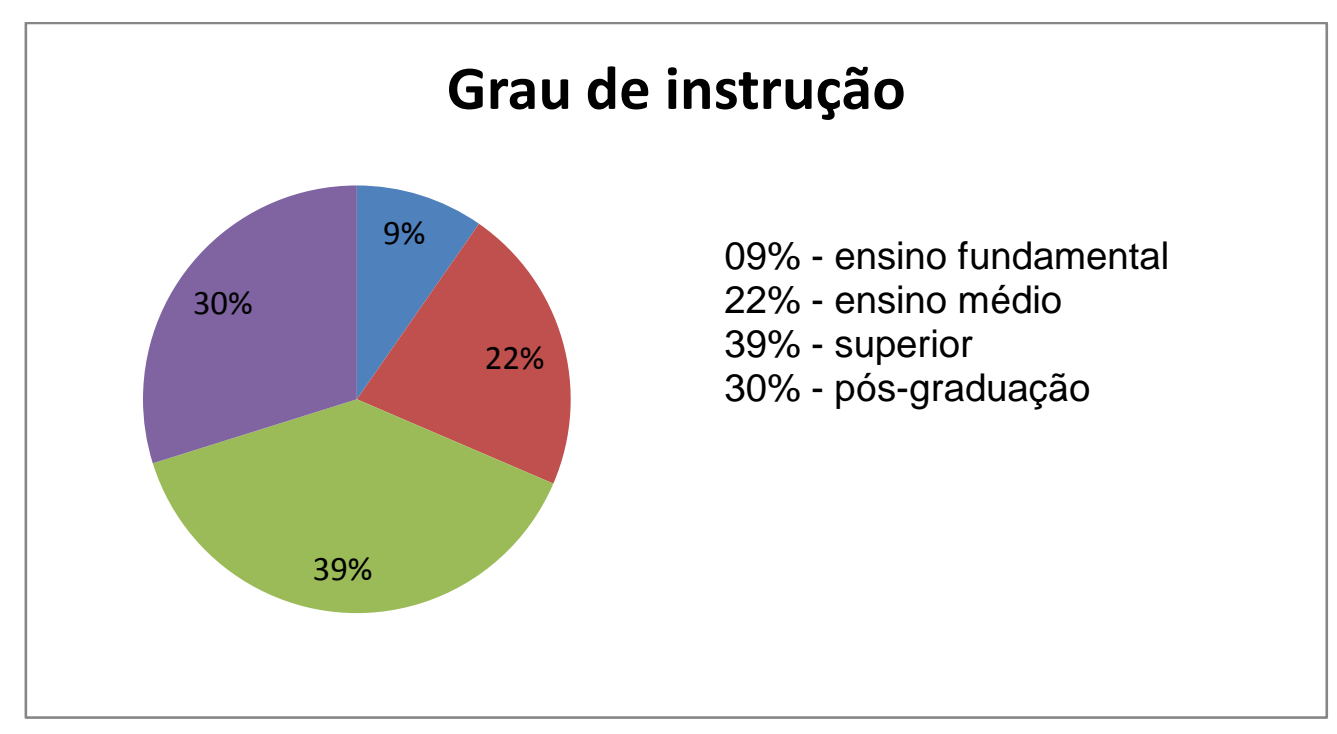

Gráfico 36 - Grau de instrução

9. Qual a atividade cultural do seu interesse?

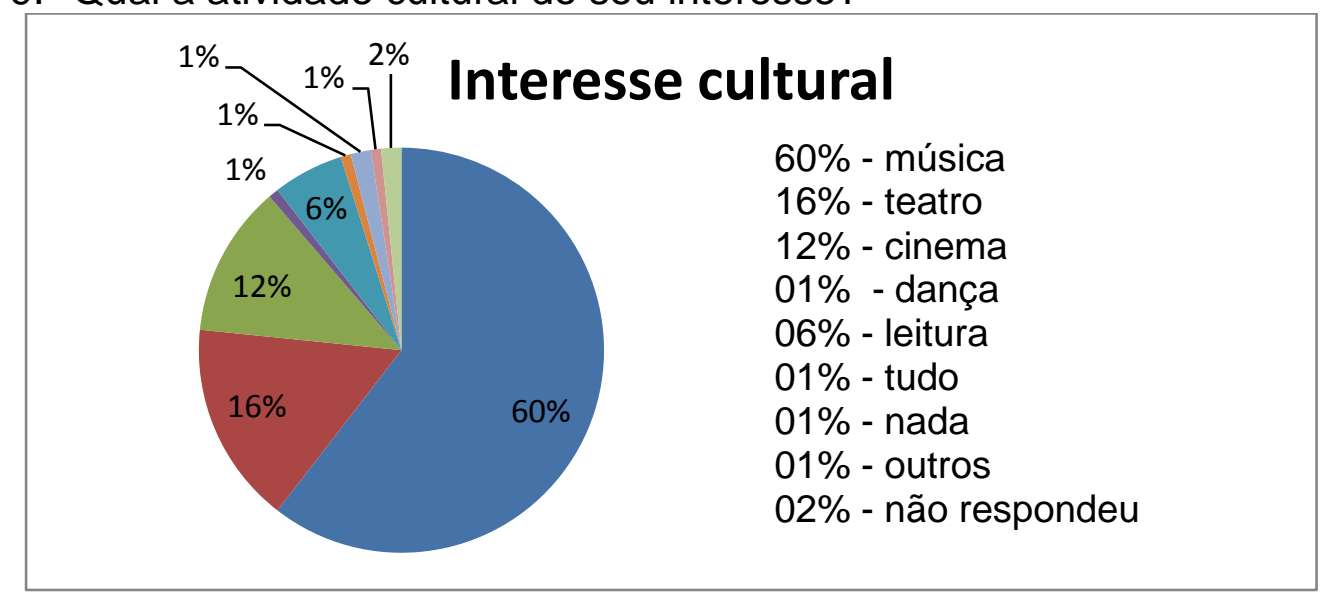

Gráfico 37 - Interesse cultural 
Essa questão foi inserida para identificar os eventos culturais de maior interesse dos visitantes e, assim, poder comparar com a preferência dos moradores. Observa-se que, dos $60 \%$ que preferem a música como atividade cultural de interesse, 38\% preferem a Música Popular Brasileira (MPB) e 15\% a sertaneja. Traçando um paralelo com a pesquisa feita com moradores, temos que igualmente a maior parte dos moradores gosta de música (58\%), porém com uma inversão de porcentagens para o tipo de música: $36 \%$ preferem a sertaneja e 15\% a MPB. Esse resultado indica que ao se programar uma apresentação musical na cidade, ela terá mais sucesso se incluir estes dois tipos de música.

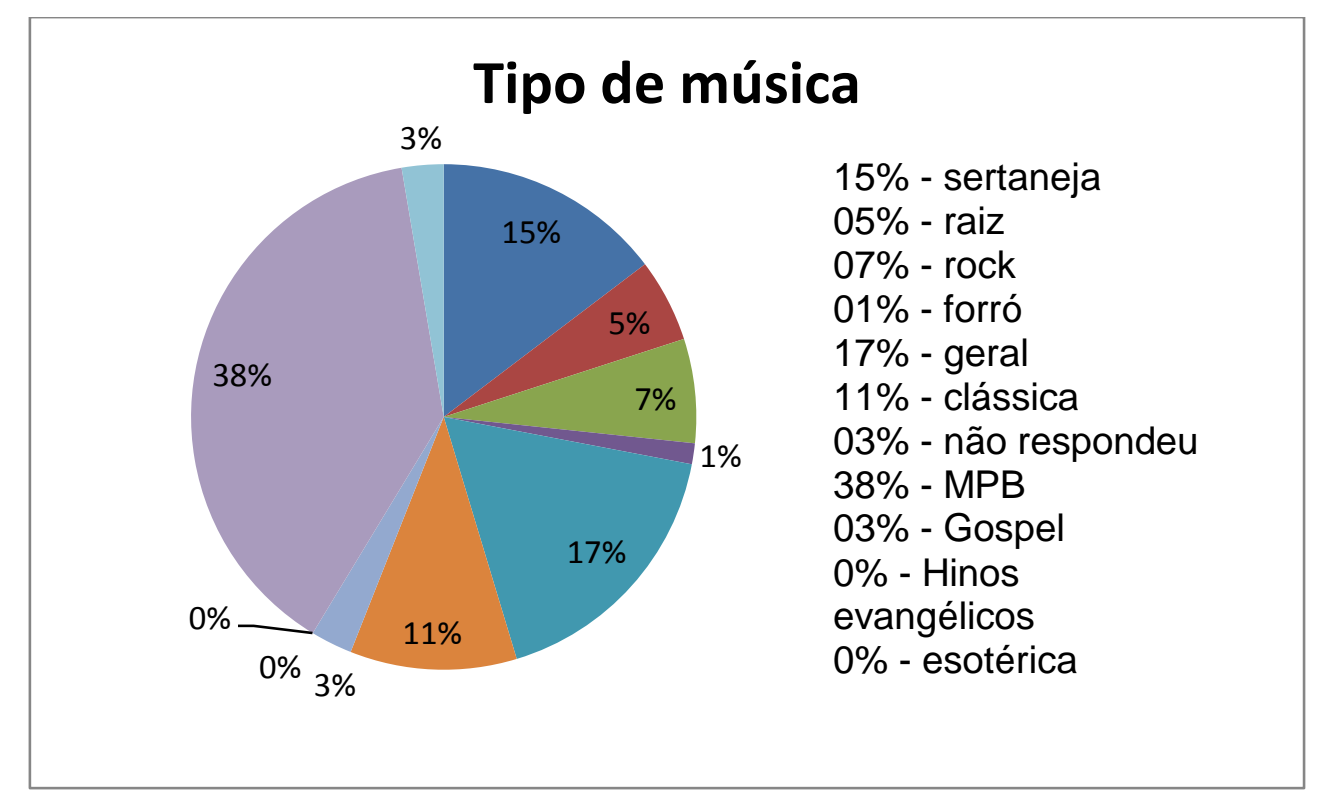

Gráfico 38 - Tipo de música

10. Conhece livros do escritor Monteiro Lobato?

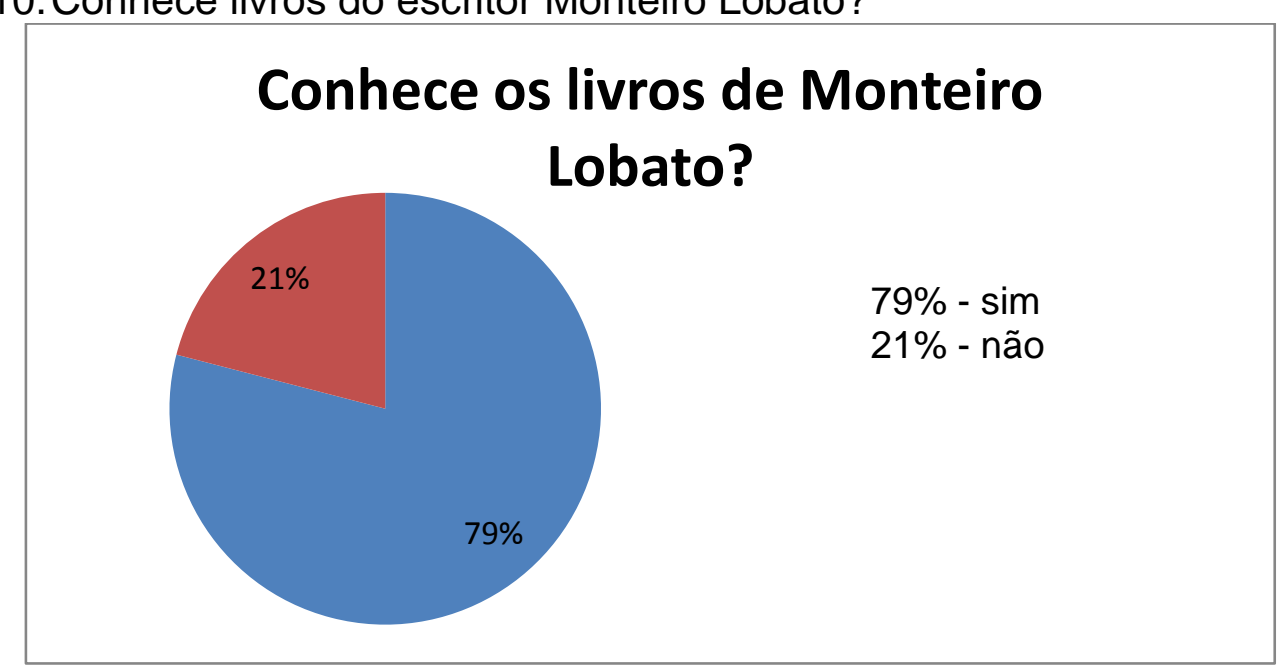

Gráfico 39 - Conhece os livros de Monteiro Lobato? 
10.1. Em caso positivo, que livro(s) já leu?

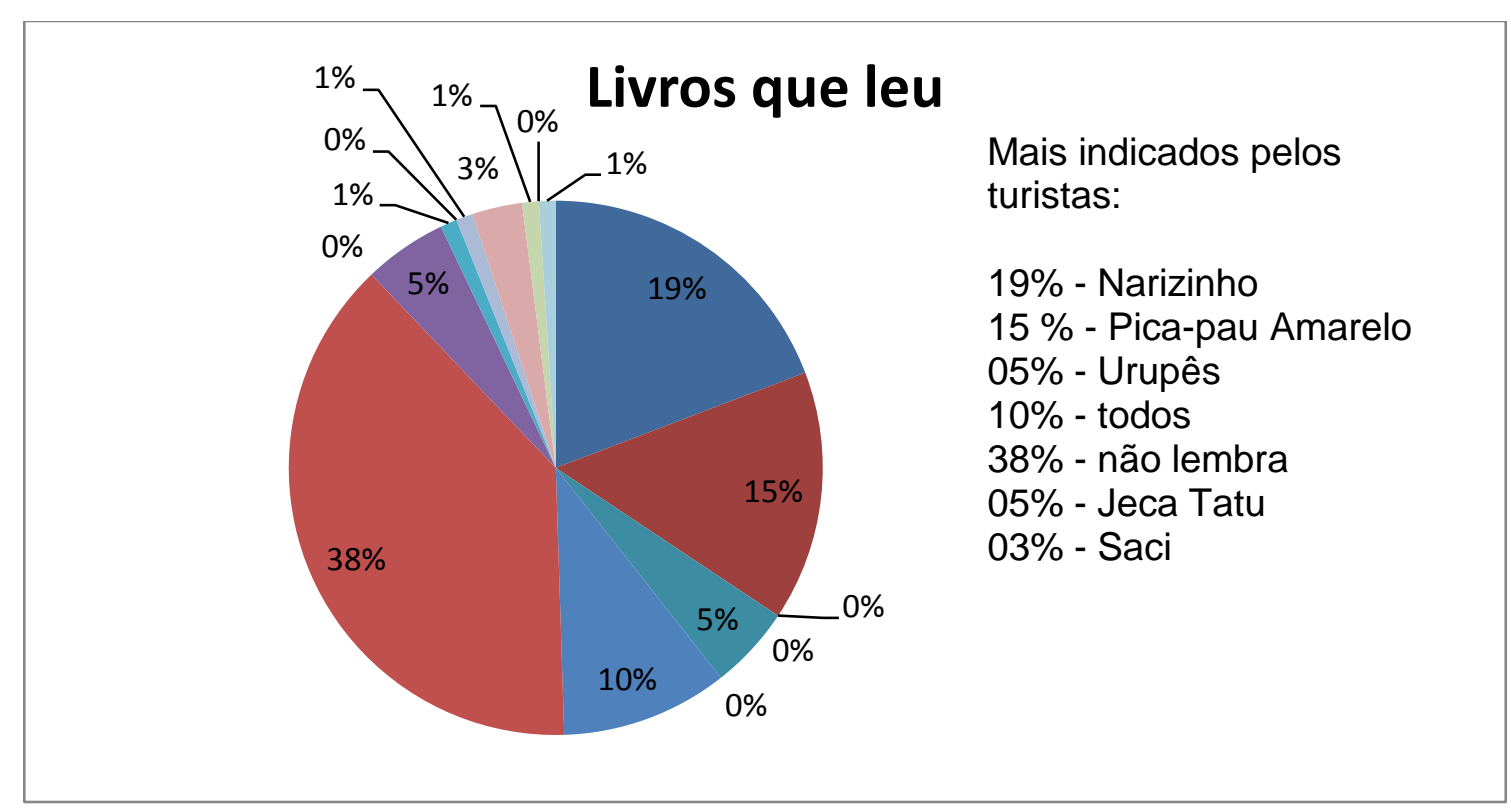

Gráfico 40 - Livros que leu

A maior parte dos turistas entrevistados (79\%) respondeu que conhece os livros de Monteiro Lobato, sendo que 19\% leram Reinações de Narizinho, 15\% leram o Sítio do Pica-pau Amarelo e 38\% não lembram quais os livros que leram. Vale também salientar que $10 \%$ desses turistas declararam ter lido a obra completa do escritor.

11. Qual o principal motivo desta viagem?

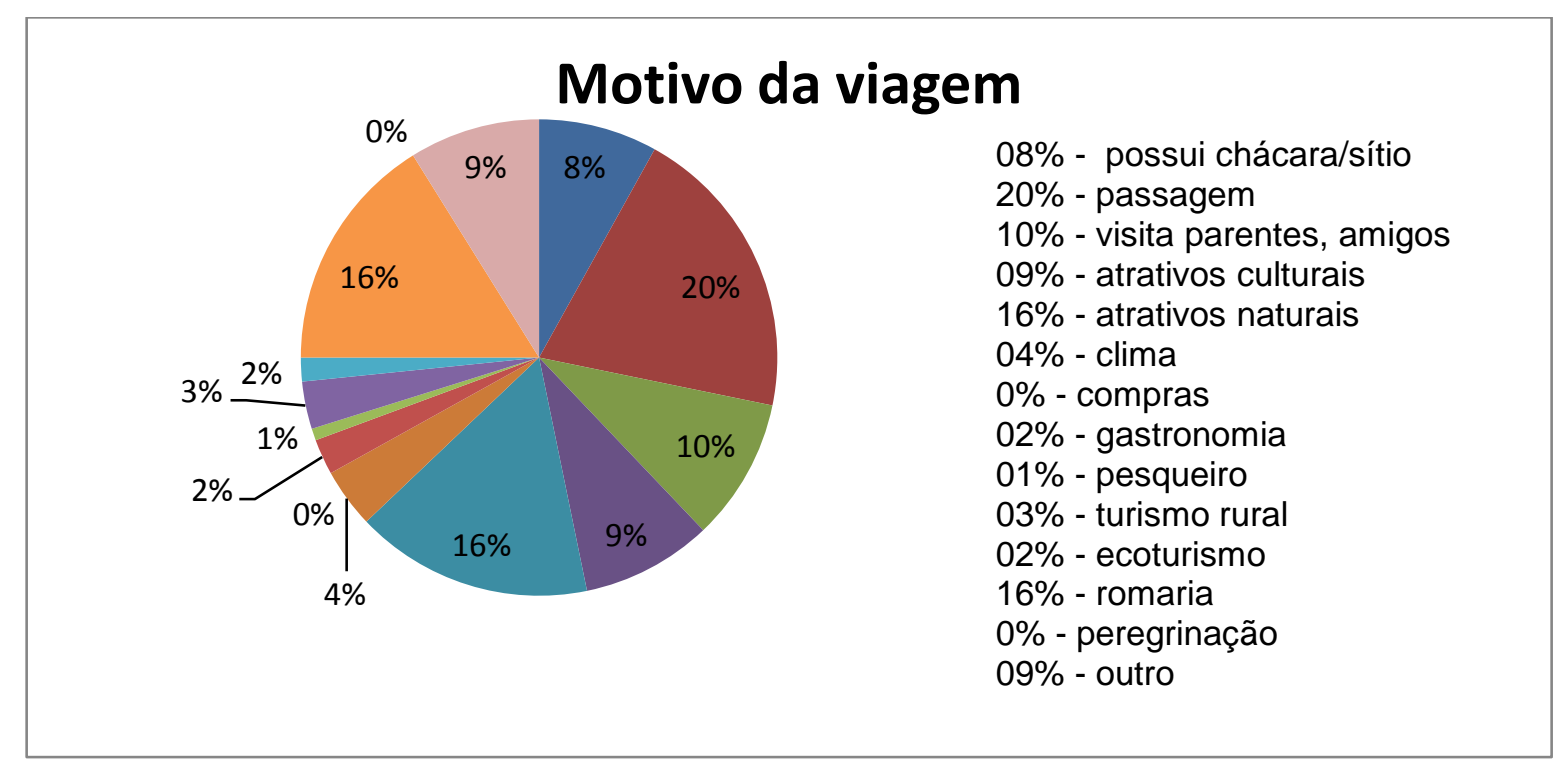

Gráfico 41 - Motivo da viagem 
Nesta amostragem, temos que as principais motivações da viagem foram a de passagem (20\%), a busca por atrativos naturais (16\%) e romarias (16\%). Evidencia também que $9 \%$ buscam atrativos culturais e que há o turista de segunda residência (8\%), ou seja, aquele que tem chácara ou sítio para lazer e descanso.

12. Como soube da cidade de Monteiro Lobato?

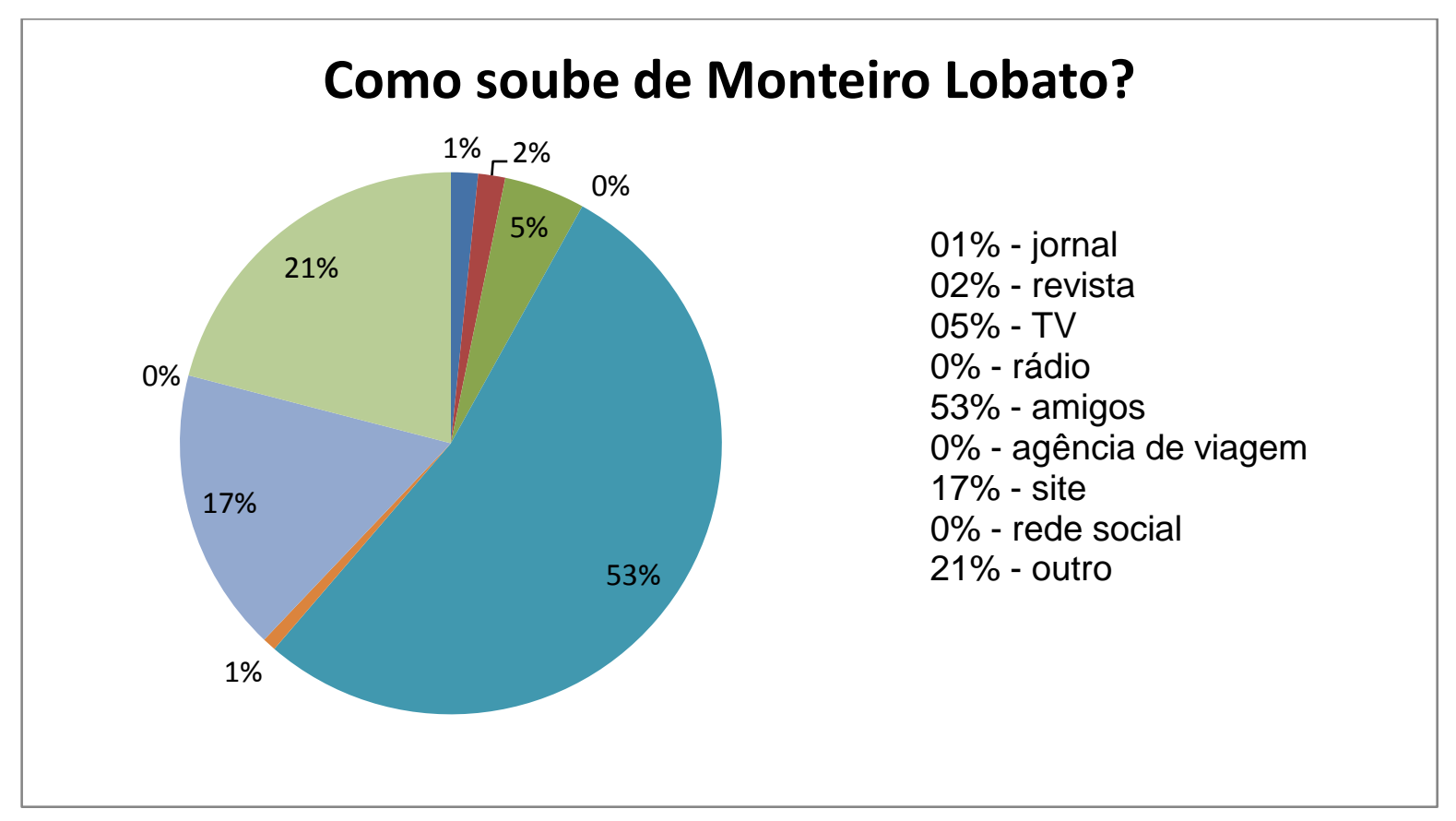

Gráfico 42 - Como soube de Monteiro Lobato?

Amigos e sites lideram a forma como os turistas tomaram conhecimento sobre o município. Conhecer um lugar através de amigos é o já consagrado "boca a boca". Os sites mencionados foram o Google, da prefeitura e da Pousada Aldeias do Paraíso. Vemos aqui uma informação importante para o plano de marketing turístico da cidade em relação aos meios de divulgação. Como "outros", foram indicados: por passagem, já morou na cidade, família, corretor de imóveis, é da região, conhece o município há anos. 
13. Com que frequência costuma visitar Monteiro Lobato?

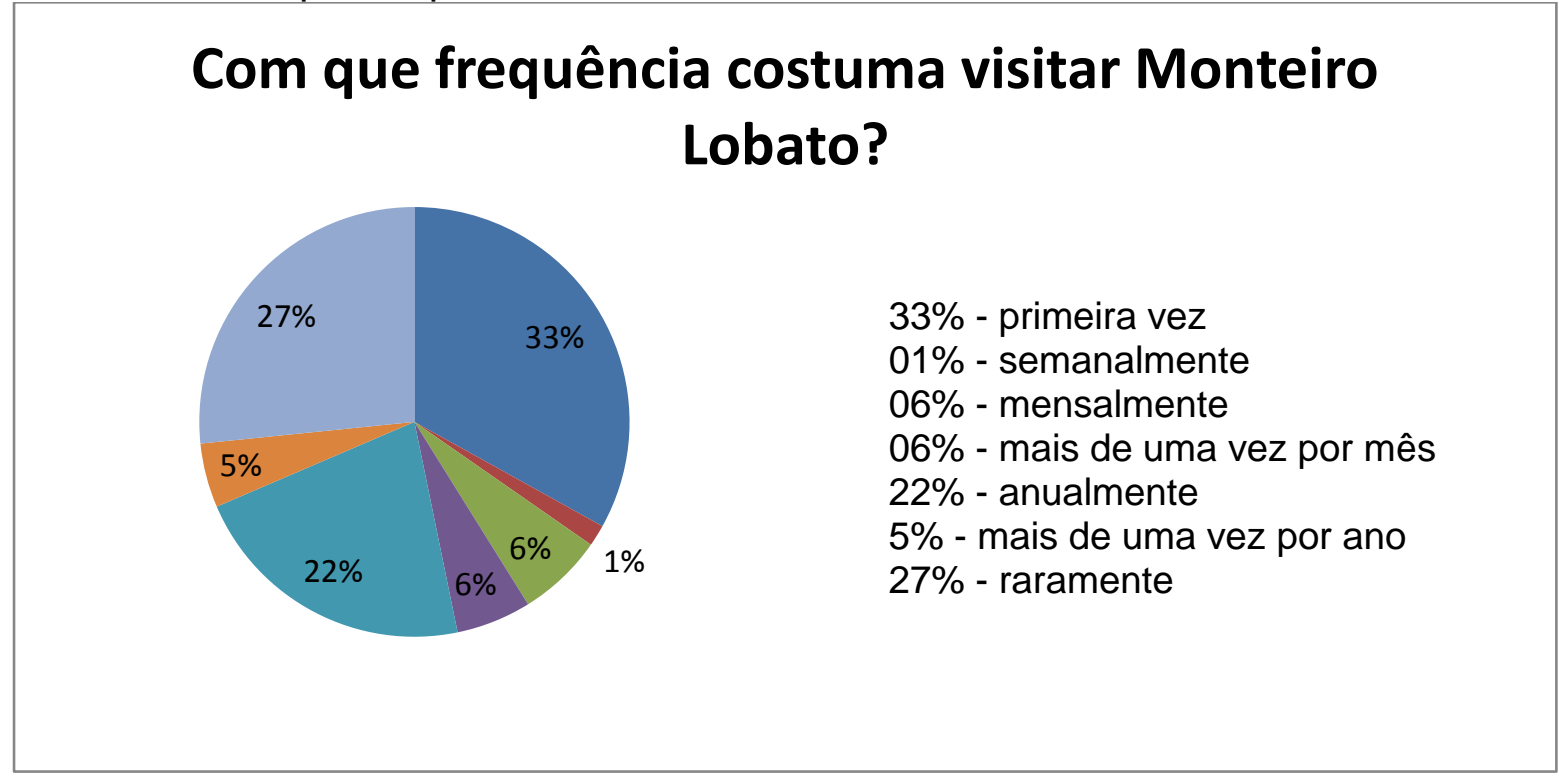

Gráfico 43 - Com que frequência costuma visitar Monteiro Lobato

Nessa amostragem houve uma distribuição diversificada entre as variáveis apresentadas para a frequência com que os turistas vêm para o município. Vale destacar que um terço dos turistas entrevistados $(33 \%)$ visitava Monteiro Lobato pela primeira vez o que indica boas perspectivas em termos de fluxo turístico uma vez que $89 \%$ responderam positivamente que voltariam ao município em outra oportunidade.

14. Tempo de permanência em Monteiro Lobato?

\section{Tempo de permanência em Monteiro Lobato?}

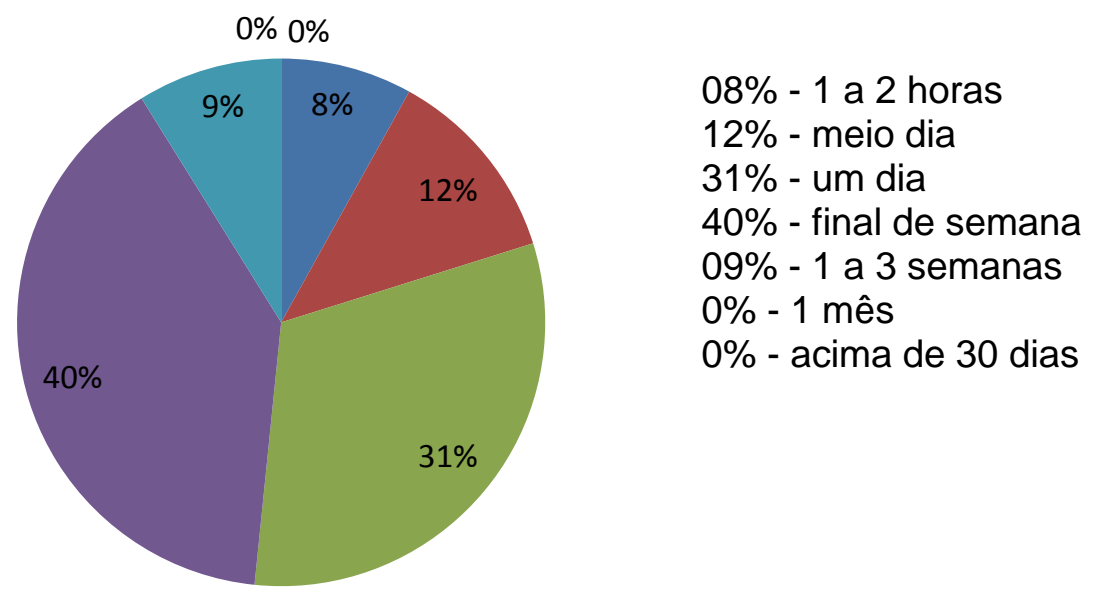

Gráfico 44 - Tempo de permanência em Monteiro Lobato? 
Há uma agradável revelação nessa amostragem, a de que 40\% dos turistas pernoitam ao passarem o final de semana no município, reforçando a informação dada pela questão de número 2 de que Monteiro Lobato já é uma destinação turística uma vez que esses turistas vêm para ficar no município.

15. Qual o meio de hospedagem utilizado neste município?

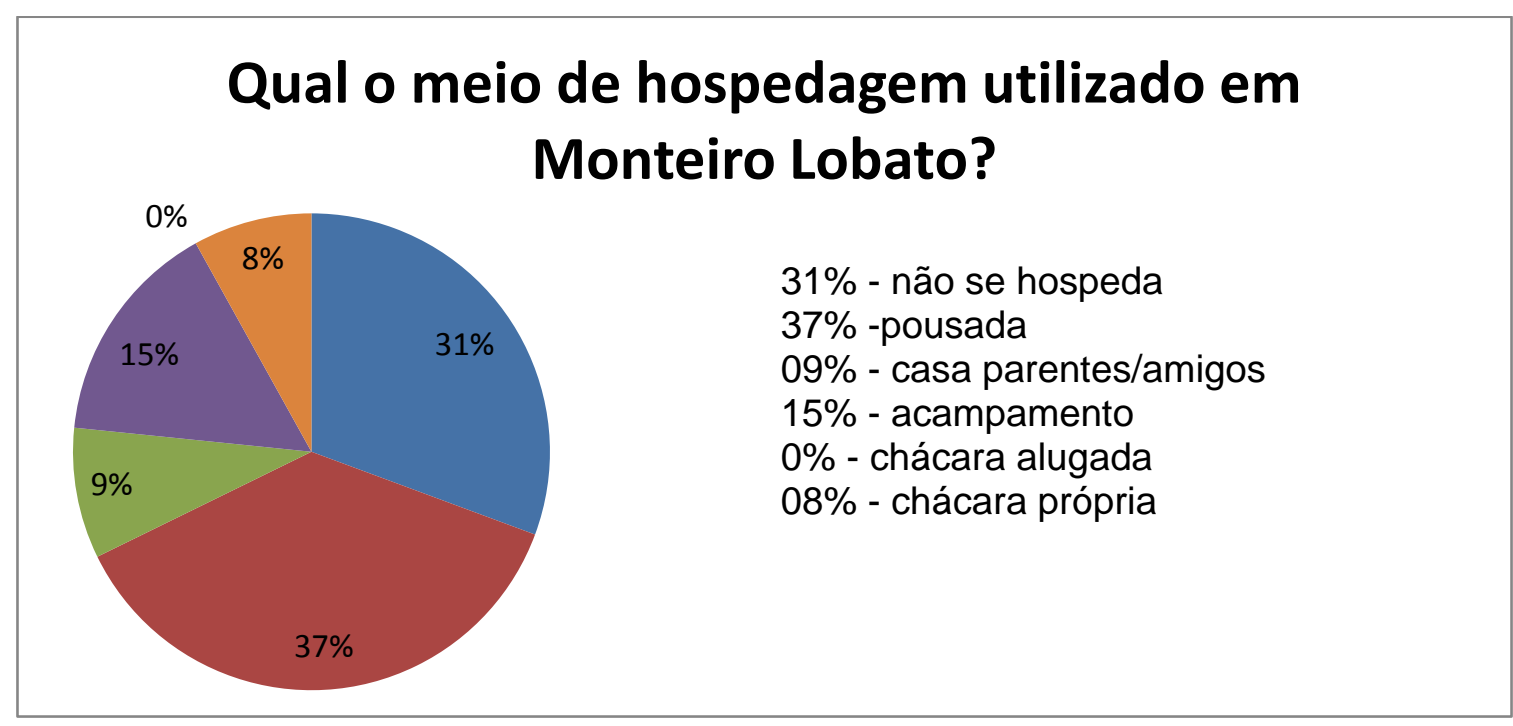

Gráfico 45 - Qual o meio de hospedagem utilizado em Monteiro Lobato?

Em consonância com a questão de número 14, temos que os turistas ocupam pousadas $(37 \%)$ e alojamentos (15\%), portanto, $52 \%$ deles colaboram para a geração de renda e trabalho no município.

16. Qual o meio de transporte utilizado nessa viagem?

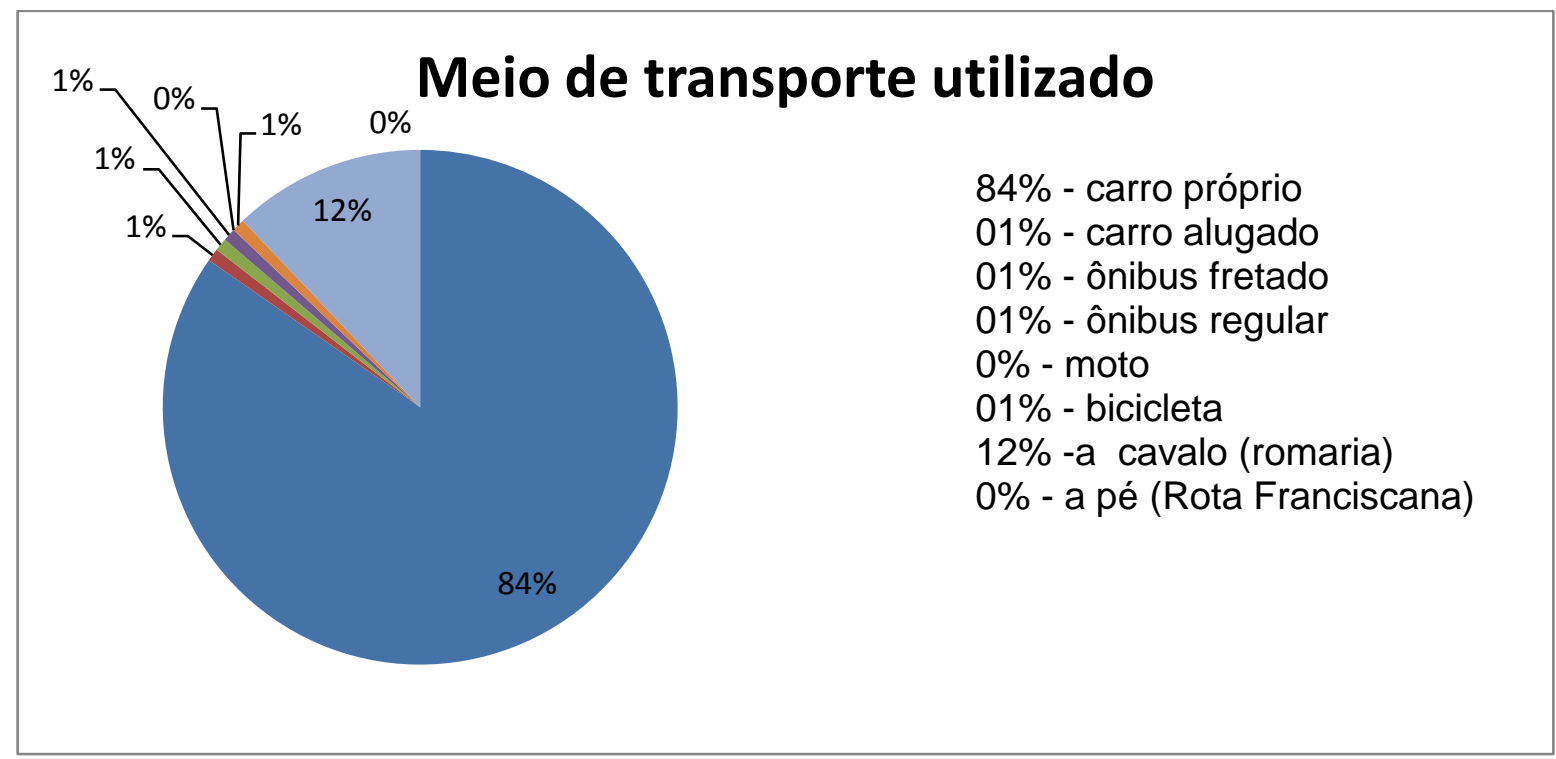

Gráfico 46 - Meio de transporte utilizado 
Nesta amostragem, a maioria dos turistas viaja com carro próprio. Pensando em oportunidades de negócios, podem-se considerar, além do posto de gasolina, os serviços de borracheiro e mesmo de mecânica. Os cavaleiros romeiros, em geral, são acompanhados por um grupo que organiza a estrutura que precisam como alimentação, hospedagem e local com pasto para descanso dos animais, representando outra oportunidade de negócio. Com referência à bicicleta, tem sido crescente a vinda de ciclistas ao município. Alguns vêm já na própria bicicleta, outros as trazem nos carros e iniciam o passeio ciclístico a partir do município. Para estes, segundo um dos ciclistas entrevistados, há a oportunidade de negócio de lhes oferecer um local seguro para deixarem os respectivos carros e um banheiro com chuveiro para retornarem as suas casas limpos.

17. Como está viajando?

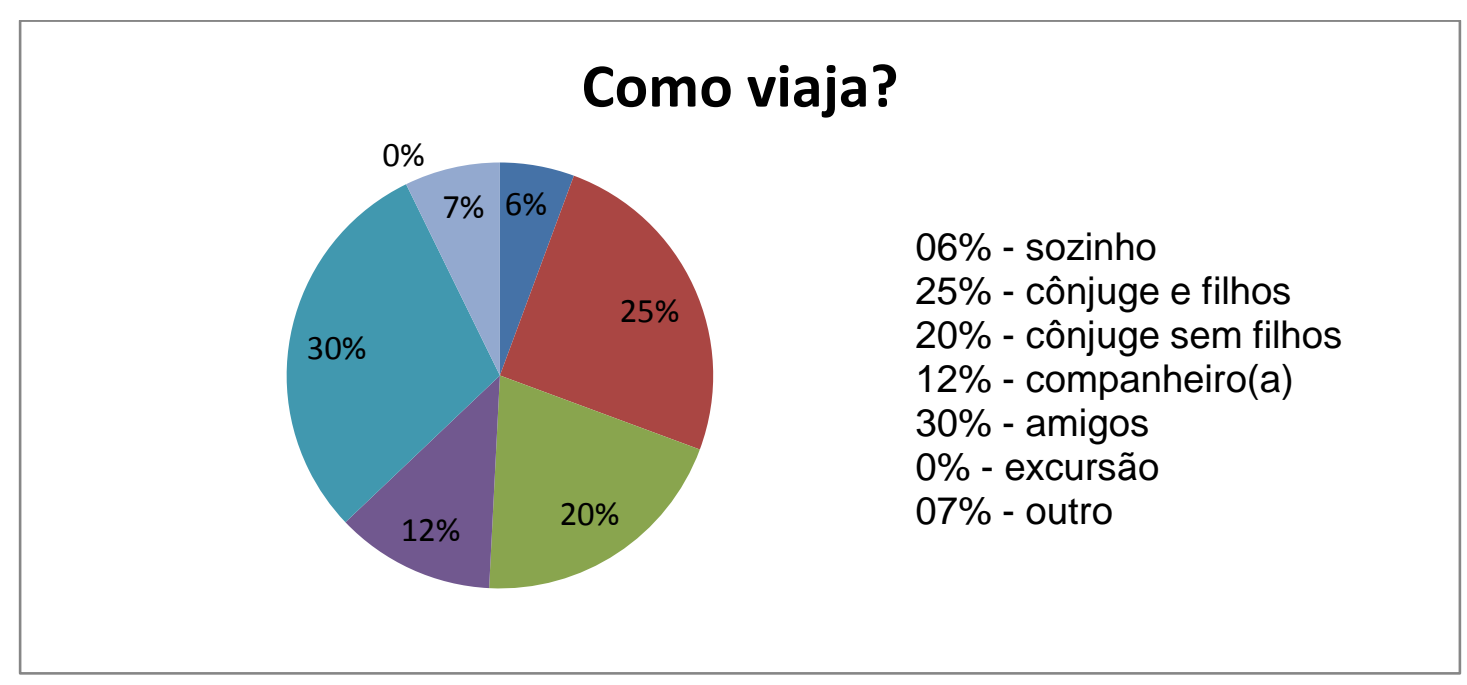

Gráfico 47 - Como viaja?

Essa questão indica que os turistas vêm acompanhados. Em "outro" foi indicada a vinda com familiares não sendo especificamente cônjuge. Se pensarmos em oportunidades de negócio, pode-se focar no casal que vem com filhos e oferecer produtos e serviços que atendam o público infanto-juvenil como um local que ofereça entretenimento para essa faixa etária. 
18. Como costuma pagar suas despesas em viagem?

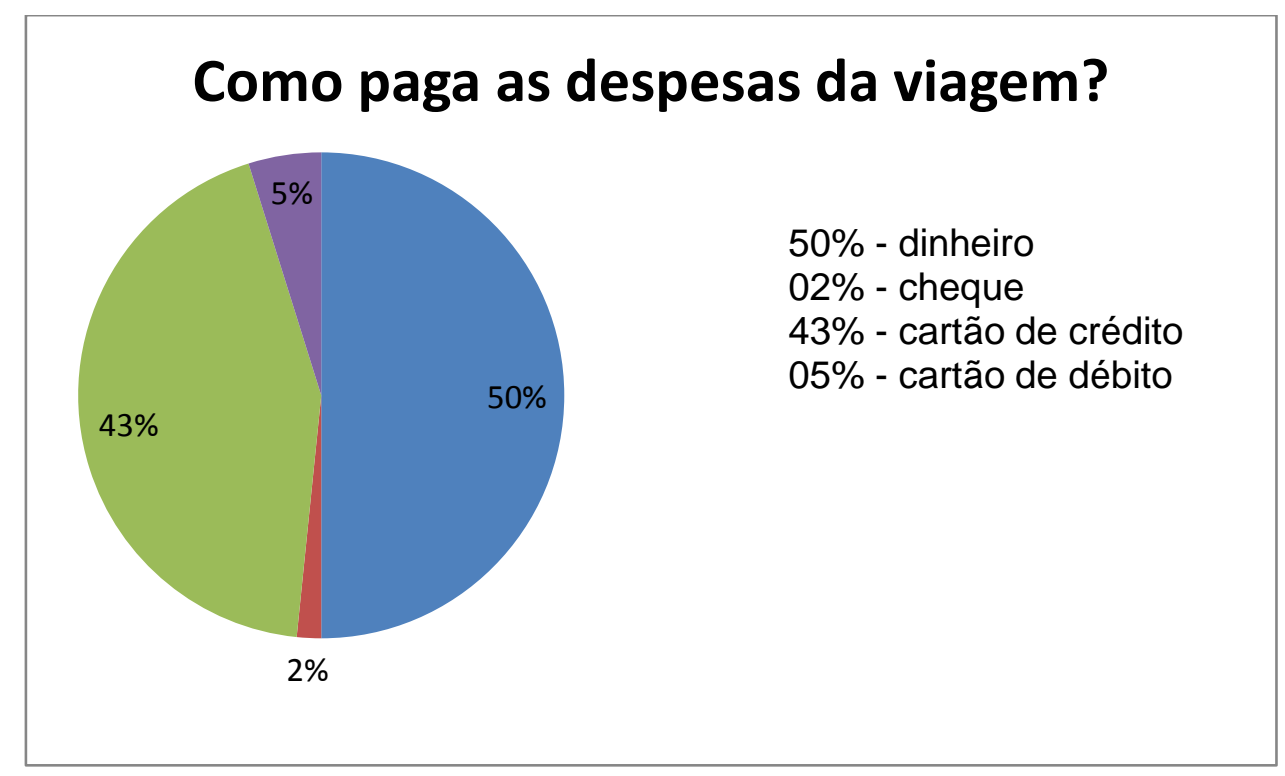

Gráfico 48 - Como paga as despesas de viagem?

Esta questão revela que, embora a metade dos entrevistados paga suas despesas com dinheiro, os cartões de crédito e débito são muito utilizados. É um alerta para os empresários que podem perder vendas por não trabalharem com cartões.

19. Você costuma fazer as refeições na cidade?

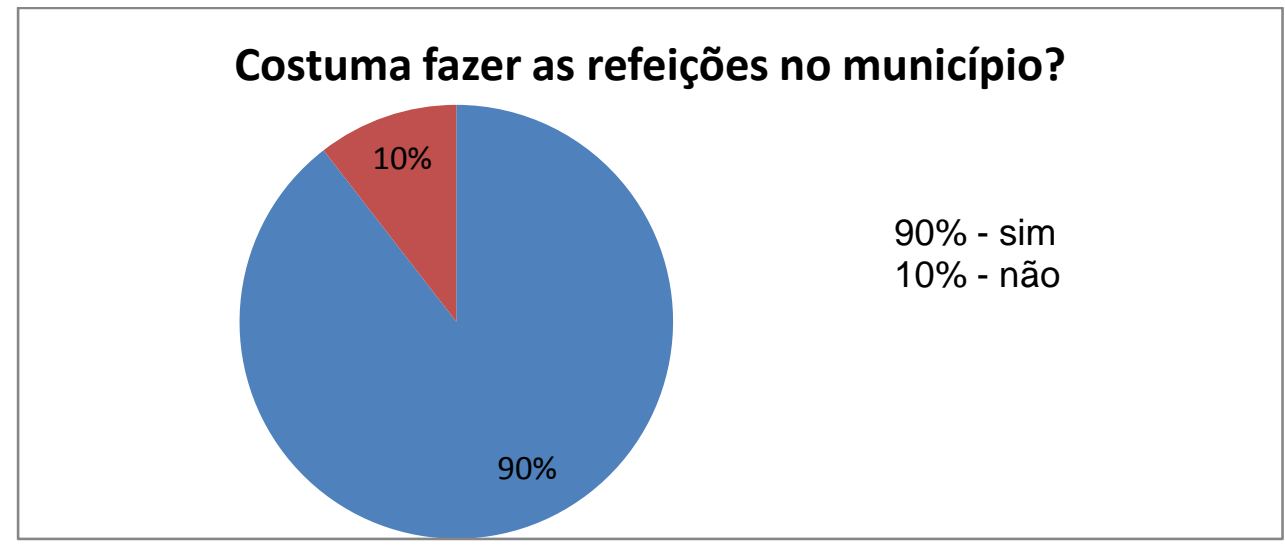

Gráfico 49 - Você costuma fazer as refeições na cidade? 
19.1. Em caso afirmativo, onde?

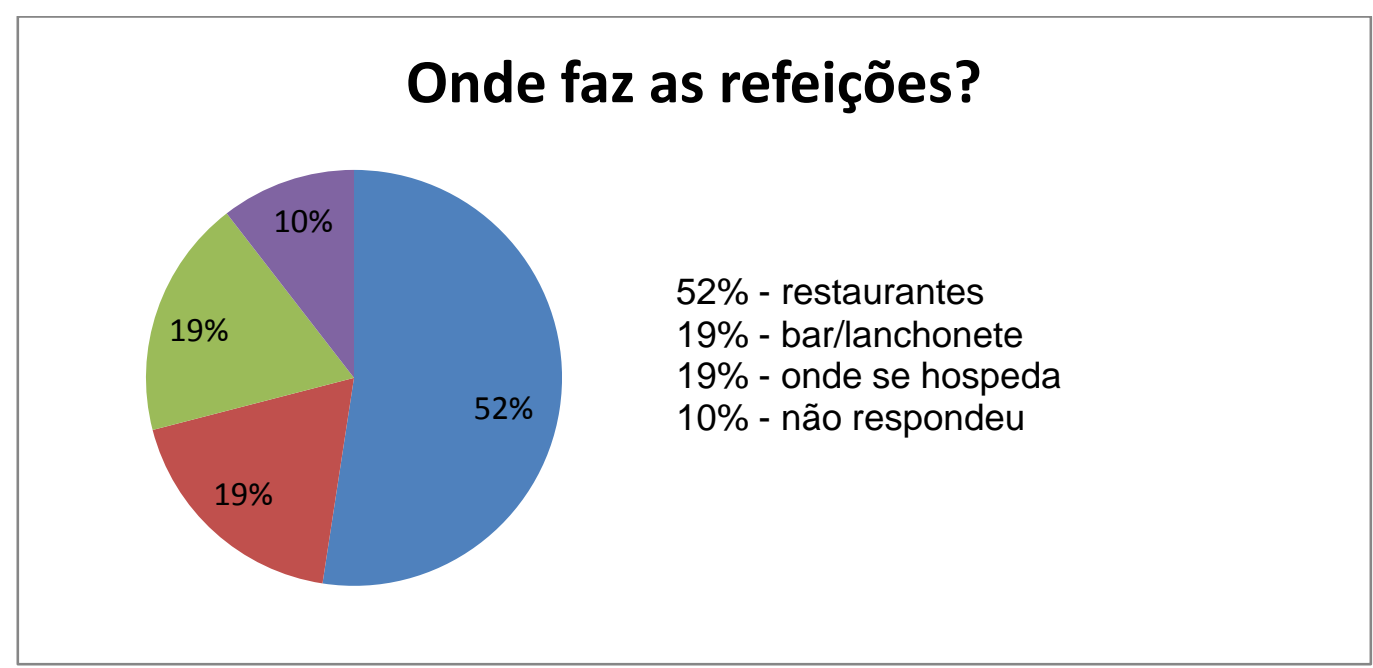

Gráfico 50 - Onde faz as refeições?

A maior parte dos visitantes utiliza os restaurantes para se alimentarem. Mas, em especial os romeiros usam mais os bares e lanchonetes enquanto há os que se alimentam nas pousadas que oferecem pensão completa.

20. Você faz compras em Monteiro Lobato?

\section{Faz compras em Monteiro Lobato?}

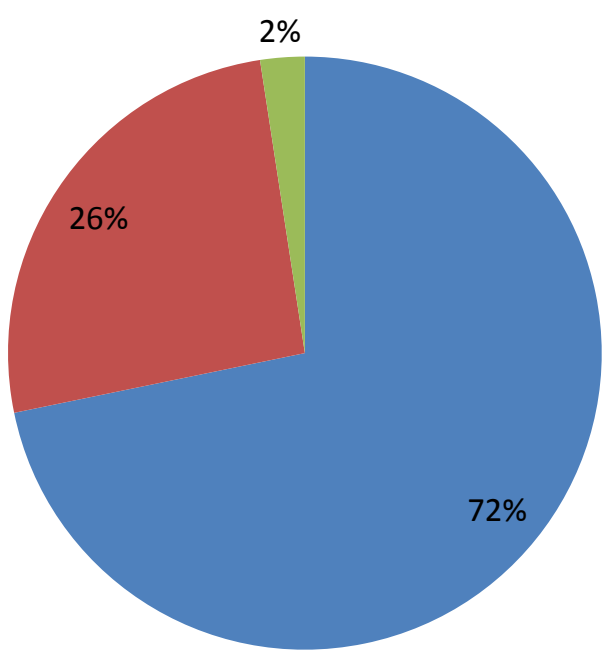

$72 \%-\operatorname{sim}$

$26 \%$ - não

$02 \%$ - não respondeu

Gráfico 51 - Você faz compras em Monteiro Lobato? 
20.1. Em caso afirmativo, o que compra?

O que compra?

\begin{tabular}{|l|l|}
\hline artesanato & $18 \%$ \\
\hline doces & $19 \%$ \\
\hline biscoitos & $11 \%$ \\
\hline queijos & $14 \%$ \\
\hline combustível & $10 \%$ \\
\hline $\begin{array}{l}\text { itens diversos no } \\
\text { supermercado }\end{array}$ & $08 \%$ \\
\hline $\begin{array}{l}\text { roupas } \\
\text { produtos } \\
\text { agropecuários }\end{array}$ & $01 \%$ \\
\hline linguiça caseira & $02 \%$ \\
\hline outros & $01 \%$ \\
\hline não respondeu & $1 \% \%$ \\
\hline
\end{tabular}

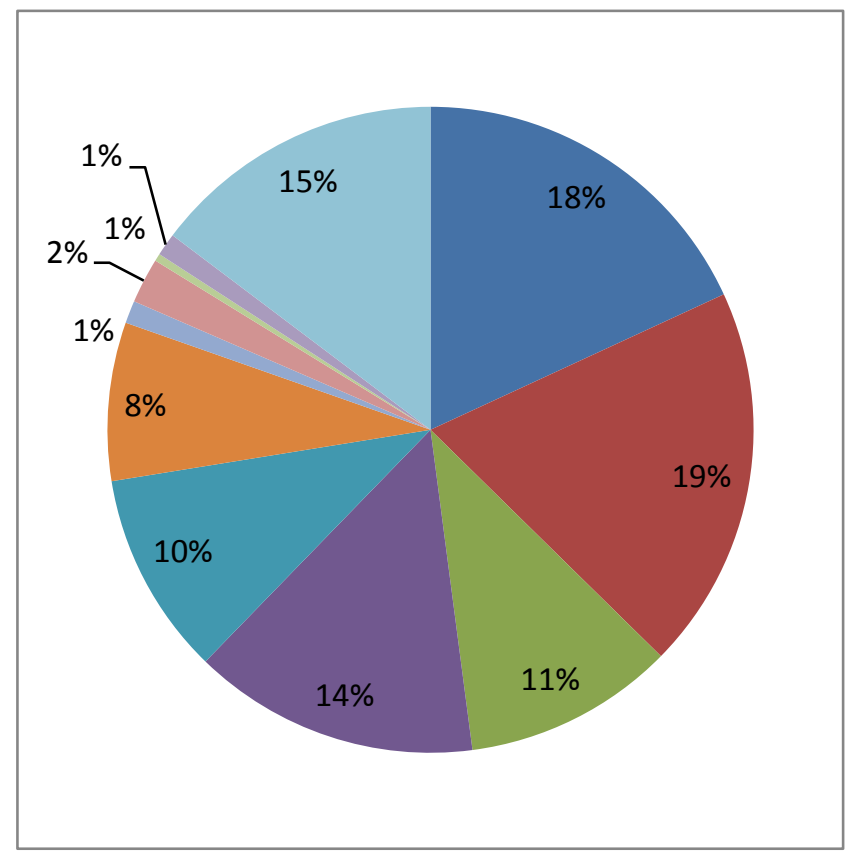

Gráfico 52 - Em caso afirmativo, o que compra?

Essa questão é muito útil porque indica quais são os produtos mais comprados e, portanto, onde há espaço para mais investimentos. Artesanato, doces, biscoitos e queijos são os líderes. Os doces caseiros são tradicionalmente degustados no Bar Urupês e isso está na memória de algumas gerações que iam a Campos do Jordão pela SP-50 no século passado. Por outro lado, os produtos das linhas diet e light e outros tipos de queijos, além do tipo fresco, também são procurados.

21. Como classifica os preços?

\begin{tabular}{|l|r|r|r|}
\hline Itens & \multicolumn{1}{|c|}{ alto } & médio & \multicolumn{1}{c|}{ baixo } \\
\hline alojamento & $3 \%$ & $88 \%$ & $9 \%$ \\
\hline refeições & $4 \%$ & $84 \%$ & $12 \%$ \\
\hline recreação & $13 \%$ & $13 \%$ & $74 \%$ \\
\hline artesanatos & $10 \%$ & $84 \%$ & $6 \%$ \\
\hline doces & $9 \%$ & $81 \%$ & $10 \%$ \\
\hline salgados & $2 \%$ & $83 \%$ & $15 \%$ \\
\hline água refrigerante & $2 \%$ & $93 \%$ & $5 \%$ \\
\hline combustível & $4 \%$ & $90 \%$ & $6 \%$ \\
\hline
\end{tabular}

Quadro 97 - Como classifica os preços dos produtos em Monteiro Lobato? 
No geral, os preços praticados foram considerados médios o que indica que os visitantes aceitam os preços como sendo justos.

As perguntas de números 22, 23, 24 e 25 buscavam saber qual era a expectativa que os visitantes tinham em relação ao município e a avaliação que fariam do que encontraram. A avaliação geral é boa, porém na questão de número 31 (Há alguma coisa em particular que poderia tornar a cidade mais atraente?) foram dadas muitas sugestões importantes, inclusive a de revitalizar o casario por meio de pintura das fachadas que, aliás, foi também sugerido na pesquisa com os moradores como resposta à pergunta: O que há de ruim em Monteiro Lobato que precisa ser melhorado? Uma ação nesse sentido agradará moradores e turistas.

22. Antes de chegar, qual era a sua expectativa em relação aos atrativos turísticos de Monteiro Lobato?

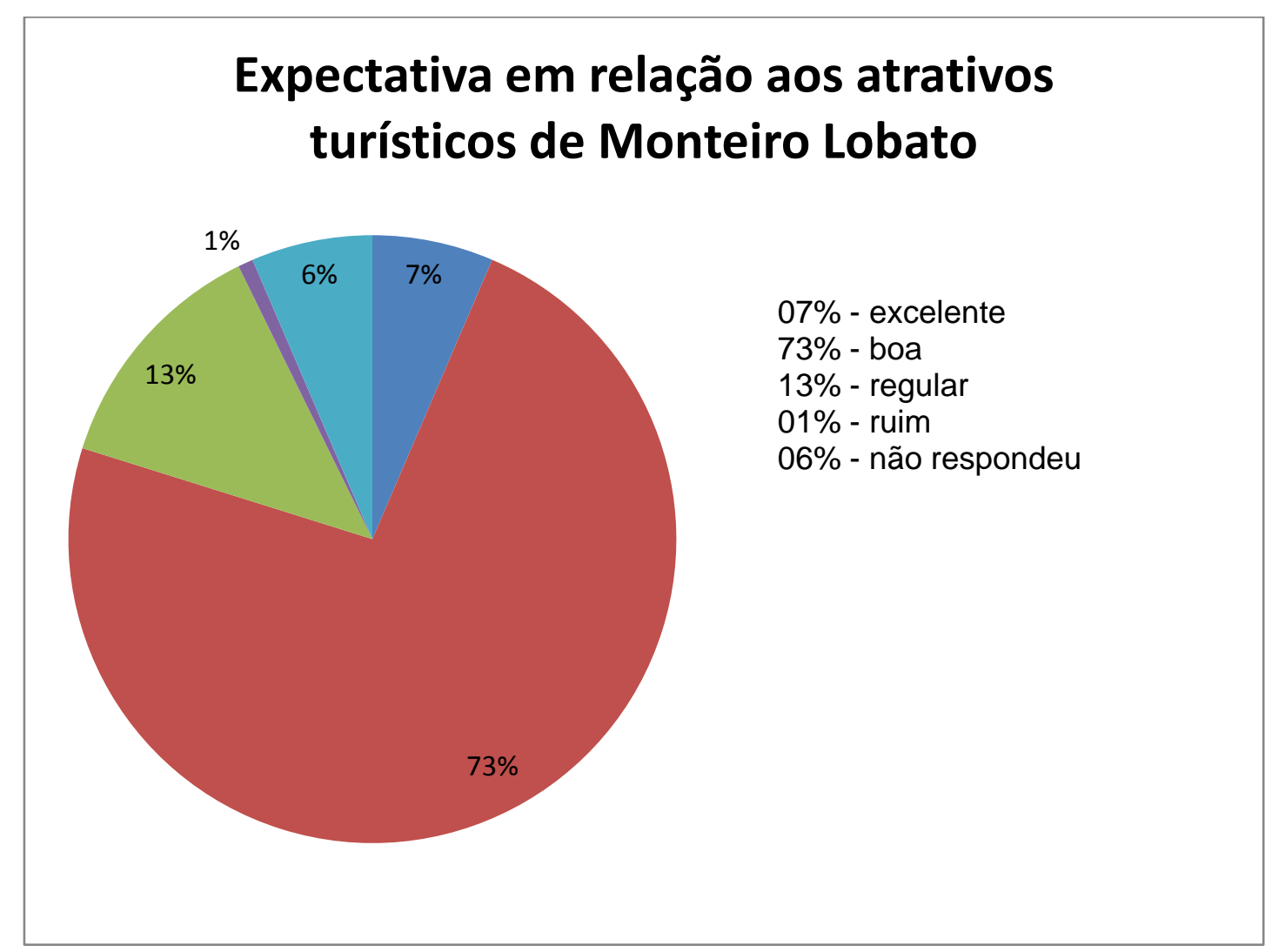

Gráfico 53 - Antes de chegar, qual era a sua expectativa em relação aos atrativos turísticos de Monteiro Lobato? 
23. Como classifica a paisagem urbana de Monteiro Lobato?

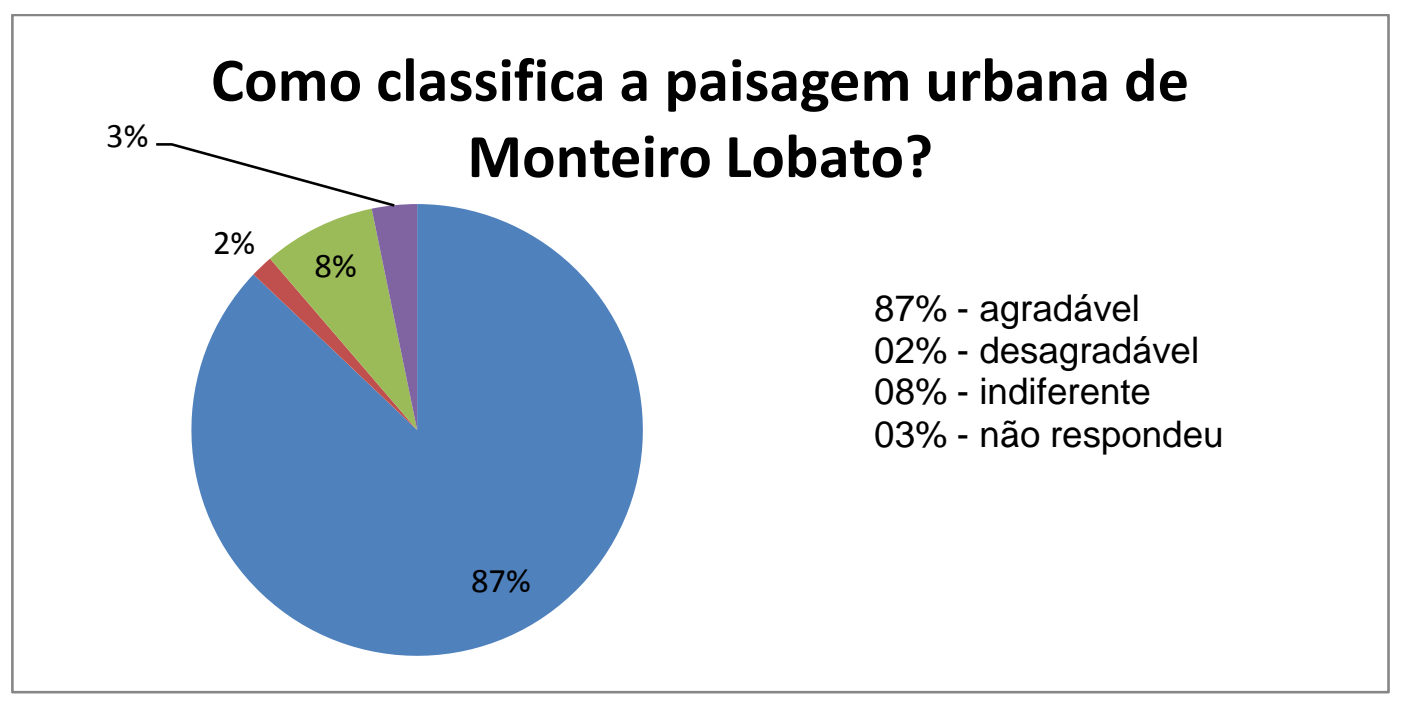

Gráfico 54 - Como classifica a paisagem urbana de Monteiro Lobato?

24. Como classifica a paisagem rural de Monteiro Lobato?

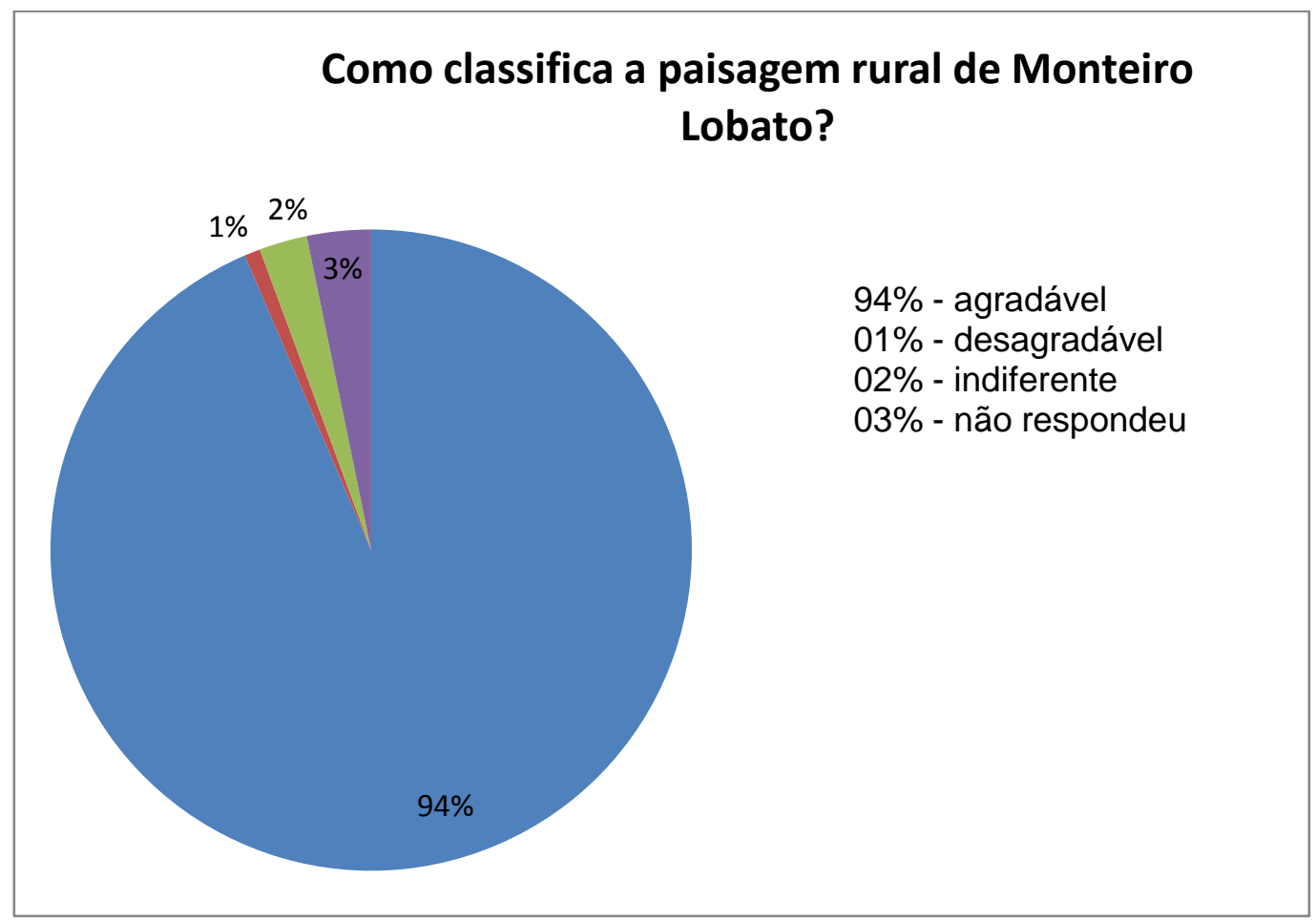

Gráfico 55 - Como classifica a paisagem rural de Monteiro Lobato? 
25. Como classifica a limpeza em Monteiro Lobato?

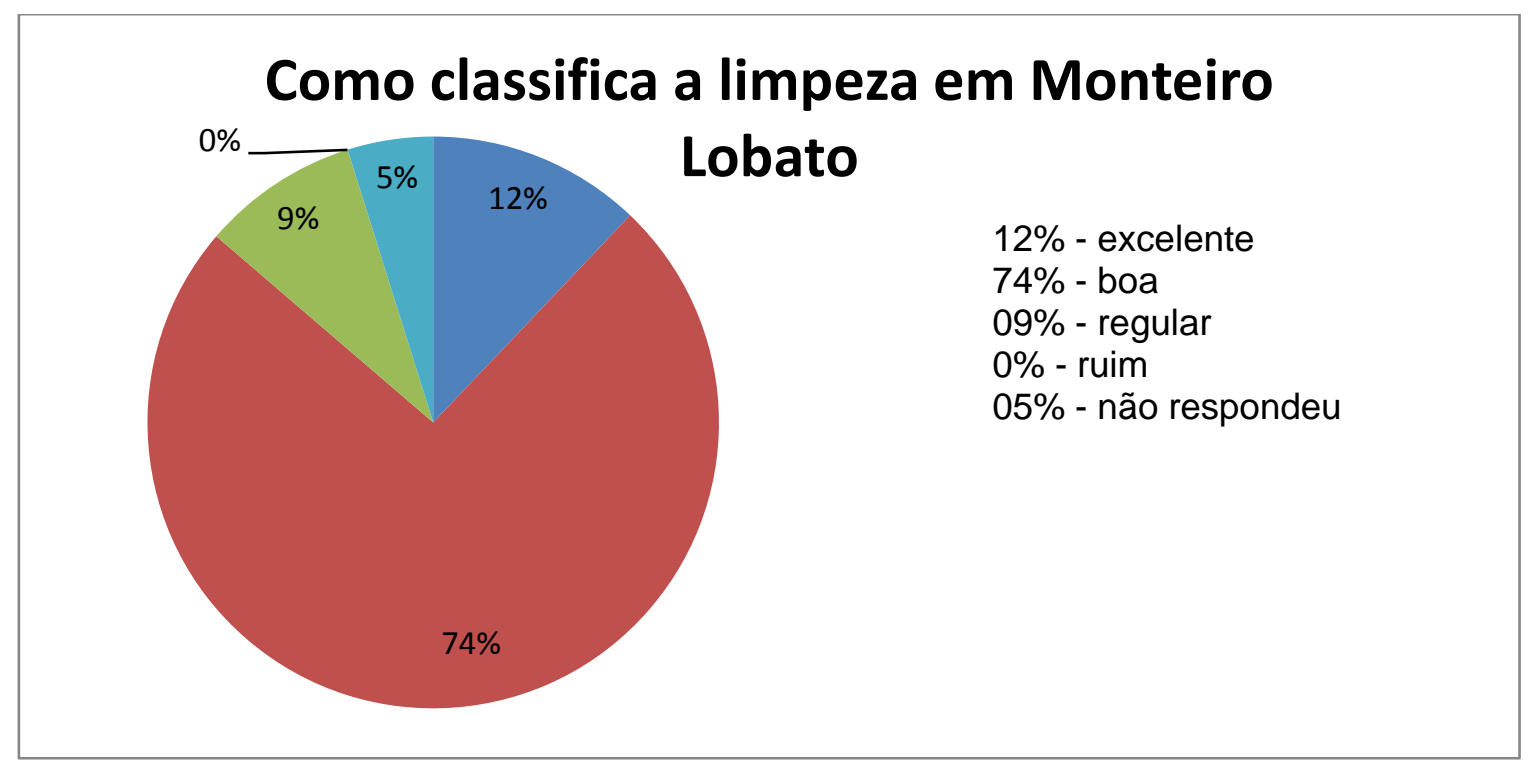

Gráfico 56 - Como classifica a limpeza em Monteiro Lobato

26. Que produtos procurou e não encontrou?

\section{Produtos que procurou e não encontrou}

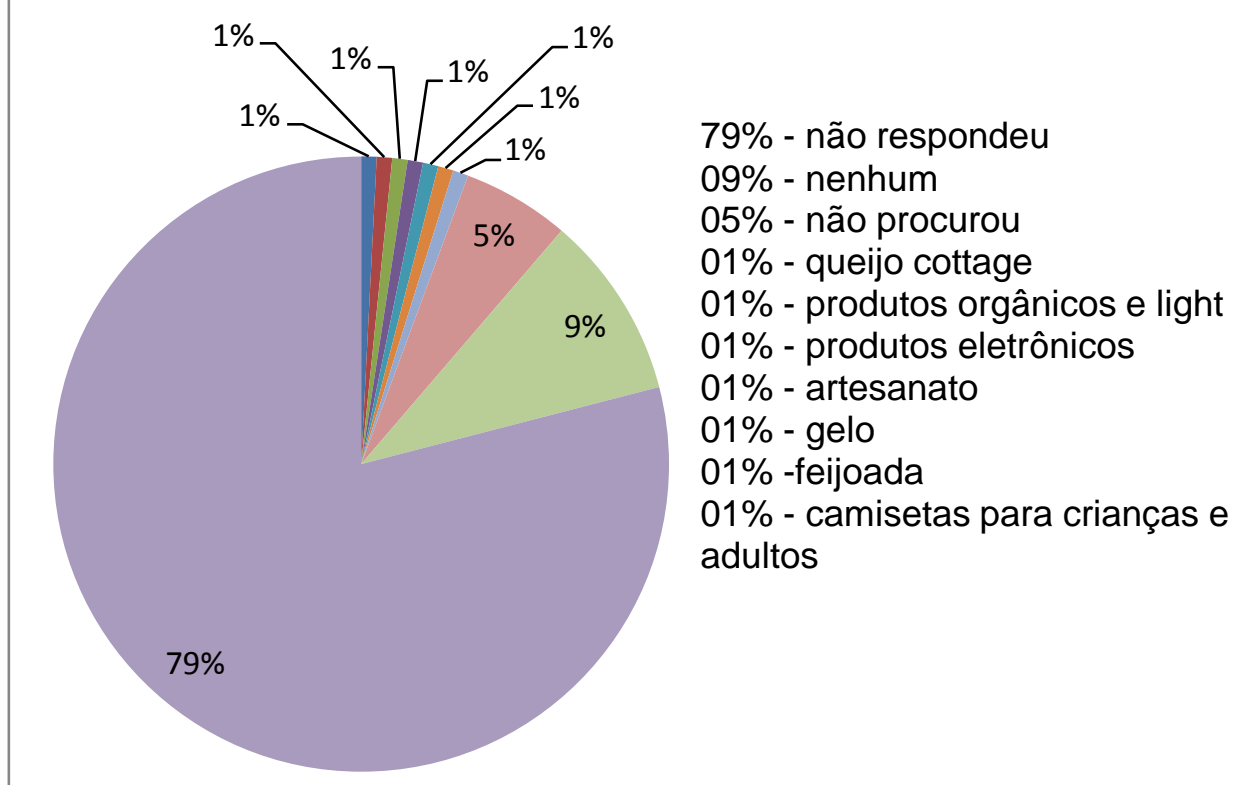

Gráfico 57 - Que produtos procurou e não encontrou? 
27. Que serviços procurou e não encontrou?

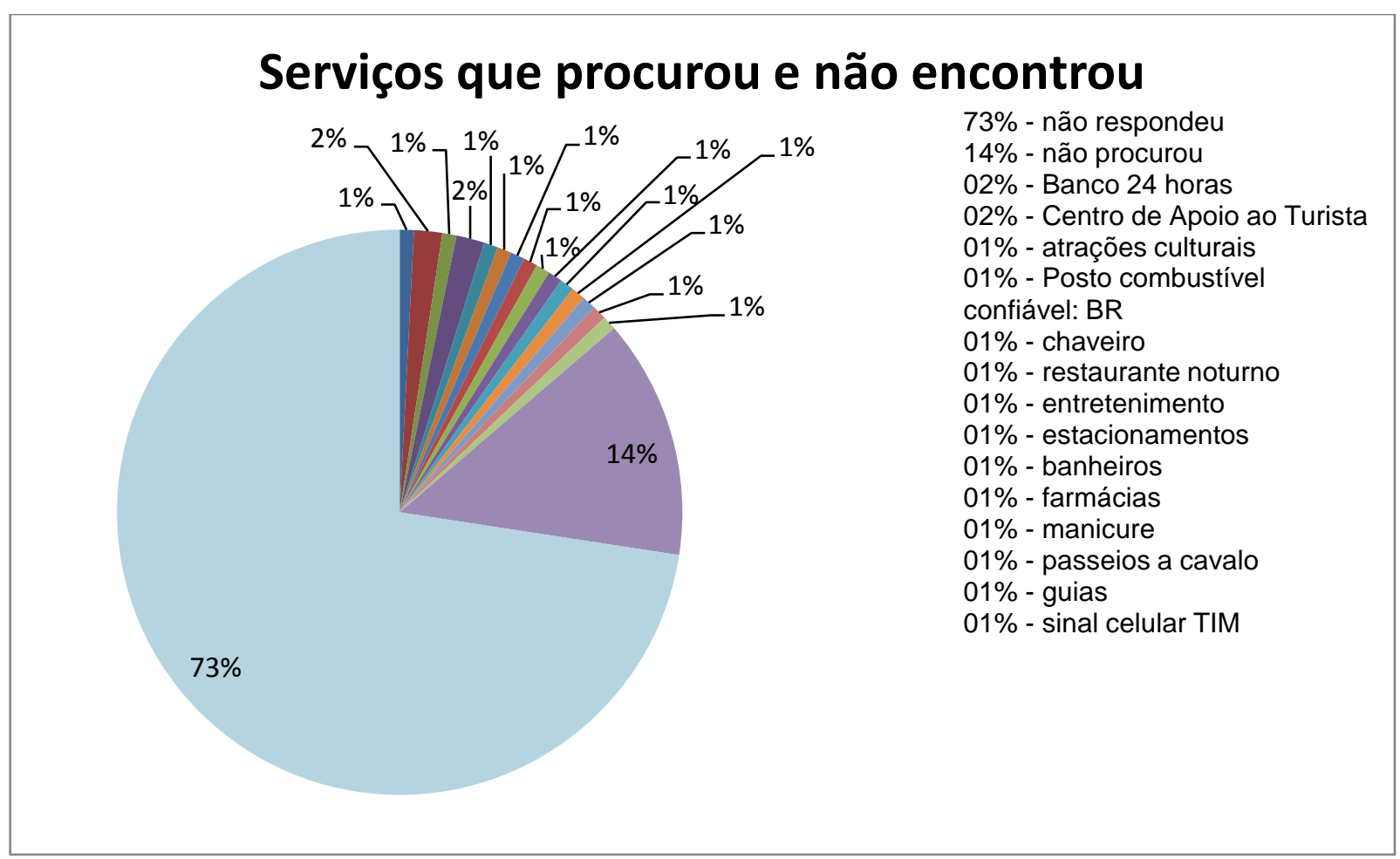

Gráfico 58 - Que serviços procurou e não encontrou?

Infelizmente a maior parte dos visitantes não respondeu as questões de números 26 e 27 . Entretanto, aqueles que o fizeram indicaram os itens de produtos e serviços que deixaram de comprar por não os encontrarem no município. Alguns dos itens registrados pelos turistas estão em consonância com o que os moradores indicaram ao responderem a pergunta de número 20 do respectivo questionário (O que deve ser feito na cidade para receber bem um turista?).

28. Como classifica o atendimento no comércio local?

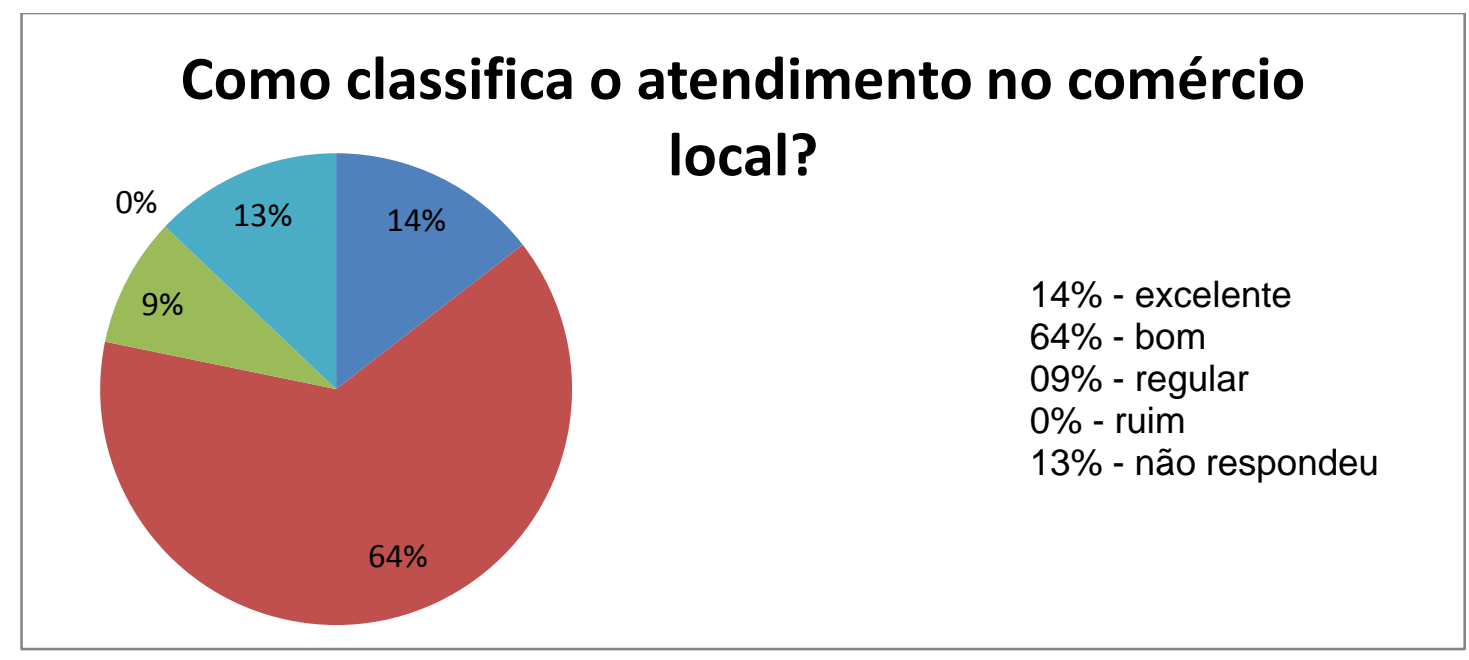

Gráfico 59 - Como classifica o atendimento no comércio? 
A avaliação do atendimento no comércio soma $78 \%$ entre bom e excelente o que é bem positivo. Porém, 9\% o consideraram regular e, assim, os empresários devem dar atenção a isso e melhorar o atendimento.

29. O que mais Ihe agradou em Monteiro Lobato?

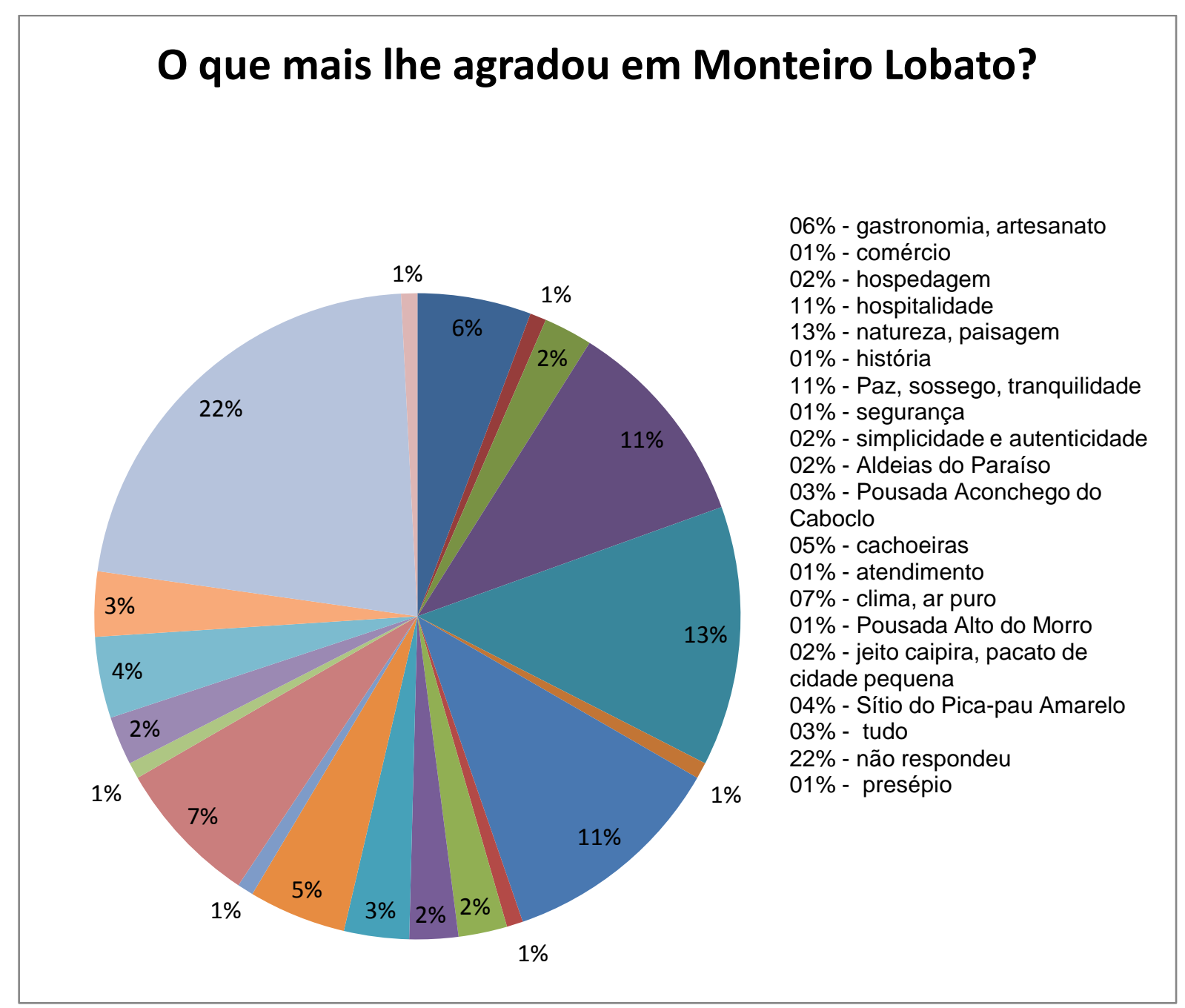

Gráfico 60 - O que mais Ihe agradou em Monteiro Lobato?

Os turistas buscam: paz, sossego, tranquilidade (11\%), hospitalidade (11\%), natureza, paisagem (13\%), clima, ar puro (07\%), simplicidade e autenticidade (02\%), jeito caipira, pacato de cidade pequena (02\%) e gastronomia, artesanato (06\%). A população de Monteiro Lobato tem um estilo de vida que os visitantes desejam compartilhar e, portanto, esse estilo não pode ser perdido porque é um valor agregado à oferta turística local. 
30. O que menos Ihe agradou em Monteiro Lobato?

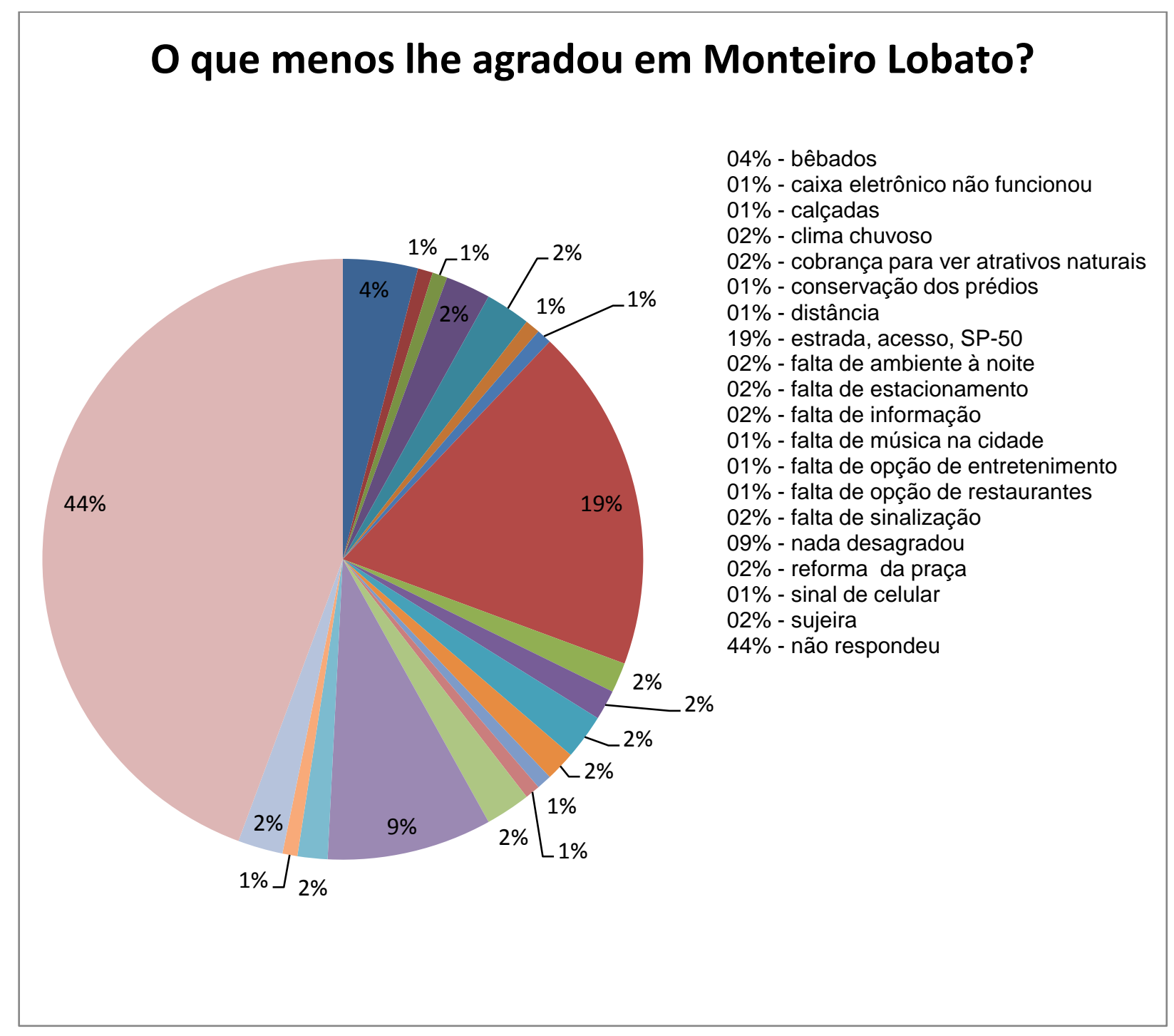

Gráfico 61 - O que menos Ihe agradou em Monteiro Lobato?

Alguns dos itens indicados nas respostas pelos turistas a essa questão coincidem com aqueles indicados pelos moradores à pergunta: O que há de ruim em Monteiro Lobato que precisa ser melhorado? Como por exemplo: bêbados, os restaurantes não abrem à noite, sinalização turística, conservação dos prédios etc. Dessa forma, para melhorar o Turismo no município, governo, empresários e comunidade devem dar atenção a essas queixas e buscar soluções para, na medida do possível, eliminá-las. 
31. Há alguma coisa em particular que poderia tornar a cidade mais atraente? Em caso positivo, o quê?

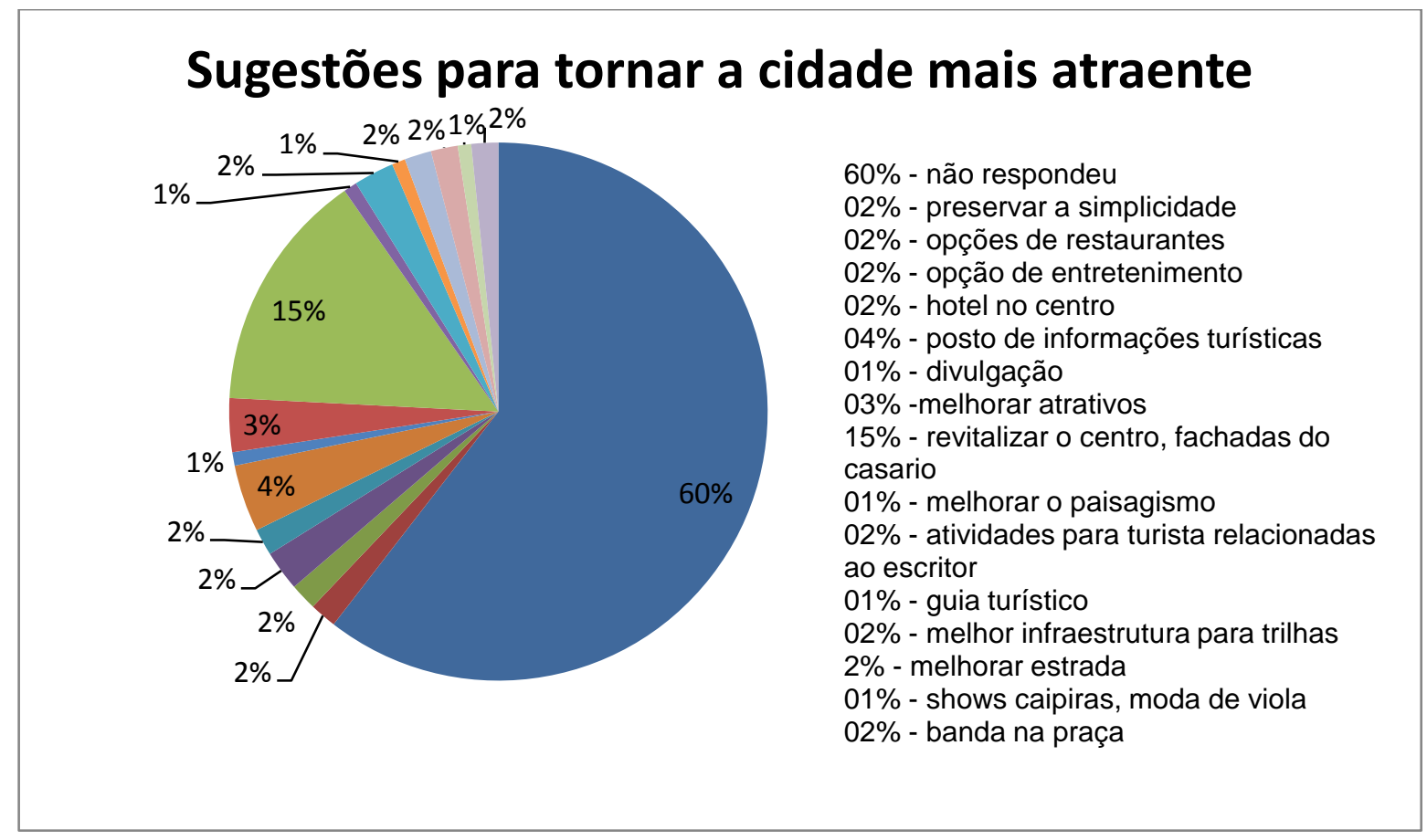

Gráfico 62 - Sugestões para tornar a cidade mais atraente

Embora $60 \%$ dos entrevistados não responderam essa questão, aqueles que o fizeram ofereceram sugestões pertinentes e merecedoras de atenção por parte do governo, empresários e comunidade porque contribuem para o planejamento turístico do município. Salienta-se que 15\% indicaram a revitalização do centro, melhorando as fachadas do casario.

32. Voltaria a Monteiro Lobato em outra oportunidade?

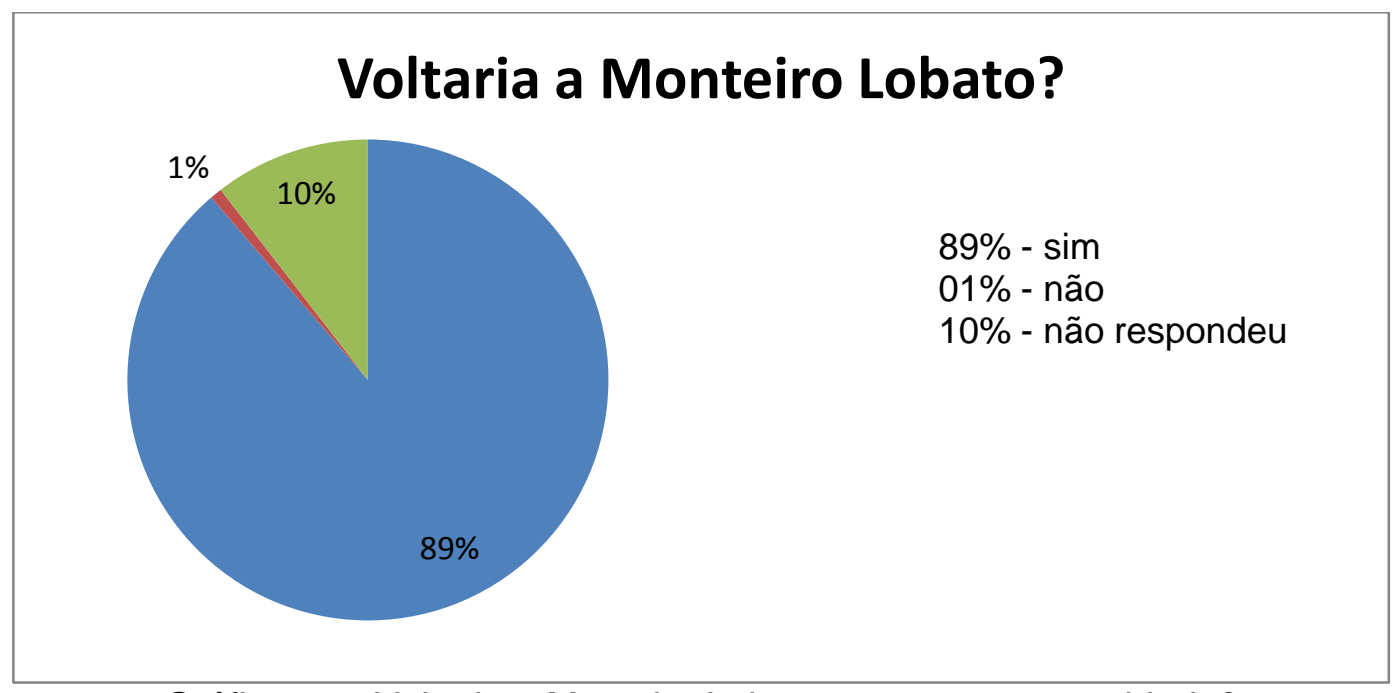

Gráfico 63 - Voltaria a Monteiro Lobato em outra oportunidade? 
Esta questão indica e reforça o motivo pelo qual o trabalho de planejar o Turismo Sustentável do município deve continuar, pois público já há.

Os resultados dos questionários para as pesquisas de opinião a respeito da atividade turística no município aplicados a 159 moradores e 124 turistas representam uma fonte importante de informações para a organização do Turismo em Monteiro Lobato, uma vez que moradores e turistas indicaram as respectivas percepções e necessidades que, em alguns casos, coincidem e, em outros, complementam-se. Houve a preocupação em aplicar questionários para moradores de vários bairros para evitar que o resultado representasse a opinião apenas daqueles que residem no centro. O motivo da viagem revelado pelos turistas demonstra que, como no passado, Monteiro Lobato tem, de fato, o chamado Turismo de Passagem devido a sua localização. Apresenta também que, além dos turistas que buscam atrativos naturais e culturais, há os romeiros que viajam a cavalo para Aparecida e os peregrinos que viajam a pé para Guaratinguetá por devoção ao Frei Galvão, seguindo a Rota Franciscana que se inicia em São Francisco Xavier, Distrito de São José dos Campos. Uma tendência identificada são as famílias que pesquisam valores de hospedagem na internet $e$, vendo que os preços praticados pelas pousadas de Monteiro Lobato são acessíveis, vêm para o município, mas com as visitas direcionadas para São Francisco Xavier (Distrito de São José dos Campos), São Bento do Sapucaí (SP), Campos do Jordão (SP) e Gonçalves (MG). Salienta-se que, ao responderem as questões sobre os produtos e os serviços que procuraram e não encontraram, os turistas indicaram oportunidades de negócios para os lobatenses que queiram empreender pequenos negócios como livraria que venda livros do escritor José Bento Monteiro Lobato, suvenires ligados à obra do escritor, um ponto de receptivo para ciclistas que querem deixar o carro em lugar seguro enquanto pedalam pela Serra da Mantiqueira etc.

Com relação aos atributos do município, a pesquisa demonstrou que o morador valoriza em especial aqueles ligados à cultura caipira e à tranquilidade de cidade pequena enquanto os turistas indicaram que vêm ao município em busca de paz, sossego, tranquilidade, hospitalidade e natureza. Portanto, a comunidade não pode permitir que esses atributos sejam perdidos tanto em relação a sua qualidade de vida quanto para manter o perfil do seu público visitante. 


\subsection{Inventário Turístico}

Apresentam-se a seguir, de forma resumida, os atrativos turísticos e as facilidades para receber o turista que compõem a oferta turística do município, constantes no Plano Diretor de Turismo Sustentável de Monteiro Lobato (GRUPO PLANEJATUR, 2014a, p. 185):

\section{Atrativos Culturais - Patrimônio Histórico/Monumentos e Igrejas}

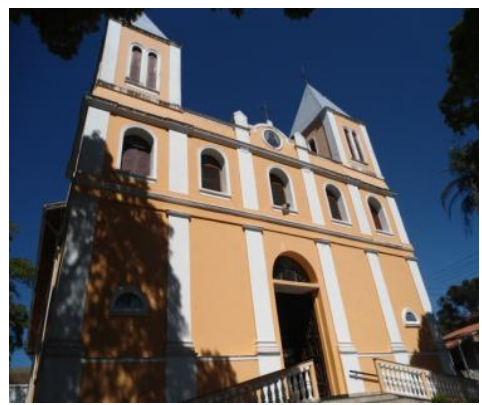

Igreja Matriz Nossa Senhora do Bonsucesso

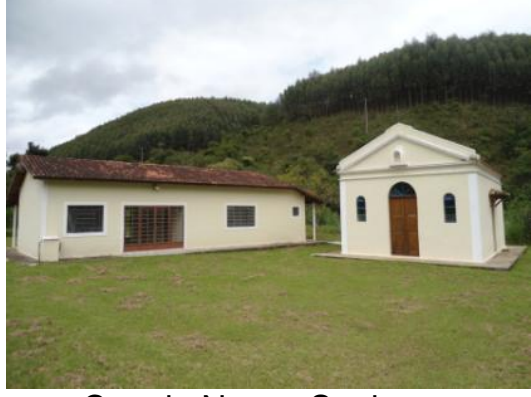

Capela Nossa Senhora

Aparecida - Descoberto

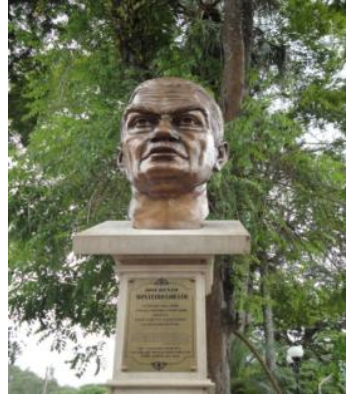

Busto de Monteiro Lobato

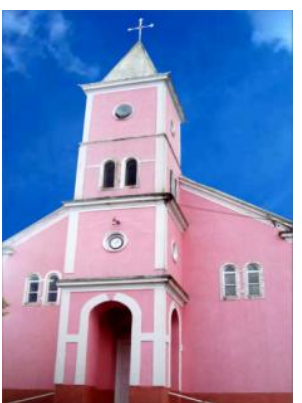

Capela de Santa Rita - Souza

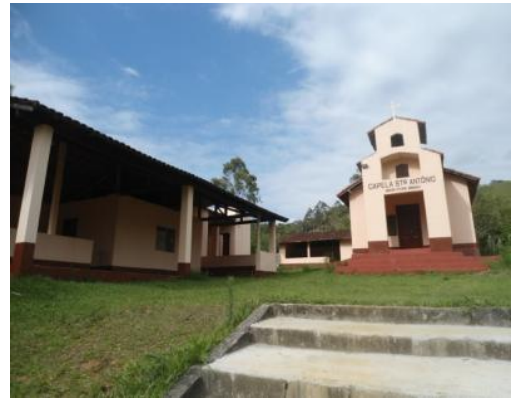

Capela de Santo Antonio Pedra Branca

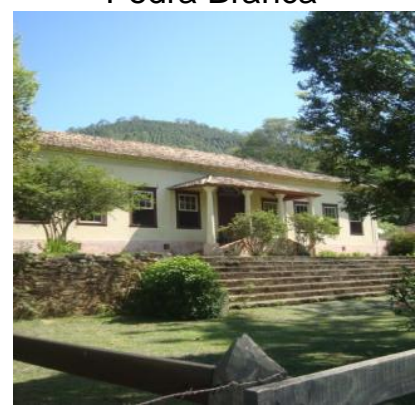

Sítio do Pica-pau Amarelo

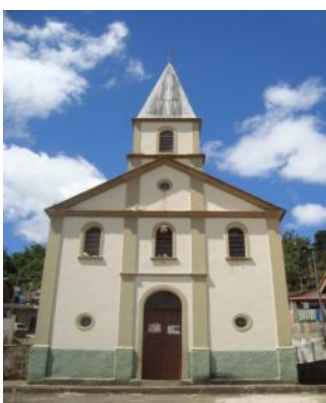

Igreja de São Benedito

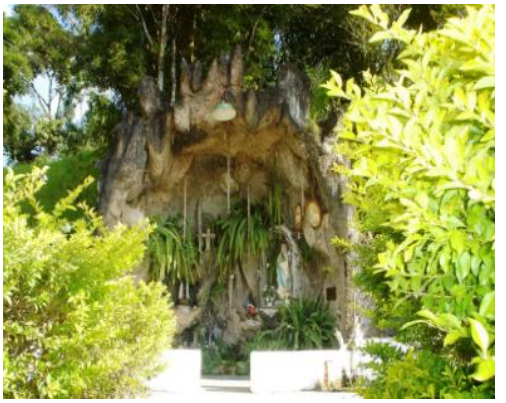

Gruta de Nossa Senhora de Lourdes

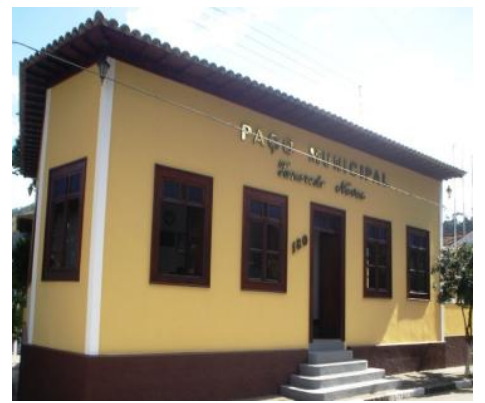

Paço Municipal Prefeito João Bueno

Foto 8 - Conjunto de fotos Atrativos Culturais - Patrimônio Histórico/Monumentos e Igrejas 


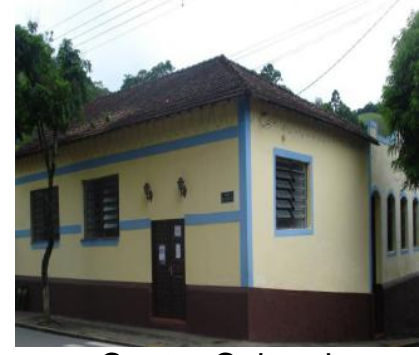

Centro Cultural

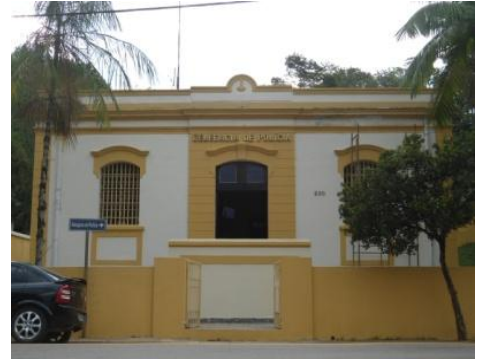

Delegacia da Polícia Civil

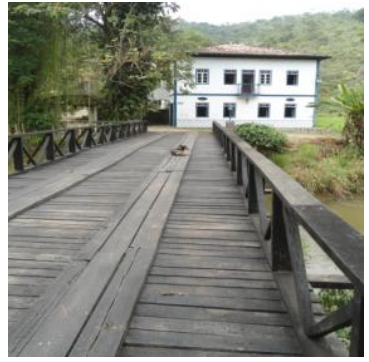

Fazenda Ponte Preta

Foto 8 - Conjunto de fotos Atrativos Culturais - Patrimônio Histórico/Monumentos e Igrejas (continuação)

\section{Manifestações Populares/Artesanatos e Gastronomia Típica}

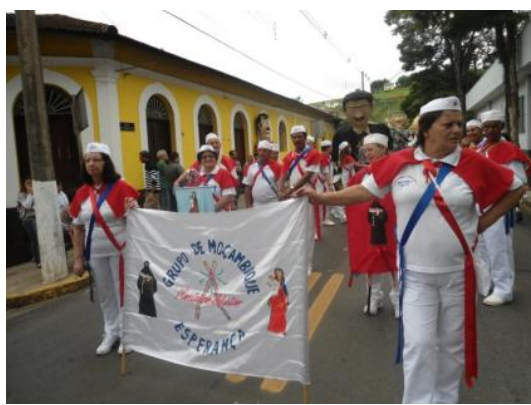

Grupo de Moçambique Esperança

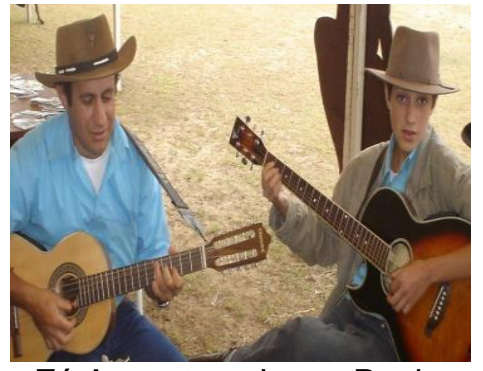

Zé Augusto e Jonas Paulo

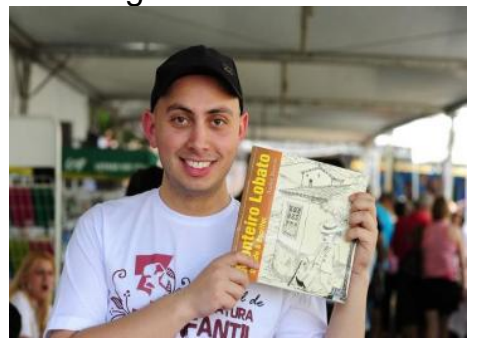

André Barreto

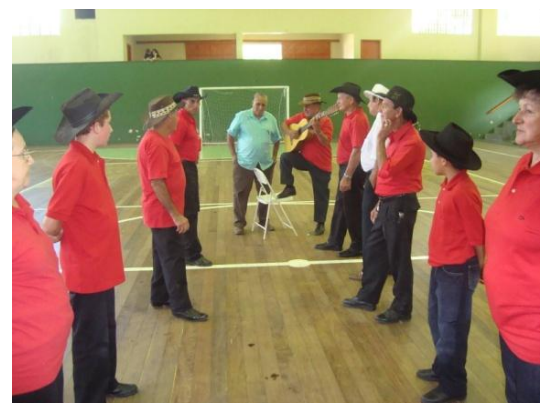

Grupo de Catira União Lobatense

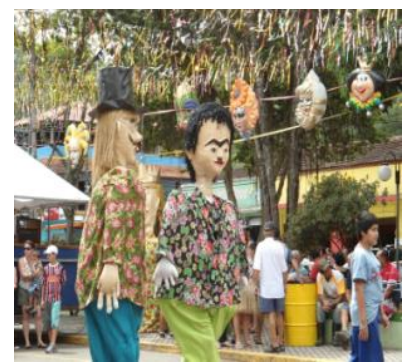

Pereirões

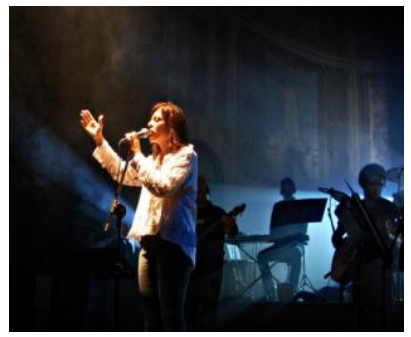

Josiane Medeiros

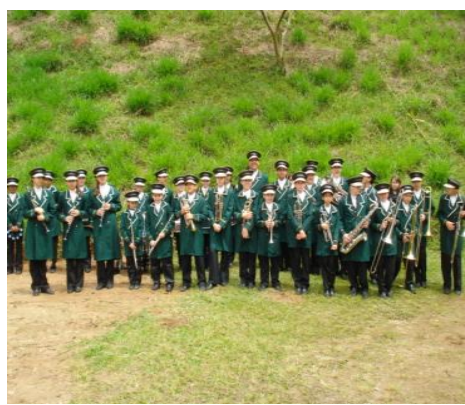

Banda Municipal de Concertos

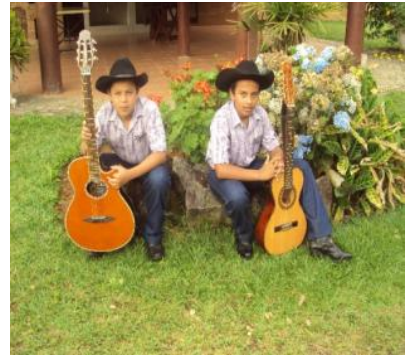

José Junior e Gabriel

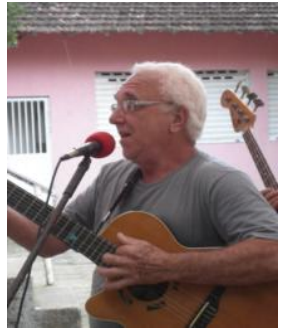

Primo Augusto Gerbelli Foto 9 - Conjunto de fotos de Manifestações Populares/Artesanatos e Gastronomia Típica 
ARTE E ARTESANATO

\begin{tabular}{|l|l|}
\hline Antigo \& Novo Móveis e Artesanato & artesanato e móveis antigos \\
\hline Aparecida Batista de Oliveira Costa & bonecos de pano \\
\hline Arte Terra Loterias & artesanato, papelaria, lotérica \\
\hline Artesanato Apícola - B. da Pedra Branca & pesos, panos de prato, taboa, bambu \\
\hline Atelier Bons Ventos & artes plásticas \\
\hline Atelier Yas e Brisa & cerâmica \\
\hline Casa da Boneca - loja & bonecos de pano \\
\hline Eduardo de Paula (Fogado) & $\begin{array}{l}\text { esculturas em argila, papel, madeira e fibras } \\
\text { naturais }\end{array}$ \\
\hline Elizete de Souza Vasconcellos & restauração de móveis \\
\hline Erivaldo dos Santos Mello & $\begin{array}{l}\text { esculturas de animais, quadros, placas, } \\
\text { chaveiros e móveis }\end{array}$ \\
\hline Graça de Fátima Moraes Albino & cestaria em taboa, flores em palha de milho \\
\hline Lázara da Conceição Moreto & bonecos de pano \\
\hline Luzia Mara Artesanatos & biscuit, porta-objetos, kit costura, outros \\
\hline Marcos Alexandre de Oliveira Quintas & móveis em madeira \\
\hline Maria Aparecida dos Santos & bonecos de pano \\
\hline Maria da Graça Dias Chaves & tricô \\
\hline Maria Laura Pereira & bonecos de pano \\
\hline Maria Lídia de Oliveira & bonecos de pano \\
\hline Mosaico da Leila & mosaico \\
\hline Nuna Artesanato - loja & bonecos de pano, bijuterias \\
\hline O Arteiro & artes plásticas - mosaico e artesanato \\
\hline Primo Augusto Gerbelli & reciclagem, pintura, música e desenho. \\
\hline Reflexo da Mata - loja & $\begin{array}{l}\text { artesanato madeira, tecido, palha de milho, } \\
\text { taboa, móveis rústicos, bonecos de pano etc. }\end{array}$ \\
\hline Sebastião Rodrigues & cestaria, monjolo, pilão \\
\hline Tania Alves Pedroso & cerâmica \\
\hline Vania Artesanato - loja & bonecos de pano, outros \\
\hline Vania Regina Palmieri & caixas de madeira e utensílios decorados \\
\hline
\end{tabular}

Quadro 98 - Relação de Artesãos e Artistas plásticos
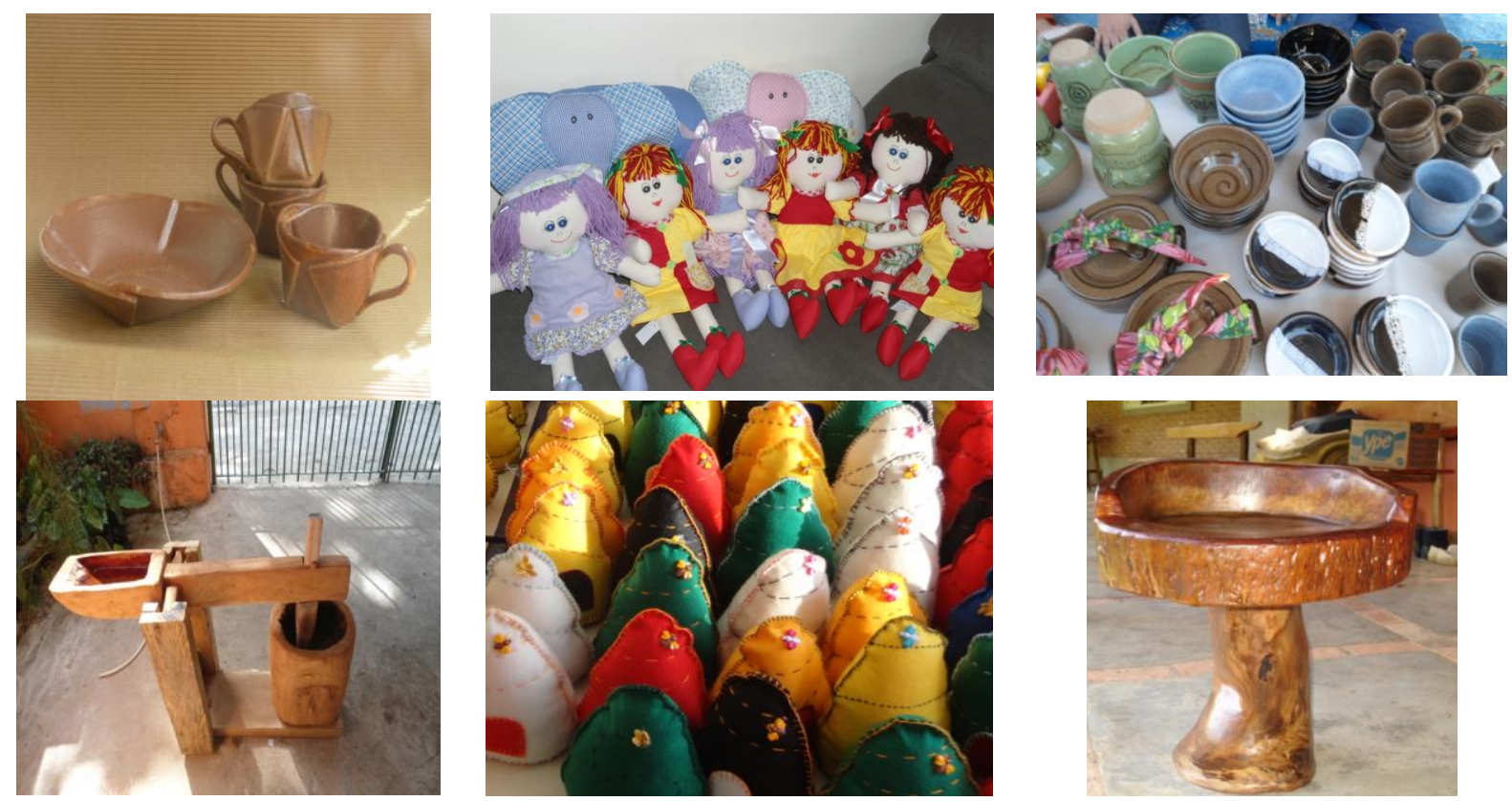

Foto 10 - Conjunto de fotos de artesanato 


\section{Turismo Rural}

\begin{tabular}{|l|l|}
\hline $\begin{array}{l}\text { Associação dos Pequenos Produtores } \\
\text { Rurais de Monteiro Lobato e Região - APPR }\end{array}$ & $\begin{array}{l}\text { Produção de verduras, legumes, mel, } \\
\text { banana, silvicultura, gado leiteiro }\end{array}$ \\
\hline $\begin{array}{l}\text { Fazenda Esperança - Laercio de Aquino } \\
\text { Bairro da Ponte Nova }\end{array}$ & Produz doces, leite, goiaba, banana etc. \\
\hline $\begin{array}{l}\text { Doces artesanais e laticínio Dona Nena } \\
\text { Bairro do Souza }\end{array}$ & $\begin{array}{l}\text { Produção de doces artesanais, queijos } \\
\text { frescos, nozinhos de mussarela }\end{array}$ \\
\hline $\begin{array}{l}\text { Rancho Boa Ventura - Bairro Vargem } \\
\text { Alegre }\end{array}$ & Geleias de frutas \\
\hline Companhia Du Sítio - Bairro do Souza & $\begin{array}{l}\text { Geleias de frutas, tomate seco e berinjela em } \\
\text { conserva, temperos }\end{array}$ \\
\hline Sítio do Jatobá - Bairro do Descoberto & Polpas de fruta \\
\hline
\end{tabular}

Quadro 99 - Relação de Propriedades que oferecem produtos rurais

\section{Trilha do Mel - Roteiro turístico - Bairro da Pedra Branca}
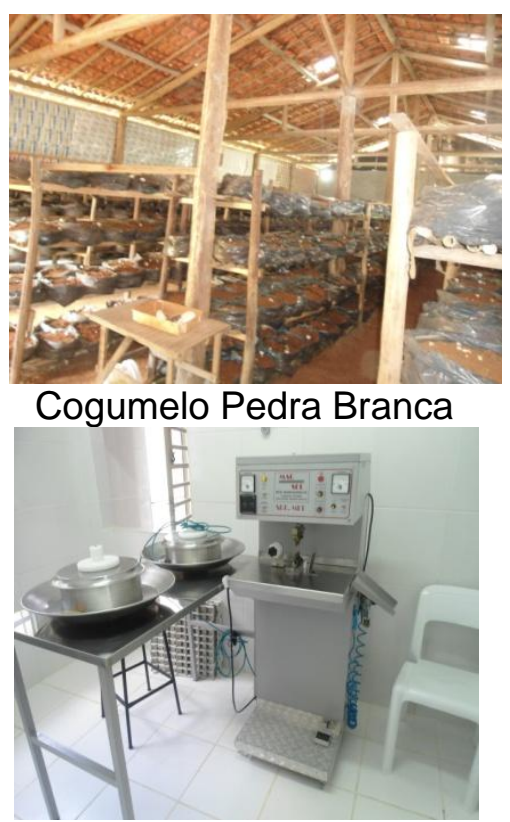

Casa do Mel

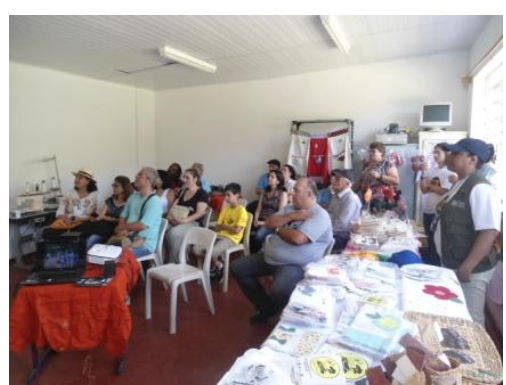

Centro Comunitário

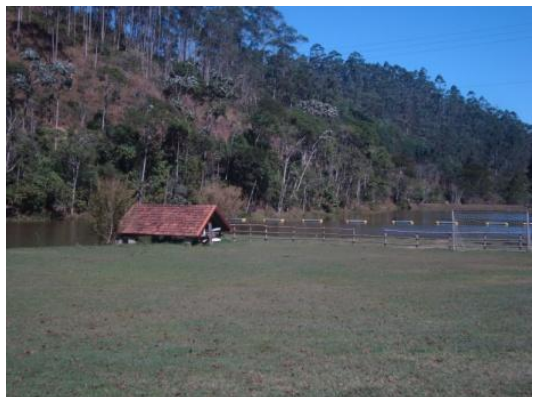

Recanto do Sauá

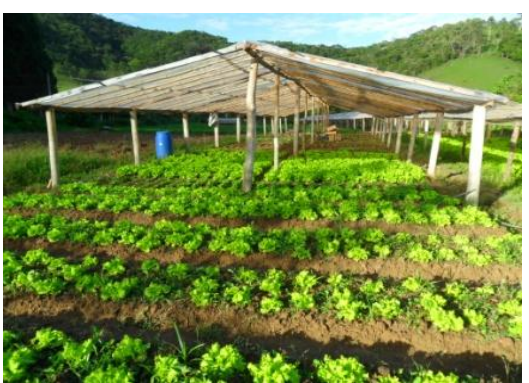

Horta do José Augusto

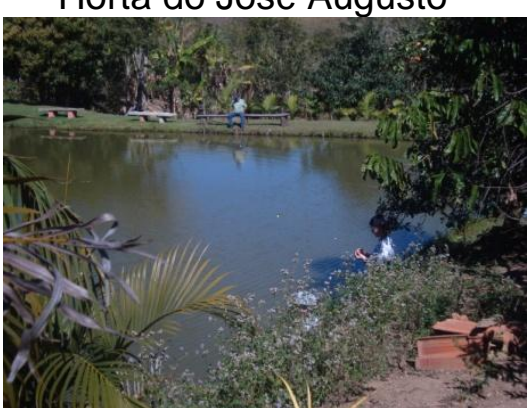

Pesca e Campo Pedra Branca

Foto 11 - Conjunto de fotos da Trilha do Mel 


\section{Atrativos Naturais - Hidrografia}
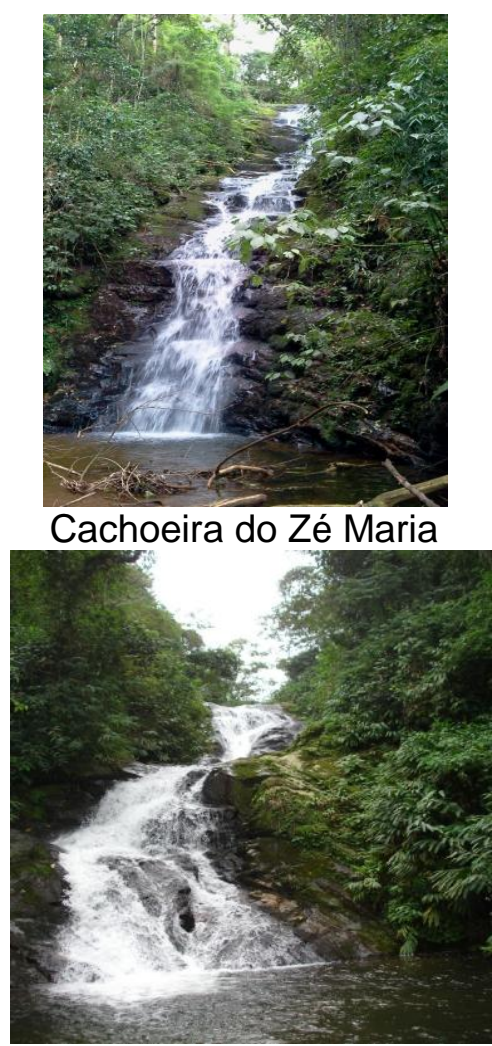

Cachoeira do João Paulo
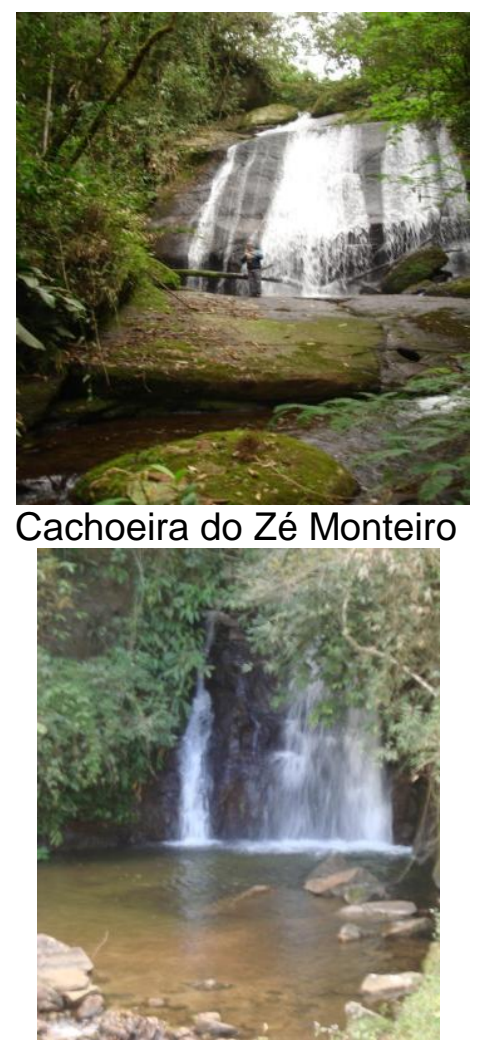

Beira do Riacho

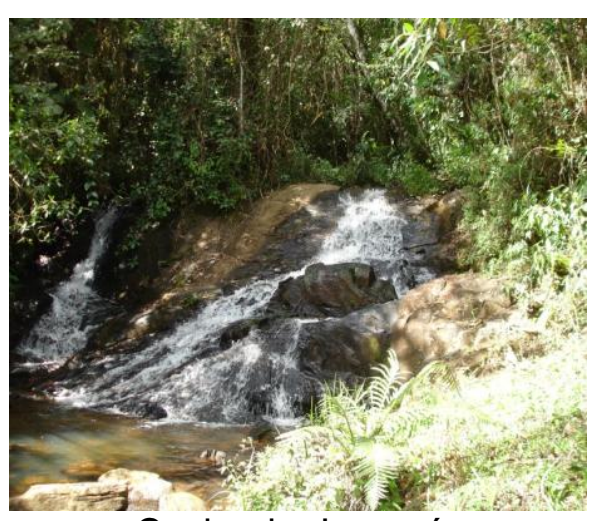

Cachoeira Lavapé

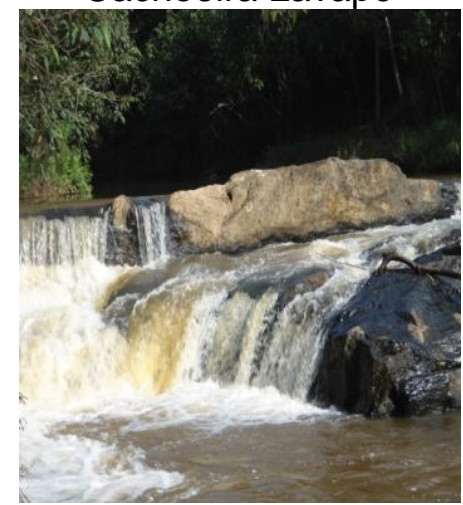

Sítio Santa Inês

Foto 12 - Conjunto fotos de Atrativos Naturais - Hidrografia

\section{Atrativos Naturais - Relevo}

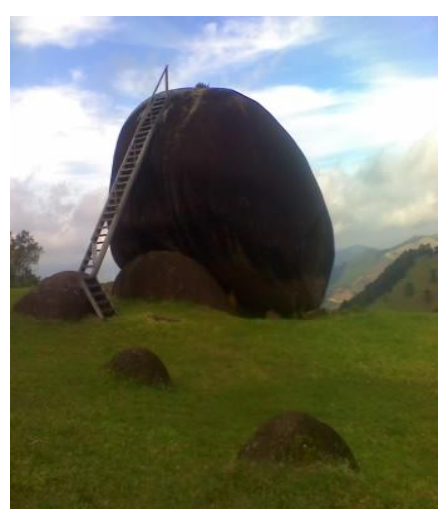

Pedra Trempe

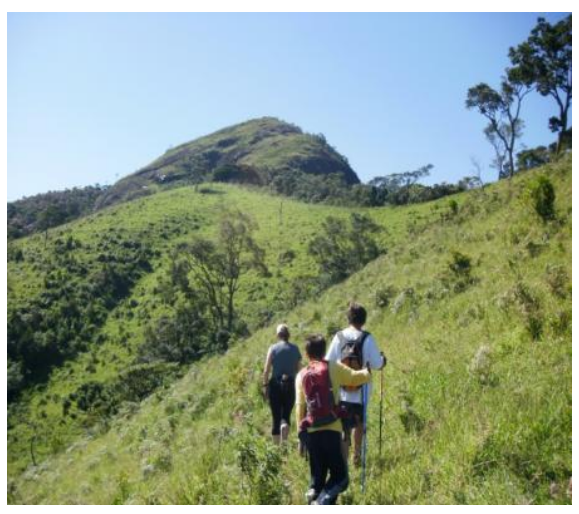

Pedra do Trabiju

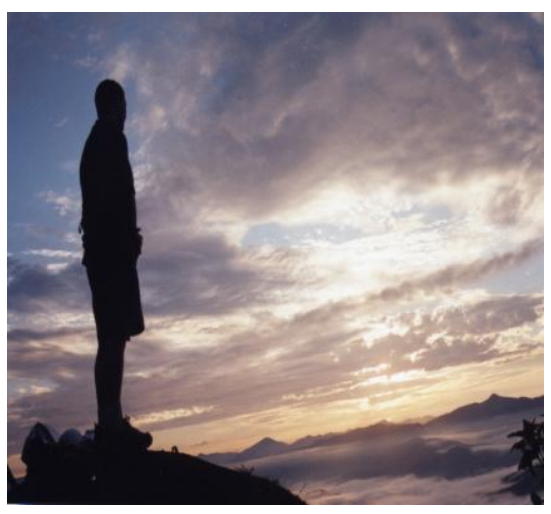

Pedra do OM

Foto: Hamilton Miragaia

Foto: Hamilton Miragaia

Foto 13 - Conjunto de fotos de Atrativos Naturais - Relevo 


\section{Atrativos Naturais - Vegetação}

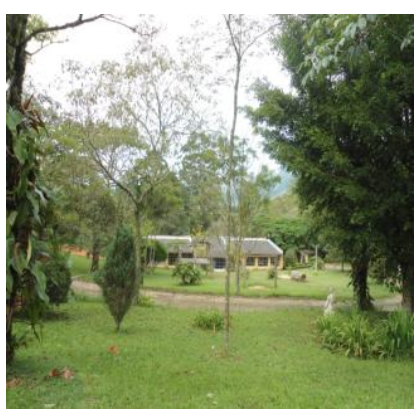

Instituto Pandavas - Reserva da Biosfera da Mata Atlântica

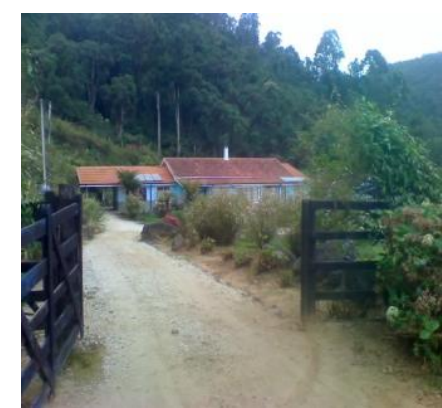

Trilha na Propriedade de Marcos Cezar Fonseca

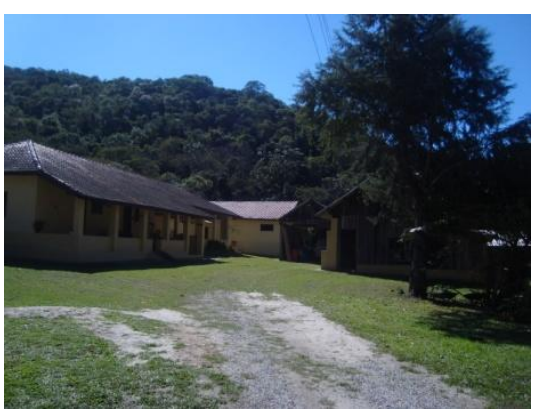

Trilha no Recanto do Sauá

Foto 14 - Conjunto de fotos de Atrativos Naturais - Vegetação

\section{EQUIPAMENTOS TURÍSTICOS}

\section{Meios de Hospedagem}

Capacidade Hoteleira - Monteiro Lobato - Novembro/2013

\begin{tabular}{|l|l|l|}
\hline NOME DA POUSADA & $\mathbf{N}^{\circ}$ UHs & $\mathbf{N}^{\circ}$ de Leitos \\
\hline Pousada e Restaurante Alto do Morro & 06 aptos. & 20 \\
\hline Pousada Aconchego do Caboclo & 6 chalés - & 15 \\
\hline Pousada Aldeias do Paraíso & 31 chalés & 100 \\
\hline Pousada Monteiro Lobato & 16 & 48 \\
\hline Pousada Bonsucesso & 06 & 18 \\
\hline Subtotal & $\mathbf{6 5}$ & $\mathbf{2 0 1}$ \\
\hline NOME SíTIO OU ALOJAMENTO & $\mathbf{N}^{\circ}$ UHs & $\mathbf{N}^{\circ}$ de Leitos \\
\hline Rancho da Amizade & 5 & 25 \\
\hline Sítio Serra da Mantiqueira & 2 chalés & 06 \\
& Casa - 3 quartos & 03 \\
\hline Recanto do Sauá & 2 blocos & Feminino: 52 \\
& & Masculino: 48 \\
\hline Recanto Shambala & 3 chalés, 3 suítes & 26 \\
\hline Sítio Juliana & 06 quartos & 36 \\
\hline Acampamento Luz e Vida & 3 suítes & \\
\hline Sítio Santa Inês & 08 quartos & 70 \\
\hline Fazenda Água Viva & 1 chalé, 3 casas & 50 \\
\hline Campo Escola Montanhismo & 1 alojamento & 90 \\
\hline Subtotal & 1 cabana & 04 \\
\hline TOTAL & $\mathbf{4 1}$ & $\mathbf{4 1 0}$ \\
\hline
\end{tabular}

Quadro 100 - Capacidade hoteleira - Monteiro Lobato - novembro/2013 
Restaurantes: 12, número de lugares: 1.077, incluindo os restaurantes das pousadas Aldeias do Paraíso e Alto do Morro.

\begin{tabular}{|l|r|}
\hline Aldeias do Paraíso & 90 \\
\hline Beira do Riacho & 150 \\
\hline Pesca e Campo Pedra Branca & 100 \\
\hline Rancho do Vale & 70 \\
\hline Tia Nastácia & 100 \\
\hline Resgate Caipira & 112 \\
\hline Alto do Morro & 40 \\
\hline Califórnia & 60 \\
\hline Zero Grau & 200 \\
\hline Bambu & 25 \\
\hline Taberna & 80 \\
\hline Sítio do Pica-pau Amarelo & 50 \\
\hline Total: & 1.077 \\
\hline
\end{tabular}

Quadro 101 - Relação de restaurantes e respectivos números de lugares

\section{Receptivo e Guias}

$\checkmark$ Passeios de Jipe com guia: Antonio Renato de Sá Sonnewend

$\checkmark$ Campo Escola Montanhismo: Educação Ambiental, Trilhas: Hamilton Rodolfo Miragaia

\section{Estrutura para Eventos}

\begin{tabular}{|l|l|}
\hline Local & $\mathbf{N}^{\circ}$ estimado \\
\hline Fazenda Serrinha & 300 pessoas sentadas e 500 pessoas em pé \\
\hline Espaço Mantiqueira & 500 pessoas sentadas \\
\hline Ginásio Poliesportivo & 600 pessoas sentadas \\
\hline Espaço de Eventos Casa Blanca & 250 pessoas sentadas \\
\hline Recinto de Exposições & 1.000 pessoas em pé \\
\hline
\end{tabular}

Quadro 102 - Estrutura para Eventos

\section{Eventos:}

\begin{tabular}{|l|l|}
\hline Festa de São Sebastião & janeiro \\
\hline Carnaval & março \\
\hline Festa de Nossa Senhora do Bonsucesso & agosto \\
\hline Festival da Literatura Infantil & setembro \\
\hline Torneio Leiteiro & novembro \\
\hline Campeonatos esportivos & Diversos meses \\
\hline
\end{tabular}




\subsection{Reativação do Conselho Municipal de Turismo de Monteiro Lobato (COMTUR-ML)}

A reativação do Conselho Municipal de Turismo de Monteiro Lobato (COMTUR-ML) foi uma necessidade identificada já na primeira Oficina. A pedido da Prefeita, o Grupo Planejatur coordenou, em 23 de maio de 2013, a reunião para sensibilização da comunidade sobre a importância da atuação do COMTUR-ML para o desenvolvimento do Turismo Sustentável no município e a gestão do Plano Diretor de Turismo Sustentável. Um forte argumento para a reativação do COMTUR-ML, sem dúvida, foi ser uma das condições para Monteiro Lobato pleitear o título de Município de Interesse Turístico, de acordo com o Projeto de Lei Estadual $n^{\circ}$ 32/2012. Dos 35 participantes dessa reunião, 15 fizeram adesão como membros titulares e 3 como suplentes no final da reunião. Na semana seguinte, estes novos membros juntamente com os membros do Grupo Planejatur empreenderam uma articulação para mais adesões para completar o quadro de 21 titulares e 21 suplentes previstos pela Lei $n^{\circ} 1.090 / 97$ que criou o COMTUR-ML. Foi interessante verificar que a equipe formada para essa tarefa analisou os nomes que iriam convidar, focando nos empresários que já investem em seus empreendimentos turísticos e que participaram das Oficinas. Após completada a lista, a relação dos nomes foi encaminhada pelo então Presidente do COMTUR-ML, Geminiano Jorge dos Santos, à Prefeita para publicação da Portaria de nomeação dos novos membros do COMTUR-ML que foi feita em 17 de junho de 2013, sob o ${ }^{0}$ 1.358/13. O próximo passo foi organizar a reunião de eleição da Diretoria realizada no dia 03 de julho de 2013. Foram eleitos: Antonio Renato de Sá Sonnewend para Presidente e Frederico Roberti de Araújo para Vice-Presidente. A convite do Presidente do COMTUR-ML recém-eleito, Anacélia de Mello Morente e Regina de Fátima Araujo assumiram os cargos de Secretária Executiva e Secretária Executiva Suplente respectivamente. Os membros do COMTUR-ML decidiram que irão se reunir na primeira quinta-feira de cada mês, às $18 \mathrm{~h} 30$ no Sindicato Rural. Em seu discurso de posse, Antonio Renato de Sá Sonnewend declarou que estava assumindo o cargo de Presidente do COMTUR-ML como "cidadão que quer ver Monteiro Lobato se desenvolver turisticamente, mas não do modo predatório, e sim um Turismo com envolvimento da sociedade e com a cara de Monteiro Lobato. Tem que ter a 
participação dos moradores, comerciantes, de todos, para conseguir desenvolver o Turismo Sustentável." Observa-se assim, que Antonio Renato de Sá Sonnewend incorporou o conceito do Turismo Sustentável e o defenderá em sua gestão como Presidente do COMTUR-ML pelos próximos 2 anos.

\subsection{0 envolvimento das escolas da rede municipal no Plano Diretor do Turismo Sustentável de Monteiro Lobato}

Os participantes da primeira Oficina com a comunidade, realizada no dia 15 de março de 2012, identificaram a necessidade das escolas ensinarem a história, a geografia, o meio ambiente e a cultura do município, bem como a vida e obra do escritor Monteiro Lobato. Na segunda Oficina, realizada no dia 28 de fevereiro de 2013, esta sugestão foi mantida e incluída no Programa de Ações - 1. Educação, Projeto - 1.1. Educação escolar e subprojeto - 1.1.1. Capacitação de professores nas áreas de Turismo Sustentável, Turismo Rural e Educação Ambiental. Nos meses seguintes conversei com a Secretária de Educação, Profa. Elisa M. César Parmera, com a Secretária de Meio Ambiente e Agricultura, Ecóloga Marilene Mesquita Silva e com o Secretário de Cultura e Turismo, Jornalista André Barreto, para planejarmos o curso para os professores da rede de ensino municipal, em 2013, programando-o para o primeiro semestre, de tal forma que os professores pudessem realizar algum projeto com os alunos no segundo semestre. Para planejar o curso para os professores, enviei a esses secretários a apostila elaborada para o curso de Capacitação em Turismo Sustentável realizado no segundo semestre de 2011 para a comunidade para avaliarem o conteúdo da mesma e darem sugestões para adaptá-la ao tempo disponível e perfil do público-alvo. Em adição, enviei a lista de atividades inerentes à organização das oficinas como modelo para que as secretarias organizassem o local, café, refeição e materiais. No dia 26 de julho de 2013, na semana de planejamento pedagógico das escolas, no horário das 08h30 às 17h30, foi ministrado por mim e pela Ecóloga Marilene Mesquita Silva o curso sobre Turismo Sustentável e Meio Ambiente para os professores da Rede Municipal de Ensino (42), os quais receberam a apostila com as informações socioambientais do município via e-mail. A abertura contou com a presença da Prefeita Daniela de Cássia Santos Brito, do Vereador João Francisco da Silva, Vice-Presidente da 
Câmara Municipal de Vereadores e de Antonio Renato de Sá Sonnewend, Presidente do COMTUR-ML.

Este curso foi realizado em duas partes: na primeira, foram apresentados conceitos e aspectos inerentes ao Turismo Sustentável e ao meio ambiente do município. A minha palestra abordou a visão geral dos aspectos do Turismo comparando os modelos tradicional (predatório e extrativista) e o Turismo Sustentável (que considera a prática da justiça social, respeito ao meio ambiente e à identidade e cultura locais), enfatizando que este último é modelo ideal que o município de Monteiro Lobato deve buscar. A Ecóloga Marilene Mesquita Silva apresentou os aspectos ambientais do município (flora, fauna, hidrografia, relevo, solos, clima, unidades de conservação e uso potencial da terra), a situação atual do saneamento básico e os projetos da Secretaria de Meio Ambiente e Agricultura, salientando as restrições do meio físico para o uso e a ocupação do solo bem como aquelas determinadas por leis federais e estaduais uma vez que Monteiro Lobato é Área de Proteção Ambiental (APA) federal porque o Rio Buquira que se une ao Ferrão, contribuindo para a Bacia Hidrográfica do Rio Paraíba do Sul.

$\mathrm{Na}$ segunda parte do curso, apresentei o conceito de interdisciplinaridade e a tarefa proposta para que elaborassem projetos interdisciplinares tendo como eixos transversais o meio ambiente e o Turismo do município. Os professores se dividiram em grupos para elaborarem propostas de projetos interdisciplinares que consideraram viáveis e os apresentaram aos demais professores em plenária. Para eventual consulta, forneci livros, trabalhos acadêmicos e mapas do município, utilizados na elaboração da apostila.

Os professores da EMEF Olivia dos Santos Feierabend, localizada no Bairro do Taquari, optaram por fazer um projeto integrado dentro do conceito de projetos verticais (há uma sequência dos temas do infantil ao $5^{\circ}$ ano) e os professores das demais escolas dividiram-se em grupos por séries dentro do conceito de projetos horizontais (acontecem em um ano, envolvendo mais de uma disciplina). Os projetos elaborados voltaram-se para os seguintes temas: Monteiro Lobato: um baú de riquezas naturais e culturais; Cultura e tradições; Nossa flora e fauna; Conhecendo nossa história; Observação, percepção, interação e contato com as histórias; Animais da Mata Atlântica; e Conhecendo o ecossistema lobatense. Nos dias 12 e 13 de dezembro de 2013, as professoras organizaram a Mostra Pedagógica com exposição dos trabalhos feitos pelos alunos na Escola Micheletto. 
Propostas de projetos apresentadas pelos professores:

\begin{tabular}{|c|c|c|}
\hline Professores & Tema & Objetivo \\
\hline $\begin{array}{l}\text { Grupo de professoras } \\
\text { da EMEF Olivia dos } \\
\text { Santos Feierabend do } \\
\text { Bairro do Taquari }\end{array}$ & $\begin{array}{l}\text { Monteiro Lobato: um baú } \\
\text { de riquezas naturais e } \\
\text { culturais } \\
\text { Infantil: Personagens } \\
\text { 1 ano: água } \\
2^{\circ} \text { ano: fauna (animais } \\
\text { domésticos) } \\
3^{\circ} \text { ano: fauna (animais } \\
\text { silvestres) } \\
\text { 4o ano: geografia } \\
5^{\circ} \text { ano: história do } \\
\text { município e literatura. }\end{array}$ & $\begin{array}{l}\text { incentivar a valorização do } \\
\text { município através do } \\
\text { conhecimento ambiental e } \\
\text { cultural característicos de } \\
\text { Monteiro Lobato, utilizando } \\
\text { recursos multimídias como } \\
\text { veículo de divulgação, } \\
\text { contribuindo com o produto final } \\
\text { para fonte de pesquisa. }\end{array}$ \\
\hline \multirow[t]{3}{*}{ Educação Infantil } & Cultura e tradições & \\
\hline & nossa flora e fauna & $\begin{array}{l}\text { Danças, lendas, pereirões, Hino } \\
\text { de Monteiro Lobato, entrevistas } \\
\text { com Moradores Antigos, Visitas. } \\
\text { desenvolver com as crianças: } \\
\text { Observação, Percepção, } \\
\text { Interação e contato com a } \\
\text { natureza. }\end{array}$ \\
\hline & $\begin{array}{l}\text { conhecendo nossa } \\
\text { história }\end{array}$ & $\begin{array}{l}\text { desenvolver com as crianças: } \\
\text { Pesquisa antes e atual/cidade de } \\
\text { Monteiro Lobato; História do } \\
\text { Escritor, história do sítio; Escolas: } \\
\text { primeiras escolas. Observação, } \\
\text { percepção, interação e contato } \\
\text { com as histórias. }\end{array}$ \\
\hline $1^{\circ}, 2^{\circ}$ e $3^{\circ}$ Anos & Animais da Mata Atlântica & $\begin{array}{l}\text { Objetivos: trabalhar os animais da } \\
\text { Mata Atlântica dando ênfase nos } \\
\text { animais da região da cidade de } \\
\text { Monteiro Lobato. Despertar na } \\
\text { criança a importância da fauna } \\
\text { local, conhecê-la para protegê-la } \\
\text { e preservá-la. } \\
\text { Produto final: exposição de arte } \\
\text { através de desenhos, } \\
\text { dobraduras, fotos, músicas, } \\
\text { danças, entre outras. }\end{array}$ \\
\hline $4^{\circ}$ e $5^{\circ}$ anos & $\begin{array}{l}\text { Conhecendo o } \\
\text { ecossistema lobatense }\end{array}$ & $\begin{array}{l}\text { Vivenciar contato direto com a } \\
\text { natureza, proporcionando } \\
\text { sensibilização sensorial } \\
\text { Internalizar conteúdos didáticos } \\
\text { estudados em sala de aula } \\
\text { Ampliar os conhecimentos sobre } \\
\text { ecossistema lobatense }\end{array}$ \\
\hline
\end{tabular}

Quadro 104 - Projetos elaborados pelos professores 

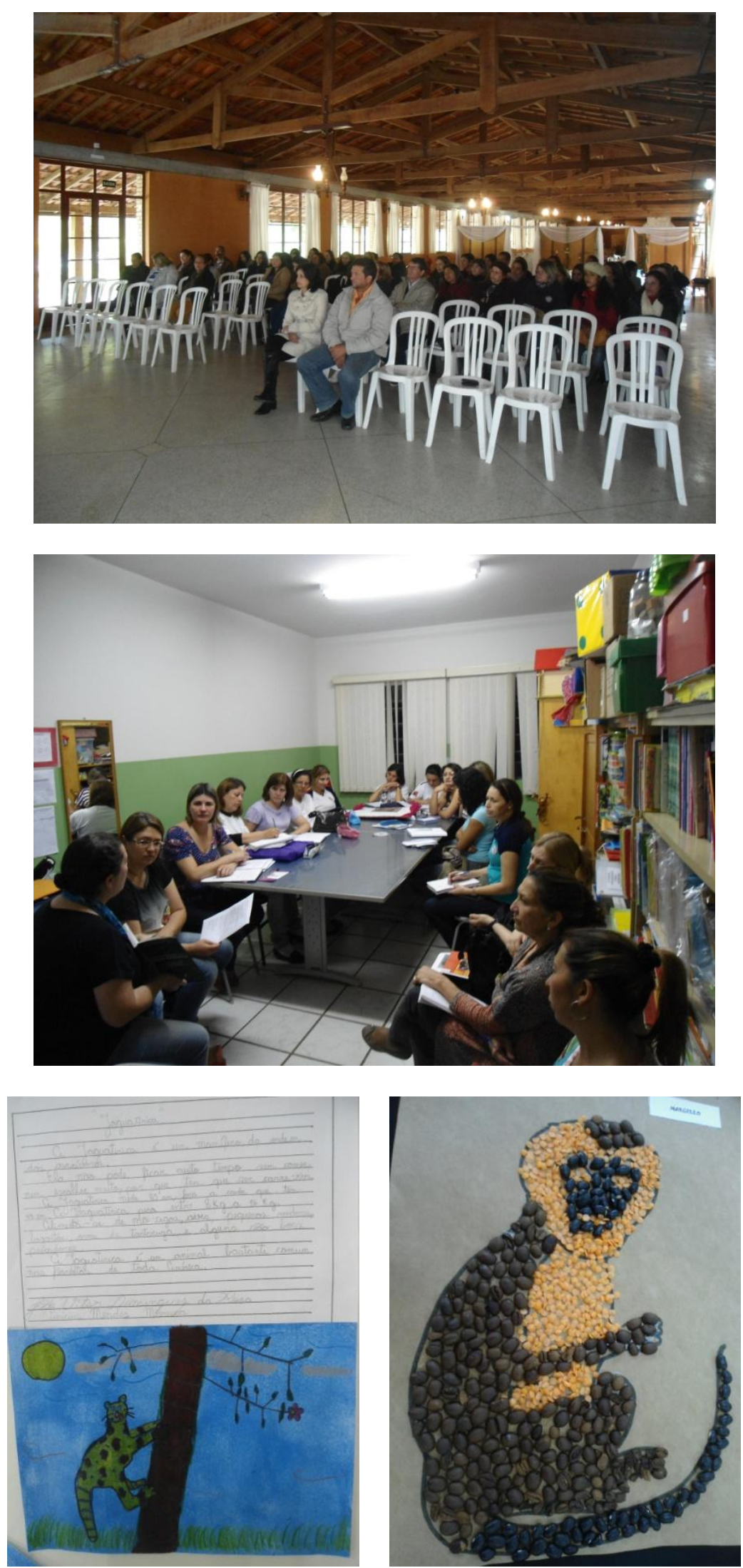

Foto 15 - Conjunto de fotos Curso para Professores e Mostra Pedagógica - alunos do 3ํAno - Tema: Animais da Mata Atlântica - 12 e 13 de dezembro de 2013 


\section{O PROCESSO DO DESENVOLVIMENTO DA PESQUISA-INTERVENÇÃO}

Este trabalho investigou a situação do contexto de Monteiro Lobato, SP e descreve a construção compartilhada de um plano de Turismo para o município, tendo a sustentabilidade como horizonte. A pesquisa classifica-se como projeto social, uma vez que se dedica à busca de solução de um problema situado dentro de uma problemática social, qual seja - a organização do Turismo Sustentável em Monteiro Lobato para evitar que a atividade ali seja implantada no modelo tradicional. As ações desta pesquisa foram projetadas como intervenção estratégica sobre problemáticas sociais, quando estabeleceu, já no projeto inicial, em 2009, a interdisciplinaridade envolvendo as áreas de conhecimento da Psicologia Socioambiental, da Participação Social e do Planejamento do Turismo Sustentável a serem utilizadas na construção de um projeto coletivo que atendesse as expectativas da comunidade. A experiência da pesquisadora na área de fomento ao Turismo, desde 1991, identificou a dificuldade de pequenos municípios elaborarem planos diretores de Turismo e a ausência de conhecimento sobre o Turismo Sustentável na Região Metropolitana Vale do Paraíba e Litoral Norte (RMVPLN).

O projeto inicial indicava como etapas da pesquisa: a) identificação das lideranças governamentais, empresariais e da sociedade organizada do município selecionado e proposição de formas de interação para busca de apoios institucionais e logísticos; b) mobilização e sensibilização dos grupos de habitantes envolvidos em um trabalho de educação popular realizado junto com e a serviço da comunidade; $c$ ) elaboração do Plano Diretor de Turismo Sustentável para o município de forma participativa, e d) análise e acompanhamento do processo de planejamento participativo adaptativo.

A pesquisa-intervenção foi a técnica utilizada no desenvolvimento desse trabalho uma vez que se propôs intervir na dinâmica do município que tivesse potencial turístico, mas que estivesse se desenvolvendo de forma espontânea, sem planejamento, correndo o risco de seguir o modelo tradicional de Turismo, predatório e extrativista. Portanto, a intervenção social se deu na tentativa de desviar o desenvolvimento turístico do município da forma espontânea para o caminho do 
planejamento turístico, especificamente para o planejamento do Turismo Sustentável. Diz-se tentativa porque o resultado efetivo só poderá ser verificado no futuro. No entanto, a mudança social produzida, dentro do possível de ser observada até o momento, é evidenciada pela incorporação da expressão "Turismo Sustentável" no discurso do governo municipal e do Grupo Planejatur que está levando-a para dentro do recém-reativado Conselho Municipal de Turismo de Monteiro Lobato (COMTUR-ML) e para a comunidade do município e região por meio de artigos no Jornal Serra da Mantiqueira, no site da Prefeitura e em vídeo de 8 minutos, editado para ser apresentado na entrega do Plano Diretor de Turismo Sustentável à comunidade, em 16 de janeiro de 2014, e publicado no site Youtube por meio do link: http://youtu.be/4bJojN9QJLM.

\subsection{Situação de contorno: a circunstância sociopolítica do município}

Por meio da pesquisa documental, encontraram-se atas de reuniões da comunidade para discussão dos problemas socioeconômicos do município. Das atas de duas reuniões de planejamento participativo, realizadas em 03 e 19 de fevereiro de 2009, no início da gestão do Prefeito Gabriel Vargas Moreira ${ }^{27}$, destacam-se as seguintes falas:

$\checkmark$ Participante 1: "grande importância deste projeto para nosso município e lembra de tantas tentativas feitas buscando o desenvolvimento sustentável desta cidade e que nunca foram levadas até o final. Comprovação disso: decreto 2001 que criou a agenda 21 para ML e que está engavetado".

$\checkmark$ Participante 2: "algumas ações fazem-nos perceber que há uma vontade de se criar uma identidade lobatense".

$\checkmark$ Participante 3: (auxiliando o funcionamento do CMDCA): "o próprio nome da cidade já demonstra sua vocação cultural. Sonha com esta cidade tendo seu escritor como tema transversal, permeando todos os setores da sociedade".

\footnotetext{
${ }^{27}$ Cópias das atas de Planejamento Participativo de Monteiro Lobato de 03 e 19 de fevereiro, 19 de março e 13 de maio de 2009, cedidas pela Secretária de Meio Ambiente e Agricultura, Marilene Mesquita Silva.
} 
$\checkmark$ Participante 4: "existe um desejo pelo novo, mas também há muitas resistências".

$\checkmark$ Participante 5: "precisamos preservar a história, a ideia, a memória. Precisamos fazer o povo gostar de ser lobatense".

$\checkmark$ Participante 6: "alerta para que precisamos tomar cuidado de não querer importar ideias, mas de se resgatar o que se é".

$\checkmark$ Participante 7: "acredita na possibilidade de termos uma representatividade, mas para isso esse fórum precisa ser instituído de verdade! Precisa-se pensar numa dinâmica que consiga abranger os bairros mais distantes".

$\checkmark$ Participante 8: "fala da importância das regulamentações para poder haver cobrança do poder público em relação à população - do zoneamento, da criação de estância turística, da importância de termos apoio dos deputados estaduais e federais".

$\checkmark$ Participante 6: "acha que a direção, o rumo da cidade, precisa ser definido pela população”.

$\checkmark$ Participante 9: "demonstra a preocupação de se envolver a população neste processo, pois este grupo representa uma pequena parcela, muito restrita e não representativa, já que a população nativa não tem hábito de participar de reuniões". [...] Nós idealizamos uma cidade melhor, mas quem garante que o que queremos é o melhor para todos?

$\checkmark$ Participante 10: "as pessoas que têm mais esclarecimento, que tiveram oportunidade de estudar mais, conhecer outras realidades, têm obrigação de clarear os horizontes dos demais, demonstrando o que seria melhor e por que".

$\checkmark$ Participante 11: "Qual é a nossa vocação? As pessoas não querem mais estudos, querem ver as coisas acontecendo na prática. Quem vai aos Conselhos? Precisamos de propostas mais claras, objetivas".

$\checkmark$ Participante 12: "volto a afirmar que nossa população está desmotivada. O povo não vê rumo, espera tudo da prefeitura, como se fosse uma mãe [...]. A prefeitura é a única geradora séria de empregos na cidade. Precisamos pensar em uma forma de ousar, arriscar. Não avançamos em nada depois de quase vinte anos de discussões, Agenda 21, DLIS, Desenvolvimento Sustentável..." 
$\checkmark$ Participante 10: "quando fazemos planos acima da realidade caímos na armadilha de não conseguir realizá-los e acabamos culpando as autoridades, esperando que façam tudo. Por isso, acho que temos que 'fazer as coisas'. Parar de criticar e fazer! Mudar de postura, ter esperança!"

As falas selecionadas revelam a situação de contorno no município do início dessa pesquisa porque esse planejamento participativo, proposto na Gestão Vargas, não aconteceu e os problemas continuaram, como comprova a árvore dos problemas construída na primeira Oficina de planejamento turístico do município em 15 de março de 2012, na qual foram levantados problemas similares. Portanto, a problemática para um desenvolvimento socioeconômico do município, na época da apresentação desse trabalho para a comunidade, em junho de 2011, continha o seguinte conjunto de problemas:

$\checkmark$ desânimo em virtude de iniciativas de planejamento do desenvolvimento sustentável do município feitas no passado que não tiveram continuidade;

$\checkmark$ necessidade de buscar uma identidade para o lobatense;

$\checkmark$ necessidade de potencializar a capacidade de atração que o nome Monteiro Lobato tem;

$\checkmark$ existência de forças entre aqueles que querem o novo e os que resistem ao novo;

$\checkmark$ percepção de que a memória, a cultura local e a autoestima do lobatense precisavam ser resgatadas;

$\checkmark$ formação de um órgão representativo da comunidade;

$\checkmark$ incentivo à participação social para decidir os rumos do município;

$\checkmark$ necessidade de motivar a população nativa a participar de reuniões da comunidade sobre as questões socioambientais do município;

$\checkmark$ definição da vocação do município;

$\checkmark$ busca de propostas mais claras e objetivas;

$\checkmark$ mudança de atitude: parar de criticar e fazer, mudar de postura;

$\checkmark$ elaboração de regulamentações que facilitem a gestão pública;

$\checkmark$ busca da classificação do município como estância turística;

$\checkmark$ articulação com deputados estaduais e federais. 
Depreende-se que a comunidade desejava participar de um movimento pródesenvolvimento socioeconômico do município, mas não havia projeto nem credibilidade em estudos por causa daqueles que não tiveram continuidade no passado e não existia uma pessoa ou uma entidade que pudesse liderar o processo. Nesse contexto, a proposta desse estudo foi recebida por alguns com descrença e como uma esperança por outros. Mas, no geral, a proposta foi bem recebida uma vez que não havia conflito nenhum e o estudo propunha o que a comunidade buscava, ou seja, um movimento que promovesse a participação da comunidade e um mecanismo que colaborasse na busca da classificação do município como estância turística. Além disso, ele estava suportado pela mais importante universidade do mundo ibero-português, a Universidade de São Paulo (USP). Sendo uma tese de doutorado, o risco para a comunidade seria pequeno, uma vez que o máximo que poderia acontecer era o projeto não ser bem-sucedido como os anteriores e nada mudar.

\subsection{Os "de fora" e a não-participação dos nativos}

Identifica-se um aspecto interessante quando o Participante 9 diz que a "população nativa não tem hábito de participar de reuniões". Há duas questões para serem analisadas: o antagonismo dos "de fora" versus os "de dentro" e a nãoparticipação da comunidade em discussões sobre o município.

A expressão "de fora" é usada quando um "nativo" se refere a qualquer pessoa que não tenha nascido em Monteiro Lobato. Em uma ocasião, a pesquisadora foi questionada por uma moradora sobre quem fazia parte do Grupo Planejatur. Assim que a resposta foi dada, essa pessoa exclamou: "Está vendo? Todos de fora!". No entanto, duas pessoas citadas nasceram e estudaram no município, mas viveram por certo período em São José dos Campos em função do trabalho e, mesmo assim, foram consideradas "de fora". Depreende-se que são considerados "de dentro" os que nasceram e não saíram do município. Porém, por não existir maternidade no município, as mães dão à luz em São José dos Campos e as crianças são registradas como joseenses, mas são criadas como lobatenses ("de dentro"). Por outro lado, é importante registrar que a cordialidade sempre existe e, embora haja a rotulação de quem é "de fora", à medida que o "forasteiro" começa 
a ficar conhecido e a conquistar a confiança das pessoas, o acolhimento e a amizade surgem e, portanto, não se trata de preconceito, mas de um processo normal no encontro de novos relacionamentos.

Mas a expressão usada para os que vêm "de fora" não é exclusivo de Monteiro Lobato. A pesquisadora observou o mesmo tratamento em São Francisco Xavier (Distrito de São José dos Campos) onde os "de fora" são chamados de "forasteiros". Essa expressão é registrada por Magalhães (2002, p. 53) para apresentar a problemática da migração em função do Turismo:

No entender dos habitantes de Porto Seguro, "os forasteiros" que invadem a cidade e vilas próximas, no intuito de fixar residência e desenvolver alguma atividade lucrativa, diminuem as oportunidades de inserção na comunidade (muitas vezes despreparada para competir) no novo mercado de trabalho, oferecido pelos empreendimentos que ali se estabelecem.

Outra consequência desse tipo de migração que Magalhães (2002, p. 74) salienta, citando a cidade de Tiradentes, MG, é a remodelação do lugar turístico de acordo com a ótica dos empresários vindos "de fora" que investem em equipamentos e serviços turísticos:

É certo que o conjunto de investimentos proporcionou a reabilitação da cidade histórica, que, se não fosse isso, estaria completamente descaracterizada ou mesmo destruída, como se tem observado em outras cidades do interior mineiro. Não se pode negar que a reorganização promoveu o desenvolvimento econômico da antiga vila. Porém, é preciso salientar que esse movimento provocou também a exclusão e a segregação de uma boa parte da população nativa, tendo em vista que a atividade turística aí desenvolvida foi direcionada para atingir uma classe superior de turistas.

A vida cotidiana de uma cidade é dinâmica (mesmo naquelas que são ditas pacatas), não é possível dizer "para tudo que vamos planejar e colocar ordem na cidade". Em geral, as pessoas visitam as cidades com potencial turístico e, se buscam uma vida alternativa em outros lugares, mudam-se viabilizando sua permanência por meio de investimentos no comércio, em equipamentos turísticos ou mesmo buscando empregos. Como têm parâmetros de comparação com outras 
realidades, acabam influenciando o local com suas ideias. O que é não é ruim como é dito nas palavras do Participante 10: "as pessoas que têm mais esclarecimento, que tiveram oportunidade de estudar mais, conhecer outras realidades, têm obrigação de clarear os horizontes dos demais, demonstrando o que seria melhor e por que". Entretanto, por terem uma visão mais ampla do que querem com objetivos e metas definidos, acabam por direcionar os rumos da cidade dentro da sua visão de mundo até porque os nativos não se manifestam e não participam das discussões de interesse da coletividade como mencionado pelo participante 9.

Em uma reunião com a comunidade de São Francisco Xavier, coordenada pela pesquisadora, uma munícipe disse que não queria o Turismo porque traz drogas, degradação do meio ambiente etc. A resposta que a pesquisadora deu foi: "Querendo ou não querendo, o turista está vindo e, assim, a comunidade precisa se organizar para estruturar a atividade e tentar minimizar os impactos negativos".

Mas como incentivar a estruturação do lugar turístico diante da nãoparticipação da comunidade? Se a comunidade autóctone não tem o hábito de participar de reuniões sobre as questões que envolvem o município, ela abre espaço no campo das decisões para os "de fora" que se preocupam com os rumos do local seja por tê-lo adotado como seu, seja pelas possibilidades econômicas que o local Ihes proporciona. Em adição, Souza (2004, p. 335) chama a atenção para o fato de que "a própria percepção da participação como um fardo é um valor destilado pela ideologia que estimula a apatia política e o desinteresse pelos assuntos coletivos" e, em complementação diz:

Muitas pessoas, por comodismo, e apesar de uma usual desconfiança em relação à chamada "classe política", podem achar ser mais fácil entregar o poder de decidir sobre assuntos que afetam a sua vida a políticos profissionais e especialistas, sem fazer ideia do quão funcional esse comportamento é para o sistema de dominação que, de um modo ou de outro, as prejudica ou pode prejudicá-las, ao tolher sua liberdade. Em vista disso, assume o autor, com convicção, que a participação não é um simples acessório, nem mesmo apenas uma ferramenta útil. Participar, no sentido essencial de exercer a autonomia, é a alma mesma de um planejamento e de uma gestão que queiram se credenciar para reivindicar seriamente o adjetivo democrático(a) (grifo do autor).

Além do entendimento da participação como um fardo quanto ao trabalho e ao tempo que o indivíduo deverá dedicar à participação em um projeto coletivo e do 
comodismo em favor da "decisão do outro", há, ainda, a não-participação causada pelo clientelismo quando interesses pessoais não serão atendidos pelo coletivo e, em represária, o indivíduo, não se envolve no processo proposto. Também, é comum encontrar resistências às mudanças que podem ser identificadas durante o processo de transformação como as seguintes:

a) Desconhecimento sobre a nova situação e seus resultados as pessoas desconhecem o que está por vir, muitas vezes porque ignoram a mudança e, principalmente, suas consequências;

b) Apego à atual situação na qual o indivíduo se sente confortável - as pessoas se perguntam: o que vou perder? Tenho que sair de onde estou? Vai valer a pena? Tenho mesmo que fazer isso? E se não fizer?

c) Perda de poder - as mudanças podem envolver situações de perda de poder ou status, dinheiro, administração de verbas;

d) Medo de se comprometer - alguém pode fazer comparações, esquecendo-se das diferenças regionais, rejeitar a proposta sem questionar os prós e contras; achar que só ele é o responsável, sentir medo de se arriscar diante do novo;

e) Ansiedade - pode ser uma manifestação de insegurança porque a pessoa não acredita em sua capacidade de trabalhar com o novo, é o medo do novo (BRASIL, 2008, p. 64).

Essas resistências levam, muitas vezes, à não-participação dos indivíduos em discussões sobre os rumos para o município, omitindo-se de compor uma força social que trabalha para o bem comum.

\subsection{As críticas ao Turismo}

Nos debates sobre a produção do Turismo, encontram-se críticas tanto por parte de acadêmicos como de pessoas de outros segmentos. Nos meios acadêmicos, os estudos são direcionados para o Turismo como fator econômico, à importância do planejamento turístico, à crítica ao Turismo de Massa e aos aspectos do consumo e produção destrutivos da atividade turística (OURIQUES, 2005, p. 70). Cada autor(a) analisa o Turismo de acordo com suas crenças e valores, ora com críticas aos impactos socioambientais, ora condenando-o como uma função prócapitalista, ora preocupados com possíveis soluções. Segundo Cruz (2000, p. 25): 
O modelo de desenvolvimento que se tem levado a cabo no Brasil, por exemplo, ao qual está subordinado também o Turismo, é concentrador de renda, excludente e perpetuador de desigualdades socioespaciais. O setor turístico (conjunto de atividades econômicas diretamente relacionadas à prática social do Turismo), inserido neste contexto, reproduz, como qualquer outro setor produtivo, as contradições do sistema.

De fato essa é a lógica do capitalismo, porém, observa-se que mesmo os países que tiveram ou têm governos socialistas e comunistas também promoveram e promovem o Turismo para obtenção de divisas. Leite Junior (2007, p. 46) analisa o Turismo como atividade produtiva e diz que seu debate não é a crítica aos investimentos turísticos (necessários à atividade), mas é "a perspectiva, a necessidade e o acerto da ampliação de participações na efetivação do Turismo em localidades sem tradição turística, mas carentes de atividades produtivas, pois há indícios fortes de que o modelo em vigor deixa a desejar nesse quesito". Romani (2007, p. 71) defende que o enfoque econômico do Turismo é positivo quando analisado sob "a perspectiva de que a atividade turística envolve produção e tem mostrado sua importância na estruturação econômica de toda uma sociedade: local e nacional". A autora também defende que o enfoque urbanístico é positivo quando "observado do ponto de vista da ordenação da imagem e da oferta local dos serviços" e, concluindo, Romani (2007, p. 72) afirma:

O problema pode estar na dimensão alcançada por esses enfoques quando prioritariamente se direcionam em favor de alguns grupos ou corporações, em detrimento de toda a sociedade que comprovadamente está envolvida diariamente no desenvolvimento da atividade.

Acredita-se, assim que, apesar das questões debatidas e críticas pelos acadêmicos com argumentações pertinentes, o Turismo representa oportunidade de trabalho e renda como atividade do setor terciário, principalmente para municípios de pequeno porte com potencial turístico que têm limitações para desenvolverem os setores primário e secundário como é o caso de Monteiro Lobato. De acordo com Sachs (1997), "dar simplesmente ao desempregado a pensão governamental não o protege contra a exclusão social e a perda da dignidade", considerando que, em nossas sociedades, o trabalho ainda tem importante função de socialização. 
Para Aznar (1996 apud SACHS, 1997), o trabalho "permite que o homem se ligue ao mundo e se ligue aos outros, instituindo um mecanismo de troca econômica, afetiva e social, ao passo que a impossibilidade de conseguir um trabalho constitui uma forma de banimento da sociedade, de uma exclusão do mundo". Defende-se, portanto, que trabalho e renda são elementos que dão condições para que o homem tenha uma vida digna com moradia, alimentação, educação e saúde e, se o Turismo colabora para a oferta de trabalho e renda, por que não fomentá-lo?

Outra crítica atribuída ao Turismo são as questões levantadas no campo das relações sociais entre visitantes e comunidade receptora. Banducci Junior (2001, p. 42) salienta que um dos aspectos dos estudos do livro "Turismo e identidade local; uma visão antropológica" que merece destaque é o fato de alertarem ou mesmo mostrarem que o Turismo:

Não é o único responsável por todas as mudanças que ocorrem numa determinada cultura, pois, se esta não é estática, os elementos que provocam suas alterações provêm tanto de fatores internos quanto das mais diversas modalidades de influências externas. $O$ Turismo, como agente desse processo amplo, pode tanto destruir como estimular respostas positivas que venham a reforçar a identidade do grupo ou outros aspectos da cultura local. Como diz Greenwood (1995, p. 182), "muito do que nós [antropólogos] vemos como destruição é construção: muito é o resultado da falta de qualquer outra opção possível; e algumas outras coisas, o resultado de escolhas que podem ser feitas de forma diferente". Cabe ao antropólogo discernir o grau de influência e o sentido dessas mudanças nas culturas locais.

Portanto, a pesquisadora não questiona a atividade turística, mas a forma como as pessoas a realizam. O aspecto que se deseja salientar é que o Turismo é uma atividade desempenhada por pessoas que fazem escolhas o tempo todo conforme seus interesses econômicos, políticos e ideológicos (Sistema EPI) na condução de suas vidas pessoais e na dos grupos sociais com os quais convivem, ou seja, são as decisões das pessoas, tomadas com base em suas crenças e valores, é que impactam positiva ou negativamente a própria comunidade e o espaço geográfico onde vivem. Rattner (1979, p. 126), ao analisar criticamente o "interesse público", alegado como valor e parâmetro do planejamento, afirma que: 
$\mathrm{Na}$ vida social, no caldeirão de ideias, aspirações e interesses individuais e grupais, simplesmente inexistem objetivos neutros, livres de juízos de valor e "apolíticos". Ao contrário, a seleção de problemas a serem atacados e resolvidos pela ação do poder público, bem como os próprios conceitos pelos quais definimos 0 problema e o inserimos em determinada realidade - objeto dos planos e programas de ação, são todos carregados de valores e, portanto, abertos ao subjetivismo e à "irracionalidade" das ideologias.

Citando Rabinovich (2005, p. 125) que indica que "o objeto da Psicologia Ambiental é estudar o modo de ocupação, no tempo e no espaço, das trajetórias dos indivíduos no território, não esvaziando-o de sua especificidade cultural, mas inscrevendo-o em sua geografia e história", evidencia-se o inter-relacionamento existente entre Turismo e Psicologia Socioambiental, salientando-se que os impactos socioambientais causados pela atividade turística modifica o espaço transformando-o em lugar turístico, mas a escala desses impactos poderão ser monitoradas quando há a participação da comunidade nas discussões sobre o desenvolvimento do Turismo no município porque seus moradores têm o saber local que, com o apoio de técnicos, podem definir os rumos do seu socioambiente por meio do planejamento participativo. Machado e Guimarães Netto (2007, p. 111) iniciam seu artigo sobre o "Projeto Cabuçu de desenvolvimento local: perspectivas para o desenvolvimento da atividade turística sustentável a partir do processo de planejamento participativo no Cabuçu" da seguinte forma:

Um processo local que tenha a atividade turística como potencial vetor de desenvolvimento, por sua capacidade de envolver diversos segmentos, descentralizar a produção e a renda, gerando oportunidades em seu planejamento e gestão e, consequentemente, distribuindo melhor seus benefícios e responsabilidades. Esses são os princípios que norteiam a ONG Projeto Cabuçu de Desenvolvimento Local na gestão das ações que sustentam o processo de desenvolvimento local, já que sem a descentralização da deliberação e da atuação, gerando uma "cultura de participação", não há possibilidade de se pensar em planejamento turístico participativo, termo ora em voga em cursos e consultorias "profissionais". Daí a necessidade de se pensar a participação como o processo de apropriação dos meios de seu desenvolvimento por moradores de comunidades, envolvendo não somente a geração de trabalho e renda, mas também o desenvolvimento social e político, no sentido de emancipação da cidadania como forma de buscar vencer a exclusão do ser humano em favor de uma racionalidade econômica. Em poucas palavras, a transformação de simples atores em sujeitos de sua própria história. 
Os autores argumentam a favor do desenvolvimento de uma cultura de participação que proporcionará que a comunidade seja corresponsável pela criação do seu futuro em termos econômicos, sociais e políticos. Portanto, para que o Turismo seja praticado com base nos critérios de sustentabilidade é necessário que haja o planejamento da atividade turística através da integração dos diversos agentes envolvidos dos setores público e privado e da comunidade receptora que deve ser incluída no processo através do planejamento participativo. No caso desse estudo, a intervenção que se fez foi conscientizar os lobatenses sobre a importância de desenvolver a atividade turística com base nos critérios de sustentabilidade objetivando um socioambiente que lhes proporcione uma vida digna, tendo trabalho e renda, respeito a sua cultura e preservando o meio ambiente.

\subsection{Grupo Planejatur}

É comum em projetos de intervenção social, os pesquisadores sociais lançarem mão da estratégia de identificarem as lideranças locais para sensibilizá-las e, com seu apoio, convidarem as pessoas da comunidade para participarem da apresentação de um projeto de intervenção social como, por exemplo, Barban (2003, p. 25) a respeito da pesquisa-ação no Grajaú e Matheus, Moraes e Caffagni (2005, p. 34), com pesquisa-participante com a comunidade do entorno da Represa do Lobo (Brotas e Itirapina, SP). No caso do estudo em Monteiro Lobato, não houve tal estratégia, porque o objetivo era ter participantes com motivação própria, mesmo correndo-se o risco de não ter interessados. Para convidar a comunidade a participar da apresentação da proposta de elaboração do Plano Diretor de Turismo Sustentável, no dia 25 de agosto de 2011, tendo como primeira etapa a realização do curso de Capacitação em Turismo Sustentável, o convite foi feito de forma ampla através de cartas, e-mails, cartazetes, telemarketing e contato pessoal feito pela pesquisadora que, ao mesmo tempo em que se apresentava, informava os objetivos do Plano. Foram 40 participantes nas apresentações feitas no centro e no Bairro do Souza, obtendo-se 20 inscrições. Os participantes do curso tinham idade entre 15 e 67 anos, e o perfil profissional era de estudantes, funcionários da Prefeitura, artesãos, comerciantes, empreendedores turísticos, professores, bancários e profissionais liberais como advogado e jornalista. Os alunos eram motivados, 
acompanhavam a exposição do conteúdo da apostila com atenção e debatiam as questões fazendo contrapontos com a realidade do município, o que enriquecia bastante a aula, tornando-a dinâmica e participativa. Os vídeos documentários de outras cidades turísticas eram bem apreciados, comentados e movimentavam a aula. Houve 6 desistências e, portanto, 14 concluintes (70\%) os quais foram assíduos às aulas.

No último dia de aula, 8 de dezembro de 2011, foi feito o convite aos alunos para formarem um grupo de trabalho voluntário para elaboração do Plano Diretor do Turismo Sustentável. Não houve argumentações por parte da pesquisadora nesse momento porque o tema tinha sido bem discutido durante o curso e se desejava que o convite fosse aceito de forma espontânea, sem pressão alguma. A questão seria quem poderia oferecer algumas horas semanais para desenvolver as etapas do planejamento turístico junto com a pesquisadora. Foi um momento de tensão para a pesquisadora, sem dúvida, porque se corria um grande risco, o de não haver interesse e/ou disposição dos participantes em aderirem ao projeto, afinal, além de ser uma tarefa a mais no seu cotidiano, era algo que nunca tinham feito antes, desconhecido para eles na prática. Se não houvesse adesões, a pesquisa teria obrigatoriamente de ser mudada, porque a pesquisadora previa em seu projeto inicial:

\begin{abstract}
A formação de uma estrutura organizativa que se conduza por meio de regras interdependentes previamente pactuadas entre os atores sociais envolvidos que podem vir a se tornarem agentes multiplicadores comprometidos com uma gestão do Turismo Sustentável no município poderá colaborar para a perenidade dos critérios de sustentabilidade turística no município.
\end{abstract}

Felizmente, para o alívio da pesquisadora, houve a adesão de 9 participantes, a saber: André Barreto (funcionário da Secretaria de Cultura e Turismo), Andrejs e Célia Ceruks (produtores rurais e proprietários do Recanto do Sauá), Antonio Renato de Sá Sonnewend (artesão), Benedita Ivana da Rocha Claro e Larissa A. Claro (proprietárias do Pesca e Campo Pedra Branca), Ednea Goulart de Andrade (proprietária da Academia Mantiqueira), Leila Miranda (moisacista) e Odette A. C. da Silva (proprietária da Loja Serralimp). Salienta-se que o casal Andrejs e Célia Ceruks e Ivana e Larissa Claro moram no Bairro da Pedra Branca, situado a 8 km do centro 
e foram assíduos às aulas, apesar da distância e das condições da estrada rural em dias de chuva.

A primeira reunião desse grupo aconteceu no dia 26 de janeiro de 2012 , quando foram definidos a periodicidade, o horário e o local dos encontros. O período e o horário foi consenso, considerando a disponibilidade de cada um (de 15 em 15 dias, no horário das $18 \mathrm{~h} 00$ às 20h00). O local foi oferecido pela Secretaria de Cultura e Turismo no Centro de Desenvolvimento Municipal (CDM). As reuniões tinham sempre uma pauta para nortear os trabalhos e eram iniciadas com um cafezinho comunitário, ora acompanhado de bolo, ora biscoitos e patê, ora doce e queijo que os membros do grupo levavam. Era uma estratégia para conversar um pouco e, ao mesmo tempo, dar um tempo até que todos chegassem. As pautas e decisões eram registradas como exemplificado no Quadro a seguir:

\begin{tabular}{|c|c|c|}
\hline Data & $\begin{array}{l}\text { Pauta: o que precisamos definir } \\
\text { hoje: }\end{array}$ & Resultados \\
\hline 26 jan & $\begin{array}{l}\text { Definição de: local de trabalho da } \\
\text { equipe de planejamento, dia da } \\
\text { semana, horário: } \\
\text { Revisão: como funciona uma oficina } \\
\text { de planejamento pela metodologia } \\
\text { ZOPP e etapas do planejamento } \\
\text { turístico. }\end{array}$ & $\begin{array}{l}\text { - Dia da semana: terça-feira - } 15 \text { x } \\
15 \text { dias - iniciando em } 14 \text { fev. } \\
\text { - local: CDM - Centro de } \\
\text { Desenvolvimento Municipal, sala } \\
\text { de treinamentos }\end{array}$ \\
\hline
\end{tabular}

Quadro 105 - Modelo de registro de pautas e decisões em reuniões

$\mathrm{Na}$ segunda reunião, em 14/02/2012, utilizando técnica ZOPP, a pesquisadora sugeriu que criassem um nome para o grupo. A tempestade de ideias resultou no Quadro 106:

\begin{tabular}{|l|l|l|l|}
\hline $\begin{array}{l}\text { RPTML (Roda de } \\
\text { Planejamento } \\
\begin{array}{l}\text { Turístico de } \\
\text { Monteiro Lobato) }\end{array}\end{array}$ & $\begin{array}{l}\text { PLANETUR, } \\
\text { SUSTENTATUR, } \\
\text { TURPLA, GPPSUS }\end{array}$ & $\begin{array}{l}\text { Sustenta Monteiro } \\
\text { Lobato }\end{array}$ & Modela Tur M.L. \\
\hline GEPLANTUR & $\begin{array}{l}\text { Grupo Planetur } \\
\text { Monteiro Lobato }\end{array}$ & MonTUR & ML Sustentável \\
\hline $\begin{array}{l}\text { GPPTUR Avança } \\
\text { Monteiro Lobato }\end{array}$ & ML Planejamento & $\begin{array}{l}\text { GPTL (Grupo } \\
\text { Planejamento } \\
\text { Turístico } \\
\text { Lobatense) }\end{array}$ & $\begin{array}{l}\text { PLANEJATUR } \\
\text { Monteiro Lobato }\end{array}$ \\
\hline
\end{tabular}

Quadro 106 - Resultado da tempestade de ideias para o nome do Grupo Planejatur 
Em consenso, o nome escolhido foi Planejatur Monteiro Lobato (Grupo de Planejamento Participativo do Turismo Sustentável de Monteiro Lobato).

A próxima atividade proposta para o grupo, nesta mesma reunião, foi levantar as expectativas para o trabalho a ser feito e o sonho de cada um para o município. Esta atividade tem especial importância porque deixa explícito o que cada membro do grupo pensa e isso colabora para o mútuo conhecimento e para o compartilhamento da visão de futuro que têm para Monteiro Lobato. O Quadro 107 apresenta o resultado dessa atividade:

\begin{tabular}{|l|l|l|}
\hline \multicolumn{1}{|c|}{ NOME } & \multicolumn{1}{|c|}{ O QUE ESPERA DESSE TRABALHO } & $\begin{array}{l}\text { SEU SONHO PARA MONTEIRO } \\
\text { LOBATO }\end{array}$ \\
\hline André Barreto & Sucesso! & $\begin{array}{l}\text { Moradores com ORGULHO de } \\
\text { sua cidade. }\end{array}$ \\
\hline Andrejs Ceruks & $\begin{array}{l}\text { Provocar o envolvimento da comunidade } \\
\text { para o desenvolvimento do Turismo } \\
\text { Sustentável. }\end{array}$ & $\begin{array}{l}\text { Conseguir para Monteiro Lobato } \\
\text { o status de Estância turística. }\end{array}$ \\
\hline $\begin{array}{l}\text { Antonio Renato de } \\
\text { Sá Sonnewend }\end{array}$ & $\begin{array}{l}\text { Que tenhamos garra e persistência para } \\
\text { atingirmos os resultados: Implantação do } \\
\text { Turismo e Plano diretor. }\end{array}$ & $\begin{array}{l}\text { Participação da comunidade e do } \\
\text { Poder Público para atingir esses } \\
\text { objetivos! }\end{array}$ \\
\hline $\begin{array}{l}\text { Benedita Ivana da } \\
\text { Rocha Claro }\end{array}$ & $\begin{array}{l}\text { Espero a participação, a união de todos } \\
\text { para que se mobilize a comunidade com } \\
\text { sucesso. }\end{array}$ & Emprego para os jovens. \\
\hline Célia Ceruks & $\begin{array}{l}\text { Que tudo dê muito certo e que as pessoas } \\
\text { cooperem. }\end{array}$ & $\begin{array}{l}\text { Que o desenvolvimento, venha } \\
\text { de forma sustentável e se torne } \\
\text { de fato uma estância turística. }\end{array}$ \\
\hline Larissa A. Claro & Que realmente mobilize a comunidade! & Que consiga se desenvolver! \\
\hline Leila Miranda & $\begin{array}{l}\text { Identificar na comunidade um grupo } \\
\text { comprometido e atuante. } \\
\text { Fortalecer costumes culturais e o nome da } \\
\text { cidade. }\end{array}$ & $\begin{array}{l}\text { Conquistar o título de } \\
\text { "CIDADE SUSTENTÁVEL". }\end{array}$ \\
\hline $\begin{array}{l}\text { Odette A. C. da } \\
\text { Silva }\end{array}$ & $\begin{array}{l}\text { Implantação de mais de 50\% dos objetivos } \\
\text { criados na oficina }\end{array}$ & $\begin{array}{l}\text { Desenvolvimento sustentável } \\
\text { sem perder as origens culturais. } \\
\text { Mais educação. }\end{array}$ \\
\hline
\end{tabular}

Quadro 107 - Expectativas para o trabalho de planejamento e o sonho para o município de cada membro do Grupo Planejatur

Observa-se que as expectativas para esse trabalho revelam o anseio pela mobilização da comunidade e os sonhos pela classificação do município como estância turística e pelo desenvolvimento sustentável. Os sonhos indicados pelos membros do Grupo Planejatur coincidem com os que foram apresentados pelos participantes da primeira Oficina. A vontade dos lobatenses de conseguir a classificação do município como estância turística manifestada na década de 1970 como um mecanismo político para a busca de mais receita para o município foi 
reforçada na primeira Oficina quando cada participante manifestou o seu sonho para Monteiro Lobato. Estes sonhos que, de forma resumida estão reproduzidos no Quadro 108, remetem a sentimentos expressos, como algo que estava preso dentro de cada um, provavelmente pela falta de esperança diante dos insucessos do passado, algo que se queria verbalizar, mas não se encontrava para quem falar e a Oficina foi o canal para a verbalização desses sonhos que representam o desejo por um socioambiente vivido com base na sustentabilidade.

\begin{tabular}{|l|ll|}
\hline$\checkmark$ União, & $\checkmark$ administração moderna e participativa, \\
$\checkmark$ interação, & $\checkmark$ desenvolva nas áreas sociais e turísticas, \\
$\checkmark$ prosperar, & $\checkmark$ crescer profissionalmente neste município, \\
$\checkmark$ continuidade, & $\checkmark$ melhor município em Turismo Sustentável, \\
$\checkmark$ plano diretor, & $\checkmark$ Moçambique e a Catira - manifestação cultural, \\
$\checkmark$ campo e Turismo, & $\checkmark$ melhores artesanatos da Serra da Mantiqueira, \\
$\checkmark$ orgulho da cidade, & $\checkmark$ recebermos turista de maneira sustentável sem \\
$\checkmark$ qualidade de vida, & $\checkmark$ perder nossas origens e cultura, \\
$\checkmark$ estância turística, & $\checkmark$ desenvolva na área de turismo sem perder o \\
$\checkmark$ cidade sustentável, & $\checkmark$ chão caipira, respeitando a natureza sempre, \\
$\checkmark$ promover a dignidade, & $\checkmark$ o principal fator de mudança será e deve ser o \\
$\checkmark$ compromisso dos & & povo, atuante e principal responsável pelo seu \\
& cidadãos, & sucesso. \\
\hline
\end{tabular}

Quadro 108 - Resumo dos sonhos para o município apresentados pelos participantes da Primeira Oficina em 15 de março de 2012

O planejamento feito com participação social permite que o conhecimento do pesquisador seja compartilhado com os atores envolvidos durante o processo. À medida que experenciam as atividades, os atores sociais ganham de forma gradual um aprendizado por meio da prática, uma vez que, ao vivenciar uma atividade, aprendem fazendo e passam a ter mais confiança em reproduzir a atividade quando necessário. Esse foi o caso da organização das Oficinas de Planejamento pelo Grupo Planejatur. O planejamento da primeira Oficina foi bem detalhado com base em um breve plano de ação que indicava o que deveria ser feito, quem faria e como seria feito. As ações eram definidas nos encontros, esquematizadas em folhas de flip chart para que todos visualizassem e acompanhassem o que estava sendo discutido. Como exemplo, quando se desenhou as possibilidades de organização de cadeiras, mesas, tela etc. no salão onde seria realizada a Oficina, todos podiam dar suas sugestões em cima desse desenho ou fazendo um novo desenho para demonstrar sua ideia. Com um check list, tinham clareza das suas tarefas e ficava mais fácil acompanhar o desenvolvimento delas. A fórmula funcionou e o grupo ficou 
surpreso com o resultado, "não sabiam que sabiam organizar eventos". As demais Oficinas e reuniões com a comunidade foram realizadas nesse modelo. O Quadro 109 reproduz o check list da primeira Oficina:

\begin{tabular}{|c|c|c|}
\hline O quê? & Quem? & Como? \\
\hline Local do evento & Dona Venina & empréstimo \\
\hline Condução da oficina & $\begin{array}{l}\text { Cleide com apoio do } \\
\text { PLANEJATUR }\end{array}$ & Metodologia ZOPP \\
\hline $\begin{array}{l}\text { Material para a oficina: } \\
\text { Papel Kraft, canetas para flip } \\
\text { chart, cartolinas cortadas, } \\
\text { cola spray, tesoura, fita } \\
\text { crepe, canetas azuis } \\
\text { Blocos de anotação }\end{array}$ & Cleide & Pedir ao SINHORES \\
\hline $\begin{array}{l}\text { Equipe para: Limpeza, } \\
\text { Cozinha, Recepção }\end{array}$ & $\begin{array}{l}\text { Limpeza: SERRALIMP } \\
\text { Cozinheiras: Bene e } \\
\text { Isaura } \\
\text { Recepção } \\
\text { Participantes dos cursos } \\
\text { do SINHORES }\end{array}$ & $\begin{array}{l}\text { Apoio: SERRALIMP = faxineiras e produtos } \\
\text { de limpeza } \\
\text { Prefeitura }=2 \text { cozinheiras } \\
\text { definir dentro da equipe Planejatur } \\
\text { Cleide ver se há alguém que queira ajudar }\end{array}$ \\
\hline Material descartável & Cleide & $\begin{array}{l}\text { Pedir patrocínio para: } \\
\text { - papel higiênico e sabonete para os } \\
\text { banheiros } \\
\text { - copos e guardanapos para refeição e café }\end{array}$ \\
\hline Louça, talheres, toalhas & Dona Venina & empréstimo \\
\hline $\begin{array}{l}\text { Alimentos = Almoço e café = } \\
\text { definir cardápio }\end{array}$ & $\begin{array}{l}\text { Prefeitura } \\
\text { Cleide }\end{array}$ & $\begin{array}{l}\text { Arroz, feijão, macarrão, molho, tempero, } \\
\text { óleo, café, leite, açúcar } \\
\text { Para almoço: } \\
\text { Buscar patrocínio para carne ou frango, } \\
\text { saladas, sucos, sobremesa } \\
\text { Para café: biscoitos, pão, bolo, frios, chás, } \\
\text { sucos, adoçante } \\
\text { Deise => queijos e doces }\end{array}$ \\
\hline Brindes para sorteios & todos & Alimentos industrializados, artesanato etc. \\
\hline Limpeza do Salão & $\begin{array}{l}\text { Dia 12/março = } \\
\text { MUTIRÃO DO } \\
\text { PLANEJATUR - Quem } \\
\text { puder ir: } \\
\text { - Odette + funcionárias } \\
\text { - Leila + funcionária } \\
\text { Dia 14/março = } \\
\text { - MUTIRÃO DO } \\
\text { PLANEJATUR } \\
\text { - Larissa e Cleide = } \\
\text { manhã }\end{array}$ & $\begin{array}{l}\text { Cleide = levar wap emprestado da Dona } \\
\text { Venina } \\
\text { Lavar: piso, vidraças, banheiros, cozinhas, } \\
\text { área externa, louças, mesas e cadeiras. }\end{array}$ \\
\hline $\begin{array}{l}\text { Equipamentos: Caixa de } \\
\text { som, ventiladores, tela, } \\
\text { datashow, computador }\end{array}$ & Cleide e André & levar \\
\hline
\end{tabular}

Quadro 109 - Check list para a organização da primeira Oficina em 15 de março de 2012 


\begin{tabular}{|l|l|l|}
\hline transporte & Cleide & Verificar com SINHORES e Prefeitura \\
\hline Divulgação: & André e Cesar Augusto & \\
fazer cartazetes e distribuir \\
gravar spot para carro de & (estagiário) & \\
som & André & \\
imprimir cartas para & André & \\
autoridades & Renato e Cleide & \\
entregar cartas para & Autoridades e corpo a corpo \\
fazer press release para \\
mídias impressa e site \\
$\begin{array}{l}\text { Faixa para entrada da } \\
\text { cidade }\end{array}$ & Cleide = buscar patrocínio & \\
\hline
\end{tabular}

Quadro 109 - Check list para a organização da primeira Oficina em 15 de março de 2012 (continuação)

O Grupo Planejatur sentiu-se encorajado pela Oficina e manifestou a intenção de convidar os que dela participaram para fazer parte do grupo, demonstrando plena consciência da importância desse trabalho e que desejavam compartilhá-lo com outros munícipes. Ainda por conta dessa consciência, o grupo teve uma ação de cidadania quando decidiu elaborar um documento com os resultados da primeira Oficina para entregar aos candidatos a prefeito nas eleições de 2012, com o objetivo de subsidiar seus respectivos planos de governos, assim como, articular a continuidade do trabalho na gestão futura.

Mantendo a coerência entre seu discurso sobre participação social e a ação, - Grupo Planejatur tem colaborado com a comunidade por meio das seguintes atividades:

a) participa das Reuniões do Circuito Mantiqueira;

b) Apoiou o SINHORES para implantação do Centro de Capacitação em Hospedagem e Gastronomia em parceria com a Pousada Monteiro Lobato;

c) colaborou no projeto Comunidade Mulher do Fundo Social;

d) participou das reuniões com artesãs do Projeto Apicultura Sustentável do Vale do Paraíba da UNITAU e Sebrae-SP;

e) coordenou reunião com empresários rurais interessados em participar de um roteiro de Turismo Rural no Bairro da Pedra Branca;

f) orientou a equipe da Prefeitura na organização do evento referente à reunião mensal do Consórcio de Desenvolvimento Integrado do Vale do Paraíba (CODIVAP) realizada no município no dia 20/04/2012; 
g) colaborou na organização do evento de comemoração dos 10 anos da Associação dos Pequenos Produtores Rurais de Monteiro Lobato (APPR) em 11/11/2012;

h) teve um representante na Diretoria do Conselho de Segurança de Monteiro Lobato (CONSEG);

i) tem 2 representantes no Conselho Municipal dos Direitos do Idoso de Monteiro Lobato;

j) colaborou com a Secretaria de Cultura e Turismo no planejamento da instalação dos totens de sinalização turística do município;

k) colabora para a formação do Núcleo de Turismo Rural da Associação de Pequenos Produtores Rurais de Monteiro Lobato e região (APPR);

I) colaborou com a Secretaria de Cultura e Turismo e COMTUR-ML na reunião com os comerciantes do centro para organizar o atendimento aos visitantes do 4 - Festival de Literatura Infantil (2013), no qual foi montado um estande para informações turísticas e foi aplicada uma pesquisa para avaliação do evento pelos visitantes.

m) Participou do 2ํㅡㄹ Encontro Estadual dos Agentes Públicos dos Municípios de Interesse Turístico do Estado de São Paulo em 23/10/2012 e Regional como o Fórum de Competitividade SEBRAE 2014 em 26, 27 e 28/11/2012, ambos em São José dos Campos. Também participou do 3ํㅡㄹ Encontro Estadual dos Agentes Públicos dos Municípios de Interesse Turístico do Estado de São Paulo em Brotas, nos dias 27 e 28 de junho de 2013 e no 4ํㅡㄹ Encontro de Municípios de Interesse Turístico em Guararema no dia 08/11/2013.

n) Colaborou com a Secretaria de Cultura e Turismo e COMTUR-ML no planejamento da elaboração de roteiros para visitas dentro do município e execução do receptivo a 36 alunos e professores do Curso de Turismo da Escola de Comunicação e Artes da Universidade de São Paulo (ECA/USP), nos dias 26 e 27 de outubro de 2013, os quais fizeram uma visita técnica para levantamento dos dados turísticos de Monteiro Lobato a serem colocados nos padrões do INVTUR do Ministério do Turismo.

Atualmente, o Grupo Planejatur conta com 9 membros: André Barreto, Antonio Renato de Sá Sonnewend, Célia Ceruks, Deise Datti Rosa, Ednea Goulart de Andrade, Leila Miranda, Odette A. C. da Silva, Regina de Fátima Araujo e a 
pesquisadora. Pelas atitudes e formas de se expressar, percebe-se que, embora os membros do Grupo Planejatur já se conhecessem, o trabalho em grupo propiciou uma maior aproximação entre eles. Há a preocupação com a saúde de um ou de outro, o acompanhamento de algo que tinha sido comentado antes, trocas de emails etc. O convívio, em função do projeto comum, criou laços de amizade, resultando em visitas às respectivas casas para café, almoço ou jantar, passeios no município e fora dele, comemoração de aniversários, participação nos eventos da cidade como bingo da paróquia, festa junina do asilo, shows na praça etc.

Como resultado, o Grupo Planejatur parece ter conquistado a confiança da comunidade. Em especial, por ter sido convidado a participar do edital para eleição das entidades que compõem o Conselho Municipal de Direitos do Idoso de Monteiro Lobato para o biênio 2012/2014 ${ }^{28}$ e quando a Prefeita solicitou seu apoio para a reativação do Conselho Municipal de Turismo. Portanto, o Grupo Planejatur demonstra ter o reconhecimento da comunidade. Ao discutir os conceitos de liderança comunitária, Souza (2010, p. 223) a apresenta como o:

Processo que pode se manifestar em qualquer membro do grupo em situações determinadas. Pessoas que lideram em uma situação deixam de liderar em outras. A vivência dessa experiência em práticas diversas faz com que a liderança passe a ser tratada como um fenômeno de situações, possível de ser vivido por todo e qualquer membro de um grupo.

Nesse sentido, o Grupo Planejatur atua como liderança comunitária para as questões do desenvolvimento do Turismo Sustentável no município. Em seu interior, não há o cargo de "presidente ou gerente do Grupo", isso nunca foi colocado em pauta por nenhum dos membros que, nas discussões, exercitam uma liderança rotativa de acordo com o maior grau de conhecimento e envolvimento que têm sobre o assunto específico em debate. A pesquisadora atuou como facilitadora, mas todas as decisões eram tomadas em consenso ou por votação na falta dele.

Enriquez (1994, p. 56) discute o vínculo grupal e diz que um grupo só se constitui em torno de uma ação a realizar, de um projeto ou uma tarefa a cumprir. Há a necessidade de um projeto comum e este significa que "o grupo possui um

\footnotetext{
${ }^{28}$ A eleição para composição do Conselho Municipal de Direitos do Idoso de Monteiro Lobato foi realizada no dia 07 de dezembro de 2012, e o Grupo Planejatur foi eleito em segundo lugar dentre as 5 entidades que se cadastraram. São representantes do Grupo Planejatur: Ednea Goulart de Andrade como titular e Célia Ceruks como suplente. Ambas tomaram posse em 14 de dezembro de 2012.
} 
sistema de valores suficientemente interiorizado pelo conjunto de seus membros, o que permite dar ao projeto suas características dinâmicas (fazê-lo passar do estágio de simples plano ao estágio da realização)". De acordo com Cavalcante e Ferraro Júnior (2002, p. 184):

\begin{abstract}
A emergência do sujeito coletivo depende de que os membros possam perceber suas origens comuns, sua partilha de universo semântico, de certezas e, assim sendo, sua partilha de destino. $O$ que parece simples na teoria é um agenciamento complexo na prática, até mesmo porque os sentimentos de grupo não se constroem com a simples mobilização de pessoas, agrupamento de subgrupos e verbalizações didáticas da necessidade do coletivo, mas a partir de um trabalho lento e minucioso, capaz de compreender as limitações de cada um, de demonstrar o significado de estar junto, de sensibilizar-se com as histórias pessoais inseridas em um coletivo, de trabalhar as nuanças das redes de aliança e redes de rejeição (Enriquez, 1997), de valorizar o encontro e buscar o significado da parceria na construção da visão de futuro comum (grifo dos autores).
\end{abstract}

Com base nos debates feitos no curso de Capacitação em Turismo Sustentável, o Grupo Planejatur aceitou e assumiu como projeto comum a elaboração do Plano Diretor de Turismo Sustentável para Monteiro Lobato. A pesquisadora compartilhou com o Grupo Planejatur a sua crença de que a atividade turística sempre causa impactos socioambientais, mas que é possível potencializar os positivos e minimizar os negativos pelo planejamento participativo do Turismo Sustentável. Concordando com essa crença, o grupo definiu e assumiu a missão de elaborar o Plano Diretor do Turismo Sustentável de Monteiro Lobato que passou a ser a razão pela qual o grupo se formou. Cada tarefa foi realizada com comprometimento e seriedade, percebendo-se a satisfação e o sentimento do dever cumprido toda vez que uma etapa era finalizada.

$\mathrm{Na}$ edição de outubro de 2013 do Jornal Serra da Mantiqueira, foi publicado um artigo sobre o planejamento do Turismo Sustentável em Monteiro Lobato que, além de divulgar o trabalho ${ }^{29}$, é um registro da história desse processo. O texto das entrevistas, reproduzidas abaixo, reflete a visão que os membros do Grupo Planejatur têm do Turismo no município após 2 anos de trabalho conjunto:

\footnotetext{
${ }^{29}$ São 5.000 exemplares que circulam nas cidades de São Bento do Sapucaí, Santo Antonio do Pinhal, Monteiro Lobato e São Francisco Xavier, Distrito de São José dos Campos.
} 
$\checkmark$ Célia e Andrejs Ceruks, proprietários do Recanto do Sauá, mudaram-se para Monteiro Lobato, há 12 anos. Ela diz que sempre buscou participar de tudo o que envolvia a área de Turismo. "Eu e meu marido vimos nesse projeto a oportunidade de fazermos um trabalho de forma comunitária, além de aprender mais sobre a matéria, já que na prática tenho meu empreendimento para gerir. Tanto no pessoal, quanto no comunitário, na minha opinião, o objetivo foi atingido, temos o Plano de Turismo Sustentável para Monteiro Lobato. Isso não significa, porém, que o trabalho acabou".

$\checkmark$ Larissa Claro é uma jovem que trabalha com sua mãe, Ivana Claro, proprietária do Campo e Pesca Pedra Branca. Ela diz que decidiu participar do curso em agosto de 2011 por estar envolvida com Turismo e comércio e do grupo de planejamento, por ser uma oportunidade de aprimorar seus conhecimentos e de colaborar com o crescimento da cidade. Larissa observa que hoje as pessoas estão mais preocupadas com a melhora do Turismo e com o turista e que se sente gratificada porque isso é o resultado de um trabalho do qual participou.

$\checkmark$ Leila Miranda trabalha com arte Musiva em seu atelier Casarão do Mosaico. Ela conta que se mudou com o marido, Antonio Renato de Sá Sonnewend, para Monteiro Lobato há 8 anos e que ainda se encanta com a simplicidade dos moradores que se cumprimentam pelo nome ao cruzar caminhos. Em sua opinião, uma cidade estruturada e preparada para bem receber o turista passa por um processo no qual o comprometimento do poder público, da iniciativa privada e principalmente dos cidadãos residentes, - falando a mesma linguagem - se conquista, se concretiza.

$\checkmark$ Em 2011, Odette Silva estava recém-chegada na cidade de Monteiro Lobato quando ficou sabendo do curso de Turismo Sustentável e viu uma oportunidade de aprendizagem, pois já tinha consciência da importância da preservação do meio ambiente. Odette conta que, com o curso, aprendeu que o significado da palavra "sustentável" é muito amplo e que Turismo Sustentável não atinge apenas a preservação do meio ambiente, mas sim a preservação da história, cultura, do trabalho, da rotina do dia a dia, da divisão justa de renda, além do respeito à diversidade. Odette relata que, após a conclusão do curso, veio a decisão de participar da formação e atuação do Planejatur porque sem a participação da comunidade o Turismo Sustentável 
não acontece. "Após dois anos de trabalho do Planejatur, olhando para trás, vejo que evoluímos bastante, fizemos pesquisas, levantamentos, oficinas e reativamos o COMTUR. Podemos dizer que hoje a população tem local e hora marcada para falar de Turismo. É só participar!", Odette convida.

$\checkmark$ Antonio Renato de Sá Sonnewend diz que hoje, pensando e interagindo com munícipes, turistas, comerciantes e a própria prefeitura que apoia o Grupo, pode-se dizer que Monteiro Lobato tem um sistema de gestão em Turismo Sustentável que é o Planejatur, o COMTUR-ML e a Secretaria de Cultura e Turismo. "Estamos fechando a proposta de um plano diretor de Turismo para Monteiro Lobato, finalizando um trabalho sério e dedicado que nasceu há 2 anos e esperamos implantá-lo e colher os frutos de um Turismo pensado em vários aspectos e sustentável para nosso município. Uma primeira ação realizada nesse sentido foi a montagem de um estande no último Festival de Literatura Infantil para dar informações turísticas aos visitantes", conta Renato.

Por mensagem eletrônica, datada de 20 de outubro de 2013, Regina de Fátima Araújo enviou seu depoimento ${ }^{30}$ :

Eu não participei o quanto gostaria, mas nos encontros que participei gostei bastante. Foram momentos de trabalhos importantes os quais, nos possibilitaram uma visão mais clara do Turismo no município de Monteiro Lobato. Acredito que estamos mais cientes do que podemos colher no desdobramento dos estudos que fizemos em busca da cidade ser uma Estância Turística.

Igualmente, por mensagem eletrônica, datada de 20 de setembro de 2013, André Barreto enviou seu depoimento ${ }^{31}$ :

O grupo Planejatur, o COMTUR e todos os envolvidos no projeto em prol do Turismo Sustentável estão de parabéns. A união de forças e ideias é essencial para o fortalecimento do Turismo local. Nosso trabalho, como gestores públicos, precisa desse apoio. Um diferencial para nossa cidade.

Deise Datti Rosa deu o seguinte depoimento em gravação do vídeo documentário “Turismo Sustentável, Monteiro Lobato merece!", apresentado no dia

\footnotetext{
30 ARAUJO, Regina de Fátima. Texto para Plano de Turismo Sustentável de Monteiro Lobato [mensagem pessoal]. Mensagem recebida por <pivott.cleide@gmail.com> em 20 out. 2013.

BARRETO, André. Declarações [mensagem pessoal]. Mensagem recebida por <pivott.cleide@gmail.com> em 20 set. 2013.
} 
16 de janeiro de 2014, quando o Plano Diretor de Turismo Sustentável foi entregue à comunidade ${ }^{32}$.

O resultado desse projeto que foi feito pela comunidade lobatense e que futuramente possa virar numa lei municipal para que dê continuidade nesse projeto e direcionar para o Turismo Sustentável da cidade. É isso que a gente espera desse projeto que está sendo entregue.

Vale comentar que cada um falou de um aspecto que enxerga no processo e, no entanto, as falas estão alinhadas e se complementam. Célia avalia que o objetivo foi atingido e sabe que isso é apenas o começo porque o plano contém um Programa de Ações com 29 projetos a serem alavancados na medida do possível, dependendo dos recursos humanos, financeiros e materiais. Um fato positivo foi a inclusão desse Programa de Ações nas metas da Secretaria de Cultura e Turismo no Plano Plurianual de 2014 a 2017, indicando que a Secretaria está autorizada a investir nos projetos dentro das limitações de seu orçamento, podendo, porém buscar alternativas como convênios com os governos federal e estadual para viabilizar os projetos. Larissa tinha 15 anos quando se inscreveu no curso de Capacitação em Turismo Sustentável em junho de 2011 e participou do Grupo Planejatur em 2012. Ela percebe que o trabalho do qual participou já está dando resultado. Leila salienta a importância do trabalho conjunto entre o governo, a iniciativa privada e a comunidade para a implantação do Turismo Sustentável. Odette avalia positivamente o trabalho do Grupo Planejatur, revela que sua compreensão de Turismo Sustentável foi ampliada e incentiva os moradores a participarem também. Renato chama a atenção para a gestão participativa do Turismo que agora se instala no município e tem consciência de que esse sistema de gestão será o elemento decisivo para o sucesso do trabalho. Regina avalia como trabalho importante que possibilita uma visão mais clara do Turismo no município de Monteiro Lobato. André diz que seu trabalho como gestor público precisa do apoio da união de forças e ideias para o fortalecimento do Turismo local. Deise diz que espera que esse plano possa virar lei municipal para que tenha continuidade.

\footnotetext{
32 ROSA, Deise Datti. Depoimento [dez. 2013]. Entrevistador: Antonio Goes. Monteiro Lobato: Imagerun Produções. 2 DVDs. Entrevista concedida para o Vídeo documentário: Turismo Sustentável, Monteiro Lobato merece!
} 
Além do vídeo editado para ser apresentado no dia da entrega do Plano Diretor de Turismo Sustentável à comunidade, a pesquisadora editou um segundo vídeo com o objetivo de registrar o entendimento daqueles que participaram dessa pesquisa-intervenção sobre o planejamento do Turismo Sustentável com Participação Social no município. Lendo a transcrição das falas dos entrevistados, é possível conhecer os sentimentos que nutrem por terem vivenciado esse processo. Essa edição foi organizada em blocos com os seguintes tópicos:

\section{Grupo Planejatur}

Fred Araújo: "O Turismo, pode-se dizer que ele vem criando força, vamos dizer assim, uns quatro ou cinco anos pra cá. Antigamente, podia-se dizer que não era esse o foco do pessoal aqui, não era o Turismo".

Ednea Goulart de Andrade: "Planejatur é um grupo de pessoas que acredita no potencial turístico de Monteiro, Monteiro Lobato e que se reuniram para fazer um trabalho juntos e para um Turismo Sustentável".

Antonio Renato de Sá Sonnewend: "Algumas pessoas que se comprometeram e uma cobrava a outra, falava: 'Vamos lá, é hoje e tal, hoje a gente vai discutir esse assunto tal, que é pertinente, vamos lá, tal'. Então, sempre dava um empurrãozinho na outra para que a coisa acontecesse".

Célia Ceruks: "A Cleide veio enriquecer nosso trabalho quando ela propôs tudo aquilo que a gente teria que fazer em termos de Turismo para o município, nos dando maior subsídio inclusive para a gente poder ter uma noção mais ampla daquilo que a gente já fazia".

Deise Datti Rosa: "Há mais ou menos um ano atrás, mais ou menos aí, eu tive um convite da Profa. Cleide pra gente estar participando de umas palestras direcionadas ao Turismo. Nós estivemos lá e achamos muito interessante e começamos a participar de um projeto ou de algumas reuniões entre pessoas que se tornaram o Planejatur. $O$ foco diretamente ligado ao Turismo e eu falo que também diretamente ligado a mim pessoalmente, porque a cada vez que a gente ia nessas reuniões, sempre tem alguma coisa pra gente tá aprendendo, como lidar, como fazer...".

Esmirna Guimarães: "O Planejatur pra mim como, eu digo, foi um presente e creio que foi pra muita gente também porque a cada encontro, foi assim, delicioso, sempre aumentando mais pessoas e eu creio que cada um que participou é... também está alimentando esse sonho, não só eu, né? No comecinho, na primeira vez que participamos, às vezes, a gente não entendeu muito, mas depois a gente foi entendendo sobre tudo que se tratava, né?". 


\section{Participação Social}

Fred Araújo: "Se não houver esse tripé, a ligação entre esse tripé, que acho que é dar murro em ponta de faca, não tem por onde, é só um atirando pra um lado e eu acho que não é por aí, tem que ter o envolvimento de todos, da comunidade, dos empresários e do poder público".

Andrejs Ceruks: "Foi uma oportunidade que nós tivemos de reunir as pessoas que já trabalhavam na área de Turismo, tinham as propriedades voltadas pra isso como pousadas, como áreas rurais, produtores rurais e a gente conseguiu envolver mais gente e que trouxe novas ideias também de como participar, de como melhorar nossa situação aqui em Monteiro. E também fazer um planejamento com a participação da população em relação à política, né? De Turismo no município, de modo que não dependa só do poder público, mas também da base que faz acontecer as coisas realmente no município e vai ficar independente de futura, vamos dizer, de mudança de governo, de administração porque a população estando unida, ela pode influir mais continuamente pra frente, então ela não deverá mais simplesmente obedecer o que se impõe de cima pra baixo, mas ter uma participação mais efetiva".

Célia Ceruks: "Este grupo que se formou e que está perseguindo esse objetivo tem que ter comprometimento absoluto pra não deixar que isso se esmoreça de forma nenhuma".

Antonio Renato de Sá Sonnewend: "E a participação, assim, até da comunidade que pela primeira vez foi consultada e pela primeira vez se manifestou na formação de uma lei para o município que tem extrema importância".

\section{Turismo Sustentável}

Célia Ceruks: "O que eu defino como sustentabilidade, é você tirar seu próprio sustento do lugar onde você vive, com consciência ecológica, não é verdade? Sem prejudicar o meio ambiente".

Andrejs Ceruks: "Porque a sustentabilidade não é só da natureza, é do ser humano também".

Antonio Renato de Sá Sonnewend: "Nossa cidade, pode-se dizer assim, ela tem orgulho porque vai errar menos, porque errar todos nós vamos errar, mas a gente vai errar menos, sabe por quê? Porque a gente se preparou, a gente está prevendo coisas que possam acontecer, então, os impactos que possa ter o Turismo, a gente pode ter uma previsão e amenizar esses impactos". 


\section{A construção compartilhada do Plano}

Daniela de Cássia Santos Brito: "Em 2007, eu estive na Prefeitura Municipal, como Secretária de Turismo e já existia o COMTUR, não tão fortalecido, mas acredito que é mais por falta de um projeto e que, com essa vinda da Profa. Cleide Pivott, nos deu essa visão, essa esperança de que realmente o Turismo pode acontecer".

Esmirna Guimarães: "Pra mim, os três que participei, eu sempre procurava trazer alguém comigo porque eu digo que pra mim foi um presente, foi mesmo, porque assim, não foi nada cansativo, uma dinâmica muito boa, muito gostoso, todo mundo expondo o que realmente queria, né?".

Andrejs Ceruks: "Eu acredito também que o Planejatur, na pessoa da Cleide, ela conseguiu transmitir também alguns conceitos assim teóricos a respeito do Turismo e práticos também".

Ednea Goulart de Andrade: "O aprendizado que assim chegou mais em mim a respeito do Turismo, que quando a gente quer realmente uma coisa e se juntar forças de todos querendo a mesma coisa, a gente consegue".

\section{O Plano Diretor de Turismo Sustentável}

Deise Datti Rosa: "O Plano Diretor que entendo é focado em que? Em população, comerciante e poder público, independente qual época for".

Antonio Renato de Sá Sonnewend: "Acho que o maior benefício é um benefício da comunidade em si porque vão deixar assim, se realmente forem feitas as propostas que nós estamos almejando, não é? Vai deixar para as outras gerações, vão deixar assim meio intocadas algumas coisas assim, principalmente na natureza. Eu tenho muita preocupação com as nascentes dos rios, as ocupações irregulares, essas coisas, né?".

Andrejs Ceruks: "Muitos empresários vêm só para ter lucro aqui, não é? Então a gente poderia orientá-los em um Turismo Sustentável.

\section{Turismo Sustentável com Participação Social}

Odette Antonia Casimiro da Silva: "Pra mim, Turismo Sustentável era simplesmente ter uma cidade com a natureza preservada. $O$ curso me abriu muito mais, ampliou meus horizontes".

André Barreto: "Dos Planos Diretores que nós encontramos nos arredores da nossa região, muitos foram feitos por empresas especializadas, consultorias, o nosso não, o nosso foi feito a muitas mãos".

Odette Antonia Casimiro da Silva: "É um presente que foi escrito com a participação da população, então, o que está escrito dentro desse Plano Diretor é o que a população quer". 


\section{Intervenção}

Deise Datti Rosa: "Eu achei que fosse, vamos dizer assim, simplesmente montar e atender, mas não direcionado ao Turismo, mas a procura, a demanda, o crescimento do município, entendeu? a gente vai acompanhando e fui vendo que o Turismo está aqui e por que não atender o Turismo? Então, comecei o meu projeto de uma forma, conheci a Profa. Cleide e, em seguida, o meu plano mudou completamente".

Esmirna Guimarães: "Percebo que a cidade está bem mais bonita, assim, sabe? As pessoas querendo melhorar, cada vez mais, né? Até as fachadas das casas, as pessoas estão querendo melhorar, a limpeza da rua, a coleta de lixo, está muito organizada. E eu creio que é reflexo de uma boa administração, né? De pessoas que estão bem engajadas pela melhoria da cidade".

Célia Ceruks: "Você quer a sua casa em ordem, não quer? Você quer o melhor para a sua casa, não quer? Então, você tem que ver o município como a sua casa".

Fred Araújo tem uma pousada, Esmirna Guimarães é moradora e Daniela de Cássia Santos Brito é a Prefeita do município. Todos eles participaram das três oficinas e, nesse vídeo, representam o empresariado, a comunidade e o governo respectivamente. Os demais entrevistados são membros do Grupo Planejatur. Observa-se que aqui também as falas se complementam, demonstrando, assim, que a intervenção proposta e realizada por meio da ação educativa, compartilhando conhecimentos sobre o Turismo Sustentável e incentivando a Participação Social, encontrou ressonância entre os atores sociais envolvidos nesse processo que, agora, mostram-se comprometidos em compartilhar o que sabem sobre os critérios de sustentabilidade com outros moradores do município. Nota-se, também, a seriedade nas declarações, a clareza das ideias manifestadas e a firmeza na intenção de dar continuidade ao planejamento do Turismo Sustentável com Participação Social. Salienta-se que as questões abordadas pelos entrevistados foram objetos de debates no Curso de Capacitação em Turismo Sustentável, nos encontros quinzenais e nas oficinas.

Pensando na continuidade e se a razão do Grupo Planejatur existir é ter um projeto comum - a elaboração do Plano Diretor de Turismo Sustentável para Monteiro Lobato - surgiu a dúvida: "O que acontecerá com o grupo agora que o plano foi finalizado?" Essa foi a pergunta que a pesquisadora fez aos membros do grupo na reunião do dia 06 de novembro de 2013. Após trocarem ideias, analisando 
o contexto, concluíram que o grupo não deve se desfazer porque é reconhecido e tem credibilidade junto à comunidade, tem compromisso assumido com o Conselho Municipal dos Direitos do Idoso de Monteiro Lobato e o Conselho Municipal de Turismo precisa de apoio porque sua formação é recente e seus membros ainda não têm experiência suficiente para gerir o Plano Diretor de Turismo Sustentável, necessitando serem capacitados para tal tarefa. Porém, considerando que dos 9 membros do grupo, 7 se voluntariaram como membros do COMTUR-ML, a pesquisadora perguntou se seria mesmo o caso de manter o Grupo Planejatur. Leila esclareceu que ela e o marido (Renato) têm acertado que apenas um deles entra para um mesmo conselho e, por isso, ela não aderiu ao COMTUR-ML. A pesquisadora esclareceu que não aderiu ao COMTUR-ML para não ocupar vaga de um residente. Novas discussões e argumentações a favor da manutenção do grupo ocorreram e a decisão foi de que o grupo seria mantido. Nesse caso, a pesquisadora perguntou: "Qual é o papel dos entes do Sistema de Gestão do Turismo Sustentável de Monteiro Lobato?" A resposta foi equacionada da seguinte forma:

$\checkmark$ Secretaria de Cultura e Turismo - representar o segmento dentro da Prefeitura;

$\checkmark$ Planejatur - capacitar os membros do COMTUR para o Turismo Sustentável;

$\checkmark$ COMTUR-ML - cumprir as atribuições previstas no Regimento Interno e fazer a gestão do plano em conjunto com os demais.

A gestão do plano ficou atribuída ao COMTUR-ML porque é um conselho formalizado pela Lei Municipal $n^{0}$. 1.090, de 18 de novembro de 1997, "com poderes normativos e de assessoramento da Municipalidade em questões referentes ao desenvolvimento turístico da cidade de Monteiro Lobato", ao passo que o Grupo Planejatur é um grupo de trabalho voluntário, não formalizado como entidade jurídica e não poderia se responsabilizar, por exemplo, por um Fundo de Turismo que venha a ser criado no futuro. Portanto, nessa reunião, o Grupo Planejatur criou uma nova razão para sua existência: capacitar os membros do COMTUR para o Turismo Sustentável. 
Para iniciar uma reflexão sobre como esses três entes irão coordenar a forma de trabalhar juntos, a pesquisadora perguntou: "Como deve ser o relacionamento entre os entes do Sistema de Gestão do Turismo Sustentável de Monteiro Lobato?" A resposta foi: "com trabalho conjunto visando os projetos coletivos". Portanto, o Grupo Planejatur tem pensado como um coletivo dentro de uma estrutura organizativa ainda não formalizada, mas que se conduz por meio de regras interdependentes previamente pactuadas entre seus membros que se tornaram agentes multiplicadores comprometidos com uma gestão do Turismo Sustentável no município como a pesquisadora previa em seu projeto de tese em 2009.

O Plano foi entregue à comunidade em uma cerimônia realizada no dia 16 de janeiro de 2014, na Câmara Municipal e, a partir desse mês, os três entes começaram um trabalho inédito no município: a gestão participativa do Turismo Sustentável. O Grupo Planejatur, com o apoio da Secretaria de Cultura e Turismo, entregou exemplares do Plano à Prefeita Daniela de Cássia Santos Brito, ao Vereador Ailton Rodolfo Martins, Presidente da Câmara Municipal, para Antonio Renato de Sá Sonnewend, Presidente do COMTUR-ML e para Antonio Ferreira Junior, Presidente do SINHORES. O Grupo Planejatur apresentou o vídeo de 8 minutos, intitulado "Turismo Sustentável, Monteiro Lobato merece!", produzido com o apoio do SINHORES, com depoimentos sobre o planejamento do Turismo Sustentável feito com participação da população. Constam do vídeo depoimentos dos membros do grupo: Andrejs e Célia Ceruks, Deise Datti Rosa, Ednea Goulart Andrade e da pesquisadora, da Prefeita Daniela de Cássia Santos Brito, do Secretário de Cultura e Turismo, André Barreto, do Presidente do SINHORES, Antonio Ferreira Junior, do Presidente do COMTUR-ML, Antonio Renato de Sá Sonnewend, do ex-Secretário de Cultura e Turismo, Eduardo Rocha Dellú, dos munícipes Geminiano Jorge dos Santos, Esmirna Guimarães e do Mestre do Grupo de Moçambique, Manoel dos Santos Almeida. 


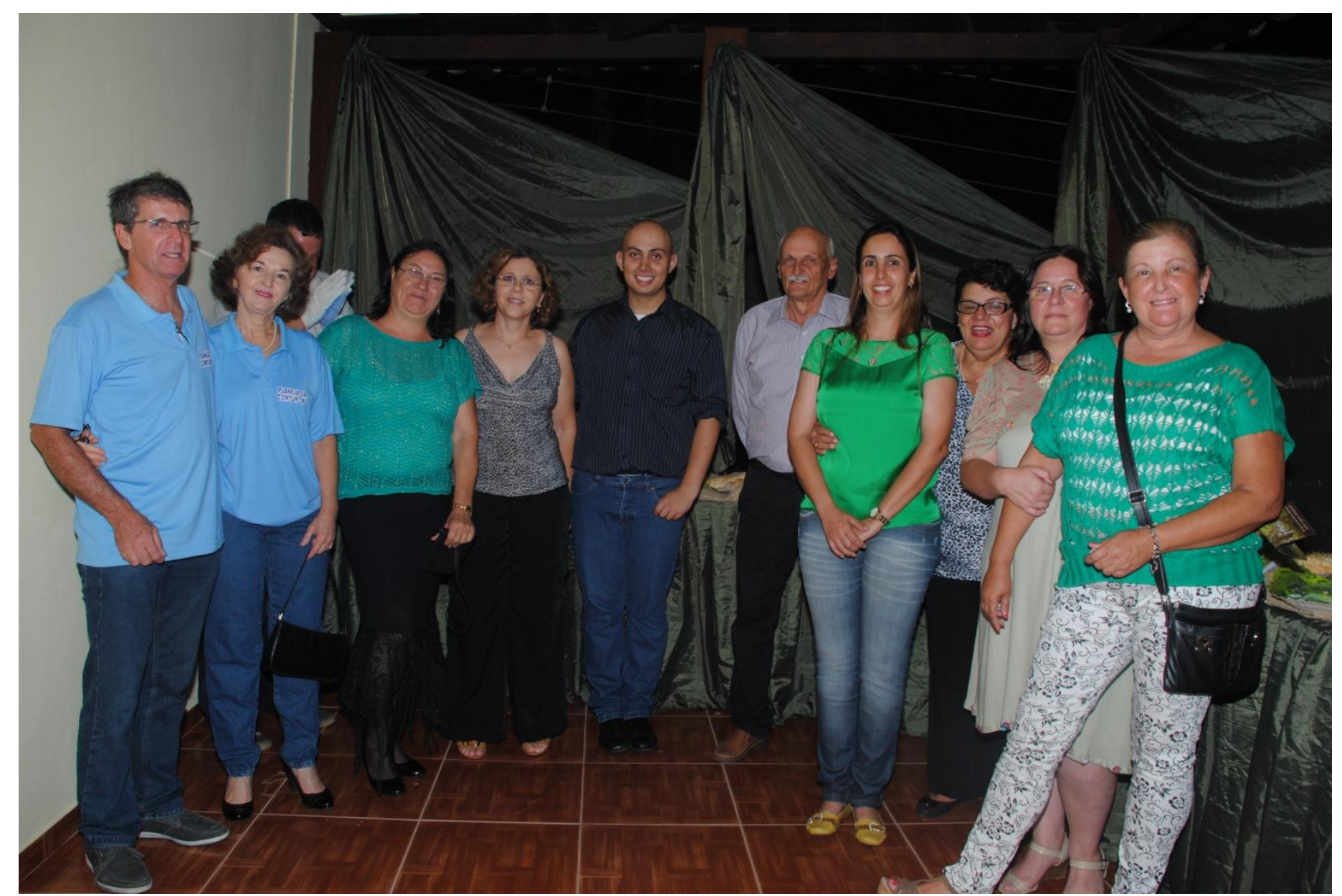

Foto 16 - Grupo Planejatur (da esquerda para a direita): Antonio Renato de Sá Sonnewend, Leila Miranda, Cleide Pivott, Regina de Fátima Araujo, André Barreto, Andrejs Ceruks, Deise Datti Rosa, Célia Ceruks, Odette A. C. da Silva e Ednea Goulart de Andrade 


\section{CONSIDERAÇÕES FINAIS}

Pode-se dizer que o planejamento é um processo que se inicia no plano mental quando o indivíduo ou um grupo de indivíduos pensam fazer algo e traçam um plano de ação para concretizar a ideia. Para tal efeito, há etapas a serem cumpridas envolvendo a coleta de informações inerentes ao que se quer atingir; sua análise; a definição dos rumos a seguir; a implementação das decisões; a avaliação e a reavaliação. É, portanto, um processo que facilita a construção de um projeto, seja individual ou coletivo. No caso do projeto coletivo, há outro processo importante para que os resultados sejam satisfatórios, é o do relacionamento entre os atores sociais. A atitude de respeito ao outro e o respeito à diversidade de opiniões, sem anular a divergência de ideias, importante por proporcionar discutir o tema por vários pontos de vista, levantando aspectos muitas vezes perdidos em uma situação de consenso. Porém, o diálogo deve ser mantido para evitar que os conflitos implodam o projeto. Estabelecer regras de convívio e manter o foco no resultado desejado são atitudes necessárias em um trabalho de planejamento participativo.

Em linhas gerais, os planos diretores são diagnósticos feitos com base no levantamento de dados sociais, culturais, ambientais e econômicos de um município com o objetivo de estabelecer ações que promovam a organização do território e melhor condição de vida para a sociedade. O Estatuto da Cidade estabelece, no seu Artigo 41, Incisos II e IV respectivamente, que o plano diretor também é obrigatório para cidades integrantes de regiões metropolitanas e de áreas de especial interesse turístico. O Inciso I, do Artigo $2^{\circ}$ desse Estatuto, aponta como diretriz a "garantia do direito a cidades sustentáveis, entendido como direito à terra urbana, à moradia, ao saneamento ambiental, à infraestrutura urbana, ao transporte e ao lazer, para as presentes e futuras gerações". No Inciso II, desse mesmo Artigo, é estabelecido que o plano diretor deve ser elaborado, executado e acompanhado com participação da população. 
O município de Monteiro Lobato necessita elaborar seu plano diretor, tanto por pertencer à Região Metropolitana Vale do Paraíba e Litoral Norte (RMVPLN) quanto por integrar a região turística da Serra da Mantiqueira. Porém, o município precisa antes viabilizar os recursos financeiros para a elaboração do plano diretor que, por envolver equipe de profissionais especializados e tratar de assuntos abrangentes, tem alto custo para 0 orçamento municipal. O ideal seria tê-lo antes do Plano Diretor de Turismo Sustentável, mas, por outro lado, quando for elaborado, o tema Turismo já estará trabalhado, cabendo fazer a integração dos planos.

Igualmente, é recomendado que o Plano Diretor de Turismo Sustentável seja construído com participação social. Quando feito com conscientização da população, como um projeto coletivo, há comprometimento com as ações definidas e fortalecimento dos laços sociais da comunidade.

$\mathrm{Na}$ pesquisa-intervenção não é possível manter uma postura de pesquisador distante do objeto de estudo. Se este tipo de pesquisa se apresenta como ação transformadora da realidade sociopolítica, não cabe neutralidade, não há como fazê-la sem se envolver nas situações locais. A relação é de sujeito/sujeito, o caminho é de dupla mão, pesquisador e atores sociais compartilham saberes, ideias, sentimentos, impressões, enfim é uma vivência conjunta, uma convivência que cria inevitavelmente laços de amizade. O pesquisador vai a campo com suas crenças e valores e, mais cedo ou mais tarde, revela sua personalidade, revela-se como "é, sendo". Ele é observado e avaliado pelas pessoas o tempo todo e é seu comportamento diante das diversas situações que gerará credibilidade na comunidade em relação a sua pessoa e seu trabalho. A confiança conquistada dá o respaldo para a execução das ações, sabe-se o que se está fazendo e por qual motivo e que é possível contar com o pesquisador sempre que necessário.

Foi com esse espírito que a pesquisadora se inseriu na comunidade lobatense, participando da diretoria do Conselho Comunitário de Segurança de Monteiro Lobato (CONSEG) por um ano, apoiando a criação do Conselho Municipal de Direitos do Idoso de Monteiro Lobato (CMDI), além de colaborar com outros grupos de discussões, em eventos e campanhas como a de castração de animais domésticos. 
Este trabalho é uma intervenção socioambiental que utilizou o mecanismo da construção compartilhada de um projeto coletivo que gerou um produto, o Plano Diretor de Turismo Sustentável. Em seu processo houve o envolvimento da população em dois níveis de participação, sendo o primeiro a formação e capacitação de um grupo de munícipes (Grupo Planejatur) que desenvolveu as estratégias participativas de planejamento do Turismo do município, tornando-se um grupo multiplicador da ideia do planejamento turístico com envolvimento da população e, o segundo, com o convite aos moradores para participarem das oficinas, pesquisas e reuniões.

Em uma reunião com a comunidade, um participante perguntou se a pesquisadora iria fazer projetos para eles. A resposta foi: "Não, farei projetos com vocês". Essa disposição permaneceu durante o trabalho de campo, uma vez que o objetivo era compartilhar conhecimentos técnicos para apoiar a comunidade na condução do planejamento turístico. Feito com participação social, o planejamento proporciona que o conhecimento do técnico, uma vez compartilhado com os atores envolvidos em um processo de investigaçãoeducação-ação ("aprender-fazendo"), seja enraizado de tal forma que os últimos passam a ter condições de discernimento para tomada de decisões e dar continuidade ao processo.

O estudo envolveu conhecimentos nas áreas do planejamento do Turismo Sustentável, da Psicologia Social e da Participação Social. Sua problemática inclui a falta de políticas públicas eficazes em Turismo Sustentável bem como para a Participação Social no Brasil. Consequentemente, não há cultura para o planejamento participativo do Turismo Sustentável. Nesse contexto, os municípios de pequeno porte com potencial turístico tendem a seguir a lógica do Turismo do modelo tradicional que é desenvolvido desordenadamente e causa impactos negativos ao socioambiente. O Turismo Sustentável planejado com Participação Social surge como outro modelo capaz, não de eliminar os impactos porque não há Turismo sem eles, mas de minimizar os que forem negativos. Quando a comunidade se apropria do plano elaborado por ela mesma, seu significado é diferente do que teria ao receber um plano de cuja elaboração não participou. O Plano de Turismo Sustentável de Monteiro Lobato é fruto desta pesquisaintervenção que levou à comunidade um novo saber sobre como a atividade 
turística é operacionalizada e as tendências de seus desdobramentos negativos quando realizada sem planejamento. O processo histórico dos municípios turísticos que não planejaram o Turismo de forma sustentável é o antimodelo àqueles que se encontram no início do ciclo de vida de um município turístico (fase da exploração) e, portanto, no caso de Monteiro Lobato, é possível iniciar a atividade dentro dos critérios da sustentabilidade, como o caminho desejável.

A inserção da pesquisadora na comunidade (entrando de forma tranquila em contato com as pessoas e conhecendo aos poucos o cotidiano do município) e o curso de Capacitação em Turismo Sustentável do qual foi formado o Grupo Planejatur foram as estratégias para iniciar o trabalho de campo. Não houve grandes dissensos porque o estudo era do interesse da comunidade para viabilizar o desenvolvimento turístico e, embora tendo sido elaborado um cronograma, a pesquisadora conduziu a sequência das atividades dentro do ritmo do Grupo Planejatur, sem pressões, de forma flexível, porque o planejamento participativo tem como característica ser adaptativo. Os resultados alcançados, incentivo à Participação Social, formação do Grupo Planejatur, organização das três oficinas de planejamento em Turismo com a comunidade, reativação do COMTUR, treinamento para professores da rede municipal para o Turismo Sustentável e elaboração do Plano Diretor de Turismo Sustentável demonstram que esta pesquisaintervenção atingiu seu objetivo de provocar a mudança na percepção da população em relação ao Turismo tradicional (caminho indesejável) versus o Turismo Sustentável (caminho desejável).

Sem dúvida, se não houvesse a formação do Grupo Planejatur que desempenhou o papel de um grupo multiplicador comprometido com a causa, exercendo uma liderança comunitária dentro do movimento pró-Turismo Sustentável, o trabalho teria outros desdobramentos ou nem teria acontecido. Portanto, para que uma intervenção social ocorra é necessária a conjunção de interesses e esforços de pessoas dispostas a oferecer seu saber e tempo para a construção de um projeto coletivo. O comprometimento e a determinação dos membros do Grupo Planejatur garantiram a execução das atividades em um relacionamento sujeito/sujeito, pois a pesquisadora apresentava as informações, mas as decisões eram tomadas em conjunto. Além disso, houve a 
troca de experiências e com eles a pesquisadora aprendeu sobre o município e seus habitantes. É o grupo multiplicador que irá trabalhar juntamente com a Secretaria de Cultura e Turismo e o Conselho Municipal de Turismo (COMTUR-ML). O Grupo Planejatur tem consciência de que o conteúdo do Plano Diretor de Turismo Sustentável de Monteiro Lobato é o que a população quer e pode dar conta. Sabe não ser o caso de investir em um plano de marketing para captar mais turistas, por ser o nome do escritor o grande atrativo. Está ciente que deve investir no Turismo Receptivo para atender melhor os turistas que já frequentam o município.

Desde a gestão do Prefeito Gabriel Vargas Moreira, o município vive uma transição no modo de governo, até então, centrado na figura e na vontade dos gestores anteriores de manter a comunidade habituada ao clientelismo. A Prefeita dá continuidade à abertura do governo para a comunidade com foco na gestão participativa. Porém, os conselhos têm dificuldades porque são poucos os munícipes dispostos a participar deles. Por conseguinte, alguns participam de dois ou mais conselhos. A articulação entre os conselhos também é recomendada por ser uma forma de fortalecimento mútuo.

O histórico do ocorrido com este trabalho, feito com o envolvimento da população, permite afirmar que os munícipes desejam o desenvolvimento socioeconômico e participam quando convocados, mas se desestimulam diante da falta de resultados práticos. Aponta-se, também, que o município precisa de uma nova geração de lideranças capazes de conquistar credibilidade para si e para suas propostas de trabalho.

Não há soluções mágicas para a implantação do Turismo Sustentável com participação da população em um município. É um processo de longo prazo, mas que precisa ser iniciado em algum momento. Antes do "Turismo ser do Brasil ou do Estado", ele é "do município", pois é no seu espaço geográfico que estão seus atrativos naturais e culturais; são seus empresários que prestam serviços, e é a comunidade local que recebe os visitantes. Dependendo de suas políticas públicas e das decisões dos atores sociais, o Turismo se materializa, podendo ou não ser orientado pelos princípios de sustentabilidade. Portanto, o resultado de um planejamento participativo é diretamente proporcional à participação dos atores sociais e, assim, vale reiterar que a receita é: vontade política dos políticos, vontade política dos 
empresários e vontade política da comunidade mais a força de vontade de um pequeno grupo de pessoas capazes de abrir espaço em seu cotidiano para trabalhar em prol do bem comum da municipalidade, porque conhecem e reconhecem o valor incalculável de se viver em comunidade. Isso envolve mudança de mentalidade, determinação pela busca da qualidade de vida em oposição ao consumo material apenas e não abrir mão de uma cultura de participação em prol do coletivo.

Este trabalho, portanto, articula vida acadêmica e militância para o Turismo Sustentável, trazendo conhecimentos sobre Turismo, Planejamento, Psicologia Social e Participação Social e, ao mesmo tempo, faz a ligação entre universidade, estado e sociedade. A visão nesse sentido, veio do percurso de estudos da pesquisadora e da sua experiência em projetos turísticos nas cidades localizadas na Região Metropolitana Vale do Paraíba e Litoral Norte. Os resultados obtidos foram de ações empíricas com respaldo da técnica e, dessa forma, demonstrou-se que é possível promover a ação educativa para a Participação Social por meio da construção de um projeto coletivo; compartilhar conhecimentos de planejamento turístico com pessoas de uma comunidade através do encontro do saber técnico com o saber local e elaborar um plano de Turismo Sustentável de forma participativa, sem custos altos, com a união do governo, do empresariado e da comunidade.

A interdisciplinaridade possibilitou a aplicação dos conhecimentos das disciplinas envolvidas nesta pesquisa-intervenção e chegar aos resultados obtidos com a clareza necessária para o desenvolvimento das atividades, proporcionando segurança e credibilidade junto aos atores sociais.

Para os municípios que almejam o Turismo Sustentável recomenda-se promover a participação social na prática, não apenas no discurso. As pessoas observam tudo e todos, percebem o que é prometido e o que não é cumprido. Assim, o discurso deve ser coerente com a prática sob pena de se perder credibilidade cujo resultado é a descrença seguida de não-participação. Os gestores públicos devem buscar o caminho do Turismo Sustentável desenvolvido com planejamento participativo em conjunto com o empresariado e a comunidade dentro dos limites e potencialidades socioambientais do município. 
Para os pesquisadores que se interessarem por projetos de pesquisaintervenção semelhante ou não, sugere-se que, além de se prepararem tecnicamente, reflitam sobre suas crenças e valores e a real disposição para entrarem na vida cotidiana de uma comunidade de cujas pessoas será preciso obter credibilidade para si e seu projeto. Isso porque a intervenção social é ação que requer responsabilidade, compromisso e respeito aos atores sociais envolvidos. Todo cuidado é pouco e toda atenção é necessária, uma vez que a relação entre pesquisador e objeto de pesquisa, nesse caso, é a de sujeito/sujeito agindo sobre o socioambiente com o objetivo de transformação da realidade local. Portanto, reitera-se que a forma como as pessoas decidem sobre a própria comunidade e o espaço geográfico onde vivem é a causadora de impactos socioambientais positivos ou negativos. E o caminho é o planejamento do desenvolvimento local com a participação da comunidade, pensando no bem comum desta e das futuras gerações.

O modelo desse estudo pode ser replicado em outros municípios de pequeno porte, porém os resultados serão diversos porque dependerão das situações de contorno. Espera-se que este trabalho contribua para uma visão interdisciplinar sobre a sociedade, o espaço e as questões relativas ao planejamento do Turismo Sustentável com Participação Social. 


\section{REFERÊNCIAS}

ABBAGNANO, Nicola. Dicionário de Filosofia, 5a․ Ed. São Paulo: Martins Fontes, 2007.

AGUIAR, Roberto. Caso do Plano Diretor - Época do Prefeito João Bueno [mensagem pessoal]. Mensagem recebida por <pivott.cleide@gmail.com> em 21 jan. 2014.

ALMEIDA, A. C.; SANTOS, A. O.; PAIVA, V. O incremento da participação comunitária em pesquisas sociais: a estratégia de trabalho com o agente local. In: Vera Paiva; Ligia Rivero Pupo; Fernando Seffner. (Org.). Vulnerabilidade e direitos humanos. Prevenção e Promoção da Saúde: pluralidade de vozes e inovação de práticas. 1ed. Curitiba: Juruá Editora, 2012, v. III, p. 253-268.

ARAUJO, Regina de Fátima. Texto para Plano de Turismo Sustentável de Monteiro Lobato [mensagem pessoal]. Mensagem recebida por <pivott.cleide@gmail.com> em 20 out. 2013.

ARGUELLO F. V. P.; SAUSEN, T. Geografia do Vale do Paraíba. In: FERREIRA, Potiguara Chagas (Coord.). A biologia e a geografia do Vale do Paraíba: trecho paulista. São José dos Campos, SP: IPEA, 2007.

BALANZÁ, Isabel Milio; NADAL, Mónica Cabo. Marketing e Comercialização de Produtos Turísticos. São Paulo: Pioneira Thomson Learning, 2003.

BANDUCCI JUNIOR, Álvaro. Turismo e Antropologia no Brasil: Estudo preliminar. In: BANDUCCI JR., Álvaro; BARRETTO, Margarita (Orgs.). Turismo e identidade local: uma visão antropológica. Campinas, SP: Papirus, 2001. - (Coleção Turismo).

BARBAN, Vilma (Org.). Fortalecimento da sociedade civil em regiões de extrema pobreza. São Paulo: Instituto Pólis, 2003.

BARBOSA, Ycarim Melgraço. Turismo: perda de identidade e produção de novos lugares. In Espaço e Geografia, UnB, Brasília, v. 3, n. 1, 1999.

BARRETO, André. Declarações [mensagem pessoal]. Mensagem recebida por <pivott.cleide@gmail.com> em 20 set. 2013. 
BARRETO, André. Monteiro Lobato: Cidade \& Escritor. São José dos Campos, SP: JAC Gráfica e Editora, 2012.

BARRETTO, Margarida. Planejamento e Organização do Turismo. Campinas, SP: Papirus, 1998.

BENI, Mário Carlos. Como Certificar o Turismo Sustentável? In: Turismo em Análise. São Paulo, v. 14, № 2, nov. 2003, 5-16.

2006.

Política e planejamento de Turismo no Brasil. São Paulo: Aleph,

BRANDÃO, Carlos Rodrigues. Pesquisa Participante. In: FERRARO JUNIOR, Luiz Antonio (Org.). Encontros e Caminhos: Formação de Educadoras(es) Ambientais e Coletivos Educadores. Brasília: MMA, Diretoria de Educação Ambiental, 2005.

BRASIL. Lei $\mathrm{n}^{\circ}$. 12.727, de 17 de outubro de 2012. (novo Código Florestal). Disponível em: <http://www.planalto.gov.br/ccivil_03/_ato20112014/2012/lei/L12727.htm>. Acesso em: 29 jan. 2014.

BRASIL. Constituição (1988). Constituição da República Federativa do Brasil. Disponível em: <http://www.planalto.gov.br/ccivil_03/constituicao/constituicao.htm>. Acesso em: 29 jan. 2014.

BRASIL. Lei $n^{\circ}$. 10.257, de 10 de julho de 2001 (Estatuto da Cidade). In: BRASIL. Ministério das Cidades. Plano Diretor participativo: guia para elaboração pelos Municípios e cidadãos, 2ª . Edição/Coordenação Geral de Raquel Rolnik e Otilie Macedo Pinheiro - Brasília: Ministério das Cidades: Confea, 2005.

BRASIL. Lei no 9.795, de 27 de abril de 1999. Dispõe sobre a educação ambiental, institui a Política Nacional de Educação Ambiental e dá outras providências. Disponível em: <http://www.planalto.gov.br/ccivil_03/leis/19795.htm>. Acesso em: 29 jan. 2014.

BRASIL. Decreto no 4.281, de 25 de junho de 2002. Regulamenta a Lei $n^{\circ}$. 9.795, de 27 de abril de 1999, que institui a Política Nacional de Educação Ambiental, e dá outras providências. Disponível em: <http://www.planalto.gov.br/ccivil_03/decreto/2002/d4281.htm>. Acesso em: 29 jan. 2014. 
BRASIL. Ministério do Turismo. Secretaria de Políticas de Turismo. Programa de qualificação a distância para o Desenvolvimento do Turismo: sensibilização, mobilização, institucionalização da instância de governança regional. Florianópolis: SEaD/UFSC, Livro 2, 2008.

BRASIL. Programa Descentralizado de Cooperação Brasil-Itália. Experiências e Resultados 2003/2010.

Disponível

em:<http://www.secretariageral.gov.br/.arquivos/imagens-

publicacoes/BrasilProximo_Final.pdf>. Acesso em: 09 set. 2013.

BRASIL. Lei no 8.181/91: Altera a denominação de Empresa Brasileira de Turismo (Embratur) para Embratur - Instituto Brasileiro de Turismo, e dá outras providências.

Disponível

em: <http://www.planalto.gov.br/ccivil_03/leis/L8181.htm >. Acesso em: 08 jan. 2014.

BRASIL. Decreto oㅜ 448/92: Regulamenta dispositivos da Lei oㅜ 8.181, de 28 de março de 1991, dispõe sobre a Política Nacional de Turismo e dá outras providências. Disponível em: <http://www.jusbrasil.com.br/topicos/11900815/decreto-n-448-de-14-defevereiro-de-1992>. Acesso em: 08 jan. 2014.

BRASIL. EMBRATUR. Brasília. Disponível em: <http://www.embratur.gov.br/conheca/programas/pnmt.asp>. Acesso em: 23 dez. 2002.

BRASIL. Ministério do Turismo. Disponível em: <http://www.Turismo.gov.br/Turismo/o_ministerio/plano_nacional/index.htm>l. Acesso em: 01 jun. 2013.

BRASIL. Lei no 11.771 , de 17 de setembro de 2008. Dispõe sobre a Política Nacional de Turismo, define as atribuições do Governo Federal no planejamento, desenvolvimento e estímulo ao setor turístico; revoga a Lei no 6.505, de 13 de dezembro de 1977, o Decreto-Lei no 2.294, de 21 de novembro de 1986, e dispositivos da Lei o 8.181, de 28 de março de 1991; e dá outras providências. Disponível em: <http://www.planalto.gov.br/ccivil_03/_ato20072010/2008/lei/l11771.htm>. Acesso em: 30 jan. 2014.

BRASIL. Lei Complementar no 101, de 4 de maio de 2000. Estabelece normas de finanças públicas voltadas para a responsabilidade na gestão fiscal e dá outras providências. Disponível em: <http://www.planalto.gov.br/ccivil_03/leis/lcp/lcp101.htm>. Acesso em: 07 fev. 2014. 
BUARQUE, Sérgio C. Construindo o Desenvolvimento Local Sustentável. Rio de Janeiro: Garamond, 2002.

- Metodologia de planejamento do desenvolvimento local e municipal sustentável. Brasília: Instituto Interamericano de Cooperação para a Agricultura (IICA), 1999.

CALEGARE, Marcelo Gustavo Aguilar. Contribuições da Psicologia Social ao estudo de uma comunidade ribeirinha no Alto Solimões: redes comunitárias e identidades coletivas. Tese (doutorado). Instituto de Psicologia. Universidade de São Paulo, 2010.

CARDOSO, Giovanna Marget Menezes. O estudo do meio como lugar de aprendizagem docente: pesquisa e formação profissional (2008). Disponível em: <http://www.partes.com.br/educacao/estudodomeio.asp>. Acesso em: 04 jun. 2013.

CARMO, Maria Lígia Moreira do. Planejamento e Gestão Municipal Integrada entre os municípios de Campos do Jordão, São Bento do Sapucaí, Santo Antonio do Pinhal e Monteiro Lobato, no Estado de São Paulo. Instituto de Pesquisa e Desenvolvimento. Universidade do Vale do Paraíba, 2003.

CARVALHO, Caio Luiz de. Políticas Públicas no Turismo Brasileiro, a cidade de São Paulo e a construção de sua identidade. 2009. 232 f. Tese (Doutorado em Ciências da Comunicação). Escola de Comunicações e Artes. Universidade de São Paulo, São Paulo, 2009.

CAVALCANTE, Ludmila Oliveira Holanda; FERRARO JÚNIOR, Luiz Antônio. Planejamento participativo: uma estratégia política e educacional para 0 desenvolvimento local sustentável (relato de experiência do Programa Comunidade Ativa). Disponível em: <http://www.scielo.br/scielo.php?script=sci_arttext\&pid=S010173302002008100009>. Acesso em: 06 fev. 2014.

CONSELHO COMUNITÁRIO DE SEGURANÇA DE MONTEIRO LOBATO (CONSEG). Pesquisa para traçar o perfil da juventude em Monteiro Lobato e direcionar políticas públicas para este segmento, 2013.

CORIOLANO, Luzia Neide. Do local ao global: 0 Turismo litorâneo cearense. Campinas: Papirus, 1998 (Coleção Turismo). 
COSTA, Cesar Rodrigues da. Elementos para o planejamento turístico no município de Monteiro Lobato, SP. Dissertação (Mestrado em Planejamento Urbano e Regional) - Instituto de Pesquisa e Desenvolvimento, Universidade do Vale do Paraíba, 2000.

Análise das Perspectivas para a Implantação da Função Econômica Turística em Monteiro Lobato, SP. Trabalho de Graduação. Univap. Curso de Geografia. 1997.

COSTA, Luiz Marcondes. Uma tentativa de desenvolvimento de comunidade. Faculdade de Serviço Social. TCC № 011. Taubaté, 1969.

CROCOMO, Celso. Relatório da Oficina de Planejamento Participativo. Estratégia para o Desenvolvimento Turístico do Município de São José dos Campos, SP. Prefeitura Municipal de São José dos Campos. COMTUR Conselho Municipal do Turismo. São José dos Campos - SP. 28 a 31 de agosto de 2000.

CRUZ, Rita de Cássia Ariza da. Turismo, Território e o Mito do Desenvolvimento. In: Espaço e Geografia. Publicação do Departamento de Geografia e do Programa de Pós-Graduação em Geografia. - ano 3, № 1 (2000) - Brasília: Instituto de Ciências Humanas, Universidade de Brasília.

DEMO, Pedro. Elementos metodológicos da pesquisa participante. In Repensando a pesquisa participante. Carlos Brandão (Org.). São Paulo: Brasiliense, 1999.

DENCKER, Ada de Freitas Maneti. Pesquisa e interdisciplinaridade no ensino superior. São Paulo: Aleph, 2002.

DÍAZ, Emilio Moyano. Uma exploração da especificidade e interdisciplinaridade metodológica em Psicologia Ambiental. In: Psicologia USP/Instituto de Psicologia, Universidade de São Paulo, Vol. 16, n. 1/2 - 2005. ISSN 01036564. Psicologia e Ambiente. Editora Convidada: Eda Terezinha de Oliveira Tassara.

ENRIQUEZ, Eugène. O vínculo grupal. In: MACHADO, Marília et al. (Orgs.). Psicossociologia: análise social e intervenção. Petrópolis, RJ: Vozes, 1994.

FERREIRA, Aurélio Buarque de Holanda. Dicionário Aurélio Básico da Língua Portuguesa. Rio de Janeiro: Editora Nova Fronteira, 1995. 
FERREIRA, P. C.; FISCH T. V. Formações Vegetais. In: FERREIRA, Potiguara Chagas (Coord.). A biologia e a geografia do Vale do Paraíba: trecho paulista. São José dos Campos: IPEA, 2007.

FRAGA, Margarida. Turismo e Desenvolvimento Sustentável: referências e reflexões. EMBRATUR, 2003. Disponível em: <http://www.embratur.gov.br/0catalogo-documentos/observatorio/TurismoeDesenvolvimentoSustentavelreferenciasereflexoes.pdf>. Acesso em: 11 jul. 2005.

FREITAS, José Carlos. Loteamentos Clandestinos: uma proposta de prevenção e repressão [s. d.]. Disponível em: <http://www.avilesp.org.br/joomla/loteamentos-clandestinos-jose-carlos-defreitas.pdf> Acesso em: 17 jan. 2014.

FRENTE PARLAMENTAR PELO DESENVOLVIMENTO DO MUNICÍPIOS DE INTERESSE TURÍSTICO (FREMITUR). Informativo da FREMITUR. Assembleia Legislativa do Estado de São Paulo, 2013.

FUNDAÇÃO MATUTU. Participação Social, Associativismo e Desenvolvimento Local. Serra do Papagaio. Carla Oddone Ribeiro (Org.). Caderno no. 3, 2011.

FUNDAÇÃO SISTEMA ESTADUAL DE ANÁLISE DE DADOS DO ESTADO DE SÃO PAULO (SEADE). Disponível em: <https://www.seade.gov.br/>. Acesso em: 29 jan. 2014.

FURRIELA, Rachel Biderman. Democracia, cidadania e proteção do meio ambiente. São Paulo: Annablume: Fapesp, 2002.

GADOTTI, Moacir. Gestão Democrática da Educação com Participação Popular no Planejamento e na Organização da Educação Nacional. Texto produzido como uma colaboração para a discussão do tema geral da Conae 2014.

em: $<$ http://conae2014.mec.gov.br/images/pdf/artigo_moacir_gadotti.pdf $>$. Acesso em: 06 fev. 2014.

GARCIA, Alexandre Navarro. Democracia Semidireta: Referendo, Plebiscito, Iniciativa Popular e Legislação Participativa. Curso de Especialização em Direito Legislativo. Universidade do Legislativo Brasileiro UNILEGIS e Universidade Federal do Mato Grosso do Sul - UFMS. Brasília, 2004. 
GERARDI, L. H. O. S. BÁRBARA, C. M. N. Quantificação em Geografia. São Paulo, DIFEL, 1981.

GERGEN, Kenneth J. A psicologia social como história. Revista Psicologia \& Sociedade. Vol. 20, no. 3, Florianópolis, Sept./Dec.,2008. Disponível em: $<$ http://www.scielo.br/scielo.php?pid=S0102-

71822008000300018\&script=sci_arttext>. Acesso em: 21 abr 2014.

GIANOTTEN, Vera; WIT, Ton de. Pesquisa participante em um contexto de economia camponesa. In: BRANDÃO, Carlos Rodrigues (Org.). Repensando a pesquisa participante. São Paulo: Brasiliense, 1999.

GOHN, Maria da Glória. Empoderamento e participação da comunidade em políticas sociais. Saúde e Sociedade v. 13, n. 2, p. 20-31, maio-ago. 2004.

Cortez, 2001.

Conselhos gestores e participação sociopolítica. São Paulo:

GODOY, Marcelo de Souza; ZIMMERMANN, Renata Isabel; ZIMMERMANN Ricardo Antonio. Mamíferos. In: FERREIRA, Potiguara Chagas (Coord.). A biologia e a geografia do Vale do Paraíba: trecho paulista. São José dos Campos: IPEA, 2007.

GOTTDIENER, Mark. A produção social do espaço urbano. São Paulo: EDUSP, 1997.

GRUPO PLANEJATUR. Plano Diretor de Turismo Sustentável de Monteiro Lobato. Monteiro Lobato, SP, 2014a, 308 p.

GRUPO PLANEJATUR. Vídeo documentário: Turismo Sustentável, Monteiro Lobato merece! Monteiro Lobato: Imagerun Produções/Antonio Goes. 1 DVD, 2014b. Disponível em: < http://youtu.be/4bJojN9QJLM >. Acesso em: 16 jan. 2014.

GTZ. ZOPP em síntese. Manual modelo CEFE. Curso ministrado para gerentes e técnicos do SEBRAE-SP (Serviço de Apoio às Micro e Pequenas Empresas de São Paulo), [1995].

HALL, Collin Michael. Planejamento turístico: políticas, processos e relacionamentos. São Paulo: Contexto, 2001. 
INSTITUTO BRASILEIRO DE GEOGRÁFIA E ESTATÍSTICA (IBGE). Disponível em:<http://www.cidades.ibge.gov.br/>. Acesso em: 29 jan. 2014.

INSTITUTO DE PESQUISAS TECNOLÓGICAS DO ESTADO DE SÃO PAULO (IPT). Plano da Bacia Hidrográfica do Rio Paraíba do Sul: Trecho do Estado de São Paulo (UGRHI 02) - 2011-2014. Síntese. São Paulo: Instituto de Pesquisas Tecnológicas do Estado de São Paulo (IPT), 2012.

INSTITUTO ECOSOCIAL. Programa Germinar. Apostila, Módulo 4, 2013.

ISSA, Márcia de Abreu. Análise da Paisagem como Subsídio ao Ordenamento Territorial do Município de Monteiro Lobato. Dissertação (Mestrado em Planejamento Urbano e Regional) - Instituto de Pesquisa e Desenvolvimento, Universidade do Vale do Paraíba, 2003.

ISSA, Yara Silvia Marques de Melo. "Turismo de um dia": uma análise socioespacial. In: Boletim de Turismo e Administração Hoteleira. Centro Universitário lbero-Americano - vol. 11, no. 1 (maio 2002) - São Paulo: UNIBERO, 2002.

JARA, Carlos Julio. A sustentabilidade do desenvolvimento local. Brasília: Instituto Interamericano de Cooperação para a Agricultura (IICA): Recife: Secretaria do Planejamento do Estado de Pernambuco-Seplan, 1998.

JORNAL O MINARETE. Publicação bimestral do município de Monteiro Lobato. Ano 1, no. 1, agosto de 1997 e Inventário Turístico do município de Monteiro Lobato,1997.

JORNAL VOZ DA SERRA. Veículo Independente a serviço da comunicação humana. Monteiro Lobato. Ano I - nº. 2, nov./dez. 2000 - jan. 2001.

JOSÉ, Mariana Aranha Moreira. Interdisciplinaridade: as disciplinas e a interdisciplinaridade brasileira. In: FAZENDA, Ivani (Org.). 0 que é Interdisciplinaridade? São Paulo: Cortez, 2008.

KUMMER, L. Metodologia participativa no meio rural: uma visão interdisciplinar. Conceitos, ferramentas e vivências. - Salvador: GTZ, 2007. 155p. Disponível em: <http://pt.slideshare.net/kcsantana/metodologiaparticipativa-no-meio-rural>. Acesso em: 27 dez. 2013. 
LEITE JUNIOR, Plínio Pimentel. Turismo e Produção. In: LEITE JUNIOR, Plínio Pimentel (Org.), O valor Social do Turismo. São Paulo: Roca, 2007.

LENCIONI NETO, Frederico. Aves. In: FERREIRA, Potiguara Chagas (Coord.). A biologia e a geografia do Vale do Paraíba: trecho paulista. São José dos Campos: IPEA, 2007.

LEWIN, Kurt. Problemas de Dinâmica de Grupo. São Paulo: Editora Cultrix, 1948.

LIMA, Adriana Rosado Maia de. Desenvolvimento Local Integrado e Sustentável - DLIS: um olhar sob a perspectiva dos agentes implementadores. 2006. Universidade Federal da Paraíba, PB. Dissertação (Mestrado), $2006 . \quad$ Disponível em: <http://bdtd.biblioteca.ufpb.br/tde_busca/arquivo.php?codArquivo=2077> .

Acesso em: 02 out. 2013.

LÓPEZ, José Luis Sieira. Estudo sobre as Necessidades de Formação no Cone Leste Paulista - Estado de São Paulo. Ago/2000.

MACHADO, Rodrigo; GUIMARÃES NETTO, Ana Carolina. Projeto Cabuçu de desenvolvimento local: perspectivas para o desenvolvimento da atividade turística sustentável a partir do processos de planejamento participativo no Cabuçu. In: LEITE JUNIOR, Plínio Pimentel (Org.), 0 valor Social do Turismo. São Paulo: Roca, 2007.

MAGALHÃES, Cláudia Freitas. Diretrizes para o Turismo sustentável em municípios. São Paulo: Roca, 2002.

MATHEUS, C. E.; MORAES, A. J.; CAFFAGNI, C. W. A. Educação ambiental para o Turismo Sustentável. Vivências integradas e outras estratégias metodológicas. São Carlos: RiMa, 2005.

MINGUILLO, Miguel. Método ZOPP: Planejamento de Projeto Orientado por Objetivos. Fundação Maurício Sirotsky Sobrinho. [s. d.]. Disponível em: $<$ http://cursos.campusvirtualsp.org/pluginfile.php/9477/mod_page/content/1/CV SERFAPS_12_ESP/M3_ESP/Lecturas_Complementarias/M3C4_Minguillo_200 3.pdf>. Acesso em: 27 dez. 2013. 
MIRA, Ricardo Garcia; STEA, David; ELGUEA, Silvia. Psicologia Ambiental e Política Ambiental: questões teóricas e práticas. Comentários a partir das contribuições. In: Revista Psicologia USP/Instituto de Psicologia, Universidade de São Paulo, USP, IP, vol. 16 - nº. 1/2 - 2005.

MONTEIRO LOBATO. Lei municipal $N^{\circ} 1.090$, de 18 de novembro de 1997. Dispõe sobre a criação do Conselho Municipal de Turismo do Município de Monteiro Lobato. Prefeitura Municipal de Monteiro Lobato, SP.

MONTEIRO LOBATO. Decreto № 1.358/13, de 17 de junho de 2013. Dispõe sobre a nomeação dos membros do COMTUR- Conselho Municipal de Turismo do Município de Monteiro Lobato. Prefeitura Municipal de Monteiro Lobato, SP.

MONTEIRO LOBATO. Lei Municipal № 1.515, de 02 de maio de 2012. Dispõe sobre a oficialização do Hino do Município de Monteiro Lobato. Prefeitura Municipal de Monteiro Lobato, SP.

MONTEIRO LOBATO. Lei Orgânica do Município de Monteiro Lobato, 05 de abril de1990. Câmara Municipal de Monteiro Lobato, SP.

MONTEIRO LOBATO. Lei Municipal № 544/81, de 01 de junho de 1981. Dispõe sobre o parcelamento do Solo Urbano no Município de Monteiro Lobato e dá outras providências. Prefeitura Municipal de Monteiro Lobato, SP.

MOREIRA, Mário José; AGUIAR, Carlos Roberto; PIVOTT, Cleide; LIMA, José Augusto Pereira. Elementos Ambientais no Planejamento Territorial da Serra da Mantiqueira. Disciplina: PLUR 232. Elementos Ambientais no Planejamento Territorial. Prof. Dr. Mário Valério Filho. Universidade do Vale do Paraíba, Instituto de Pesquisa e Desenvolvimento - IP\&D. Curso: Mestrado em Planejamento Urbano e Regional. São José dos Campos, SP, 2004.

MOSER, Gabriel. A Psicologia Ambiental: competência e contornos de uma disciplina. Comentários a partir das contribuições. In: Revista Psicologia USP/Instituto de Psicologia, Universidade de São Paulo, USP, IP, vol. 16 - $\mathrm{n}^{\circ}$. $1 / 2-2005 a$.

Psicologia Ambiental e estudos pessoas-ambiente: Que tipo de colaboração multidisciplinar? In: Revista Psicologia USP/Instituto de Psicologia, Universidade de São Paulo, USP, IP, vol. $16-n^{0} .1 / 2-2005 b$. 
MÜLLER, Nice Lecocq. O Fato Urbano na Bacia do Rio Paraíba. Rio de Janeiro. IBGE. 1969.

NASCIMENTO, Elimar Pinheiro do. Trajetória da sustentabilidade: do ambiental ao social, do social ao econômico. Dossiê Teorias Socioambientais. Estudos Avançados. Estud. av. vol. 26 no. 74. São Paulo: Instituto de Estudos Avançados. USP, 2012. Versão impressa ISSN 0103-4014. Disponível em: < http://dx.doi.org/10.1590/S0103-40142012000100005>. Acesso em: 26 maio 2013.

NICOLESCU, Basarab. O manifesto da transdisciplinaridade. São Paulo: TRIOM, 1999.

O GRITO DA RAM. Ano I - Boletim 3 - maio de 2012.

OKAMURA, C. et al. Documento Síntese do Fórum "Olhando para o Futuro". In: Psicologia USP/Instituto de Psicologia, Universidade de São Paulo, Vol. 16, n. 1/2 - 2005. ISSN 0103-6564. Psicologia e Ambiente. Editora Convidada: Eda Terezinha de Oliveira Tassara.

OLIVEIRA, Roberto Cardoso de. O mal-estar da ética na antropologia prática. In: VÍCTORA, Ceres et al. (Orgs.) Antropologia e Ética. 0 debate atual no Brasil. Niterói: EdUFF, 2004.

ORGANIZAÇÃO MUNDIAL DO TURISMO - OMT. Guia de desenvolvimento do Turismo sustentável. Porto Alegre: Bookman, 2003.

ORGANIZAÇÃO MUNDIAL DO TURISMO - OMT. Desenvolvimento de Turismo Sustentável: Manual para Organizadores Locais. Programa nacional de Municipalização do Turismo. Brasília: EMBRATUR, 1998.

OURIQUES, Helton Ricardo. A produção do Turismo: fetichismo e dependência. Campinas, SP: Editora Alínea, 2005.

POL, Enric. Retos y aportaciones de La Psicología ambiental para un desarrollo sostenible. La detección de Impactos Sociales como muestra. In: MARTíNEZ, Javier Guevara; DOMÉNECH, Serafin Mercado (Orgs.). Temas selectos de Psicologia Ambiental. UNAM - Greco - Fundación Unilibre, 2002. 
PORTAL ODM - Acompanhamento Municipal dos Objetivos de Desenvolvimento do Milênio. Disponível em: <http://www.portalodm.com.br/relatorios/sp/monteiro-lobato>. Acesso em: 19 fev. 2014.

RABINOVICH, Elaine P. Por uma Psicologia Ambiental das diferenças. In: Revista Psicologia USP/Instituto de Psicologia, Universidade de São Paulo, USP, IP, vol. $16-\mathrm{n}^{\circ} .1 / 2-2005$.

RATTNER, Henrique. Planejamento e Bem-estar Social. São Paulo: Editora Perspectiva, Coleção Debates, 1979.

RODOVIA FLORIANO RODRIGUES PINHEIRO (SP-123). Disponível em: $<$ http://www.camposdojordaocultura.com.br/fotografiassemana_det2.asp?idfoto=1024>. Acesso em: 02 jun. 2013.

ROMANI, Telma. Desenvolvimento Turístico a partir de uma perspectiva local. In: LEITE JUNIOR, Plínio Pimentel (Org.), 0 valor Social do Turismo. São Paulo: Roca, 2007.

ROSA, Deise Datti. Depoimento [dez. 2013]. Entrevistador: Antonio Goes. Monteiro Lobato: Imagerun Produções. 2 DVDs. Entrevista concedida para 0 Vídeo documentário: Turismo Sustentável, Monteiro Lobato merece!

RUIZ, J. A. Metodologia científica: guia para eficiência nos estudos. 3 ed. São Paulo: Atlas, 1991.

RUSCHMANN, Doris van de Meene. Turismo e planejamento sustentável: a proteção do meio ambiente. Campinas. SP. Papirus, 1997.

Planejamento Turístico. In Turismo: como aprender, como ensinar. São Paulo: SENAC, 2001. v. 2.

; MARCHINI, Silvio. Sistemas de Informação Geográfica (SIG) e suas aplicações na gestão e no planejamento do Turismo. AECOTURIS Turismo sustentável. São Paulo, 2005 (brochura).

Plano de Desenvolvimento Integrado de Turismo Sustentável (PDITS) de São Francisco Xavier, Distrito de São José dos Campos, SP, 2003. 
SACHS, Ignacy. Meio Ambiente e Desenvolvimento. Desenvolvimento numa economia mundial liberalizada e globalizante: um desafio impossível? In: Estudos Avançados. av. v.11 n.30 São Paulo maio/ago. 1997. Disponível em: <http://dx.doi.org/10.1590/S0103-40141997000200014>. Acesso em: 17 jan. 2014.

SAMARA, Beatriz Santos e BARROS, José Carlos. Pesquisa de marketing: conceitos e metodologia. 2a Edição. São Paulo: Makron Books, 1997.

SANTOS, Kelly Elaine dos. Economia Regional e Urbana - Consumo: vínculos com o mercado e descaso para com o meio ambiente. Problemas de geração de lixo. Bragança Paulista. Universidade São Francisco. In Monografias. IV Prêmio CORECON-SP de excelência em economia. 1998.

SANTOS, Milton. Espaço e método. 4⿳亠丷a ed. São Paulo, Nobel, 1985.

Metamorfoses do espaço habitado. Fundamentos teóricos e metodológicos da Geografia. 4⿳亠丷a . ed. São Paulo: Editora de Humanismo, Ciência e Tecnologia HUCITEC Ltda., 1988.

SANTOS, Silvia Aparecida Martins dos. Políticas públicas de formação de educadores ambientais: análise do processo de constituição do coletivo Educador de São Carlos, Araraquara, Jaboticabal e região. Tese (Doutorado). Escola de Engenharia de São Carlos. USP. 2010.

SÃO PAULO (Estado). Secretaria do Meio Ambiente do Estado de São Paulo. Coordenadoria de Planejamento Ambiental. Subsídios ao Planejamento Ambiental. Unidade Hidrográfica de Gerenciamento de Recursos Hídricos Paraíba do Sul (UGRHI 02), 2010a.

SÃO PAULO (Estado). Secretaria de Saneamento e Energia do Estado de São Paulo. Coordenadoria de Saneamento. Descrição dos Sistemas existentes e projetados e avaliação da prestação dos serviços de saneamento básico do Município de Monteiro Lobato - Produto 2. Planos integrados regionais de saneamento básico para as unidades de gerenciamento de recursos hídricos da Serra da Mantiqueira, Paraíba do Sul e Litoral Norte (UGRHIs 1, 2 e 3), 2010b.

SÃO PAULO (Estado). Secretaria do Meio Ambiente do Estado de São Paulo. Coordenadoria de Planejamento Ambiental. Meio Ambiente Paulista: Relatório de Qualidade Ambiental 2011. Organização: Fabiano Eduardo Lagazzi Figueiredo. São Paulo: SMA/CPLA, 2011. 
SÃO PAULO (Estado). Secretaria de Saneamento e Recursos Hídricos. Coordenadoria de Saneamento. Programa Estadual de Apoio à Elaboração de Planos Municipais de Saneamento. Monteiro Lobato. Plano Municipal de Saneamento Básico, [2012].

SÃO PAULO (Estado). Proposta de Plano Municipal Integrado de Saneamento Básico. Versão revisada com a incorporação dos comentários da SSRH Secretaria de Saneamento E Recursos Hídricos. Relatório R4 - Revisão 02. 2013

SÃO PAULO (Estado). Levantamento Censitário das Unidades de Produção Agropecuária do Estado de São Paulo (LUPA), no período de 2007 a 2008, pelo Governo Estadual através da Secretaria de Agricultura e Abastecimento do Estado de São Paulo e CATI - Escritório de Desenvolvimento Rural de Pindamonhangaba, 2009.

SÃO PAULO (Estado). Projeto de Lei Complementar № 32, de 2012. Estabelece condições e requisitos para a classificação de Estâncias e de Municípios de Interesse Turístico e dá providências correlatas. Assembleia Legislativa.

SCHMIDT, Maria Luisa Sandoval. Pesquisa participante: alteridade e comunidades interpretativas. Revista Psicologia USP, 17 (2), 2006: 11-41.

SEMACTUR-MONTEIRO LOBATO. Ata de reunião no Instituto Eco-Solidário em 18/09/2007 com Marcos Fernandes Costa, Roberto Aguiar, Roberto Simão e Daniela de Cássia Santos (cópia cedida por Roberto Aguiar).

SILVA, Maria da Glória Lanci da. Cidades turísticas: identidades e cenários de lazer. São Paulo: Aleph, 2004 (Série Turismo).

SOUZA, Marcelo Lopes. Mudar a Cidade: Uma Introdução Crítica ao Planejamento e à Gestão Urbanos. $2^{\underline{a}}$ ed. Rio de Janeiro: Bertrand Brasil, 2004.

SOUZA, Maria Luiza de. Desenvolvimento de comunidade e participação. 10. Ed. São Paulo: Cortez, 2010.

STIGLIANO, Beatriz Veronese; CÉSAR, Pedro de Alcântara Bittencourt. Inventário turístico: primeira etapa da elaboração do Plano de desenvolvimento turístico. Campinas, SP: Editora Alínea, 2005. 
TIBÚRCIO, Carlos; BAVA, Silvio Caccia. Quem está na frente é o povo. Cadernos Lê Monde Diplomatique. Ed. Especial, n. 2, jan. 2001.

THIOLLENT, Michel. Notas para o debate sobre pesquisa-ação. In: BRANDÃO, Carlos Rodrigues (Org.). Repensando a pesquisa participante. São Paulo: Brasiliense, 1999.

Metodologia da pesquisa-ação. São Paulo: Cortez: Autores Associados, 1986.

UNIVERSIDADE DE SÃO PAULO. Sistema Integrado de Bibliotecas. Diretrizes para apresentação de dissertações e teses da USP: documento eletrônico e impresso. São Paulo, 2. ed. 2009. Disponível em: $<$ http://www.usp.br/sibi/produtos/imgs/Caderno_Estudos_9_PT_1.pdf >. Acesso em: 04 jan. 2014.

VEIGA, José Eli da. Indicadores de sustentabilidade. Dossiê Teorias Socioambientais. Estudos Avançados. Estud. av. vol. 24 no. 68. São Paulo: Instituto de Estudos Avançados. USP, 2010. Versão impressa ISSN 0103-4014. Disponível em: <http://dx.doi.org/10.1590/S0103-40142010000100006>. Acesso em: 26 maio 2013.

WIESENFELD, Esther. A Psicologia Ambiental e as diversas realidades humanas. In: Revista Psicologia USP/Instituto de Psicologia, Universidade de São Paulo, USP, IP, vol. 16 - n. 1/2 - 2005a.

YARED, Ivone. O que é interdisciplinaridade? In: FAZENDA, Ivani (Org.). 0 que é Interdisciplinaridade? São Paulo: Cortez, 2008.

YASOSHIMA, José Roberto. Hospitalidade e Turismo: um modelo de acolhimento para as Estâncias Paulistas. 2003. $192 \mathrm{f}$. Tese (Doutorado em Ciências da Comunicação). Escola de Comunicações e Artes. Universidade de São Paulo, São Paulo, 2003. 


\section{APÊNDICE A}

\section{PROGRAMA DE ENSINO}

\begin{tabular}{|l|l|l|}
\hline 01 & CURSO PARA CAPACITAÇÃO EM TURISMO SUSTENTÁVEL \\
\hline Carga Horária: $24 \mathrm{~h}$ & $\begin{array}{l}\text { Período: } \\
\text { setembro a dezembro de 2011 }\end{array}$ \\
\hline Horas Aulas Semanais: $2 \mathrm{~h}$ & $\begin{array}{l}\text { Município: } \\
\text { Monteiro Lobato }\end{array}$ \\
\hline PROFESSOR: Cleide Pivott & \\
\hline
\end{tabular}

02 EMENTA

O que é Turismo. Quem é o turista. O que é o Turismo Sustentável. O que é planejamento turístico. O que é planejamento participativo. Como acontece a formação de cidades, em especial as turísticas. Quais os impactos positivos e negativos que o Turismo causa para a sociedade e o meio ambiente. Como minimizar impactos negativos e maximizar os positivos. Quais as etapas da elaboração de um plano diretor de Turismo para um município. (Re)conhecendo Monteiro Lobato.

\begin{tabular}{|l|l|}
\hline 03 & \multicolumn{1}{|c|}{ OBJETIVOS } \\
\hline & $\begin{array}{l}\text { Objetivos Gerais: } \\
\text { Apresentar e debater os fatores que compõem a atividade turística, em especial } \\
\text { aqueles inerentes ao Turismo Sustentável, levando os participantes do curso ao } \\
\text { entendimento das conceituações específicas, da dinâmica do setor e da } \\
\text { importância do planejamento do Turismo Sustentável. }\end{array}$ \\
\hline $\begin{array}{l}\text { Objetivos Específicos: } \\
\text { - conceituar os termos específicos relacionados ao Turismo; } \\
\text { - debater questões relacionadas ao desenvolvimento turístico; } \\
\text { - entender como ocorre a formação de cidades, em especial as turísticas; } \\
\text { - entender a dinâmica do Turismo; } \\
\text { - entender as etapas do planejamento do Turismo Sustentável; } \\
\text { - conhecer e debater o potencial turístico de Monteiro Lobato. }\end{array}$ \\
\hline
\end{tabular}

\section{METODOLOGIA}

Aulas Expositivas com discussão de textos através de debates e seminários.

Trabalhos em Grupo para apresentação oral e/ou por escrito.

Elaboração de pesquisas.

\section{5 MATERIAL DIDÁTICO}

Datashow, quadro branco, vídeos, textos, mapas, fotos, apostila. 


\begin{tabular}{|l|l|}
\hline 06 & FORMAS DE AVALIAÇÃo / CRITÉRIO \\
\hline & Função Formativa: Participação em sala de aula \\
\hline
\end{tabular}

\begin{tabular}{|l|l|r|}
\hline $\mathbf{0 7}$ & PROGRAMA DE ENSINO & $\begin{array}{r}\text { Carga } \\
\text { horária }\end{array}$ \\
\hline $\mathbf{1 5 / 9}$ & $\begin{array}{l}\text { O que é Turismo. Quem é o turista. O Turismo como fator } \\
\text { econômico. Viajante, visitante, turista e excursionista. Marketing } \\
\text { Turístico. O produto turístico. A oferta turística. A demanda } \\
\text { turística }\end{array}$ & 2 \\
\hline $\mathbf{2 2 / 9}$ & $\begin{array}{l}\text { A segmentação turística. Ciclo de vida da região turística. } \\
\text { Mapeamento e desenho propostos da cadeia produtiva do } \\
\text { Turismo. Trade turístico. Cluster turístico }\end{array}$ & 2 \\
\hline $\mathbf{2 9 / 9}$ & O que é o Turismo Sustentável. Desenvolvimento Sustentável. & 2 \\
\hline $\mathbf{0 6 / 1 0}$ & $\begin{array}{l}\text { Impactos positivos e negativos que o Turismo causa para a } \\
\text { sociedade e o meio ambiente }\end{array}$ & 2 \\
\hline $\mathbf{1 3 / 1 0}$ & Como minimizar impactos negativos e maximizar os positivos & 2 \\
\hline $\mathbf{2 0 / 1 0}$ & Como maximizar os impactos positivos. & 2 \\
\hline $\mathbf{2 7 / 1 0}$ & Evento Iniciativa Araucária - Sebrae-SP - Campos do Jordão & 2 \\
\hline $\mathbf{0 3 / 1 1}$ & Participação Social. & 2 \\
\hline $\mathbf{1 0 / 1 1}$ & $\begin{array}{l}\text { O que é planejamento participativo O que é planejamento e } \\
\text { plano diretor. }\end{array}$ & 2 \\
\hline $\mathbf{1 7 / 1 1}$ & $\begin{array}{l}\text { O que é planejamento turístico } \\
\text { Etapas da elaboração de um plano diretor de Turismo para um } \\
\text { município: } \\
\text { - Estudo preliminar } \\
\text { - Diagnóstico } \\
\text { - Prognóstico Como acontece a formação de cidades, em } \\
\text { especial as turísticas }\end{array}$ \\
\hline $\mathbf{2 4 / 1 1}$ & Como acontece a formação de cidades & 2 \\
\hline $\mathbf{0 1 / 1 2}$ & Como acontece a formação de cidades turísticas & 2 \\
\hline Total: & (Re)Conhecendo Monteiro Lobato & \\
\hline
\end{tabular}

\section{BIBLIOGRAFIA}

BENI, Mario Carlos. Análise Estrutural do Turismo. São Paulo: SENAC, 2002.

HORKHEIMER Max; ADORNO Theodor W. Sociedade. In Sociologia e Sociedade. Rio de Janeiro: Editora LTC. 1978.

JARA, Carlos Julio. A sustentabilidade do desenvolvimento local. Brasília: Instituto Interamericano de Cooperação para a Agricultura (IICA): Recife: Secretaria do Planejamento do Estado de Pernambuco-Seplan,1998a. 
Repensando o desenvolvimento comunitário: o essencial nem sempre é visível. In: Globalização e desenvolvimento local sustentável (Textos de Referência). Instituto Interamericano de Cooperação para a Agricultura IICA. 1998b.

ORGANIZAÇÃO MUNDIAL DO TURISMO - OMT. Introdução ao Turismo. São Paulo: Roca, 2001.

ORGANIZAÇÃO MUNDIAL DO TURISMO - OMT. Guia de desenvolvimento do Turismo Sustentável. Porto Alegre: Bookman, 2003.

PETROCCHI, Mário. Gestão de Polos Turísticos. São Paulo. Futura. 2001.

PETROCHI, Mário. Turismo, Planejamento e Gestão. São Paulo. Futura. 1998.

PIVOTT, Cleide. O Turismo e a produção social do espaço urbano. Estudos sobre Campos do Jordão. 2006. Dissertação (Mestrado em Planejamento Urbano e Regional) - Instituto de Pesquisa e Desenvolvimento, Universidade do Vale do Paraíba, 2006. Orientador: Prof. Dr. José Oswaldo Soares de Oliveira.

; SILVA, Daniela Corrêa da. Participação popular no Brasil: teoria e prática, um ensaio no município de Campos do Jordão, SP. In: Limites e Perspectivas do Planejamento Participativo. OLIVEIRA, José Oswaldo Soares de (org.). São José dos Campos, SP: UNIVAP, 2006.147 p. ISBN 85-7586-0305 .

RAMOS, Célia Maria. Sistema Informático de apoio ao planejamento e ordenamento turístico. In: Planejamento Turístico municipal com suporte em sistemas de informação. São Paulo. Futura. 1999.

RUSCHMANN, Doris van de Meene. Turismo e planejamento sustentável: a proteção do meio ambiente. Campinas. SP. Papirus, 1997. 


\section{APÊNDICE B}

\section{PESQUISA DE OPINIÃO DE MORADORES SOBRE O TURISMO EM MONTEIRO LOBATO - Grupo PLANEJATUR - 2013}

Bom dia/Boa tarde. Meu nome é . Estamos realizando uma pesquisa com os moradores de Monteiro Lobato para conhecermos a sua opinião sobre o Turismo no município. Podemos contar com a sua colaboração? Obrigado(a).

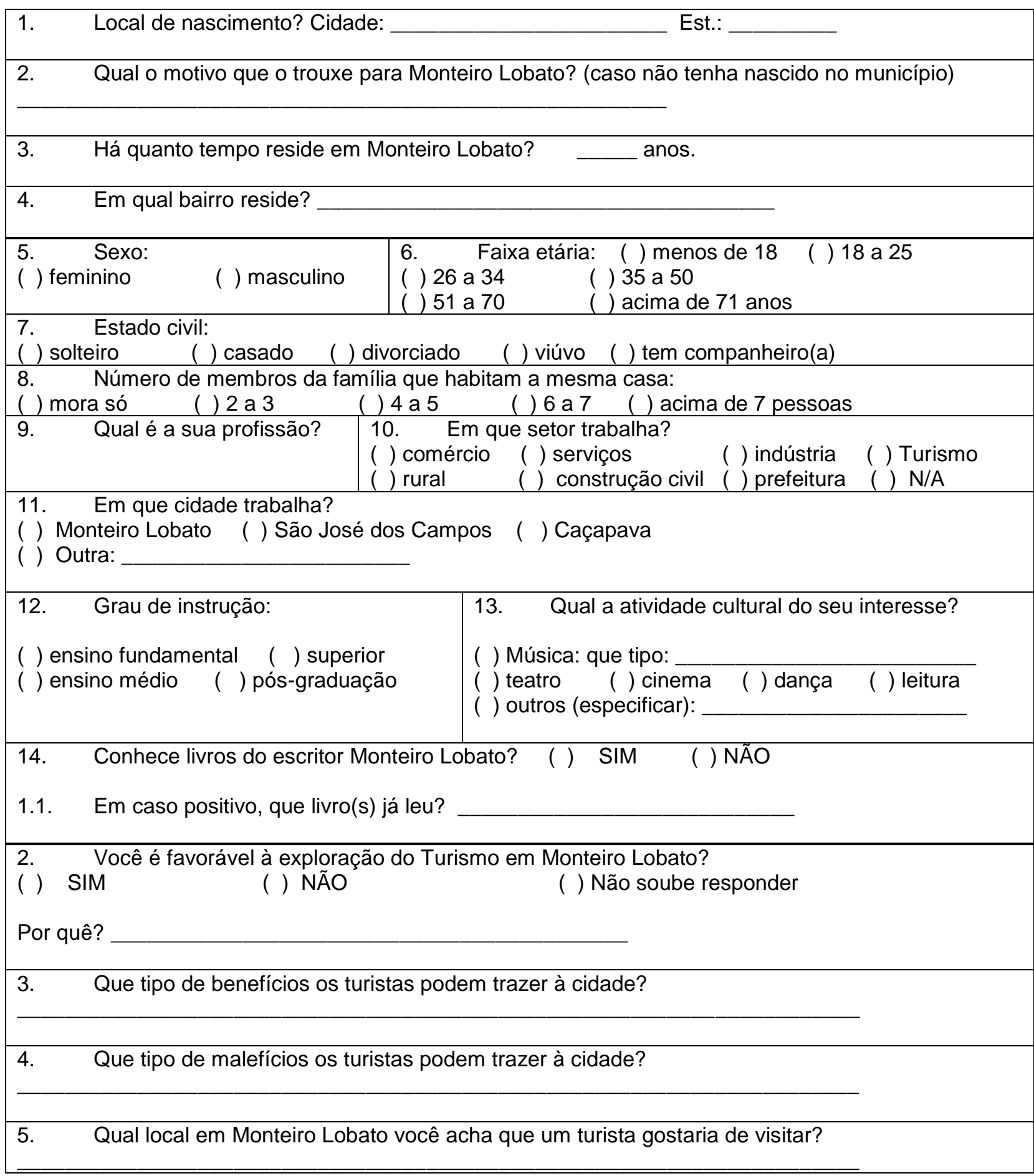




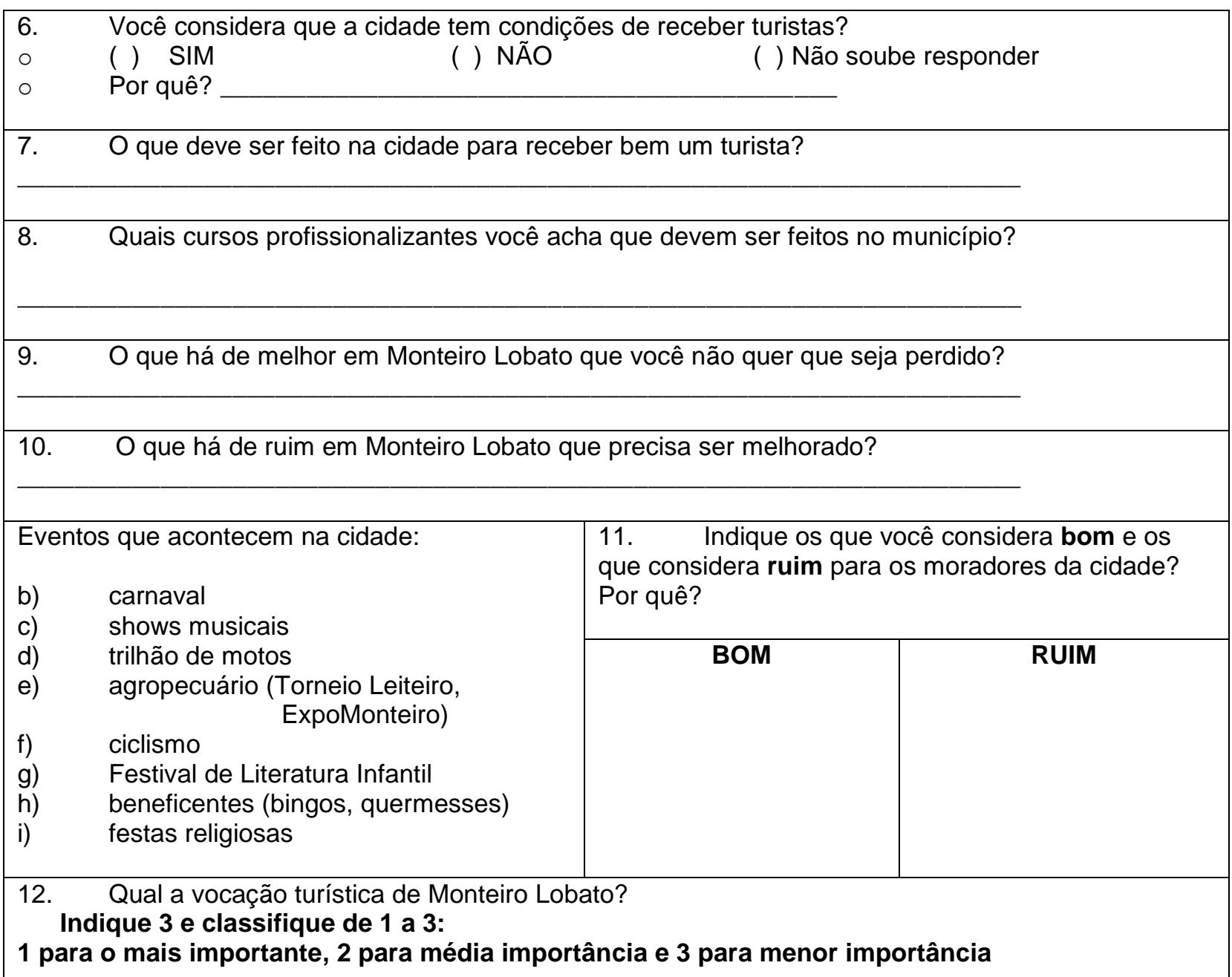

( ) o turista vem para conhecer o município de Monteiro Lobato

( ) romeiros (rota para Aparecida)

( ) peregrinos (Rota Franciscana)

( ) Turismo de um dia (passeios, banhos de cachoeira)

( ) Turismo ecológico (fazer trilhas)

( ) Turismo rural

( ) Turismo gastronômico

( ) Turismo cultural: 1) o escritor Monteiro Lobato

( ) Turismo cultural: 2) manifestações populares (Moçambique, Catira, Pereirões, artesanato)

( ) Turismo de passagem (parada para usar banheiro, comer, beber e seguir viagem)

( ) Turismo de aventura (rafting, escalada etc.)

( ) Turismo de segunda residência (chácaras)

( ) Turismo religioso

13. De uma maneira geral, o que considera que seja bom para toda a comunidade de Monteiro Lobato? 


\section{APÊNDICE C}

PESQUISA DE DEMANDA TURÍSTICA - Grupo PLANEJATUR - Monteiro Lobato - 2013

Momento da pesquisa: ( ) chegada do turista ( ) saída do turista ( ) durante a estada

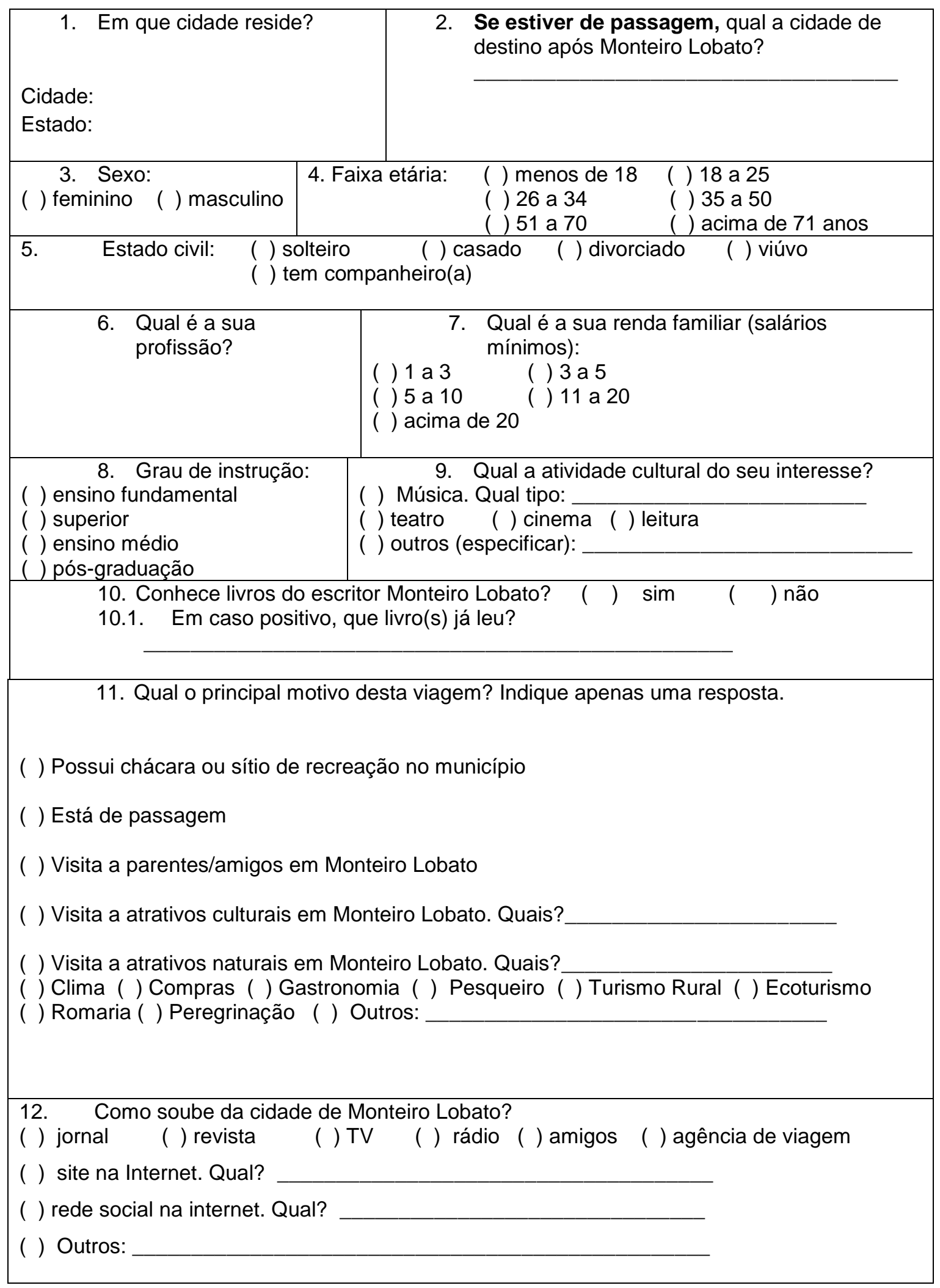


13. Com que frequência costuma visitar Monteiro Lobato?
( ) $1^{\text {a }}$ vez
( ) Semanalmente
( ) Mensalmente
( ) Mais de 1 vez por mês
( ) Anualmente
( ) Raramente

14. Tempo de permanência em Monteiro Lobato?

( ) 1 a 2 horas ( ) meio dia ( ) um dia ( ) final de semana ( ) 1 a 3 semanas

( ) 1 mês ( ) acima de 1 mês

15. Qual o meio de hospedagem utilizado neste município?

( ) não se hospeda ( ) Pousada ( ) Casa de parentes/amigos ( ) Acampamento

( ) Chácara de recreação alugada ( ) Chácara de recreação própria

16. Qual o meio de transporte utilizado nessa viagem?

( ) Carro de passeio próprio ( ) Ônibus fretado ( ) moto ( ) a cavalo (romaria)

( ) Carro de passeio locado ( ) Ônibus de linha regular ( ) bicicleta

( ) a pé (Rota Franciscana)

( ) Outros:

17. Como está viajando?

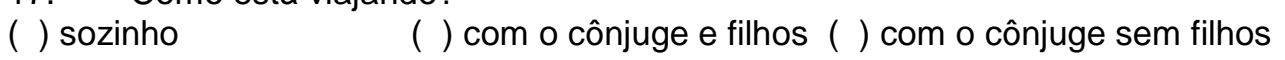

( ) com companheiro(a) ( ) com amigos

Em excursão organizada por: ( ) agência de viagem ( ) entidades associativas

( ) algum conhecido

( ) Outros:

18. Como costuma pagar suas despesas em viagem:

( ) dinheiro ( ) cheque ( ) cartão de crédito ( ) cartão de débito 
19. Você costuma fazer as refeições na cidade? ( ) Sim ( ) Não

19.1. Em caso afirmativo, onde:

( ) Restaurantes ( ) Bar/Lanchonete/Similares

( ) Refeições no próprio local onde está alojado

( ) Outros:

20. Você faz compras em Monteiro Lobato? ( ) Sim ( ) Não

20.1. Em caso afirmativo, o que compra?

( ) artesanato ( ) doces ( ) biscoitos ( ) queijos ( ) combustível

( ) itens diversos no supermercado

( ) roupas ( ) produtos agropecuários ( ) outros (especificar):

21. Como classifica os preços de produtos e serviços em Monteiro Lobato?

\begin{tabular}{|l|l|l|l|}
\hline \multicolumn{1}{|c|}{ Item de despesa } & alto & médio & baixo \\
\hline Alojamento & & & \\
\hline Alimentação (refeições) & & & \\
\hline Recreação & & & \\
\hline Artesanatos & & & \\
\hline Doces & & & \\
\hline Salgados & & & \\
\hline Água, refrigerante & & & \\
\hline Combustível & & & \\
\hline
\end{tabular}

22. Antes de chegar, qual era a sua expectativa em relação aos atrativos turísticos de Monteiro Lobato?
( ) Excelente
( ) Boa
( ) Regular
( ) Ruim

23. Como classifica a paisagem urbana de Monteiro Lobato?
( ) agradável
( ) desagradável
( ) indiferente

24. Como classifica a paisagem rural de Monteiro Lobato?
( ) agradável
( ) desagradável
( ) indiferente

25. Como classifica a limpeza em Monteiro Lobato?
( ) Excelente
( ) Boa
( ) Regular
( ) Ruim

26. Que produtos procurou e não encontrou?

27. Que serviços procurou e não encontrou? 
28. Como classifica o atendimento no comércio local?

( ) Excelente ( ) Bom ( ) Regular ( ) Ruim

29. O que mais the agradou em Monteiro Lobato?

30. O que menos Ihe agradou em Monteiro Lobato?

31. Há alguma coisa em particular que poderia tornar a cidade mais atraente?

( ) Sim ( ) Não

Em caso positivo, o que?

32. Voltaria a Monteiro Lobato em outra oportunidade? ( ) Sim ( ) Não 
APÊNDICE D

\begin{tabular}{|c|c|c|}
\hline 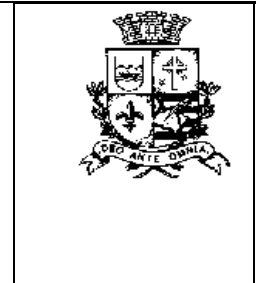 & $\begin{array}{l}\text { A Prefeitura Municipal, o Conselho } \\
\text { Municipal de Turismo e o Sindicato } \\
\text { Rural de Monteiro Lobato, } \\
\text { juntamente com o Sindicato dos } \\
\text { Hotéis, Restaurantes, Bares e } \\
\text { Similares (SINHORES) oferecem o } \\
\text { curso: }\end{array}$ & $\begin{array}{l}\text { CAPACITAÇÃO EM TURISMO } \\
\text { SUSTENTÁVEL } \\
\text { CURSO GRATUITO }\end{array}$ \\
\hline \multicolumn{2}{|c|}{$\begin{array}{l}\text { Período: } \\
\text { de } 15 \text { de setembro a } 08 \text { de dezembro/2011 } \\
\text { às quintas-feiras, das } 18 \mathrm{~h} 30 \text { às } 21 \mathrm{~h} 30\end{array}$} & $\begin{array}{l}\text { Local: } \\
\text { Sindicato Rural de } \\
\text { Monteiro Lobato }\end{array}$ \\
\hline \multicolumn{3}{|c|}{$\begin{array}{l}\text { Público-alvo: } \\
\text { Todos os residentes no município que estão interessados em colaborar na } \\
\text { construção do futuro de Monteiro Lobato com base no Turismo Sustentável. }\end{array}$} \\
\hline \multirow{2}{*}{\multicolumn{3}{|c|}{$\begin{array}{l}\text { Profa. Cleide Pivott: } \\
\text { Pós-graduada em Planejamento Urbano e Regional (UNIVAP) com } \\
\text { especialização em Turismo: Planejamento, Gestão e Marketing (UCB) e } \\
\text { cursando Doutorado em Psicologia Social (USP). } \\
\text { Conteúdo do Curso: } \\
\text { O curso visa apresentar as questões relacionadas ao planejamento do Turismo } \\
\text { Sustentável e as possibilidades de se maximizar os impactos positivos e } \\
\text { minimizar os negativos com a participação da comunidade de Monteiro Lobato. }\end{array}$}} \\
\hline & & \\
\hline \multicolumn{3}{|c|}{$\begin{array}{l}\text { Destaque e entregue a sua ficha de inscrição na Secretaria de Cultura e Turismo } \\
\text { de Monteiro Lobato, ou envie e-mail: turismomonteirolobato@yahoo.com.br / } \\
\text { pivott.cleide@gmail.com } \\
\text { Informações: Tel.: 3979-1314 / 8844-4020. }\end{array}$} \\
\hline \multicolumn{3}{|c|}{ FICHA DE INSCRIÇÃO - CURSO PARA CAPACITAÇÃO EM TURISMO } \\
\hline \multicolumn{3}{|c|}{ SUSTENTÁVEL } \\
\hline \multicolumn{2}{|l|}{ Nome: } & Data de nascimento: \\
\hline \multicolumn{2}{|l|}{ Endereço: } & Endereço: \\
\hline \multicolumn{2}{|l|}{ Telefone: } & \\
\hline \multicolumn{3}{|l|}{ Profissão: } \\
\hline Empresa: & & Cargo: \\
\hline
\end{tabular}




\section{APÊNDICE E}

\section{DOCUMENTO AOS CANDIDATOS A PREFEITO - ELEIÇÕES 2012}

Monteiro Lobato, 19 de julho de 2012.

Ilustríssimo(a) Senhor(a)

Prezado(a) Senhor(a),

O grupo PLANEJATUR MONTEIRO LOBATO (Grupo de Planejamento Participativo do Turismo Sustentável de Monteiro Lobato) foi formado como resultado do Curso de Capacitação em Turismo Sustentável realizado no segundo semestre de 2011 pela Profa. Cleide Pivott com apoio da Prefeitura, do COMTUR, do SINHORES e do Sindicato Rural.

O PLANEJATUR MONTEIRO LOBATO se propõe a colaborar com a organização e o planejamento turístico de Monteiro Lobato, tendo como objetivos estruturar a operacionalização do Turismo no município de forma sustentável e apoiar a busca da classificação de Monteiro Lobato como Município de Interesse Turístico.

Considerando que o Turismo em Monteiro Lobato está no estágio inicial de sua atividade, acreditamos que o município conseguirá implantar o Turismo Sustentável se houver participação da população, incluindo o poder público, a iniciativa privada e a comunidade local. Este é um novo modelo de exploração turística que zela pelo meio ambiente, que respeita a cultura local e que organiza as receitas advindas da atividade para beneficiar direta ou indiretamente os moradores do município. Para tal efeito, é necessário que a sociedade lobatense crie um pacto social em direção a um objetivo comum qual seja, o desenvolvimento socioeconômico do município preservando sua qualidade de vida e seu meio ambiente.

O documento que anexamos, apresenta o resultado da Oficina PlaneJÁtur Monteiro Lobato, realizada em 15 de março de 2012, com a participação de 48 munícipes representantes de 6 bairros que deram a sua contribuição para 
identificar as situações referentes ao Turismo do município que necessitam de planejamento e organização. Esse resultado foi trabalhado pelo Grupo Planejatur, de março a junho, no sentido de levantar os possíveis projetos para solucionar os aspectos negativos que foram apontados.

O objetivo do grupo Planejatur é entregar esse documento aos candidatos a Prefeito para que considerem as sugestões contidas no documento em suas respectivas propostas de governo. Agradecemos a atenção e ficamos à disposição para quaisquer esclarecimentos pertinentes.

Atenciosamente,

\section{PLANEJATUR MONTEIRO LOBATO}

(Grupo de Planejamento Participativo do Turismo Sustentável de Monteiro Lobato)

Componentes: André Barreto, Andrejs Ceruks, Antonio Renato de Sá Sonnewend, Benedita Ivana da Rocha Claro, Célia Ceruks, Cleide Pivott, Deise Datti Rosa, Ednea Goulart de Andrade, Larissa A. Claro, Leila Miranda, Mario Francisco Tomás, Odette A. C. da Silva, Ricardo Azevedo, Simone Azevedo. 


\section{PLANEJÁTUR - OFICINA DE PLANEJAMENTO PARTICIPATIVO EM TURISMO SUSTENTÁVEL NO MUNICÍPIO DE MONTEIRO LOBATO, MATRIZ DE PLANEJAMENTO ORIENTADO PARA PROJETO}

Os participantes da Oficina de Planejamento em Turismo Sustentável de Monteiro Lobato, realizada em 15 de março de 2012, identificaram 9 aspectos em relação ao Turismo do município que precisam ser objetos de planejamento e organização: educação, infraestrutura turística, infraestrutura da cidade, comunicação, comportamento, legislação, saúde pública, cultura e recursos financeiros.

Para a solução das questões relativas a esses resultados, deve-se contar com o envolvimento da Câmara de Vereadores, Prefeitura e das suas Secretarias, em especial de Educação, de Meio Ambiente e Agricultura e de Cultura e Turismo, do Sindicato Rural, da Associação dos Pequenos Produtos Rurais de Monteiro Lobato (APPR), do Centro de Capacitação em Hospitalidade e Gastronomia do SINHORES, SEBRAE-SP, UNITAU, Governo do Estado, concessionárias de água, de energia elétrica, empresas de telefonia, Conselho de Segurança de Monteiro Lobato (CONSEG), Conselho Tutelar, Conselho Municipal de Turismo entre outros possíveis parceiros. Abaixo são indicados os meios para atingir os objetivos identificados e sugestões de ações.

\section{Resultado 1: Educação:}

\subsection{Educação escolar:}

1.1.a. as disciplinas de Geografia e História devem incluir em seus planos de ensino conteúdos sobre a geografia, a história, a cultura e as manifestações populares (gastronomia, artesanato, danças, pereirão etc.) do município;

1.1.b. a disciplina de Língua Portuguesa deve incluir em seus planos de ensino conteúdos sobre a vida e a obra do escritor Monteiro Lobato;

1.1.c. as escolas devem capacitar professores para a educação em Turismo para que possam promover projetos interdisciplinares sobre o Turismo Sustentável para o município; 
1.1.d. as escolas devem oferecer cursos supletivos para adolescentes e adultos.

1.1.e. as escolas devem promover projetos interdisciplinares sobre a educação ambiental.

\subsection{Educação para a população:}

1.2.a. Encontros educativos sobre a vida e a obra do escritor Monteiro Lobato;

1.2.b. oferta de cursos profissionalizantes para jovens e adultos (garçom, camareira, recepcionista, balconistas, monitor de Turismo local, Turismo Receptivo, inglês, informática, Espanhol etc.);

1.2.c. conscientização da população sobre o Turismo do município, promovendo visitas dos morados aos seus atrativos turísticos;

1.2.d. promoção da cultura do empreendedorismo para jovens e adultos;

1.2.e. conscientização da população sobre a importância da conservação e preservação do meio ambiente do município;

1.2.f. a biblioteca municipal precisa de uma sede que abrigue o acervo e usuários com segurança e ambiente próprio para estudos, com supervisão de um bibliotecário.

\section{Resultado 2: Infraestrutura turística:}

\subsection{Organização do município para o Turismo:}

2.1.a. formatação dos atrativos como produtos turísticos com infraestrutura adequada e preparados para receberem turistas com qualidade no atendimento;

2.1.b. formatação de roteiros turísticos no município;

2.1.c. criação da sinalização turística para indicar localização dos atrativos e dos equipamentos turísticos (pousadas, restaurantes, pesqueiros, cachoeiras, bairros, estradas rurais etc.);

2.1.d. criação do Centro de Apoio ao Turista com pessoas treinadas para darem informações sobre o Turismo do município;

2.1.e. conscientização dos taxistas em relação ao Turismo e ao turista; 
2.1.f. instalação de um Banco 24 horas para atendimento de correntistas de outros bancos além do Banco do Brasil e Bradesco.

\section{2. criação de uma agenda de eventos:}

2.2.a. fomento à promoção de festivais gastronômicos (comida típica, doces etc.);

\section{3. organização da Feira de Artesanato e de Produtos da Terra:}

2.3.a. incentivo aos artesãos e produtores da terra para participarem da feira da Praça Cunha Bueno nos finais de semana e feriados;

2.3.b. apoio à organização dos mesmos para que façam a auto-gestão da feira; 2.3.c. promoção de atividades culturais e de lazer para moradores e turistas nos finais de semana;

\section{4. criação do Museu Histórico de Monteiro Lobato:}

2.4.a. Definição de um local para instalação do museu;

2.4.b. Elaboração de um projeto do museu histórico com temáticas rural, cultural, das famílias formadoras do município e da vida e obra do escritor Monteiro Lobato;

\section{Resultado 3: Infraestrutura da cidade:}

\section{1. conservação das estradas rurais:}

3.1.a. buscar inclusão do município no projeto BOM CAMINHO do Governo do Estado (1 vez por ano: 6 km/ano o que resultará em 24 km em uma gestão de 4 anos);

3.1.b. implantar plano de conservação de estradas incluindo bom encascalhamento e contratação de conserveiros.

\section{2. acessibilidade nas vias públicas urbanas:}

3.2.a. acessibilidade para portadores de deficiências especiais (físicas, auditivas e visuais);

3.2.b. construção de rampas para uso de cadeirantes;

3.2.c. melhoria das calçadas. 


\section{3. energia elétrica:}

3.3.a. conservação da rede elétrica para evitar interrupções de energia que causam danos aos aparelhos eletrodomésticos;

3.3.b. manutenção dos para-raios de linha;

3.3.c. instalação de iluminação nas entradas dos bairros;

3.3.d. melhoria na iluminação das ruas.

\section{4. banheiro público}

3.4.a. implantar banheiro público incluindo instalações para portadores de deficiências físicas;

3.4.b. manutenção dos banheiros da Rodoviária (hidráulica e limpeza);

3.4.c. ter uma pessoa responsável e cobrar pelo uso.

\section{5. esportes e lazer:}

3.5.a. revitalização e organização dos usos do Ginásio Poliesportivo com outras modalidades de esportes (basquete, vôlei, Tae Ken Do etc.) além das já realizadas;

3.5.b. criação de pista para corrida e atletismo em volta do prédio;

3.5.c. Instalação de academia ao ar livre nos bairros;

3.5.d. oferecimento de atividades de lazer para a população;

3.5.e. organização de atividades para pessoas da melhor idade: promover outras atividades de convivência, xadrez, damas etc.;

3.5.f. há lugar e equipamentos adequados para exercícios físicos principalmente para a melhor idade.

\section{6. segurança pública:}

3.6.a. melhoria da atuação das polícias civil e militar (mais profissionais e rodízio de policiais);

3.6.b. organização da aplicação de multas por meio de convênio entre a Prefeitura e a Polícia Militar para que o município tenha receita;

3.6.c. melhoria da sinalização de trânsito.

\section{7. transporte público:}

3.7.a. melhoria no atendimento dos motoristas aos idosos; 
3.7.b. manutenção dos ônibus da empresa de ônibus;

3.7.c. oferta de mais horários de ônibus;

3.7.d. implantar ônibus de Turismo além dos de linha.

\section{8. serviço público municipal:}

3.8.a. oferta de salário compatível com o mercado regional para funcionárioschave da prefeitura. Ex.: operador de máquinas para conservação de estradas; 3.8.b. contratação de técnicos para desenvolvimento de projetos da Prefeitura para o município.

\section{9. espaços públicos:}

3.9.a. espaços públicos iluminados e com segurança policial;

3.9.b. revitalização da praça de baixo;

3.9.c. definição de estacionamentos para turistas no centro da cidade;

3.10. telefonia para a zona rural.

\section{Resultado 4: Comunicação}

\section{1. acessibilidade digital:}

4.1.a. instalação de WIFI para o centro da cidade;

4.1.b. internet para a zona rural;

\section{2. marketing turístico:}

4.2.a. elaboração de plano de marketing turístico para o município (definição da vocação turística, formatação dos produtos turísticos, produção de folhetos e mapas turísticos, divulgação em feiras e eventos regionais e estaduais, criação de site específico para a divulgação turística do município etc.);

4.2.b. divulgação institucional pela Prefeitura;

4.2.c. divulgação comercial pelos empresários.

\section{3. divulgação dos eventos:}

4.3.a. divulgação de eventos através de painéis instalados em local de fácil visualização para moradores e turistas nas 2 praças e na rodoviária;

4.3.b. divulgação de eventos nos bairros. 


\section{4. rádio:}

4.4.a. instalação de uma rádio para o município.

Resultado 5: Comportamento: neste tópico foram reunidas todas as questões levantadas pelos participantes que se referem a atitudes e impressões atribuídas aos moradores do município. Nota-se que os participantes consideram importante a necessidade de mudança de atitudes por parte das lideranças governamentais, dos empresários e da comunidade em relação a si próprios e ao convívio social.

\section{1. aspectos pessoais:}

5.1.a. há uma visão melhor do potencial das pessoas: é preciso reconhecer os talentos dos lobatenses e convidá-los para participar dos projetos para melhoria do município;

5.1.b. há esperança;

5.1.c. há humildade e solidariedade pelo próximo;

5.1.d. o Lobatense tem amor próprio, gosta do lugar onde reside;

5.1.e. o Lobatense não teme o progresso.

\section{2. aspectos sociais:}

5.2.a. há integração das iniciativas: é preciso identificar os grupos representativos da sociedade e promover reuniões com esses grupos;

5.2.b. há uma visão positiva do município pelos munícipes: moradores têm interesse de conhecer, elogiar e indicar a cidade;

5.2.c. todos são tratados como iguais;

5.2.d. aqui todos podem e trabalha-se para a mudança de mentalidade;

5.2.e. o povo daqui é valorizado;

5.2.f. há compreensão por parte de todos (não há preconceitos);

5.2.g. a sociedade civil é organizada.

\section{3. aspectos empresariais:}

5.3.a. há uma associação com força para morador e comércio: é preciso haver união dos moradores e dos empresários; trabalhar em conjunto;

5.3.b. reativar a associação comercial que existe, mas está inativa; 
5.3.c. o Conselho Municipal de Turismo (COMTUR) deve se reestruturar;

5.3.d. acredita-se no potencial turístico, a prefeitura apoia Turismo;

5.3.e. há oportunidades de empregos: estas surgirão a partir do planejamento e da execução do plano de Turismo;

5.3.f. incentivar a participação entre a prefeitura, a iniciativa privada e a comunidade;

5.3.g. incentivar o empreendedorismo.

\section{4. incentivar a mudança de atitudes da prefeitura, da iniciativa privada e} da comunidade: deve-se criar objetivos coletivos:

- há interesse político e faz-se muito pelo município;

- há união entre os munícipes;

- iniciar parcerias e solidariedade, o munícipe pensa no coletivo;

- o munícipe tem interesse, pois todos querem melhorias e participam das palestras maravilhosas realizadas no município;

- há comprometimento e ética, resultando no crescimento do município;

- a população não espera tudo do poder público;

- "comunidade - poder público - setor privado" estão sensibilizados para os assuntos de Turismo;

- os espaços públicos são cuidados: há zelo pela limpeza e segurança e não há depredação;

- há continuidade dos projetos;

- há muitas ideias e muitos incentivos;

- a grandeza da cidade depende da participação do seu povo. Participem!;

- os historiadores da cidade são valorizados.

\section{Resultado 6: Legislação:}

\subsection{Administração Pública e Câmara de Vereadores:}

6.1.a. promover o orçamento participativo;

6.1.b. a lei da acessibilidade é cumprida: Lei $n^{\circ} 10.098$, de 19 de dezembro de 2000; 
6.1.c. criar incentivos fiscais para que empresas se instalem na cidade;

6.1.d. reavaliar os incentivos fiscais versus retorno para o município (empregos, impostos etc.);

6.1.e. criar lei para proibir automóveis estacionados na cidade com som alto;

6.1.f. incentivar os políticos a buscarem mais capacitação para exercerem seus cargos;

6.1.g. há organização e regulamentação para o comércio ambulante (cadastro na Prefeitura; concessão para trabalhar, critérios de horários e locais, capacitação para a atividade exercida, curso de manipulação e higiene de alimentos, ter fiscalização);

6.1.h. há tribuna livre para a população expor críticas e elogios na Câmara de Vereadores;

6.1.i. imóveis não utilizados: aplicar a Lei do Estatuto da Cidade (Lei 10.257/2001 - função social de propriedades ), ter fiscalização;

6.1.j. campanha de conscientização para a regularização dos empreendimentos comerciais no município: levantar as empresas irregulares e promover a regularização.

\subsection{Tráfego:}

6.2.a. a lei que proíbe o tráfego de carretas na SP-50 é cumprida: há posto de fiscalização da Polícia Rodoviária ou DER na SP-50.

\subsection{Plano Diretor do Município:}

6.3.a. elaborar Plano Diretor do Município (lei de uso e ocupação do solo, zoneamento - proteção ao meio ambiente);

6.3.b. elaborar Plano Diretor de Turismo Sustentável (com critérios de sustentabilidade: proteção ao meio ambiente, justiça social, respeito à cultura local).

\section{Resultado 7: Saúde Pública:}

\section{1. abandono de animais:}

7.1.a. criação de um centro de zoonose no município; 
7.1.b. promover a castração em massa (dos animais que têm donos e daqueles abandonados);

7.1.c. promover a vacinação em massa (dos animais que têm donos e daqueles abandonados);

7.1.d. fazer campanha para a posse de animais de forma responsável.

\section{2. alcoolismo:}

7.2.a. identificar e dar assistência social para os alcoólatras e viciados em drogas do município;

7.2.b. criar programa para a prevenção ao alcoolismo e às drogas;

7.2.c. dar orientação e apoio às famílias com indivíduos alcoólatras e viciados.

\subsection{Posto de Saúde:}

7.3.a. oferecer serviços emergenciais aos finais de semana no posto de saúde; 7.3.b. divulgar o telefone de emergência do Posto de Saúde e ter atendente 24 horas.

\section{Resultado 8: Cultura:}

\subsection{Pereirões:}

8.1.a. os pereirões são utilizados em todas as festas;

8.1.b. os jovens que movimentam os bonecos pereirões são remunerados (apadrinhamento por empresas locais);

8.1.c. as técnicas de produção artística do pereirão e do artesanato são melhoradas.

\subsection{Moçambique, Catira e Cacuriá:}

8.2.a. dar mais incentivo e apoio aos grupos de danças populares;

8.2.b. incentivar e apoiar o ensino das danças para moradores e turistas;

8.2.c. apoiar a divulgação da cultura popular: dança CACURIÁ, que acontece no Bairro do Souza. 


\subsection{Artesanato:}

8.3.a. melhoria das técnicas de artesanato; produtos com criatividade e qualidade na confecção;

8.3.b. assessoria de profissionais técnicos e designers para novos produtos e aperfeiçoamento do artesanato existente;

8.3.c. criar identidade para artesanato local;

8.3.d. campanha para o resgate da cultura e valorização por meio da apresentação de resultados.

\subsection{Cinema:}

8.4.a. apresentação de cinema ao ar livre, inclusive nos bairros.

Resultado 9: Recursos Financeiros:

\subsection{Financiamentos}

9.1.a. há recurso financeiro para pequenos produtores, artesão. Há investimento em seres humanos em potencial, e eles se sentem valorizados;

9.1.b. implantação do banco do povo;

9.1.c. assessoria do SINHORES (CONSULTOR).

Monteiro Lobato, 23 de janeiro de 2014. 


\section{ANEXO A}

PRAÇA DEPUTADO A. S. CUNHA BUENO, 180- CENTRO -

TELEFONE: (012) 3979-9000 CEP 12250-000 pmml@uol.com.br

\section{Convite}

A Secretaria de Cultura e Turismo de Monteiro Lobato, o Conselho Municipal de Turismo de Monteiro Lobato e o Sindicato dos Hotéis, Restaurantes, Bares e Similares (SINHORES) convidam a população para o lançamento do projeto que tem como objetivo a elaboração do Plano Diretor do Turismo Sustentável para Monteiro Lobato. O evento acontece no dia 25 de agosto de 2011, das 19 h00 às 21h00, no Sindicato Rural de Monteiro Lobato, na Rua Abílio Pereira Dias, $n^{\circ} 181$.

A primeira etapa desse projeto se inicia com a realização do Curso para Capacitação em Turismo Sustentável para os moradores de Monteiro Lobato no período de setembro a dezembro de 2011, todas as quintas-feiras no Sindicato Rural de Monteiro Lobato, das 18 h30 às 21 h30.

\section{Contamos com a sua presença!}

Informações: Tel.: 3979-1314 ou 8844-4020,

E-mail: turismomonteirolobato@yahoo.com.brou pivott.cleide@gmail.com.

Atenciosamente,

Eduardo Rocha Dellú

Secretário de Cultura e Turismo

Município de Monteiro Lobato

Apoio: 


\section{ANEXO B \\ 5. Caracterização do Município - Dados secundários}

\subsection{História}

No que se refere à aldeia, não há registro histórico de um fundador. Presume-se que, mandados por Jacques Félix, alguns bandeirantes em direção a Minas Gerais tenham montado passagem onde atualmente é o centro urbano da cidade.

Levando-se em conta a criação da Freguesia, nos anos 40 do século 19, os fundadores seriam os doadores das terras para a formação do patrimônio da Freguesia de Nossa Senhora do Bonsucesso. Anna Martins da Rocha era proprietária de uma extensa área territorial e, por ser uma mulher de fé e dedicada à eucaristia, decidiu doar parte de seus bens aos cuidados da igreja católica, na condição de que se criasse uma Freguesia em homenagem a Nossa Senhora do Bonsucesso, santa venerada pelos imigrantes portugueses. A doação das terras, descrita como 130 braças, era insuficiente para a criação de uma freguesia e, assim, os fazendeiros Comendador José Manoel Freire, Capitão Francisco Alves Fagundes e Capitão Luciano José das Neves também doaram terras.

A Freguesia foi reconhecida em 1850, sendo registrada como "Estância Eclesiástica" pelo Deputado paulista José Baptista Barata (BARRETO, 2012, p. 13). Sob o aspecto eclesiástico, a povoação foi elevada à Freguesia e Distrito de Paz em 25 de abril de 1857, e incorporada ao município de Taubaté.

Buquira só ascendeu à condição de Vila em 26 de abril de 1880 e, depois, a de cidade, em 19 de dezembro de 1900, criada através de lei estadual. Reduzida à condição de distrito em 1934, pela Lei 6.448 aprovada pelo Presidente Getúlio Vargas, Buquira foi incorporada ao município de São José dos Campos.

Em 1948, começou o movimento visando a recuperação da autonomia política, tendo como principal defensor o Sr. Caetano Manzi Sobrinho, que se elegeu vereador à Câmara Municipal de São José dos Campos, como representante do distrito do Buquira. Após um plebiscito, é restabelecida a 
condição de Município sob a Lei Estadual n. 233, de 24/12/1948 (ISSA, 2003, p. 30).

Antes de se chamar Monteiro Lobato, o município teve quatro denominações: Freguesia das Estacas, Freguesia de Nossa Senhora do Bonsucesso do Buquira, Vila das Palmeiras do Buquira e Vila do Buquira. Na língua tupi, Buquira quer dizer Ribeirão dos Pássaros.

O nome é uma homenagem ao eminente escritor José Bento Monteiro Lobato que viveu parte da infância na Fazenda São José do Buquira e onde também residiu no período de 1911 a 1917. Na Fazenda do Buquira, iniciou sua carreira literária escrevendo os contos Urupês e nela se inspirou para escrever as histórias do Sítio do Pica-pau Amarelo. Mais tarde, a Fazenda do Buquira passou a se chamar Fazenda do Visconde e, depois, Sítio do Pica-pau Amarelo, que até hoje atrai grande número de turistas. $O$ aniversário do município de Monteiro Lobato é comemorado no dia 26 de abril.

\subsection{Símbolos Municipais}

O Parágrafo único do Artigo $2^{\circ}$ da Lei Orgânica do Município de Monteiro Lobato, TITULO I (Dos Fundamentos do Município), CAPÍTULO I (Do Município), SEÇÃO I (Disposições Gerais), estabelece:

Art. $2^{\circ}$ São poderes do Município, independentes e harmônicos entre si, o Legislativo e o Executivo.

Parágrafo único. São símbolos do Município a Bandeira, o Brasão e o Hino, representativos de sua cultura e história.

\subsubsection{Hino Municipal}

Monteiro Lobato ganhou seu hino municipal somente 132 anos após sua fundação. Vale ressaltar este fato histórico. O ex-Secretário de Cultura e Turismo do Governo Gabriel Vargas Moreira, Eduardo Rocha Dellú, convidou seu amigo e Diretor de Cultura do município de Cerqueira Cesar, Adauto Felisário Munhoz, para conhecer Monteiro Lobato em 2011. Adauto sendo compositor, cantor e escritor, ficou encantado com a história e também com a beleza da natureza do município. 
Quando soube que Monteiro Lobato não possuía ainda seu hino, sentiuse motivado a compor a letra e a música para dar como presente aos amigos e ao povo lobatense, e para esta criação poética e musical, aprofundou-se no conhecimento da história da cidade e na sua magia junto ao escritor José Bento Monteiro Lobato. O Hino Municipal foi apresentado pela primeira vez no dia 26 de abril de 2012 dentro da programação das comemorações do aniversário da cidade, cantado pelo coral dos "Pequenos Cantores de Cerqueira César", também cantado pela cantora lobatense Josiane Medeiros e executado pela Banda Municipal de Concerto de Monteiro Lobato. A Lei Municipal $n^{0} 1.515$ de 02 de maio de 2012 que dispõe sobre a oficialização do Hino do Município de Monteiro Lobato foi aprovada, sancionada e promulgada pelo Prefeito Gabriel Vargas Moreira e pelos vereadores da Câmara Municipal. Adauto sempre afirmou que além da sua admiração pela cidade, o hino é fruto de uma amizade sincera e verdadeira entre ele e os amigos Eduardo Dellú, o Prefeito Gabriel Vargas e André Barreto. 
Hino do Município de Monteiro Lobato

\section{Letra e Música: Adauto Felisário Munhoz}

A Senhora do Bonsucesso, Por Deus és abençoada,

É a tua leal padroeira, "Cidade Natureza".

Oh! Joia preciosa!

Da Serra da Mantiqueira. No ponteado da viola, E na culinária saborosa,

Na trilha dos bandeirantes, Faz de ti, Monteiro Lobato, Reluzente igual safira, A Cidade mais formosa. Nasceste fulgurante,

Com o nome de Buquira. Teu povo é tão contente, Neste solo de Buquira, Tens a honra de ser a mãe, Preserva as tradições, Da mais famosa filha, Da tua raiz caipira. No teu seio de magia, Nasceu a boneca "Emília". Repleta de encantamento, És lindo cartão postal, És uma terra privilegiada, Da literatura infantil, Um paraíso tão belo, Sois majestosa capital.

De um "Sitio Encantado, Do Pica-Pau Amarelo". Lobato te engrandeceu, Meu torrão amado, Com reluzentes fanais, De encanto e rara beleza, No brilho forte e perene, Por Deus és abençoada, De suas obras imortais. Oh! Cidade Natureza.

Meu torrão amado... 


\subsubsection{Brasão}

\begin{tabular}{|c|c|}
\hline & $\begin{array}{l}\text { O Brasão de Armas do Município de Monteiro Lobato foi } \\
\text { elaborado em } 1962 \text { a pedido do prefeito Caetano Manzi } \\
\text { Sobrinho. Escudo português dividido em quatro partes com os } \\
\text { seguintes dísticos: }\end{array}$ \\
\hline & $\begin{array}{l}\text { a) Primeiro quartel: sobre fundo verde, um sobredisco } \\
\text { mostrando o céu em sua cor natural, a serra e o rio com uma } \\
\text { canoa, para lembrar a exploração do lugar e a fixação do } \\
\text { homem ao campo. }\end{array}$ \\
\hline & $\begin{array}{l}\text { b) Segundo quartel: com fundo em cor cardeal, uma cruz e } \\
\text { duas estrelas em ouro, em relevo, lembrando a formação } \\
\text { cristã do município e uma homenagem à padroeira da cidade. }\end{array}$ \\
\hline & $\begin{array}{l}\text { c) Terceiro quartel: sobre fundo em cor prata, uma Flor-de-lis, } \\
\text { em ouro, em relevo, símbolo da nobreza, representando os } \\
\text { títulos ou honrarias, mas a nobreza do gesto da doação das } \\
\text { terras pelo Barão de Tremembé que deram ao município. }\end{array}$ \\
\hline & $\begin{array}{l}\text { d) Quarto quartel: como fundo, a maior e mais significante } \\
\text { figura heráldica do nosso Estado, a Bandeira Paulista, tendo } \\
\text { em relevo um livro e uma pena em ouro, justa homenagem ao } \\
\text { eminente escritor Monteiro Lobato. }\end{array}$ \\
\hline & $\begin{array}{l}\text { e) Encimado: por uma coroa em ouro, com quatro torres e } \\
\text { quatro portas simétricas, significando, em linguagem heráldica, } \\
\text { a fortaleza protetora, ou seja, o forte ao redor da cidade, } \\
\text { significando autonomia, segurança, ordem, paz e } \\
\text { tranquilidade. }\end{array}$ \\
\hline & $\begin{array}{l}\text { f) Listel: em vermelho, com as letras em prata, seguindo-se a } \\
\text { divisa DEO ANTE OMNIA, "Deus acima de todas as coisas" ou } \\
\text { "Deus antes de tudo". }\end{array}$ \\
\hline
\end{tabular}

Figura 6 - Brasão do município

Fonte: Barreto (2012, p. 111) 


\subsubsection{Bandeira}

A Bandeira do Município de Monteiro Lobato foi instituída pela Lei no 600 , de 03 de maio de 1985, sancionada pelo prefeito João Bueno da Silva, com a seguinte descrição: esquartelado em cruz, o $1^{\circ}$ e $4^{\circ}$ de verde e o $2^{\circ}$ e $03^{\circ}$ de vermelho, com uma cruz de azul coticada de branco, brocante sobre 0 esquartelado, tendo brocante sobre 0 cruzamento de seus ramos, um círculo de branco, carregado do Brasão de Armas

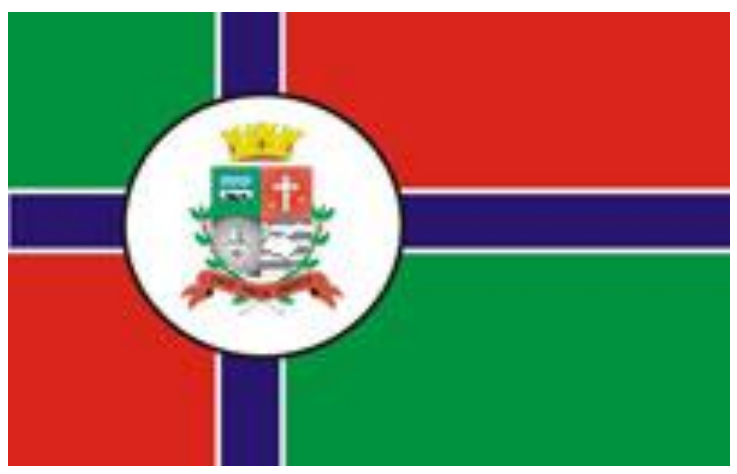
instituído pela Lei no 213 , de 20 de novembro de 1962.

Figura 7 - Bandeira do Município de Monteiro Lobato Fonte: Barreto (2012, p. 112)

\subsection{Localização}

O Quadro 110 apresenta as informações relativas à localização de Monteiro Lobato.

\begin{tabular}{|c|c|c|c|c|}
\hline Coordenadas & \multicolumn{4}{|c|}{ Latitude: $22^{\circ} 57^{\prime 2} 25^{\prime \prime} \mathrm{S}$ (sul) / Longitude: 4550'24”W (oeste) } \\
\hline \multirow{4}{*}{ Limites } & Norte & \multicolumn{3}{|c|}{ Sapucaí Mirim (MG) e Santo Antonio do Pinhal (SP) } \\
\hline & Leste & \multicolumn{3}{|c|}{ Pindamonhangaba (SP), Tremembé (SP) e Taubaté (SP) } \\
\hline & Sul & \multicolumn{3}{|c|}{ São José dos Campos (SP) e Caçapava (SP) } \\
\hline & Oeste & \multicolumn{3}{|c|}{ São José dos Campos (SP) (São Francisco Xavier, Distrito) } \\
\hline \multirow[t]{7}{*}{ Distâncias (em km) ${ }^{34}$} & \multicolumn{2}{|c|}{ São Paulo (capital) } & \multicolumn{2}{|c|}{$130 \mathrm{Km}$} \\
\hline & \multicolumn{2}{|c|}{ São José dos Campos } & \multicolumn{2}{|l|}{$27 \mathrm{Km}$} \\
\hline & \multicolumn{2}{|c|}{ Campos do Jordão } & \multicolumn{2}{|l|}{$58 \mathrm{~km}$} \\
\hline & \multicolumn{2}{|c|}{ São Bento do Sapucaí } & \multicolumn{2}{|l|}{$42 \mathrm{~km}$} \\
\hline & \multicolumn{2}{|c|}{ Santo Antonio do Pinhal } & \multicolumn{2}{|l|}{$38 \mathrm{~km}$} \\
\hline & \multicolumn{2}{|c|}{ Itajubá } & \multicolumn{2}{|l|}{$112 \mathrm{~km}$} \\
\hline & \multicolumn{2}{|c|}{ Rio de Janeiro } & \multicolumn{2}{|l|}{$346 \mathrm{~km}$} \\
\hline \multirow[t]{2}{*}{ Acesso Rodoviário } & SP-50 & S. J. dos Campos/Campos do Jordão & BR-116 & Rod. Pres. Dutra \\
\hline & SP-90 & Rodovia dos Tamoios & SP-75 & Rod. Carvalho Pinto \\
\hline
\end{tabular}

Quadro 110 - Localização do município de Monteiro Lobato

Duas estradas secundárias ligam Monteiro Lobato a São Francisco Xavier, Distrito de São José dos Campos (Estrada Municipal Pedro David) e a Caçapava (Estrada do Livro).

\footnotetext{
${ }^{33}$ Nomes Geográficos da Base Cartográfica Contínua do Brasil ao Milionésimo - BCIM, por categoria de informação, Unidade da Federação e coordenadas geográficas. Disponível em: $<\mathrm{ftp}: / / g e o f t p . i b g e . g o v . b r / d o c u m e n t o s / c a r t o g r a f i a / i n d i c e \_n o m e s \_g e o g r a f i c o s . p d f>$. Acesso em: 07 jun. 2013.

${ }^{34}$ Fonte: Disponível em: < http://br.distanciacidades.com>. Acesso em: 07 jul. 2013.
} 
De acordo com Carmo (2003, p. 128), a Rodovia Monteiro Lobato (SP50) é uma via transversal à Rodovia Presidente Dutra, sendo uma alternativa à Rodovia Floriano Peixoto (SP-123) que liga Taubaté a Campos do Jordão. A SP-50 inicia-se na zona norte de São José dos Campos e atravessa áreas rurais, lugarejos típicos da região serrana, que Ihe dão características bucólicas com "túneis de árvores" em alguns trechos. Essa estrada tem entroncamento com a SP-42, que a liga à Estância de São Bento do Sapucaí (SP), ao sul de Minas Gerais (através da MG-295). A estrada SP-50 é considerada de alto risco de acidentes, por ter pouca sinalização, não ter acostamento e contar com 670 curvas em seus $98 \mathrm{Km}$ de extensão (MARTINI et. al., 1978 apud CARMO, 2003, p. 128.). Em 2013, na SP-50, foram concluídas as obras de recapeamento e de recuperação dos pontos com desmoronamentos, recebendo melhorias na sinalização. No entanto, os riscos de acidentes não diminuíram por causa da imprudência de motoristas que fazem ultrapassagens arriscadas em trechos que não oferecem nenhuma visibilidade da pista oposta.

O município de Monteiro Lobato está inserido na Região de Governo de São José dos Campos, enquanto São Bento do Sapucaí, Santo Antonio do Pinhal e Campos do Jordão, localizam-se na Região de Governo de Taubaté (MOREIRA et al., 2004, p. 13). 


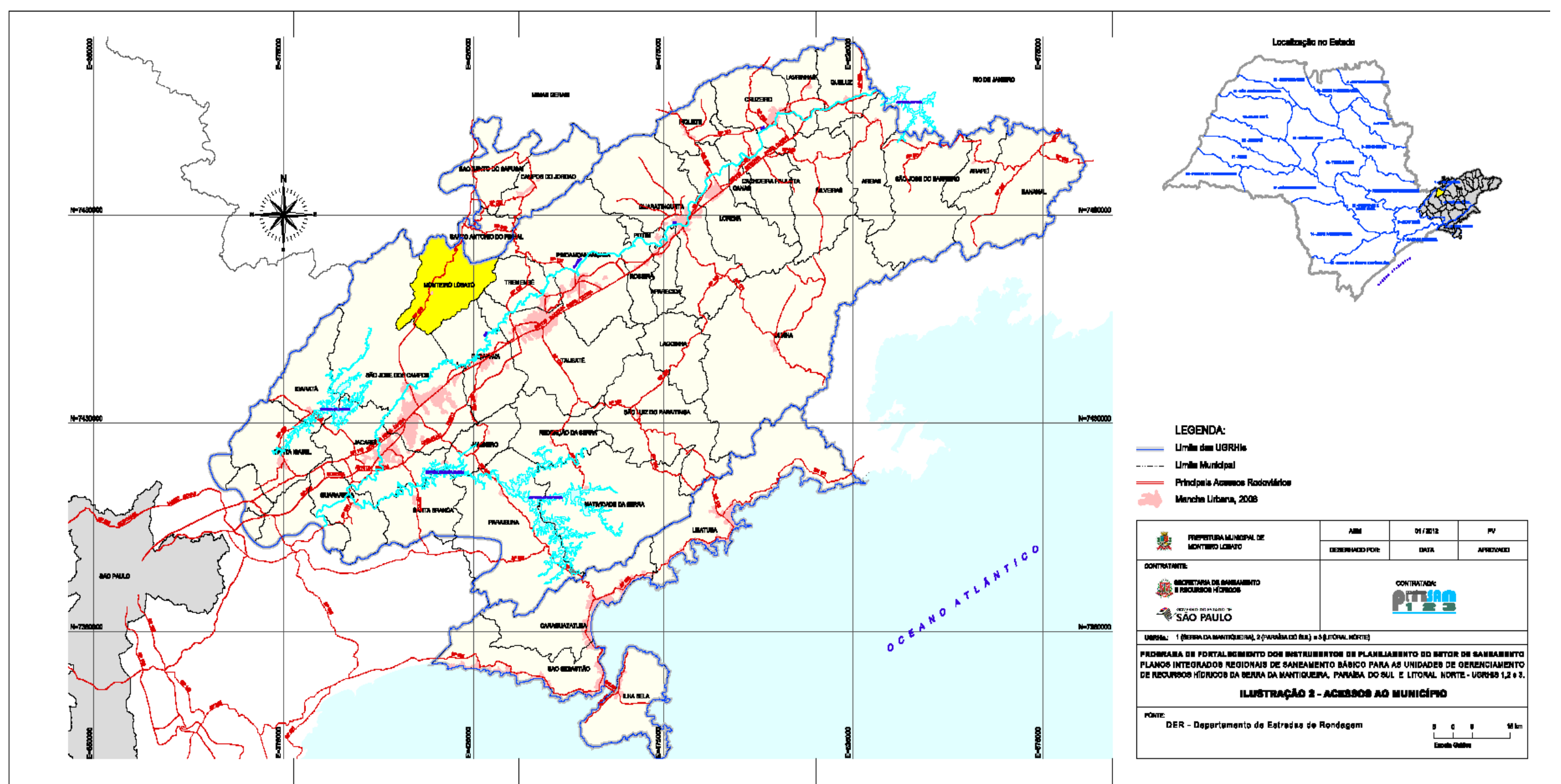

Figura 8 - Mapa de localização do município de Monteiro Lobato Fonte: São Paulo (2012, p. 20) 
Monteiro Lobato possui 19 bairros, além do Centro, a saber:

\begin{tabular}{|l|l|l|l|}
\hline Damião & Pedra Branca & Santa Rita do Souza & Teixeiras \\
Descoberto & Ponte Nova & São Benedito & Trabiju \\
Ferreira & Rio do Braço & Serrinha & Turvo \\
Forros & Rio Manso & Taquari & Vargem Alegre \\
Matinada & Santa Maria & & Visconde \\
\hline
\end{tabular}

Quadro 111 - Relação de Bairros

\begin{tabular}{|l|l|}
\hline Acessos & \\
\hline Rodoviária & $\begin{array}{l}\text { Rodoviária de Monteiro Lobato } \\
\text { Rua Humberto Cappelli, Centro }\end{array}$ \\
\hline Aeroporto mais próximo: & $\begin{array}{l}\text { Professor Urbano Ernesto Stumpf } \\
\text { Av. Brigadeiro Faria Lima, s/n, Jardim Martim Cererê São } \\
\text { José dos Campos, 12227-000 - (12) 3946-3000 }\end{array}$ \\
\hline Porto (marítimo) & Porto de São Sebastião, SP \\
\hline Vias de acesso rodoviário: & $\begin{array}{l}\text { 01. BR-116 - Rodovia Presidente Dutra } \\
02 . \text { SP-050 - São José dos Campos - Campos do Jordão }\end{array}$ \\
\hline
\end{tabular}

\subsection{Educação}

Monteiro Lobato possui, ao todo 11 escolas do nível pré-escola ao ensino médio. No Bairro do Souza, localiza-se o Instituto Pandavas - Núcleo de Educação, Cultura e Ações Socioambientais que realiza há 33 anos, atividades socioeducacionais, culturais e de Proteção Ambiental, além do ensino fundamental.

Quanto a curso superior, o município conta com os cursos de Administração e de Pedagogia oferecidos pela Fundação Hermínio Ometto (FHO/UNIARARAS) em sistema de ensino a distância, alternado com aulas presenciais monitoradas, funcionando em convênio com a EMEF Prof ${ }^{a}$ Elizabeth Coelho Micheletto.

A Taxa de Analfabetismo, segundo o Censo do IBGE (2010) de Monteiro Lobato é de 10,5\%. Em 2000, era de 14,53\% (IBGE, 2010). A Avaliação no IDEB é de 5,2 (2013), pelos dados da Secretaria Municipal de Educação de Monteiro Lobato. 
Quadro de informações sobre as escolas ${ }^{35}$ :

\begin{tabular}{|c|c|}
\hline Monteiro Lobato & \begin{tabular}{|l|} 
Código: \\
3531704
\end{tabular} \\
\hline \multicolumn{2}{|l|}{ Ensino - Matrículas, Docentes e Rede Escolar 2012} \\
\hline Matrícula - Ensino fundamental - 2012 (1) & 716 \\
\hline Matrícula - Ensino fundamental - escola pública estadual - 2012 (1) & 241 \\
\hline Matrícula - Ensino fundamental - escola pública municipal - 2012 (1) & 357 \\
\hline Matrícula - Ensino fundamental - escola privada - 2012 (1) & 118 \\
\hline Matrícula - Ensino médio - 2012 (1) & 208 \\
\hline Matrícula - Ensino médio - escola pública estadual - 2012 (1) & 208 \\
\hline Matrícula - Ensino pré-escolar - 2012 (1) & 92 \\
\hline Matrícula - Ensino pré-escolar - escola pública municipal - 2012 (1) & 92 \\
\hline Docentes - Ensino fundamental - 2012 (1) & 53 \\
\hline Docentes - Ensino fundamental - escola pública estadual - 2012 (1) & 17 \\
\hline Docentes - Ensino fundamental - escola pública municipal - 2012 (1) & 24 \\
\hline Docentes - Ensino fundamental - escola privada - 2012 (1) & 12 \\
\hline Docentes - Ensino médio - 2012 (1) & 18 \\
\hline Docentes - Ensino médio - escola pública estadual - 2012 (1) & 18 \\
\hline Docentes - Ensino pré-escolar - 2012 (1) & 8 \\
\hline Docentes - Ensino pré-escolar - escola pública municipal - 2012 (1) & 8 \\
\hline Escolas - Ensino fundamental - 2012 (1) & 5 \\
\hline Escolas - Ensino fundamental - escola pública estadual - 2012 (1) & 1 \\
\hline Escolas - Ensino fundamental - escola pública municipal - 2012 (1) & 3 \\
\hline Escolas - Ensino fundamental - escola privada - 2012 (1) & 1 \\
\hline Escolas - Ensino médio - 2012 (1) & 1 \\
\hline Escolas - Ensino médio - escola pública estadual - 2012 (1) & 1 \\
\hline Escolas - Ensino pré-escolar - 2012 (1) & 5 \\
\hline Escolas - Ensino pré-escolar - escola pública municipal - 2012 (1) & 5 \\
\hline
\end{tabular}

Quadro 113 - Informações sobre as escolas do município.

Fonte: (1) Ministério da Educação, Instituto Nacional de Estudos e Pesquisas Educacionais (INEP) Censo Educacional 2012.

\footnotetext{
${ }^{35}$ Disponível em:

$<$ http://cidades.ibge.gov.br/xtras/temas.php?lang=\&codmun=353170\&idtema=117\&search=sao-

paulo|monteiro-lobato|ensino-matriculas-docentes-e-rede-escolar-2012>. Acesso em: 22 nov. 2013.
} 


\subsection{Demografia}

Tabela 1 - População do município

\begin{tabular}{lrrr}
\hline População & \multicolumn{2}{l}{ homens } & \multicolumn{2}{l}{ mulheres } \\
\hline urbana & 905 & 873 & 1.778 \\
rural & 1.245 & 1.097 & 2.342 \\
& 2.150 & 1.970 & 4.120 \\
\hline
\end{tabular}

Fonte: IBGE (Censo 2010)

A população urbana e rural em Monteiro Lobato, apresentada na Tabela 2, tem evoluído de maneira marcadamente desigual. Enquanto que a população urbana apresentou um significativo crescimento gradativo, da ordem de $168 \%$ do total, no período de 1980 a 2010, a rural passou por um pequeno incremento de $15,8 \%$ em seu número de habitantes. Entretanto, a população da área rural continua sendo superior à da área urbana (SÃO PAULO, 2013, p. 24).

Tabela 2 - Evolução da População Urbana e Rural em Monteiro Lobato

\section{Evolução da População urbana}

\begin{tabular}{ccccccc}
\hline Local & 1980 & 1985 & 1990 & 1995 & 2000 & 2010 \\
\hline Monteiro Lobato & 667 & 880 & 1.128 & 1.322 & 1.514 & 1.790 \\
\hline \multicolumn{7}{c}{ Evolução da população rural } \\
\hline Total & 2.015 & 2.103 & 2.171 & 2.151 & 2.099 & 2.333 \\
\hline & 2.682 & 2.983 & 3.299 & 3.473 & 3.613 & 4.123
\end{tabular}

Fonte: SEADE (2010 apud SÃO PAULO, 2013, p. 24) 
Tabela 3 - Evolução da taxa de crescimento populacional de Monteiro Lobato

\begin{tabular}{lccc}
\hline & $1991-2000$ & $2000-2010$ & $2010-2020$ \\
\hline $\begin{array}{l}\text { Taxa de crescimento } \\
\text { populacional (\% ao } \\
\text { ano) }\end{array}$ & 0,80 & 1,49 & 0,82 \\
\hline
\end{tabular}

Fonte: São Paulo (2010a, p. 46)

Tabela 4 - Faixa etária da população de acordo com o Censo 2010 do IBGE

\begin{tabular}{|c|c|c|c|c|}
\hline Faixa Etária & homens & mulheres & Total & $\%$ \\
\hline Menos de 1 ano & 34 & 25 & 59 & 1,43 \\
\hline 1 a 4 anos & 97 & 105 & 202 & 4,90 \\
\hline 5 a 9 anos & 170 & 155 & 325 & 7,88 \\
\hline 10 a 14 anos & 194 & 176 & 370 & 8,98 \\
\hline 15 a 19 anos & 192 & 149 & 341 & 8,27 \\
\hline 20 a 24 anos & 154 & 132 & 286 & 6,94 \\
\hline 25 a 29 anos & 145 & 140 & 285 & 6,91 \\
\hline 30 a 34 anos & 144 & 160 & 304 & 7,37 \\
\hline 35 a 39 anos & 151 & 160 & 311 & 7,54 \\
\hline 40 a 44 anos & 153 & 131 & 284 & 6,89 \\
\hline 45 a 49 anos & 135 & 144 & 279 & 6,77 \\
\hline 50 a 54 anos & 145 & 106 & 251 & 6,09 \\
\hline 55 a 59 anos & 107 & 104 & 211 & 5,12 \\
\hline 60 a 64 anos & 94 & 85 & 179 & 4,34 \\
\hline 65 a 69 anos & 82 & 67 & 149 & 3,61 \\
\hline 70 a 74 anos & 61 & 56 & 117 & 2,83 \\
\hline 75 a 79 anos & 34 & 30 & 64 & 1,55 \\
\hline 80 a 84 anos & 37 & 24 & 61 & 1,48 \\
\hline 85 a 89 anos & 14 & 15 & 29 & 0,70 \\
\hline 90 a 94 anos & 05 & 4 & 9 & 0,21 \\
\hline 95 a 99 anos & 02 & 2 & 4 & 0,09 \\
\hline 100 anos ou + & 00 & 0 & 0 & 0 \\
\hline Total & 2.150 & 1.970 & 4.120 & 100 \\
\hline
\end{tabular}

Fonte: IBGE (Censo 2010)

\subsubsection{População jovem}

Em Monteiro Lobato, segundo o Censo 2010 do IBGE, a população com idade de 1 a 14 anos é de $23,19 \%$ e os jovens, na faixa etária de 15 a 29 anos, representam $22,12 \%$ da população. Os dois percentuais somados totalizam $45,31 \%$, indicando ser de crianças e jovens quase metade da população do município. 


\subsubsection{Mães adolescentes}

O percentual de mães adolescentes (com menos de 18 anos) de acordo com o Censo IBGE (2009) em Monteiro Lobato foi de 16,67\%. Essa taxa era mais do que o dobro da ocorrência na Região de Governo de São José dos Campos que, em 2009 , foi de $7,18 \%$. Por outro lado, em 2011 , a taxa caiu para $2,2 \%$, representando um terço da média da Região e do Estado ${ }^{36}$.

Tabela 5 - Mães adolescentes

\begin{tabular}{lcccc}
\hline Estatísticas Vitais e Saúde & Ano & Município & Reg. Gov. & Estado \\
\hline $\begin{array}{l}\text { Mães Adolescentes (com } \\
\text { menos de 18 anos) (Em \%) }\end{array}$ & 2011 & 2,22 & 6,53 & 6,88 \\
\hline
\end{tabular}

Fonte: SEADE (2013)

\subsubsection{Densidade Demográfica e Taxa de Urbanização em Monteiro Lobato}

A densidade demográfica relaciona o número de habitantes com a extensão territorial de uma região. Ao identificar as concentrações populacionais, o indicador de densidade demográfica torna-se uma importante ferramenta para auxiliar na tomada de decisões e elaboração de políticas de planejamento urbano (SÃO PAULO, 2010a, p. 45).

A densidade demográfica de Monteiro Lobato, em 2000, era de $10,86 \%$, passando para 12,59\% em 2010 (SÃO PAULO, 2010a, p. 45).

A taxa de urbanização indica a tendência de o município se tornar urbano, ou seja, quando o número de residentes na área urbana for maior do que o daqueles na área rural.

\footnotetext{
${ }^{36}$ Disponível em: <http://www.seade.gov.br/produtos/perfil/perfilMunEstado.php>. Acesso em: 08 jun. 2013.
} 
Tabela 6 - Densidade Demográfica

\begin{tabular}{lccccc}
\hline Município & Ano & População & $\begin{array}{c}\text { Área } \\
\text { Territorial } \\
\left(\mathrm{Km}^{2}\right)\end{array}$ & $\begin{array}{c}\text { Densidade } \\
\text { Demográfica } \\
\left(\mathrm{Hab}^{2} \mathrm{~km}^{2}\right)\end{array}$ & $\begin{array}{c}\text { Taxa de } \\
\text { Urbanização (\%) }\end{array}$ \\
\hline $\begin{array}{l}\text { Monteiro } \\
\text { Lobato }\end{array}$ & 2010 & 4.120 & 332,742 & 12,38 & 43,15 \\
\hline
\end{tabular}

Fonte: IBGE (2010); SÃO PAULO (2010a, p. 46); SÃO PAULO (2010b, p. 16); SEADE (2011)

A densidade demográfica de Monteiro Lobato, ao ser comparada com as da Região de Governo de São José dos Campos e do Estado, apresenta taxa bem menor. Por outro lado, segundo Issa (2003, p. 31), o município tem tido um processo gradual de urbanização de aproximadamente 10\% nas últimas três décadas. Em 2000, a taxa de urbanização foi de $41,91 \%$.

Tabela 7 - Densidade Demográfica Região de Governo de São José dos Campos e Estado:

\begin{tabular}{|c|c|c|c|}
\hline Local & Ano & $\begin{array}{c}\text { Densidade } \\
\text { Demográfica } \\
\mathrm{Hab}^{2} \mathrm{~km}^{2}\end{array}$ & $\begin{array}{c}\text { Taxa de } \\
\text { Urbanização em } \\
(\%)\end{array}$ \\
\hline $\begin{array}{l}\text { Região de Governo de São } \\
\text { José dos Campos }\end{array}$ & 2010 & 258,24 & $95,01 \%$ \\
\hline Estado & 2010 & 167,97 & $95,94 \%$ \\
\hline
\end{tabular}

Fonte: IBGE (2010); SÃO PAULO (2010a, p. 46); SÃO PAULO (2010b, p. 16); SEADE (2011)

\subsubsection{Déficit Habitacional}

O conceito de déficit habitacional utilizado neste trabalho está ligado diretamente às deficiências do estoque de moradias. Ele compreende tanto aquelas moradias sem condições de serem habitadas, devido à precariedade das construções ou em virtude de terem sofrido desgaste da estrutura física precisando ser repostas, como também aspectos relacionados à necessidade de incremento do estoque, decorrente da coabitação familiar ou da moradia em locais destinados a fins não residenciais (SÃO PAULO, 2010a, p. 47). 
A estimativa do déficit habitacional para Monteiro Lobato (município com menos de 20 mil habitantes em área urbana) segundo São Paulo (2010a, p. 47 apud IBGE 2000) era de 95 unidades domiciliares para 2007.

\subsubsection{Eleitores}

Tabela 8 - Eleitores

\begin{tabular}{ccc}
\hline Município & Ano & No. de Eleitores \\
\hline Monteiro Lobato & 2010 & 3.568 \\
& & \\
\hline \multicolumn{3}{c}{ Fonte: IBGE (2010) }
\end{tabular}

\subsubsection{Religião}

O município tem forte ligação com a religião católica desde a sua origem com a doação de terras por Anna Martins da Rocha para a criação da Freguesia em homenagem a Nossa Senhora do Bonsucesso, no século 19. Dessa forma, de acordo com dados do IBGE (2010), Monteiro Lobato possui $75,61 \%$ da sua população de católicos, $18,06 \%$ de evangélicos e 6,33\% divididos entre as demais religiões.

\subsection{Saúde}

A Prefeitura Municipal de Monteiro Lobato, através da sua Secretaria de Saúde, mantém o Centro de Saúde "Doutor João Auricchio", no centro da cidade, com atendimento básico ambulatorial, por meio de convênio com o Sistema Único de Saúde (SUS). Atualmente a unidade possui plantonistas 24 horas, Programa Saúde da Família (PSF) e equipe de apoio técnico e administrativo. Esse centro não oferece internação. 


\subsection{Indicadores Sociais e Econômicos}

\subsection{1 Índice Paulista de Responsabilidade Social (IPRS)}

O IPRS foi criado para subsidiar os trabalhos do Fórum São Paulo Século XXI, instituído pela Assembleia Legislativa de São Paulo. É um índice formado pelas dimensões: Riqueza Municipal, Longevidade e Escolaridade.

Do cruzamento das dimensões e variáveis consideradas, bem como os escores atingidos, os municípios paulistas foram classificados em cinco grupos:

Grupo 1: Polos,

Grupo 2: Economicamente Dinâmicos e Baixo Desenvolvimento Social,

Grupo 3: Saudáveis e de Baixo Desenvolvimento Econômico,

Grupo 4: Baixo Desenvolvimento Econômico e em Transição Social e

Grupo 5: Baixo Desenvolvimento Econômico e Social”.

Vale detalhar o Grupo 3 que se refere a municípios com nível de riqueza baixo, mas com bons indicadores nas dimensões escolaridade e longevidade. Caracterizado por pequenos e médios municípios ${ }^{37}$, atualmente inclui Monteiro Lobato que passou do Grupo 4 para o Grupo 3, em virtude da melhora no indicador de escolaridade. Praticamente todos os componentes dessa dimensão avançaram no município, sendo que a taxa de atendimento à pré-escola quase duplicou, registrando o melhor desempenho entre as variáveis municipais ${ }^{38}$.

\subsection{2 Índice de Desenvolvimento Humano (IDH)}

O Índice de Desenvolvimento Humano (IDH), estabelecido pela Organização das Nações Unidas (ONU), é um Indicador que focaliza o município como unidade de análise a partir das dimensões de longevidade, educação e renda.

\footnotetext{
${ }^{37}$ Disponível em: <http://www.seade.gov.br/projetos/iprs/ajuda/2008/sintese.pdf>. Acesso em: 25 nov. 2011.

${ }^{28}$ Disponível em: <http://www.seade.gov.br/produtos/iprs/analises/Monteiro_Lobato.pdf>. Acesso em: 25 nov. 2011.
} 
$\mathrm{Na}$ determinação do IDH, esses indicadores participam com pesos iguais, segundo a fórmula: IDH = (1/3) (IL + IE + IR), onde IL é o índice de longevidade, IE é o índice de educação e IR é o índice de renda.

Os indicadores são obtidos a partir do Censo Demográfico do IBGE. O IDHM se situa entre 0 (zero) e 1 (um). Os valores mais altos indicam níveis superiores de desenvolvimento humano. Para referência, segundo classificação do Programa das Nações Unidas para o Desenvolvimento (PNUD), os valores distribuem-se em 3 categorias:

1) $0,0<\mathrm{IDH}<0,5=$ (Baixo Desenvolvimento Humano)

2) $0,5<\mathrm{IDH}<0,8=$ (Médio Desenvolvimento Humano)

3) $0,8<\mathrm{IDH}<1,0=$ (Alto Desenvolvimento Humano)

O município de Monteiro Lobato está classificado como sendo de médio desenvolvimento humano, com o índice de IDH no valor de $0,710^{39}$.

A classificação dos Municípios de Monteiro Lobato, São José dos Campos e Campos do Jordão quanto ao IDH ${ }^{40}$ aparece na Tabela a seguir:

Tabela 9 - IDH do município e região

\begin{tabular}{lc}
\hline \multicolumn{1}{c}{ Municípios } & IDH \\
Monteiro Lobato & 0,710 \\
São José dos Campos & 0,807 \\
Campos do Jordão & 0,749 \\
\hline
\end{tabular}

Fonte: PNUD/IBGE (2013)

\footnotetext{
${ }^{39}$ Disponível em:

$<$ http://cidades.ibge.gov.br/xtras/temas.php?lang=\&codmun=353170\&idtema=118\&search=saopaulo|monteiro-lobato|Índice-de-desenvolvimento-humano-municipal-idhm->. Acesso em: 25 nov. 2013.

${ }^{40}$ Disponível em: <http://www.seade.gov.br/produtos/perfil/perfil.php 2000>. Acesso em: 25 nov. 2011.
} 


\subsubsection{Taxas de natalidade e mortalidade infantil}

Tabela 10 - Condições de Vida do município, Região de Governo de São José dos Campos e Estado de São Paulo

\begin{tabular}{|c|c|c|c|c|}
\hline Condições de Vida & Ano & Município & Reg. Gov. & Estado \\
\hline $\begin{array}{l}\text { Renda per Capita (Em reais correntes) } \\
\text { Domicílios Particulares com Renda per }\end{array}$ & 2010 & 547,76 & 863,69 & 853,75 \\
\hline $\begin{array}{l}\text { Capita de até } 1 / 4 \text { do Salário Mínimo (Em } \\
\% \text { ) }\end{array}$ & 2010 & 9,29 & 6,24 & 7,42 \\
\hline $\begin{array}{l}\text { Domicílios Particulares com Renda per } \\
\text { Capita de até } 1 / 2 \text { Salário Mínimo (Em \%) }\end{array}$ & 2010 & 28,61 & 17,20 & 18,86 \\
\hline
\end{tabular}

Fonte: SEADE (2013)

A taxa de natalidade de Monteiro Lobato é de $10,84 \%$ por 1.000 habitantes ${ }^{41}$.

Tabela 11 - Taxa de natalidade do município, Região de Governo de São José dos Campos e Estado:

\begin{tabular}{lllll}
\hline Estatísticas Vitais e Saúde & Ano & Município & Reg. Gov. & Estado \\
\hline Taxa de Natalidade (por mil habitantes) & 2011 & 10,84 & 14,97 & 14,68
\end{tabular}

Fonte: SEADE $(2013)^{42}$

Por não haver maternidade no município de Monteiro Lobato, um fato a ser salientado é que a maioria das crianças tem seu local de nascimento em São José dos Campos. Embora os pais possam registrá-las no Cartório de Monteiro Lobato, a unidade de nascimento no registro permanecer em São José dos Campos.

A taxa de mortalidade é um coeficiente utilizado na medição do número de mortes (em geral ou causadas por um fato específico), em determinada população, adaptada ao tamanho dessa mesma população e por unidade de morte ${ }^{43}$. Assim, a taxa de mortalidade infantil é a relação entre os óbitos de menores de um ano, residentes numa unidade geográfica, em determinado período de tempo (geralmente um ano) e os nascidos vivos da mesma unidade no período. Esse dado é um aspecto de fundamental importância para se avaliar a qualidade de vida, pois, por

\footnotetext{
${ }^{41}$ Disponível em: <http://www.seade.gov.br/produtos/perfil/perfilMunEstado.php>. Acesso em: 07 jun. 2013.

${ }^{42}$ Disponível em: <http://www.seade.gov.br/produtos/perfil/perfilMunEstado.php>. Acesso em: 08 jun. 2013.

${ }^{43}$ Disponível em: <http://www.infoescola.com/demografia/taxa-de-mortalidade/>. Acesso em: 22 nov. 2013.
} 
meio dele é possível obter informações sobre a eficácia dos serviços públicos, tais como: saneamento básico, sistema de saúde, disponibilidade de remédios e vacinas, acompanhamento médico, educação maternidade, alimentação adequada, entre outros ${ }^{44}$.

Segundo Issa (2003, p 31), nesse aspecto, as taxas baixas ou moderadas indicam graus de desenvolvimento superiores e melhores níveis de qualidade. Por outro lado, as altas indicam menor grau de desenvolvimento acompanhado de baixa expectativa de vida, baixa escolaridade e acesso precário a serviços de saúde.

Os dados sobre a taxa de mortalidade infantil em Monteiro Lobato são inexistentes em alguns períodos, segundo o banco de dados da Fundação Sistema Estadual de Análise de Dados do Estado de São Paulo (SEADE). Portanto, abaixo, apresentam-se os dados existentes/levantados para os períodos indicados nas Tabelas que foram coletados nos sites do DATASUS e SEADE, onde Monteiro Lobato é relacionado especificamente ou está incluso como nos relatórios do Departamento Regional de Saúde (DRS) em Taubaté e na Região de Governo de São José dos Campos.

Em 2000, a ONU fixou metas sociais para os países e estipulou 15 anos para que governos chegassem perto dos objetivos. A base de comparação usada foi 0 ano de 1990. No caso do Brasil, a meta era de que as 58 mortes registradas para cada mil crianças, em 1990, fossem reduzidas para 19 por grupo de mil em 2015. Mas, ao final de 2011, a taxa já era de 16 para cada mil crianças ${ }^{45}$.

Tabela 12 - Coeficiente de Mortalidade Infantil

\begin{tabular}{ccccc}
\multicolumn{4}{c}{ Coeficiente de Mortalidade Infantil por Ano Município do Est. São Paulo, 1989-1998 } \\
\hline Município & 1989 & 1990 & 1994 & 1998 \\
Monteiro Lobato & 32,24 & 29,53 & 24,44 & 23,30 \\
\hline
\end{tabular}

Fonte: DATASUS $(2013)^{46}$

\footnotetext{
${ }^{44}$ Disponível em: <http://www.brasilescola.com/brasil/mortalidade-infantil-no-brasil.htm>. Acesso em: 08 jun. 2013.

${ }^{45}$ Disponível em: <http://www.estadao.com.br/noticias/vidae,pais-atinge-antes-meta-de-mortalidadeinfantil,929638,0.htm>. Acesso em: 08 jun. 2013.

${ }^{46}$ Disponível em: <http://tabnet.datasus.gov.br/cgi/mortinf/municsp.htm>. Acesso em: 08 jun. 2013.
} 
As taxas de mortalidade infantil, segundo os Departamentos Regionais de Saúde (DRSs) do Estado de São Paulo no período de 2000 a 2011 constam da Tabela a seguir.

Tabela 13 - Taxa de mortalidade infantil Estado de São Paulo e DRS 17 Taubaté

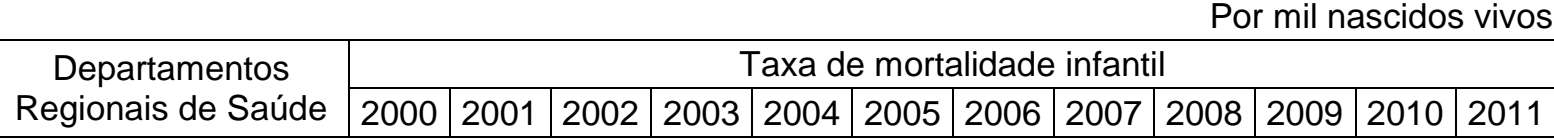

\begin{tabular}{llllllllllllllllllllllll}
\hline Estado de São Paulo & 16,97 & 16,07 & 15,04 & 14,85 & 14,25 & 13,44 & 13,28 & 13,07 & 12,56 & 12,48 & 11,86
\end{tabular} DRS 17 - Taubaté $\quad 16,78 \quad 16,7916,16 \quad 15,84 \quad 15,36$ 14,38 14,95 14,05 13,35 13,30 12,02 11,95 Fonte: Fundação Seade; Secretaria Estadual da Saúde; Secretarias Municipais da Saúde. Base Unificada de Nascimentos e Óbitos ${ }^{47}$.

Em 2009, a taxa de mortalidade infantil em Monteiro Lobato foi de 37,04, representando mais que o dobro das médias regionais. Ressalta-se que, atualmente, o município não consegue contratar pediatra o que obriga encaminhar as crianças a hospitais de São José dos Campos, quando necessário.

Tabela 14 - Taxa de Mortalidade Infantil (Por mil nascidos vivos) Monteiro Lobato e São José dos Campos

\begin{tabular}{|c|c|c|c|c|c|c|c|c|c|c|c|c|c|c|}
\hline Localidade & 1998 & 1999 & 2000 & 2001 & 2002 & 2003 & 2004 & 2005 & 2006 & 2007 & 2008 & 2009 & 2010 & 2011 \\
\hline \multicolumn{15}{|l|}{ Monteiro } \\
\hline Lobato & - & - & 39,22 & - & 40,82 & 42,55 & 20,41 & 22,73 & - & - & - & 37,04 & - & - \\
\hline $\begin{array}{l}\text { São José } \\
\text { dos Campos }\end{array}$ & 16.73 & 14.53 & 13.09 & 13.49 & 1327 & 11.94 & 11.15 & 1139 & 1169 & 1144 & 1143 & 10.83 & 927 & 1237 \\
\hline aos campos & 10,13 & 14,53 & 13,09 & 13,49 & 13,21 & 11,94 & 11,10 & 11,39 & 11,09 & 11,44 & 11,43 & 10,03 & 9,21 & \\
\hline
\end{tabular}

Fonte: SEADE $(2013)^{48}$

De acordo com o SEADE, a taxa de mortalidade infantil no Estado de São Paulo, em 2012, foi de 11,48 óbitos por 1.000 nascidos vivos. No período, a Região Metropolitana Vale do Paraíba e Litoral Norte atingiu uma taxa de 12,04 óbitos. A taxa de mortalidade infantil em Monteiro Lobato, no ano de 2012 , foi de $18,87^{49}$.

\footnotetext{
${ }^{47}$ Disponível em: <http://www.seade.gov.br/produtos/mortinf/>. Acesso em: 08 jun. 2013.

48 Disponível em: <http://www.seade.gov.br/produtos/imp/index.php?page=tabela>. Acesso em: 08 jun. 2013.

${ }^{49}$ Disponível em: <http://www.seade.gov.br/produtos/perfil/perfil.php>. Acesso em: 19 dez. 2013.
} 


\subsubsection{Proporção de moradores abaixo da linha da pobreza e indigência - 2010}

Neste município, de 2000 a 2010, a proporção de pessoas com renda domiciliar per capita inferior a $\mathrm{R} \$ 140,00$ reduziu em $44,1 \%$; para alcançar a meta de redução de 50\%, deve ter, em 2015, no máximo 12,7\%. Para estimar a proporção de pessoas que estão abaixo da linha da pobreza foi somada a renda de todas as pessoas do domicílio, e o total dividido pelo número de moradores, sendo considerado abaixo da linha da pobreza os que possuem renda per capita até $R \$$ 140,00. No caso da indigência, este valor será inferior a R\$70,00 (PORTAL ODM, 2014).

Tabela 15 - Proporção de moradores abaixo da linha da pobreza e indigência $-2010$

\begin{tabular}{lc}
\hline Acima da linha da pobreza & $85,8 \%$ \\
Entre a linha da indigência e a pobreza & $10,7 \%$ \\
Abaixo da linha da pobreza & $3,5 \%$ \\
\hline
\end{tabular}

Fonte: Portal ODM (2014) ${ }^{50}$

Em Monteiro Lobato, não há crianças menores de 2 anos desnutridas dentre as 921 pesadas pelo Programa Saúde Familiar, entre os anos 1999 e 2010 (SIAB DATASUS).

${ }^{50}$ Disponível em: <http://www.portalodm.com.br/relatorios/sp/monteiro-lobato>. Acesso em: 19 fev. 2014. 


\subsection{Indicadores Econômicos}

\subsubsection{Emprego e Rendimento ${ }^{51}$ :}

Tabela 16 - Emprego e Rendimento - Participação dos Empregos Formais

\begin{tabular}{|c|c|c|c|c|}
\hline Emprego e Rendimento & Ano & Município & $\begin{array}{l}\text { Reg. } \\
\text { Gov. }\end{array}$ & Estado \\
\hline $\begin{array}{l}\text { Participação dos } \\
\text { Agricultura, Pecuária, Produção Formais da } \\
\text { Pesca e Aquicultura no Total de Empregos } \\
\text { Formais (Em \%) }\end{array}$ & 2011 & 11,4 & 1,2 & 2,7 \\
\hline $\begin{array}{l}\text { Participação dos Empregos Formais da } \\
\text { Indústria no Total de Empregos Formais (Em \%) }\end{array}$ & 2011 & 7,4 & 25,5 & 20,9 \\
\hline $\begin{array}{l}\text { Participação dos Empregos Formais da } \\
\text { Construção no Total de Empregos Formais (Em } \\
\% \text { ) }\end{array}$ & 2011 & 4,5 & 5,6 & 5,5 \\
\hline $\begin{array}{l}\text { Participação dos Empregos Formais do } \\
\text { Comércio Atacadista e Varejista e do Comércio }\end{array}$ & & & & \\
\hline $\begin{array}{l}\text { e Reparação de Veículos Automotores e } \\
\text { Motocicletas no Total de Empregos Formais } \\
\text { (Em \%) }\end{array}$ & 2011 & 34,5 & 18,7 & 19,3 \\
\hline $\begin{array}{l}\text { Participação dos Empregos Formais dos } \\
\text { Serviços no Total de Empregos Formais (Em \%) }\end{array}$ & 2011 & 42,2 & 49,0 & 51,6 \\
\hline
\end{tabular}

Tabela 17 - Rendimento Médio dos Empregos Formais

\begin{tabular}{|c|c|c|c|c|}
\hline Emprego e Rendimento & Ano & Município & $\begin{array}{l}\text { Reg. } \\
\text { Gov. }\end{array}$ & Estado \\
\hline $\begin{array}{l}\text { Rendimento Médio dos Empregos Formais da } \\
\text { Agricultura, Pecuária, Produção Florestal, Pesca e } \\
\text { Aquicultura (Em reais correntes) }\end{array}$ & 2011 & 740,28 & $1.497,59$ & $1.234,37$ \\
\hline $\begin{array}{l}\text { Rendimento Médio dos Empregos Formais da } \\
\text { Indústria (Em reais correntes) }\end{array}$ & 2011 & $1.472,67$ & $4.149,27$ & $2.548,90$ \\
\hline $\begin{array}{l}\text { Rendimento Médio dos Empregos Formais da } \\
\text { Construção (Em reais correntes) }\end{array}$ & 2011 & $1.166,41$ & $1.489,37$ & $1.903,48$ \\
\hline $\begin{array}{l}\text { Rendimento Médio dos Empregos Formais do } \\
\text { Comércio Atacadista e Varejista e do Comércio e } \\
\text { Reparação de Veículos Automotores e Motocicletas } \\
\text { (Em reais correntes) }\end{array}$ & 2011 & 913,94 & $1.299,68$ & $1.590,37$ \\
\hline $\begin{array}{l}\text { Rendimento Médio dos Empregos Formais dos } \\
\text { Serviços (Em reais correntes) }\end{array}$ & 2011 & $1.719,67$ & $1.976,42$ & $2.309,60$ \\
\hline $\begin{array}{l}\text { Rendimento Médio do Total de Empregos Formais } \\
\text { (Em reais correntes) }\end{array}$ & 2011 & $1.283,59$ & $2.376,36$ & 2.170 \\
\hline
\end{tabular}

Fonte: SEADE (2013)

\footnotetext{
${ }^{51}$ Disponível em: <http://www.seade.gov.br/produtos/perfil/perfilMunEstado.php>. Acesso em: 08 jun. 2013.
} 


\subsubsection{Estabelecimentos em Monteiro Lobato}

Tabela 18 - Número de estabelecimentos em Monteiro Lobato - ano 2012

\begin{tabular}{lccc}
\hline & Indústria & Comércio & Serviços \\
\hline Empresas cadastradas no município & 2 & 246 & 773 \\
Empresas instaladas no município & 2 & 60 & 200
\end{tabular}

Fonte: Secretaria de Finanças e Tributação de Monteiro Lobato, 2013

As alíquotas de Imposto sobre Serviços de Qualquer Natureza (ISSQN), em Monteiro Lobato, variam de $2 \%$ a $4 \%$, de acordo com o Anexo I - Tabela de Serviços e Alíquotas - ISSQN, da Lei Complementar $\mathrm{N}^{\circ} 02$ de 14 de dezembro de 2010. Por serem alíquotas menores do que as praticadas por outras cidades da região, muitas empresas abrem no município para fins de recolhimento de impostos, mas são efetivamente operadas em outros. Isso explica a diferença entre o número de empresas cadastradas e instaladas nos ramos de comércio e serviços. Quanto à indústria, o número apresentado se refere, a exatamente, duas indústrias instaladas no município: Palazzo do Diet Light e Água Mineral Monteiro Lobato.

\subsubsection{Agropecuária}

Os dados sobre agropecuária foram obtidos no documento final do Levantamento Censitário das Unidades de Produção Agropecuária do Estado de São Paulo (LUPA), no período de 2007 a 2008, pelo Governo Estadual através da Secretaria de Agricultura e Abastecimento do Estado de São Paulo e CATI Escritório de Desenvolvimento Rural de Pindamonhangaba. De forma resumida, apresentam-se os dados sobre os produtores rurais e a produção do total de 314 UPAs levantadas. 
Tabela 19 - Dados sobre os produtores rurais e a produção do total de 314 UPAs

\begin{tabular}{|c|c|c|c|}
\hline Dados dos proprietários & $\begin{array}{l}\text { No. } \\
\text { UPAs }\end{array}$ & Unidade & Total \\
\hline $\begin{array}{l}\text { Familiares do produtor que trabalham } \\
\text { na UPA }\end{array}$ & 305 & unidade & 432 \\
\hline Trabalhadores permanentes & 147 & unidade & 224 \\
\hline Proprietário residente na própria UPA & 105 & unidade & $(33,4 \%)$ \\
\hline Casa de moradia (total) & 300 & unidade & 739 \\
\hline Casa de moradia habitada & 298 & unidade & 737 \\
\hline $\begin{array}{l}\text { Proprietário sem instrução ou com } \\
\text { instrução incompleta }\end{array}$ & 13 & unidade & $(4,1 \%)$ \\
\hline $\begin{array}{l}\text { Proprietário com o antigo primário } \\
\text { completo }\end{array}$ & 48 & unidade & $(15,3 \%)$ \\
\hline $\begin{array}{l}\text { Proprietário com o } 1^{0} \text { Grau completo } \\
\text { (ou antigo ginasial) completo }\end{array}$ & 73 & unidade & $(23,2 \%)$ \\
\hline $\begin{array}{l}\text { Proprietário com } 2^{\circ} \text { Grau (ou antigo } \\
\text { colegial) completo }\end{array}$ & 99 & unidade & $(31,5 \%)$ \\
\hline $\begin{array}{l}\text { Proprietário com curso superior } \\
\text { completo }\end{array}$ & 75 & unidade & $(23,9 \%)$ \\
\hline Não utiliza assistência técnica & 270 & unidade & $(86,0 \%)$ \\
\hline
\end{tabular}

Tabela 20 - Propriedades que dispõem de energia elétrica

\begin{tabular}{llll}
\hline Dados das propriedades & No. de UPAs & Unidade & Total \\
\hline Dispõe de energia elétrica & 277 & unidade & $(88,2 \%)$ \\
para uso na atividade & & & \\
agrícola & & & \\
\hline
\end{tabular}

Tabela 21 - Dados do uso e ocupação do solo das propriedades

\begin{tabular}{llll}
\hline Dados do uso e ocupação do solo & $\begin{array}{l}\text { No. de } \\
\text { UPAs }\end{array}$ & Unidade & Total \\
\hline Área total & 314 & hectare & $26.162,8$ \\
Área com cultura perene & 45 & hectare & 79,3 \\
Área com cultura temporária & 32 & hectare & 84,1 \\
Área com pastagens & 283 & hectare & $14.325,6$ \\
Área com reflorestamento & 59 & hectare & $3.376,5$ \\
Área com vegetação natural & 275 & hectare & $6.357,4$ \\
Área com vegetação de brejo e várzea & 31 & hectare & 69,5 \\
Área em descanso & 35 & hectare & $1.397,9$ \\
Área complementar & 308 & hectare & 472,5 \\
Maior $\mathrm{n}^{\circ}$ de UPAs: áreas entre 20 e 50 hectares & 96 & hectare & $3.075,7$ \\
\hline
\end{tabular}


Tabela 22 - Produção rural - Cultura

\begin{tabular}{llll}
\hline Cultura & No. de UPAs & Unidade & Total \\
\hline Braquiária & 254 & hectare & $11.110,2$ \\
Eucalipto & 59 & hectare & $3.376,5$ \\
Outras gramíneas para pastagem & 30 & hectare & $2.386,4$ \\
Capim gordura & 18 & hectare & 462,9 \\
gramas & 08 & hectare & 314,3 \\
Capim-napier (ou capim-elefante) & 30 & hectare & 50,8 \\
Banana & 21 & hectare & 38,1 \\
Cana-de-açúcar & 17 & hectare & 32,3 \\
Milho & 13 & hectare & 17,4 \\
Outras frutíferas & 10 & hectare & 14,9 \\
Café & 07 & hectare & 14,5 \\
Pomar doméstico & 11 & hectare & 7,1 \\
Mandioca & 05 & hectare & 5,5 \\
Laranja & 03 & hectare & 3,2 \\
Feijão & 02 & hectare & 2,5 \\
\hline
\end{tabular}

Tabela 23 - Produção rural - animais

\begin{tabular}{llll}
\hline Dados da produção & No. de UPAs & Unidade & Total \\
\hline Bonivicultura de corte & 96 & cabeças & 3.284 \\
Bonivicultura de leite & 64 & cabeças & 1.866 \\
Bonivicultura mista & 160 & cabeças & 8.763 \\
bubalinocultura & 02 & cabeças & 36 \\
apicultura & 06 & colmeias & 225 \\
Asininos e muares & 10 & cabeças & 21 \\
Caprinocultura & 08 & cabeças & 63 \\
Equinocultura & 181 & cabeças & 1.018 \\
Ovinocultura & 11 & cabeças & 264 \\
Suinocultura & 26 & cabeças & 286 \\
\hline
\end{tabular}




\subsubsection{Economia}

\subsubsection{Dados econômicos do município}

Tabela 24 - Dados econômicos do município

\begin{tabular}{|l|c|r|r|r|}
\hline & \multicolumn{1}{|c|}{ Ano } & \multicolumn{1}{c|}{ Município } & \multicolumn{1}{c|}{ Reg. Gov. } & \multicolumn{1}{|c|}{ Estado } \\
\hline PIB (Em milhões de reais correntes) & 2010 & 51,08 & $33.403,92$ & $1.247 .595,93$ \\
\hline PIB per Capita (Em reais correntes) & 2010 & $12.410,81$ & $34.287,08$ & $30.264,06$ \\
\hline Participação no PIB do Estado (Em \%) & 2010 & 0,00 & 2,677463 & 100,000000 \\
\hline $\begin{array}{l}\text { Participação da Agropecuária no Total do } \\
\text { Valor Adicionado (Em \%) }\end{array}$ & 2010 & 24,98 & 0,50 & 1,87 \\
\hline $\begin{array}{l}\text { Participação da Indústria no Total do Valor } \\
\text { Adicionado (Em \%) }\end{array}$ & 2010 & 15,22 & 51,69 & 29,08 \\
\hline $\begin{array}{l}\text { Participação dos Serviços no Total do Valor } \\
\text { Adicionado (Em \%) }\end{array}$ & 2010 & 59,80 & 47,81 & 69,05 \\
\hline
\end{tabular}

Fonte: SEADE $(2013)^{52}$

\subsubsection{Valor Adicionado}

O valor adicionado por setor da economia mede a contribuição de cada setor da economia no Produto Interno Bruto (PIB) de determinada região, no período de um ano. $O$ valor adicionado por setor permite identificar a participação relativa de cada setor econômico, com base no seu valor agregado, fornecendo dados que podem subsidiar a elaboração de políticas públicas (SÃO PAULO, 2010a, p. 45).

Tabela 25 - Valor Adicionado do município

\begin{tabular}{|c|c|c|}
\hline Monteiro Lobato & $\begin{array}{c}\text { Valor Adicionado em } \\
2009 \\
\text { (milhões de } \mathrm{R} \$ \text { ) }\end{array}$ & $\begin{array}{l}\text { Valor Adicionado em } \\
2010 \\
\text { (milhões de R\$) }\end{array}$ \\
\hline Agropecuária & 2.821 & 12.124 \\
\hline Indústria & 4.896 & 7.387 \\
\hline Serviços & 26.241 & 29.020 \\
\hline PIB a preços correntes & 36.345 & 51.083 \\
\hline
\end{tabular}

Fonte: (IBGE, 2010)

\footnotetext{
${ }^{52}$ Disponível em: <http://www.seade.gov.br/produtos/perfil/perfilMunEstado.php>. Acesso em: 08 jun. 2013.
} 


\subsubsection{População Economicamente Ativa (PEA)}

De acordo com o IBGE, a População Economicamente Ativa (PEA) é composta pelas pessoas de 10 a 65 anos de idade que foram classificadas como ocupadas ou desocupadas na semana de referência da pesquisa.

Tabela 26 - População Economicamente Ativa (PEA)

\begin{tabular}{|l|l|l|l|l|}
\hline & Homens & Mulheres & Total & $\%$ \\
\hline $\begin{array}{l}\text { Pessoas de 10 anos ou mais de } \\
\text { idade com condição de atividade na } \\
\text { semana de referencia de } \\
\text { economicamente ativas }\end{array}$ & & & & \\
\hline $\begin{array}{l}\text { Pessoas de 10 anos ou mais de } \\
\text { idade com condição de atividade na } \\
\text { semana de referência de não } \\
\text { economicamente ativas }\end{array}$ & 575 & 912 & 1.487 & 36,10 \\
\hline & & & 3.059 & 49,97 \\
\hline
\end{tabular}

Fonte: (IBGE, 2010) $)^{53}$

\subsubsection{Finanças Públicas}

Tabela 27 - Receitas e Repasses de Tributos aos municípios em 2012

\begin{tabular}{rlllr}
\hline Município & $\begin{array}{l}\text { Receita } \\
\text { municipal } \\
(\mathrm{R} \$)\end{array}$ & $\begin{array}{l}\text { Repasse de } \\
\text { Tributos Estaduais } \\
(\mathrm{R} \$)\end{array}$ & $\begin{array}{l}\text { Fundo } \\
\text { Participação } \begin{array}{r}\text { des } \\
\text { Municípios } \\
(\mathrm{R} \$)\end{array}\end{array}$ \\
\hline Monteiro Lobato & $12.314 .097,29$ & $2.940 .174,88$ & $5.497 .352,86$ \\
\hline Fonte: Secretaria de Finanças e
\end{tabular}

\footnotetext{
${ }^{53}$ Disponível em: <http://www.ibge.gov.br/cidadesat/link.php?uf=s>. Acesso em: 08 jun. 2013.
} 
Tabela 28 - Arrecadações

\begin{tabular}{ll}
\hline Arrecadação ICMS (R\$) & $2.484 .584,23$ \\
\hline Arrecadação IPTU (R\$) & $148.620,76$ \\
\hline Arrecadação ISS (R\$) & $776.496,91$ \\
\hline $\begin{array}{l}\text { Receita Municipal Total per capita } \\
\text { (R } \$ \text { ) }\end{array}$ & $2.988,86$ \\
\hline Cota-parte do ICMS (R $\$$ ) & 603,05 \\
\hline Cota-parte do FPM per capita (R\$) & $1.334,31$ \\
\hline Indice de participação no ICMS (\%) & 0,00925451 \\
\hline Fonte: Secretaria de Finanças e Tributação de Monteiro Lobato, 2013
\end{tabular}

\subsubsection{Função do município e fluxos de bens e serviços}

Segundo o Instituto de Pesquisas Tecnológicas (IPT, 2012, p. 33), Monteiro Lobato tem vocação agrícola e turística incluindo o Turismo Rural e Ecológico e o Cultural. Carmo (2003, p. 141) afirma que o crescimento das atividades turísticas significa o crescimento do comércio, das atividades dos prestadores de serviços, entre outros, assim como impulsionam a aplicação de recursos particulares no setor imobiliário, investimentos públicos no setor viário, na implantação de centros de lazer, entre outros, impulsionando, também, a economia regional. Porém, a autora pondera que as atividades turísticas só causam impactos positivos quando conduzidas com planejamento, organização e sustentabilidade, sendo assim e através de ações articuladas, podem elevar a qualidade de vida dos municípios e da região do entorno.

Em complementação, Carmo (2003, p. 141) alerta que, em todos os municípios, o Turismo sofre influências de agentes locais, representados pelo governo municipal e pela população que busca desenvolver suas atividades econômicas, como exemplificam o artesanato, a implantação de pousadas. Além do mais, sofre influências de agentes externos, como os investidores na área hoteleira, de alimentação, imobiliária etc. Essa complexidade de relações deve ser norteada pela ação dos governos locais, cujas principais atribuições devem ser zelar pelo bem-estar da população. Nas pesquisas de opinião com moradores e turistas realizadas em Monteiro Lobato, nos meses de janeiro e fevereiro de 2013, ficou evidenciado que os lobatenses prezam pela tranquilidade e sossego no seu ritmo de 
vida, enquanto que os turistas revelam que vêm em busca exatamente disso no município com jeito de cidade pequena do interior.

\subsection{Saneamento Ambiental}

De acordo com a Lei Federal $n^{0} 11.445 / 07$, que estabelece as diretrizes nacionais e a política federal de saneamento, o saneamento básico é composto pelo conjunto de serviços, infraestruturas e instalações operacionais de: abastecimento de água potável; esgotamento sanitário; limpeza urbana e manejo de resíduos sólidos e drenagem e manejo das águas pluviais urbanas (SÃO PAULO, 2011, p. 107).

Em Monteiro Lobato, dos 1.335 domicílios particulares permanentes, 1.291 $(96,70 \%)$ têm o lixo coletado e 1.335 (100\%) contam com água canalizada e alguma forma de abastecimento de água (IBGE, 2010).

\subsection{1 Água}

Os serviços de abastecimento de água e esgotos sanitários de Monteiro Lobato estão concedidos à Companhia de Saneamento Básico de São Paulo (SABESP), cujo contrato de concessão $n^{0}$ 097/2008, com duração de 30 anos, finalizar-se-á em 2037. Desde 2010, os serviços prestados pela SABESP em água abrangem toda a área urbana do município e o índice de atendimento é de $99 \%$ (SÃO PAULO, 2010b, p. 47). Segundo a Coordenadoria de Recursos Hídricos (CRHi) da Secretaria de Meio Ambiente, o Índice de Atendimento de Água (IAA) acima de 90\% é classificado na categoria "Bom" (SÃO PAULO, 2011, p. 107).

O município de Monteiro Lobato conta com 3 sistemas de abastecimento de água (SÃO PAULO, 2010b, p. 48;51;52) como apresentado a seguir:

- SEDE (captação superficial do córrego Serrinha). A Estação de Tratamento de Água (ETA), Sede de Monteiro Lobato, localiza-se na Rua Abílio Pereira Dias, 260, Centro. É do tipo convencional e trata o esgoto coletado no sistema Sede.

- SOUZAS (captação superficial tendo como manancial o Ribeirão Farias ou Souzas). A Estação de Tratamento de Água (ETA) do Bairro do Souza está localizada na Av. Santa Rita de Cássia, 3 (SÃO PAULO, 2010b, p. 49;52). 
- SÃO BENEDITO (captação subterrânea em poço tubular profundo). A Estação de Tratamento de Água (ETA) São Benedito localiza-se no bairro de mesmo nome, na Estrada SP-50, km 138.

\subsubsection{Esgotamento Sanitário}

Os serviços do sistema de esgotamento sanitário são prestados também pela SABESP e abrangem a área urbana do município, com índice de coleta de $73 \%$ e de tratamento de $88 \%$ do coletado. A Estação de Tratamento de Esgoto (ETE) de Monteiro Lobato está localizada próxima às margens do Rio Buquira (SÃO PAULO, 2012, p. 35). De acordo com o SEADE (2013), o Nível de Coleta do Esgoto Sanitário na área urbana é de $77,98 \%$. O sistema conta também com 2 Estações Elevatórias de Esgoto Bruto (EEE):

1) EEE Vila Esperança que coleta os esgotos do bairro Nova Esperança,

2) EEE Final Vila Iracema.

O Bairro do Souza possui um sistema isolado composto somente por rede coletora, com lançamento do esgoto in natura no Córrego Faria. A rede existente contempla $50 \%$ da comunidade. A construção de ETE está em andamento - até 2014). As edificações não atendidas por essa rede possuem fossa negra ou séptica ou fazem o lançamento diretamente sobre o solo (SÃO PAULO, 2010b, p. 62). O Bairro São Benedito não conta ainda com sistema de esgotamento sanitário. Há um projeto elaborado pela SABESP para uma ETE e uma EEE que deveria ter tido sua construção iniciada em janeiro de 2010 (SÃO PAULO, 2010b, p. 64). Segundo Marilene Mesquita Silva, Secretária de Meio Ambiente e Agricultura, existe um processo junto ao Ministério Público para que a SABESP instale a ETE no Bairro São Benedito o mais rápido possível - a previsão é de conclusão em 24 meses (a partir de 2012).

Há, ainda, um Projeto da Prefeitura financiado pelo FEHIDRO, que trata de uma Estação de Tratamento de Esgoto Compacta para atendimento do Bairro do Souza. A Prefeitura Municipal cedeu esse projeto à SABESP para que a mesma possa adequá-lo com vistas a sua implantação. O escopo abrange o atendimento de $50 \%$ das residências que não são contempladas atualmente em termos de coleta e tratamento de esgoto.

Para aferir a situação dos municípios paulistas quanto ao desempenho de 
seus sistemas de tratamento de esgotos sanitários, a CETESB desenvolveu 0 Indicador de Coleta e Tratabilidade de Esgoto da População Urbana do Município (ICTEM). Monteiro Lobato, em 2009, foi classificado como "REGULAR" $(5,3)$, enquanto que São José dos Campos, Santo Antonio do Pinhal e São Bento do Sapucaí foram classificados como "RUIM" e Campos do Jordão como "PÉSSIMO" (SÃO PAULO, 2011, p. 112;114).

\subsubsection{Limpeza Urbana e Manejo dos Resíduos Sólidos Domiciliares (RSD)}

É fundamental para diminuir os impactos ambientais uma adequada disposição final dos resíduos sólidos domiciliares. A CETESB criou uma metodologia de classificação das áreas de disposição final e de usinas de compostagem, baseada no Índice de Qualidade de Aterro de Resíduos (IQR) e no Índice de Qualidade de Compostagem (IQC). Os sistemas analisados são enquadrados em 3 condições: Inadequados, Controlados e Adequados, conforme pontuação de 0 a 10 (MOREIRA et al., 2004, p. 23). O IQR de Monteiro Lobato é classificado como “ADEQUADO” (10,0) (IPT, 2012, p. 48).

A Tabela 29 apresenta a geração de RSD e o percentual das quantidades geradas pelo município de Monteiro Lobato em 2009 em relação aos demais da Unidade de Gerenciamento de Recursos Hídricos (UGRHI 02), levando em conta os grupos adotados para aplicação do índice de geração de resíduos por habitante. No caso de um município de até 100.000 habitantes, o índice de geração de RSD por habitante (kg/hab.dia) é de 0,4 (SÃO PAULO, 2011, p. 115).

O total de RSD produzido pelos municípios da UGRHI 02 é de 1.034,20 (t/dia) que equivale a 3,93\% ao RSD produzido no Estado de São Paulo.

Tabela 29 - Resíduos Sólidos Domiciliares (RSD) gerados pelo município de Monteiro Lobato, em 2009, em relação aos demais municípios da UGRHI 02

\begin{tabular}{cccc}
\hline Município & $\begin{array}{c}\text { População } \\
\text { (hab.) }\end{array}$ & $\begin{array}{c}\text { RSD } \\
\text { (t/dia) }\end{array}$ & $\begin{array}{c}\text { Percentual de RSD } \\
\text { em relação ao total } \\
\text { da UGRHI }\end{array}$ \\
\hline Monteiro Lobato & até 100.000 & 0,70 & $0,07 \%$ \\
\hline
\end{tabular}

Fonte: (SÃO PAULO, 2010a, p. 56) 
Tabela 30 - Resumo dos dados do saneamento básico do município

\begin{tabular}{cccc}
\hline $\begin{array}{c}\text { Município } \\
2010\end{array}$ & $\begin{array}{c}\text { Abastecimento } \\
\text { de Água } \\
\text { (área urbana) }\end{array}$ & $\begin{array}{c}\text { Esgoto Sanitário } \\
\text { Nível de Coleta } \\
\text { (área urbana) }\end{array}$ & $\begin{array}{c}\text { Coleta de Lixo } \\
\text { Nível de } \\
\text { Atendimento }\end{array}$ \\
\hline Monteiro Lobato & $89,35 \%$ & $77,98 \%$ & $99,64 \%$ \\
\hline
\end{tabular}

Fonte: SEADE (2013)

De acordo com o IPT (2012, p. 61), Monteiro Lobato coleta $87 \%$ da carga poluidora dos rios e trata $67 \%$ dessa carga. Lagoinha é o único município da UGRHI 02 que coleta e trata $100 \%$ da carga poluidora.

Os serviços de limpeza urbana, de varrição e poda são realizados pela administração pública local, por meio da Secretaria de Transporte, abrangendo $100 \%$ da área urbana, na coleta porta a porta e, em sete bairros rurais, em pontos específicos predeterminados (SÃO PAULO, 2010b, p. 65).

Os resíduos coletados nos domicílios e recolhidos após o serviço de varrição são transportados para o Aterro Sanitário, localizado no município de Tremembé por meio de contrato com a empresa particular Resicontrol. Os Resíduos Sólidos dos Serviços de Saúde (RSS) são enviados para São José dos Campos onde são incinerados por meio de contrato com a empresa particular Faria \& Silva Ltda. Por tais motivos, Monteiro Lobato está classificado como "ADEQUADO" nesses itens. O índice de geração de Resíduos Sólidos Urbanos (RSU) é de aproximadamente 40 toneladas/mês, equivalendo a uma geração anual de 480 toneladas (SÃO PAULO, 2012, p. 45). Em Monteiro Lobato, a municipalidade promove a separação na origem dos materiais passíveis de reaproveitamento pela reciclagem, numa média de 5 t/mês, através do serviço de coleta seletiva, em operação há aproximadamente 5 anos (SÃO PAULO, 2012, p. 43). O lixo reciclável é recolhido às terças e quintasfeiras, em toda a área urbana e em sete bairros da zona rural. Os materiais recolhidos pela coleta seletiva são encaminhados para uma central de triagem, montada num galpão alugado pela municipalidade, onde 2 funcionários cuidam da separação dos resíduos (SÃO PAULO, 2012, p. 45).

Em 2007, a Coordenadoria de Planejamento Ambiental da SMA desenvolveu o Índice de Gestão dos Resíduos Sólidos (IGR) que resulta de uma fórmula matemática com os índices: IQR, IQC e IGR e classifica a gestão municipal em 3 
categorias: Ineficiente, Mediana e Eficiente. A gestão municipal de Monteiro Lobato está classificada como "Mediana".

\subsubsection{Drenagem de Águas Pluviais Urbanas}

A drenagem e manejo das águas pluviais urbanas consistem no conjunto de atividades, infraestruturas e instalações operacionais de drenagem urbana de águas pluviais, de transporte, detenção ou retenção para o amortecimento de vazões de cheias, tratamento e disposição final das águas pluviais drenadas nas áreas urbanas (SÃO PAULO, 2010b, p. 22).

Com a expansão populacional da área urbana, cresce na mesma medida o número de domicílios, estabelecimentos comerciais, escolas e postos de saúde que, de maneira geral, configuram áreas impermeáveis. Por conseguinte, as águas anteriormente absorvidas pelo solo são conduzidas para a malha de macrodrenagem por meio das estruturas de microdrenagem do município, tornando mais rápido e elevado o escoamento superficial, e incrementando a vazão dos corpos d'água (SÃO PAULO, 2012, p. 50).

De uma maneira geral, portanto, entende-se que o município requer uma revisão de seus equipamentos de drenagem, com a implantação de macro e microdrenagem compatíveis com suas peculiaridades naturais, com suas condições de uso e ocupação do solo e com regime de cheias dos corpos d'água que cortam a área urbana, além de estabelecer diretrizes para nortear o processo de ocupação urbana. Medidas referentes à gestão e manejo do sistema também devem ser estabelecidas, em especial a ocupações irregulares em áreas de preservação permanente (APP) ao longo do Rio Buquira (SÃO PAULO, 2012, p. 55).

\subsection{Elementos do Meio Ambiente}

\subsubsection{Relevo}

Localizada nas escarpas e reversos da Serra da Mantiqueira, Monteiro Lobato tem topografia montanhosa. A área urbana está a $650 \mathrm{~m}$ de altitude em relação ao nível do mar. As maiores altitudes ocorrem ao norte e ultrapassam os $1.500 \mathrm{~m}$ (SÃO PAULO, 2013, p. 17). 
A declividade das vertentes é um elemento que interfere de forma significativa na distribuição de classes de solos, bem como exerce influência nos processos de erosão, exigindo manejos agrícolas diferenciados para uma ocupação adequada das terras (MOREIRA et al., 2004). A declividade é um dos principais condicionadores da capacidade de uso das terras (ISSA, 2003, p. 50).

Tabela 31 - Valores relativos das classes de declividade em relação à área total de Monteiro Lobato

\begin{tabular}{lcllc}
\hline $\begin{array}{r}\text { Classes de } \\
\text { declividade }\end{array}$ & \multicolumn{1}{c}{$\%$} & \multicolumn{1}{c}{ Graus } & \multicolumn{1}{c}{ Descrição } & $\begin{array}{c}\text { Áreas das } \\
\text { classes em \% }\end{array}$ \\
\hline $\mathrm{E}$ & $15-45$ & $8,5-24,5$ & Forte & 57,69 \\
$\mathrm{AB}$ & $0-5$ & $0-2,8$ & Suave & 18,63 \\
$\mathrm{D}$ & $10-15$ & $4,5-8,5$ & Moderada & 17,75 \\
$\mathrm{C}$ & $5-10$ & $2,8-4,5$ & Moderada & 5,34 \\
$\mathrm{FG}$ & $>45$ & $>24,5$ & Forte e Muito & 0,59 \\
& & Forte & \\
\hline
\end{tabular}

Fonte: Issa (2003, p. 49)

A Lei Federal n 6.766/79 determina que a ocupação urbana não pode ocorrer em áreas com declividade acima de $30 \%$, salvo se atendidas exigências específicas das autoridades competentes.

As declividades menores estão associadas às áreas de várzeas dos rios Buquira/Ferrão e Buquirinha (ISSA, 2003, p. 49). O rio Buquira/Ferrão, com 40 km de extensão, percorre os municípios de Monteiro Lobato e São José dos Campos, abrangendo uma área de 413,29 km² (ARGUELLO; SAUSEN, 2007, p. 24).

De acordo com Issa (2003, p. 53), 59,72\% da área do município estão entre as cotas altimétricas de 700 a 1.000 m, que representam a transição entre o relevo de morros e as escarpas da Serra da Mantiqueira. As maiores altitudes aparecem ao norte do município, na divisa com o município de Santo Antonio do Pinhal e na divisa com o Estado de Minas Gerais. As menores altitudes estão associadas ao sul do município e às várzeas dos rios Buquira/ Ferrão e Buquirinha. 


\subsubsection{Solos}

Segundo Müller (1969, p. 228):

A Serra da Mantiqueira, na porção que se desenvolve a Leste do Rio Buquira, (à altura de Monteiro Lobato), está próxima da bacia terciária, caindo sobre ela quase que abruptamente, sem níveis intermediários, oferecendo poucas possibilidades à fixação de cidades. [...] a Oeste do Rio Buquira, a Mantiqueira se apresenta rebaixada, com frente recuada, desdobrando-se em vários níveis, tendo, à sua frente, toda uma área amorreada; as condições oferecidas à implantação de centros urbanos são mais favoráveis, aí se encontrando três centros - Santa Isabel, Igaratá e Monteiro Lobato.

Monteiro Lobato situa-se sobre Latossolo Vermelho-Amarelo. Em termos geológicos, está sobre rochas gnáissicas de origem magmática e/ou sedimentar de médio grau metamórfico e rochas graníticas desenvolvidas durante o tectonismo, ao norte; sedimentos arenosos do Pleistoceno, na porção central; sedimentos arenosos e argilosos, podendo incluir níveis carbonosos do Terciário, ao sul (SÃO PAULO, 2013, p. 17).

De acordo com Issa (2003, p. 56), dos solos em Monteiro Lobato, 83,64\% correspondem ao grande grupo Latossolo Vermelho Amarelo. A abundância de Cambissolos, presentes em todos os grupos, caracteriza o relevo montanhoso do município enquanto que o grupo do Podzólico Vermelho Amarelo recobre pequena área no sul do município.

Arguello e Sausen (2007, p. 17-19) descrevem esses tipos de solos encontrados no município:

$\checkmark$ Latossolos Vermelho Amarelos: são solos originários de filitos, xistos e rochas granito-gnáissicas das Serras do Mar e da Mantiqueira. Para agricultura, eles são considerados de regulares a não adequados, pois, apresentam problemas de fertilidade. Para pecuária, não apresentam grandes problemas.

$\checkmark$ Cambissolos: solos provenientes dos filitos, granitos e gnaisses. Para a agricultura são inadequados, pois, geralmente apresentam graves problemas a respeito da fertilidade e erosão, além de serem prejudicados na mecanização de lavoura devido ao relevo acentuado e ao fato de se situarem em regiões com possíveis ocorrências de geadas. Quanto à pecuária, são considerados mais apropriados, devido aos relevos montanhosos erodidos. 
$\checkmark$ Podzólico Vermelho Amarelo ou Argissolos: o material originário desses solos compreende rochas graníticas e gnáissicas da Serra do Mar, da Mantiqueira e sedimentos argilosos. O risco de serem erodidos conforme o uso em pastagem associado à declividade do forte relevo na região do Planalto Atlântico, é uma limitação para a pecuária. Para a agricultura, esses solos são considerados regulares, pois são ácidos e esgotados, necessitando de correção e adubação.

Segundo Costa (1997), "a existência de solos mais rasos e de terrenos acidentados em Monteiro Lobato e em boa parte da região, restringem a implantação de atividades agrárias. Por isso, o predomínio de pastagens sobre outros usos do solo".

De acordo com o IPT (2012, p. 22) a sub-bacia CP3-PS-B ${ }^{54}$ na qual 0 município de Monteiro Lobato está inserido figura entre aquelas que apresentam as maiores áreas classificadas como de alta suscetibilidade natural à erosão. Em adição, considerando que os tipos de solo de Monteiro Lobato são semelhantes ao de Campos de Jordão, constata-se que o primeiro corre o risco de ter os mesmos deslizamentos do segundo. Daí a importância do plano diretor do município que estabeleça regulamentação para o uso e ocupação do solo, respeitando o meio físico-natural do município.

\subsubsection{Vegetação}

De acordo com Ferreira e Fisch (2007, p. 41), em Monteiro Lobato o tipo de vegetação predominante é a Floresta Ombrófila Densa, cuja maior característica é a presença de árvores altas, atingindo entre 20 e $30 \mathrm{~m}$. Estas árvores possuem folhas largas e sempre verdes de longa duração (perenifólias), além de mecanismos adaptados para resistir tanto a períodos de calor extremo, quanto de muita umidade.

A cobertura vegetal natural, representada pelas matas, não se encontra mais em seu estado original, pois dela já foram removidas as árvores de grande porte fornecedoras de madeira (ISSA, 2003, p. 69). Mesmo assim, Monteiro Lobato

${ }^{54}$ Conforme o Plano de Bacias 2009-2012, CP3-PS-B, Região do Paraíba do Sul - B, é uma das quatro subdivisões da Unidade de Gerenciamento de Recursos Hídricos (UGRHI 02) para fins de facilitar a análise e a gestão do território, abrangendo o trecho do Rio Paraíba do Sul entre os municípios de São José dos Campos e Potim (SÃO PAULO, 2010a, p. 12). 
preserva $50,80 \%$ de sua vegetação nativa que soma 16.912 hectares (SÃO PAULO, 2010a, p. 64).

Monteiro Lobato possui, em seu território, parte de uma Unidade de Conservação de Uso Sustentável, a Área de Preservação Ambiental (APA) da Bacia do Rio Paraíba do Sul, além da Reserva de Particular de Patrimônio Natural (RPPN) Sítio do Cantoneiro, que é federal, criada pela Portaria IBAMA oㅡ 116N/1994, com área de 102,54 ha (SÃO PAULO, 2013, p. 22; IPT, 2013, p. 38).

\begin{tabular}{|l|}
\hline Unidade: APA Bacia do Rio Paraíba do Sul \\
\hline Área: 291.601 hectares \\
Esfera: Federal \\
Diplomas Legais de instituição a UC: Decreto № 87.561 , de 13/9/1982 \\
Objetivos de criação da UC: Proteger os mananciais de abastecimento da Bacia \\
Hidrográfica do Rio Paraíba do Sul e proteger a diversidade biológica, disciplinar o \\
processo de ocupação e assegurar a sustentabilidade do uso dos recursos naturais. \\
Órgão gestor: ICMBio - Instituto Chico Mendes de Conservação da Biodiversidade \\
Instrumento de gestão: não possui \\
Instituição de Conselho Gestor: não possui \\
\hline
\end{tabular}

Quadro 114 - Unidades de Conservação

Fonte: São Paulo (2010a, p. 124)

O Índice de Avaliação Ambiental (IAA) é estabelecido: 1) pelo somatório dos Indicadores de Atendimento das Diretivas Ambientais (acréscimo máximo de 80 pontos); 2) pelo somatório dos Indicadores das ações Pró-ativas do Município, relativos às Diretivas Ambientais (acréscimo máximo de 20 pontos); e 3) pelas pendências e/ou passivos ambientais de responsabilidade do município.

Em 2008, Monteiro Lobato figurou entre os municípios mais críticos da UGRHI 02 no item esgoto tratado. O IAA de Monteiro Lobato está na faixa entre 40 e 60, tal como São José dos Campos. Lagoinha é o único município que tem o IAA acima de 80. 


\subsubsection{Uso Potencial da Terra}

\begin{tabular}{|c|c|c|}
\hline $\begin{array}{l}\text { Classe de Usos } \\
\text { das terras }\end{array}$ & Descrição & $\%$ \\
\hline Mata/capoeira & $\begin{array}{l}\text { Matas com cobertura vegetal natural (mata) ou com matas em processo } \\
\text { de regeneração (capoeira), mais restritas a topos de morros e encostas. }\end{array}$ & 45,02 \\
\hline Pastagem & $\begin{array}{l}\text { Predomina no município, cobrindo extensas regiões. Inclui a subclasse } \\
\text { "pasto sujo" que corresponde a locais onde a prática da pecuária foi } \\
\text { abandonada. }\end{array}$ & 43,46 \\
\hline Reflorestamento & $\begin{array}{l}\text { Aparece em pontos isolados do município, de forma aglomerada e é } \\
\text { representada pelo plantio de eucalipto para a produção de celulose. }\end{array}$ & 11,02 \\
\hline Área agrícola & $\begin{array}{l}\text { A classe "culturas anuais" é a menos expressiva e é representada por } \\
\text { uma agricultura de subsistência incipiente e pelo cultivo de forrageiras } \\
\text { para o gado. }\end{array}$ & 0,37 \\
\hline Área urbana & $\begin{array}{l}\text { Está restrita ao centro urbano do município, dois conjuntos habitacionais } \\
\text { populares e a alguns pontos isolados representados pelos poucos } \\
\text { bairros rurais. }\end{array}$ & 0,13 \\
\hline
\end{tabular}

Quadro 115 - Uso Potencial da Terra

Fonte: Issa (2003, p. 69;70;73)

Segundo Issa (2003, p. 71), o desmatamento tem avançado em direção aos topos dos morros para formar novas pastagens ou para introdução de alguma cultura. Ainda há queimadas usadas como técnica por alguns proprietários para evitar a recuperação de matas e consequente restrição de uso. Além do eucalipto, há o plantio da braquiária como substituto do capim-gordura.

\subsubsection{Fauna}

De acordo com Godoy, Zimmermann e Zimmermann (2007, p. 161), relacionam-se abaixo os mamíferos encontrados no Vale do Paraíba:

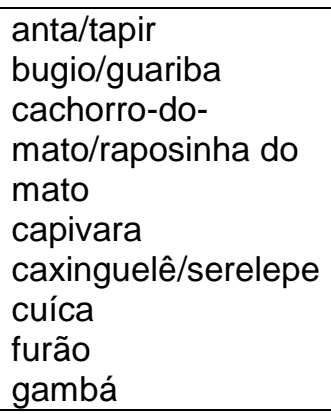

\begin{tabular}{|l|l|l|} 
gato-do-mato & ouriço-cacheiro & sauá \\
irara & paca & tamanduá- \\
jaguatirica & porco do & mirim/tamanduá- \\
lobo-guará & mato/cateto/caititu & colete \\
lontra & preá & tapiti \\
macaco-prego & preguiça & tatu-de-rabo-mole- \\
mão-pelada/guaxinim & quati & pequeno \\
muriqui/mono- & sagui-da-serra- & tatu-galinha \\
carvoeiro & escuro & veado-catingueiro \\
onça-parda/suçuarana & & veado-mateiro \\
\hline
\end{tabular}

Quadro 116 - Relação de mamíferos encontrados no Vale do Paraíba 
Segundo Lencioni Neto (2007, p. 141), a Floresta Atlântica contém aproximadamente 680 espécies de aves, com cerca de 100 espécies endêmicas. Destas, o Vale do Paraíba possui 55 espécies.

Quanto à avifauna, os seguintes pássaros são encontrados na Floresta Ombrófila Densa, de acordo com Lencioni Neto (2007, p. 143):

\begin{tabular}{|l|l|l|l|}
\hline Araçaris & Jacutinga & Papa-mosca-real & Saíra-de-cabeça- \\
Araponga & Juritis & Periquitão & castanha \\
Beija-flores & Macuco & Pica-paus & Saíras (Tangarás) \\
$\begin{array}{l}\text { Bico-chato-de-crista- } \\
\text { amarela }\end{array}$ & Maitaca-verde & Pombas & Surucuás \\
$\begin{array}{l}\text { Inhambu-guaçu } \\
\text { Jacu }\end{array}$ & $\begin{array}{l}\text { Papa-formigas } \\
\text { papagaio-de-peito- } \\
\text { roxo }\end{array}$ & $\begin{array}{l}\text { Rendeira } \\
\text { Sabiás }\end{array}$ & Tié-de-topete \\
Tucanos
\end{tabular}

Quadro 117 - Relação de pássaros encontrados na Floresta Ombrófila Densa

Observa-se também, em Monteiro Lobato, entre outras aves, a presença de canários, quero-quero, garças de pescoços curto (Egretha thula) e longo (Ardea alba), bem-te-vi, pássaro preto, rolinha e aves migratórias como as andorinhas, patos selvagens, colhereiro, curicaca entre outros.

\subsubsection{Hidrografia}

A UGRHI 02 - Paraíba do Sul é constituída pela Bacia do Rio Jaguari e de outros tributários do Rio Paraíba do Sul, tanto da margem esquerda como da direita, desde as nascentes de seus formadores (rios Paraibuna e Paraitinga) até a divisa dos Estados de São Paulo e do Rio de Janeiro, a montante da barragem do Funil. Em condições naturais, a UGRHI 02 não recebe contribuições nem deságua em outras bacias hidrográficas do Estado de São Paulo (FCR, 2009 apud SÃO PAULO, 2010a, p. 13).

O Rio Paraíba do Sul, que se forma através da confluência dos rios Paraibuna e Paraitinga, cujas nascentes se localizam nos municípios de Cunha e Areias, respectivamente, no Estado de São Paulo percorre cerca de $900 \mathrm{~km}$ antes de desembocar no Oceano Atlântico, no Estado do Rio de Janeiro. Os principais afluentes do Rio Paraíba do Sul no seu trecho paulista são: o Paraibuna, o Paraitinga, o Jaguari, o Una, o Buquira/Ferrão, o Embau/Piquete, o Bocaina e o Pitangueiras/Itagacaba. (SÃO PAULO, 2010a, p. 13). A sub-bacia do Rio Buquira, no município de Monteiro Lobato, integrada à bacia do Rio Paraíba do Sul, é composta, 
entre outros, pelos rios Buquira/Ferrão, Braço e Descoberto; pelo córrego do Machado e pelos ribeirões Souzas e Matinada. De acordo com o IPT (2012, p. 6), a sub-bacia do Rio Buquira ou Ferrão está classificada como uma das prioritárias da UGRH1 02, inserida no compartimento 1 e sub-compartimento CP3-PS-B que envolve o trecho do Rio Paraíba do sul entre os municípios de São José dos Campos e Potim. Monteiro Lobato pertence à Bacia Hidrográfica do Paraíba do Sul (Unidade de Gerenciamento de Recursos Hídricos 2 - UGRHI-02), integrando com o Rio Buquira sua área de drenagem em São José dos Campos (MOREIRA et al., 2004, p. 13). Segundo o IPT (2012, p. 56;57), a vazão mínima do sub-compartimento CP3-PS-B do qual Monteiro Lobato faz parte está na faixa de 50 a $70 \mathrm{~m}^{3} / \mathrm{s}$.

\subsubsection{Clima}

Segundo o Centro de Pesquisas Meteorológicas e Climáticas Aplicadas à Agricultura - CEPAGRI (apud SÃO PAULO, 2013, p. 18), o clima da região é caracterizado por temperatura média anual de $20,9^{\circ} \mathrm{C}$, oscilando entre mínima média de $14,6^{\circ} \mathrm{C}$ e máxima média de $27,2^{\circ} \mathrm{C}$.

Observa-se que a maioria dos municípios localizados na UGRHI 02 foi classificada como Cwa e caracterizada pelo clima tropical de altitude, com chuvas no verão, seca no inverno e temperatura média do mês mais quente superior a $22^{\circ} \mathrm{C}$ (SÃO PAULO, 2010a, p. 16).

Classificação climática de Köppen para os municípios do Vale do Paraíba:

\begin{tabular}{|c|l|l|}
\hline Tipo & \multicolumn{1}{|c|}{ Características } & \multicolumn{1}{|c|}{ Municípios } \\
\hline Cwa & $\begin{array}{l}\text { Caracterizado pelo clima } \\
\text { tropical de altitude, com chuvas } \\
\text { no verão e seca no inverno e } \\
\text { temperatura média do mês mais } \\
\text { quente superior a } 22^{\circ} \mathrm{C} .\end{array}$ & $\begin{array}{l}\text { Caçapava, Cunha, Guararema, Igaratá, } \\
\text { Jacareí, Jambeiro, Lagoinha, Monteiro } \\
\text { Lobato, Natividade da Serra, Paraibuna, } \\
\text { Pindamonhangaba, Piquete, Redenção } \\
\text { da Serra, Roseira, Santa Branca, Santa } \\
\text { Isabel, São José dos Campos, São Luís } \\
\text { do Paraitinga, Silveiras, Taubaté e } \\
\text { Tremembé. }\end{array}$ \\
\hline
\end{tabular}

Quadro 118 - Classificação climática de Köppen para os municípios do Vale do Paraíba Fonte: (SÃO PAULO, 2010a, p. 17) 
A precipitação média anual é de $1.870,4 \mathrm{~mm}$. O Gráfico 64 possibilita uma análise temporal das características das chuvas na região, apresentando a distribuição das mesmas ao longo do ano, bem como os períodos de maior e menor ocorrência (SÃO PAULO, 2013, p. 18).

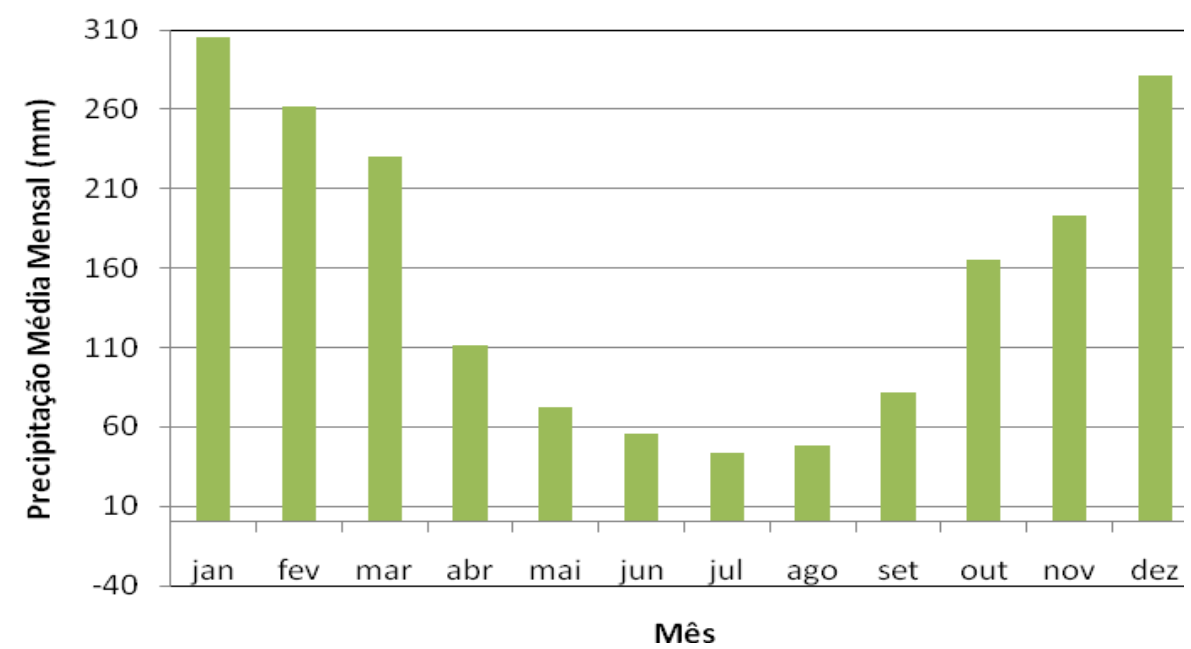

Gráfico 64 - Precipitação média mensal no período de 1939 a 2004 - posto D2-020 Fonte: DAEE (apud SÃO PAULO, 2013, p. 18) 


\subsection{Política do município}

Dentro do modelo de democracia representativa no país, com eleições municipais a cada quatro anos, os serviços públicos estão diretamente ligados à política partidária, o que historicamente causa descontinuidades nas ações da gestão que deixa a administração pública. Porém, esse não foi o caso da atual Prefeita que tem dado continuidade às ações do governo anterior. Com 34 anos, a Prefeita é filiada ao Partido Socialista Brasileiro (PSB). Foi Secretária de Meio Ambiente, Cultura e Turismo (SEMACTUR) no governo do Prefeito Sebastião Coelho de Andrade, Presidente da Associação Cachoeira das Artes de Monteiro Lobato, trabalhou no Fundo Social do Estado de São Paulo e foi Chefe de Gabinete e Presidente do Fundo Social na última gestão. Com tal experiência na área pública, a Prefeita tem facilidade de articulação política nos meios políticos regional, estadual e federal. O município participa do Consórcio de Desenvolvimento Integrado do Vale do Paraíba (CODIVAP), do Consórcio da Mantiqueira e da Associação de Desenvolvimento Integrado do Território da Mantiqueira (ADITM) ${ }^{55}$. O Secretário de Turismo do Estado de São Paulo, Claudio Valverde, também é do PSB e apoia a Prefeita. Em nível nacional, a prefeita participa da Confederação Nacional dos Municípios (CNM).

A atual gestão se compromete com o desenvolvimento econômico e social do município de forma participativa. A participação social envolve vários espaços de cogestão pública entre governo e comunidade, quais sejam: orçamento participativo, conselhos temáticos (saúde, educação, moradia, assistência social etc.), conselhos de gestão de unidades (escolas, unidades de saúde, centros comunitários etc.) e fóruns. Os Conselhos existentes no município são: Conselho Municipal da Saúde (COMUS); Conselho Municipal de Assistência Social (CMAS); Conselho Municipal de Meio Ambiente (CMMA); Conselho Municipal de Turismo (COMTUR-ML); Conselho de Educação - FUNDEB (CACAS); Conselho de Alimentação Escolar (CAE); Conselho de Escola; Conselho Tutelar; Conselho Municipal dos Direitos da

${ }^{55}$ O Codivap envolve 39 municípios da Região Metropolitana Vale do Paraíba e Litoral Norte (RMVPLN). O Consórcio da Mantiqueira envolve 5 municípios da microrregião da Serra da Mantiqueira, incluindo Tremembé e a Associação de Desenvolvimento Integrado do Território da Mantiqueira (ADITM) envolve 15 municípios da Serra Mantiqueira (5 do lado paulista e 10 do lado mineiro). 
Criança e do Adolescente (CMDCA); Conselho Municipal de Direitos do Idoso de Monteiro Lobato (CMDI); Conselho Comunitário de Segurança de Monteiro Lobato (CONSEG). Outras entidades atuantes no município são:

$\checkmark$ Grupo Planejatur - grupo de trabalho voluntário, criado em janeiro de 2012, no âmbito do Projeto de Doutorado da Profa. Ma. Cleide Pivott, em Psicologia Social na USP, com o objetivo de elaborar o Plano Diretor de Turismo Sustentável de Monteiro Lobato com participação social, apoiando os trabalhos da Secretaria de Cultura e Turismo e o COMTUR-ML com os quais forma o Sistema de Gestão do Turismo Sustentável de Monteiro Lobato.

$\checkmark$ Associação dos Pequenos Produtores Rurais de Monteiro Lobato e Região (APPR), criada em 2002, trabalha para atender às necessidades dos pequenos produtores rurais em diversos aspectos, tendo como preceito a realização de parcerias e participação em editais e projetos. Entre eles estão - Programa PAA - Programa de Aquisição de Alimentos, o Projeto Desenvolvimento Sustentável da Apicultura de Monteiro Lobato com a UNITAU e patrocínio da FIBRIA.

$\checkmark$ Associação de Agroecologia de Monteiro Lobato e Região (AGROECO), é uma associação sem fins lucrativos, criada em 2012, tendo como seus principais objetivos: a promoção da prática da Agricultura Orgânica e da Agroecologia.

$\checkmark$ Sindicato Rural de Monteiro Lobato, fundado em 1975.

$\checkmark$ Pastoral da Saúde, ligada à Paróquia de Nossa Senhora de Bonsucesso.

$\checkmark$ A Associação Sociedade de Obras Religiosas de Monteiro Lobato mantém o asilo Cantinho de São Vicente. Tem 39 anos como entidade formalizada.

$\checkmark$ Rede Intersetorial, criada pela Prefeitura, no âmbito da Secretaria da Saúde em conformidade com a Portaria № 936, de 18 de maio de 2004, do Ministério da Saúde que dispõe sobre a estruturação da Rede Nacional de Prevenção da Violência e Promoção da Saúde e a Implantação e Implementação de Núcleos de Prevenção à Violência em Estados e Municípios. Seu plano de trabalho é estabelecido de acordo com o Art. 4은 dessa Portaria que define as atribuições dos componentes da Rede Nacional de Prevenção da Violência e Promoção da Saúde.

$\checkmark$ Roda de Adolescentes Multiplicadores (RAM), criada em 2010, após a 
formação de Multiplicadores realizada pelo GAM (Grupo de Adolescentes Multiplicadores) e desde agosto de 2011 se tornou um projeto intersetorial em parceria com a Secretaria de Saúde, Secretaria de Desenvolvimento Social e Escola Sonnewend. O projeto atualmente atende cerca de 30 adolescentes ${ }^{56}$.

Jara (1998, p. 235) chama a atenção para o papel dos Conselhos Municipais que se inserem na "lógica de ampliação das práticas democráticas, enquanto processo educativo que busca fortalecer a consciência de cidadania das pessoas para que possam assumir, de forma crescente, o papel de sujeitos na definição dos processos de desenvolvimento". Porém, o autor alerta:

Não adianta fomentar a criação de Conselhos Municipais sem
considerar as diferentes alterações complementares necessárias
para impulsionar a municipalização: sistemas de informação,
capacidades de planejamento, construção de parcerias,
fortalecimento do associativismo. Não adianta multiplicar as
instâncias de poder sem formular uma estratégia democrática capaz
de fazer reexame do papel do Estado, das prefeituras, das
instituições da sociedade civil, bem como das práticas decisórias.
Não adianta promover conselhos sem ter uma estratégia que possa
estimular a educação política.

Considera-se de grande valor o desenvolvimento dos trabalhos realizados pelos Conselhos Municipais de Monteiro Lobato, tanto daqueles criados pela Prefeitura quanto dos que foram criados por outras iniciativas. Entretanto, em concordância com Jara, acredita-se que os membros dos conselhos necessitam de capacitação para desempenharem suas atividades as quais devem ser acompanhadas e apoiadas pela administração pública local que, igualmente, precisa se capacitar para conseguir "orquestrar" e integrar os trabalhos dos conselhos municipais e, assim, efetivar uma gestão participativa com a população de fato.

${ }^{56}$ O Grito da RAM. Ano I - Boletim 3 - maio de 2012. 


\subsubsection{Legislação}

A Câmara Municipal é composta por 9 vereadores: José Donizeti Pereira (Donizeti da Prefeitura, PP - Partido Progressista); Ailton Rodolfo Martins (PMDB Partido do Movimento Democrático Brasileiro); Edjelson Aparecido de Souza (PSDB - Partido da Social Democracia Brasileira); Carlos Renato Prince (PMDB - Partido do Movimento Democrático Brasileiro); Jarbas Luiz de Noronha Filho (PSB - Partido Socialista Brasileiro); João Francisco da Silva (João Cunha, PV - Partido Verde); Luis Pereira de Melo Filho (Luizinho do Colchão, PP - Partido Progressista); Maria das Gracias de Siqueira Leiva (PT - Partido dos Trabalhadores); e Leandro Jesus da Costa (Leandro do Cartório - PT do B - Partido Trabalhista do Brasil).

Com relação à legislação para o uso e ocupação do solo do município, há a Lei Municipal no 544/81 que se refere ao uso e ocupação do solo urbano apenas, sendo que nada consta em relação à zona rural. No Parágrafo $2^{\circ}$ do Artigo 178 da Lei Orgânica do Município (1990) consta: "Fica estabelecida uma faixa marginal, cuja largura mínima seja de $2 \mathrm{~m}$ (dois) metros, a contar do nível mais alto do curso d'água, para a preservação e recuperação das matas ciliares". Por outro lado, o Inciso I do Artigo 4․․ da Lei Federal no 12.727, de 17 de outubro de 2012, (novo Código Florestal) estabelece:

I - as faixas marginais de qualquer curso d'água natural perene e intermitente, excluídos os efêmeros, desde a borda da calha do leito regular, em largura mínima de: (Incluído pela Lei no 12.727, de 2012). a) 30 (trinta) metros, para os cursos d'água de menos de 10 (dez) metros de largura;

b) 50 (cinquenta) metros, para os cursos d'água que tenham de 10 (dez) a 50 (cinquenta) metros de largura; [...]

Complementando, o Inciso III do Parágrafo único do Artigo 3․ da Lei Federal no 6.766/79 que dispõe sobre o Parcelamento do Solo Urbano e dá outras Providências estabelece: 
Art. 3‥ Somente será admitido o parcelamento do solo para fins urbanos em zonas urbanas, de expansão urbana ou de urbanização específica, assim definidas pelo plano diretor ou aprovadas por lei municipal. (Redação dada pela Lei no 9.785, de 1999)

Parágrafo único - Não será permitido o parcelamento do solo:

[...] III - em terrenos com declividade igual ou superior a $30 \%$ (trinta por cento), salvo se atendidas exigências específicas das autoridades competentes;

IV - em terrenos onde as condições geológicas não aconselham a edificação; [...]

Portanto, além das sugestões para criação de leis contidas no Programa de Ações 6 do Plano Diretor de Turismo Sustentável de Monteiro Lobato, é fortemente recomendado que os governos executivo e legislativo priorizem a elaboração do Plano Diretor do município para que as leis municipais sejam adequadas à legislação federal, colaborando para a preservação do meio ambiente de Monteiro Lobato. 